

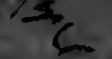

University of Colifomis IRVINE

(n)

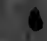

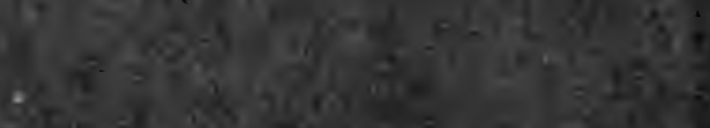


1,

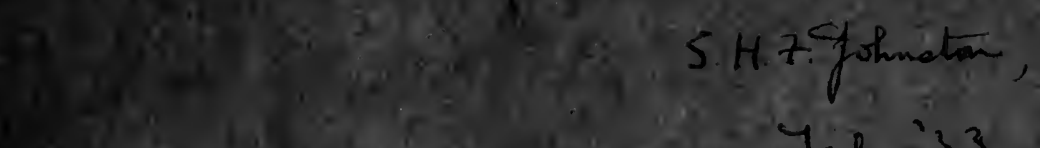

1
4

$x_{1}=8$

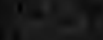

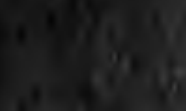

3 (6) $1, \frac{1}{14}$

$x^{2}+x^{3} y$

(5. 1 (y)

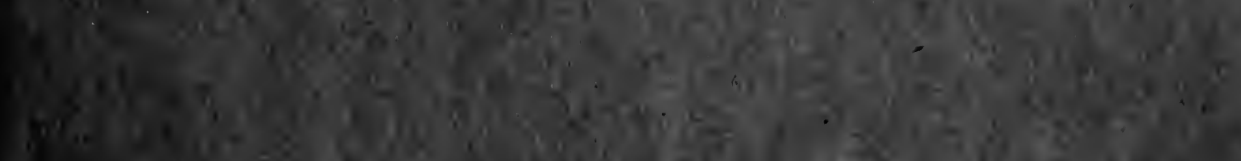

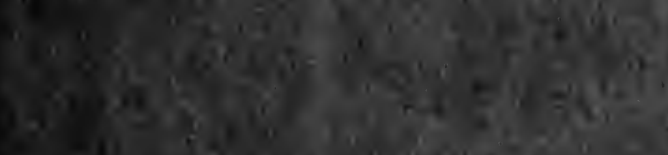

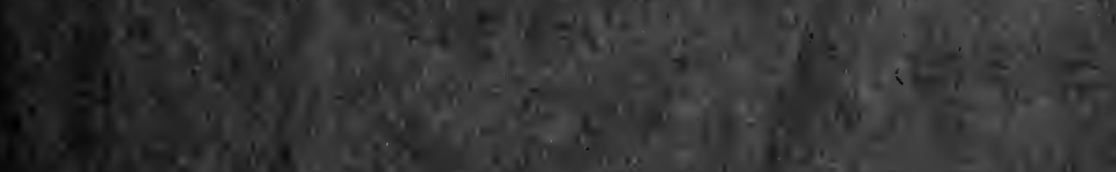

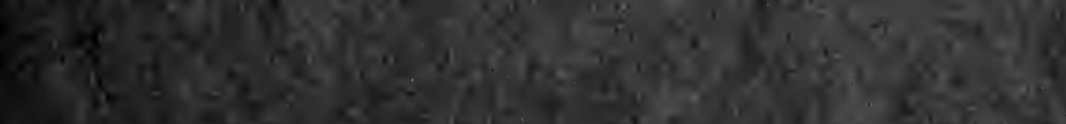

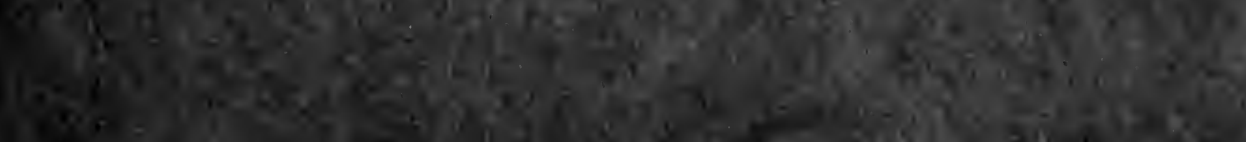

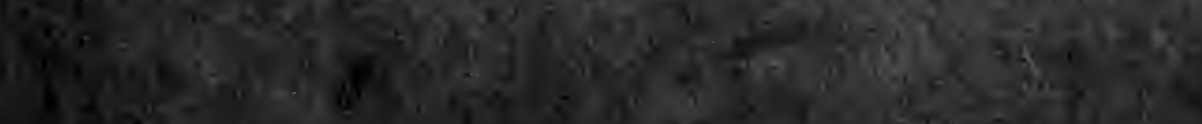

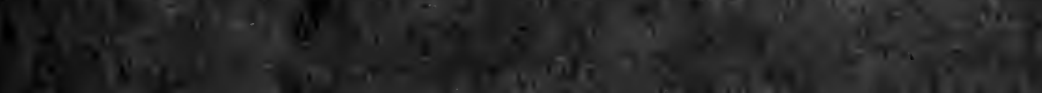

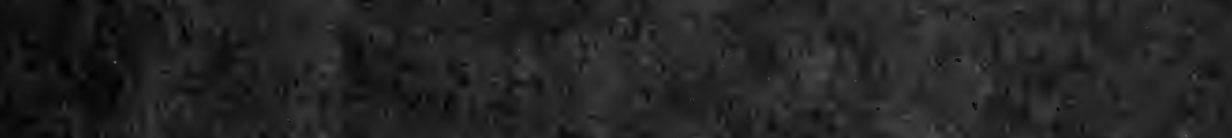

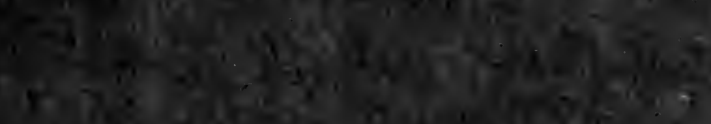




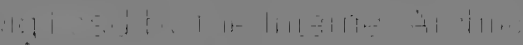

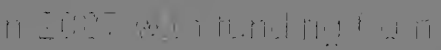

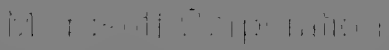

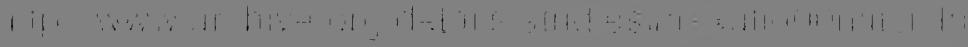




\section{YALE \\ HISTORICAL PUBLICATIONS STUDIES \\ II}

Published under the Direction of the

Departuent of History

From the Incone of

The Frederick John Kingspury

Memorial Fund 



\title{
STUDIES IN TAXATION UNDER
}

\section{JOHN AND HENRY III}

\author{
By \\ Sydney Knox Mitchell, Ph.D. \\ Assistant Professor of History \\ in Yale College
}

NEW HAVEN: YALE UNIVERSITY PRESS

LONDON: HUMPHREY MILFORD OXFORD UNIVERSITY PRESS MDCCCCXIV 


$$
\begin{aligned}
& \text { HJ } \\
& 2605 \\
& M 5
\end{aligned}
$$

Copyright, 1914, BY

Yale University Press

Printed from type, 400 copies, June, 1914 
TO MY MOTHER 



\section{PREFACE}

THE following studies on taxation were originally 1 written several years ago to fulfil in part the requirements for the degree of doctor of philosophy at Yale University. Since that time they have been rewritten and material taken from manuscript sources has been added. My plan has been to give as complete an account as possible of each tax levied during the reigns of John and Henry III, presenting all the material in print and as much from the unprinted rolls as could be gathered within a limited time. A more careful study of the unprinted exchequer rolls will undoubtedly modify many of the statements made here, but until that study has been completed, or until the rolls have been printed and put into the hands of students of English history, this essay may be of service.

In common with other students, I have enjoyed the privileges of the Public Record Office, meeting always with unfailing courtesy on the part of the officials who often aided me in reading difficult passages in the manuscript. To the officials of the Yale University Library also I am grateful for generous consideration in the use of books. For assistance in preparing the volume for the press, I am indebted to Professor Charles M. Andrews, who has read both the manuscript and the proof and made suggestions and corrections from which $I$ have profited much. Above all, I wish to acknowledge my obligation to Professor George Burton Adams, at whose suggestion these studies were undertaken. $\mathrm{He}$ has at all times placed freely at my disposal his wide and accurate 


\section{PREFACE}

knowledge of the period, and at the cost of time taken from his own researches has read and criticised the work with unwearied care and kindness. Lastly, I record with gratitude the coöperation of my wife, whose constant aid in collecting the material and in preparing it for publication has been of the greatest service.

S. K. M. 


\section{TABLE OF CONTENTS}

\section{Chapter I}

\section{INTRODUCTION}

Analysis of the royal income at the close of the twelfth century-The ordinary revenue-The extraordinary revenue-Insufficient amount of the ordinary income-Inquests of 1166-Number of knights' fees in England-Scutage in the twelfth century-Taxes on property before John-Subjects treated in the studies of this book-General statement concerning each of the following in the thirteenth century: dona from religious bodies, tallage, scutage and military service, aids-Amount of the ordinary

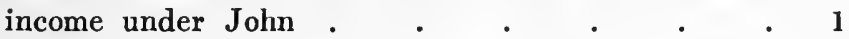

\section{Chapter II}

The Taxes in Detail from 1199 to 1206

General statement of the matter contained in the chapter-The taxes of 1199, military service, scutage and fines, tallage, dona from religious houses-The carucage of 1200 , occasion, composition allowed, opposition to the tax, assessment-The taxes of 1201, military service, scutage and fines, tallage, aid on men of the Channel Isles, the fortieth for the crusade-The taxes of 1202, military service, scutage and fines-The taxes of 1203, military service, scutage and fines, tallage, dona 


\section{TABLE OF CONTENTS}

from religious houses, the seventh of personal property, pretext for its levy, when levied, by whom paid, method of assessment, significance of the levy, the fifth of revenues in the Channel Isles-The taxes of 1204, military service, scutage and fines, dona from religious houses, tallage, fifteenth of the property of merchants, amount yielded, method of assessment and collection-The taxes of 1205 , military service, scutage and fines, tallage-The taxes of 1206, military service, scutage and fines, tallage .

\section{Chapter III}

\section{The Thirteenth of 1207}

Summary of the matter in the chapter-Grant of the tax by the great council-Men taxed-Composition allowed-Taxation of the royal demesne-Assessment and collection-Amount yielded-Significance of the levy

\section{Chapter IV}

The Taxes in Detail from 1208 to 1216

Summary of the matter contained in the chapter-The expedition against the Scots, military service, levy of scutage-The expedition to Ireland, military service, levy of scutage, fines, tallage-The expedition to Wales, military service, levy of scutageDevelopment of the account of scutage rendered in the Pipe Roll-Taxation of religious houses and the Jews-Royal income from church lands during the interdict-Partial service rendered by tenants in 1213-The taxes of 1214, military service, levy of scutage, tallage . . . . . . 


\section{TABLE OF CONTENTS}

\section{Chapter V}

The Taxes in Detail from 1216 to 1229

Summary of material in the chapter-The twentieth of 1216-The taxes of 1217, fines during the civil war, carucage, indemnity in connection with the peace of 1217, methods of raising money, aid on the knight's fee, tallage, contribution from IrelandThe carucage of 1220-The Biham campaign, levy of scutage-The poll tax of 1222-The Welsh expedition of 1223, levy of scutage, tallage-The taxes of 1224, the Bedford campaign, levy of scutage, carucage of the clergy-The fifteenth of 1225, a grant by the great council, classes taxed, assessment and collection-The receipts from the fifteenth-The sixteenth of 1226, assessment and collection-The tallage of 1226, connection with the confirmation of charters-The Welsh campaign of 1228, levy of scutage-The papal tenth of 1229, occasion, assessment and collection

\section{Chapter VI}

The Taxes in Detall from 1229 to 1242

Summary of the matter contained in the chapter-The expedition to Gascony, two scutages levied, the scutage of Brittany, grant of aid by the bishops instead of scutage, dona from religious houses, tallage, taxation of the Jews, the scutage of Poitou, opposition of the clergy-The expedition to Wales in 1231, levy of the scutage of Elveyn-The fortieth, 1232, occasion, grant by the great council, classes which paid the aid, assessment and collection, amount yielded, points of difference between the fifteenth and the fortieth-The campaign against Richard Marshal in 1233, no scutage levied-The 


\section{TABLE OF CONTENTS}

tallage of 1234-The aid of 1235, occasion, granted by the great council, assessment and collection, inquest into knights' fees, dona from religious houses, taxation of sergeants, tallage-The thirtieth of 1237, occasion, grant by the great council, classes taxed, assessment and collection, the receipts, tallage of the Jews, contribution from IrelandTallage of 1238-Tallage of the Jews in 1241Expedition to Wales in 1241, tallage, roll of reduced servitium debitum

\section{Chapter VII}

The Taxes in Detail from 1242 to 1253

Summary of the matter in the chapter-The taxation of 1242, the expedition to France, levy of scutage and fines, assessment and collection, inquest into military service, aid from the bishops instead of scutage, dona from religious houses, other contributions, cost of the expedition-The Scottish campaign-The aid of 1245, grant by the great council, assessment and collection, dona from religious houses-The expedition to Wales, levy of scutage and fines, tallage-Royal devices to raise money from 1246 to 1253 . . . . . . . .

\section{Chapter VIII}

The Taxes in Detail from 1253 to 1258

Summary of the matter contained in the chapter-The expedition to Gascony of 1253, fines, dona, aid from the towns, the aid to knight the king's son, assessment, expenses of the king in Gascony, further royal requests for men and money against the king of Castile-The tenth of the clergy, cases of papal taxation of the clergy after 1229, grant of the tenth 


\section{TABLE OF CONTENTS}

in 1253, assessment and collection, the receipts, poverty of the royal exchequer-The tallage of 1255-Welsh campaign of 1257, levy of scutage . 252

\section{Chapter IX}

\section{The END of The ReIGN}

Summary of the matter in the chapter-Tallage of 1260-Papal taxation of the clergy in 1262-Tenth of the clergy in 1264-Fines in 1265-The tenth of three years in 1266, occasion, grant by the prelates, assessment and collection-Tallage of 1268Twentieth of the clergy in 1268-Twentieth of 1269, its grant, assessment and collection, receipts . 288

\section{Chapter X}

\section{SuMMary}

Subject of the chapter-Military service under John and Henry III-Commutation for service in fines and scutages-Tallage-Dona from religious bodies-The king's income-Origin of modern taxation was the gracious aid; its three formsAid on the knight's fee-Carucage and taxation on moveables-The great council under John and Henry III-Composition and authority of the council-Conclusion 



\section{ABBREVIATIONS}

A. H. R.-American Historical Review.

E. H. R.-English Historical Review.

Rot. Litt. Claus., I, II-Rotuli Litterarum Clausarum, Record Commission, vols. I, II.

Close Rolls, I, II, III, IV-Close Rolls, 1227-1231, 12311234, 1234-1237, $1237-1242$.

Rot. Litt. Pat.-Rotuli Litterarum Patentium, Record Commission.

Pat. Rolls, I, II-Patent Rolls, 1216-1225, 1225-1232.

Cal. Pat. Rolls, I, II, III, IV-Calendar of Patent Rolls, 1232-1247, 1247-1258, 1258-1266, 1266-1272.

Select Charters-Stubbs, Select Charters, 8 th ed. 



\section{CHAPTER I}

\section{INTRODUCTION}

THE king's revenue at the close of the twelfth century 1 may be classed as ordinary and extraordinary. By the ordinary revenue is meant that which came into the exchequer every year through the ordinary administration of the government. It was made up of several items, the chief of which were: the county farm, a fixed sum paid by the sheriff for the privilege of farming the revenue of the royal demesne and the fines of the local courts; amercements imposed by the king's justices for violations of the law; the firma burgi, a lump sum paid by certain towns for the privilege of farming the town revenues; the income from the feudal incidents, reliefs, marriages, wardships, escheats, etc.; fines or oblations, payments to the king for such privileges as the permission to marry a certain person, the custody of the lands of minors, the bringing of cases into the king's court, the delaying or expediting a trial, and the grant and confirmation of charters. ${ }^{1}$ With the income derived mainly from these sources, the king had to carry on his government in ordinary times. In a general way, he probably knew the amount.

Besides the ordinary revenue, which did not always suffice for his needs, the king obtained in certain unusual cases an additional contribution, the extraordinary revenue. This revenue consisted of: 1 , the three regular feudal aids; 2 , scutage from those military tenants who

1 The fines would include many of the cases under the head of the feudal incidents. 


\section{STUDIES IN TAXATION}

failed to perform their service in the army in time of war; 3, an extra contribution called tallage, occasionally levied on his demesne; 4, sums called dona, or auxilia, taken less often from Jews, moneyers, prelates, and religious houses. ${ }^{2}$ None of these contributions would be taken to raise money for the ordinary expenses of the government. There was no assessment of property. In the case of the scutage, an attempt was made to proportion it to the size of the tenant's holding. It was paid at a fixed rate per fee for those fees from which service was owed to the king. The tallage varied in amount from one levy to another. ${ }^{3}$ The dona on religious houses, Jews, etc., were set at round sums. These levies (except the scutage) were arbitrarily exacted by the king. The money was collected in different ways. The great lords responded personally for their contributions. The sheriff might assess the lesser tenants of the king. The tallages were usually assessed by the itinerant justices; the money might be collected by the sheriff, but sometimes the towns paid it directly into the exchequer.

In the twelfth century the customary income from all sources was already becoming insufficient. This was due in part to the great development of the machinery of the government which took place in Henry II's reign; in part to the numerous foreign wars, the heavy expenses of the crusade and of Richard's ransom, and careless adninistration. A rise in prices was going on, probably slowly, from about 1190 to $1250 .{ }^{4}$ It is likely that this increased the difficulties of the government somewhat. The machinery for collecting the income was inefficient. It

2 Baldwin, The Scutage and Knight Service in England, pp. 21, 22, $31,39$.

3 In 1156 , London paid $£ 120$; in $1159, £ 1043$. York paid $£ 40$ in $1156, £ 650$ in 1162 , and $£ 200$ in 1165 . The variation is not usually so great (Baldwin, pp. 24, 25, 27).

4 Ramsay, Dawn of the Constitution, p. 301. 


\section{UNDER JOHN AND HENRY III}

was impossible for the exchequer to compel the prompt payment of dues. The rolls are full of debts which have run on for years. Instead of insisting on the payment of the full sum as a government would do to-day, arrangements were often made with a debtor to pay a certain amount each year till the debt was discharged. ${ }^{5}$ A considerable part of the revenue was thus continually in arrears.

The government was accordingly forced to devise means to increase the national income. This seems to have been the purpose of the inquest of knights' fees of 1166. The military service owed by tenants to the king had been fixed at some time after the conquest; it corresponded only very roughly to the amount of land held by each vassal. While a few tenants had enfeoffed exactly the number of knights whose service they owed the king, some had enfeoffed more, and others fewer. The inquest asked each tenant in chief: 1 , for how many knights he owed service to the king (this was the servitium debitum); 2, how many knights had been enfeoffed before the death of Henry I (this was the old enfeoffment); 3, how many had been enfeoffed since (this was the new enfeoffment). Whenever the number of knights enfeoffed, both new and old, exceeded the servitium debitum, the king considered this as the servitium of the holding and collected scutage on it. If, however, the number of knights enfeoffed fell short of the old servitium, the latter remained as the servitium debitum of the holding. ${ }^{\circ}$ This attempt to

${ }^{5}$ E.g. Walter de Lacy owed $£ 933$ 6s 8 d. He paid $£ 1136$ s 8 d and thereafter was to pay 200 marks yearly (Rotulus Cancellarii, 3 John, p. 108).

6 In the case of a churchman, the servitium debitum is usually referred to as the knights "quos recognoscit," and the excess charged against them as the knights "quos non recognoscit." On the subject of the service owed by the tenants in chief originally and the changes introduced by Henry II, see Round, Feudal England, pp. 225-314, and Baldwin, pp. 33-39. 


\section{STUDIES IN TAXATION}

increase the knights' service owed to the king, and consequently the scutage, was not entirely successful. ${ }^{7}$

The number of fees of the servitium debitum is estimated by Round at about 5,000. ${ }^{8}$ The number does not seem too small. The aid of 1168 amounted to about 6,000 marks. ${ }^{9}$ As the rate was one mark per fee, the number of fees would be about 6,000, but the account is incomplete and includes fees of the new enfeoffment. No attempt has been made in this essay to ascertain the total servitium debitum of England. It has been shown below that the number of fees in the kingdom which might pay scutage in the thirteenth century approached $7,000 .{ }^{10}$ This number is larger than the old servitium debitum, for the custom seems to have been to collect scutage on the old enfeoffment when that was larger than the servitium debitum and from the old servitium when that in turn exceeded the old enfeoffment. ${ }^{11}$ The new enfeoffment was not taxed, except in the case of honors in hand when all the fees enfeoffed were taxed. The calculations which are given below of the number of fees which paid scutage and those which were exempt on account of service are based not on the servitium debitum, but on the number which might pay scutage. Such calculations will not vitiate the correctness of the proportion existing between the part taxed and the part exempt, for an excess over the servitium debitum in the fees taxed will be balanced by a similar excess in the fees exempt.

During the reign of Henry II, the scutage was the commutation of service with the host. Early in the reign, the rate had risen to two marks per fee $(1 \mathrm{~m}=13 \mathrm{~s} 4 \mathrm{~d}$, or two-thirds of a pound), though after 1161, the customary

7 Baldwin, pp. 43, 67.

8 Round, Feudal England, p. 292.

9 Baldwin, p. 39.

10 See below, p. 302.

11 See below, p. 301. 


\section{UNDER JOHN AND HENRY III}

rate was twenty shillings or less. ${ }^{12}$ But the wages of the knight had increased and twenty shillings was not enough to enable the king to hire a substitute for the tenant whose service was thus commuted into money. ${ }^{13}$ For this reason, apparently, the effort was made to obtain from the tenants who did not wish to take part in a campaign a larger sum which would more nearly equal the real value of the tenant's service. The practice is found in Richard's reign, if not earlier. The sums were called fines ne transfretent or pro passagio. ${ }^{14}$ They were larger than the scutage would have been, were taken in place of it, and were not at a fixed rate per fee. In return, the tenant in chief was allowed to absent himself from the campaign and collect scutage from his tenants and thus partly recoup himself.

Besides these purely feudal devices for increasing the revenue, there were, just before the accession of John, some levies of an entirely different nature. They began the transition from feudal to modern taxation for they were based on property, not tenure, and they employed new machinery, ${ }^{15}$ the local bodies (the county, the hundred, and the vill), to assist the royal officials who represented the central government, to assess and collect the tax. The new taxes finally supplanted most of the feudal taxes because they yielded more money. The first case

12 In 1162, 1165, and 1168, one mark; in 1172 and 1187, 20s; in $1190,10 \mathrm{~s}$; the scutages of Richard were at $20 \mathrm{~s}$.

13 In Richard's reign a knight might receive is a day (William Salt Archaological Society Collections, II, 54); in 1199, knights in castles in Devon received the same (Pipe Roll, 1 John, m. $17 \mathrm{~d}$ ). In 1198 the abbot of St. Edmunds paid knights for service in Normandy 3s a day (Chronica, Joceline de Brakelond, p. 63).

14 "de hiis qui finem fecerunt pro passagio"; "habet quietantiam de scutagio suo per finem quem fecit cum rege"; "isti finem fecerunt pro passagio" (Red Book of the Exchequer, Rolls Series, I, 102, 106, note, 115).

15 That is, new in assessing and collecting taxes. 


\section{STUDIES IN TAXATION}

was not a levy for national purposes. In 1166, a tax of six pence in every pound's worth of personal property was taken for the relief of the Holy Land. ${ }^{16}$ In 1188, an important step was taken introducing a modern idea of taxation. A tenth of personal property (except arms, horses, dress, and precious stones) was levied for the crusade. The assessment was made by parishes. In each, two churchmen of the parish, a Templar, a Hospitaller, a sergeant and a clerk of the king, a sergeant and a clerk of the baron of the parish, and a clerk of the bishop of the diocese formed the body of assessors. Each man swore to the value of his revenues and personal property before this commission. If it was believed that anyone had sworn falsely, the value of his property was fixed by a jury of four or six men of the parish. Crusaders were exempt and also received the tithes of their men. Those who tried to evade the tax were excommunicated. ${ }^{17}$ Though the purpose of this levy was religious, it was a national tax, and what is more significant, it suggested to the king the source from which an increased revenue could be drawn and indicated the machinery of assessment. That this suggestion did not pass unnoticed is shown by the fact that when in 1193-1194 it was necessary to raise 100,000 marks for Richard's ransom, the same kind of a tax was levied, amounting on this occasion to a fourth of revenues and moveables. ${ }^{18}$ The amount raised

16 Two pence in each pound the first year and then a penny in the pound for four successive years, making six pence in all; those whose property was less than a pound should pay a penny (Gervase of Canterbury, I, 198); Chronica Roberti de Toreigni, in Chronicles of the Reigns of Stephen, Henry II and Richard I, Rolls Series, ed. Richard Howlett, IV, 227; Pipe Roll, 13 Henry II, p. 194; A. Cartellieri, Philipp II, August, Vol. I.

17 Benedict of Peterborough, ed. Stubbs, Rolls Series, II, 31; Stubbs, Select Charters, ed. 1895, p. 160; Cartellieri, Vol. II.

18 Roger of Hoveden, ed. Stubbs, Rolls Series, III, 225; the total ransom was $£ 100,000$. 


\section{UNDER JOHN AND HENRY III}

was insufficient and this was said to be due to the peculation of the collectors. No special machinery was employed and there may not have been a careful assessment, a fact which may account for the failure to obtain a larger sum. ${ }^{19}$

Another new expedient for taxing property was the hidage or carucage. The first example of this was in connection with Richard's ransom. It was a tax on the hides or carucates of the Domesday assessment ${ }^{20}$ and was called a hidage in the accounts which we have, but as hide and carucate were names for the same thing in different parts of England, hidage and carucage were the same tax. The next levy was the carucage of 1198, which was taken to supply money for the war in France. ${ }^{21}$ The tax met with opposition, for the religious houses refused to pay it, and in consequence the king took from them the protection of the courts. By this act their position was rendered so unbearable that they had to buy back the royal protection and thus furnish the king with the desired contribution. ${ }^{22}$ The taxable unit was the ploughland or carucate of 100 acres. $^{23}$ A new assessment was made which should be noticed, for, with some variation, it was that which was employed in the new taxes of the thirteenth century. Two commissioners, a knight and a clerk, were sent into each county. Probably the sheriff summoned the county court to meet them and then two knights were chosen from each hundred. Before this body of four, the reeve and four men of each vill and the bailiffs of barons holding lands in that vill made oath to the number of carucates in the vill. Four rolls of the

19 Baldwin, pp. 68, 70 .

20 Ibid.; Hov., III, 240.

21 Hov., IV, 46, 47.

227 bid., IV, 66. On the carucage of 1198 , see Round, $E . H . R$., III, 501.

23 That is, 100 long acres or 120 acres. 


\section{STUDIES IN TAXATION}

vill were drawn up: one each for the clerk, the knight, and the sheriff, and one for the bailiff, containing an account of the lands of his lord. The money was to be collected by the two elected knights and the bailiff of each hundred, who paid it to the sheriff, and he delivered it at the exchequer with the rolls. ${ }^{2 *}$ It is doubtful whether this assessment was fully carried out. Later in the year, the itinerant justices were ordered to inquire how far the assessment and collection had been made. ${ }^{25}$ Many counties fined for their carucage in lump sums, the amount charged against twenty-three counties being 1,516 marks. ${ }^{28}$ At this rate, the total sum realised from Eng-

24 Hor., IV, 46.

25 Ibid., 62.

26 Accounts of a carucage appear in twenty counties in the Pipe Roll of 1199 and of three counties (York, Warwick, and Leicester) in 1200. In eighteen of these the county paid a lump sum; in four, round sums were charged against the hundreds and in Wilts, one vill was charged with $£ 10$. These probably did not belong to the carucage of 1200 levied by John, for in some cases it is stated that they belonged to the carucage of Richard's time: "pro quietantia ne fiat inquisitio de carrucagio posito tempore regis Ricardi" (Pipe Roll, $1 \mathrm{John}, \mathrm{m} .3 \mathrm{~d}$ ). They can hardly refer to the carucage of 1194 ; in every case, the amount charged was a round sum; it was plainly the first proffer at the exchequer. It seems reasonable, therefore, to assign these sums to the levy of 1198. The entries follow: Rutland, $20 \mathrm{~m}$ "de fine comitatus pro carrucagio"; Gloucestershire, $100 \mathrm{~m}$ "pro quietantia carrucagii"; Worcestershire, $35 \mathrm{~m}$ "de comitatu pro quietantia de inquisitione carrucagii"; Warwickshire, $100 \mathrm{~m}$; Leicestershire, 100m; Salop, 30m; Hertfordshire, $60 \mathrm{~m}$; Essex, $150 \mathrm{~m}$; Bedfordshire, $80 \mathrm{~m}$; Bucks, $120 \mathrm{~m}$; Berks, $70 \mathrm{~m}$; Northamptonshire, $150 \mathrm{~m}$ "de comitatu pro remanenda inquisitione carrucagii"; Yorkshire, $100 \mathrm{~m}$; Staffordshire, 30m; Oxfordshire, 120m; Surrey, $40 \mathrm{~m}$; Hereford, $30 \mathrm{~m}$; Dorset, $150 \mathrm{~m}$; Cambridge and Huntington, $51 \mathrm{~m}$ (17 hundreds charged with $40 \mathrm{~s}$ each); Norfolk and Suffolk, 165m (48 hundreds at 40 s each, 3 hundreds at 60 s each and 2 hundreds at $£ 4$ each); Wilts, 15m (one vill). See also Ramsay, Angevin Empire, p. 358. Possibly these fines refer, not to the original payment of carucage, but to fines made by the counties in order to escape the further inquest into the assessment which the itinerant justices had been ordered to make. 


\section{UNDER JOHN AND HENRY III}

land could hardly have exceeded 2,500 marks, only a fraction of what a strict assessment would have yielded.

Thus, at the close of the twelfth century, there were examples of all the taxes levied under John and his son. The machinery for their assessment and collection had been devised and it will be found that it did not vary much throughout the period. The change which took place lay in the attitude of the government toward these levies, for they soon came to be regarded as regular sources of the king's income. The increase in their frequency and the severity with which the royal rights in connection with them were insisted on led to the combination of the barons which resulted in the establishment of an effective check on the king's control of taxation.

In the following sections, each tax will be treated in detail in chronological order; the chief points to be studied are the occasion and the circumstances under which it was levied, the incidence, the assessment and collection, and the amount yielded. This method involves considerable repetition, but in no other way can the facts of the taxation of the period be presented. In a final chapter an effort will be made to draw the conclusions which the details warrant; and at that point some new material will be introduced concerning military service and the growth of corporate unity among the baronage. The taxes to be discussed are the dona on religious houses, the tallage, the scutage levied in connection with campaigns, and the aids, under which term are grouped three levies: the aid on knights' fees, called also scutage, the carucage, and the tax on personal property.

The dona from religious houses were in theory purely voluntary. In practice, they may be regarded as compulsory. By 1250, they were taken with some regularity. Whenever the king took an aid from other classes, or when he made an expedition to France, the religious 


\section{STUDIES IN TAXATION}

houses usually paid dona. In 1248, a further step was taken by Henry III when he collected dona from them although no other class made him a contribution. We may say therefore that when he was in great need, the king was establishing the right to take dona from the religious houses. The sums paid were not based on an assessed valuation of property and there was no concerted action among the heads of the houses. Each paid a lump sum fixed by a bargain between the royal officer and the house.

The tallage became a more regular levy and was taken independently of levies on other classes. It was not voluntary, but owed. It was not based on property, whether the town fined for it or paid a per capita tax. It was assessed by royal officials, usually judges. Both the tallage and the dona added considerable sums to the royal income of the year. They illustrate the tendency to have service performed in money, but except in this very general sense they did not lead to further development in taxation. In other words, the taxation of property did not grow out of either of these levies.

The scutage for war would naturally be an important levy, taken as it was from the most powerful class in society. It not only added a considerable amount to the royal income, but it was also one of the causes of Magna Carta. The provision inserted in that instrument concerning scutage is one of the early steps leading to the control of the king in taxation. The points which will later be considered in connection with this tax are the occasion for the levy, the authority by which it was taken, the rate, the accompanying fines, the incidence of both fines and scutage, the method of collection, the amount, and the military service which tenants rendered to the king. A study of these topics should give the character of the scutage and explain the grievance which was regis- 
tered in the charter. Two alternative theories of John's levies may be offered. First, that the king changed scutage from the commutation for service into a general tax on the knight's fee, while at the same time he exacted the military service due from each holding, or collected a fine which would be the money equivalent of that service; second, that scutage did not lose its original character as the composition for service, though as such, it might be replaced by a fine. In the first case, the grievance of the tenants would be clear; they would still have to perform the service due from their fees, while in addition the king gained a new customary levy, a tax on the land. Though the evidence is left for future discussion, it may be said at once that the second alternative is the true one-scutage did not become a general tax. The grievance of the tenants, therefore, is less obvious, but it will be found to lie in the fact that John did not observe the limits which had been customary when tenants compounded for their services. He increased the rate; he took fines; he took composition on improper occasions; and he levied the tax at the opening rather than at the close of campaigns. But the grievance of the increase of the rate and the fines is hardly intelligible unless we consider the military service of the time. In the majority of cases, the yield from the scutage, or even the fine, would not enable the king to put in the field a number of knights equal to the number of fees which were exempted. The fact to be noticed is that the amount of military service had been reduced. There was no regularity in this reduction, sometimes indeed there was no reduction at all. ${ }^{27}$ The greatcr tenants usually served with reduced

27 Thus in 1258 the abbot of St. Albans sent six knights to the host, his full service (see below, p. 285). It is usually the lesser tenants who continue to perform their full service or serve with contingents which are comparatively only slightly reduced; see for examples, below, pp. 97, 110, 111, 150. 


\section{STUDIES IN TAXATION}

contingents; of the lesser tenants some continued to serve while others had their service in practice entirely commuted into money. The reduced number of knights which the tenant led to the host was regarded as the entire service due from his holding. Thus the sum total which the tenants paid in fine or scutage was really the composition for a smaller number of knights than was furnished under the old nominal service. Consequently the rate of commutation per knight actually furnished was much higher than the nominal rate of the scutage or the fine $;^{28}$ it is likely that a rate of composition at one pound ( $11 / 2$ marks) per fee was not far from a fair rate of commutation for the knights whom the tenant in chief would otherwise furnish. But a further element must be considered. The king had broken away from the old customary rate. If he could raise the rate, what limit would there be to his exactions? He had the right to full military service from his tenants. A sum which would be the full equivalent would raise the rate of scutage or fine to six, eight, or ten marks per fee. Probably neither the king nor the tenants reasoned the matter out beyond the point that the former would take all he could get. But that the latter would demand and obtain composition at these high rates is not pure theory, for in 1210 and 1211 we find John levying such fines. Thus the grievance of the tenants as expressed in Magna Carta cannot be based on the sum total which the scutage yielded, for that is often not very large, often not so large even as the tallage, and it is not found if we consider merely the amount which a tenant paid in fine or scutage. The cause of complaint becomes evident only when we examine the amount of composition in connection with military ser-

${ }^{28}$ The term, fine, is here used to mean the scutage plus the extra amount which a tenant might pay in order to be exempt from service. The fine was ordinarily a lump sum. 


\section{UNDER JOHN AND HENRY III}

vice. From the study of the scutages of Henry III, it will be seen that while in many respects they resemble John's levies, there is enough difference to show that the king took them in accordance with the law and that the tenants no longer feared that the king would find in them a weapon of oppression. If we consider the effects of scutage on the relations between the king and his vassals, we shall find that it was the most important levy of John's reign. After Magna Carta, it was still levied, but its importance declined. It was supplanted by the aids which came to be the king's main resource for extraordinary levies and over which the king and the barons struggled.

Under the term aid are embraced three sorts of levies: the aid on knights' fees, called also scutage; the carucage; and the tax on moveables. The last named, the aid on moveables, came to be the favorite levy of the king because it yielded so much more than the others. These were all general levies and the royal revenue was greatly increased by them. Of the points discussed in connection with each case of taxation, viz., the occasion of the levy, the authority by which it was taken, the incidence, the assessment and collection, and the amount, the second, concerning the authority for the levy, should be especially mentioned here, for it was along this line that an unusual development occurred. The tallage was a tax which the king levied arbitrarily on his demesne; the scutage was a composition for service and was therefore taken by virtue of the king's right to military service from his vassals. But most of the aids were voluntary just as were the dona from the clergy. In theory, the king could not take either of these levies except by the consent of the contributors, but in fact he had practically been able to establish the right to take dona from relig- 


\section{STUDIES IN TAXATION}

ious bodies on certain important occasions, the consent of the latter being purely formal. This he was unable to do with the aids on the tenants in chief because of the development of corporate opposition to his demands. Thus the great council came to be a part of the financial machinery in a new sense; out of individual consent was developed a measure of corporate consent. In connection with the aids, therefore, we shall consider the composition of the great council, the completeness of the corporate feeling among its members, the extent of its authority over the taxes, and its aims in taxation. Furthermore a final feature of the reign of Henry III will enjoy our attention, the taxation of the beneficed clergy. Between 1253 and the close of his reign, Henry III repeatedly taxed them. It is at first sight surprising that he should have succeeded where his father failed. Some precedent may perhaps be sought for these levies in the sixteenth of 1226 and the dona of the religious clergy, but it is likely that these taxes were of slight importance. The direct historical preparation for this taxation is to be found rather in the similar taxation of the English clergy levied by the pope before 1250. The union of the pope and the king made it possible for Henry III to tax the English clergy.

Thus by the reign of Edward I, the scutage, the tallage, and the donum had all become fixed in form and amount; they were incapable of further development. Progress lay along another line. Precedents had been established for the taxation of all classes in the kingdom, a taxation based on property, assessed and collected by special royal officials in combination with representatives of the locality. At the same time a series of precedents had established the fact that the king could not levy aids at will. 


\section{UNDER JOHN AND HENRY III}

The ordinary revenue, as it has been called in this study, was also increased at about the beginning of John's reign. The farms of boroughs and manors were raised. ${ }^{29}$ The fines seem to have become heavier as the reign went on. ${ }^{30}$ The county farm had become a fixed sum in the closing years of the twelfth century, amounting to about 16,000 marks, ${ }^{31}$ but the exchequer was beginning to charge an additional sum in some counties. The earliest case is that of Bucks in 14 Henry II, an increase of $£ 10$. This increase was called increment, and was kept separate from the farm. In John's reign it was charged against thirteen sheriffs and amounted to 1,525 marks. ${ }^{32}$ In 1205 a further charge was made (kept separate from the other two), called the proficuum; it amounted to about 2,000 marks. $^{33}$ For purposes of comparison with the sums realized from the scutages, tallages, and the taxes on personal property, some calculations of the ordinary income are here given.

29 Farrer, Lancashire Pipe Rolls and Early Charters, p. 137; in 1201, some towns were paying an increment on their farms (Rot. Canc., 3 John, pp. 35, 63, 116, 324).

$30 \mathrm{E} . \mathrm{g}$. for the custody of Doun Bardolf's land, 1,000 marks (Pipe Roll, 10 John, Cumberland); Roger Fitz Adam, 1,000 marks "pro habenda benevolentia regis" (ibid., 11 John, Hants); R. de Cornhull, 10,000 marks to be quit of the debts, etc., of his father (ibid., 12 John, Kent); the monks of Battle Abbey, 1,500 marks for confirmation of their liberties (ibid., 13 John, Sussex post Linc.); the citizens of Lincoln, a fine of 2,000 marks "pro excessu suo" (ibid., 14 John, Linc.); Hugh de Nevill, 6,000 marks "pro habenda benevolentia regis pro duobus prisonibus ... qui ... evaserunt" and for other things (ibid., 14 John, Wilts; Madox, History and Antiquities of the Exchequer, ed. 1769, I, 475, n. $k$ ); the countess of Albemarle, 5,000 marks for having her inheritance and dowry and not to be forced to marry (Pipe Roll, 14 John, York).

31 Turner, in the Royal Historical Society Transactions, New Series, XII, 142-149.

32 Rot. Canc., 3 John.

33 These figures are not exact; the amount of the proficuum was not always the same. 


\section{STUDIES IN TAXATION}

In 1201 :

County farm and increment (about) . . 17,000 marks

Town farms, fines, escheats, etc. (sums paid) 22,000

Total . . . . . . . 39,000

In 1205 :

County farm and increment . . . 17,000 marks

Town farms, etc. . . . . . 20,000

Proficuum . . . . . . 2,000

Total . . . . . . 39,000

On the basis of the returns of these two years, the amount of the ordinary income hardly reached 40,000 marks $(£ 26,666 \% 3)$, for part of the farm was granted out to various persons and the revenue from the county was thus diminished. ${ }^{34}$ Sir James Ramsay makes the total for 8 John somewhat larger, $51,774 \mathrm{~m} \mathrm{12s} \mathrm{3d} \mathrm{(£34,516} \mathrm{12s} \mathrm{3d)}{ }^{83}$ The account of that year was swelled by the income of the archbishopric of Canterbury, amounting to $£ 5,16919$ s $5 \mathrm{~d}$ (a little over 7,500 marks). Deducting this, the sum total will not be much greater than in the years just cited. It is not possible to say how complete a statement of the ordinary income was rendered in the Pipe Roll. It is striking that the accounts of the three years should be so nearly equal. Part of the income was certainly not given in the roll. Of the carucage of 1200 , of the seventh in 1203 , of the thirteenth of 1207 , no return is given. These levies, however, belonged to the extraordinary revenue.

34 Turner, p. 117.

85 Ramsay, Angevin Empire, p. 304. 


\section{CHAPTER II}

\section{The Taxes in Detall from 1199 to 1206}

THE taxes, which had been taken more often under 1 Richard than under Henry II, became still more frequent in John's reign. From 1199 till the fall of 1206, an intermittent struggle was carried on against Philip Augustus for the possession of the Angevin lands in France. This occasioned in one form or another seven scutages, four or five tallages, a carucage, a seventh of moveables, and two or three dona from religious houses which did not hold by military tenure. The scutages were all scutages in the strict sense; they were not aids taken on all the fees. Each year some tenants received writs of quittance and the rest paid a money composition, either scutage or fine. Now the writ of quittance did not, as might be supposed, cover merely the personal service of the tenant in chief; it included also the service of his whole holding. ${ }^{1}$ In order to make this fact clear, we must say something about the accounts of scutage rendered in the Pipe Roll. The names entered were regularly those of the tenants in chief. The only exception to this statement was when an honor was in hand; then the rearvassals would sometimes be enrolled charged with scutage or acquitted. ${ }^{2} \quad$ A baron who held lands in more than one

1 It often happens that a tenant is entered as acquitted in one county because he renders his account in another. The statement in the text applies to the case when a tenant is entered as acquitted wherever his name appears in the roll.

2 The tenants of the honor of Gloucester appear in the roll in the first scutages of John; the tenants of the honor of William de Mohun appear in the second and third scutages of John. When these honors pass into the hands of tenants in chief, the rear-vassals no longer 
county would sometimes be entered in the accounts of the different counties, but under his own name, not under the names of his vassals. ${ }^{3}$ When, therefore, we find a tenant acquitted of scutage whenever his name appears in the roll, we may conclude that this writ of quittance applies to all the land which he holds of the king. ${ }^{4}$ The scutage rolls contain the names of those tenants to whom the king has granted their scutage because they have performed their service. Many exist for the reign of Henry III, but only one for John's reign, that of Poitou, 1214. A comparison of the Scutage Roll with the corresponding Pipe Roll shows that the tenants who are entered in the former as having their scutage are entered in the latter in the list of those having writs of quittance. It seems fair to conclude, therefore, that the lists of writs of quittance under John contain the names of those who have performed their service, have been exempted from paying scutage at the exchequer, and have been granted writs de habendo scutagio. ${ }^{5}$

appear ( $c f$. the entry for the honor of Gloucester in Rot. Canc., p. 55, with Pipe Roll, 16 John, Glouc. m. 5 d; for the honor of Dunstor, cf. Rot. Canc., pp. 205-209, with Pipe Roll, 7 John, Dors. and Somers. m. $11 \mathrm{~d}$ ). This does not mean that when an honor is in hand the rear-vassals always appear in the roll.

3 In 1199, Ralph de Sumery was entered as acquitted in six bailiwicks : Staff., Bucks and Bedf., Berks, Wigorn., Rutland, War. and Leic. (Pipe Roll, 1 John).

4 An analysis of the account of any scutage shows that there is no amount of scutage charged large enough to represent a scutage paid by the rear-vassals of those tenants who have performed their service and have received writs of quittance. Thus in 1199, the first scutage of John, about 2,500 fees are charged with fine or scutage; that leaves about 3,500 fees with no charge against them. The amount charged against the 2,500 fees can be practically identified as charged against certain clergy and greater lay tenants. Such amount as cannot be thus identified will be entirely inadequate to represent a scutage against rear-vassals of the remaining tenants in chief.

5 There are some writs in the Close Roll under John by which a tenant is granted his scutage; such a man will appear in the Pipe 


\section{UNDER JOHN AND HENRY III}

These scutages were then taken in connection with expeditions, but not always fairly. They were levied at the opening rather than at the close of a campaign and sometimes the character of the operations which followed would hardly justify their levy. Thus in 1199, John concluded a truce immediately after landing in France; in 1201, there seems to have been no fighting at all. In 1202 and 1203, there is no existing copy of a summons, though probably one was issued; at any rate a scutage was taken. In 1204 and 1205, the host was summoned but not despatched, and a scutage was levied. In 1206, the levy of the scutage was entirely legal. All these levies were accompanied by fines which in many cases increased the amount of composition of those tenants who failed to perform their service.

The levy of 1204 merits special notice. It was taken at a meeting of the great council and is said to have been granted by it. Probably this expression does not mean anything more than that the barons agreed to the increase in the rate of that year and to the proposition of the king that the levy should be put in charge before the host was summoned so that he could have the use of more of the money in that campaign.

We have already said that these scutages were not

Roll in the list of those who have been granted writs of quittance. "Mandatum est vicecomiti Bukingh' quod faciat habere Sahero de Quency scutagium suum in balliva sua. Similiter mandatum est aliis vicecomitibus in quorum ballivis terras habet" (Rot. Litt. Claus., I, 43b, 6th scutage); in the Pipe Roll this tenant is entered as acquitted in Bucks and Bedf., Norf. and Suff., and Oxford. "Rex cancellario suo salutem. Mandamus robis quod habere faciatis Thomæ de Nevill' scutagium suum de feodo militis que tenet de nobis in capite scilicet de scuto iii marcas pro exercitu Pictaviæ in quo militem suum nobiscum habuit" (ibid., 177a); Thomas de Nevill is among the list of those having writs of quittance in Bucks and Bedf. (Pipe Roll, 16 John, m. 2). Cf. also the men who are granted their scutage in Rot. Litt. Claus., I, 200b with the account of the scutage of Poitou in Pipe Roll, $16 \mathrm{John}$. 


\section{STUDIES IN TAXATION}

general taxes. It seems clear that in general the king did not collect them from the rear-vassals of the tenants in chief who were liable, but as had been customary collected them from the tenants in chief.

The tallage calls for no special comment here other than to say that it was taken less often than the scutage. The explanation for this is probably that the king had the excuse for levying the scutage in the summons to the host. The tallage was owed, but it would seem that there was no such convenient excuse for taking it as often as the scutage.

The carucage, it will be found, was taken with the feudal excuse that it was to pay the relief for the lands in France. It was customary to take an aid to pay the lord's relief, but the so-called relief of this year was not for the kingdom of England, but for other lands which the king of England held. The levy of the carucage for this purpose may therefore have been considered an abuse. Regarding the actual assessment and collection, we know little. The fact that the carucage was to be based on the ploughlands instead of being paid in lump sums indicates that the government wanted to base the levy on property. That would not only give a more definite basis for the tax, but would also make it necessary for those who did not wish to pay it to obtain special exemption from the king.

The seventh also was taken under a feudal plea, viz., that the tenants had deserted the king. Hence their lands would be technically forfeit. John seems to have made this tax a general levy, basing it on property and applying it to men who could not have been guilty. From the seventh, the tenant had also to get a special writ of exemption.

Other levies which fell in this period are these: the fortieth for the crusade; the fifteenth on merchants; and 


\section{UNDER JOHN AND HENRY III}

taxes on the Channel Isles, all of which were taken on property or income. Some local machinery was used to assess and collect them. Thus they illustrate the general tendency to base taxation on property and to get at the value of the property through the jury, that is, the jury was used for the advantage of the king and not to protect the taxpayer.

\section{The Taxes of 1199}

On June 20 or 21 , within a month after his coronation on May 27, John returned to Normandy to carry on the struggle against Philip Augustus. The host was assembled ${ }^{6}$ and a considerable army crossed the channel with the king. ${ }^{7}$ This force was partly composed of mercenaries. ${ }^{8}$ The campaign lasted till the end of October, but there was no fighting in July and August." Just how many English tenants performed their service in the field this year cannot be stated. Not more than 2,500 fees were charged in the roll with fines or scutage. If we deduct this number from the total number of fees in England, we get about 4,000 knights serving, a number which seems far too large. ${ }^{10}$ The array however included

o "de hanc summonitione exercitus"; "pro remanendo quod non transfretet cum domino rege"; "pro militibus quos debuerat misisse in servicio domini regis in Normanniam" (Rotuli do Oblatis et Finibus, pp. 2, 11, 27).

7 "Maximum exercitum" (Ralph of Coggeshal, Chronicon Anglicanum, ed. Stevenson, Rolls Series, p. 100); "collecta multitudine militum et peditum" (Ralph of Diceto, Opera Historica, ed. Stubbs, Rolls Series, II, 166).

8 "Et in quingentis Walensibus peditibus et $\mathrm{x}$ Walensibus equitibus ... qui transfretaverunt in servicium regis per breve regis" (Pipe Roll, $1 \mathrm{John}$, Hereford); in 1200, payments were made to mercenaries, so that the practice was not uncommon (Rotuli de Liberate, p. 6).

9 Hov., IV, 92, 93, 97; there was a truce from June 24 till August 16 and hostilities were not renewed till September.

10 These figures, as has been said above (p. 4), are based on the number of fees which paid scutage and hence are somewhat larger 


\section{STUDIES IN TAXATION}

many of the greater tenants in chief and about half of the service of the clergy. ${ }^{11}$

In connection with this expedition there were levied a scutage, a tallage, and sums, called variously dona, tallagia, or promissa, on religious houses. The taxation was put in charge and the collection begun during the summer, perhaps before the expedition sailed. It appears in the Pipe Roll of 1199 as partly paid; there is an order for the collection of the scutage on September $1 ;^{12}$ the demand for dona from religious houses was made before June $20 .^{13}$

The levy on knights' fees usually took the form of a scutage at two marks per fee, sometimes accompanied or replaced by a sum, called a fine ne transfretet, pro passagio, etc., which was not at a fixed rate per fee. The following account will show the character of this levy:

Scutage at $2 \mathrm{~m}$.

$M \quad s \quad d$

$\begin{array}{lllllll}\text { Clerical tenants } & \text { • } & \text {. } & 1049 & 11 & 6\end{array}$

Forty-three ${ }^{14}$ lay tenants (each 5

or more fees $)^{15}$. $\quad$. $\quad \begin{array}{lll}1972 & 0 & 1\end{array}$

Lay tenants (each fewer than 5

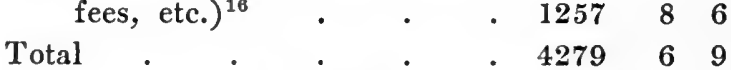

than the servitium debitum. A tenant who refused to serve might be disseized. Matthew Turpin, a sergeant, was disseized (Madox, I, 663, n. $u$ ); Henry Faulkner, 1 fee (Rot. Obl., p. 40).

11 These were excused from any money payment.

12 Madox, I, 680, n. n. In the Memoranda Roll of Michaelmas, 1199, is the following item: "Eustachius de Baillol habet respectum per justic' de debito suo de secundo scutagio (of Richard) et tercio et novo (i.e. of 1199)" (Exch., L. T. R., Bundle 1, no. 3, m. 1 d). Thus the scutage was to be paid at the exchequer at Michaelmas, 1199.

13 "de auxilio quod dominus rex exegit ab eis ante transfretationem suam" (Rot. Obl., p. 22).

14 Of this number, four are tenants on honors in hand and there are three honors which account in one sum through the custodian: Wallingford (2001/2m); Brittany (280m); Chokes (30m). 


\title{
UNDER JOHN AND HENRY III
}

\author{
Fines
}

$M \quad s \quad d$

Clerical tenants . $\quad . \quad 320 \quad 0 \quad 0$ on 53 fees

Eleven lay tenants (each 5 or more

fees $)^{17}$. . . . $705 \quad 6 \quad 8$ " 149 “

Other lay tenants (each fewer than

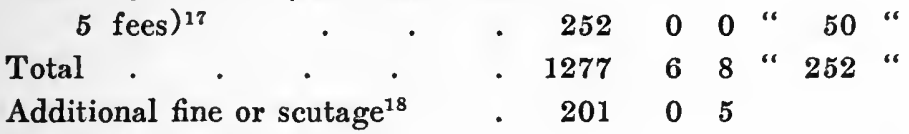

Fees taxed (about) 2500.

Total fine and scutage $\quad \begin{array}{lllll}5758 & 0 & 6\end{array}$

Paid, 1 and $2 \mathrm{John}^{19} \quad$. $\quad \begin{array}{lll}3395 & 3 & 7\end{array}$

Thus tenants holding about 2,500 fees are entered in the roll as owing scutage or fine. Some of these seem to have also performed service with the host. The abbot of

15 In this essay, the lay tenants in chief have been arbitrarily divided into two classes, those who held five or more fees, called here the greater lay tenants, and those who held fewer than five fees, the lesser lay tenants. We do not claim that it was necessary for a tenant to have at least five fees in order to be considered a great tenant, but there can be no doubt that the division into greater and lesser tenants which was recognized in the thirteenth century rested mainly on the number of fees which the tenant held. For purposes of illustrating the incidence of the scutage, it is convenient to draw a horizontal line between the greater and the lesser tenants, and to draw it at ten fees seemed too high. Inasmuch as the unit of the allotment of lands by the Conqueror (Round, Feudal England, p. 259) was a five-knight unit, it seems fair to take the number five as the line of division between the greater and the lesser tenants. If an honor in hand accounted in one sum through the custodian, that too has been included in this group. But if the sub-tenants on an honor in hand accounted separately to the sheriff or the exchequer, they have been included in the group of greater or lesser tenants according as they held more or fewer than five fees and the honor as a whole has not been counted as one great tenant. Thus the group of greater lay tenants will usually include some honors in hand and some sub-tenants on honors in hand, while the group of lesser tenants will always include some tenants who are sub-tenants.

16 Besides tenants in chief, this group includes tenants who are on honors in hand and are entered by name in the roll; when an honor 


\section{STUDIES IN TAXATION}

Ramsey paid eight marks on his four fees, yet his knights were with the king $;^{20}$ the bishop of Winchester likewise $;^{21}$ the earl of Devon had knights in the king's service and paid 30 marks scutage ${ }^{22}$ William de Braose was charged with 56 marks on 28 fees and he performed at least part of his service. ${ }^{23}$ The first three are clear cases of double exaction, ${ }^{2+}$ but in general it seems to be true that tenants who performed their service received writs of quittance and either paid nothing at the exchequer, or only the amount due on fees detached from the main body of their holding. They might also pay a part of their scutage, apparently because the sheriff had not yet received notification of their exemption from the levy. But all sums collected in this way were small; they are not sufficient to show that the tenants as a rule paid scutage and served as well. ${ }^{25}$ Men who served were granted writs of

is only partly accounted for by the custodian, it is entered in this group. Detached fees of a barony not in hand are included here unless it is certain that they should be included in the main account of the barony. This year, $628 \mathrm{~m}$ were charged against honors in hand and $60 \mathrm{~m}$ against detached fees of great barons, leaving less than $600 \mathrm{~m}$ against tenants in chief.

17 Both tenants in chief and tenants on honors in hand who are entered by name in the roll.

18 I cannot find the number of fees held by these men.

19 That is, the payment is enrolled in the Pipe Rolls of these years. Of this sum, $2,645 \mathrm{~m} 4 \mathrm{~s} 3 \mathrm{~d}$ were paid in 1199 and $749 \mathrm{~m} 12 \mathrm{~s} 8 \mathrm{~d}$ in 1200 .

20 Pipe Roll, 1 and 7 John, Cant. and Hunt.; Rotuli Curia Regis, ed. Palgrave, 1835, II, 122.

21 Pipe Roll, 2 John, Hants, m. 7 d; Rot. Cur. Regis, II, 67.

22 Pipe Roll, $1 \mathrm{John}$, Devon, m. 14 d; 2 John, Devon; Rot. Cur. Regis, II, 38.

23 Pipe Roll, ibid.; Rot. Cur. Regis, II, 8. He never paid it.

24 The explanation of these cases may be that the tenants bargained to pay their scutage and perform part of their service, instead of paying a fine. Different sorts of bargains were made (see below, p. 27); see the bargains made with Fulk Painel and the earl of Devon in the second scutage (see below, p. 39, note 117).

25 The following men were quit, but paid some small sums as 


\section{UNDER JOHN AND HENRY III}

quittance which are listed in each county under the heading: "Isti habent quietantiam per brevia." Thus the bishop of London had his knights with the king and had a writ of quittance $;^{28}$ also, William de Mowbray $;^{27}$ the earl of Warwick $;^{28}$ Ralph de Sumery $;^{29}$ William de Longchamp $;^{30}$ Gilbert Peke $;^{31}$ the earl of Chester. ${ }^{32}$ If a tenant performed his service, but failed to secure the writ of quittance, he would be charged with scutage in the roll. But he would not be forced to pay. Time would be granted him and later when he secured the necessary writ, his debt would be crossed off. ${ }^{33}$

described in the text: Walter de Lacy, $511 / 4$ fees, paid $2 \mathrm{~m}$ in Berks; Gilbert Peke, 19 fees, paid 1m in Berks; Guido de Laval, 20 fees, paid $3 \mathrm{~m}$ in Oxford; Gerard de Canvill paid $1 / 2 \mathrm{~m}$ in Berks, was charged with $2 \mathrm{~m}$ in Oxford, of which he paid $1 \mathrm{~m}$ "et debet $\mathrm{i}$ marcam sed postea habuit quietanciam de marca illa per breve regis" (Pipe Roll, 1 John, Oxf., m. 16 d).

28 "habet milites suos cum rege" (Rot. Cur. Regis, II, 7); he has quittance of the first scutage in Glouc., Essex and Hertf., Wilts, Oxford, and Linc. (Pipe Roll, 1 John, m. 3 d, 11, 13 d, $16 \mathrm{~d}$ ).

27 Rot. Cur. Regis, II, 42; has quittance of the first scutage (Pipe Roll, 1 John, War. and Leic., Northamp., York).

28 Rot. Cur. Regis, II, 76; Pipe Roll, 1 John, War. and Leic., Wigorn., Northamp.

29 William Salt Arch. Soc. Coll., III, 31; Pipe Roll, 1 John, Staff.

so Rot. Cur. Regis, II, 33; is quit of scutage (Pipe Roll, 1 John, Linc., War. and Leic.).

31 Gilbert Peke "dicit quod ipse milites habet cum domino rege" (Rot. Cur. Regis, II, 122); has quittance of his scutage (Red Book, I, 119).

32 William Salt, etc., III, 36; has quittance in five bailiwicks.

33 This seems to be the meaning of cases where a tenant is charged with scutage in the roll and the amount later written off with the note that afterward he had a writ of quittance. Simon de Beauchamp "debet quater xx et xi marc. et dimidiam de scutagio sed postea habuit quietantiam per breve Galfridi filii Petri" (Pipe Roll, 1 John, Bucks and Bedf., m. 8 d); also, William de Mowbray, Robert de Turnham, and Guido de Laval (ibid., York, m. 4 d); "Philippus de Columbieres debet $\mathrm{xx}$ marc. de scutagio; sed habet quietantiam per breve regis de ultra mare" (ibid., Dors. and Somers., m. $17 \mathrm{~d}$ ). A small part of the scutage of such a tenant might be paid before the writ of quittance arrived; e.g. see note 25, for Guido de Laval. 


\section{STUDIES IN TAXATION}

The levy of the scutage proper was not confined to the lesser tenants. Of the forty tenants who held five or more fees, four held more than twenty. The earl of Clare was charged with $283 \mathrm{~m} 10 \mathrm{~s} 4 \mathrm{~d}$ of scutage (paid $51 \mathrm{~m}$ ) $;^{34}$ Henry de Oilli with $65 \mathrm{~m} ;^{35}$ Hervey Bagot with $120 \mathrm{~m} ;^{36}$ William de Braose with $56 \mathrm{~m} ;{ }^{37}$ the earl of Devon (15 fees) paid his scutage. ${ }^{38}$

Fines ne transfretet began to be taken at least in Richard's reign. ${ }^{39}$ By virtue of the fine, the whole fee of the tenant escaped service in the host. The fines did not form an important part of the levy this year as only about 250 fees were charged with them. Some important tenants are included. Eustace de Balliol was charged with $60 \mathrm{~m}$ scutage and $200 \mathrm{~m}$ fine on 30 fees $;^{40}$ William Fitz Alan with $55 \mathrm{~m}$ scutage on $27 \frac{1}{2}$ fees and $60 \mathrm{~m}$ fine $;^{41}$ Ralph

34 Pipe Roll, I John, Norf. and Suff., m. 20.

35 Ibid., Oxf., m. 16 d. About half was paid.

36 Ibid., Staff., £35 paid.

37 Ibid., Deron, m. 14 d. No payment is recorded. Another tenant holding more than 20 fees was Henry de Tracy, who is charged with $501 / 2 \mathrm{~m}$ of scutage for the fee of William de Tracy (ibid.). The charge appears in the roll till 1209, when this note is added: "sed inquisitum est que habuit quietantiam de $\mathrm{L}$ marcis et dim. per breve regis" (Pipe Roll, 11 John, Devon, m. 8). In 1199, he accounts for 1,000 marks for having all the land of his father, William de Tracy, and his scutage is perhaps to be included in this fine (ibid., 1 John, m. 14 d).

${ }^{3 s}$ Ibid., 1 and 2 John, Devon.

${ }_{39}$ "De illis qui finem fecerunt pro passagio" (Red Book, I, 99, 102, 115). They perhaps go back to the time of Henry II: "de scutagio baronum qui nec abierunt cum rege in Hiberniam nec milites nec denarios pro se miserunt" (Pipe Roll, 18 Henry II, p. 187).

40 Pipe Roll, 1 John, Northumb., m. 8 d; 2 John, Northumb.

${ }^{41}$ Ibid., Salop, m. 6. His servitium debitum was 10 fees (Round, Feudal England, p. 256). His old enfeoffment was $221 / 2$ fees in Salop, and Wilts, and 5 fees in Norfolk; his new enfeoffment was 8 fees (Red Book, I, 271-274). In 1194 and 1196, he was charged with scutage on $271 / 2$ fees (ibid., pp. 86, 105), and accounted for this number in 1199, 1201 and 1202 (Pipe Roll, Salop, 1 John and 4 John; Rot. Canc., p. 128); in 1203, he is charged with 20m, i.e., 10 fees (Pipe Roll, 


\section{UNDER JOHN AND HENRY III}

Fitz Stephen with $40 \mathrm{~m}$ fine on $131 / 2$ fees $;^{42}$ the abbot of St. Albans with $150 \mathrm{~m}$ fine on 40 fees. ${ }^{43}$ It is impossible to say why these tenants paid fines while other tenants paid scutage only. Sometimes the fine was so large that it doubled what the scutage would have been. The fine was reckoned in two ways : a lump sum by virtue of which the tenant was exempt from service and was given the right to collect scutage from his vassals $;^{44}$ a fine for his personal service and for the right to collect scutage from his demesne while he paid scutage on the infeudated part of his holding. ${ }^{45}$ The difference was one of form, not of principle; it depended on the bargain made between the king and the tenant. In effect, the tenant paid a sum larger than his scutage and his whole fee escaped service with the host.

Ultimately the rear-vassals paid the scutage, whether the tenant in chief paid fine or scutage. In paying either contribution, the tenant in chief received the right to

5 John, Salop). In 1214, the guardian of the fee accounted for 221/2 fees old and 8 fees new enfeoffment (ibid., 16 John, Salop); in 1218 and thereafter, John Fitz Alan, who succeeded to the barony, accounted for 221/2 fees (Pipe Roll, 2 Henry III, Salop).

42 Ibid., Notts. and Derby, m. $15 \mathrm{~d}$.

43 Ibid., Norf. and Suff., m. 20.

44 "Willelmus de Scalariis dat domino regi xl marc. pro habenda quietantia de hac summonitione exercitus et pro habendo scutagio suo de feodo quod tenet de domino rege in capite" (Rot. Obl., p. 27). He held 15 fees.

45 Walter de Cormeiles "r c de viii li. de scutagio suo præter feoda trium militum qui sunt in dominico suo de quibus pacem habet per finem quod fecit qui infra annotatur" (Pipe Roll, 1 John, Heref. m. $16)$; the fine referred to was for $£ 10$ "pro eodem, i.e. ne transfretet et pro habendo scutagio de dominico suo" (ibid.). In 1166, this fee consisted of 6 fees of old enfeoffment and 3 fees "de dominio" (Red Book, I, 286). Henry de Pinkney paid 100s fine "pro habenda pace ne transfretet et pro habendo scutagio de dominico suo"; he also paid scutage on 131/2 fees (Pipe Roll, 1 John, Bucks, Berks, Northamp., m. $2 \mathrm{~d}, 8 \mathrm{~d}, 18 \mathrm{~d}$ ). In 1166, the servitium debitum was 15 fees of which 2 fees were "in dominico" (Red Book, I, 317). 


\section{STUDIES IN TAXATION}

collect scutage from his vassals. ${ }^{48}$ Barons were charged with scutage and acquitted in several counties. They might indeed pay the whole amount in one sum, but often that part due from a detached part of the honor was paid separately. Thus Henry de Pinkney accounted for $27 \mathrm{~m}$ in Bucks, of which sum, $7 \mathrm{~m}$ were paid in Berks and $15 \mathrm{~m} 4 \mathrm{~d}$ in Northamptonshire. ${ }^{47}$ Henry de Oilli paid $8 \mathrm{~s} 10 \mathrm{~d}$ in Staffordshire, 6s 8d in Berks, $4 \mathrm{~m}$ in Bucks, $30 \mathrm{~m} 8 \mathrm{~s}$ in Oxfordshire and $2 \mathrm{~m}$ in Northamptonshire. ${ }^{48}$ This also shows that the exchequer was trying to find out the location of fees. The practice had already begun in Richard's reign. ${ }^{49}$ A good example is the case of the bishop of Winchester. He owed scutage in Essex, but the sheriff reported that he did not know how many fees the bishop held in that bailiwick. ${ }^{50}$ - The total service of the bishopric was of course known. The rear-vassal was not responsible for the fine; he paid scutage only. The writ which the tenant in chief received when he paid a fine gave him permission to collect scutage from his vassals. ${ }^{51}$

The collection of the scutage and fine was made in different ways. Part of the levy was paid at the exchequer,

46 Above, notes 44 and 45 ; "Præcipimus tibi (the sheriff of Nottingham) quod justicies milites de balliva tua quos archiepiscopus Eboracensis tenet in comitatu tuo de dono regis, quod sine dilatione reddant ballivis ipsius archiepiscopi scutagium suum, scilicet, duas marcas de scutagio" (Madox, I, 680, n. $n$ ). The archbishop pays scutage this year so he is collecting it from his tenants to pay at the exchequer.

47 See note 45.

48 Pipe Roll, 1 John. See also the account in Berks; the sheriff accounts for $f 7 \mathrm{~lm}$ of earl Ferrers, $2 \mathrm{~m}$ of the abbot of Hide, etc.

49 "de hiis qui non habent capitales honores" (Red Book, I, 100, 104, 107).

50 "Isti debent respondere de scutagio sed vicecomes nescit quot feoda habeant: Comes de Ferrariis, episcopus Winton'" (Pipe Roll, 1 John, Essex and Hert., m. 13 d).

51 A bove, note 44. 


\section{UNDER JOHN AND HENRY III}

or to the king directly, in camera, by the tenants in chief in person, or by their representatives. ${ }^{52}$ Part they paid to the sheriff who accounted for it at the exchequer, not in a lump sum, but with the amounts due from and paid by each. ${ }^{53}$ In some cases, the sheriff seems to have collected from the rear-vassals. ${ }^{54}$ Sometimes this may have been done after an arrangement was made with the lord. At any rate, the royal official did not make a general collection from the rear-vassals. His business was with the tenant in chief. Thus he collected nothing, or practically nothing, from the fees of tenants who had writs of quittance, or who were performing their service, though the latter might not yet have received their writs of exemption. ${ }^{55}$ In the cases of men who owed fine or scutage, he often reported fees in his district which belonged to them, but he did not collect the money and

52 Ralph Fitz Stephen accounts for 20 marks, the balance of his fine; "in thesauro nichil et G. filio Petri xx marc. per manum Ricardi filii Roberti senescalli ipsius Radulfi per breve regis" (Pipe Roll, 2 John, $m .1 \mathrm{~d}$ ). William Fitz Alan " $\mathrm{r} \mathrm{c}$ de $\mathrm{lx}$ marcis ne transfretet cum rege; in thesauro nichil et ipsi regi in camera sua $1 \mathrm{x}$ marc. de prædicto fine per breve regis" (ibid., 1 John, Salop, m. 6). The sheriff reports the names of tenants who had promised to pay at the exchequer and who failed to come: "Hugo de Morba senescallus Henrici de Trasci affidavit facere pacem de $\mathrm{L}$ marcis et dim. de scutagio suo sicut vicecomes dicit et non venit" (Exchequer, L. T. R., Bundle 1, No. 3, Mem. Roll, 1 John, m. 19 d); "Senescallus Hugonis Bard cujus nomen vicecomes nescit affidavit facere pacem de iiii marcis de scutagio suo duorum militum et non venit" (ibid., m. 14 d); see also cases in Staffordshire (ibid., m. 14); for the earl of Clare (ibid., m. 20 d). The Pipe Roll has two sorts of entries: A (tenant) $\mathrm{r}$ c de $\mathrm{y}$ marcis; idem vicecomes $\mathrm{r} c$ de $\mathrm{y}$ marcis de $\mathrm{A}$. This difference in form suggests that some tenants account in person or through their steward at the exchequer.

53 Pipe Roll, 1 John, passim.

54 E.g. above, notes $25,47,48$; the sheriff of Northamptonshire accounts for 10 s of the scutage of the priory of Coventry and 14 of that of Gilbert Gaunt and the sums are paid (Pipe Roll, 1 John, Northamp., m. 2 d).

55 Above, note 25. 


\section{STUDIES IN TAXATION}

it is stated that payment was made in another bailiwick. ${ }^{50}$ In the main, he was to supervise the levy and be able to render a statement at the exchequer concerning all the fees which were liable for scutage in his bailiwick. One sheriff had been remiss in his duty. A list of thirteen tenants, some of them great men in his bailiwick, is given concerning whom he had made no report. The comment of the exchequer barons shows what he was expected to do, viz., either to collect the scutage and pay it at the exchequer, or to produce the writs of quittance, or to report the number of fees for which each tenant owed scutage. $^{57} \mathrm{He}$ also aided tenants in chief to collect

56 "Idem vicecomes xl sol. de scutagio feodorum comitis Alberici de quibus $\mathrm{H}$. Cantuariensis archiepiscopus debet respondere sicut vicecomes dicit" (Pipe Roll, 1 John, Northamp., m. 2 d); William de Erlega "debet ii marcas; sed respondet in Berchscira sicut vicecomes dicit" (ibid., Dors. and Somers., m. 17 d); Fulk de Alno "debet ii marcas de scutagio; sed respondet in Wiltscira" (ibid.); the bishop of Durham "debet $\mathrm{xx}$ marc. de scutagio; sed respondet inde in Everwicscira" (ibid., Linc., m. 11). When an honor in hand is given over to a custodian, the latter is often charged with and responds for the scutage and in doing so seems to be acting as a tenant in chief; thus Alexander de Pointone accounts for the scutage of the honor of the countess of Brittany (ibid., 2 John, Linc., $\mathrm{m}$. 6 d); Nicholas Poinz for the honor of William de Mohun (ibid., 1 and 2 John, Dors. and Somers.).

57 "Hii omnes invenientur in rotulo anni vii annotati inter quietos de primo scutagio regis Ricardi nec vicecomes aliquid pro eis reddidit nec brevia de acquietantia eorum ostendit nec baronibus (i.e. scaccarii) certificavit de quot feodis debeant respondere in his comitatibus" (Pipe Roll, 1 John, War. and Leic., m. $18 \mathrm{~d}$; Red Book, I, 126, with slightly different wording). The collection referred to is not necessarily from rear-vassals. In the Pipe Roll there are occasional references that the sheriff is keeping track of all the fees in his district; the sheriff of Kent " $r c$ de xvii marc. de scutagio militum honoris Pererelli quos invenire potuit" (Pipe Roll, 1 John, m. $5 \mathrm{~d}$ ); similarly for the honor of Mortain (ibid., Northamp., m. 2 d); William Fitz Martin " $r \mathrm{c}$ de $x i$ marc. de scutagio sicut vicecomes dicit" (ibid., Dors. and Somers., m. 17 d); $c f$. John Fitz Richard (ibid.); Adam de Tindale (ibid., Northumb., m. $8 \mathrm{~d}$ ); chapel of Boseham and William de Kahaignes (ibid., Suss., m. 9); "idem 


\section{UNDER JOHN AND HENRY III}

scutage from their vassals. ${ }^{58}$ If a baron refused to pay his scutage or fine, he might be distrained. ${ }^{59}$

The tallage was levied on the king's demesne which included the towns and on lands in hand. ${ }^{60}$ It amounted to about 5,500 marks. ${ }^{61}$ The assessment and collection were made in 1199 and 1200. Not much was paid thereafter. The work of assessment was done in part by the itinerant justices on their rounds. ${ }^{62}$ Some of the towns compounded in a lump sum, settling the incidence of the levy themselves and responding for it to the exchequer or to the sheriff. But this was not always the case. In Northampton the justices assessed the individual burghers. $^{03}$ In those vills or lands in which the justices personally made the assessment, a roll of the persons

vicecomes ii marc. de feodo Alberici de Danmartin de quibus comes Boloniæ debet respondere sicut vicecomes dicit" (ibid., Norf. and Suff., m. 20).

58 Above, note 46.

59 'Idem Henricus (de Pinkeni) promisit coram justic' quod acquietabit averia sua que capta sunt pro scutagio; recognovit enim quod idem debet" (Rot. Cur. Regis, II, 43). I think that this is probably a reference to the scutage of 1199 ; at any rate the case is entered in the fall of this year and illustrates the point that at this time distraint is in use to enforce payment of scutage. "Walterus de Cormeiles debet .c. sol. de scutagio suo .ii. marcarum; vicecomes distringat eum de .iiii. marc. et de .c. sol." (Exch., L. T. R., Bundle 1, No. 3, Mem. Roll, 1 John, m. 14).

${ }^{60}$ London does not appear in the roll of any year charged with this tallage. It paid, however, $£ 3,000$ "pro habenda confirmatione regis de libertatibus suis" (Pipe Roll, 2 John, m. 11) and the tallage may have been included in this sum.

${ }_{61}$ The following counties are omitted: Cant. and Hunt., Notts. and Derby, and Lanc.

${ }^{62}$ E.g. in Wigorn., the tallage was laid by the abbot of Tewkesbury, the archdeacon of Stafford, and Simon de Pateshull, who were the justices of the year (Pipe Roll, 1 John, Wig., Oxf., m. $6 \mathrm{~d}, 16 \mathrm{~d}$ ).

63 "Homines de Norhanton' $\mathrm{r}$ c de $\mathrm{lx}$ li. et xviii sol. de taillagio facto per G. de Norwiz et socios suos quorum particulæ sunt in rotulo que ipse G. liberavit in thesauro" (ibid., 2 John, Northamp., m. 4 d). 


\section{STUDIES IN TAXATION}

and the amount of their tallage was drawn up in duplicate, one copy sent to the exchequer and the other given to the sheriff for collection. ${ }^{64}$ Some vills had a lump sum of tallage charged against them..$^{65}$ The first assessment might be reduced later by the exchequer. Winchester had its tallage reduced from $807 \mathrm{~m}$ to $400 \mathrm{~m}^{68}$ A contribution was exacted from some religious houses called donum, promissum, or tallagium. Houses which held by military service and those which did not were included. In the case of the former, the contribution was a payment in addition to the scutage. The abbot of Winchcomb paid $4 \mathrm{~m}$ scutage and $30 \mathrm{~m}$ de promisso; ${ }^{67}$ the abbot of Evesham $9 \mathrm{~m}$ scutage and $50 \mathrm{~m}$ de dono ${ }^{68}$ the abbey of St. Edward $14 \mathrm{~m}$ scutage and $20 \mathrm{~m}$ de taillagio. ${ }^{69}$ The amount of these contributions was $868 \frac{1}{2}$ marks. The sums were assessed and collected by the itinerant justices and the sheriffs. ${ }^{70}$

In January, 1200, John and Philip Augustus met and made a treaty of peace. By it the king of England promised 20,000 marks as a relief for his lands in France. ${ }^{{ }^{1}}$ To raise the money to meet this promise, an auxilium was taken throughout England under the name of a caru-

64 "De taillagio facto per Ricardum Malebisse et socios suos; idem vicecomes $\mathrm{r}$ c de ... taillagiis hominum et villarum quorum nomina annotantur in rotulo que prædicti (justices) liberaverunt in thesauro" (ibid., York, m. $8 \mathrm{~d}$ ); the sheriff accounts for a total of f4 16s $8 \mathrm{~d}$ charged against twelve men, who are named (ibid., Kent, m. 15).

65 Ibid., 1 John, War. and Leic., m. 18 d; 2 John, Westm., m. 2 d. 66 Ibid., 4 John, Hants.

or Pipe Roll, 1 John, Glouc., m. 3 d.

68 1bid., Wigorn., m. 6 d.

69 Ibid., Dors. and Somers., m. $17 \mathrm{~d}$.

70 "Promissa abbatum et priorum facta regi per prædictos" (i.e. Henry, Archdeacon of Stafford, William de Falesia, and their companions) (ibid., Glouc., m. 3 d). These were the itinerant justices.

71 Rymer, Foedera, etc., ed. 1816, I, 80; Hov., IV, 107; Cogg., p. 101; Annales Prioratus de Dunstaplia, ed. Luard, Rolls Series, p. 27; the last three sources say that the amount was 30,000 marks. 


\section{UNDER JOHN AND HENRY III}

cage, ${ }^{72}$ a tax of three shillings on each ploughland under cultivation. ${ }^{33}$

How strict an assessment was made cannot be stated. One item suggests that it was searching. The men of Ketsteven and Holland in Lincolnshire paid $£ 100$ that the carucage be taken from them as in the past, viz., " 5 carrucae contra 2 carrucas de Lindeseia." "The exchequer did not insist on an assessment, but allowed men to compound for the tax, all of whom, as the notices of composition show, were of the clergy. The abbot of Furness gave $£ 100$ for the renewal of his charters and in order to be quit of the aid of the carucage. ${ }^{75}$ The abbot of St. Albans paid 310 marks for his charters and for exemption from the carucage. ${ }^{76}$ Perhaps the churchmen usually compounded; the annals of St. Edmunds say that the carucage was not allowed on religious houses, but that

72 Rot. Obl., pp. 45, 55; Walter of Coventry, Memoriale, ed. Stubbs, Rolls Series, II, 158; Hov., IV, 107; "de universitate Angliæ" (Madox, I, 400, n. z); "per totam Angliam" (Liebermann, Ungedruckte Anglo-Normannische Geschichts-quellen, Annales S. Edmundi, p. 139).

73 Cogg., ibid. Hov., ibid. Dunst., ibid. Some of the documents catalogued as Lay Subsidies at the Record Office record an assessment of a carucage levied at three shillings. This assessment may refer to the levy of 1200 , for the rate is the same. It may, however, relate to the tax of 1198 , for that was first to be taken at three shillings and the king later took two shillings more. This assessment was probably based on the land, for the fractional parts which appear are not easily explainable on the theory that it was based on the team: quarta pars unius car'; octava pars unius car'; sexta pars unius car'; tercia pars unius car' (Lay Subsidies, Bundle 242, no. 113). Sometimes, however, the oxen are mentioned: "apud Westone viii car' et quinque boves"; "iiii carr' et duos boves" (ibid., Bundle 73, No. 1a). This carucage included the lands of priors, abbots, bishops, Templars, and churches: de elemosina abbatis Croil; de feodo episcopi Lincoln' xxix car', de terra ecclesiæ i car'; etc.

$7+$ Madox, I, 401, n. $e$.

75 Rot. Obl., p. 55.

76 Rot. Obl., p. 45; Madox, I, 400, n. $z$; 401, n. $d$. 


\section{STUDIES IN TAXATION}

the king took large sums from the bishops, abbots, and other clergy. ${ }^{77}$

The tax met with opposition. The archbishop of York refused to allow his lands to be assessed. His refusal availed nothing, for the king disseized him. ${ }^{78}$ The Cistercians, who had a general immunity from taxation, would not pay a fine for the carucage without the consent of their order. The king at first deprived them of the protection of the courts, but was finally reconciled with them. ${ }^{79}$ The tax was collected by special officials. ${ }^{80}$ There is no statement about the machinery of assessment other than this and nothing about the method of assessment. We are not told how much the tax yielded; one writer states that after John returned to France in April, he paid his debt to Philip. ${ }^{81}$ As the money could not have been collected at that time, the king must have made up the sum in other ways.

War between the Lusignans and John broke out in March, 1201. Writs were issued summoning the host to meet at Portsmouth on May 13 for an expedition to Normandy. ${ }^{82}$ When the force assembled, many were allowed to remain at home $;^{83}$ with the rest, which included most of the greater barons, the king crossed. ${ }^{84}$ Besides

77 Liebermann, p. 139.

78 Hov., IV, 140.

${ }^{79}$ Cogg., pp. 102-110.

80 "servientes regis" (Hov., IV, 140); "Willelmus de Wrotham et socii sui, receptores carrucagii" (Rot. Canc., p. 23).

81 Cogg., p. 103. The king received some of it in August, 1200 (Rotuli Normannice, ed. Hardy, Record Com., p. 28). In September, 1200 , he received $8,000 \mathrm{~m}$ from the English treasury, not necessarily from the carucage (ibid., p. 36).

82 Diceto, II, 172; Hov., IV, 160.

83 Hor., IV, 163.

84 "Puis s'en revint en Normendie, li reis o tot sa baronie" (Histoire de Guillaume le Maréchal, ed. Paul Meyer, 1. 12005). If the account of the scutage given in the Pipe Roll is at all complete, just 


\section{UNDER JOHN AND HENRY III}

the tenants, the army included mercenaries. ${ }^{85}$ This expedition was the occasion of the second scutage of the reign, although there seems to have been no fighting after John arrived in France. ${ }^{80}$ It was accompanied by many fines ne transfretet, which till 1209 were characteristic of John's scutages. The tax was determined on and collection was begun before the departure of the army and not at the close of the campaign. The chroniclers state that when the barons met at Portsmouth, the king took from some of them the money which they would spend in his service and allowed them to return home. ${ }^{87}$ Fines were assessed and the right to collect scutage from rearvassals was granted by the king to tenants in chief before the host gathered, hence the scutage must have been already put in charge as the rate was known. Some tenants compounded for their service, half to be paid on the king's departure and half at a later date. ${ }^{88}$ The sheriff of Somersetshire was to collect the scutage on all the fees of Fulk Painel and have it at Portsmouth on May 5 with the writ. ${ }^{89}$

about half of the feudal service of England was represented in the host. The number of fees which compounded is not over 3,250.

85 "Et (rex) præmisit in Normanniam Villelmum Marescallum . . . cum centum militibus soldariis et Rogerum de Lasci, ... cum aliis centum militibus, ad reprimendum impetum inimicorum suorum in finibus Normanniæ. Et rex tradidit Huberto de Burgo .... centum milites, et constituit eum custodem finium Angliæ et Valliæ" (Hov., above); "et quater viginti libras et xiii libras et $\nabla$ solidos ad liberationem Lupilionis et aliorum balistorum nostrorum qui transfretant nobiscum" (Rotuli de Liberate ac de Misis, ed. Hardy, Record Com., p. 14).

86 Hov., IV, 161, 164; Norgate, John Lackland, p. 81; Adams, Political History of England, 1066-1216, p. 398.

87 Cov., II, 184; Hov., IV, 163.

88 Rot. Obl., pp. 127, 134, 135, 136, 137.

89 Ibid., p. 131. This was a fine. On June 10, the king pardoned Thomas de Burgh, a rear-vassal, his scutage and wrote to Geoffrey Fitz Peter as follows: "et si quid de feodis ipsius Thomæ captum 


\section{STUDIES IN TAXATION}

The account follows:

Scutage at 2 marks

M s d

Clerical tenants . $\quad . \quad\left[\begin{array}{llll}717 & 5 & 4\end{array}\right.$

Thirty-six lay tenants (each 5 or

more fees $)^{90} \quad$. $\quad . \quad 2090 \quad 711$

Lay tenants (each fewer than 5 fees,

Total

etc. $)^{91}$

$\begin{array}{lll}894 & 9 & 5\end{array}$

Total . . $\quad . \quad 6702 \quad 94$

$\begin{array}{llllllll}\text { Clerical tenants } & . & 0 & 0 & 1200 & 5 & 8 & 272\end{array}$

Fifty-seven lay tenants (each 5 or



Other lay tenants (each fewer than

Total

5 fees, etc. $)^{93}$

- $\begin{array}{llll}1401 & 0 & 8 & 385\end{array}$

Sergeants, thegns, drengs, etc. $\quad \cdot \quad \begin{array}{rrr}199 & 0 & 0\end{array}$

$\begin{array}{lllllllll}\text { Additional }^{94} & . & . & & & & 56 & 0 & 0\end{array}$

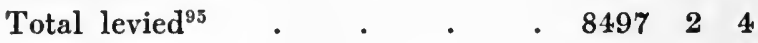

Paid, 3 John . . . $\quad 532110 \quad 5$

Paid, 4 John • . $\quad$ • $\quad \begin{array}{rrr}391 & 2 & 3\end{array}$

Fees, taxed, not over 3200 .

Tenants who performed their service were acquitted of scutage. William Earl Marshal, Warren Fitz Gerold, and Robert de Tateshal were in France on the king's

fuerit de scutagio suo" (Rot. Lib., p. 15). Hence scutage must have been put in charge at this time.

90 Almost all are tenants in chief.

91 Of this sum, $375 \mathrm{~m}$ are on honors in hand and $127 \mathrm{~m}$ on detached fees of great barons, leaving about $392 \mathrm{~m}$ on tenants in chief.

92 Of these, 24 are tenants on honors in hand and are charged with $575 \mathrm{~m}$ fine on 169 fees, leaving 33 tenants in chief charged with 1,363m on 456 fees.

93 Of this sum, $997 \mathrm{~m}$ are charged on 236 fees on honors in hand.

${ }_{94}$ Number of fees unknown. One man charged with $20 \mathrm{~m}$ is entered in the Fine Roll and not in the Pipe Roll.

95 Of the total fine, $167 \mathrm{~m}$ are charged on 43 fees which are entered in the Fine Roll and not in the Pipe Roll. 


\section{UNDER JOHN AND HENRY III}

service in May $;^{9 \theta}$ Robert de Turnham and the earl of Chester were there in September $;^{97}$ Eustace de Vescy, the earl of Albemarle, the constable of Chester, Adam de Novo Mercato (four fees of the honor of Tickhill), Roger de Valtort, the earl of Winchester, and Robert de Cardigan were probably in France, for they received loans made by the king ultra mare. ${ }^{98}$ All these received writs of quittance of their scutage. ${ }^{99}$

About half of the clergy paid scutage. Several of the chief laymen of the kingdom were also charged with it: Hervey Bagot, 60 fees; Ralph de Sumery, 50 fees $;^{100}$ the earl of Clare, about 140 fees $;{ }^{101}$ Walter de Lacy, 51 $1 / 4$ fees $;^{102}$ earl Aubrey de Ver, 301/8 fees $;^{103}$ Richard de Munfichet, 32 fees $;^{104}$ Henry de Nonant, 55 $51 / 21 / 3$ fees $;^{105}$

96 Rymer, Fœdera, I, 83.

97 Rot. Litt. Pat., p. 1 a.

98 "De præstitis factis a rege ultra mare"; the names and sums follow (Rot. Canc., pp. 89, 94, 302-303). Robert de Muscamp also receives a loan ultra mare; he held 4 fees in Northumberland for which he has this year a writ of quittance (ibid., p. 65); but he paid $10 \mathrm{~m}$ fine for his crossing in Notts. and Derby (ibid., p. 318). In no other year is he entered in Notts. and Derby.

09 Such a tenant may pay part of his scutage either on a detached fee, or because the sheriff had not received notice concerning the writ of quittance; such payments are, however, too small to show that there was a general levy on the rear-vassals, e.g. the earl of Albemarle paid $5 \mathrm{~m}$ in War. and Leic. and $16 \mathrm{~d}$ in Norf. and Suff. (Rot. Canc., pp. 13, 339). None of the other barons mentioned in the text paid anything. When the tenant is apparently performing his service, but has neglected to secure his writ of quittance, he is charged with scutage in the roll, but he does not necessarily pay anything, and later when he secures the writ his debt is crossed off; Robert Fitz Walter and William Malet are both charged with scutage, but no payment is made. A note is added "sed postea habuit quietanciam per breve" (ibid., p. 162); Hamo de Valoignes (ibid., p. 87).

100 Ibid., pp. 50, 51.

101 Ibid., p. 338.

102 Ibid., p. 110.

103 Ibid., p. 162.

104 Ibid. The old enfeoffment was $471 / 2$ fees and the servitium debitum 40 fees (Red Book, I, 351). Why he pays on 32 fees, I do 


\section{STUDIES IN TAXATION}

Robert de Albini, 25 fees. ${ }^{108}$ Thus the great barons were liable for scutage, for these sums were not merely charged, but were partly paid.

Some tenants apparently performed part of their service and paid for the rest. This is probably the explanation of cases in which part of the scutage was paid and the rest pardoned. Thus half of the scutage of Earl Ferrers was pardoned. ${ }^{107}$ Godfrey de Luvein owed $181 \mathrm{~m}$ for the honor of Eye, of which he paid $£ 6710$ s and was pardoned the rest. ${ }^{108}$ Henry de Nonant owed $111 \mathrm{~m} 8 \mathrm{~s} 10 \mathrm{~d}$ in Devon; he paid $21 \mathrm{~m} \mathrm{11s} 11 \mathrm{~d}$ and was pardoned the remainder. ${ }^{109} \mathrm{~A}$ case which seems to be of this kind comes from the honor of Gloucester. The custodian still owed six and a half marks on the five fees of Robert de Gouiz for "which Robert was performing his service in Normandy. ${ }^{110}$

Only a few of the great vassals fined for their service: $:^{111}$ Henry de Oilli, $97 \mathrm{~m}$ on $321 / 3$ fees $;{ }^{112}$ Simon de Beauchamp, $100 \mathrm{~m}$ on $45 \frac{1}{2} \frac{1}{4}$ fees $;^{113}$ William de Longchamp,

not know. It is not a mistake of the clerk, for in the roll of 1202 , the same amount is repeated with partial payment; he makes a payment of $11 \mathrm{~m}$ in 1201 in Norf. and Suff. (Rot. Canc., p. 339), but this is included in the charge of $64 \mathrm{~m}$ (Pipe Roll, 4 John, Essex and Hert.).

105 Rot. Canc., p. 26.

100 Ibid., p. 355.

${ }_{107}$ Rot. Canc., p. 319 ; Pipe Roll, 4 John, Berks and War. and Leic. 108 Pipe Roll, 4 John and 7 John, Norf. and Suff.

${ }^{109}$ Rot. Canc., p. 26; Pipe Roll, 4 John, Devon.

110 "de quibus $(61 / 2 \mathrm{~m})$ facit servicium in Normannia" (Rot. Canc., p. 57). The other $31 / 2$ marks were evidently paid, for in 4 John this fee paid 10 marks.

111 It might be suggested that the fines would not normally be found in the Pipe Roll, but would only appear in the Fine Roll. This is not so. In 1201, some 400 tenants appear in the Fine Roll charged with fines for their military service; all but 30 of these are also in the Pipe Roll.

112 Rot. Canc., p. 279.

113 Ibid., p. 354. 
$60 \mathrm{~m}$ on 25 fees $;^{114}$ Simon de Avranches, $60 \mathrm{~m}$ on $21 \frac{1}{2}$ fees $;{ }^{115}$ the abbot of St. Augustine, $40 \mathrm{~m}$ on 15 fees. ${ }^{116}$ The earl of Devon fined in an unusual way: he allowed the exchequer to collect scutage from all his fees whether or not they owed service to the king, thus paying $30 \mathrm{~m}$ on 15 fees quos recognoscit and $90 \mathrm{~m}$ on 45 fees quos non recognoscit. ${ }^{117}$ For tenants holding five or more fees, the rate of the fine per fee (including scutage) was a little more than three marks. The extra sum over and above the scutage was neither an equivalent of the total service of the holding, nor so burdensome that the tenant would prefer to perform his service in the field, if he performed full service. ${ }^{118}$

The lesser tenants (holding 385 fees) bore heavier fines. The average rate was nearly four marks per fee, or almost double what the scutage would have amounted to and in some cases the rate was still higher. Simon de Kyme paid 10 marks on 2 fees $;{ }^{119}$ Walter de Bolebec, 30 marks on 5 fees; and Richard de Umfravill, 50 marks on $21 / 2$ fees. ${ }^{120}$ Most of these lesser tenants were not tenants in chief, but rear-vassals on honors in hand. ${ }^{121}$ This year the tenant usually paid a lump sum as a fine and in return performed no service for his fee and was allowed

114 Ibid., p. 191 ; Rot. Obl., p. 152.

115 Rot. Canc., p. 220.

116 Ibid., p. 219; Rot. Obl., p. 128.

117 Rot. Canc., p. 26. This formula is used usually of ecclesiastical fees only. Fulk Painel made a similar bargain: "Fulco Painel dat domino regi scutagium viite militum et aliorum militum si plures de domino rege teneat in capite pro passagio suo et passagio prædictorum militum" (Rot. Obl., p. 131).

118 As we increase the average holding, the rate of the fine diminishes. On tenants holding 10 or more fees, the average rate of the fine is under 3 marks per fee.

119 Rot. Canc., p. 192.

120 Ibid., p. 64.

121 See above, p. 36, note 93. 


\section{STUDIES IN TAXATION}

to collect scutage from his vassals. ${ }^{122}$ But he might pay a fine for his crossing in addition to his scutage. ${ }^{123}$ Abbots and priors paid fines, but not usually the bishops. The bishopric of Lincoln fined this year, but was vacant ${ }^{124}$ the bishop of Winchester paid a fine of 300 marks, but in return he also obtained certain rights enjoyed by his predecessors. ${ }^{125}$

The account of the scutage of this year as given in the Pipe Roll does not suggest that the king collected a scutage from the sub-tenants of those tenants who performed their service, ${ }^{126}$ so that the scutage was not a

122 E.g. "Nigellus de Luretot debet L marcas ne transfretet et pro habendo scutagio suo de $x v$ militibus" (Rot. Canc., p. 318).

123 "Walterus de Cormeilles $r$ de xii libris de fine suo ne transfretet et de xii libris de scutagio suo" (ibid., p. 110). An unusual sort of fine was one at a fixed rate per fee: "Henricus de Oilli $r$ c de quater $\mathrm{xx}$ et xvii marcis de fine que fecit scilicet pro quolibet milite que tenet de rege iii marcis" (ibid., p. 279). A tenant might pay a fine larger than his scutage in order to be allowed to send a substitute: "Radulfus de Cruminwell dat vi marcas. Tenet feodum i militis. Si filius transfretat dabit nisi iii marcas; sin autem vi marcas" (Rot. Obl., p. 153).

124 Rot. Canc., p. 98.

125 Ibid., p. 211.

126 See above, p. 36. Thus the total number of fees taxed is not over 3,200 , leaving about 3,000 at least who are not charged with a tax and who are represented by the lists of those who receire writs of quittance in each county. It may be observed that the great bulk of the scutage and fine are charged against certain men, viz., clerical tenants and lay tenants holding 5 or more fees who, we know, are either tenants in chief or tenants on honors in hand. Now the only part of the account where the sub-tenants of those tenants in chief who hare receired writs of quittance might possibly be found is in the two groups of lay tenants holding fewer than 5 fees each and in the group headed "Additional." The total amount in these three groups which I have not identified with honors in hand will not exceed $852 \mathrm{~m}$. From this would have to be deducted all the scutage levied on tenants in chief who hold fewer than 5 fees each and some allowance would have to be made for tenants on honors in hand who have not been identified. The remainder would be far too small to represent anything like a general tax on the rear-vassals of those 


\section{UNDER JOHN AND HENRY III}

general tax, but retained its old form of the composition for service. Though this is true, yet in some cases the levy was collected by the sheriff, apparently from the rear-vassals. That official accounted for $11 \frac{1}{2}$ marks of the scutage of the Earl Ferrers in Berks. ${ }^{127}$ The sheriff of Bucks accounted for $£ 810 \mathrm{~s}$ of the scutage of the earl of Clare, 3 marks for Henry de Oilli, and 25s 4d for the count of Perche. ${ }^{128}$ Some of these sums may have been paid to the sheriff by the tenant in chief; most of the amounts were small. In many cases, the sheriff did not collect from the sub-tenants. He took little, if any, from the rear-vassals of those tenants who served. ${ }^{129}$ Often the charge against a tenant in one county was crossed off with the statement that payment was made in another county. ${ }^{130}$ All this seems to indicate that the royal official

tenants in chief who have received writs of quittance. With this statement should be combined the evidence given above that the tenants who served are exempt from a money payment and the further fact that the tenants who fined obtained the exemption of their whole fee from paying scutage to the king (see above, pp. 37, 39). All this points to the conclusion that the king did not take a scutage from the rear-vassals while at the same time he obtained the whole service of the fee from the tenant in chief, either by a money fine or by a quota of knights. In other words the scutage was not a general tax, but was the composition for service, though, as such, it might be replaced by the fine.

127 Rot. Canc., p. 263.

128 Rot. Canc., p. 355 ; Henry de Oilli is quietus in War. and Leic.; the sheriff accounts for him for $8 \mathrm{~s} 10 \mathrm{~d}$ in Staff., for $2 \mathrm{~m}$ in Northamp., for $6 \mathrm{~s} 8 \mathrm{~d}$ in Berks, for $3 \mathrm{~m}$ in Bucks and Bedf., and Henry himself accounts for $97 \mathrm{~m}$, his whole charge, in Oxfordshire (Rot. Canc., pp. 14, 51, 88, 262, 279, 355); Fulk Painel, $5 \mathrm{~m}$ on 1 fee "de quibus vicecomes de Sumersete redidit ii marc. in Sumersate" (ibid., p. 233); see other cases, pp. 239, 262-263, 339, 355.

129 See above, p. 37.

130 "Galfridus de Paveilli debet $\mathrm{x}$ li. et $\mathrm{i}$ palefridum; sed non debet summoneri quia respondit in Norhantesira" (Rot. Canc., p. 317, Notts. and Derby); Robert de Mara, Lucia de Mohun, Anselmus Biset, Nigel de Luvetot (ibid., pp. 44, 143, 220, 318). He may be charged with scutage and the charge written off with the statement that the 


\section{STUDIES IN TAXATION}

dealt with the tenant in chief rather than with the subtenant. But the rear-vassal ultimately paid the scutage. Both the barons who fined and those who paid scutage obtained the right to collect the tax from their tenants, given them by the writ de scutagio habendo. ${ }^{131}$ A further indication of the same thing is that tenants rendered their accounts in more than one county. ${ }^{132}$ This does not mean that the rear-vassal was responsible to the exchequer for the scutage. The debt to the king was not his debt, but his lord's and it was the lord's name that appeared regularly in the roll. When the sub-tenant is found charged with fine or scutage, it means probably that the honor was in hand and that the tenants were treated for the time as immediate vassals of the king. ${ }^{133}$ The rear-vassal

tenant has a quittance in another county: William de Windsor, Richard Fitz Nigel, Warren Fitz Gerold (ibid., pp. 209, 354). The fine of the earl of Devon illustrates the point that the sheriff ordinarily did not collect from the rear-vassals; he fined under the conditions that no scutage was to be demanded of him personally, but that the king should take scutage from all his knights. "A Willelmo comite de Vernun nullum scutagium requirendum est in aliqua summa quia finivit cum rege pro licentia remanendi ut rex capiat de omnibus militibus suis scutagium suum quos tenet de rege in capite" (ibid., p. 263); cf. Fulk Painel, Rot. Obl., p. 131. The earl therefore paid on 15 fees of his servitium debitum and on 45 fees of new en feoffment (ibid., p. 26). The fact that the sheriff collects from the sub-tenants seens to be unusual as well as the fact that the earl pays on the extra fees. This was not the first time that the earl had made such a payment (Red Book, I, 88).

131 See above, notes 122,123 . I have found no writ this year granting a tenant in chief who pays only scutage the right to collect it from his vassals. That such was the case, however, is shown by the fact that if a rear-vassal was pardoned his scutage by the king, that amount was deducted from the scutage of his lord. Thomas de Burgo holds $21 / 2$ fees of both Aubrey de Ver and of the abbot of St. Edmunds, both of whom pay scutage only this year; he is pardoned the $10 \mathrm{~m}$ due (Rot. Lib., p. 15); and his lords likewise (Rot. Canc., pp. 162, 337).

132 See above, note 128.

133 Thus the tenants on great honors like that of Gloucester appear in the roll; cf. the entry of Adam de Port's fee (Rot. Obl., p. 145); 


\section{UNDER JOHN AND HENRY III}

on an honor in hand should have paid the king what he paid his lord. If the tenant in chief had enfeoffed more knights than his servitium debitum, he collected from them all. ${ }^{134}$ When the honor fell into the king's hand, the latter did likewise. ${ }^{135}$ The rear-vassal was not responsible for the fine. The king granted his lord permission to collect scutage only. ${ }^{138}$ From tenants on honors in hand, however, John exacted fines which were larger than the scutage, as though they were tenants in chief. ${ }^{137}$

The king could not at will collect from a tenant in chief from a larger number of fees than the tenant was accustomed to respond for. The law of the land was a protection. Some dispute arose over the amount of service owed by Gerard de Canvill in Oxfordshire; an inquest

the knights of the honor of Walter de Dunstanvill appear in the roll "de finibus militum ne transfretent" (Rot. Canc., p. 233), but the honor was in hand: "de remanenti firmæ terrarum Walteri de Dunestanvill' de anno præterito" (ibid., p. 224). There are exceptions to this, e.g. the tenants of Sibilla de Fesnes (ibid., p. 162); but two cases show that such appearance was not the rule. William Luvel was a tenant of the earl of Leicester; he gave $20 \mathrm{~m}$ and a palfrey for his crossing and "pro habendis litteris domini regis deprecatoriis ad regem Franc" (Rot. Obl., p. 144); he thus had some special privilege to gain. His payment this year led to his being charged with scutage in 1202, but it was crossed off because he held of the earl of Leicester (see below, p. 52, note 186). The following extract needs no comment: "Willelmus de Lumeneye dat $3 \mathrm{~m}$ qui nichil tenet de domino rege in capite et qui summonitus fuit ad transfretandum per sic quod dominus rex non habeat malam voluntatem erga ipsum eo quod non transf retet secum et faciat servicium suum quod facere debet Mabilie de Soliis de qua tenet" (Rot. Obl., p. 135); cf. William de Lond' (ibid., p. 145).

134 Chron., Joc. de Brak., pp. 48-49.

135 The bishopric of Lincoln which was in hand paid on $1021 / 2$ fees instead of on 60 fees (Rot. Canc., p. 98).

${ }^{136}$ See above, p. 40, note 122 ; "et mandatum est justic' quod eidem episcopo faciat habere scutagium suum de militibus suis, scilicet, de scuto, duas marcas" (Rot. Obl., pp. 156-157); the same as to John de Hastings and William de Muntcheney (ibid., p. 128).

137 See above, p. 36, notes $92,93$. 


\section{STUDIES IN TAXATION}

was held in the county court by knights of the county who determined the amount of service as that of one fee only in that county. ${ }^{138}$ What seems to be evidence that the exchequer was trying to obtain a more exact account of the number of fees held by each of the king's vassals is suggested by the frequent statement that " $x$ tenet $y$ feoda, sicut dicit," or "sicut vicecomes dicit."139 There is no evidence as to how the scutage was put in charge. The fines were assessed partly at the meeting of the host and partly by special justices, perhaps the itinerant justices on their rounds. ${ }^{140}$ Some of the fines were laid before the host met. ${ }^{141}$ Some of the tenants in chief accounted for their scutage or fine at the exchequer or in camera, in person or by a representative; some paid it to the sheriff who rendered the account at the exchequer. $^{142}$ Some of the fines were this year brought to Portsmouth when the king sailed.

138 "non debet respondere nisi ad feodum 1 militis sicut inquisitum fuit per milites comitatus" (Rot. Canc., p. 279). The total service of Gerard was sixteen fees.

139 "Rogerus de Sumeri dat domino regi c marcas pro transfretatione sua. Tenet feoda $\mathrm{L}$ militum in capite et non plus ut dicit" (Rot. Obl., p. 146); "Comes de Clare vicecomes pro eo r c de xiii libris de scutagio, scilicet, de ix feodis et dimid' et quarta parte feodi $\mathbf{i}$ militis que prædictus comes habet in Surreia sicut vicecomes dicit" (Rot. Canc., p. 32).

140 Hov., IV, 160-161; "de scutagio militum ... quorum nomina et debita annotantur in rotulo que magister Radulfus de Stoke liberavit in thesauro ex parte justic' de finibus militum ne transfretent" (Rot. Canc., p. 233); "Cecilia comitissa Herefordiæ r c de xl marcis per quas finivit sicut recordatum est per justiciarium pro habendo scutagio suo et pro passagio suo" (Madox, I, 676, n. y).

141 E.g. Fulk Painel, Giffard Whiting (Rot. Obl., pp. 131, 136).

142 The roll has two sorts of entries: A (tenant) r c de y marcis; idem vicecomes $r$ de $y$ marcis de $B$ (tenant). The difference seems to be intentional, for the first form may appear: $A$ vicecomes pro eo $r$ c etc. (Rot. Canc., p. 32). Again, the tenant may account and yet the payment be made at the exchequer by the sheriff, but in that case, the roll sometimes states the fact: Henry de Oilli "r c etc.; in thesauro xxiii li. et vi sol. et ix den. per manum vicecomitis" (ibid., 


\section{UNDER JOHN AND HENRY III}

Some notices of a tallage appear, but there was no general levy. The bishopric of Lincoln, in hand, was charged with $£ 5225 \mathrm{~s} 2 \mathrm{~d}$ of tallage. ${ }^{143}$ In Yorkshire, $379 \mathrm{~m} 6 \mathrm{~s} 6 \mathrm{~d}$ of tallage were charged, 100 marks of which fell on the city of York, 60 marks on Scarborough, 15 marks on Richmond, and the rest on persons. ${ }^{144}$ The men who were charged with tallage held of the king; others were not liable. ${ }^{145}$ The assessment was made by the itinerant justices. ${ }^{146}$ An aid of some sort was collected this year from the men of the Channel Islands, no matter of whom they held. It is of interest because of the way in which the assessment was made, viz., by four legal knights of the islands. ${ }^{147}$

In 1201 a fortieth of revenues for one year was levied for the Holy Land. ${ }^{148}$ Churchmen paid it on their spiritualities and temporalities by order of the pope; each bishop had charge of the collection from the clergy of his diocese. The king granted a fortieth of the revenues of his demesne, his escheats, wardships, and lands in hand and he asked the earls, barons, knights, and freemen to contribute. The first three classes were to pay a fortieth of the annual value of each vill held by them in whole or

p. 279); $c f$. the cases of the éarl of Clare and Aubrey de Ver (ibid., pp. 162, 338). However, the tenant who is said by the roll to account for his scutage does not always do so; see the cases of the earl of Devon and Fülk Painel (ibid., pp. 26, 207, 263; Rot. Obl., p. 131). As to payment in camera, see the bishop of Norwich (Rot. Canc., p. 338). The fines which were to be brought to Portsmouth when the king sailed would be paid in camera (see above, note 141).

143 Rot. Canc., pp. 96-97.

144 Ibid., p. 297 ; other notices of a tallage, pp. 255, 337.

145 "Rogerus de Schipton' c sol. de eodem [taillagio], sed non debent exigi quia per inquisicionem factam percepto justic' nichil tenet de rege" (ibid., p. 297).

146 Ibid.

147 Rot. Litt. Pat., p. 3a.

148 Hov., IV, 187; Wend., III, 167; Rot. Litt. Pat., p. 5a; Diceto, II, 169 ; Cogg., pp. 115-117. 


\section{STUDIES IN TAXATION}

in part, based on an estimate of what it would yield if farmed. The freemen were to pay a sum equal to the fortieth of the annual rent owed to their lords. There was no assessment by the royal officials. Each man calculated the amount of his contribution. The sheriff appointed discreet and legal men to receive it. A roll was drawn up by the collectors, arranged by vills; it contained the names of the contributors and the amount paid by each. The royal demesne was enrolled separately. If anyone refused to pay, his name was reported to the king. ${ }^{149}$ Assessed and collected in this way, the tax could not have been very productive, but it should be noted as an experiment in taxation. The detailed account which was enrolled and the use of some local machinery of collection are of interest.

\section{The Taxation of 1202}

The occasion for new taxation was the war between John and Philip Augustus which had broken out again in the spring of 1202 . No writ exists of a general summons to the host, but in April the barons of the Cinque Ports were ordered to place their ships at the command of Hubert de Burgh, probably to bring forces, from England, ${ }^{130}$ and in May Flemish knights who held feoda of John were summoned to perform their service. ${ }^{151}$ Others were summoned who were to receive wages. ${ }^{152}$ Sev-

149 Hov., IV, 188-189; the royal contribution is given in the Pipe Roll (William Salt, etc., II, 108, 112).

150 Rot. Litt. Pat., p. 9 b.

151 Ibid., p. $11 \mathrm{~b}$.

152 Ibid., p. 10a, 12a ; Pipe Roll, 4 John, Suss., Wilts, m. 9d; payment of mercenaries is also mentioned in Rot. Norm., pp. 47, 53, 55. The king was well provided with money. He acknowledges the receipt of $7,000 \mathrm{~m}$ from England on June 12 and on June 17 is providing transport for treasure from England (ibid., pp. 49, 51); at the end of the month, he acknowledges the receipt of $2,000 \mathrm{~m}$ (Rot. Litt. Pat., p. 13a). 


\section{UNDER JOHN AND HENRY III}

eral of the English barons were serving with the king: the earl of Albemarle and Robert de Tresgoz $;{ }^{153}$ Roger de Tony, William de Roches and the earl of Chester $;^{15 *}$ William Earl Marshal, William de Braose, ${ }^{155}$ William Briwerre, the earl of Salisbury, the earl of Leicester, the earl of Arundel, and Geoffrey de Say. ${ }^{158}$ It seems probable therefore that a general summons was issued. For this campaign a scutage was levied and in some counties there are notices of a tallage. ${ }^{157}$

The levy appears in the Michaelmas roll of 1202 and was partly paid when the roll was made up. The scutage was levied at two marks per fee, the rate which had now become usual. The account follows:

Scutage at 2 marks.

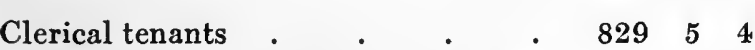

Seventeen lay tenants (each 5 or

$\begin{array}{llllllll}\text { more fees) } & \cdot & \cdot & \cdot & & 489 & 8 & 8\end{array}$

Other lay tenants (each fewer than 5

Total

fees, etc. $)^{158} \quad \cdot \quad \cdot \quad \cdot \quad 70910 \quad 4$

153 Rot. Litt. Pat., p. 12.

154 Ibid., p. 8 a.

155 Ibid., p. 19a.

${ }^{156}$ Ibid., p. 19b.

157 There are notices of this in 8 counties, amounting to about 800 marks. Sometimes the tallage is mixed with amercements so that it is impossible to tell how much it amounted to. These sums have not been included. Such composite accounts probably occur because the tallage was levied by the itinerant justices and was reported by them with the amercements; e.g. "De ammerciamentis et taillagiis maneriorum regis in Berchscira factis per Galfridum filium Petri et Ricardum de Heriet et socios suos. Idem vicecomes $\mathrm{r}$ c de $\mathrm{c}$ li. et xvi $\mathrm{d}$ de prædictis misericordiis et taillagiis hominum quorum nomina et debita et causæ debitorum annotantur in rotulo que prædicti liberaverunt in thesauro" (Pipe Roll, 4 John, Berks, m. 1 d).

$158127 \mathrm{~m}$ are on honors in hand like Peverel, Wallingford, Lancas- 


\section{STUDIES IN TAXATION}

Fines Fees

$\begin{array}{lllllllllll}\text { Clerical tenants } & \text { - } & & \text { - } & & 362 & 0 & 0 & & 98\end{array}$

Thirty-nine lay tenants (each 5 or $\begin{array}{llllllll}\text { more fees })^{159} & \text {. } & \text {. } & \text {. } & 1611 & 3 & 4 & 569\end{array}$

Lay tenants (each fewer than 5 fees,

$$
\text { etc. })^{160}
$$

Total

Sergeants

Additional ${ }^{161}$

Total charged

Paid, 4 and 5 John

Fees taxed, not over 2100 .

$$
\begin{array}{rrrrr}
\text {. } & 1892 & 2 & 6 & 303 \\
. & 3865 & 5 & 10 & 970 \\
. & 202 & 3 & 4 & \\
. & 122 & 13 & 0 & \\
. & 6219 & 6 & 6 & \\
. & 4418 & 1 & 9 &
\end{array}
$$

The bulk of the scutage proper fell on the prelates and the greater lay tenants. The laymen holding more than 20 fees and charged with scutage were: Simon de Avranches, 43m ; ${ }^{162}$ Walter de Lacy, 1021/2m ; ${ }^{163}$ Guido de Laval 20 fees ; $^{164}$ William Fitz Alan 271/2 fees. ${ }^{165}$ A little more than half of the church fees paid the scutage proper. Tenants who performed their service in the field were exempted from any payment. All the barons mentioned above had writs of quittance. In some cases the roll states that the tenant was exempt from scutage on account of service performed in person or by deputy. ${ }^{166}$

ter, Tickhill, Brittany, and Gloucester. $85 \mathrm{~m}$ are on detached fees of great baronies, not in hand. This leares not more than $500 \mathrm{~m}$ on lesser tenants in chief.

159 In this case, 17 men holding 188 fees are charged with $558 \mathrm{~m}$ fine who hold of honors in hand, leaving 22 tenants in chief who are charged with $1,053 \mathrm{~m}$ on 381 fees.

160 In this case, $977 \mathrm{~m}$ are charged against 209 fees on honors in hand.

161 Number of fees unknown.

162 Pipe Roll, 4 John, Kent, m. 15 d.

163 Ibid., Hereford, m. 19 d.

164 Ibid., 4 John, York, m. 5.

165 Ibid., Salop, m. 3 d.

166 Richard de Munfichet is quit "quia est in servicio regis"; also Warren Fitz Gerold and others (ibid., Essex and Herts, m. 19 d); 
Only three of the clergy paid fines: the abbot of Sherburne, $20 \mathrm{~m}$ on $21 / 5$ fees; the abbess of St. Edward, $50 \mathrm{~m}$ on 7 fees and the abbot of Michelney, $10 \mathrm{~m}$ on 1 fee. ${ }^{107}$ The tenants of the abbey of Ramsey and of the bishopric of Lincoln fined, but both honors were in hand. ${ }^{188}$ Of the laymen, three great lords fined: the earl of Warwick, $20 \mathrm{~m}$ and the scutage on his $102 \frac{1}{3}$ fees $;{ }^{169}$ Hervey Bagot, $20 \mathrm{~m}$ and his scutage on 60 fees $;{ }^{170}$ and Robert de Cardinan, $120 \mathrm{~m}$ on 71 fees of the honor of Mortain. ${ }^{171}$ The average rate per fee for the larger holdings (five fees each) was about three marks (though the fine was not reckoned at so much per fee). ${ }^{172}$ The lesser tenants paid heavier fines, the average rate being over six marks per fee. But there was no fixed rate; William de Nova Mercato paid $50 \mathrm{~m}$ on $17 \frac{1}{2} \frac{1 / 4}{4}$ fees $;^{173}$ Robert de Muschans, $50 \mathrm{~m}$ on 4 fees. ${ }^{174}$ Most of the fines were lump sums for service and scutage. Sometimes the fine and scutage were separate; the tenant paid his scutage and in addition a fine pro passagio, ne transfretet. The latter was apparently for his personal service and for the scutage of his demesne. ${ }^{175}$ In such cases the fine was not large enough to represent the service of the whole holding.

Brian Fitz Ralph is quit "per militem que misit ultra mare" (ibid., Norf. and Suff., m. 8 d). As he held 5 fees, he was thus exempt from scutage by performing only part of his service.

167 Ibid., Dors. and Somers., m. 7 d.

168 Ibid., Cant. and Hunt., m. 10 d, m. 20; Cart. Mon. de Rameseia, I, 227.

169 Pipe Roll, War. and Leic., m. 3 d.

170 Ibid., Staff.

171 Ibid., Corn., m. 12 d. These fees paid scutage at $5 / 8$ the regular rate, so that the scutage would have been $883 / 4 \mathrm{~m}$.

172 On tenants holding 10 or more fees each, the rate is about $21 / 2 \mathrm{~m}$ per fee, the fine including scutage.

173 Pipe Roll, 4 John, Dors. and Somers., m. 7 d.

174 Ibid., Northumb., m. 14 d.

173 See the earl of Warwick and Hervey Bagot abore; "Willelmus filius Ricardi ... r c de $15 \mathrm{~m}$ de scutagio ... et de $5 \mathrm{~m}$ de fine suo 


\section{STUDIES IN TAXATION}

The king did not as a rule take scutage from the rearvassals while he obtained the whole service of the fief either in money or knights from the tenant in chief, that is, the scutage was not a general tax levied in addition to service in the host, or a money equivalent. ${ }^{178}$ We may take first the case of the tenant who performed his service with the host. He obtained a writ of quittance which exempted from paying scutage to the exchequer not only his demesne but also the lands which he had enfeoffed. Thus his writ was entered in the roll in all counties where his lands lay. ${ }^{177}$ Some tenants, however, who were evidently performing service did not receive their writs of quittance till after the sheriff had rendered his account of the year at the exchequer and the roll had been drawn up. From some of these men part of their scutage was collected. Philip de Colombiers paid eight shillings out of twenty marks, then obtained his writ of quittance and the remainder of the debt was cancelled. ${ }^{178}$ Robert Fitz Payn paid one mark out of thirty and then was acquitted the balance. The earl of Devon paid six marks in Dorset and Somersetshire and was acquitted the rest. ${ }^{179}$ In this last bailiwick, the rear-vassals paid the sheriff $£ 2013 \mathrm{~s}$ before the writs of quittance of their lords arrived. ${ }^{180}$ Yet it will be noticed that the amounts thus paid were small. Furthermore, pro passagio et pro scutagio de dominico suo" (ibid., Northamp., m. 11 d); Richard Foliot (ibid.).

176 It may be observed at the outset that only about 2,100 fees were taxed this year.

177 The earl of Leicester has quittance in ten bailiwicks. It should be remembered that rear-vassals do not appear in the roll unless the honor is in hand. Consequently when the tenant in chief is thus returned as quit, none of his land pays scutage to the king.

178 "Philippus de Columbieres $\mathrm{r} c$ de $\mathbf{x x} \mathrm{m}$. de feodis $\mathrm{x}$ militum. In thesauro nichil et Galfrido filio Petri viii s. . . . et debet xix marc. et $\nabla$ sol. et iiii den. Sed habet quietanciam per breve regis" (Pipe Roll, 4 John, m. 7 d).

179 Ibid., and m. 18 d.

180 "De scutagiis militum tenentium de pluribus baronibus quæ 


\section{UNDER JOHN AND HENRY III}

they might be returned by the sheriff. ${ }^{181}$ Other tenants in the same circumstances paid nothing at all and later when their writs of quittance were received, their debts were cancelled in the roll. ${ }^{182}$ The tenant who had not performed his service and paid a fine or scutage sometimes paid part of it to the sheriff of the county containing the head of his barony and part to the sheriffs of other counties where his land lay. This may mean that sometimes the royal official collected from the rearvassals. $^{183}$ In other cases, the tenant in chief accounted for his fine or scutage in one county and was entered as acquitted in the other counties where he held fees. ${ }^{184}$ The sheriff also reported fees in his bailiwick, but stated that the payment was made in other counties. ${ }^{185}$ Occasionally

capta fuerunt antequam brevia de quietantia scutagiorum baronum illorum pervenirent ad vicecomitem. Idem vicecomes $\mathrm{r} c$ de $\mathrm{xx}$ li. et xiii sol. etc." It was all paid into the treasury (ibid., m. $7 \mathrm{~d}$ ).

181 The earl of Devon had his six marks returned to him by the sheriff: "et comiti Willelmo de Vernun iii li. pro iiii li. quas recepit (vicecomes) ab eo de tercio scutagio regis" (Pipe Roll, 5 John, m. 12).

182 "Willelmus filius Martini debet xxx marc. de fine suo pro $x$ militibus et dim. Sed postea habuit quietanciam per breve Galfridi filii Petri" (ibid., 4 John, m. 7 d); Robert de Seccheville (ibid., Deron, m. 18 d); John Fitz Hugh (ibid., Berks, m. 1 d).

183 Walter de Lacy owed $1021 / 2$ marks; he paid in 1202 thirty marks in Hereford, two marks in Berks, $£ 13$ 7s $7 \mathrm{~d}$ in Gloucestershire "quos vicecomes potuit invenire in hoc comitatu," was charged with five marks in Oxfordshire and the sheriff of Salop accounted for 20 marks on 10 fees of Walter "in hoc comitatu sicut vicecomes dicit," of which 10 marks were paid in 1202 (Pipe Roll, 4 John); the earl of Warwick, 4 marks in Northamptonshire, £4 7s $9 \mathrm{~d}$ in Gloucestershire on the fees "quos (vicecomes) potuit invenire"; 6 marks in Berks; 101/2 marks in Rutland; the whole sum due from his barony was charged in War. and Leic. (ibid.).

184 Guido de Laval was charged with 40 marks in Yorkshire and was quit in Linc., Oxford, and Surrey; the archbishop of York, with 40 marks in Yorkshire and quit in Oxford; William de Novo Mercato, 50 marks fine in Dors. and Somerset and quit in Gloucester (Pipe Roll, 4 John); see William de Reimes, Geoff rey Fitz Geoffrey, and John de Venecia (ibid., Norf. and Suff., m. 8 d).

185 "Henricus de Taiden debet etc. Et debent requiri in honore 


\section{STUDIES IN TAXATION}

the exchequer seemed to recognize that it could not legally collect from the rear-vassal. William Luvel owed two marks on one fee, but the amount was cancelled because he held of the earl of Leicester and not of the king. ${ }^{186}$ Milo de Buteford owed four marks on one fee, but the following year the charge was crossed off because he held of William Briwerre who had a writ of quittance. ${ }^{187}$ That scutage fell back on the rear-vassal is shown by three facts: the king sometimes collected from him, tenants in chief were entered in the roll in the different counties in which they held lands, and if rear-vassals were pardoned their scutage, their lords were also pardoned an equal amount. ${ }^{188}$ When a fee fell into the king's hand, scutages and fines were collected from all the knights enfeoffed. The abbot of Ramsey owed the service of four knights, but in 1202, when the abbey was vacant, it paid eight marks of scutage and forty-five marks of fines. ${ }^{189}$ The bishopric of Lincoln was also vacant at that time. It

de Wallingf' sicut vicecomes dicit" (ibid., Glouc., m. 13). Cf. the case of the fee of Oliver de Tracy which owed 56 marks of scutage (ibid., Deron, m. $18 \mathrm{~d}$ ); "sed amodo requiri a Willelmo de Braiosa qui habet feoda militum illorum per concordiam factam inter ipsum Willelmum et Oliverum per regem" (ibid., 5 John, Devon). Evidently the sheriff had not collected from the rear-vassals.

188 "Willelmus Luvel debet ii marcas pro i feodo. Sed non debet summoneri quia recordatum est quod non tenet feodum illud de rege sed de comite Leircestrie" (ibid., 4 John, Oxf., m. 15).

187 Milo de Buteford, $4 \mathrm{~m}$ on 1 fee (ibid., Deron, m. $18 \mathrm{~d}$ ); "sed Willelmus Briwerre habet quietanciam de quo . . . Milo tenet feodum (illud) (ibid., 5 John, Devon).

188 Stephen de Longchamp held 1 fee of Walter de Lacy, was pardoned the scutage on this fee and the amount was deducted from Walter's debt to the exchequer (ibid., 4 John, Heref., m. 19 d); Alfred of Lincoln held 5 fees of the abbot of Glastonbury, was acquitted the scutage due from them and the sum was accordingly deducted from the abbot's scutage (ibid., m. $7 \mathrm{~d}$ ). Each of these tenants in chief paid scutage this year only, and these extracts show that they were allowed to collect scutage from their vassals.

189 Ibid., 4 John, Cant. and Hunt., m. 10 d. 


\section{UNDER JOHN AND HENRY III}

owed the service of sixty knights, but it paid $\$ 189$ 19s of fines on $102 \frac{1}{2}$ fees. ${ }^{190}$ The method of accounting shows no change. The fines were assessed by special officials, perhaps the itinerant justices. ${ }^{191}$ The king could not at will increase the number of fees on which a tenant paid scutage; the tenant clung to his previous assessment and the law upheld him. ${ }^{192}$

\section{The Taxation of 1203}

The following year, the war in France continued. ${ }^{193}$ No copy of a summons to the English tenants for a campaign at this time exists, but in March the Flemish knights who held feoda of John were summoned to meet at Easter. ${ }^{194}$ One can collect from the Patent Roll a fair list of great English barons who were in France this year. In June, the king wrote of the service which the barons were performing. ${ }^{195}$ At Easter, English barons were

190 "de finibus $\mathrm{lx}$ militum . . . quos episcopus debet regi et de xlii militibus et dim. quos habet in dominico" (Pipe Roll, 4 John, m. 20). 191 "Radulfus filius Main' $\mathrm{r}$ c de $\mathrm{x}$ marcis pro i feodo sicut continetur in breve justic' quod est in forulo marescalli" (ibid., Northumb., m. 14 d); "postea recordatum fuit per justic' quod non finivit nisi per tres marcas" (ibid., Oxf., m. 15).

102 "Willelmus Malet habet quietanciam de xxii militibus et dim. et duabus terciis et $\mathbf{i}$ quarta et $\mathbf{i}$ vicesima per breve regis. Sed de his non debet respondere regi nisi de $x x$ feodis militum et unius militis et dim. et duabus quintis sicut carta ipsius testatur" (ibid., 4 John, Dors. and Somers., m. 7 d). In 1166, this fee contained $222 / 31 / 21 / 51 / 20$ fees of the old enfeoffment and $11 / 2 \% 5$ fees of the new enfeoffment in Somerset and $1 / 2$ fee in Kent (Red Book, I, 227-228).

$193 \mathrm{John}$ remained in France through the winter of 1202-1203 to carry on the war. In December he received 3,000m from England and in January, 1203, 1,000m (Rot. Norm., pp. 65, 72). There are several notices of mercenaries (ibid., pp. $69,70,75,77$ ).

194 Rot. Litt. Pat., p. 26b.

195 "ipse Thomas nobis faciet servicium suum de baronia sua sicut alii barones nobis faciunt... et milites ipsius Thomæ distringatis que ei servicia sua faciant" (Rot. Lib., p. 44). 


\section{STUDIES IN TAXATION}

compelled to remain in the king's service; there were rumors that some were plotting to abandon him, ${ }^{108}$ though one might be disseized for failure to be in the king's service. ${ }^{197}$ Finally, only a little over 2,000 fees were taxed; the rest were excused probably on account of service. All these facts indicate that a general summons was issued. The king's desire to have more men in his army than were furnished him by his English tenants is shown by his summons to Flemish knights and by his pardoning debts to men who in return were to supply him with knights. ${ }^{198}$

The taxation for the year consisted of a scutage at two marks per fee, accompanied by fines pro passagio, a tallage in some counties, contributions called dona from religious houses, and later in the year, what was really a tax, but took the form of a fine for military service, a seventh of personal property. The scutage was probably put in charge in the spring of 1203 . The account appears in the Michaelmas roll of this year; an entry dated September 19 refers to it as in process of collection $;^{108}$ on May 19, there is reference to its collection on the lands of William of Albini. ${ }^{200}$

The account follows: $:^{201}$

196 Rot. Litt. Pat., p. 29a; Rot. Norm., p. 96.

197 "unde disseisitus fuit eo quod non fuit in servicio nostro in quo ipse modo est" (Rot. Lib., p. 69); "Radulfus de Bolebec debet xx marcas et $\mathrm{i}$ palefridum ut sit quietus de concelatione servitii quartæ partis feodi i militis unde retatus fuit" (Pipe Roll, 5 John, York, m. 17).

198 "pro ista quietacione (of a debt) tenebit prædictus Radulphus (de Ruperia) tres milites in servicio nostro cum equis et armis" for a stated period (Rot. Litt. Pat., p. 32b); Thomas de Arcy (Rot. Lib., p. 44).

199 "et si scutagium illud captum fuerit" (Rot. Lib., p. 64).

200 Rot. Lib., p. 34. This is not the scutage of 1202, for which William had a writ of quittance.

201 The account for Norfolk and Suffolk is in Pipe Roll, $10 \mathrm{John}$, m. 19 . 


\section{UNDER JOHN AND HENRY III}

Scutage at $2 \mathrm{~m}$

M s d

$\begin{array}{lllllllllll}\text { Clerical tenants } & . & . & . & 818 & 0 & 0\end{array}$

Twenty-eight lay tenants (each 5 or $\begin{array}{llllllll}\text { more fees })^{202} & \text {. } & \text {. } & \text {. } & 986 & 7 & 2\end{array}$

Other lay tenants (each fewer than

5 fees, etc. $)^{203} \quad \cdot \quad \cdot \quad \begin{array}{lllll}611 & 5 & 0\end{array}$

Total

- 2415122

Fines Fees

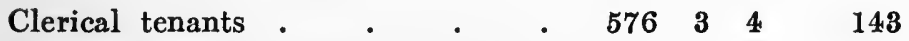

Thirty-seven lay tenants (each 5 or more fees $)^{204}$. $\quad . \quad$. 1466810

Other lay tenants (each fewer than 5

fees, etc. $)^{205} \quad$. $\quad$. $\quad$. $\begin{array}{llll}1881 & 8 & 6\end{array}$

Total

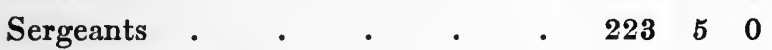

$\begin{array}{llllllll}\text { Additional }^{206} & . & . & . & 53 & 12 & 0\end{array}$

Grand total charged $\quad . \quad$. $6617 \quad 9 \quad 10$

Paid, 5 and 6 John $\quad$. $\quad . \quad 4748 \quad 6 \quad 11$

Fees taxed, about 2300.

Those who performed their service did not as a rule pay scutage. William Earl Marshal, and others were thus exempt. ${ }^{207}$ Robert de Gouiz of the honor of Gloucester was charged with $10 \mathrm{~m}$ on 5 fees, but was acquitted

202 Of these, 14 held 10 or more fees.

203 Of this sum, $76 \mathrm{~m}$ are on detached fees of great barons and $307 \mathrm{~m}$ on honors in hand, leaving about $228 \mathrm{~m}$ on tenants in chief.

204 Of this number, 18 tenants on honors in hand held 242 fees and were charged $580 \mathrm{~m}$, leaving 19 lay tenants in chief holding 314 fees charged with $880 \mathrm{~m}$.

205 Of this sum, $793 \mathrm{~m}$ are charged against 214 fees on honors in hand, leaving not over $1,088 \mathrm{~m}$ against 208 fees of tenants in chief.

208 Number of fees unknown.

207 William Earl Marshal, the earls of Chester, Leicester, Albemarle, Salisbury, Robert Fitz Walter, Saher de Quincy, Geoffrey Fitz Peter, Fulk Painel, Robert de Tresgoz, and Roger de Lacy were in France 


\section{STUDIES IN TAXATION}

because of service in the field. ${ }^{208}$ William of Albini was in the army in France; the sheriff had collected eight marks on his land in Oxfordshire. This sum the king ordered to be paid into the exchequer, but it was to be placed to the account of other debts, not scutage. ${ }^{209}$ Exceptions however occurred. Hervey Bagot was charged with 120 marks, ${ }^{210}$ yet he was in the king's service in France. ${ }^{211}$ Nicholas de Verdun who held one fee paid his scutage, ${ }^{212}$ though he was in the army. ${ }^{213}$

Not much scutage was charged against the greater lay tenants. Other men than Hervey Bagot (holding twenty fees or more) were Henry de la Pomeraie, 631/4 marks, of which only $8 \frac{1}{2}$ marks are recorded as paid $;{ }^{214}$ Aubrey de Ver, $601 / 4$ marks, all of which was paid $;^{215}$ and Henry de Oilli, $64 \mathrm{~m} 8 \mathrm{~s} 10 \mathrm{~d}^{216}$ Nearly all of the sum charged against clerical tenants was paid promptly. The remaining 610 odd marks of the scutage proper fell on some lesser tenants in chief, on detached holdings of great lords, on escheats, and on parts of baronies in hand. ${ }^{217}$ Some of these sums should be probably included in the main accounts of great lords, so that this amount is too large. In any case, it is much too small to represent a

(Rot. Litt. Pat., pp. 26-34; Roger of Wendover, Flores Historiarum, ed. Coxe, Engl. Hist. Soc., III, 173) and all receive writs of quittance in the Pipe Roll; Thomas de St. Valery was in France and had his scutage (Madox, I, 668, n. $x$ ).

208 "sed facit servicium suum in Normannia" (Pipe Roll, 5 John, Glouc., m. 3 d).

209 Rot. Lib., p. 34; see also Thomas de St. Valery (Madox, I, 668, n. $x$ ).

$1_{10}$ Pipe Roll, 5 John, Staff. No payment was made however.

211 William Salt Arch. Soc. Coll., III, 116.

212 Pipe Roll, 5 John, Staff.

213 William Salt, etc., III, 117.

214 Pipe Roll, 5 John, Devon, m. 6.

215 Ibid., 5 and 11 John, Essex and Hert.

216 Ibid., 5 John, Oxf., m. 15; ibid., 6 John.

217 See above, p. 55, note 203. 


\section{UNDER JOHN AND HENRY III}

general payment by rear-vassals while the king was obtaining also scutage, fine, or service from the tenants in chief.

As before, not many fines were levied on clerical tenants. Fifteen abbots and priors holding 93 fees paid fines-the chief being Abingdon, 80 marks on 30 fees $;{ }^{218}$ Tavistock, 40 marks on 16 fees $;^{219}$ Coventry, 25 marks on 10 fees $;^{220}$ Ramsey, in hand, 30 marks on 4 fees $;^{221}$ St. Albans, 100 marks on 6 fees. ${ }^{222}$ The amounts were paid promptly. Worcester was the only bishopric which fined, $123 \mathrm{~m} 3 \mathrm{~s} 4 \mathrm{~d}$ on about 50 fees. $^{223}$ The lay barons holding more than 20 fees who fined were: the earl of Warwick, 60 marks and his scutage on $102 \%$ fees $;^{224}$ Doun Bardolf, 60 marks on 25 fees ; ${ }^{225}$ Robert de Cardinan, 120 marks on 71 fees, and Roger de Valtort, 100 marks on 60 fees. $^{226}$ It will be noticed from the table given above that the fines of vassals holding five fees or over were at a rate of less than three marks per fee. ${ }^{227}$ The fine therefore did not represent the whole service of the holding in addition to the scutage. The bulk of the fines in rate and amount fell on the small tenants. About half of these held of honors like Tickhill, Peverel, Gloucester, etc., which were in hand. ${ }^{228}$ Usually the fine included the

218 Pipe Roll, 5 John, Berks, m. 4.

219 Ibid., Devon, m. 6 . The service was either 15 or 16 fees.

220 Ibid., War. and Leic., m. 3 d.

221 Ibid., Cant. and Hunt., m. 1.

222 Ibid., Essex and Hert., m. 10 d.

223 The original service was 60 fees (Round, Feudal England, p. 250).

224 Pipe Roll, 5 John, War. and Leic., m. 3 d.

225 Ibid., Notts. and Derby, m. 13 d.

226 Ibid., Cornw., m. 6 d. These held of the honor of Mortain which always paid scutage at five-eighths the ordinary rate.

227 The scutage on these holdings is included; fees on the honor of Mortain are not included.

228 See above, p. 55, notes 204, 205. 


\section{STUDIES IN TAXATION}

scutage, but there were some cases in which they were separate. $^{229}$

As noted in previous years, barons who received writs of quittance were entered as exempt in all counties where they held fees and therefore all their land, not their demesne only, was exempt from scutage. Thus Warren Fitz Gerold was quit in nine counties and the earl of Leicester in eleven. Sometimes, however, the sheriff collected part of the scutage for the exchequer, apparently taking it from the rear-vassal. Robert Marmiun was exempt, but paid a mark in Northamptonshire; Gilbert Peke also, but the sheriff collected one mark on his fee in Berks; that official took eight marks from the fees of William of Albini in Oxfordshire before the writ of quittance was received. ${ }^{230}$ The number of fees taxed indicates that this was not a common practice and the sums taken in most cases were small. It was illegal to collect from such men, and the sums could be and were recovered by the tenant. ${ }^{231}$ In those baronies which paid scutage or fine, the sheriff sometimes seems to have collected from the sub-tenants. The earl of Warwick had

229 E.g. as above, the earl of Warwick.

230 Rot. Lib., p. 34; see Thomas de St. Valery (Madox, I, 668, ก. $x)$.

231 In the account of allowances and payments made by the sheriff is the item: "et Hugoni de Ferrariis lxxvi sol. et $\mathbf{i}$ den. pro scutagio militum suorum capto in hoc comitatu" (Pipe Roll, 5 John, Wig., m. $4 \mathrm{~d}$ ). This may refer to the scutage of 1202 , but the point holds good, for he had writs of quittance both in 1202 and 1203. The $8 \mathrm{~m}$ collected from William of Albany are not returned to him, but they are placed to his credit at the exchequer for other debts, not scutage (Rot. Lib., p. 34). William de Braose was in France (Rot. Litt. Pat., pp. 27, 28, 31b) and was charged with $56 \mathrm{~m}$ of scutage on the honor of Berdestaple, $56 \mathrm{~m}$ on the honor of Torrington, and $56 \mathrm{~m}$ on the honor of Oliver de Tracy; of this sum $£ 3315 \mathrm{~s}$ 1d were paid and the rest pardoned (Pipe Roll, 5 John, Devon, m. 6 d). Thus he seems to have performed his service and paid part of his scutage, but as the amount paid was credited to William in another 


\section{UNDER JOHN AND HENRY III}

his whole account entered in the counties of Warwick and Leicester where part is entered as paid; part was also paid in three other counties. ${ }^{232}$ Yet that this was not a general practice is shown by the fact that the tenant in chief might account for the whole sum due from him in one county and be acquitted in the other counties where his fees lay. ${ }^{233}$ The law seems to have upheld the rear-vassal who refused to pay the scutage to the sheriff. In several cases a tenant protested that he was not an immediate vassal of the king and hence owed him no scutage. An inquest was held which showed that his contention was true, that he did not hold of the king in chief, and consequently the demand for scutage was remitted. ${ }^{234}$

debt, he really paid no scutage: 'et in perdonis ipsi Willelmo xxxiii li. et $x v$ sol. et $i$ den. per breve regis quia denarios illos reddidit de scutagio prædicto de quo habuit quietantiam" (Pipe Roll, 5 John, Heref., m. 4 d).

232 In Glouc., $f 47 \mathrm{~s} \mathrm{9d}$; in Berks, $6 \mathrm{~m}$ and in Northamp., $41 / 2 \mathrm{~m}$ (Pipe Roll, 5 John).

233 Thus Baldwin Wak accounts for $20 \mathrm{~m}$ for his whole barony in Linc. and is acquitted in Rutl. and War. and Leic.; Hervey Bagot $120 \mathrm{~m}$ in Staff., pays $9 \mathrm{~s}$ in Berks through the sheriff and is quit in War, and Leic., and Oxf.; Doun Bardolf $60 \mathrm{~m}$ fine on 25 fees in Notts. and Derby and quit in War. and Leic.; Ralph Musard $30 \mathrm{~m}$ in Glouc. and quit in Bucks and Bedf., Berks, and War. and Leic., and Oxford; the bishop of Winchester $120 \mathrm{~m}$ in Hants and quit in Berks; Elias Giffard $27 \mathrm{~m}$ on 9 fees in Glouc. and quit in Berks; all of the Pipe Roll, 5 John.

234 "Arnaldus de Bosco debet xx marc. de feodis $\mathrm{x}$ militum, sed non debet inde summoneri per inquisitionem factam que non tenet de rege sed de comite Leircestr' Wintonie" (ibid., 8 Joln, Glouc., in the account of the fourth scutage); the lord here had a writ of quittance. "Milo de Buteford debet iii marc. de feodis ii militum, sed W. Briewerre habet quietanciam de quo prædictus $M$. tenet feoda per breve G. filii Petri nec debet ulterius Milo inde summoneri sed W. Briewerre de quo idem M. tenet feoda [illa]" (ibid., 5 John, Devon, m. 6). "Sewal' filius Fulcherii debet i marcam (of the fourth scutage), sed non debet summoneri propter causam superius annotatam viz., per inquisitionem factam que non tenet prædictum feodum 


\section{STUDIES IN TAXATION}

The tenant in chief shifted the scutage onto the rearvassal. In the roll the fine is said to have been paid for this privilege. ${ }^{235}$ If a rear-vassal was exempted from scutage by the king, his lord was pardoned that amount. ${ }^{236}$ That the exchequer officials had the liability of the subtenant in mind is shown by the entry of the name of a tenant in chief in the different counties in which he held fees, either when payments were made or when the tenant received a writ of quittance. The fines were not shifted to the rear-vassal. Tenants on honors in hand paid fines to the king as though they were tenants in chief. ${ }^{237}$ The exchequer desired to have an exact account of all fees in each county, and information on this point was supplied by the sheriff. ${ }^{238}$ As usual some of the tenants in chief rendered their accounts directly at the exchequer, ${ }^{238}$ though the sheriff responded for considerable sums.

de rege sed de comite de Warewic'" (ibid., 6 John, m. 9, fourth scutage); in this case the lord owes fine and scutage this year. See also Ralph de Marci (ibid., 7 John, Essex and Herts, m. 16); William Fitz Geoffrey (ibid., 7 John, Notts. and Derby, m. 19 d); Richard Engaine (ibid., 9 John, Northamp., m. 13); Geoffrey de la Hose (ibid., 9 John, Berks, m. $18 \mathrm{~d}$ ); all in the accounts of the fourth scutage of these years.

235 "Episcopus Wigorn' $\mathrm{r}$ c de quater $\mathrm{xx}$ li. et xliii sol, et iiii den. de fine suo ne transfretet et pro habendo scutagio suo" (Pipe Roll, 5 John, Wig., m. 4 d).

${ }^{236}$ The abbess of Godestow was pardoned her scutage on half a fee held of Geoffrey de Chausi and he also was pardoned that amount (ibid., Berks, m. 4); the king held 3 fees of the bishop of Worcester who was therefore pardoned the scutage on them; William Marshal was pardoned 20s scutage on fees held of the same bishop and the latter was likewise exempt (ibid., Wig., m. 4 d).

${ }^{237}$ E.g. in the honor of Gloucester (ibid., m. 3 d).

238 David earl of Huntingdon 8m of scutage "sicut vicecomes dicit scilicet de iiii feodis" (ibid., m. $3 \mathrm{~d}$ ). This is also shown by the entry of men in counties other than where the heads of their baronies lie.

${ }^{239}$ Simon Basset and Richard de Vernun account for $10 \mathrm{~m}$ on 3 fees: "in thesauro $\checkmark$ marc. per manum prædicti Simonis" (ibid., Notts. and Derby, m. 13 d). 


\section{UNDER JOHN AND HENRY III}

Part at least of the fines were assessed by special justices. ${ }^{240}$

Notices of the tallage appear in thirteen counties. It was assessed by the itinerant justices ${ }^{241}$ and was collected by the sheriff. Sums were charged against persons, vills, and towns. Towns often assumed the work of repartition. ${ }^{242}$

The contributions from religious houses in 1203 were usually called dona. In Dorset, the title was "De auxilio abbatum et priorum." 'These dona were round sums exacted arbitrarily. The list of contributors included houses which held by military tenure and those which did not. In the first case the donum sometimes acquitted the tenant from paying scutage; sometimes another payment was made for the military service due. ${ }^{243}$ Part of the money was collected by the sheriff, ${ }^{244}$ though some houses responded to the exchequer by their own representa-

240 "qui finis intravit per os justiciar" (ibid., Linc., m. 9).

241 In Gloucestershire, the tallage was laid by Simon de Pateshull, William de Cantelu and Henry de Northampton (ibid., Glouc., m. 5 ); in the county of Northampton is the following title: "De ammerciamentis per $\mathbf{S}$. de Pateshull et socios suos; idem vicecomes $\mathbf{r}$ c de $C$ et quater $x x$ et $i x$ li. et $x i$ sol. et vii den. de misericordiis et tallagiis hominum et villarum quorum nomina et debita et causæ debitorum annotantur in rotulo que prædicti liberaverunt in thesauro" (ibid., m. $14 \mathrm{~d}$ ). These men seem to be the itinerant justices.

242 "Civitas Ebor' $r$ c de D marc. de taillagio; in thesauro $x v$ li. et episcopo Norwiz xxx li. ... et debet civitas" 4321/2 marks (ibid., York, m. 17). The tallage of these thirteen counties amounted to about $£ 1,500$, but this sum is incomplete for these bailiwicks, as it does not include sums in which the tallage was mixed with amercements.

243 Abbot of Evesham " $\mathrm{r}$ de $\mathrm{xl}$ marcis de dono et pro habendo scutagio suo" (Wigorn.); the abbot of Abingdon $40 \mathrm{~m}$ donum and $80 \mathrm{~m}$ fine on 30 fees (Berks); the abbey of Ramsey, in hand, $40 \mathrm{~m}$ de dono and $30 \mathrm{~m}$ fine on 4 fees (Cant. and Hunt.). These are from the Pipe Roll of $5 \mathrm{John}, \mathrm{m} .1,4,4 \mathrm{~d}$.

244 "Idem vicecomes $r$ c," etc. 


\section{STUDIES IN TAXATION}

tive. ${ }^{245}$ Seventy-three houses scattered over twenty-six counties contributed 1,577 marks.

Another levy of importance was the seventh of personal property. According to the chroniclers, this tax was taken on the pretext that the barons had deserted him after the return of John to England in December, $1203 .^{246}$ That there was disaffection was evident in the spring. ${ }^{247}$ During the year some of the tenants had withdrawn from John's service, but they were disseized and in November returned to their allegiance, receiving their lands again. ${ }^{248}$ The seventh was not levied however at the end of the year, but at the beginning of the summer of 1203. ${ }^{249}$ If at first it was a fine for default of service, it was apparently extended, when the levy was once begun, to all the tenants in chief and to the clergy as well. ${ }^{250}$ We do not know whether property was actually assessed. The donum already discussed may be the exaction from the clergy which is spoken of by the chroniclers. If so, no assessment of property was made, but lump sums were demanded under the name of an aid. ${ }^{251}$ The collection

245 The donum of the abbot of Westminster was paid in camera at Rouen, probably by the agent of the abbot (ibid., $6 \mathrm{John}$, Lond. and Midd., m. 8).

246 Wend., III, 173; Cogg., p. 144; Liebermann, Ann. S. Edm., p. 142. Wendover is the one who says that the king pretended it was on account of desertion.

247 Rot. Litt. Pat., p. 29a.

248 Rot. Lib., pp. 73, 74. For other cases of withdrawal from the king's service, see Rot. Norm., pp. 92, 93.

249 "Rex etc., Galfrido filio Petri salutem. Mandamus robis quod faciatis habere comiti Albemarl' septimam denariorum de terra sua. Teste me ipso apud Aurivall,' xviii die Junii" (Rot. Lib., p. 43); "Sciatis quod quietavimus dilectum et fidelem nostrum W. Maresc' comitem de Penbroc de septena de dominico suo; et ideo robis mandamus quod eum inde quietum 'esse faciatis. Teste me ipso apud Roth', x die Julii" (ibid., p. 47).

250 Thus William Earl Marshal who did not desert the king had to get a special writ of exemption; Wend., abore.

251 An item in the Pipe Roll suggests that an assessment was 


\section{UNDER JOHN AND HENRY III}

from the clergy was in charge of the archbishop of Canterbury, and from laymen, of the justiciar. ${ }^{252}$ Refusal to pay was punishable by fine, payment of which might be long deferred. ${ }^{253}$ The account of the levy is not in the Pipe Roll.

The tax is noteworthy for it shows that the attention of the government was directed more and more to the personal property of the kingdom as a source of revenue. Another example of taxation of this character is worth notice. In the Channel Islands, a fifth of revenues of one year was to be collected on the lands of bishops, abbots, clerks, knights, rear-vassals, and others to support the knights and sergeants who were defending the islands. ${ }^{254}$

\section{The Taxation of 1204}

After a disastrous year in Normandy, John returned to England in December, 1203, for men and money to continue the struggle against Philip Augustus. ${ }^{255}$ On January 2, 1204, the great council of lay and clerical tenants met at Oxford and the state of the king's affairs in France was discussed. An expedition to be led by John was proposed and the host was summoned to Ports-

made. In the compotus of the lands of William de Longchamp rendered by the custodian is the entry: "et in septima data regi per assisam 77s 2d de dominico ipsius Willelmi" (Pipe Roll, $6 \mathrm{John}$, Wilts, m. $19 \mathrm{~d}$ ).

252 Wend., above.

253 "Willelmus de Berton $\mathrm{r}$ c de $\mathrm{C}$ libris pro concelamento septime. In thesauro $£ 395 \mathrm{~s} 3 \mathrm{~d}$ et debet $£ 60$ 14s $9 \mathrm{~d}$ " (Pipe Roll, $12 \mathrm{John}$, Hants).

254 Rot. Litt. Pat., pp. 32b, 33b; Rymer, I, 89.

255 "sperans se copiosum exercitum . . . congregaturum et violentiam regis Philippi exterminaturum" (Cogg., p. 144); "omnes in regno Angliæ... nos efficaciter faciunt auxilium tam in veniendo corporaliter in servicium nostrum in Normanniam quam de militibus et pecuniis" (letter of John to the clergy of Ireland asking for an aid, February 10, 1204; Rymer, I, 90); Wend., III, 173. 


\section{STUDIES IN TAXATION}

mouth. ${ }^{258}$ For some reason, the invasion did not take place as planned. The king remained at home with the body of the host; a few of the barons were sent. ${ }^{257} \mathrm{Mer}$ cenaries were to have been employed, ${ }^{258}$ and when John decided not to go, money was still sent to hire soldiers abroad. ${ }^{259}$

To defray the expenses of the war, it was determined in the council to levy a scutage at the advanced rate of two and a half marks per fee. Religious houses which did not hold by military service were also compelled to contribute. ${ }^{200}$ This is a case of a levy put in charge before the expedition was to set out, and collected although the host was not dispatched.

The account follows:

Scutage at $2 \frac{1}{2} \mathrm{~m}$

$M$ s d

Clerical tenants . $\quad . \quad \begin{array}{llllll} & \text {. } & 553 & 10 & 0\end{array}$

Four lay tenants (each 5 or more

$\begin{array}{lllllllllllllll}\text { fees }) & \cdot & \cdot & \cdot & \cdot & 102 & 6 & 8\end{array}$

Other lay tenants (each fewer than 5

Total

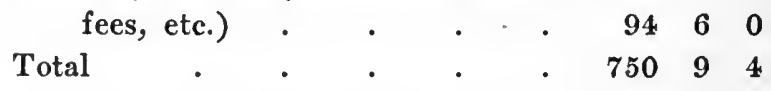

250 Rymer, above; "comites et barones se transfretaturos cum rege spoponderunt" (Liebermann, p. 144) ; Hist. de G. le Mar., 11. 12922-6, anno 1204; Miss Norgate suggests that this may be the summons of 1205 (John Lackland, p. 102); but an entry on the Pipe Roll implies that the host was summoned in 1204 and that writs of quittance were issued to those who came: "isti habent quietantiam præter eos qui inbreviati sunt ad transfretandum in rotulo que rex misit" (Pipe Roll, 6 John, Honor Glouc., m. 17 d).

257 The earl of Albemarle went with knights (Rot. Litt. Pat., p. 41b, May, 1204); Henry de Scalariis crossed with two knights apparently for his father, Hugh, who held 15 fees (Rot. Lib., p. 89).

258 "et Willelmo de Braiosa $10 \mathrm{~m}$ ad opus Leisani Walensis qui venit in servicium regis cum 200 Walensibus"; "et Cadwalano Walensi $10 \mathrm{~m}$ ad preparandumse ad transfretandum in servicium regis" (Pipe Roll, 6 John, Glouc.; Rot. Lib., p. 88).

259 28,000 marks (Cogg., p. 147).

260 Wend., III, 175; Liebermann, p. 143; Pipe Roll, 6 John, passim. 


\section{UNDER JOHN AND HENRY III}

\section{Fines}

Fees

Clerical tenants . $\quad . \quad . \quad \begin{array}{llll}1375 & 0 & 0\end{array}$

229

Twenty-three lay tenants (each 5 or

$$
\text { more fees })^{261} \quad \text {. } \quad \text {. } \quad \begin{array}{rrr}
1482 & 2 & 2
\end{array}
$$

Other lay tenants (each fewer than 5

Total

$$
\text { fees, etc. })^{262} \text {. . . . }
$$

- $2194 \quad 9 \quad 4 \quad 334$

$\begin{array}{lllllllll}\text { Sergeants } & \cdot & . & . & . & & 499 & 6 & 8\end{array}$

$\begin{array}{llllllll}\text { Additional }^{263} & . & . & 0 & 157 & 0 & 0\end{array}$

Abbots, priors (not military tenants) $\quad 748 \quad 0 \quad 0$

Total charged . . . . $\quad \begin{array}{llll}7207 & 0 & 10\end{array}$

Paid, 6 and 7 John $\quad . \quad$. 5291108

Fees taxed, not over 1300 .

It is seen that this levy was not a general tax although the host did not carry on the campaign. Of the men who were acquitted, some actually served and others appeared at Portsmouth at the appointed time ready to serve. ${ }^{264}$. The men who paid scutage or who fined were those who had sought exemption from the expedition while the host was gathering. Only about 300 fees paid the scutage proper and these were nearly all churchmen. Only one lay tenant holding more than ten fees (the countess of Warwick, fifteen fees) paid it. ${ }^{265}$ The bulk

261 Of these, 11 men holding 184 fees on honors in hand paid $673 \mathrm{~m}$, leaving 12 tenants in chief charged with $809 \mathrm{~m}$ on 165 fees.

262 Of this sum, $1,207 \mathrm{~m}$ were charged against 224 fees on honors in hand, leaving not more than $987 \mathrm{~m}$ charged against 110 fees of tenants in chief.

263 Number of fees unknown.

264 The earl of Albemarle who served and Hugh de Scalariis who sent part of his service (above, p. 64, note 257) were acquitted of scutage. "Isti habent quietantiam præter eos qui inbreviati sunt ad transfretandum in rotulo que rex misit" (Pipe Roll, $6 \mathrm{John}$, Honor Glouc., m. $17 \mathrm{~d}$ ).

265 The countess of Perche paid $471 / 2$ marks on 19 fees in Kent, but she had made a special arrangement with the king to pay scutage whenever it should be levied (Pipe Roll, 6 John, m. 3 d, m. 16 d; Rot. Lib., p. 74). 


\section{STUDIES IN TAXATION}

of the levy consisted of fines. Of churchmen, only abbots and priors were so charged ( $2291 / 2$ out of 318 fees). The average rate on them was very heavy, about six marks per fee. The abbey of Ramsey, in hand, paid $100 \mathrm{~m}$ on 4 fees; the abbot of St. Edmunds, $100 \mathrm{~m}$ of scutage and $120 \mathrm{~m}$ de dono; the abbot of Peterborough, $150 \mathrm{~m}$ of scutage and $100 \mathrm{~m}$ de fine; the abbot of St. Albans, $100 \mathrm{~m}$ on 6 fees. ${ }^{268}$ In general, sums levied on religious houses were heavier than before. Of the greater lay tenants, Hervey Bagot paid $20 \mathrm{~m}$ and his scutage on 60 fees; ${ }^{267}$ Roger de Valtort, 200m on 60 fees; Robert de Cardinan, $300 \mathrm{~m}$ on 71 fees $;^{288}$ Hubert Fitz Ralph, $105 \mathrm{~m}$ on 15 fees, and Robert de Novo Burgo, $100 \mathrm{~m}$ on 15 fees. ${ }^{269}$ The fines on tenants holding five fees or over average more than four marks per fee. Tenants holding fewer than five fees each paid heavier fines, nearly seven marks per fee. ${ }^{270}$ Sometimes the fine and scutage formed a lump sum; sometimes the tenant paid a fine in addition to his scutage. ${ }^{271}$ In the latter case, the sheriff perhaps collected the scutage from the rear-vassals. ${ }^{272}$ The pro-

286 Pipe Roll, 6 John, Cant. and Hunt., Norf. and Suff., Northamp., Essex and Hert., m. 3 d, 9 d, 11 d, 18 d.

267 Ibid., Staff.

268 Ibid., Cornw., m. 4. The king granted Robert the right to collect $21 / 2$ marks per fee from each of his tenants (Rot. Litt. Claus., I, 2b) ; this honor of Mortain usually paid at five-eighths the regular rate; on this occasion, the vassals had to help pay the fine of their lord.

269 Ibid., Notts. and Derby, Dors. and Somers., m. 13 d, 14 d.

270 See above, p. 65.

272 Sometimes the fine is only for his demesne and the scutage is only for the knights whom he had enfeoffed; William de Heliun accounts for $6 \mathrm{~m}$ "de dominico suo" and for $221 / 2 \mathrm{~m}$ "de scutagio militum suorum" (ibid., Essex and Hert., m. $3 \mathrm{~d}$ ). This barony in 1166 consisted of 10 fees, nine enfeoffed and one on the demesne (Red Book, I, 357).

272 "Comitissa Herefordiæ $\mathrm{r}$ c de $\mathrm{L}$ marcis de dóminico suo et scutagium capiatur de hominibus suis" (Pipe Roll, 6 John, Glouc., m. 12); her scutage was $36 \mathrm{~m} \mathrm{40d} \mathrm{"de} \mathrm{scutagio} \mathrm{militum} \mathrm{suorum} \mathrm{de}$ 


\section{UNDER JOHN AND HENRY III}

cedure depended apparently on a bargain between the king and the tenant. That the exchequer did not arbitrarily take scutage from the sub-tenant without the knowledge or consent of his lord is shown by cases in which it was demanded, but remitted when it was found that the tenant was a rear-vassal. ${ }^{273}$ If a tenant in chief did not secure a writ of quittance, the sheriff might collect some scutage from his lands. Later, when he had secured the necessary writ, the money was returned to him. ${ }^{274}$ If a tenant refused to pay the scutage, the sheriff did not take it from the rear-vassal but disseized his lord. ${ }^{275}$ The

feodis xir militum et dim." (ibid., Kent, m. $16 \mathrm{~d}$ ). The form of this entry suggests that the king collected scutage from her knights. Yet it is doubtful whether this was the case. She held part of the barony of Walter de Mayenne which in 1166 consisted of 20 fees of the old enfeoffment, $11 / 2$ fees of the new enfeoffment, and 9 fees on the demesne (Red Book, I, 195; servitium debitum, 30 fees, Round, Feudal England, p. 254, note 80). In 1201, 1202, and 1203, she accounted for $141 / 2$ fees, or half of 29 fees, the sum of the old enfeoffment and the demesne. Thus apparently all of the 141/2 knights were not enfeoffed so that the sheriff could not collect from them. The entry cited at the beginning of this note probably means that the countess paid all the scutage due from her lands in addition to a fine.

273 In the list of those granted writs of quittance is a name now blurred of one who is quit "quia nichil tenet de rege" (Pipe Roll, 6 John, Bucks and Bedf., m. 2); "Ricardus de Bellocampo et Milo frater ejus . . . quieti sunt per inquisitionem factam qui nichil tenent de rege" (ibid., Notts. and Derby, m. 13 d); Gilbert de Hastings is quit in 1207 of the fourth and fifth scutages "per inquisitionem quia nichil tenet de rege" (Lancashire Pipe Rolls and Early Charters, ed. W. Farrer, p. 214). He held of the barony of Penwortham which came into the king's hand in 1200. In 1205, it was turned over to the constable of Chester and this was evidently the reason why Gilbert was excused payment by the exchequer in 1207 of the two scutages mentioned (ibid., pp. 139, 146, 161, 379).

274 The sheriff was ordered to allow Robert de Tresgoz to have his scutage "et si aliquid scutagii captum est idem que sit ad scaccarium solutum idem ei de aliis denariis reddi facias et nos tibi alias idem locari faciemus" (Rot. Lib., p. 93).

275 The archbishop of York had been disseized "occasione scutagii que ipse debet domino regi" (Rot. Litt. Claus., I, 11b). 


\section{STUDIES IN TAXATION}

sub-tenant, however, ultimately paid the scutage, whether his lord paid scutage or fine, or served. This was done by the royal writ de scutagio habendo. ${ }^{276}$

A charge, amounting to 748 marks, appears in the roll against twenty-six religious houses which did not hold by military tenure. Probably the increase in the fines of those houses which held by knight service was due to this exaction from the regular clergy. ${ }^{277}$

There are accounts of a tallage in fourteen counties, amounting to about 5,000 marks. ${ }^{278}$ Sometimes the town fined in a lump sum and sometimes the assessment was made per capita by the justices. ${ }^{279}$ In the latter case, a roll of the sums charged against all persons was drawn up in duplicate, one copy was sent to the exchequer and the other delivered to the sheriff who made the collection. ${ }^{280}$

276 Robert de Cardinan, the archbishop of York (ibid., I, 2b, 11b); William de London and Robert de Tresgoz (Rot. Lib., pp. 88, 93). Tenants who obtained writs of quittance on account of service (see above, p. 65, note 264) probably receired this right. The writ sometimes, not always, stated the rate which was the rate of scutage of the year. The tenant in chief was not to collect more than this amount: Ralph Teisun, warden of the lands of Henry de Tilli, had apparently violated this rule and the additional money collected from the sub-tenants was ordered to be returned (Rot. Lib., p. 92).

${ }^{27}$ Sometimes the donum on a house which held by military service was called a fine.

278 It was not always called a tallage: "Cives Lond' $M$ li. pro fine passagii" (Pipe Roll, 6 John, Lond. and Midd., m. 8). In the total sum is included a tallage of $£ 10418 \mathrm{~s}$ in Oxfordshire, which first appears in the roll of $9 \mathrm{John},(\mathrm{m} .5)$, but seems to belong to the tallage of 1204 .

279 "Homines de Solopesbiria r c de quater xx marcis de taillagio facto per S. de Pateshull' et Willelmum de Cantel' in villa de Solopesbiria per capita" (ibid., $6 \mathrm{John}$, Salop, m. $12 \mathrm{~d}$ ). Probably these men were the itinerant justices, for they also laid the amercements in Salop.

280 "Idem vicecomes $\mathrm{r}$ c de $\mathrm{xv}$ li. et xiiii sol. et viii den. de taillagiis hominum de villa de Hereford' quorum nomina et debita annotantur in rotulo que prædicti (tallagers) liberaverunt in thesauro" (ibid., Heref., m. 2 d). 


\section{UNDER JOHN AND HENRY III}

Another levy which was collected at this time was the fifteenth on the property of merchants. The amount yielded by this tax furnishes a basis for estimating the relative importance of scutage and tallage in the budget of the year, for these three levies were all part of the extraordinary revenue. Such a comparison is fairer than one with the ordinary income. In the Pipe Roll of 1204 an account of the fifteenth is rendered for a period of about sixteen months; the sum received was $£ 4,958 \mathrm{rs}$ $31 \frac{1}{2} \mathrm{~d}^{281}$ The assessment and collection of the fifteenth in the different towns was in general charge of three men appointed by the king. Under them, six, seven, or more men of each port, one knight, and one clerk were to be chosen, called the bailiffs (ballivi) of the fifteenth. These latter had direct charge of the tax in their own town and were responsible to the three chief supervisors. They were to draw up a roll containing the names of the merchants and a list of their payments. ${ }^{282}$ Here is another example of a levy on personal property. The use of local machinery to assess and collect the tax is seen to have been a royal device to get at a fair valuation of property.

\section{The Taxation of 1205}

In June, 1205, a very large army was gathered for the invasion of Poitou and Gascony. ${ }^{283}$ The expedition was opposed by the barons and the king was obliged to yield. Instead, there was sent a picked force of knights and

281 Pipe Roll, 6 John, Kent, m. 16 d; Madox, I, 722, n. i. 282 Rot, Litt. Pat., p. 42.

283 "cum maximo et nobili exercitu" (Cogg., p. 152); "exercitum grandem" (Wend., III, 182) ; militumque et peditum populus innumerabilis" (Gervase of Canterbury, Historical Works, ed. Stubbs, Rolls Series, II, 98); Annales Monasterii de Waverleia, ed. Luard, Rolls Series, p. 256. 


\section{STUDIES IN TAXATION}

barons under the leadership of the earl of Salisbury and John's natural son, Geoffrey, to relieve La Rochelle, and the body of knights remained at home. ${ }^{284}$ In connection with this expedition, fines and scutages were levied, a tallage was taken in several counties, and some sums were received from religious houses, though only a few of these appear in the roll. ${ }^{285}$

The scutage (at two marks) was put in charge, at the latest, immediately after the knights were dismissed, ${ }^{288}$ but some fines were made while the host was waiting to sail, and it is possible that the scutage also was levied at that time. ${ }^{287}$ Inasmuch as only a small force of knights was sent, we should expect to find an unusually large number of fees contributing. Such is the case, as the following table will show:

Scutage at $2 \mathrm{~m}$

$M$ is d

$\begin{array}{lllllll}\text { Clerical tenants } & \text {. } & \text {. } & \text {. } & 106010 & 8\end{array}$

Sixty-one lay tenants (each 5 or more fees) $)^{288}$

3444 $6 \quad 0$

Other lay tenants (each fewer than

5 fees, etc.) ${ }^{289} \quad$. $\quad . \quad . \quad 954129$

Total

. $\quad .546029$

284 "quosdam ex proceribus Angliæ fore mittendos cum strenuis militibus ... Rex denuncians principibus atque militibus quatinus ad propria remearent" (Cogg., p. 153).

285 Wend., abore: "pro communi auxilio abbatum Angliæ" (Rot. Litt. Claus., I, 52a, 32b, 59b).

280 "Reversus autem rex cepit de comitibus, baronibus, militibus et viris religiosis pecuniam infinitam" (Wend., above); writs granting tenants the right to collect scutage from their vassals were issued in July (Rot. Litt. Claus., I, 43b).

287 The earl Warenne makes a fine of $120 \mathrm{~m}$ (60 fees so that it really scutage) that his knights shall not cross, to be paid in camera in the octave of St. John, that is, before the host was to sail and before it was dismissed. The archbishop of Canterbury also fined 


\section{UNDER JOHN AND HENRY III}

Fine Fees

$\begin{array}{llllllll}\text { Clerical tenants }^{290} & \text {. } & \text {. } & 740 & 0 & 0 & 116\end{array}$

Fifty-two lay tenants (each 5 or

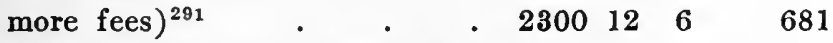

Other lay tenants (each fewer than

Total 5 fees, etc.) $)^{292} \cdot \quad . \quad .180147$

$\begin{array}{llllllll}\text { Additional }^{293} & \text {. } & \text {. } & \text {. } & 808 & 1 & 8\end{array}$

Sergeants . $\quad . \quad \begin{array}{rrrrrr} & \cdot & 0 & 80 & 1 & 8\end{array}$

Grand total $\quad . \quad$. $\quad .10690 \quad 910$

Paid, 7 and $8 \mathrm{John} \quad . \quad$. 74121011

Fees taxed, nearly 4000 .

In many counties, no list of writs of quittance is given and in the others comparatively few names appear of tenants who were exempt. As we know that only a small number of knights performed their service, we may conclude that the writs of quittance correspond quite closely to the tenants who served in the host. Furthermore, we

in $200 \mathrm{~m}$ to be paid at the same time (Rot. Obl., p. 366). These entries are given under the year 1206, but the next item in the roll is of 1205 and refers to this scutage; and the Pipe Roll of 1205 makes the earl fine in $120 \mathrm{~m}$.

288 Six men are tenants on honors in hand holding 182 fees; the following holdings respond in one amount through the sheriff or a custodian: Gilbert de l'Aigle 35 fees, rape of Hastings $621 / 2$ fees, the earl of Warwick, $1021 / 3$ fees.

289 Of this sum, $187 \mathrm{~m}$ were on scattered fees of great barons and $424 \mathrm{~m}$ on honors in hand, leaving not over $350 \mathrm{~m}$ on tenants in chief.

290 Of this sum, $500 \mathrm{~m}$ were on the abbot of St. Edmunds and were only partly a fine for service. He paid $500 \mathrm{~m}$ "pro passagio militum suorum et pro habendo scutagio suo et de auxilio de quolibet feodo militis $\mathbf{i}$ marc. et pro habenda una feria octo dierum apud Becles et pro habendo uno cuneo apud S. Edmund' cum cambio" (Pipe Roll, 7 John, Norf. and Suff., m. 19b; Rot. Obl., p. 293).

291 Of this sum, 17 men holding 115 fees on honors in hand were charged with $510 \mathrm{~m}$, leaving 35 lay tenants in chief who fined.

292 Of this sum, $860 \mathrm{~m}$ are charged against 157 fees on honors in hand.

293 Number of fees unknown. 


\section{STUDIES IN TAXATION}

know that some of the men who are given as quieti accompanied the army. ${ }^{294}$

Nearly all the churchmen were taxed this year; only three however fined: the archbishop of Canterbury, $200 \mathrm{~m}$ on 60 fees $;^{295}$ the abbot of Tavistock, $40 \mathrm{~m}$ on his 15 or 16 fees $;{ }^{296}$ the abbot of St. Edmunds, $500 \mathrm{~m}$ on 40 fees. Among the greater barons who paid scutage were: Earl Roger, 125 1/4 fees; Earl Warenne, 60 fees ; $^{297}$ the earl of Arundel, 84 $1 / 2$ fees $;^{298}$ Earl Ferrers, 68 $1 / 2$ fees ; ${ }^{298}$ William de Albini, 33 fees; $;^{300}$ Warren Fitz Gerold, about $\mathbf{5 3}$ fees $;^{301}$ Walter de Lacy, $51 \frac{1 / 4}{4}$ fees $;^{302}$ William de Mowbray, 60 fees $;^{303}$ Hervey Bagot, 60 fees. ${ }^{304}$ The sums were not merely charged; they were partly paid. An increased number of the greater lay tenants paid fines. Those holding 20 or more fees were: Thomas de St. Valery, $100 \mathrm{~m}$ fine and the scutage of 10 fees; $;^{305}$ Robert Fitz Walter, $20 \mathrm{~m}$ fine and the scutage of $631 / 2$ fees; $;^{308}$ the earl of Chester, $100 \mathrm{~m}$ fine which includes his scutage on $40 \frac{1}{2}$ fees; $;^{307}$ Simon de Beauchamp, $100 \mathrm{~m}$ fine which

294 The earl of Salisbury who led the expedition is quit (Pipe Roll, $7 \mathrm{John}$, Wilts, m. 14 d); Robert de Turnham was fighting in France this year (Cogg., p. 152) and is quit (Pipe Roll, 7 John, York, m. 5 d); Gilbert Gaunt had his scutage because his brother was in the king's service (ibid., Notts. and Derby, York, Linc., m. 5 d, 18 d, 19 d; Rot. Litt. Claus., I, 46a).

295 Rot. Obl., p. 366.

298 Pipe Roll, 7 John, Devon, m. 2 d.

297 Ibid., Norf. and Suff., m. 19b.

298 Ibid., Suss., m. 9.

299 Ibid., Notts. and Derby, m. 19 d.

300 Ibid., War, and Leic., m. 3 d.

301 Ibid., Essex and Herts., m. 15.

302 Ibid., Heref., m. 22 d.

303 Ibid., York, m. 5 d.

304 Ibid., Staff.

305 Ibid., Oxf., m. 12. He usually paid on 25 fees.

306 Ibid., Essex and Hert., m. 15.

307 Ibid., York, m. 5 d. 
includes his scutage on $451 / 21 / 4$ fees $;^{308}$ Ralph de Sumery, $20 \mathrm{~m}$ fine plus his scutage on 50 fees $;{ }^{309}$ Norman de Arescy $50 \mathrm{~m}$ fine which includes his scutage on 20 fees. $^{310}$ Except the first, the fines were not heavy. The separation of the fine from the scutage seems to imply that the former was for the personal service of the tenant in chief. ${ }^{311}$ The heaviest fines fell on the small tenants. The average rate per fee (including the scutage on those fees which fined) on the lesser lay tenants (each fewer than five fees) was about seven marks, while on the larger lay holdings (each five fees or more) it was about three marks. ${ }^{312}$

This scutage was not a general tax levied by the exchequer on rear-vassals. The exemption from a money contribution of those tenants who received writs of quittance extended to all their fees. ${ }^{313}$ But did the sheriff ordinarily collect from the rear-vassals of those tenants who were liable for scutage or fine who did not secure writs of quittance, or did the tenant in chief respond for his whole tax either to the sheriff or to the exchequer? Sometimes the former was the case. The sheriff paid in at the exchequer sums which seem to have been paid him

308 Pipe Roll, 7 John, Bucks and Bedf., m. 6.

309 Ibid., Staff.

310 Ibid., Linc., m. $18 \mathrm{~d}$.

311 Thirteen out of twenty-three tenants, each holding ten or more fees, separate the fine from the scutage. In the small holdings there is no separation.

312 See above, p. 71 .

813 "Mandatum est vicecomiti Bukingh' quod faciat habere Sahero de Quency scutagium suum in balliva sua. Similiter mandatum est aliis vicecomitibus in quorum ballivis terras habet" (Rot. Litt. Claus., I, 43b). Gilbert Gaunt has writs of quittance in three bailiwicks: Notts. and Derby, York, and Linc. If a tenant has not secured such a writ, scutage would not necessarily be taken from him. Hugh de Nevill was charged with $10 \mathrm{~m}$ scutage; no payment was made and later a note is added: "sed postea habuit quietantiam per breve regis quod est in forulo marescalli in anno sequenti" (Pipe Roll, 7 John, Glouc., m. 8 d); see also Peter de Stokes, m. 7 d. 


\section{STUDIES IN TAXATION}

by the rear-vassal, though perhaps he received them from the steward of the tenant in chief. ${ }^{314}$ But many of the sums received in this way were small, due from detached fees of baronies, the heads of which lay in other counties. ${ }^{315}$ The government seems to have recognized that it could not collect from the sub-tenant. In Devonshire eleven men were charged with scutage, but the accounts were crossed off because an inquest showed that the men held nothing in chief of the king. ${ }^{316}$ The case of Cecilia de Crevequor illustrates this point. She was disseized because she had not fined with the king for her passage. She then fined in forty marks, received back her lands, and was granted the right to collect scutage from her tenants. It is to be observed that in her case the sheriff dealt directly with the tenant in chief and collected no

$314 E . g$. the sheriff accounts for $2 \mathrm{~m}$ of Walter Clifford in this county, $2 \mathrm{~m}$ on one fee of the abbot of Hide, etc. (Pipe Roll, 7 John, Berks, m. 6 d); see like cases in Rutland, Warwick, Bucks and Bedf. Orders exist to the sheriff to return any moneys which he may have collected to a tenant in chief who has obtained the right to collect his scutage from his vassals, e.g. for the earl of Clare (Rot. Litt. Claus., I, 43b). Henry de Pinkeny accounts for $34 \mathrm{~m}$, his full charge, in Northamp., where he pays $12 \mathrm{~m}$ this year, for $34 \mathrm{~m}$ in Bucks and Bedf., where he pays $2 \mathrm{~m}$ and the sheriff accounts for him for $7 \mathrm{~m}$ which is paid in Berks (Pipe Roll, $7 \mathrm{John}, \mathrm{m} .6,6 \mathrm{~d}, 21 \mathrm{~d}$ ).

315 Sometimes the sheriff of the county where the head of the barony lies accounts for the scutage; this does not necessarily mean that he collects it from the rear-rassals; the tenant in chief may have paid it to him to deliver at the exchequer. The sheriff continually reports the number of fees held by tenants in chief in his district: "Comes Ebroic debet scutagium sed vicecomes dicit que nullum habet feodum in comitatibus suis" (ibid., Bucks and Bedf., m. 6) ; William Marshal $5 \mathrm{~m}$ on $21 / 2$ fees "sicut vicecomes dicit" (ibid., Berks, m. 5a); Geoffrey de Say (ibid., m. 6).

816 "sed omnes isti non debent summoneri quia per inquisitionem factam nichil tenent de rege in capite" (Pipe Roll, 9 John, Notts. and Derby); also, wife of John de Crioil (ibid., $10 \mathrm{John}, \mathrm{War}$, and Leic., m. 3). 
scutage from sub-tenants. ${ }^{317}$ Further, for his fees lying in one county a tenant often accounted in another, showing that there was no collection by the sheriff. ${ }^{318}$ The tenants in chief would oppose such a collection, for they preferred to do the work themselves. When they fined for their passage, they were allowed not only to remain at home, but also to collect scutage from their tenants. ${ }^{319}$ Those tenants who did not fine, but paid scutage only, obtained the same privilege. ${ }^{320}$

317 Rot. Obl., p. 302; another case of disseizin, Henfridus de Criketot (ibid., p. 301).

318 Earl Ferrers owed $111 / 2 \mathrm{~m}$ in Berks "sed respondet in Notinghamsira" (Pipe Roll, 7 John, Berks, m. 5a); Eustace de Vescy held fees in York, Northumberland, and Norfolk and Suffolk; he pays $4 \mathrm{~m}$ in York, pays fine and scutage in the second and is quit in the last; William Earl Warenne is quietus in Essex and Herts., is charged with $120 \mathrm{~m}$ fine in Norf. and Suff., with $120 \mathrm{~m}$ fine in Bucks where the roll adds "sed requirendus est in Surreia," and in Surrey with $120 \mathrm{~m}$ "qui requirebatur" in Bucks. Robert Fitz Walter "debet iii marc. de eodem (i.e. scutage of 1205), sed non debet summoneri quia respondit de toto hoc scutagio in Essex" (ibid., $10 \mathrm{John}$, Cant. and Hunt., m. 9); William de Cornhull (ibid., 7 John, m. 5a).

319 "Roaldus constabularius Richemund" dat domino regi $80 \mathrm{~m}$ pro passagio suo et pro habendo scutagio suo" (Rot. Obl., p. 288). The separation of the fine from the scutage does not mean that the tenant in chief pays the king a fine for his personal service while the king collects scutage from the sub-tenants, unless there is a bargain to that effect. Robert Fitz Walter fined in $20 \mathrm{~m}$ in addition to his scutage and he collected the scutage with his own hand from his vassals (Rot. Litt. Claus., I, 43b); a similar case in Matilda de Chandos (Rot. Obl., p. 304).

320 William de Mowbray paid only scutage this year (see above, p. 72, note 303; he received a writ to collect his scutage by his own hand and respond for it at the exchequer (Rot. Obl., p. 306); the archbishop of York paid scutage only and received a like writ (Rot. Litt. Claus., I, 46a); the earl of Arundel paid scutage only in 1205; one of his tenants was pardoned his scutage (Roger de la Zouche, $16 \mathrm{~m}$ ) and the earl was likewise acquitted this amount, so that he must have collected from his vassals (Pipe Roll, 7 John, Suss., m. 9) ; for William de Albini and the earl of Clare (Rot. Litt. Claus., I, 43b). "Johannis filius Hugonis habet scutagium suum et dominus rex illud computari faciet dominis de quibus ipse tenet" (ibid., 46a). 


\section{STUDIES IN TAXATION}

All this shows, moreover, that the scutage was shifted by the lord to his vassal, though to do so required the king's consent, the sheriff being instructed to allow the tenant to collect his scutage. The sheriff was also to report the amount. ${ }^{321}$ Compliance with this order may explain the entries in the Pipe Roll of amounts written opposite the names of tenants with no statement concerning payment. In this way the king had a check on his tenants. But the writ to the sheriff meant more than this; if the tenant were unable to force his vassals to pay, the sheriff came to his aid and distrained them. ${ }^{322}$ The fine of the tenant in chief did not fall upon the rearvassal, who was liable for scutage only ${ }^{323}$ The king dealt directly with the rear-vassal in another way, by pardoning him his scutage. In that case, his lord was also acquitted of that amount. ${ }^{324}$

Returns of a tallage were made in twenty-six counties. Some of the shires were the same as those tallaged in 1204 ; in part of these the accounts seem to have been additional returns of the same tax; in others a new levy was made. ${ }^{325}$ The assessment was made by the itinerant justices and was collected by the sheriff. ${ }^{326}$ Some towns

321 The writs for William de Albini and the archbishop of York (Rot. Litt. Claus., I, 43b, 46a).

322 The writ for the archbishop of York (ibid., 46a).

323 Thus when the tenant in chief fined in a lump sum for his passage and his scutage, he could collect only scutage from his vassals (Rot. Obl., p. 288); when he fined in a certain sum and his scutage, the latter is evidently the sum which the rear-vassals are to pay; see the case of Robert Fitz Walter (see above, p. 75).

324 See above, p. 75.

325 Worcester pays $£ 43$ 3s $11 \mathrm{~d}$ in 1204 and $40 \mathrm{~m}$ in 1205 (Pipe Roll, 6 and $7 \mathrm{John}$, Wig.); Salop $80 \mathrm{~m}$ in 1204 and $50 \mathrm{~m}$ in 1205 (ibid., Salop); Hereford to the sheriff $58 \mathrm{~m} 10 \mathrm{~s} 4 \mathrm{~d}$ in 1204 and $50 \mathrm{~m}$ in 1205 (ibid., Heref.).

326 In Kent, the tallage was laid by the justiciar, "per justiciarium" (Pipe Roll, 7 John, Kent, m. 9 d). In Worcestershire is the title: "de amerciamentis et taillagiis per Robertum de Berkelai et Johannem 


\section{UNDER JOHN AND HENRY III}

and vills had lump sums charged against them, that is, they agreed to pay a certain sum and settle the incidence themselves; in others the assessment was made per capita. $^{327}$ The amount charged was over $3,000 \mathrm{~m}^{328}$

\section{The Taxation of 1206}

This year John was able to carry out his invasion of France. On May 27, he sailed for La Rochelle with a great army. ${ }^{329}$ The campaign lasted till October 6, or over four months. ${ }^{330}$ The taxation of the year consisted of a scutage at twenty shillings per fee with fines ne transfretet and a tallage. ${ }^{331}$ The following is the account:

Scutage at 20s

$M \quad s \quad d$

Clerical tenants . $\quad$. $\quad$. $\quad \begin{array}{llll} & 251 & 3 & 4\end{array}$

Lay tenants (each 5 or more fees) . $\begin{array}{llll}112 & 10 & 0\end{array}$

Other lay tenants (each fewer than 5

Total

fees, etc.) . . . . 180114

filium Hugonis"; the sheriff accounts for these sums at the exchequer (ibid., m. 22).

327 Ibid.; e.g. in Devon, there are many persons in the roll charged with tallage, but the city of Exeter accounts for $£ 100$ and three palfreys (ibid., Devon, m. 2 d).

328 In this sum are included the following tallages:

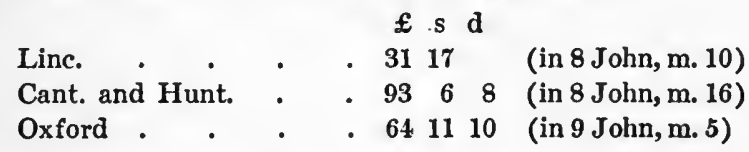

These seem to belong to the tallage of 1205 .

329 Rot. Litt. Pat., pp. 62b, 64b, 65a; Wend., III, 186; Liebermann, p. 144; Wav., p. 258; Annales Monasterii de Wintonia, ed. Luard, Rolls Series, p. 79.

330 Rymer, I, 95.

331 There are also some references to a contribution by religious houses, irrespective of their tenure. They may be deferred entries 


\section{STUDIES IN TAXATION}

Fine Fees

$\begin{array}{lllllllll}\text { Clerical tenants } & \cdot & . & . & & 670 & 11 & 7 & 220\end{array}$

Thirty lay tenants (each 5 or more

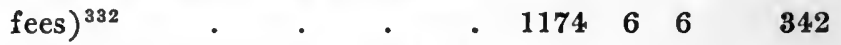

Other lay tenants (each fewer than 5

Total

$$
\text { fees, etc. })^{333}
$$$$
\text { - } \begin{array}{llll}
1349 & 5 & 4 & 306
\end{array}
$$

Additional $^{334}$

Sergeants .

Total charged

Paid, 8 and 9 John

Fees taxed, not over 1500 .

If a tenant performed his service, he obtained a writ of exemption from scutage. A considerable number of barons and knights went from Devonshire and Cornwall, as nine naves were employed to carry them. The only fees taxed in these counties were those of the abbot of Tavistock, the bishop of Exeter, and four small tenants who held together about ten fees. The list of writs of quittance is long and complete; it included William Briwerre, Henry Fitz Count, and Reginald de Mohun who led the fleet. ${ }^{335}$ The earl of Salisbury, Hugo de Chaurces, and Paganus de Chaurces were in the campaign $^{336}$ and received writs of quittance. ${ }^{337}$ The scutage

of the dona of 1205. The abbot and convent of Cernel,' $30 \mathrm{~m}$ "ut sint quieti de communi auxilio"; the abbot of Burton, $40 \mathrm{~m}$ "de promissione ad sustentationem regni"; the abbot of Peterborough, 60m (Rot. Obl., pp. 343, 354, 356).

332 Of this sum, 9 men who held 56 fees on honors in hand were charged with 172 marks.

333 There were $688 \mathrm{~m}$ charged against 197 fees on honors in hand, leaving $661 \mathrm{~m}$ on 109 fees of tenants in chief.

334 Scutage or fine; number of fees unknown.

335 Pipe Roll, 8 John, Devon, Dors. and Somers., m. 13 d, 14, 14 d. 336 "De præstitis factis in Pictavia: Comes Sarresbiriæ 100m," etc. (ibid., Wilts, m. $18 \mathrm{~d}$ ).

${ }^{337}$ The earl of Salisbury in Wilts and Yorkshire; Paganus in Bucks and Dorset. 


\section{UNDER JOHN AND HENRY III}

proper was not very important. No great lay tenant paid it, though several of the chief prelates did so (the bishops of Hereford, Bath, Exeter, Salisbury, and Worcester, and the abbot of Hide). No bishop was charged with a fine. The fines on religious houses amounted to about double what their scutage would have been. In some cases it might be much more than this; the abbot of Malmesbury paid $21 \mathrm{~m} 10 \mathrm{~s} 6 \mathrm{~d}$ on his three fees. ${ }^{38}$ Lay tenants holding 20 fees or more who fined were: Walter de Lacy, $40 \mathrm{~m}$ fine and $£ 51$ 5s scutage $;^{339}$ Thomas de St. Valery, $150 \mathrm{~m}$ fine on 25 fees $;{ }^{340}$ Gilbert Peke, $40 \mathrm{~m}$ fine and $£ 19$ 1s $6 \mathrm{~d}$ scutage $;^{341}$ and Hervey Bagot, $12 \mathrm{~m}$ fine and $45 \mathrm{~m}$ scutage. ${ }^{342}$ The fines fell heaviest on the men with small holdings, many of whom were not tenants in chief, but tenants on honors in hand..$^{343}$ Among the lesser tenants, the fine and the scutage were almost always lumped together; while among the greater vassals, they were often separated. The abbot of Glastonbury paid $40 \mathrm{~m}$ fine and $60 \mathrm{~m}$ scutage $;^{344}$ William Fitz Hamon, $20 \mathrm{~m}$ fine and $221 / 2 \mathrm{~m}$ scutage $;^{345}$ Nigel de Luvetot, $20 \mathrm{~m}$ fine and $221 / 2 \mathrm{~m}$ scutage ${ }^{346}$ Richard Basset, $20 \mathrm{~m}$ fine and $22 \frac{1}{2} \mathrm{~m}$ scutage $;^{347}$ the abbot of

338 Pipe Roll, 8 John, Wilts, m. 18; the abbey of Ramsey, in hand, paid $£ 4$ of scutage and $£ 73$ s $1 \mathrm{~d}$ "de auxilio posito per maneria" (Cartularium Monasterii de Rameseia, Rolls Series, I, 231). Probably this should be classed as a tallage on the demesne rather than as a fine.

339 Pipe Roll, 8 John, Heref., m. 7.

840 Ibid., Oxf., m. 12 d.

341 Ibid., Norf. and Suff., m. 4.

342 Pipe Roll, 8 John, Staff. This entry is peculiar; he held 60 fees.

343 See above, p. 78, note 333.

344 Pipe Roll, 8 John, Dors. and Somers., m. 13 d.

345 Ibid., Bucks and Bedf., m. 4 d.

346 Ibid., Cant. and Hunt., m. 16 d.

347 Ibid., Northamp., m. 17 d. 


\section{STUDIES IN TAXATION}

Westminster, $10 \mathrm{~m}$ fine and $22 \frac{1}{2} \mathrm{~m}$ scutage. ${ }^{348}$ In some of these cases the fine represented not merely the personal service of the tenant in chief and that of his demesne, but an amount as large as the scutage from his holding, so that the king was really being paid for the same thing twice over. The scutage thus had the appearance of a royal tax on the rear-vassals.

Other indications, as in previous years, show not only that the scutage fell ultimately on the rear-vassal, but also that the exchequer knew to an extent the distribution of the fees of the tenants in chief, and was thus prepared to collect and in some cases actually did collect the amounts charged against the latter from the sub-tenants. Tenants who secured writs of quittance had that fact noted in each county where their lands lay, not merely in the one where the head of the barony was. ${ }^{349}$ The prior of Coventry held most of his fees in the counties of Warwick and Leicester, but owed 10 shillings in Northamptonshire. ${ }^{350}$ The abbot of Westminster (10m fine and $£ 15$ scutage) paid $\mathfrak{£ 1 2}$ of his scutage in Worcestershire and

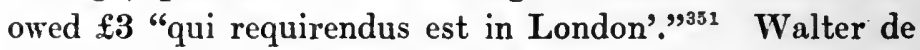
Baillolet held of the abbot of Peterborough. He was pardoned his scutage on two fees per breve regis and so both he and the abbot were quit. ${ }^{352}$ Walter de Lacy paid his scutage in five counties. ${ }^{353}$ But it does not follow that the sheriff in general collected from the rear-vassals of those tenants who owed scutage or fine. The tenant in chief might personally account in one sum for the

348 Ibid., Lond. and Midd., m. 6.

$349 \mathrm{E.g}$. the earl of Chester is quit in five bailiwicks: Gloucester, Bucks and Bedf., Notts. and Derby, York, Berks; Warren Fitz Gerold in eight; William Earl Marshal in eight.

350 Ibid., Northamp., m. 17 d.

351 Ibid., Wigorn., m. 20 d.

352 Ibid., Northamp., m. 17 d.

353 Ibid., Hereford, Gloucester, Oxford, Salop, and Berks. 


\section{UNDER JOHN AND HENRY III}

whole amount due from his holding. The fine of Thomas de St. Valery covered all his lands. ${ }^{354}$

In each of the cases cited, the tenant compounded this year; he obtained no writ of quittance. A different sort of case would be where the baron was exempted, yet the rear-vassal paid a scutage to the king. If this were commonly done, the scutage would not be a composition for the service of the tenants in chief, but an aid, a general tax on all the fees in England. Robert Marmiun had a general writ of quittance yet the sheriff collected ten shillings in Northamptonshire. ${ }^{355}$ The practice of the exchequer seems to have been not to collect such sums if the tenant in chief had a writ of exemption. The archbishop of York was charged with 63s $4 \mathrm{~d}$ in Gloucestershire, but the roll adds that he was quit in Yorkshire; ; $^{356}$ the bishop of Durham owed half a mark in Rutland, but he did not pay it as he was quit in Yorkshire ${ }^{357}$ Peter de Anesie of the fee of Baldwin Wak owed ten shillings, but was acquitted as his lord was exempted $;^{358}$ John Briwerre who held one fee of William Briwerre was charged with two marks, but for the same reason it was not collected. ${ }^{359}$

354 Thomas de St. Valery is quit in Bucks and Bedf. and in Berks, pays $£ 100$ fine in Oxfordshire, is charged with $£ 100$ fine in Lond. and Midd,, but the roll states "sed respondet inde in Oxeneford" " (ibid., Lond. and Midd., m. 6); Gilbert Peke pays 10s in Berks, is charged with his whole fine and scutage in Norf. and Suff. and is quit in Cant. and Hunt.; Cecilia countess of Hereford is quit in Gloucester and pays in Kent; Ralph Dairel pays 20s on $1 / 2$ fee in Berks, is charged with it in Lond. and Midd., but "quietus est in honore Warengef" (ibid., m. 6, 21 d); Philip de Girund pays the sheriff of Bucks and Bedf. $9 \mathrm{~m}$ on 3 fees; he is also charged in the roll with scutage in Kent for these 3 fees, "sed quietus est in Bukinghamsira in summa ix marc." (ibid., Kent, m. 5 d).

355 Pipe Roll, 8 John, Oxf., War. and Leic., m. 1 d, 12 d; 9 John, Northamp.

356 Ibid., 8 John, Glouc., m. 2.

357 Ibid., Rutland, m. 13 d.

358 Ibid., 9 John, Rutland.

359 Ibid., 8 John, Norf. and Suff., m. 4. Four tenants on the honor 


\section{STUDIES IN TAXATION}

Returns of the tallage are given in thirty-two counties; the amount charged was nearly 4,000 marks. ${ }^{380}$ Persons appear in the roll charged with tallage; vills and towns have lump sums charged against them; that is, the tallage was made in some cases per capita and in others the town or vill fined in a lump sum for its contribution. The sheriff collected the tax, but the assessment was probably made by the itinerant justices. ${ }^{361}$

Despite the long campaign, John did not lack ready money in the autumn. Early in November he acknowledged the receipt of 14,000 marks from England. ${ }^{362}$ In December he seems to have had over 15,000 marks of treasure at Porchester. ${ }^{363}$

of Richmond were charged with scutage; "sed isti quatuor non debuerunt summoneri quia per inquisitionem factam tenent per feodum militis de honore Richemund' et debet servitium eorum exigi a Petro de Leonibus" (ibid., 9 John, Hants, m. $14 \mathrm{~d}$ ). The exchequer acts toward this warden probably as it does toward a tenant in chief.

360 There is no tallage on London in the roll. The return for Oxfordshire is given in $9 \mathrm{John} \mathrm{(m.} \mathrm{5).} \mathrm{In} \mathrm{some} \mathrm{counties} \mathrm{(Salop,}$ Cant. and Hunt., Bucks and Bedf., Northamp.) two levies appear, one of which probably belongs to a preceding year.

361 For an example of persons charged with tallage, see Pipe Roll, 8 John, Surr., m. 12; "De taillagiis et ammerciamentis per Walterum de Creppinges et Henricum de Ver et socios suos. Idem vicecomes $r$ de $c$ et xlvii marcis et iiii sol. et iii den. de misericordiis et taillagiis hominum et villarum quorum nomina annotantur in rotulo que prædicti liberaverunt in thesauro; in thesauro liberavit in Ixxi talliis et quietus est" (Pipe Roll, 8 John, Berks, m. 21 d). When a town pays a round sum, it is probable that it fined with the justices for this amount and apportioned the tax itself; when it pays an irregular amount, it is probable that the justices levied the tallage per capita; e.g. "Burgus de Notingeham r c de xii li. et iiii sol. de taillagio" (ibid., Notts. and Derby, m. 8 d).

362 Rot. Litt. Claus., I, $75 a$.

3e3 Ibid. and 75b, 77a. In these two references from the Close Roll there are four sums of money: $12,000 \mathrm{~m}, 2,000 \mathrm{~m}, 10,000 \mathrm{~m}$, and $5,000 \mathrm{~m}$. If there is no duplication, we have the interesting fact that John received in November and December nearly $30,000 \mathrm{~m}$. There can be no doubt that he received $14,000 \mathrm{~m}$, for he acknowledged the receipt 


\section{UNDER JOHN AND HENRY III}

of that sum while he was in Poitou and it is possible that he brought part of it back with him to England, yet in that case, it is strange that he immediately sent $5,000 \mathrm{~m}$ back to Poitou. It would seem more likely that the $5,000 \mathrm{~m}$ were a fresh sum which he sent out. It is also possible that the $5,000 \mathrm{~m}$ were a part of the sum of $10,000 \mathrm{~m}$ which was in the hands of the wardens of the treasure. 


\section{CHAPTER III}

\section{The Thirtensth of 1207}

TE thirteenth of revenues and moveables was the last 1 of a series of taxes on property which were levied in John's reign. The basis of this levy was that on which the great taxes of the future were to be taken; the amount which it yielded was very large; the assessment was quite generally carried out; and the plea for its levy was ingenious and unanswerable at the time. These facts combine to make the thirteenth of 1207 the most important single levy of the reign. That it was so regarded by the men of the time is doubtful. To them it seems to have appeared as a rather unusual levy, but on the whole as of less importance than the scutage because it was taken only once. Since this is the last example of a series of taxes on property on both a great and a small scale in John's reign, it looks as though the government had experimented till finally it knew the form of taxation that would yield the most. But that was not enough. There must be found a method by which the new tax could be legally taken. Different devices had already been employed in the case of the carucage and the seventh of 1203 , but they could only be employed in very exceptional cases. The method was found in 1207 when the king asked for a gracious aid. Such an aid needed the consent of the taxpayers. This was considered to have been obtained when the tenants in chief agreed to the thirteenth. Thus the root of the levy is to be found in feudal custom. A request from the king for a gracious aid was almost without precedent, though the practice 
was common among his vassals. At first sight, it might be thought surprising that the king could succeed in taking an aid from the great barons while he seems to have failed to obtain a grant from the parochial clergy. The explanation lies in the fact that the aid on the clergy was without precedent while the aid on the tenants in chief found plenty of precedent in feudal practice.

Now the feudal aid was to be taken only in case of a lord's great need. What was the need in 1207? John had a large sum of money on hand in the fall of 1206 ; he had just made a truce with Philip II and he had no debts to pay. Nevertheless the excuse assigned was the war against the French, ${ }^{1}$ which the king planned to renew at some future time not definitely fixed. Levied as it was to provide money against a remote need, the thirteenth was a precedent of great importance for establishing a right of arbitrary taxation by the king. The ease with which the opposition to the tax in the council was overcome shows the great power of John; it also reveals the lack of unity among the baronage and the difficulty of finding an effective ground for resistance. The opposition did not end with the dissolution of the council, but it was fruitless; the collection went steadily on. This throws an instructive light on scutage. After the tax had been put in charge, it was difficult to resist payment. Here lay one advantage to the king of putting the scutage in charge when the host assembled.

The method of assessment shows a return to the plan employed in the tenth of 1188, the personal oath of the

1 "ad defensionem regni nostri et recuperationem juris nostri" (Select Charters, Stubbs, 8th ed., p. 283; Rot. Litt. Pat., p. 72b); "ad recuperandam hæreditatem suam in Normannia" (Wav., p. 258); "ad manutenendum guerram suam contra regem Francix" (Historia et Cartularium Monasterii S. Petri Gloucestrice, Rolls Series, I, 23); "ad opus regium, sub prætextu terrarum quas ... amiserat, per werram recuperandarum" (Cov., II, 198). 


\section{STUDIES IN TAXATION}

property holder before the justices. Perhaps the king thought that the fear of punishment for false swearing would be more effective if each man were held to account for his own property than if a jury were employed. Perhaps it was thought that the former method would be quicker. The clergy opposed the assessment on their demesne lands and the king allowed them to compound, an illustration of the strength of the opposition to a tax on property.

At first sight, the thirteenth secms to have been without result on the financial policy of the government, for another tax on moveables did not come till 1225. The reason why none was taken in John's reign lies in the political situation. The king could not levy it again till a certain interval had passed. By 1212, the trouble with the pope and the barons had reached such a pass that a tax on moveables was no longer feasible. In Henry III's reign, when an unusual effort was to be put forth in $\mathbf{1 2 2 5}$ in order to retain the provinces in France, the scutage and the carucage were passed over and a tax on moveables taken. There can hardly be a doubt that this was because of the memory of the great yield of the thirteenth of $120 \% .^{2}$

Two meetings of the magnates were held in connection with the taxation of 120\%. John had returned from Poitou in December, 1206; the great council was summoned and met at London on January 8, 1207. It was composed of the bishops, abbots, priors, earls, and barons. The king asked the bishops and abbots to make him a grant from the revenues of the beneficed clergy. ${ }^{3}$ It was

2 That the thirteenth was not forgotten is shown by the reference to it in 1242 when the barons speak of it as granted to Henry III (Matthew Paris, Chronica Majora, IV, 186). As a thirteenth had never been granted to him, it is clear that the barons were thinking of the levy of 1207 .

3 Wav., p. 258. 


\section{UNDER JOHN AND HENRY III}

not the first time that he had tried to levy a tax on them, for in $\mathbf{1 2 0 2}$ he had written to the clergy of the province of Canterbury asking for an aid." In 1207, the prelates refused to accede to his request. The council was prorogued till February 2, when it met at Oxford with a very full attendance. The king repeated his request and after discussion he was again refused. He then apparently abandoned his attempt to persuade the ecclesiastics present to consent to this tax on the property of the churches, but he did not give up his intention of getting a tax granted. After a session of a week, the council agreed to levy a thirteenth on personal property and revenues. ${ }^{5}$ Although there was opposition to this also, it was unsuccessful. ${ }^{8}$ The tax was levied on the property not only of laymen, but also of the clergy. The chroniclers state that both the clergy and the laity paid it. ${ }^{7}$ When some of the prelates compounded in a lump sum for their thirteenth, the king advised his collectors of the fact and this was evidently a notice to them not to make

4 Rot. Litt. Pat., p. 18 a.

s "congregata infinita multitudine prælatorum ecclesiæ et magnatibus regni" (Wav., p. 258); Wend., III, 209; Cov., II, 198; Gerv. Cant., II, lvii; Select Charters, p. 283; Wint., p. 79; Annales de Margan, ed. Luard, Rolls Series, p. 28; Annales Monasterii de Burton, ed. Luard, Rolls Series, p. 209; Dunst., p. 29; Annales Monasterii de Bermundeseia, p. 450; Annales Cambria, p. 66. The Waverley chronicle says that the council was held on February 9 and Wendover on February 2; February 9 was the close of the session "in octavis Purificationis B. Mariæ, scilicet ad terminum concilii," Select Charters, p. 283) and probably February 2 was the date of the opening.

"cunctis murmurantibus"; $c f$. the action of the archbishop of York.

7 "quilibet laicus homo . . . de cujuscunque feodo sit ... det nobis in auxilium etc." (Select Charters, above); "tam de laicis quam viris ecclesiasticis et prælatis" (Wend., III, 210); "ab ecclesiasticis sicut a laicis" (Cov., II, 199); "de episcopis, abbatibus, prioribus, canonicis, clericis, laicis, divitibus, et de omni populo simul" (Chronicles of the Reigns of Stephen, Henry II and Richard I, ed. Howlett, Rolls Series, Continuation of William of Newburgh's History, II, 509). 


\section{STUDIES IN TAXATION}

the assessment on those lands. ${ }^{8}$ Further, when some churchmen refused to pay anything, the king dealt with them in summary style. The case of the archbishop of York is familiar. As he refused to yield, he was obliged to leave England, and the king took the archbishopric into his hand. 9 The abbot of Seleby had to pay forty marks and two palfreys that the king would remit his malevolence because he had refused to give the thirteenth, for which he was ordered to be amerced ad plus quod posset. $^{10}$ The abbot of Furness refused to pay and his goods were seized and sold. ${ }^{11}$ This is evidence enough to show that the clergy as well as the laity were liable for the thirteenth. The churches were probably not taxed, or if they were, the collectors did not at once make a general assessment on them, though some of the fines are said to have been paid partly for quittance of the aid owed by the parochial churches. ${ }^{12}$ After the council in February, the king sent letters to the clergy of Canterbury, and received a reply that they would decide after Easter what aid they would make him. Probably no grant was made at that time, for John wrote again in May asking that each give him a lump sum. ${ }^{18}$ At any rate the king did not collect the thirteenth from the churches on the authority of the grant in the great council. The Cistercians and the Hospitallers were exempt. ${ }^{14}$ The king did not insist on an assessment of the property of the prelates. Some paid a lump sum called a fine or a donum. This was not a payment

8 Rot. Litt. Claus., I, 79a, bishop of Bath; 84b, abbot of Abingdon; 79b., prior of Hurl'.

9 Wend., III, 210.

10 Madox, I, 474, n. a.

11 Rot. Litt. Claus., I, 85a.

12 Ibid., I, 79a, 80b.

13 Rot. Litt. Pat., pp. 71b, 72a.

14 Rot. Litt. Claus., I, 81b; Wav., p. 258. 


\section{UNDER JOHN AND HENRY III}

extorted from tenants who did not hold by lay tenure and hence were not liable for the thirteenth; for by reason of this fine, the king, in some cases at least, granted to the tenants of each prelate exemption from assessment by the county officials. ${ }^{15}$ These fines were round sums which did not bear any direct relation to the value of the property. The bishop of Bath paid 700 marks; ${ }^{16}$ the prior and monks of Canterbury 1,000 marks $;{ }^{17}$ the abbot of Abingdon 600 marks; ${ }^{18}$ the prior of Dunstable 111 marks. ${ }^{19}$ Perhaps the churchmen as a rule made their contribution in this way. An entry in the Fine Rolls favors such a conclusion for it summarizes the returns under the headings, the common thirteenth, the fines of religious men, and the dona of bishops. ${ }^{20}$ The prelate could recoup himself, in part at least, by levying an aid on his tenants with the king's permission. ${ }^{21} \quad$ A single reference shows that the towns, that is, the royal demesne, were assessed for the thirteenth: the king ordered the bailiffs of Bristol not to prevent the departure of the merchants of Breteuil on account of this tax. ${ }^{22}$ Hence we may conclude that other towns as well were paying it.

The assessment was made by special justices sent into each county. The number seems to have been large; in Lincolnshire there were fourteen. ${ }^{23}$ They were divided

15 "pro habenda quietancia de dominicis, feodis, hominibus, et omnibus tenentibus suis ... de auxilio" (Rot. Litt. Claus., I, 84b, 79a).

16 Rot. Obl., p. 413.

17 Ibid.

18 Rot. Litt. Claus., I, 84b.

18 Dunst., p. 29.

20 Rot. Obl., p. 459.

21 Rot. Litt. Claus., I, 84b, the abbot of Abingdon; "Philippus episcopus Dunelmensis $\mathbf{r}$ de $\mathrm{M}$ libris, pro habenda benevolentia regis ... et pro habendo ausilio de terris suis quod modo assisum est, scilicet de marca xii d" (Madox, I, 408, n. u.).

22 Rot. Litt. Claus., I, 81a.

23 Gerv. Cant., II, lix. 


\section{STUDIES IN TAXATION}

into groups, each taking a different part of the county, in order to conclude the work more quickly. They were to assess each vill by itself. Probably the sheriff summoned all the men of the vill to meet the justices. The bailiffs of the earls and barons holding property in the vill swore to the value of their lords' revenues and moveables as well as that of their own. The other men of the vill made oath in person. A roll was drawn up in duplicate. One copy was given to the sheriff; the other was retained by the assessors for delivery at the exchequer. The officials took oath to perform their duties faithfully ${ }^{24}$ and attempts to defraud by false swearing or by concealment of goods were punishable by imprisonment and confiscation of chattels. The assessment was made quickly ; in May much of it was completed, for on May 25, the king sent a new set of justices to Warwickshire to correct mistakes of the first assessment. ${ }^{25}$ As soon as the assessment of a vill was completed, the roll was delivered to the sheriff and he began the collection. It was to be paid within two weeks, ${ }^{28}$ but in fact it took the whole summer to finish the work. ${ }^{27}$ The punishments threatened in the writ were carried out. Men were fined, disseized, and imprisoned for false swearing and for refusal to swear to the value of their property. William and Gerard de Lancaster were thrown into the Fleet

24 Rot. Litt. Pat., p. 72; Select Charters, p. 283.

25 Ibid.

26 "Liberentur (rotuli) vicecomiti colligendum per terminum quindenæ in quindenam cum omni festinatione."

27 Liebermann, p. 184: "et incepit hæc collecta a Purificatione beatæ Mariæ et duravit usque ad festum S. Michælis" (Ann. do Bermundeseia, p. 450). A collector might keep the money for a long time. In 1212, the sheriff of Hertfordshire was ordered to produce Thomas de Wylie before the exchequer "ad ostendendum quare non pacavit nobis ducentas marcas de lacto tredecime" (Rot. Litt. Claus., I, 117a). 


\section{UNDER JOHN AND HENRY III}

prison for the thirteenth ${ }^{28}$ Roaldo Fitz Alan was disseized of Richmond castle for refusal to swear. ${ }^{29}$ Some men in Lincolnshire sought to escape assessment by depositing their property with religious houses and the king threatened to seize the property of the houses if they did not surrender it. ${ }^{30}$ The amount raised was over

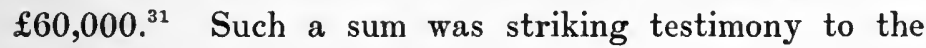
inefficiency of the scutage as a tax, which in 1206 amounted only to about 4,000 marks. ${ }^{32}$

This tax is a step in the transition from feudal to national taxation, and certain features of it are deserving of attention. It was levied not as one of the three aids, or in connection with a campaign just completed, as the composition for service, or one in progress, or about to be begun. Its purpose was to carry on a war to be undertaken at some undetermined time in the future; this principle, if established, would give the king an almost unrestricted right of taxation. It was levied on property. It was national in scope, all classes (except perhaps the beneficed clergy and some religious orders) being subject to the same levy. The method of assessment and collection was national, not feudal. The territorial unit of the levy was the vill, a national unit, and not the feudal holding; the work was done by royal officials, not the

28 Rot. Litt. Pat., p. 73a.

29 Ibid.; Rot. Obl., p. 372; see also the cases of William Frankelein (ibid., p. 374) and Philip de Valoines (Rot. Litt. Claus., I, 85a).

30 Rot. Litt. Pat., p. 71a.

31 "Recepta totius tredecime tam de communi quam de finibus religiosorum et de donis episcoporum quinquaginta et septem millia CCCC xxi li. xi s $\mathbf{v}$ d. Summa debiti totius tredecime, duo millia sexcent' $x v$ li. $v$ sol. $x$ den. excepto debito vicecomitis Sussex' et vicecomitis Cumberland' qui nondum computaverunt et exceptis aliis quibusdam que robis plenius dicemus cum ad vos reniemus" (Rot. Obl., p. 459).

32 See above, p. 78. $C f$. also the amounts realized by aids levied on the knight's fee, below, pp. 126, 243, 257. 


\section{STUDIES IN TAXATION}

feudal tenants. Another fact worth noticing is that there was no use of local machinery in the work of assessment; each man assessed himself in the presence of the justices. 


\section{CHAPTER IV}

\section{The Taxes in Detail from 1208 to 1216}

$\mathrm{D}^{\mathrm{c}}$ URING the next few years, much of the property of the church was in hand and the king derived considerable income from it; there were also exactions from religious orders. While these returns increased the royal revenue, they had little or no result in developing a system of taxation. The regular levies of the period consisted of four scutages and two tallages. ${ }^{1}$ The scutages differed on the whole from those of the earlier part of the reign. Only one, the scutage of Scotland, could be legally questioned; the others were fully justified by the law. But there is evidence that the barons were beginning to criticise the occasions on which the king took scutage, and in 1214, as is well known, the northern barons refused to pay the scutage of Poitou on the ground that they did not owe service in France. Only one of the scutages, that of Ireland, was generally accompanied by fines, which, as it happened, were the highest that had ever been levied. In the scutage of Scotland, some tenants paid scutage at a rate higher than the prevailing rate of the year, so that in effect they paid fines. It is also to be noticed that the rate of scutage in two cases, those of Ireland and Poitou, was three marks per fee, the highest ever reached in the history of the tax. In every case the scutages were taken only from those tenants who had failed to perform their

1 In 1211, there were some fines levied on the fees of Robert Fitz Walter, Eustace de Vescy, and the bishops who were in exile (Dunst., p. 35). 


\section{STUDIES IN TAXATION}

service, though some of the tenants served with only part of their contingents.

The tallage, it will be noticed, was levied only once in connection with a scutage, viz., in 1210, and then it resembled the scutage of Ireland of the same year in the enormous amounts paid. The total tallage charged would approach 15,000 marks, an unprecedented sum. The only other tallage of this period was taken in 1214, but it had no connection with the scutage of that year. It was taken to raise money to pay the indemnity for the interdict. The king does not seem to have lacked money during this period, a condition due in part to the additions to his income from the church lands.

\section{The Scutage of Scothand}

In June or July, 1209, John summoned the host against the king of Scots to enforce security for his loyalty. He marched north as far as Norham where, without any fighting, a treaty was made on August $7 .^{2}$ In connection with this expedition, a scutage at twenty shillings was levied. Some accounts of it appear in the rolls of 1209 and 1210, but most of the counties reported in 1211 (13 John). ${ }^{3}$

2 Norgate, John Lackland, p. 133; Gerv. Cant., II, 203. One of the terms of the treaty was that King William was to pay John 15,000 marks (Rymer, I, 103) ; $£ 13,000$ (Chronicon de Lanercost, ed. Stevenson, Bannatyne Club, p. 7); 12,000 marks (Wend., III, 226); 11,000 marks (Matthew Paris, II, 525). Part of this sum had been paid in 1211: "et in cariagio vii milia marcarum de fine regis Scottorum a Norham usque ad Notingeham" (Pipe Roll, 13 John, m. 4 d).

3 Devon and Cumberland account in full and Dorset and Somerset, Bucks and Bedford in part in 1209; in 1210, there are returns for Sussex, Berks, and part of Essex and Hertford. No full returns appear in any year for Dorset and Somerset, Kent, Stafford, Salop, or Wigorn. 


\section{UNDER JOHN AND HENRY III}

The account follows:

\begin{tabular}{|c|c|c|c|c|}
\hline & & $\mathbf{M}$ & $\mathbf{s}$ & d \\
\hline Fines ${ }^{4}$ & . & 873 & 8 & 8 on 240 fees \\
\hline Scutage at 20 s & • & . 1303 & 10 & 9 on 869 fees \\
\hline Additional $^{5}$ & . & 8 & 0 & 0 \\
\hline Total $^{6}$ & • & . 2185 & 6 & 1 \\
\hline
\end{tabular}

Fees taxed, about, 1110

$\begin{array}{llllll}\text { Paid, } 13 \text { John } & \text { • } & 769 & 11 & 8\end{array}$

Practically all the tenants holding five fees or more received writs of quittance, probably because of service with the host. Stephen de Hamton was charged with twenty shillings on one fee.' He was quit because he sent his son in his stead. ${ }^{7}$ There is no account of the scutages of Lancashire or Hereford because all the knights of those counties were in the host. ${ }^{8}$ Thus John did not allow the military service to be commuted into money at the will of the tenants. One very important tenant fined: the earl of Albemarle. ${ }^{9}$ He paid $132 \mathrm{~m}$ on 33 fees, or $4 \mathrm{~m}$ per fee,

4 Some tenants pay at rates different from the prevailing one of 20s. In Devon, several pay sums "de scutagio Scociæ" which equal $3 \mathrm{~m}$ per fee: knights of the honors of Oliver de Tracy, $72 \mathrm{~m}$ on 24 fees; Hawise de Courtney, $£ 18511$ s $8 \mathrm{~d}$ on $92+$ fees; abbey of Tavistock, $£ 32$ on 16 fees; tenants of the honor of Berdestaple, $84 \mathrm{~m}$ on 28 fees. Part of one honor (Toteness) pays at $2 \mathrm{~m}$ per fee (Pipe Roll, 11 John, m. 8, 13). The earl of Albemarle paid 132m on 33 fees "scilicet iiii marc. de scuto" (ibid., $13 \mathrm{John}, \mathrm{m} .1,4)$. These have been added as fines.

5 Number of fees unknown.

6 The bulk of this levy falls on honors in hand: at least, $1,219 \mathrm{~m} 3 \mathrm{~s} 4 \mathrm{~d}$ on 731 fees are of this description. Of the remainder, $966 \mathrm{~m} 2 \mathrm{~s} 9 \mathrm{~d}$, over a fourth, fell on one holding, the honor of Okehampton, held by Hawise de Courtney, $278 \mathrm{~m} 5 \mathrm{~s}$ on $92+$ fees.

8 "Sed non debet summoneri quia misit filium suum in exercitum" (Pipe Roll, 13 John, Oxf., m. 21 d).

8 Farrer, Lanc. Pipe Roll, p. 241; Pipe Roll, 13 John, Heref., m. $7 \mathrm{~d}$; likewise for the archbishopric of Canterbury, m. $5 \mathrm{~d}$; for Brian de L'Isle, m. $2 \mathrm{~d}$; for Robert de Vieux-Pont, m. 4.

9 Other lay tenants who held more than five fees and were not exempt were: Baldwin $W a k$ and Cecilia de Crevequor in Lincolnshire; William de Windsor in Bucks and Bedford; Robert de Turn- 


\section{STUDIES IN TAXATION}

though the rate of scutage was $20 \mathrm{~s}^{10}$ The tenant who failed to perform his service did not always escape with the payment of scutage or a moderate fine. Duncan de Lascels was disseized of $3 \frac{1}{2}$ fees, because he was not in the army of Scotland and he had to pay a fine of $65 \mathrm{~m}$ to recover his land. ${ }^{11}$ The abbot of Michelney had to pay $100 \mathrm{~m}$ because he neither came himself nor sent his service. ${ }^{12}$ The exchequer might deal directly with the rearvassal. When the tenant in chief was charged with scutage, the amount due from the sub-tenant might be pardoned. ${ }^{13}$ This also shows that the scutage fell back on the rear-vassal.

\section{The Scutage of Ireland (1210)}

The expedition to Ireland set sail on June 6, 1210, and was back again in England on August 29. The campaign lasted therefore about eighty days. ${ }^{14}$ According to the chroniclers the army was large, ${ }^{15}$ being composed of knights and sergeants holding by military service and of mercenaries as well. ${ }^{18}$ Those who responded to the summons to the array usually did not furnish the whole ham in York; and Roger de Berkeley in Gloucestershire. Some of these may have been in hand.

10 Pipe Roll, 13 John, Norf. and Suff., Bucks and Bedf. and York, m. 1, 4, 21.

11 Pipe Roll, 12 John, m. 2.

12 Ibid., 11 John, m. 9 d.

13 The earl of Albemarle owed 132m of fine in Yorkshire; he paid so much "et in perdonis Ricardo de Argent' iii marc. per breve regis" (Pipe Roll, $13 \mathrm{John}, \mathrm{m}$. 4); the sheriff accounted for $£ 13$ of the scutage of Cecilia de Crevequor, paid so much "et in perdonis Alexandro de Nevilla lxx sol. per breve regis" (ibid., 14 John, m. $12 \mathrm{~d})$.

14 Wend., III, 233, 234.

15 "collecto multo exercitu" (Wav., p. 265); "copioso exercitu congregato" (Wend., above).

16 "Præstitum factum militibus Flandren"" (Rot. Lib., pp. 174, $195,210,224)$. 


\section{UNDER JOHN AND HENRY III}

number of knights due from them, nor was it expected apparently that they should. The abbot of Pershore owed the service of two knights and one was summoned; the abbot of Evesham owed the service of four and a half knights and two were summoned. ${ }^{17}$ Gilbert Peke held $19+$ fees and sent two knights. ${ }^{18}$ The Præstita Roll of this year contains long lists of sums loaned by the king to the members of his force and in several cases enters the number of knights for whose use the money was advanced. This number probably represents the knights present with the tenant in chief. As a rule it was much smaller than either the servitium debitum or the number for which the tenant in chief usually responded for scutage. The following are some examples:

Knights Fees present held ${ }^{19}$

\begin{tabular}{|c|c|c|c|}
\hline Earl Warenne & • & . 8 & 60 \\
\hline Robert de Tateshall & . & 3 & 25 \\
\hline William Malet & • & 5 & $21+$ \\
\hline Earl Albericus & • & 6 & $301 / 8$ \\
\hline Bishop of Salisbury & • & 9 & 32 \\
\hline Ralph Sudley & • & . 2 & 3 \\
\hline Robert de Mara & • & . 2 & 4 \\
\hline Robert de Turnliam & • & 3 & $31+$ \\
\hline Henry de Oilly & • & . 2 & $321 / 3$ \\
\hline Geoffrey Fitz Peter & . & . 10 & $981 / 3$ \\
\hline Earl of Hereford & . & . 10 & $30^{1 / 2}$ \\
\hline Countess of Clare & • & - 2 & $9+$ \\
\hline Nigel de Luvetot. & . & . 2 & 15 \\
\hline Robert Marmion & • & 3 & 25 \\
\hline Gilbert Gaunt & • & . 6 & $681 / 3$ \\
\hline Gilbert Peke & • & - $2^{20}$ & $19+$ \\
\hline
\end{tabular}

17 Pipe Roll, 12 John, Wigorn., m. 15 d. 18 Ibid., Norf. and Suff., m. 4.

19 In this list the numbers are either the servitium debitum or the number of fees for which the tenants in chief usually respond.

20 This is the number of knights that we know Gilbert sent; see 


\section{STUDIES IN TAXATION}

In connection with this campaign there were collected a scutage, fines, and a tallage.

The roll is incomplete. Most of the tenants do not appear at all. In only one bailiwick (Norfolk and Suffolk) is a list of writs of quittance given. For Yorkshire and Northumberland it is stated that only part of the account was rendered at the exchequer. For Salop no return was made. Many names appear which cannot be identified and which never appear again. The following is the account:

Fines

M $\quad$ s $\quad$ d Fees

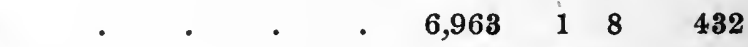

Scutage . . . $\quad \begin{array}{rrrrr} & 800 & 3 & 4 & 271 \frac{1}{21}{ }^{21}\end{array}$

$\begin{array}{llllllll}\text { Additional }^{22} & \text {. } & \text {. } & \text {. } & 1,471 & 7 & 4\end{array}$

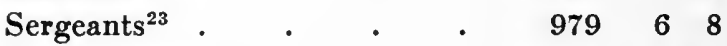

Total charged . . . $10,214 \quad 58$

Paid, 12 and 13 John $\quad$. $\quad 8,496126$

According to the Red Book, the rate of this scutage was two marks, ${ }^{24}$ but most of the tenants who accounted for sums de scutagio paid at the rate of three marks; for example, the honor of Eye was charged with $270 \mathrm{~m}$ (90 fees) $j^{25}$ that of Walter de Lacy $^{26}$ and of Hawise de

note 18. For the number of knights present as given in this list, see Rot. Lib., pp. 177, 189, 193, 207, 216, 219, 221, 222, 225, 226.

$212561 / 2$ fees pay at $3 \mathrm{~m}$ per fee. Ralph Basset pays $30 \mathrm{~m}$ "pro concelamento servitii sui et pro fine passagii" (Pipe Roll, 12 John, Notts. and Derby, m. 12). He held 15 fees. I have included this amount as a scutage at $2 \mathrm{~m}$.

22 Number of fees unknown.

23 Of this sum, $4941 / 2 \mathrm{~m}$ are charged in Cumberland on sergeants, drengs, etc.

24 Red Book, I, 12.

$25 £ 180$, "de scutagio militum honoris de Eia, scilicet de quater xx et $x$ feodis" (Pipe Roll, 12 John, Norf. and Suff., m. 4). Usually, 901/2 fees.

${ }_{26}$ Ibid., Heref., m. 13 d. 
Courtney ${ }^{27}$ at three marks. On the average the fines exceeded anything imposed before. Though the number of fees recorded in the roll is small, yet, as both great and small holdings are included, the sums demanded may fairly be regarded as typical. The abbey of Ramsey (in hand) paid $258 \mathrm{~m} 6 \mathrm{~s} 4 \mathrm{~d}$; the abbey of Peterborough (in hand, 60 fees) paid $364 \mathrm{~m} 5 \mathrm{~s} 4 \mathrm{~d} ;^{28}$ the bishopric of Durham (in hand, 10 fees) paid $2,279 \mathrm{~m} 3 \mathrm{~s} 4 \mathrm{~d}^{29}$ Aside from these three holdings, about 360 fees paid about 4,000 marks of fines, or at the rate of over 10 marks per fee.

Some greater lay tenants who fined were: the earl of Clare, $500 \mathrm{~m}$ on $140+$ fees $;^{30}$ Henry Luvel, $330 \mathrm{~m}$ on 18 fees $;{ }^{31}$ Hubert Fitz Ralph, $210 \mathrm{~m}$ on 15 fees. $^{32}$ These fines are heavy. Some tenants in chief sent knights in their stead, but had to fine for the privilege. ${ }^{33}$ Cases of disseizin occur for failure to answer the summons, either by sending the quota of knights demanded or by making

27 She accounts for $£ 185$ 10s "de scutagio Yberniæ de scutagio quater $\mathrm{xx}$ et xii militibus et tribus partibus unius militis . . s scilicet de quolibet feodo iii marc." (ibid., Devon, m. 15). The custodian of the abbey of Abbotsbury in his account has the item "et de xl sol. de scutagio feodi i militis de scutagio Yberniæ" (ibid., m. 1). It seems probable that the rate of this scutage was $3 \mathrm{~m}$. However part of the fee of William de Braose, in hand, paid scutage at $4 \mathrm{~m}$ per fee (ibid., m. 6 d), which has been added as a fine.

28 Pipe Roll, 12 John, m. 19.

29 Ibid., 13 John, m. 4 d.

30 Ibid., 12 John, Norf. and Suff., m. 4.

31 Ibid., Dors. and Somers., m. 6; 300m and 3 "optimos" palfreys.

32 Ibid., Notts. and Derby, m. 12; 200m and 2 palfreys.

33 Gilbert Peke paid $40 \mathrm{~m}$ to send 2 knights pro se (ibid., Norf. and Suff.); Hugh de Bolebec $30 \mathrm{~m}$ to send 2 knights pro se (5 fees) (ibid., Northumb., m. $10 \mathrm{~d}$ ); Ralph de Trihamton 1 palfrey to send his uncle pro se (ibid., Linc., m. 2); Walter de Ver one good palfrey to send 1 knight pro se (ibid.); he held of the bishopric of Lincoln which was in hand. 


\section{STUDIES IN TAXATION}

a satisfactory fine. ${ }^{34}$ The king could not at will collect scutage or fine from those who were not tenants in chief. The law protected them. Hugh de Canvill was summoned to cross with the king. He protested and paid thirty marks for an inquest to determine whether or not his two and one-fourth fees were held of the king. ${ }^{35}$ The inference is that if he were not an immediate vassal, he was not liable to the king for anything in connection with this expedition. The tallage was levied on cities, towns, and the king's manors, ${ }^{36}$ and lands in hand. The greater part accounted for fell on towns and cities, all of which compounded and determined the incidence themselves. Sometimes the towns paid the tallage into the exchequer and sometimes to the sheriff. ${ }^{37}$ Sums were also charged against persons, probably of the king's manors, which were collected by the sheriff. ${ }^{38}$ The total amount entered in the roll, not including lands in hand, was $12,416 \mathrm{~m}$ 1s

34 Albreda de Lincoln "quia non habuit 1 militem in servitio regis" (ibid., Dors. and Somers., m. 7); Malgerus le Vavasour "eo quod non transfretavit ... nec finem fecit pro passagio suo" (ibid., York, m. 19 d); Matthew de Clivedon "eo quod non transfretavit ... quia finis $x$ marcarum non fuit sufficiens (ibid., Heref., m. 9 d); Geoff rey de Mandeville $50 \mathrm{~m}$ and 1 palfrey "pro habenda saisina terræ suæ unde fuit dissaisitus eo quod non ivit cum rege in Yberniam (ibid., 14 John, Wilts, m. 16); Roger de Cramavill, Elias Ginant (Madox, I, 491, n. $d, 663$, n. $x$ ).

35 "pro habenda inquisitione an teneat de rege feoda ii militum et i quartem, unde summonitus fuit ad transfretandum" (Pipe Roll, 12 John, War. and Leic., m. 9).

36 "taillagia maneriorum"; "compotus non redditur hic ... de taillagiis hominum vel maneriorum" (ibid., Cornw., Northumb., m. $7,10 \mathrm{~d})$.

37 "Homines de Bristou $\mathrm{r}$ c de mille marcis de eodem; in thesauro D marc. et Engelardo de Cigoni D marc. ad ponendum in thesauro regis per breve regis et quieti sunt" (Pipe Roll, 12 John, m. 13). Usually the sheriff accounts for the tallage at the exchequer.

38 The sheriff accounts for $421 / 2 \mathrm{~m}$ of the tallage "hominum quorum nomina annotantur in originali" (Pipe Roll, 12 John, Wilts, m. 8). 
and it was nearly all paid in $1210 .^{30}$ The account given is incomplete. Both the sums levied on individual towns and the sum total show a marked increase in the tallage this year.

\section{The Scutage of Wales, 1211}

John made two expeditions against the Welsh in 1211, one in May and one in July. The first failed through lack of supplies, but the second with a larger army and abundance of provisions was successful. ${ }^{40}$ The full quota of knights either did not respond to the first summons or was not summoned, and there is one case which suggests that individual tenants did not furnish their full contingents. ${ }^{41}$ The second campaign lasted about forty days, from July 8 till August 15. At the close, a scutage was taken from those who had not taken part. ${ }^{42}$ A few tenants paid fines.

39 This includes 30 counties. London is entered in 1211: "Cives London' $r$ c de MM marc. de dono" (Pipe Roll, 13 John, m. 9 d). The tallage of the following counties is not entered in the Pipe Roll: York, Kent, Sussex, Salop, Stafford, and Lancashire. Only a small part of the levy in Northumberland and Lincolnshire is recorded. A complete account of this levy would probably bring it up to 15,000 marks, though this figure would not include tallages levied on lands in hand.

${ }^{40}$ Ann. Camb., pp. 67, 68; Cov., II, 203; Wend., III, 235; Norgate, John Lackland, p. 158; Liebermann, Ungedr. Anglo-Norm. Gesch.Quellen, Annales S. Albani, p. 169.

41 Robert de Mandevill was charged with $291 / 2 \mathrm{~m}$ of scutage. $\mathrm{He}$ was first pardoned $8 \mathrm{~m}$ by the king for some reason which is not stated. He was later pardoned the balance because he sent knights to Poitou (Pipe Roll, 13 John, Dors. and Somers., m. 7 d). May not the first sum pardoned refer to the service of 4 knights in Wales?

42 Wend., III, 236; Liebermann, Ann. S. Edm., p. 150: "de scutagio militum qui non fuerunt in exercitu Walliæ" (Pipe Roll, $13 \mathrm{John}$, York, m. 4 d). 


\section{STUDIES IN TAXATION}

The account of the scutage follows:

M s d

Clerical tenants ${ }^{43}$. $\quad . \quad$. $\quad . \quad$. $1,714 \quad 2 \quad 9$

Seventy-two lay tenants (each 5 or more

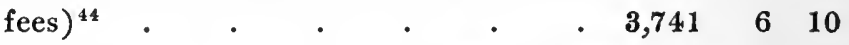

Other lay tenants (each fewer than 5 fees,

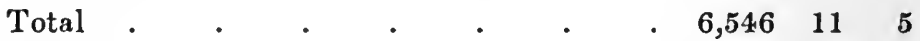

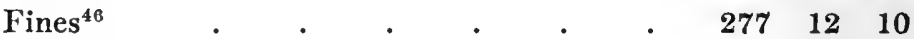

$\begin{array}{llllllllll}\text { Total }^{47} & \text {. } & . & 0 & 0 & 0 & 6,824 & 10 & 11\end{array}$

Paid, 13 and 14 John . . \. $\quad \begin{array}{lllll}\cdot & 3,774 & 10 & 2\end{array}$

Fees taxed, over 3300 .

Thus the levy was charged against about half of the fees of England. Nearly all the churchmen were taxed. The number of lay tenants holding five fees or more who contributed, seventy-two in number, is noteworthy. The list includes the earl of Hereford, 301/8 fees; Henry de Oilli, $32+$ fees; the earl of Albemarle, 33 fees; Alfred

43 This entry includes charges of $436 \mathrm{~m} 6 \mathrm{~s} 5 \mathrm{~d}$ against the new enfeoffment of church lands in hand.

44 Some of these are in hand: Peverel, $127 \mathrm{~m}$; Robert de Tateshal, $50 \mathrm{~m}$; Chokes, $30 \mathrm{~m}$; Honor of Gloucester, $654 \mathrm{~m} \mathrm{4s}$; honor of Thomas of St. Valery accounts for $86 \mathrm{~m} 8 \mathrm{~s}$; the rape of Hastings accounts for $104 \mathrm{~m}$.

45 About $885 \mathrm{~m}$ were on honors in hand: Lancaster, $40 \mathrm{~m}$; honor of the count of Perche, 214m 6s 10d (Pipe Roll, 14 John, m. 1); of the constable of Chester, $231 \mathrm{~m} 3 \mathrm{~s} 4 \mathrm{~d}$ (ibid.); of the honor of Brecknock, etc., of William de Braose, $109 \mathrm{~m} 5 \mathrm{~s} 8 \mathrm{~d}$ (ibid., m. 17); part of the honor of Angrie, $52 \mathrm{~m} 5 \mathrm{~s}$; half of the old enfeoffment and all the new enfeoffment of Totness, $91 \mathrm{~m} \mathrm{15s}$; part of Wallingford, $114 \mathrm{~m}$; Knaresburgh, $34 \mathrm{~m} 6 \mathrm{~d}$. This leaves about $200 \mathrm{~m}$ on tenants in chief holding fewer than 5 fees each.

48 The abbey of Ramsey paid $100 \mathrm{~m}$ on 4 fees (Pipe Roll, 13 John, Cant. and Hunt., m. 8); the men in note 59 may be military tenants. $177 \mathrm{~m} 12 \mathrm{~s} 10 \mathrm{~d}$ are charged against $881 / 2+$ fees of the honor of Mortain; this is a fine, for these fees paid at $\% / 8$ the ordinary rate. 47 At least $1,100 \mathrm{~m}$ of this sum were pardoned. 


\section{UNDER JOHN AND HENRY III}

\section{of Lincoln, $25+$ fees $;^{48}$ Robert de Cardinan $;^{49}$ the earl of Devon, 89 fees. $^{50}$}

This scutage was in general a commutation for service. Tenants who performed their service paid no scutage on any of their fees, ${ }^{51}$ but those who were liable for scutage might pay on their fees in the different counties where their lands lay. Sometimes the sheriff collected from the rear-vassals, ${ }^{52}$ though it may be doubted whether this was ordinarily done. The charge in the roll was regularly made against the tenant in chief, not against the subtenant. If for any reason part of the fee changed hands temporarily, the debit was changed accordingly. Had

48 Pipe Roll, 13 John, Wilts, m. 12; Oxf., m. 21 d; York, m. 4; Dors. and Somers., m. $7 \mathrm{~d}$.

49 Ibid., Corn., m. 15 d. 71 fees of Mortain paying at $5 / 8$ the regular rate.

50 Ibid., Devon, m. 10 d. The only account of the reign of John before this year which seems to give a complete statement of the earl's fees, states that he holds 15 fees "quos recognoscit" and 4.5 fees "quos non recognoscit" (Rot. Canc., 3 John, p. 26; see also the scutage of 1195, Red Book, I, 88, for the same statement). Round says that the earl's servitium debitum under Henry II was 15 fees as "the scutages record him as paying always on 15 knights, quos recognoscit-the formula for servitium debitum" (Feudal England, p. 255). From 1211 on, this holding always paid on $89 \mathrm{fees,} \mathrm{but} \mathrm{the} \mathrm{figure} \mathrm{does} \mathrm{not}$ represent a new assessment as the Red Book states that in 1167 Earl Reginald of Cornwall held 89 fees which belong to the earl of Devon (Red Book, I, 43).

51 Thus a tenant was acquitted in more than one county: the earl of Arundel in Kent, Sussex, Norf., and Suff. If the writ of exemption was not at first secured, the tenant was able to prevent the sheriff from collecting scutage from himself or his men. This is the meaning of cases where tenants are entered in the roll as owing scutage, but no payment has been made. A note was added after the roll had been drawn up: "sed postea habuit quietanciam per breve" (e.g. Fulk Fitz Warren, Robert de Berkeley, William Earl Marshal, Pipe Roll, 13 John, m. 11 d, 12 d).

52 Henry de Oilli accounts for $64 \mathrm{~m} 8 \mathrm{~s} 11 \mathrm{~d}$; in Oxford, he pays in thesauro $241 / 2 \mathrm{~m}$ 2s $5 \mathrm{~d}$ "in xii talliis in quibus nomina militum suorum annotantur qui denarios reddiderunt" and $4 \mathrm{~m}$ by the sheriff of Bucks and Bedf. (ibid., Oxf., m. 21 d)). 


\section{STUDIES IN TAXATION}

the scutage been collected from the rear-vassal by the sheriff, such bookkeeping would not have been necessary. ${ }^{53}$ Nevertheless, the scutage was shifted to the rear-vassal. If he for any reason were unable to pay, his lord would be granted a delay $;^{54}$ scutage on land in hand was not demanded of the tenant in chief, ${ }^{55}$ and rear-vassals were also pardoned their scutage by the king. ${ }^{56}$ Honors in hand paid on all the knights enfeoffed. Thus the bishopric of Lincoln paid on about 104 fees instead of on 60; the archbishopric of York, on about 43 fees instead of on 20 ; the bishopric of Exeter, on 151/2 fees quos recognoscit and about 23 fees quos non recognoscit; the archbishopric of Canterbury, on $843 \%$ fees instead of on $60 .^{57}$

The accounts of the scutages of Scotland and Wales as given in the roll of $13 \mathrm{John}$ were evidently made out from the same lists of names. That more care than hitherto was taken in drawing up these accounts is shown

53 The heirs of Doun Bardulf account for $50 \mathrm{~m}$ on 25 fees: "in thesauro xii marc. et super dominicum quod est in manu regis" $13 \mathrm{~m} 4 \mathrm{~s} 5 \mathrm{~d}$ on $62 / 3$ fees "et super dominicum quod domina habet in dote" $6 \mathrm{~m}$ 8s 11d on $31 / 3$ fees "et in perdonis Huberto de Burgo $x$ marc. de $\mathrm{r}$ feodis" (ibid., Notts. and Derby, m. 2 d); see below, note 55. The custodian of an honor in hand might collect from the rear-vassals and in that case he was doubtless acting as did the tenant in chief; thus Giun de Chancels accounts for the honor of Gloucester "per manum suam colligat" (m. $12 \mathrm{~d}$ ).

54 Geoffrey de Chausir" accounts for $3 \mathrm{~m}$ on $11 / 2$ fees, "in thesauro $\operatorname{xxx}$ sol. et debet $\mathrm{x}$ sol. qui sunt super terram Turstani de Claudon' qui est in prisona" (ibid., Berks, m. 18).

${ }^{55}$ The earl of Hereford accounts for $61 \mathrm{~m}$, pays in Wilts so much "et per manum vicecomitis de Berkesira i marc." . . . "et debet $x$ li. de quibus ri marc. sunt super Milonem de S. Mauro pro iii feodis et ii marc. super Ricardum de Lukinton' quorum terræ sunt in manu regis" (ibid., Wilts, m. 12); for Robert de Chandos, debts of the 4th, 5 th and 6 th scutages (ibid., Heref., m. 7 d).

${ }_{58}$ E.g. Richard de Argent' (scutage of Scotland, ibid., York, m. $4)$; in the archbishopric of Canterbury, in hand (m. $5 \mathrm{~d}$ ); honor of Gloucester (m. 17 d); abbot of Peterborough (m. 13); Godfrey de Craucumb, holding of the heirs of Walter de Cormeilles (m. $7 \mathrm{~d}$ ). 57 Pipe Roll, 13 John, m. 14 d, 10 d, 5 d. 


\section{UNDER JOHN AND HENRY III}

by the fact that the number of fees held by the tenant was always stated whether he paid scutage or was acquitted..$^{58}$ Such a statement was not regularly entered until this year, though the practice was customary afterward. Some fines were levied on the royal demesne for the expedition to Wales. ${ }^{59}$

The chroniclers state that after the Irish campaign, enormous sums were levied on the religious houses; according to one, they were taxed $£ 100,000$ of which $£ 40,000$ were levied on the Cistercians; ${ }^{80}$ according to another, that order paid $£ 18,000 ;^{61}$ according to a third, $£ 22,200,{ }^{62}$ but no such sums appear in the Pipe Roll. The Jews also were tallaged, one chronicler stating that they were charged with 66,000 marks. ${ }^{63}$ According to the Pipe Roll, the tallage was levied on the Jews on November 1, 1210, but the total amount is not given.

58 When both scutages appear in the roll, the Scottish levy precedes that of Wales; the number of fees in the latter account is often omitted, particularly in the lists of writs of quittance. This omission is due to the fact that the number has just been given in the account of the other levy. The reason for such a careful account is probably that the clerks made use of the information obtained from the inquest made by John about this time (Round, Commune of London, p. 261; Hall, Preface, Red Book of the Exchequer, II, ccxxii-ccxxviii, for the discussion of this inquest). The entries of the Scottish scutage given on the rolls of 1209 and 1210 do not give the same detailed information (Pipe Roll, $11 \mathrm{John}, \mathrm{m} .13 \mathrm{~d}$; $12 \mathrm{John}, \mathrm{m} .2,10$ ).

$59 £ 110$ "de minutis finibus hominum comitatuum ut remaneant ab exercitu Walliæ" (Pipe Roll, 12 John, War. and Leic., m. 9 d); Dunst., p. 32.

60 Wend., III, 235; 33,333 marks, Liber de Antiquis Legibus, p. 201. 61 Margan, pp. 29-30; £22,000 (Cogg., p. 164).

${ }_{62} W a v .$, p. 265; for other notices of exactions from the clergy, see Cont. Chron. Will. de Novo Burgo, in Chron. of Reigns of Stephen, Henry II, and Richard I, II, 510, 512; Gerv. Cant., II, 105; Hist. et Cart. Mon. S. Petri Glouc., I, 24; Dunst., p. 32; Wint., p. 81; Theok., p. 59 ; Cov., II, 201-202.

e3 Wav., p. 264; Wend., III, 231 ; Cov., II, 203; Cont. Flor. Wig., ed. Thorpe, Engl. Hist. Soc., II, 169; Dunst., p. 32; Wint., p. 81; Gerv. Cant., II, 105. 


\section{STUDIES IN TAXATION}

Isaac of Norwich is said to have made a fine of 5,100 marks; John Fitz Hugh accounted in 1211 for $£ 2,159$ 11s of the tallage of the Jews which had been actually paid him. ${ }^{64}$

From 1206 to 1212, John's income was considerably increased by the profits of church lands in hand. The entries given below amount to over $£ 50,000$. Some of this money was spent for the upkeep of the manors of the clergy, donations, etc., but by far the greater part came into the royal exchequer or was laid out for the king's benefit. ${ }^{65}$ As this account is not exhaustive, the total amount received must have been much larger. A

64 Pipe Roll, 13 John, m. 22. Ramsay, Angevin Empire, p. 426, thinks that this Isaac was the Jew mentioned by Wendover who was to lose a tooth a day till he agreed to pay 10,000 marks, but believes that the amount has been exaggerated by the chronicler. In this case, however, Wendover was correct as far as the amount goes. In 1220, Hubert de Burgh accounted for $£ 604$ which he had received from Isaac of Norwich, Jew, "de fine unius marcæ qualibet die regi reddendæ a prædicto Isaac quamdiu vixerit donec de fine $x$ milium marcarum que fecerat cum rege Johanne patre regis sit quietus" (Rot. Litt. Claus., I, 459a; Pipe Roll, 4 Henry II, m. $4 \mathrm{~d})$. If this Isaac is the Jew of the roll of 1211 , he had his fine reduced to 5,100 marks or had paid previously 4,900 marks.

65 Some accounts were rendered in camera and do not appear in the Pipe Roll (see Pipe Roll, 11 John, Devon, m. 8; 12 John, m. 19).

1206

Archbishopric of Canterbury . . . . . $\quad \begin{array}{lllll} & 5,169 & 19 & 5\end{array}$

Abbey of Hide . . . . . . . $\quad \begin{array}{llllll} & & 375 & 15 & 5\end{array}$

1207

$\begin{array}{lllll}\text { Bishopric of Lincoln (part of } 8 \text { th and all of 9th year) } & 1,838 \quad 6 \quad 9\end{array}$

Abbey of Ramsey, one year . . . . . $\begin{array}{lllll} & 581 & 7 & 3\end{array}$

Bishopric of Exeter, one year . . . . . $\quad \begin{array}{lll}655 & 8 & 10\end{array}$

1208

Bishopric of Durham (fines) . . . . . . 2,666134

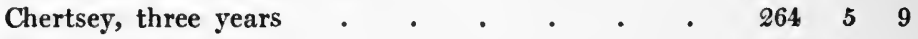

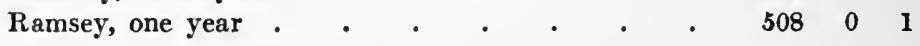

1209

Abbey of Whitby, three years .

414 19 


\section{UNDER JOHN AND HENRY III}

1210

$\begin{array}{lll}£ & s & d\end{array}$

Abbey of Einesham, one year . . . . . $\begin{array}{lllll} & 187 & 6 & 2\end{array}$

Abbotsbury, one year . $\quad$ - $\quad$. $\quad \begin{array}{llllll} & \text {. } & 152 & 19 & 3\end{array}$

Holme, one and one half years . . . $\quad \begin{array}{lllll} & & 361 & 2 & 8\end{array}$

Bishopric of Chichester, one year . . . . $\begin{array}{lllll} & 306 & 0 & 4\end{array}$

Priory of Kenilworth, Stanes, and Kalewich, one

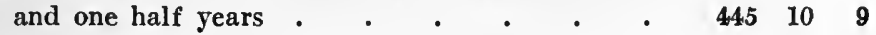

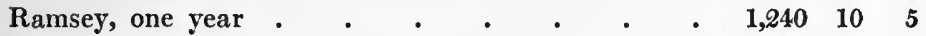

Peterborough, one year . . . . . . . $1,00015 \quad 2$

\section{1}

Tewkesbury, three and one half years $\quad \begin{array}{lllllll} & 0 & 359 & 1 & 8\end{array}$

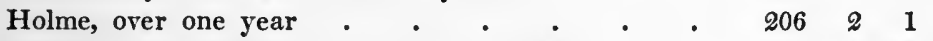

Bishopric of Salisbury, more than one year $\begin{array}{rrrr}\text { - } & 1,607 \quad 4 \quad 2\end{array}$

Archbishopric of Canterbury, one-half year . $\quad \begin{array}{rr}1,105 & 17\end{array}$

$\begin{array}{llllllll}\text { Priory of Canterbury, one-half year } \quad . \quad & 809 & 0 & 7\end{array}$

Kenilworth, Stanes, Kalewich, one year - $\quad$ - $\quad 372 \quad 24$

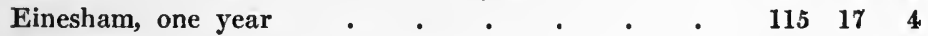

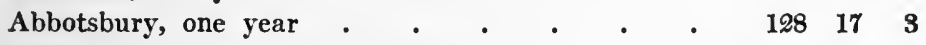

Durham, three and one half years . . . $\quad \begin{array}{llll} & 16,787 & 14 & 10\end{array}$

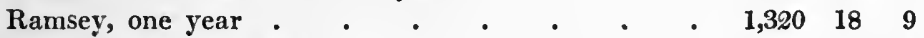

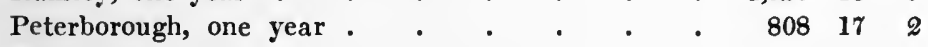

Exeter, one year . $\quad . \quad$. $\quad . \quad \begin{array}{llllll} & 0 & 516 & 9 & 7\end{array}$

Battle, two years . $\quad . \quad$. $\quad . \quad \ldots \quad . \quad 468210$

\section{2}

Bishopric of Lincoln, one year

Archbishopric of York, one year

Whitby, two years. . .

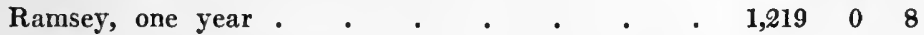

Exeter, one-half year ․ . . . $\quad \begin{array}{llllll} & \text {. } & 157 & 9 & 5\end{array}$

Bishopric of Bath, one year . $\quad$. $\quad \begin{array}{lllllll} & \text {. } & & 640 & 6 & 9\end{array}$

$\begin{array}{lllllllll}\text { Chichester, two years . } & \text {. } & & 591 & 9 & 6\end{array}$

London, one and three fourths years $\quad \begin{array}{llllll} & \text {. } & 978 & 7 & 3\end{array}$

$\begin{array}{lllllllll}\text { Kenilworth, one-half year } \quad . \quad & \text {. } & 160 & 5 & 9\end{array}$

Archbishopric of Canterbury, one year . $\begin{array}{rrrrr}\text {. } & 1,152 & 15 & 9\end{array}$

Priory of Canterbury, one year . . . . 865210

$\begin{array}{lllllllll}\text { Salisbury, one year . } \quad . \quad & 0 & 625 & 15 & 9\end{array}$



Durham, one year • • . . . . $\quad \begin{array}{rrrr}2,650 & 10 & 6\end{array}$

Bishopric of Worcester, one year . . $\begin{array}{lllllll}4 & 482 & 5 & 2\end{array}$

Sherburne, one and one half years . $\quad \begin{array}{llllll} & . & 205 & 8 & 1\end{array}$

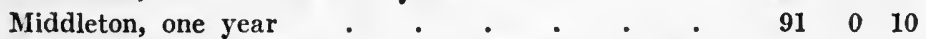

Prior of St. Edmunds, farm of abbey of St. Total

Edmunds for three fourths year . . .

$\begin{array}{lll}375 & 0 & 0\end{array}$

$\begin{array}{lll}53,474 & 3\end{array}$ 
statement in the Red Book of the exchequer makes it about $£ 100,000{ }^{68}$ The arrangements made when the king and the pope were reconciled show that the total sum must have been very large. Innocent III thought that the indemnity should be about 100,000 marks. ${ }^{67}$ John himself offered to compound with the clergy for a lump sum at this figure and promised to pay any additional damages which should be fixed by the bishops and the legate. This offer was not accepted by the English prelates as they preferred to ascertain first the total amount of compensation due. ${ }^{68}$ It was finally agreed that there should be an investigation of the whole amount of damages. In the meantime, John was to pay or give security for 40,000 marks and the interdict was to be raised. Then the king

It will be understood that these sums were the total income of each of the clerical divisions during the time indicated. They were not in all respects extraordinary levies. The amount in each case was swelled by tallages, aids, or scutage levied by the king, such, for example, as are given in the following extracts from the roll of $13 \mathrm{John}$ : Clerici of Wilts and Dorset, $£ 4753 \mathrm{~s} 9 \mathrm{~d}$ de dono; abbey of Holme, $£ 57$ 12s 4d de auxilio; clerici of Durham, $£ 7359 \mathrm{~s} 5 \mathrm{~d}$ de dono; and the following, de tallagio: abbey of Ramsey, $£ 8816 \mathrm{~s} \mathrm{8d}$; Peterborough, $£ 8016 \mathrm{~s} \mathrm{8d;} \mathrm{Exeter,} £ 139$ 18s 4d; Battle, $£ 73$ 11s 9d (Pipe Roll, 13 John, m. 4 d, 5 d, 13 d, 17 d). The account of Brian de Insula also has a few interesting items: $40 \mathrm{~m}$ of the abbot of York de dono; $100 \mathrm{~m}$ of the canons of York de dono; $£ 20$ of the abbot of Seleby de dono; $50 \mathrm{~m}$ of master Columb, canon of York, de fine; $300 \mathrm{~m}$ of the abbot of Rucford de fine; $429 \mathrm{~m}$ "de dono clericorum de Notingehamsira"; 3,390m 12s 4d "de dono clericorum de Everwicsira cum Lankastr" "; 667m 12d "de dono clericorum episcopatus Karleoli" (ibid., m. 14 d).

66 "Recepta a rege Johanne de episcopatibus, abbatiis, et aliis clericis Anglix, tempore interdicti pro Stephano archiepiscopo Cantuariensi. . . . Summa totalis CM li. et $\mathrm{v}$ marc. et $\mathrm{v}$ sol. et iii den." (Red Book, II, 772-773). Possibly this is the amount reached by the investigation mentioned below.

67 Ramsay, Angevin Empire, p. 446; Letters of Innocent III, lib. xvi, no. clxiv, in Migne, Patrologice Cursus Completus (Series Latina), Vol. CCXvi, col. 953.

68 Wend., III, 275. 
should pay 12,000 marks annually in two payments of 6,000 marks each, one on Ascension Day and the other on All Saints Day, till the total amount of compensation had been paid. ${ }^{69}$

An indication of discontent among the laity, or of John's fear of them, seems manifest from the numerous fines imposed by the king from 1209 till 1211 "pro. habenda benevolentia regis. 970

In 1213, there was danger of an invasion by the French. John summoned the host for defense. Efforts were made to gather as large an army as possible, and with success. But even in this case, it is found that the tenants in chief came to the host with only part of their contingents. ${ }^{71}$

\section{The Taxes of 1214}

In February, 1214, John invaded Poitou. ${ }^{72}$ The campaign lasted about eight months, till September, when a

69 Cogg., p. 169; Wend., III, 282; Rot. Chart., 199a, 208b; Rot. Litt. Pat., p. 139a; Norgate, John Lackland, p. 206. Sums already paid to the clergy were to be included. Of the sum of $40,000 \mathrm{~m}$, to be paid before the interdict was lifted, $27,000 \mathrm{~m}$ seem to have been actually paid (Wend., III, 283, 284); the payment of this amount is mentioned in Rot. Litt. Pat., pp. 106a, 107a, in December, 1213, and January, 1214; of 15,000m in December, 1213 (Rot. Litt. Claus., I, 158a). John seems to have been faithfully carrying out his part of the bargain till the war broke out between him and the barons. About November 1, 1214, he paid the bishops $6,000 \mathrm{~m}$ as had been agreed: "et liberate domino S. Cantuariensis archiepiscopo et episcopis vi millia marcarum apud S. Paul London' die Sabbati in festo Omnium Sanctorum anno eodem, de xii millia marcarum solvendum per annum per taxacionem domini papæ" (Rot. Litt. Claus., I, 175b).

70 Roger Fitz Adam " $\mathrm{r}$ c de mille marcis pro habenda benevolentia regis" (Pipe Roll, 11 John, m. 15); see cases, ibid., 12 John, Kent, m. $11 \mathrm{~d}$; Michael Belet, ibid., 13 John, m. $21 \mathrm{~d}$.

71 There is an account of præstita made by John to members of an army at Canterbury. The date is given as 14 John and probably relates to the host gathered to repel Philip's invasion. In each case the number of knights supplied by each tenant is given: "Præstitum factum militibus apud Cantuar" (Exch. K. R. Accounts, Bundle 325, 


\section{STUDIES IN TAXATION}

truce was concluded with Philip. ${ }^{73}$ The force which accompanied the king was considerable, though according to one writer, most of the earls remained at home. ${ }^{74}$ In the Pipe Roll, however, many of the chief barons account

No. 2, m. 2, 3). It will be noticed that some of the tenants have more than their required service. The following are some cases:

\begin{tabular}{|c|c|c|c|c|}
\hline & & & $\begin{array}{c}\text { Service } \\
\text { owed }\end{array}$ & $\begin{array}{l}\text { Knights } \\
\text { furnished }\end{array}$ \\
\hline William de Tresgoz. & . & . & 6 & 3 \\
\hline Ralph Musard . & . & . & 15 & 10 \\
\hline Robert de Mortemer . & . & - & 23 & 9 \\
\hline Hugo Poinz & . & . & 7 & 2 \\
\hline Gilbert de Gaunt & . & . & 68 & 10 \\
\hline John de Munemue & . & . & 15 & 15 \\
\hline John de Balun . & . & . & 1 & 2 \\
\hline Geoffrey Hose . & . & - & 1 & 2 \\
\hline Ralph de Saliceto & . & . & 1 & $\left\{\begin{array}{l}3 \\
1 \text { sergeant }\end{array}\right.$ \\
\hline Simon de Kime & . & . & $11 / 2$ & 5 \\
\hline Walter de Estlegh & . & . & 10 & 2 \\
\hline William de Puntdelarc & & . & 1 & 2 \\
\hline Philip de Columbiers & . & . & 10 & 3 \\
\hline Wiscard Leidet . & . & - & 13 & 2 \\
\hline Thurstan Basset & . & - & 6 & 2 \\
\hline William de Albini & - & - & 33 & 10 \\
\hline William de Escotigni & & - & 5 & 2 \\
\hline Simon de Cancy & - & - & 5 & 2 \\
\hline Geoffrey de Pavilly & - & . & 4 & 2 \\
\hline Earl Devon . & - & - & 89 & 20 \\
\hline Ingelram Pratell & - & . & 1 & 3 \\
\hline
\end{tabular}

The service owed is the number of fees for which each tenant is charged in the Pipe Roll in John's reign when the number of fees is given in the roll.

72 Cogg., p. 168; Wend., III, 280. He had plenty of money; "et in cariagio xl milia marcarum ... a Divisis usque ad Winton'" (Pipe Roll, 16 John, Wilts, m. 4); "ad perficiendum $\checkmark$ milia marcarum missarum in Flandr" (ibid., m. 3); a payment of $40,000 \mathrm{~m}$ was ordered on February 1 (Rot. Litt. Pat., p. 110a); see also Rot. Litt. Claus., I, 206, 209a.

73 Rymer, I, 124, 125.

74 "cum paucis comitibus sed infinita multitudine militum inferioris fortunæ" (Cogg., p. 168). 


\section{UNDER JOHN AND HENRY III}

for loans received in Poitou and still others receive writs acquitting them of scutage. ${ }^{75}$ This indicates that they performed at least part of their service. The number of fees taxed was somewhat over 3,200. This leaves about 3,000 exempt on account of service. But the number of English knights who were with the host did not reach the latter figure because the tenants in chief sent only part of their service. The rape of Hastings, 62 $\frac{1}{2}$ fees, sent four knights, the others contributing to their support. $^{78}$ Besides the greater tenants, the army contained lesser tenants and mercenaries. ${ }^{77}$ The array was, however, insufficient for the king's needs and in July he wrote

75 Pipe Roll, 16 John, passim.

78 Rot. Litt. Claus., I, 198a; "Habere faciatis Thomæ de Nevill" scutagium suum ... pro exercitu Pictaviæ in quo militem suum nobiscum habuit" (ibid., 177a); he held 41/21116 fees (Pipe Roll, 16 John, Bucks and Bedf., m. 2). In the Pipe Roll of 16 John there are for the first time systematic accounts in nearly all the counties of loans made by the king to men with the host under some such title as "De præstito Pictaviæ." These loans were in part repaid. Occasionally the number of knights is given for whose use the money was borrowed. There is no statement that this is the whole number of knights furnished by the tenant, but it seems probable that often such was the case. The examples follow:

\begin{tabular}{|c|c|c|c|c|c|c|c|}
\hline & \multicolumn{4}{|c|}{ County } & & $\begin{array}{l}\text { Knights } \\
\text { furnished }\end{array}$ & $\begin{array}{c}\text { Service } \\
\text { owed }\end{array}$ \\
\hline Roger de Nevill, & Essex & and & Hert. & • & . & . 1 & 1 \\
\hline William de Tresgoz, & \& & “ & “ & & & & 6 \\
\hline Matthew Mantel, & “ & " & “ & & • & . 1 & 1 \\
\hline Robert Malduit, & Bucks & and & Bedf. & ${ }^{\circ}$ & $\cdot$ & . 1 & $13 / 4$ \\
\hline Geoffrey de Say, & Kent & . & - & . & • & . 1 & 27 \\
\hline William de Nevill, & Wilts & . & . & $\cdot$ & • & . 1 & $81 / 3$ \\
\hline Robert de Valoines, & Berks & . & . & • & • & . 1 & 2 \\
\hline Robert de Amenevill, & Glouc. & . & . & • & & . 1 & 1 \\
\hline Henry de Nevill, & Linc., & York & 5. & • & & . 2 & 3 \\
\hline Earl Arundel, & Sussex & & . & $\bullet$ & & . 5 & $841 / 2$ \\
\hline William de Bocland, & Berks & & . & & & & 1 \\
\hline
\end{tabular}

77 "et in liberatione CCC Walensium euntium versus Portesmue in servitio regis" (Pipe Roll, 16 John, Heref., m. 13); the writs of quittance include lesser tenants; see also note 76 . 


\section{STUDIES IN TAXATION}

asking that more of the English knights come to his aid. ${ }^{78}$

The taxation consisted of a scutage at the increased rate of three marks per fee. A tallage was levied this year, though not for the campaign. The accounts appear in the roll of Michaelmas, 1214. The order for the levy of the scutage was issued on May 26, during the campaign. Scutage was to be taken from all tenants in chief, royal demesne, vacant bishoprics, wardships, and escheats, except from such tenants as had performed their service in France. ${ }^{79}$ Thus it was the composition for service. No fines are recorded. The amount charged was $\mathfrak{f 6 , 3 5 3}$ 16 s of which sum $\mathfrak{f 1 , 4 0 2} 13 \mathrm{~s} 11 \mathrm{~d}$ were paid in $1214 .^{80}$

There was opposition to the levy. The Red Book states that it could not be collected from the prelates or the barons. ${ }^{81}$ The Coventry annals say that the Northern barons refused to pay it. ${ }^{82}$ The letter of Innocent III in 1215 urging the payment testifies to this feeling. ${ }^{83}$ In some counties, no account was rendered in $1214 .{ }^{84}$ The

78 Rot. Litt. Pat., p. 118b.

79 Rot. Litt. Claus., I, 166b.

${ }^{80}$ The following is the account:

Clerical tenants . . . . . . . . 955124

Eighty-four lay tenants (each 5 or more fees) . $\quad \begin{array}{llll}4612 & 1 & 7\end{array}$

Other lay tenants (each fewer than 5 fees, etc.) . $\quad \begin{array}{llll}786 & 2 & 1\end{array}$

Total . . . . . . . . . . 6353160

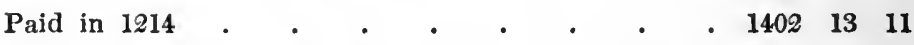

Of the 84 lay holdings above, 17 were in hand or on honors in hand. In the group of lay tenants holding fewer than 5 fees each and honors in hand are included Berchamstead, $£ 29$ 18s 6d; Peverel, £82 2s 8d; Wallingford, $£ 12614 \mathrm{~s}$; Laxington, $£ 2711 \mathrm{~s} 4 \mathrm{~d}$; half of the old enfeoffment of the honor of Totness, $£ 5517 \mathrm{~s} \mathrm{3d}$; Lancaster, $£ 127$ $12 \mathrm{~s} 4 \mathrm{~d}$; the total is $£ 449 \mathrm{16s} 1 \mathrm{~d}$, leaving less than $£ 350$ on tenants in chief.

81 Red Book, I, 12.

82 Cov., II, 217-218.

83 Rymer, I, 128.

st E.g. in Lancashire, and Essex and Hertfordshire, nothing is 


\section{UNDER JOHN AND HENRY III}

ground on which the opposition was based was not that the scutage had been refused by the barons, but that this particular scutage was illegal because service in France was not owed. ${ }^{85}$ This contention of the barons was historically wrong; but during the past few years they had been continually summoned to $\operatorname{arms}^{86}$ and their protest seems to have been directed against these repeated summons, as the expression of a desire to restrict the amount of service which the king could demand from his tenants.

It is not true to say that none of the barons paid the scutage. ${ }^{87}$ The earl of Gloucester paid $£ 72$ out of $£ 523 ;^{88}$ Gilbert Gaunt, £31 13s 9d out of $£ 138$ 1s $4 d{ }^{89}$ Nigel de Luvetot, $£ 1310$ s $8 \mathrm{~d}$ out of $£ 20 ;^{90} \mathrm{John}$ de Wahull, $£ 17$

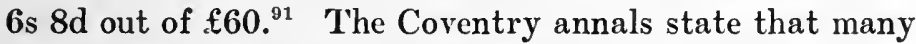
paid it but that some of the northerners refused. ${ }^{92}$ Thus while the whole scutage of Northumberland was paid in 1214 or 1215 , no return was made for Yorkshire. ${ }^{93}$ The government of John therefore considered that the scutage was legally exacted; the government of the barons during the minority of Henry III took the same ground. The accounts of this levy appear constantly in the Pipe Rolls

recorded as paid, and in Norfolk and Suffolk almost nothing. In Yorkshire there is no account at all in 1214.

85 Cov., above; Rymer, above; in 1213, the northern barons had objected to foreign service on the ground that they were not bound to do this by the tenure of their lands (Cogg., p. 167).

86 In 1209, the Scottish campaign; in 1210, Ireland; in 1211, a long campaign in Wales; in 1212, in Wales (summoned and then dismissed) and Scotland; in 1213, to guard the coasts against Philip.

87 See above, note 80 , for the amount of scutage paid.

88 Pipe Roll, 16 John, Glouc., m. 5 d.

89 Ibid., Linc., m. 14 d.

${ }^{90}$ Ibid., Cant. and Hunt., m. 7 ; on ten fees in capite, not his whole holding.

91 Ibid., Bucks and Bedf., m. 2.

92 "dantibus enim illud plurimis, contradixerunt ex Aquilonaribus nonnulli" (Cov., II, 217).

93 Pipe Roll, 16 and 17 John, Northumb. 


\section{STUDIES IN TAXATION}

of the succeeding years and from time to time small sums are entered as paid..$^{2 t}$

Yet there was enough opposition to make the collection difficult. At some time before Magna Carta was granted, the financial department of the government ceased to work. ${ }^{05}$ The great difference between the amount charged and that paid was probably due in part to the opposition, and in part to the fact that either a complete list of the barons who received writs of quittance had not been sent to the exchequer or that it was lost before the clerks had entered it in the roll, in consequence of which, men were

94 E.g. see in Pipe Roll, 2 Henry III, Berks; in 3 Henry III, Essex and Hert., Bucks and Bedf., Notts. and Derby, Berks, Devon, Oxford, Northamp. In Yorkshire, there is no account in 1214, but the following note appears: "Require scutagium Pictaviæ de hoc comitatu assisum ad iii marc. in secundo rotulo regis Henrici tertii post Everwicsiram quia a termino rotuli hujus fuit in respectu usque ad rotulum illum" (Pipe Roll, 16 John, York, m. 8 d). In the Pipe Roll of 3 Henry III, the account is entered (m. 16) with a note to the same effect as above; this was done after the matter had been brought before the council and discussed, for in the Memoranda Roll, this question is entered as one which is to be considered: "loquendum" (in the margin, opposite the item) "de scutagio Pictaviæ in comitatu Eboracsiræ" (Exch. L. T. R. Misc. Rolls, bundle 1, no. 5, Mem. Roll, 3 Henry III, m. 2 d). No payment is entered, but the exchequer evidently considers the money as due and plans to collect it. Sereral religious houses paid part of the scutage in 1214: Peterborough, St. Augustine, Wilton, Abingdon, Evesham, and Westminster (Pipe Roll, 16 John, m. 2 d, 3 d, 4, 5, 10). The prior of Coventry paid all but $5 \mathrm{~m}$ in 1227 (Madox, I, 640, n. $w$ ); the abbot of Peterborough made his last payment in the same year (Chronicon Petroburgense, ed. Stapleton, Camden Soc., p. 10). Cf. Norgate, John Lackland, p. 219: "The men of highest standing . . . had either gone to the war or paid their scutage for it without a murmur and stood utterly aloof from the group of "Northerners." "

95 "Cessaverunt placita scaccarii et vicecomitatuum per Angliam, quia nullus inventus est, qui regi censum daret rel in aliquo obediret" (Wend., III, 301); "Cancellatur hic quia respondit de omnibus receptis suis suprascriptis de tempore pacis ... sed nichil de tempore guerræ" (Pipe Roll, 17 John, Berks, m. 4); see Turner, "The Minority of Henry III," in Transactions of the Royal Historical Society, New Series, XVIII, 284. 


\section{UNDER JOHN AND HENRY III}

charged with scutage who had served. Later, tenants had to furnish evidence that they had performed their service in order to be exempt. The earl of Salisbury did this $;^{98}$ William de St. John was charged in 1214 with $£ 114$ of scutage $;^{97}$ but in 1222 it was shown that he had performed his service $;^{98}$ William de Scalariis was charged with $£ 30$, of which he paid $20 \mathrm{~m}$; the remainder was crossed off later because it was proved that he had knights with the king. ${ }^{99}$ The scutage of Poitou was therefore put in charge and collected in the regular way. ${ }^{100}$

The tenant who furnished an acceptable number of knights was quit of scutage and was allowed to collect it from his vassals by the writ de scutagio habendo. ${ }^{101}$ Nor was it necessary to furnish the full quota to obtain this writ. ${ }^{102}$ Exceptions however occurred. Robert de Ros sent his son and paid part of his scutage also, ${ }^{103}$ and John de Wahull furnished some knights, was charged with scutage, and paid part of it. ${ }^{10 *}$ Thus the rear-vassal had

98 "Quia protestatum est coram nobis (i.e. rege) et consilio nostro per recordum multorum quod W. comes Sarr' fuit in Flandr' in servicio domini J. regis" (Rot. Litt. Claus., II, 4b); also, Robert de Nevill, Warren Fitz Gerold (ibid., I, 511, 519b).

${ }_{97}$ Pipe Roll, 16 John, Hants, m. 12 d.

98 Rot. Litt. Claus., I, 521b.

99 "Ricardus filius Willelmi de Scalariis debet 25 marc. de scutagio Pictavix, sed non debet inde summoneri quia testatum est coram H. de Burgo justiciario et baronibus de scaccario quod Willelmus de Scalariis pater ipsius Ricardi habuit milites suos in Pictavia" (Madox, I, 668, n. $w, 6$ Henry III); Pipe Roll, 16 John, m. 7; Rot. Litt. Claus., I, 546b.

${ }^{100} \mathrm{Cf}$. Ramsay, Davn of the Constitution, pp. 47-48. That little of this scutage was paid in Henry III's reign is no evidence that it was not considered legally due; little of any scutage was paid over three years after it was put in charge.

101 Rot. Litt. Claus., I, 201.

102 Those men who furnished partial service received writs of quittance.

${ }_{103}$ Pipe Roll, 16 and 17 John, Northumb., York.

$104 \mathrm{He}$ accounts for $10 \mathrm{~m}$ of prastita of Poitou pro militibus suis; he is also charged with $£ 60$ of scutage, pays so much and is par- 


\section{STUDIES IN TAXATION}

to pay scutage. If, however, the latter had performed his service, neither he nor his lord was liable for the amount owed by the sub-tenant. Peter Fitz Herbert was in the army ${ }^{105}$ and the scutage due from two fees which he held of the abbot of Hyde was pardoned to him and to the abbot also. ${ }^{108}$ The fact already stated that in previous levies the exchequer did not make a practice of collecting scutage from the rear-vassal receives further illustration this year. Peter de Scidmore was charged with fifteen marks on five fees, but was acquitted because he held nothing of the king in chief. ${ }^{10 \pi}$

A tallage appears in the roll of 1214. We might expect that one would be levied in connection with the campaign in Poitou, for no tallage had been taken since

doned $£ 30$ (Pipe Roll, 16 John, Bucks and Bedf., m. 2). Cf. William de Scalariis who paid $20 \mathrm{~m}$ and was acquitted the rest on account of service (above, note 99 ).

$105 \mathrm{He}$ received 53 marks as a loan in Poitou.

106 Ibid., Hants, m. 12 d. Cf. Geoffrey de Lucy, one fee of the abbot of Peterborough (ibid., Northamp., m. 2 d). Two tenants of Richard de Redvers sent knights to Poitou for which service they and their lord were quit of scutage (Rot. Litt. Claus., I, 176b); also Hugh Pincerna who held of earl David (ibid., 178a); William de Bedham, not to pay scutage to his lord on account of service performed (ibid., 189a).

107 Peter de Scidmore owes $£ 10$ on 5 fees which were of Robert de Ewias "sed inde quietus est quia nichil tenet in capite de rege sed de honore de Wias" (Pipe Roll, 16 John, Wilts, m. 4). The statement concerning Peter in the scutage of Wales further illustrates this point. He was charged with $10 \mathrm{~m}$; "in thesauro nichil et in perdon' ipsi Petro $x$ marc. per breve regis quia sunt de baronia Roberti de Wias de quibus Robertus respondet et quietus est" (Pipe Roll, 14 John, Wilts, m. 16). Cf. the writ to the sheriff of Berks to collect scutage from the bishop of Bath "et si illud tibi reddere voluerit illud capias sin autem audias responsum illius et nobis illud scire facias set nullam districtionem ei feodis vel hominibus suis inde facias vel fieri permittas" (Rot. Litt. Claus., I, 210a). The ordinary procedure thus seems to have been to demand scutage from the tenant in chief; then if he refused to pay, distraint would be brought to compel payment. 


\section{UNDER JOHN AND HENRY III}

$1210,{ }^{108}$ but instead the grounds assigned for the tax were to raise money to help pay the indemnity for the withdrawal of the interdict. ${ }^{109}$ It was all charged against manors and towns; no names of persons appear in the

108 A tallage was not always levied in connection with a campaign; none was levied for the campaign of 1201, or for the campaigns of Scotland or Wales.

109 Rot. Litt. Pat., p. 111b. The writs were sent out March 8. There is no statement in the Pipe Roll of 1214 that this tallage was levied for the interdict, but later references show it. Bristol is charged in 1214 with $£ 500$ of tallage and paid $£ 3214 \mathrm{~s} 6 \mathrm{~d}$ and owed still $£ 178$ 15s 6d (Pipe Roll, 16 John, Glouc., m. 5 d). In 1219, the king issues his writ of computate to the exchequer barons for the men of Bristol for $40 \mathrm{~m}$ "quas liberaverunt in camera nostra apud Gloucestriam iii die Julii anno etc. tercio .... in partem solutionis debiti quod nobis debent de tallagio facto in villa Bristoll' pro relaxacione interdicti tempore Johannis regis" (Rot. Litt. Claus., I, 394b). The barons then credit the men of Bristol with these 40 marks on the debt still due of their tallage of 1214: "villata de Bristoll' $r$ c de c et lxxviii li. et xv sol. et vi den. de veteri tallagio; in thesauro nichil et ipsi regi in camera sua apud Gloecestriam tertio die Julii anno etc. tertio ... xl marcas" (Pipe Roll, 4 Henry III, Glouc., m. 6). In 1219, the burgesses of Northampton account for £218 $\mathrm{lm}$ "de tallagio ad relaxationem interdicti" (ibid., 3 Henry III, Northamp., m. 7). That is the sum remaining unpaid of the tallage of Northampton in 1214 (ibid., $16 \mathrm{John}, \mathrm{m} .2 \mathrm{~d}$ ). In 1218, four villatas owe sums "pro eodem" (viz., "auxilio ... ad relaxacionem interdicti tempore regis Johannis"), "sed non debent summoneri quia quiete sunt in rotulo xvi regis Johannis" (ibid., \& Henry III, m. $4 \mathrm{~d})$. These villatas are charged with these same sums in the tallage of 1214 and pay them and are quit (ibid., $16 \mathrm{John}, \mathrm{m} .10 \mathrm{~d}$ ). The town of Leicester was charged with an aid of $200 \mathrm{~m}$ "de auxilio... ad relaxacionem interdicti tempore regis Johannis" (ibid., 2 Henry III, m. 4 d); its tallage in 1214 was $100 \mathrm{~m}$ of which $50 \mathrm{~m}$ were paid (ibid., $16 \mathrm{John}$, War, and Leic., m. $10 \mathrm{~d}$ ). It may be therefore that a second request for money was made. The king also made an appeal to tenants by military service for an aid to raise the interdict (Rot. Litt. Pat., p. 111b). For other references to this aid or tallage, see Rot. Litt. Claus., I, 208, 209a, 213a; Madox, II, 259 , n. $l$. London paid $2,000 \mathrm{~m}$ "de tallagio ad relaxationem interdicti" (Madox, I, 388, n. $f ; 707$, n. $m$ ). This is the amount of its tallage of 1214. Lincoln is not charged with tallage in 1214; in 1218 , it is charged with $£ 500$ for the interdict (Pipe Roll, 2 Henry III, Linc., m. 9 d). 


\section{STUDIES IN TAXATION}

roll. The account was rendered in part by the towns themselves and in part by the sheriff. The round numbers in the charge against each manor or town indicate that each fined in a lump sum and arranged the incidence itself. In fixing the amount of the fine, the king was represented by the sheriff and some other royal officials. ${ }^{110}$ The king might pardon the sum charged against any person, in which case the tallage on the town was diminished by that amount. ${ }^{111}$ The sum charged was $9,163 \mathrm{~m}$ 0s $11 \mathrm{~d}$, of which $4,186 \mathrm{~m} 8 \mathrm{~s} 6 \mathrm{~d}$ were paid in $1214 .^{112}$

110 The tallage of Wallingford was made by the sheriff and two other men (Pipe Roll, 16 John, Berks, m. 5); the aid of $200 \mathrm{~m}$ on Leicester was assessed by William Briwerre and William de Chanteloup, the sheriff (ibid., 2 Henry III, m. 4 d).

111 For Geoff rey de Lucy (ibid., 16 John, Kent, m. 3 d).

112 No tallage was entered in Norfolk and Suffolk and Lancashire. In Yorkshire, only York was entered. 


\section{CHAPTER V}

\section{The Taxes in Detail from 1216 to 1229}

M

AGNA CARTA stands between the reigns of John and Henry III. To the levy of scutage it set bounds which were in the main observed. The barons no longer feared that the king would develop a means of oppression through this levy. Tenants were still obliged to serve in the host, though they brought only part of their nominal contingents and the scutage was the full composition for their service. The fines were no longer levied. An interesting feature of this period is that five aids were levied: three carucages, a levy on knights' fees, and a tax on personal property. The levy of so many taxes is to be explained in part by the indemnity to Louis and in part by the poverty of the country after the civil war, but it is altogether likely that a factor of importance was the reduction in the royal income due to the regulations of the charter. This decrease can be well illustrated from the four scutages, which were taken. The sums received from each were much smaller than under John. In the scutage of Bedford, the whole sum charged, much less the amount actually paid, would not have met the expenses of the siege of Bedford castle. ${ }^{1}$ Three tallages were taken, but only one of these was in connection with a scutage.

For the levy of the aids, it will be noticed, the great council was always summoned. The composition of this body can not be definitely determined, but its members

1 See below, pp. 150, 159. 


\section{STUDIES IN TAXATION}

were the tenants in chief and theoretically all were present, though in practice this theory was not always carried out. The assessment and the collection of the aids show nothing new. The aid of 1217 (a general scutage) probably gives us the ordinary method of collecting the scutage. The methods employed in the carucage and the tax on moveables resemble in general those in use under Richard and John, though there were variations in detail. The clergy sought to control the assessment and collection of the taxes on their own property.

There were attempts to assess the property of religious bodies which were not represented at the great council and which did not hold by military tenure. These attempts were made, not because the great council represented these religious bodies and its consent to a tax rendered them liable to pay it, but rather because it was customary for the king to ask the religious houses for dona when other parts of the community made a contribution, such as scutage. In general, these efforts of the king were not successful; for the religious bodies paid lump sums when they paid anything. Had the attempts succeeded and had the levies been made as the government expected, the relation of these religious bodies to taxation would have been completely changed. They would have become regular contributors to the government on the assessed value of their property. By the old method, no house was liable unless the royal officers, specially delegated for this work, asked for a donum. By the new method, all houses possessing property would have been liable to assessment by the regular assessors of the county and would have had to get a special writ from the king either to be exempt or to be allowed to compound. The presumption would have been that they owed a tax to the king, because they had property.

Another feature of this period was that the tenants in 


\section{UNDER JOHN AND HENRY III}

chief watched carefully over their interests in taxation. This feature is illustrated by the refusal of the bishop of Winchester to pay the aid of 1217, by the general resistance to the carucage of 1220 , by the exaction of the promise to the clergy that the carucage of 1224 should not be considered a precedent, by the demand for the reissue of the charter before the aid of 1225 was granted, and by the levy of scutage without additional fines.

\section{The Twenteme for the Holy Land, 1216}

In 1216, a twentieth of spiritualities for three years was ordered by the council of the Lateran for the benefit of the Holy Land. In England it was collected by the legate. ${ }^{2}$ Some kind of an appraisal of the revenues was made. $^{3}$

\section{The Taxes of 1217}

During the war against Louis, attempts to raise money were made by the earl marshal. Some clerical tenants paid fines for failure to send knights to the army. ${ }^{4}$ In certain cases, levies were arbitrarily made on religious houses: the abbot of St. Albans paid 1,4421/2m during the civil war, part to Louis and part to the partisans of the king, ${ }^{5}$ and it is probable that this was not an isolated instance.

The carucage of 1217 seems to have been another expedient to raise money for the war. A truce had been

2 Wend., III, 343; Wint., p. 83; Dunst., p. 52; Ann. Camb., p. 72; Annales Monasterii de Theokesberia, ed. Luard, Rolls Series, p. 64.

3 "vicesimam reddituum nostrorum secundum communem æstimationem bonorum virorum ... de tribus annis" (Dunst., p. 52); see below, p. 178, note 288 .

4 Pat. Rolls, I, 60, 61, 63.

5 Gesta Abbatum Monasterii S. Albani, ed. Riley, Rolls Series, I, 296; Theok., p. 62; Wend., III, 358, 380; IV, 6, 11. 


\section{STUDIES IN TAXATION}

made in January between Louis and the barons to last till April 22. During this period, with Louis absent in France, fighting had continued with the advantage on the side of the young king. During this truce the carucage was levied after consultation with some at least of the barons $;^{6}$ it was in process of collection in April, but was probably put in charge as early as March. ${ }^{7}$ The notices refer to it as "auxilium," "carucagium" (or "caruagium") and "hidagium," separately or together. ${ }^{8}$ The use of both terms, hidage and carucage, means that the tax was assessed on the land, which was measured in some counties by hides and in others by carucates.

A complete description of the machinery of assessment and collection is not given, but from the brief references in several writs, part of the machinery may be made out. In each county there was a body of knights, called the collectors of the aid, who had general charge of the assessment and collection. ${ }^{\circledR}$ The sheriff may have united

6 "assisum fuit per consilium regni nostri" (Rot. Litt. Claus., I, $348 \mathrm{~b})$.

7 Rot. Litt. Claus., I, 306a, 335b; on April 14, Falkes de Bréauté was ordered to pay at once to Hubert de Burgh $500 \mathrm{~m}$ of the carucage received in his counties. Some time therefore must have elapsed since the tax was put in charge (Pat. Rolls, I, 56).

8 "hydagium" (Annales Prioratus de Wigornia, ed. Luard, Rolls Series, p. 408); "hidagium et caruagium"; "hidagium, caruagium, et auxilium"; "carrucagio et hydagio"; "scire autem facias comiti W. Marescallo ... quot hidas vel carucatas terræ habeant in ballia tua et de quanto debeant de caruagio vel hidagio respondere" (Rot. Litt. Claus., I, 306a, 310a, 335b, 348b); "de hidagio et auxilio" (Pat. Rolls, I, 56).

9 'Rex vicecomiti Berksir' et collectoribus auxilii ejusdem comitatus" (Rot. Litt. Claus., I, 307a); "Rex ... vicecomiti Berkes,' Waltero Foliot, Waltero de Ripar,' et Johanni Wigenholt' salutem. Mandamus vobis quod omnes denarios quos recepistis et quos recipietis de hidagio et caruagio"; "mandavimus vicecomiti Berkes' et Waltero de Ripar' et aliis militibus quos attornavimus ad assidendum et recipiendum hidagium et caruagium comitatus Berkes" " (ibid., 306a). The men named in the second and third passages are the collectors named in the first. Of them, Walter Foliot held in 1212 


\section{UNDER JOHN AND HENRY III}

with them in this work. ${ }^{10}$ It is not clear whether the money was actually paid by the taxpayers directly to these county collectors, or to the sheriff, but it is significant that tenants in chief did not make the collection on their lands, except by special permission. ${ }^{11}$ The sheriff naturally enforced payment. ${ }^{12}$ The money in each county was finally delivered to the sheriff and the collectors. Sometimes it was put in an abbey for safe-keeping..$^{13}$

We cannot say how generally the tax was paid throughout England. Orders concerning its payment exist, addressed to the sheriffs of nearly all the counties except in the southeast where Louis' power was greatest. ${ }^{14}$ Nor can we say what proportion of the land paid it in those counties where it was assessed. We know that it was charged against both the laity and the clergy. Some of the religious bodies opposed it. By the influence of the legate, they were induced to make some sort of a grant, probably in lump sums. ${ }^{15}$ None of the notices of the tax

two and a fourth fees of the honor of Wallingford (Red Book, II, 598), so that this board may have been made up of knights of the county. No reference to the board of assessors appears for any county but Berkshire, but the method of collection would be the same throughout the kingdom.

10 The writs are addressed to him with the collectors.

11 For Henry de Trublevill to assess and collect (ibid., 306b); for William Marshal, the younger, "capere hidagium quod assisum fuit in terris et tenementis quod dominus rex ei concessit (ibid., 318b); for William Briwerre "colligere hidagium terræ suæ quoniam inde respondebit domino regi" (ibid., 318a).

12 To him were issued orders to permit tenants to collect the tax themselves, to refrain from collecting the tax from certain ones (ibid., 335b, 336a); see also the references in note 11 .

13 In Berks, to the abbot of Abingdon (ibid., 306a).

14 Ibid., 307a, 310a, 318, 319, 335b; Pat. Rolls, I, 56.

15 On April 9, 1217, the sheriffs were ordered not to collect the tax for the present from the Hospitallers because they were to appear on April 25 before the legate to hear his advice on the subject. They were however to report to the regent the number of carucates held by this order in their counties. Then on June 13, the sheriff of Hants was ordered to exempt all religious orders from the carucage 


\section{STUDIES IN TAXATION}

specifically refer to the clerical tenants in chief, but on July 8, 121\%, the pope wrote Guala that the bishops and prelates were to make an aid juxta facultates suas which was to be paid to the legate. ${ }^{16}$ This may have been a payment in addition to the carucage; at any rate the clergy made some sort of an aid. Some tenants were allowed to retain the carucage for their own use. ${ }^{17}$ - An interesting feature of the levy was the use of local machinery in the assessment and collection.

The treaty of Lambeth on September 11 closed the civil war. Louis was to receive $\mathbf{1 0 , 0 0 0}$ marks and withdraw from England. ${ }^{18}$ The efforts to pay this indemnity show the financial straits of the government. Part of the money was paid before the French prince departed. ${ }^{19}$ A charter binding Henry III to pay 6,000 marks was drawn up and deposited with the Templars at Paris. Whether this was the balance that remained unpaid or not

"quoniam ipsi nobis inde satisfecerunt" (Rot. Litt. Claus., I, 335b, 336a). This second order seems to have been issued as a result of the conference held by Guala.

16 Shirley, Royal Letters of Henry III, I, 532.

17 E.g. Robert de Mortimer (Rot. Litt. Claus., I, 310a).

18 " $10,000 \mathrm{~m}$ que ei (Lodovico) conrencionatæ fuerunt quando pax formata fuit inter nos et ipsum L." (Pat. Rolls, I, 284); "Comes Willelmus Marescallus se domino Ludovico pro nobis obligavit, sub poena non modica, ad solutionem 10,000 marcarum pro bono pacis inter nos et ipsum L. reformatæ ... tenemur satisfacere" (Shirley, I, 7) ; 15,000 marks (Dunst., p. 51); $£ 10,000$ (Chronica de Mailros, Bannatyne Club, p. 131) ; 17,000 marks (Histoire des ducs de Normandie, p. 204); Wav., p. 288; Cov., II, 239. The two references from official documents are sufficient to fix the amount of the indemnity which the English government paid at 10,000 marks. Louis was also to receive sums from towns and individuals (Norgate, The Minority of Henry III, p. 83), a fact which will perhaps explain, as Miss Norgate suggests, why the chroniclers fixed the indemnity at more than 10,000 marks. The Londoners lent Louis $£ 1,000$ (Liber de Antiquis Legibus, p. 204); according to Wendorer, the sum was $£ 5,000$ (Wend., IV, 32).

19 "receptisque suis (i.e. of Louis) qui in vinculis tenebantur et parte pecuniæ promissæ, ... rediit ad sua" (Cor., II, 239). 


\section{UNDER JOHN AND HENRY III}

on Louis' departure is not clear. ${ }^{20}$ This sum was to be received by merchants of St. Omer who acted as Louis' representatives and who had advanced him part or all of this amount. The government hoped to pay the 6,000 marks quickly. Two thousand marks were to be cancelled by the immediate delivery to the merchants of 100 lasts of leather and 100 sacks of wool. From the sale of the leather and wool the merchants would be able to recoup themselves for part of the money which they had advanced to Louis and have some profit for their trouble. In case the goods were not delivered, the merchants were to receive 2,000 marks in money plus 500 marks for themselves. The balance of 4,000 marks was to be paid them, half on November 1, 1217, and half on February 2, 1218. ${ }^{21}$ But these arrangements could not be carried out. Wool and leather were seized, money was borrowed, ${ }^{22}$ but in August, 1218, 2,150 marks of the debt still remained unpaid. ${ }^{23}$ In addition to the seizure of goods and the loans, the government raised money by an aid on knights' fees and a tallage. The final payment of the indemnity was not made till $1221 .^{2 *}$

The aid was at the rate of two marks per fee and was granted by a great council held on October $20 .{ }^{25}$ That

20 "carta nostra, quam domino Lodovico fecimus de debito vi milium marcarum, quam magister Templi de Parisius habet in custodia" (Pat. Rolls, I, 168).

21 Ibid., I, 114. Provision was made to secure both Louis and the merchants if the agreement was not carried out (ibid., I, 114, 115).

22 Ibid., I, 153; Rot. Litt. Claus., I, 351b, 360b, 369, 383a, 388b, 459a, 602a.

${ }^{23}$ Pat. Rolls, I, 168; Rot. Litt. Claus., I, 381 b.

${ }^{24}$ Rot. Litt. Claus., I, 415a; Pat. Rolls, I, 284. The last payment of $500 \mathrm{~m}$ was made with money borrowed from the bishop of Norwich. 25 "ponitum est per commune consilium regni nostri" (Rot. Litt. Claus., I, 371a); a council was summoned to meet on October 20 and writs concerning collection were sent out on October 30, so that probably the business of the council was to make the aid: "ad concilium quod erit London' a die S. Michaelis in tres septimanas" 


\section{STUDIES IN TAXATION}

this levy was made for the purpose of paying the indennity to Louis is shown by the statement in the Pipe Roll that it was assessed to deliver England from the French. ${ }^{26}$ Further, the king in his letter asking for an aid from Ireland stated that he was bound to pay money to Louis on November 30, which was the date set for the payment of the first part of the aid in England. It is clear that the payment to Louis was connected with the grant of this aid by the English tenants. The first half was to be paid on November 30 and the balance on the following January $13{ }^{27}$ The collection was not completed on those dates and a new order was issued that the balance should all be paid on March 25, 1218, ${ }^{28}$ but the command was not carried out. ${ }^{29}$

The account follows:

M $\quad s \quad d$

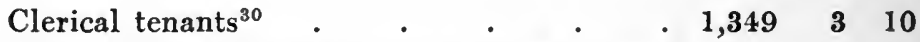

One hundred and sixty-five lay tenants (each

5 or more fees $)^{31} \quad \cdot \quad \cdot \quad \begin{array}{lllll} & . & 9,145 & 9 & 0\end{array}$

Other lay tenants (each fewer than 5 fees,

Total etc. ${ }^{32}$

\begin{tabular}{|c|c|}
\hline 603 & 11 \\
\hline 11,098 & 11 \\
\hline 4,227 & \\
\hline
\end{tabular}

(ibid., 336b); "quando scutagium primum assisum fuit tempore nostro ad auxilium nobis faciendum" (ibid., II, 87b); "scutagium positum de novo per consilium commune comitum et baronum nostrorum Angliæ" (Pat. Rolls, I, 125).

26 "de scutagio assiso anno secundo regni regis Henrici III ad Angliam deliberandam de Francis" (Pipe Roll, 17 John, Compotus honoris Boloniæ, m. 1); cited in Petit-Dutaillis, Étude sur la vio et le rène de Louis VIII, p. 17\%: "scutagio . . a assiso . . . ad aquietandum nos versus ipsum $L$. de debito quod ei debuimus (Close Rolls, I, 171).

27 Rot. Litt. Claus., I, 371a.

28 Ibid., $377 \mathrm{~b}$.

29 See the account of the scutage below for the amount paid.

30 Two holdings are omitted: Canterbury, 60 fees, and Norwich, 40 fees. The abbot of Westminster accounted for only $22 \mathrm{~m}$ instead 


\section{UNDER JOHN AND HENRY III}

- As this scutage was an aid on all fees, ${ }^{33}$ it had no connection with the military service which had been performed by the tenants in chief during the war. It is true that some men were excused from paying it. Robert Fitz Walter received a grant of all his scutage; William Cantilupe received half of his; Falkes de Bréauté after five years was pardoned his; Hubert de Burgh received fifty marks collected from land of which he was in temporary possession. ${ }^{34}$ But in these cases it seems to have been a matter of favor; they were men high in the government. The case of the bishop of Winchester should be noted. He was excused by the barons of the exchequer because he had never assented to the levy. ${ }^{35}$ Probably the fact that the bishop was one of the chief men of the council

of $30 \mathrm{~m}$. The bishop of Winchester accounted for $159 \mathrm{~m}$ instead of $120 \mathrm{~m}$; he paid nothing in the end. There are some other variations from the numbers given by Round for the service of the clergy: the

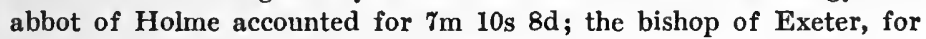
$31 \mathrm{~m}$; the abbot of Sherburne, for $4 \mathrm{~m} 5 \mathrm{~s} 6 \mathrm{~d}$.

31 This includes the following honors, each as one tenant: Reginald de Valtort for half of the honor of Totness, old enfeoffment, $55 \mathrm{~m}$ $12 \mathrm{~s} 5 \mathrm{~d}$; the sheriff for the other half and for half of the new enfeoff-

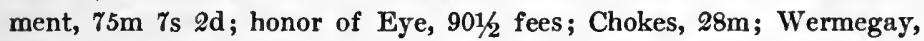
$281 / 2 \mathrm{~m}$; rape of Hastings, $125 \mathrm{~m}$; Lancaster, $157 \mathrm{~m}$ 8s $6 \mathrm{~d}$; Wallingford, $197 \mathrm{~m}$ 11s 2d; Peverel, 128m 7s 6d.

32 This includes $25 \mathrm{~m}$ of the honor of Brittany.

${ }^{33}$ This gives a total of about 5,500 fees in England which account at the exchequer, but certain holdings were omitted, the chief of which were: 100 fees of the clergy; the county of Cornwall, about 220 fees; 128 fees of the honor of Brittany (see above, note 32); about 112 fees of Boulogne; 106 fees of the honors of Henry de Essex and Hawenet (see Pipe Roll, 38 Henry III, Essex and Hertford); 54 fees of the holding of William de Braose (ibid., Heref.); 65 fees of the old enfeoffment of Roger Bigot; 60 fees of the honor of Tickhill. This gives a total of 6,395 fees. Roger Bigot held $1251 / 4$ fees of the old enfeoffment. In John's reign he fined with the king to answer for 60 fees for his whole holding as long as he lived (Madox, I, $190, \mathrm{n} . f$ ); consequently he is entered in the roll of this aid as owing on 60 fees only.

34 Rot. Litt. Claus., I, 349b, 518a ; Pat. Rolls, I, 476.

35 Madox, I, 675, n. $q$. 


\section{STUDIES IN TAXA'TION}

had something to do with this decision. Some men were excused for service. Geoffrey de Costentin was in Ireland on the king's service at this time and his assessment was pardoned, but it was here clearly a matter of favor, not of right. ${ }^{36}$

The tax really fell on the rear-vassal rather than on the tenant in chief. Many tenants obtained writs allowing them to collect it from their vassals and respond for it at the exchequer. The sheriff was to aid them with distraint. ${ }^{37}$ The vassals of other tenants in chief were to pay it to the sheriff who accounted for it..$^{38}$

Writs for the levy of a tallage on the royal demesne were issued in November. It was assessed by the sheriff in conjunction with special officials sent into the county, who were sometimes royal justices, ${ }^{39}$ and was to be paid and forwarded to the exchequer each week. The towns usually fined in lump sums for their tallage and thus obtained the privilege of making their own assessment and collection. ${ }^{40}$ Persons and vills were also assessed by the justices, for their names are entered in the Pipe Roll..11 The amount charged in the roll is about 2,500 marks and 1,613 marks are entered as paid. ${ }^{42}$ Several counties

36 Close Rolls, I, 171.

37 Rot. Litt. Claus., I, 371a.

38 Pat. Rolls, I, 171.

39 Pat. Rolls, I, 170, 171. In Kent, Sussex, Surrey, and Hants, the tallagers were three men who were apparently royal clerks, for at the same time they were to examine into the king's escheats in those counties; they were to coöperate with the sheriff. In Gloucester, the tallage was assessed by William Earl Marshal, William de Cantilupe, Ralph Musard (the sheriff) and Henry Fitz Gerold (Rot. Litt. Claus., I, 375a); in 1218 William de Cantilupe was itinerant justice (Pat. Rolls, I, 207); Mauricius de Turevill and Gilbert de Abingwurth were tallagers and itinerant justices (ibid., I, 172, 207, 208).

40 Pipe Roll, 2 Henry III, passim; Rot. Litt. Claus., I, 359a, 364b.

41 Pipe Roll, 2 Henry III, Norf. and Suff., m. 3 d; War. and Leic., m. 5 d; 3 Henry III, Northumb., m. 14.

42 Pipe Roll, 2-6 Henry III. 


\section{UNDER JOHN AND HENRY III}

are omitted. ${ }^{43}$ Probably the tallage did not yield as much as usual this year because of the confusion into which the war had thrown the kingdom. This is indicated by the king's letter to the pope explaining why the tribute had not been paid. ${ }^{44}$ An aid was also asked of all the knights in Ireland and a tallage was taken on the king's demesne there. ${ }^{45}$

\section{The Carucage of 1220}

The government was unable to pay all its expenses from the ordinary revenue although the country was at peace. In 1218, it had asked for a loan of 2,000 marks to defray the outlay in Aquitaine. ${ }^{46}$ The pope's tribute had not been paid, money was still due to Louis, and there were debts to others. ${ }^{47}$ Queen Berengaria's annual fee of $£ 1,000$ had not been paid since the beginning of the reign. The exchange of England was assigned to her with other revenues and in addition a thousand marks

43 Thirteen counties are omitted, among them London. Perhaps the money given by the capital to Louis was considered as its tallage. Some towns may have made a fine for the tallage with other things as did Lincoln. The towns of Lincolnshire do not appear in the roll as tallaged, but the citizens of Iincoln fined in $200 \mathrm{~m}$ "ne tallientur hoc anno occasione tallagii quod assisum fuit super dominica regis; et quod habeant villam suam ad firmam hoc anno sicut habuerunt tempore regis $J$. patris regis et quod de hoc anno prædicto sint quieti de $£ 40$ de cremento firmæ villæ suæ" (Pipe Roll, 2 Henry III, Linc., m. 9 d). Also in 3 Henry III with slightly different wording, quoted in Madox, I, 413, n. $h$. The accounts are incomplete in those counties in which returns are made.

44 "non est facultas hactenus comitata, tum quia ballivi nostri, partibus suis depauperatis per guerram, minus solito sufficiunt ad scaccarium nostrum respondere" (Shirley, I, 7).

45 Pat. Rolls, I, 125; Rot. Litt. Claus., I, 375a.

46 Two thousand marks had been asked from La Rochelle and Bordeaux (Pat. Rolls, I, 198); Rymer, I, 155, 156; Shirley, I, 43-45. 47 Pat. Rolls, I, 229, 232, 253, 284; Rot. Litt. Claus., I, 442a. 


\section{STUDIES IN TAXATION}

were promised to her at once. ${ }^{48}$ In September, 1220, the sum of $2,007 \frac{1}{2}$ marks was borrowed from the legate. ${ }^{49}$ This condition of the exchequer forced the government to levy an extraordinary contribution. ${ }^{50}$ In the summer of 1220, probably in August, ${ }^{51}$ an aid was taken in the form of a carucage. According to the writs of collection, the tax was levied by the consent of a council composed of all the magnates and faithful of the realm. ${ }^{52}$ This description is not accurate, for the barons were not all present, nor had they all been summoned. The tenants of Yorkshire had not attended the meeting and had not been called to it. $^{53}$

The opposition of the Yorkshiremen to the carucage reveals the existence of two views regarding the constitution of a council which should have the authority to grant a tax. As to the theory in the case there was no difference of opinion. It is apparent from the wording of the writs that the government no less than the northern barons recognized that an aid had to be granted by all the tenants in chief and not arbitrarily levied by the king.

48 Pat. Rolls, I, 244, 265; she seems to have brought pressure to bear on the government by the pope, for William Marshal speaks of a threat of an interdict (Shirley, I, 70).

49 Pat. Rolls, I, 253. This was money collected for the crusade.

50 "pro magna necessitate nostra et urgentissima debitorum nostrorum instancia necnon et pro conservacione terræ nostræ Pictaviæ concesserunt etc." (Rot. Litt. Claus., I, 437a).

51 The writs for its assessment were issued on August 9 (ibid.). It is unlikely that the government would wait long after the grant was made to begin the collection of the tax. Ramsay, Dawn of the Constitution, p. 23, says that it was granted on May 18 at the time of the coronation. The authorities whom he cites say nothing of a grant at that time (Dunst., p. 60; Wint., p. 83; Wav., p. 293).

52 "caruagio assiso per commune consilium nostrum"; "concesserunt nobis sui gratia communiter omnes magnates et fideles tocius regni nostri donum nobis faciendum" (Rot. Litt. Claus., I, 442a, 437a).

53 The opposition of the Yorkshire barons is described in a letter of the sheriff of Yorkshire to Hubert de Burgh, given in Shirley, I, 151. 


\section{UNDER JOHN AND HENRY III}

It is equally clear that in practice this theory was not carried out, but that part only of the barons might be summoned to a council, and their consent would be regarded as sufficient authority for the levy of an aid. Nor does there seem to be anything new in this procedure. $^{54}$ The tenants of Yorkshire recognized the danger to them of such a policy. Their protest was directed not against the levy of the aid, but against the method by which it had been granted. They insisted that they must give their consent to the tax before it could be assessed on them. That is, they proposed to hold the king strictly to the letter of the law. ${ }^{55}$ This opposition was still more significant from the fact that there seems to have been concerted action among the barons. The refusal of the bailiffs to take any action at all, their persistent unanimity in their reply, the constitutional grounds which they alleged for their refusal, all suggest this conclusion. ${ }^{56}$

54 The action of the government in levying an aid in this manner at a time when contests with the barons were of frequent occurrence and when it would not wish to provoke opposition by illegal exactions, the evident surprise of the chamberlain at the opposition of the Yorkshiremen, his willingness to proceed to extreme measures against them, and his belief that he was in a position to enforce his demands are evidence of the truth of this statement. The provision in Magna Carta (c. 14) that the consent of those present should bind the absent is somewhat similar to this practice, though all were to be summoned. A scutage for war was usually declared by those tenants who were present with the host and by this declaration absentees were bound; such scutage was not however an aid but a levy taken because of the king's right to the military service of his vassals, and moreover in this case absentees had been summoned to the host. Yet there is a similarity in all these meetings of the tenants in chief and it is apparently that on which the government relied in 1220, viz., that most of the chief men of the kingdom had been consulted.

35 "Didici tamen a quibusdam eorum, quod si dominus rex in adventu suo apud Eborum dictos magnatos convocaverit, et de prædicto negotio rogaverit, ipsi acquiescent, et prædictum auxilium dari facient" (Shirley, I, 151).

50 The barons were not present at the court in which the king's writ for the assessment was read out. Their bailiffs after consultation 


\section{STUDIES IN TAXATION}

It is probable that the carucage was finally levied in Yorkshire, but under circumstances which are not known. ${ }^{57}$ In some other counties, the king's officers did not collect the tax. The reason for the opposition is not given, but it is plain that if the tenants were unwilling to pay the carucage, it could not be assessed and collected.$^{58}$ It is

among themselves replied "quod eorum domini de hoc auxilio et tallagio domino regi dando nihil sciverunt, nec rogati fuerunt. Unde ipsi, dominis suis inconsultis, huic tallagio dando non ausi fuerunt consentire, dicentes quod magnates de partibus illis, sicut et alii de Anglia, vel viva voce domini regis, vel ipsius literis, ad hoc faciendum rogari debuerunt." This reply did not seem conclusive to the sheriff; he still urged them to proceed to the assessment, but at length at their request, granted them a delay till the next county court that in the meantime "præceptum domini regis dominis suis exponerent. Unde ad diem illum nihil aliud ab eis obtinere potui." Stubbs, Const. Hist., II (3rd ed.), 223, believes from this that "the concession of a grant was regarded as falling within the lawful power of a local assembly," viz., the county court. That the question involved is not the power of the county court, but the feudal right of a tenant not to pay an extraordinary contribution unless he gives his consent to it has been stated by Adams, $A . H . R ., \mathrm{V}, 649$.

57 See the statement of the barons in note 55 . Inman, Feudal Statistics, p. 33, note, cites a payment in Yorkshire in 4 Henry III, but does not give his authority. "Vicecomes habet respectum de compoto carruagii usque ad festum S. Michaelis per literas domini regis de magno sigillo" (Exch. L. T. R., Mem. Roll, 7 Henry III, D 11, for Yorkshire).

${ }^{58} \mathrm{~A}$ list of names is given, among them the earl marshal, the earl of Salisbury, the bishop of Winchester, the earl of Chester, and the abbot of Reading, and the following comment is made: "et in prædictis terris nullum carucagium fuit assisum vel collectum eo quod domini dictorum feodorum non permiserunt homines suos coram baylivis domini regis comparere ad dictum carucagium assidendum" (Subsidies, Bundle 73, No. 1b). The above is in Berks and refers to the levy of 1220, because in the document there is a reference to William de Wancy as one of the assessors and he had that office in Berks in 1220. "Vicecomes dicit quod barones de Launcastre noluerunt dare carucagium" (Exch., L. T. R. [Compotus of 7 Henry III], 8 Henry III, m. 9 d). The counties of Stafford and Salop "non respondent de karrucagio" (ibid., m. 17); "vicecomes dicit quod comes Warenn' et comes Arundelli non permiserunt carrucagium poni super terras suas" (ibid., 9 Henry III, m. 6 d, in Sussex); this 


\section{UNDER JOHN AND HENRY III}

possible that the cause of the resistance of these other barons was the same as that of the Yorkshire men.

The tax was levied on the land which was under cultivation on June 24, of this year. It has been suggested that the levy was based on the plough team, not on the land. This interpretation rests on the statement that the levy was made "de qualibet caruca sicut juncta fuit." 'Caruca' however was in use at the time for the word 'carucata.' In 1224, Coggeshal states that two men were summoned to the siege of Bedford castle de qualibet carruca, an expression which refers to the land and is so given in the Dunstable annals, duos operarios de singulis hidis. ${ }^{60}$ The whole phrase used in the writ of collection refers as well to the land under cultivation as to the team. ${ }^{61}$ Some of the items in the returns show that the land itself was measured and not estimated by counting the number of teams. In the Testa de Nevill, most of the items say "pro $x$ carucis $y$ solidi," an abbreviated form of "pro $\mathrm{x}$ carucis terræ," which occasionally appears and means 'carucate. ${ }^{62}$ Further, if the teams were counted, it is difficult to see how such fractional amounts could be due as, $2 \mathrm{~d}, 7 \mathrm{~d}$ ob., $5 \mathrm{~d}, 7 \mathrm{~d}, 3 \mathrm{~d}, 10 \mathrm{~d}$; while these would be expected if the land cultivated were the basis of assess-

last item comes after the date of the carucage of 1224, but belongs, I think, to the carucage of 1220 (see below, p. $153 f f$ ).

59 "Whereas under Richard I, as under all his predecessors, the levy was made upon the ploughland (carucata), we find it raised under Henry III not from the land, but on the plough team (caruca)" (Round, in E.H.R., III, 507, and note 22 ).

60 Cogg., p. 206 ; Dunst., p. 86.

61 "de qualibet caruca sicut juncta fuit in crastino B. Johannis Baptistæ proximo præterito ... duos solidos" (Rot. Litt. Claus., I, 437a).

62 "de Saudon, pro $\mathrm{x}$ carucis terre $\mathrm{xx}$ solidi" (Testa de Nevill, pp. 131-133); that the meaning of "caruca terræ" is carucate is shown by the following: "Ibi sunt in dominico duæ carucæ terræ, nesciunt quid contineant" (Cartularium Monasterii de Rameseia, ed. Hart, Rolls Series, II, 42), cited by Norgate, below. 


\section{S'TUDIES IN TAXATION}

ment. ${ }^{63}$ It seems certain therefore that the land was assessed and not the team. ${ }^{64}$ But even if the teams were counted, the purpose of the enumeration was not to levy a tax on them, but to find out the amount of land under cultivation, so that in any case it was a land tax. The main significance of the levy does not lie here, but in the fact that an attempt was made to graduate the tax to a certain kind of property which was producing wealth, instead of taking an old customary basis. Thus land which was waste, although formerly cultivated, escaped. In this particular, the carucage was a step toward taxation based on personal property.

The writs of collection were sent out August 9 and the money was to be paid at the exchequer September $29 .^{65}$ By November, a large amount had been collected. ${ }^{66}$ The carucage was paid on the royal demesne ${ }^{67}$ and on all

pro 46 carucis et parte $£ 412 \mathrm{~s} 2 \mathrm{~d}$.

29 carucis et dim' et parte $59 \mathrm{~s} 4 \mathrm{~d}$.

6 carucis et parte $12 \mathrm{~s} 7 \mathrm{~d}$ ob.

16 carucis et dim' et parte $33 \mathrm{~s} 5 \mathrm{~d}$.

36 carucis et parte $72 \mathrm{~s} 7 \mathrm{~d}$.

20 carucis et parte $40 \mathrm{~s} 7 \mathrm{~d}$.

1 caruca et dim' et quadam particula $3 \mathrm{~s} 3 \mathrm{~d}$ ob.

pro partibus car' $17 \mathrm{~d}$.

pro parte carucæ lod (Testa, abore).

Entries similar to the following suggest that the levy was based on the land: "vi car' et vii toftæ soluerunt xiii sol. ix den." (Lay Subsidies, bundle 120, no. 1.)

64 Round's statements are combatted by Miss Norgate in $E . H . R$, III, 702-704, and by W. H. Stevenson, ibid., IV, 108-110. The latter says, "Surely we require stronger evidence than this (i.e. Round's) before we can believe that carucage was ever levied on the team."

65 Rot. Litt. Claus., above.

68 "Liberate de tribus millia marcarum quas recepistis de caruagio etc." (ibid., I, 442a).

67 The honor of Wallingford, in hand, paid it (Vincent, Lancashire Lay Subsidies, p. 140); "de quingentis marcis de auxilio nobis promisso de civitate London'" (Rot. Litt. Claus., I, 461a, June 9, 1221); this may be an aid in a lump sum for the carucage. 


\section{UNDER JOHN AND HENRY III}

lands held by tenants in chief including their demesnes. ${ }^{68}$ Religious houses which held no land by knight's service paid auxilia in lump sums to the diocesan who transmitted the money to the king. ${ }^{68}$ The Cistercians and Premonstratensians were exempt; the property of the Templars and Hospitallers was assessed; they obtained a stay of collection and perhaps paid nothing in the end. ${ }^{70}$ The tenants on the royal demesne in Ireland were asked for an aid. $^{71}$

The machinery of assessment and collection was as follows: the sheriff convened the county court and had two knights elected from the whole county. These aided him in the assessment and collection of the tax. ${ }^{72} \mathrm{~A}$ roll containing the vills in each hundred was drawn up, probably in duplicate, and forwarded to the exchequer at Michaelmas. ${ }^{73}$ When the money was collected, it was sent to London under the seals of the three assessors. The writ which we have does not give the sheriff full

88 That the lay tenants in chief paid it on their demesnes, see ibid., 442a, in which Robert Fitz Walter obtained special exemption for his demesne. The royal officials were not to assess the demesnes of the clergy (ibid., 437a; Testa, p. 132; Dunst., p. 60), but that the clerical tenants paid the tax on their demesnes is shown by an order to the sheriff of Worcestershire to return to the bishop of Worcester "totum carucagium quod per manum tuam cepisti de dominicis terris et feodis ipsius episcopi de quo ipse debet per manum suam nobis respondere"; similar orders were given concerning all the carucage taken from the lands of any religious orders which "per manum suam nobis inde respondebant" (Fine Roll, 5 Henry III, part 1, m. 6).

69 Shirley, I, 152; Dunst., p. 60.

70 Rot. Litt. Claus., I, 428b. The number of their carucæ was however reported to the exchequer by the sheriff.

71 Pat. Rolls, I, 253.

72 Rot. Litt. Claus., I, 437a. In Berks there were four knights: "distringas quatuor milites de comitatu tuo qui assignati fuerunt ad caruagium illud assidendum" (Exch., L. T. R., Mem. Roll, 7 Henry III, m. 12).

${ }^{73}$ Rot. Litt. Claus., I, 428b, 437a. Testa, pp. 131-133, where the roll of Berks is summarized by hundreds, giving the total of each vill; Vincent, p. 135, has given in detail the return for the vill of 


\section{STUDIES IN TAXATION}

instructions concerning the assessment. It does not tell him how the roll, which it mentions, was to be drawn up, nor by what method he and the two knights were to ascertain the number of ploughlands. Either there was another writ, or the sheriff followed some customary method. ${ }^{74}$ The lands of churchmen held by their knights and free tenants were assessed by the county officials, but the clergy obtained the privilege of collecting the tax themselves, ${ }^{75}$ a concession which might be extended to lands of which a clerical tenant had the custody. ${ }^{76}$ Sometimes a county fined in a lump sum for the carucage. ${ }^{77}$ The tax yielded at least $£ 5,48311 \mathrm{~s} 2 \mathrm{~d}^{78}$ It does not seem to have been heavier than a scutage. ${ }^{79}$

\section{The Scutage of Biham, 1221}

In January, 1221, William, earl of Albemarle, rebelled and seized several castles in the north. He was excommunicated; efforts at mediation made by some of the

Windsor with the names of the persons taxed and the number of carucæ charged against each. The sheriff and the knights were all equally held accountable for the tax by the exchequer (Mem. Roll, 7 Henry III, above).

74 Sometimes the sheriff collected the tax without the knights: “Alexander de Poutton' et Henricus de Lagngeton' milites assignati ad caruagium assidendum et colligendum venerunt (ad scaccarium) et dixerunt quod ex precepto vicecomitis missi sunt unus in Lindesie et alius in Catstevene ad colligendum carrucagium sed nullum habuerunt rotulum nec aliquid inde receperunt ut dicunt sed vicecomes totum recepit" (ibid., m. d11).

75 Rot. Litt. Claus., I, 437b.

78 Excerpta, I, 53.

77 'Episcopus Exon', barones, milites et omnes de comitatu Cornubiæ $\mathbf{r} \mathbf{c}$ de $\mathrm{D}$ marcis ut rex constituat eis vicecomitem ex ipsis et pro quietantia carrucagii nuper assisi in Anglia" (Pipe Roll, 6 Henry III, Cornw., m. 9 d).

78 Ramsay, Dawn of the Constitution, p. 297.

79 In Norfolk and Suffolk, except in the liberties of St. Edmunds, St. Eldredo, and the honor of Eye, the carucage amounted to 


\section{UNDER JOHN AND HENRY III}

barons had no result. When Fotheringay castle was taken, it was decided by a council, then holding at London, to take active measures against the earl. ${ }^{80}$ On January 23, Geoffrey de Neville was summoned to come with all the men whom he could raise as soon as possible to Northampton to proceed against the earl. ${ }^{81}$ On February 2, Philip Mark was summoned to Biham with all his forces. ${ }^{82}$ Before January 27, writs had been sent out to other sheriffs ordering them to summon the knights to Northampton. ${ }^{83}$ Fotheringay castle was abandoned by the partisans of the earl ${ }^{84}$ and the royal army then proceeded to Biham where it was on February $6{ }^{85}$ The castle surrendered after a siege of a few days. ${ }^{86}$ With this capture the insurrection soon came to an end. ${ }^{87}$

£224 4s (Exch., L. T. R., Mem. Roll, 9 Henry III, m. 2); in Cambridgeshire, to $£ 1346 \mathrm{~s} 8 \mathrm{~d}$; in Northamptonshire, to £257 $16 \mathrm{~s} 4 \mathrm{~d}$ (ibid., 7 Henry III, m. D11).

80 For an account of this insurrection, see Turner, "The Minority of Henry III," Part II, in Transactions of the Royal Historical Society, Third Series, I, 243-256. "Quod cum audisset dominus Pandulfus, ... et totum concilium regis, quod tunc Londoniis pro quibusdam regni negotiis forte convenerat" (Dunst., pp. 63-64); besides the legate there were present the archbishop of York, ten bishops, the earls of Chester and Salisbury. "Convenerunt interim magnates Angliæ ad regem apud Westmonasterium ut de negotiis regni tractarent" (Wend., IV, 67); "concilio quodam quod apud Londonias post octavas Epiphaniæ coadunaverat" (Cov., II, 247).

81 Shirley, I, 169.

82 Rot. Litt. Claus., I, 448b.

83 "ad opus nunciorum nostrorum missorum cum brevibus nostris de militibus summonendis ad veniendum usque ad Norhamt" (ibid., 447a); on February 3, Hubert de Burgh issued orders to attack other castles (ibid., $474 \mathrm{~b}$ ).

84 Dunst., p. 64.

85 Hubert de Burgh witnesses a writ on the Close Roll at Biham on February 6 (Rot. Litt. Claus., I, 448b).

${ }^{86}$ Wendover (IV, 67) says that the siege began on February 6 and ended on February 8; 6 days (Dunst., above).

87 On February 17, the sheriff of Cambridgeshire was ordered to take no measures against tenants who had failed to answer the summons "quia inde ad præsens eis parcere volumus" (Rot. Litt. 


\section{STUDIES IN TAXATION}

The army of Biham is spoken of as large by one chronicler, but both the statements of the chroniclers and the official records show that the government acted with such quickness that the whole feudal array would not have had time to assemble. ${ }^{88}$ The tenants present at the council probably came with their familia and some of their vassals. ${ }^{89}$ The writs for summoning the host did not go out till January 23 and the siege ended early in February. ${ }^{90}$ Even the tenants of the neighboring county of Cambridge were not all present, but part at least of the contingents of the adjacent counties attended..$^{91}$ In addition to tenants, the army contained mercenariesknights, sergeants, and crossbowmen. ${ }^{92}$ As will be seen from the table below, only about 800 fees were charged with scutage. This means that over 5,000 fees were exempt on account of service. It is hardly probable that such an array would have been gathered. Only a part of the service can have been performed..$^{93}$ The condition of the exchequer is shown by the necessity of borrowing money to carry on the siege. ${ }^{94}$

In connection with this campaign, a scutage at ten shillings on the fee was taken. It was probably deter-

Claus., I, 475a). Apparently there was no further use for the knights; notice that this was in an adjacent county.

88 Wend., above; "postmodum vero, communi consilio, contra eum indixerunt, et statim cum exercitu ipsum sequentes" (Dunst., above).

89 "comitante secum domino legato et quibusdam episcopis, ... confluentibus etiam ad eum tam comite Cestrensi quam aliis magnatibus, in manu valida ad comitem insequendum" (Cov., II, 248); the writs de habendo scutagio specially exempt rear-vassals who have performed their service (Rot. Litt. Claus., I, 475a).

90 Ibid.

91 Madox, $\mathrm{I}, 668$, n. $\&$ and $t$.

92 Rot. Litt. Claus., I, 448, 453.

93 Tenants in the northern counties were summoned to attack other castles of the earl (ibid., 474b). All this would hardly make necessary the whole force of England.

94 Ibid., I, 465b. The legate lent $£ 200$. 


\section{UNDER JOHN AND HENRY III}

mined on at the close of the siege. This conclusion is suggested by the low rate which would be due to the shortness of the campaign. No statement has come down to us as to the authority by which this tax was levied. ${ }^{95}$ Probably the government acted because it had the right to the military service of the tenants, for writs of summons had been issued and a campaign had been fought, though a short one. The barons can hardly have granted the scutage as it was levied only on those tenants who had not performed their service. ${ }^{96}$ The account follows :

Clerical tenants $\begin{array}{lll}£ & \mathrm{~s} & \mathrm{~d}\end{array}$ Thirty lay tenants (each 5 or more fees) ${ }^{97} \cdot$
Other lay tenants (each fewer than 5 fees, Total etc.) ${ }^{98}$

Paid in 1221 and 1222

$\begin{array}{lll}50 & 12 & 8\end{array}$

$\begin{array}{lll}236 & 9 & 3\end{array}$

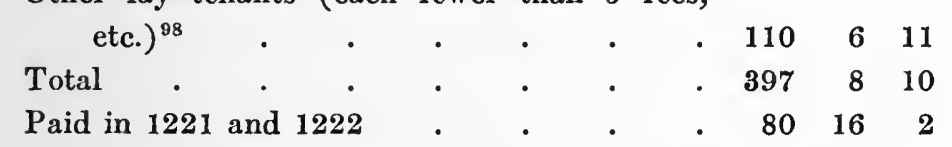

95 "Vigorous action was taken against him (earl of Albemarle). . . The council of the kingdom granted a scutage of ten shillings on the knight's fee and before the end of February Biham was dismantled" (Stubbs, Const. Hist. [4th ed.], II, 33); "Troops were called out, the council granting a scutage of 10s on the knight's fee" (Ramsay, Dawn of the Constitution, p. 26, but based on Stubbs). "Before January was over, Pandulf excommunicated him and a great council granted a special scutage, 'the scutage of Bytham,' to equip an army to crush the rebel" (Tout, Political History of England, 1216-1377, p. 21). The chronicles do not mention the scutage; the official documents say nothing about a grant. As to when it was levied, see the text.

90 There would doubtless be discussion as to whether the king would be entitled to a scutage after so brief a campaign, but the question would be what were his rights according to the law.

97 Two men are charged at the rate of $2 \mathrm{~m}$ per fee (Pipe Roll, 5 Henry III, Dors. and Somers., m. 6 d). It is probably a clerical error.

98 Of this sum, $£ 57$ were charged against tenants on honors in hand: Wallingford, Boulogne, and Cornwall chiefly, leaving not over $£ 53$ against tenants in chief, or 106 fees. 


\section{STUDIES IN TAXATION}

Thus less than one-seventh of the fees were charged with scutage. The whole sum, if received promptly, would not have paid the expenses of the campaign. Of the amount charged, almost nothing was paid except by the lesser tenants. This scutage was the composition for service. ${ }^{99}$ No fines were levied. Those men who answered the summons, but were not present at Biham, were also granted writs of quittance. The knights of Lancashire were at the castle of Skipton and were acquitted. ${ }^{100}$ In some cases, fees of the new enfeoffment were charged with scutage, but in no case was it paid. If a rear-vassal performed his service, both he and his lord were exempt. ${ }^{101}$ This was not a new regulation, but up to this time it had been unusual for the king's writ granting the right to collect scutage to mention the sub-tenant in this way. The inability of the exchequer to compel prompt payment is illustrated by the case of a tenant in Berkshire, who after two and a half years had not paid her scutage on one fee. ${ }^{102}$ Tenants were assisted by the sheriff to collect scutage from their vassals; distraint was used. ${ }^{103}$ The amount of the returns of this levy shows that there was not a general collection from the rear-vassals by the sheriff.

99 It was not paid by tenants who had performed their service; it was a scutage in the strict sense and not an aid. $C f$. Madox, I, $668, \mathrm{n} . s$ and $t$, for the counties of Lincoln, Notts. and Derby; Pipe Roll, 6 Henry III, for Notts. and Derby, Linc., and Lanc. The abbot of Pershore "habet quietantiam per breve regis quod est in forulo marescalli quia milites sui fuerunt in exercitu" (ibid., 7 Henry III, Wigorn.); see Nicholas Avenel (ibid., 8 Henry III, Devon, m. 16).

100 Rot. Litt. Claus., I, 546b.

101 Ibid., 475a; Pipe Roll, 5 Henry III, Hereford, m. 2 d.

102 Rot. Litt. Claus., I, $574 \mathrm{~b}$; the earl of Albemarle was pardoned his scutage in 1227 (ibid., II, 172b).

103 Madox, I, 677, n. a. There are references to the use of distraint to compel tenants to perform service or pay scutage in Rot. Litt. Claus., I, 465b, 475a. 


\section{UNDER JOHN AND HENRY III}

\section{The Poll Tax of 1222}

We next get a new device in taxation, a poll tax. It was granted in $\mathbf{1 2 2 2}$ in the great council as an aid for the Holy Land. The writs for its collection were issued on June 25. Each earl was to pay three marks, each baron one mark, each knight one shilling, each free tenant a penny, and anyone who held no land, but who had chattels to the value of half a mark, one penny. ${ }^{104}$ Tenants of churchmen, men in cities, boroughs, and the rest of the king's demesne were included. ${ }^{105}$ The Templars were exempt. ${ }^{106}$ There was immediate opposition to the tax; some barons declined to pay it, and the grant in the council was not regarded as binding on all tenants. The Waverley annals state that it was soon contradictum; a short time after the writs of collection had been issued, another writ was sent out, stating that the aid was made sine districtione. ${ }^{107}$ The consent given to the tax therefore was individual; there was no corporate action of the great council.

The method of assessment is worth notice. In each vill, the chaplain, the sergeants of lords in the vill, and two legal men of the vill assessed and collected the tax. ${ }^{108}$ In cities and boroughs, this work was done by two legal men of the corporation. ${ }^{109}$ Any tenant who desired was allowed to assess and collect the levy on his own lands. ${ }^{110}$ The receipts were to be deposited with the Templars, or

104 Rot. Litt. Claus., I, 516b, 567a ; Wav., p. 296; Cov., II, 252;

Dunst., p. 67 .

105 Rot. Litt. Claus., I, 593a, 630a.

$10 \mathrm{l}$ Ibid., 594b.

107 Wav., above; "præcepti quod fieri fecimus quod comites, barones, milites et libere tenentes facerent eidem regi auxilium sine districtione" (Rot. Litt. Claus., I, 518b).

108 Ibid., 516b, $567 \mathrm{a}$.

109 Ibid.

110 Ibid., 593a, 630a. 
Hospitallers, or in a monastery, till they were brought to the Temple at London, the sheriff aiding in the transportation. Some of the tax was paid to the sheriff, who also compelled tenants who had collected it on their own lands to transmit the money to the exchequer. ${ }^{111}$ The tenants in chief were not legally bound to contribute, but if they collected anything from their tenants, they were not allowed to keep it for their own use, but were compelled to deliver it to the sheriff or to the exchequer. ${ }^{12}$ The collection lasted for the next three years. ${ }^{113}$ Not much would be realized from such a tax; the payment of two sums is recorded, amounting to 800 marks. ${ }^{114}$

This is another case of a national tax which, though not levied for national purposes, helped to prepare the way for national taxation. On the one hand, the government became accustomed to taking a tax from all men in the realm without regard to their status; on the other hand, tenants of all grades were becoming familiar with the practice of paying a contribution, not to their lords, but to the royal officials. The repeated use of men of the locality in the assessment helped to make the government continue this practice. The feudal tenant was protected by making the sergeants of the lords of the vill members of the board of assessors and by his being allowed the privilege of levying the tax himself. The amount realized was summed up by the exchequer; it almost seems as though the government intentionally made an experiment for its own guidance in the future. ${ }^{115}$

111 Rot. Litt. Claus., I, 516b, 567a, 593a, 630a.

112 Ibid., I, 630a.

113 See orders for collection in 1223 (ibid.); in 1224 (ibid., 593, 594).

11* The Warerley annals say that the grant produced little or nothing. The two payments are recorded in Pat. Rolls, I, 512, 527; Rot. Litt. Claus., II, 21b.

115 "ut possint scire quid et quantum de terra cujuslibet exierit et summam auxilii tocius regni nostri" (Rot. Litt. Claus., I, 516b). 


\section{UNDER JOHN AND HENRY III}

\section{The Taxation of 1223}

There had been fighting for some time on the frontier between the English lords and the Welsh, especially in the south where William Marshal's land lay. At first the government had taken no part in this struggle, but finally in May, 1223, it summoned the host to meet in June at Worcester for a campaign against the Welsh. ${ }^{116}$ Some operations took place during the summer. ${ }^{117}$ In September, Llewellyn laid siege to Builth, one of the king's castles, and on September 12, the host was again summoned and Hubert with the king marched into Wales. ${ }^{118}$ After a

116 Madox, I, 653, n. $x$; Rot. Litt. Claus., I, 569b; Lords' Report on the Dignity of a Peer, Vol. III, Appendix I, pp. 3-4.

117 Pat. Rolls, I, 407, letters of protection for men on the king's service in Wales with horses and arms; Dunst., pp. 82-83.

118 Wendover states that in 1221, Llewellyn besieged Builth castle, that the warden, Reginald de Braose, appealed to the king for help, that there was a royal expedition to Wales which relieved the castle, at the close of which the magnates were granted their scutages: "concessis magnatibus de quolibet scuto duas marcas argenti." $\mathrm{He}$ speaks of a war in 1223 between William Marshal and Llewellyn, but says nothing of a royal expedition or a scutage (Wend., IV, 72, 85). It is probable that he has confused the accounts of the two years. The truce of 1221 was between William Marshal, Reginald de Braose, and the Welsh prince (Rymer, I, 166); the king was not a party to it. Further, Hubert de Burgh who accompanied the king on all these expeditions (Biham, Kerry, Bedford, Brittany) was not in Wales in 1221; he did not witness any writ that year on either the Patent or Close Roll in Wales. The host therefore probably did not go to Wales in 1221. The reference to a scutage may mean that the king granted to those barons who were fighting in Wales the right to collect it from their tenants, but there was no general levy of the scutage for the king in 1221. It was in 1223 that the king marched into Wales. On May 23, the host was summoned to meet at Worcester on June 19 (Madox, I, 653, n. $x$ ), where Hubert arrived on July 5 and where he remained till July 15 (Pat. Rolls, I, 376, 377). Some negotiations seem to have taken place (ibid., $376,406)$. On July 13, orders were issued to protect tenants who were fighting in Wales under William Marshal and the earl of Salisbury (ibid., 407), but the whole host does not seem to have gone, for on September 12, it was summoned and marched into Wales 
brief campaign, a truce was concluded. ${ }^{118}$ The scutage of Wales was levied for these campaigns and it was strictly in accordance with the feudal law. It appears in the Pipe Roll of 1224. ${ }^{120}$

The account follows:

\begin{tabular}{|c|c|c|c|c|c|}
\hline & & & & M & $s$ \\
\hline Clerical tenants & & & & $266^{\circ}$ & 2 \\
\hline Thirty-seven lay & tenants & (each 5 & or more & & \\
\hline fees) & . & & . & 1550 & 12 \\
\hline ther lay tenants & $($ each $f$ & ewer than & 5 fees, & & \\
\hline etc. $)^{121}$. & $\cdot$ & & . $\quad$. & 780 & 1 \\
\hline Cotal & . & . & . & 2597 & 2 \\
\hline aid, 1224,1225 & . & & . & 683 & 12 \\
\hline
\end{tabular}

Fees taxed, about, 1,300.

The amount of the tax which had been paid two years after the levy had been put in charge was trifling. It would by no means meet the expenses of the expedition. A considerable number of the greater lay tenants were liable. In some cases part of the amount due from a vassal was

(Rymer, I, 170). Hubert was at Montgomery from September 30 till October 10 (Rot. Litt. Claus., I, 564-565). Cf. an entry of 1224: "anno proximo præterito quando fuimus apud Montgom' cum exercitu nostro" (ibid., 619a); see also, Lords' Report on the Dignity of a Peer, above.

119 Pat. Rolls, I, 411, 412.

120 The account for Worcestershire is in the Pipe Roll, 18 Henry III, m. $10 \mathrm{~d}$, not in 8 Henry III. The date of the levy of the scutage is uncertain. In August, 1223, many tenants received writs granting them the right to collect scutage at $2 \mathrm{~m}$ from their vassals (Rot. Litt. Claus., I, 570b, 571). This was for the fighting which took place during the summer. It is likely that the exchequer did not collect a scutage till the close of the campaign which the king waged in September. Some of the tenants who received writs of scutage in August also received writs allowing them to collect an aid from their freemen.

121 Of this sum, 415 marks were levied on tenants holding of honors in hand: Lancaster, $77 \mathrm{~m}$; Brittany, 38m; Wallingford, $95 \mathrm{~m}$; Cornwall, $18 \mathrm{~m}$; Peverel, $86 \mathrm{~m}$; Boulogne, $101 \mathrm{~m}$; this leaves not over $365 \mathrm{~m}$ on tenants in chief, or $1821 / 2$ fees. 


\section{UNDER JOHN AND HENRY III}

pardoned. The countess of Oxford, 301/8 fees, part pardoned ;122 Richard de Cheltenham, 14 fees, half pardoned $; ;^{123}$ Gilbert Gaunt, $£ 91$ 19s $11 \mathrm{~d}$, half pardoned $\dot{;}^{124}$ the earl of Warwick, 204m $8 \mathrm{~s}$ 10d, half pardoned $;^{125}$ the countess of Winchester, $142 \mathrm{~m} 4 \mathrm{~d}$, paid $30 \mathrm{~m}$ and the rest was pardoned. ${ }^{126}$ This scutage was not an auxilium in the technical sense, but was a commutation of military service. Those tenants who were present in the host were not required to pay it. The writs excusing them are numerous. ${ }^{127}$ But the tenant could not commute his service into scutage at will. The king retained the right to demand the presence of his tenants in the field and this right was enforced. The abbess of Wilton and twenty-one other tenants failed to send their knights to the army and, as a consequence, they were disseized. ${ }^{128}$ Their lands were returned to them in October, to some because they claimed that they had performed their service with the host. Some of these tenants were on the Welsh frontier and this may explain the strictness with which they were treated.

Those tenants who performed a satisfactory amount

122 Pipe Roll, 8 Henry III, Essex and Herts., m. 7 d.

123 Ibid., Kent, m. 9 d.

124 Ibid., Linc., m. 4 d.

125 Ibid., War. and Leic., m. 8.

126 Ibid. See the Scutage Rolls, no. 3 (7 Henry III) for several tenants who were to receive half their scutage and the king the other half.

${ }^{127}$ Rot. Litt. Claus., I, 574a, 579a, 580a, 609b; II, 22b. "Isti sunt nomina illorum qui in propria persona sua venerunt vel qui debitum domino regi servicium pro se miserunt et hii habent scutagia" (Scutage Rolls, no. 3, m. 3). No fines were levied. One tenant offered the king the choice between five shillings and a horse with a "saccum cum broc" (Rot. Litt. Claus., I, 565a).

128 Rot. Litt. Claus., I, 572b, 566b, 573b, 628b, 629a. John de Ponte Arch owed $5 \mathrm{~m}$ "pro habenda saisina terræ de Swindon' que capta fuit in manu regis eo quod non fuit in exercitu Walliæ" (Pipe Roll, 8 Henry III, Wilts, m. 10). 


\section{STUDIES IN TAXATION}

of service got the right to take scutage from their vassals. The bishop of Worcester had his knights in the army and the sheriff was ordered to cause his tenants to pay him scutage. ${ }^{129}$ Placing part of his contingent in the field would sometimes acquit a tenant of all money payment. Theoretically he would be excused from paying only such an amount as corresponded to the number of knights which he had furnished, but in practice, if this number were satisfactory, the rest of the amount due from him might be written off in whole or in part. William de Nevill owed $16 \mathrm{~m} 8 \mathrm{~s} 10 \mathrm{~d}$ on $8 \frac{1 / 3}{3}$ fees. He sent two knights to the army and was acquitted of four marks of scutage and then was pardoned the rest. ${ }^{130}$ Robert de Cardinan sent his son and was allowed one-third of his scutage. ${ }^{131}$ But the tenant could not be sure that this would be done by the exchequer. The prior of Coventry sent four sergeants (= two knights). Four marks of his scutage of twenty marks were pardoned, but the rest was paid. ${ }^{132}$ A rear-vassal might be pardoned his scutage and in that case his lord also would be quit. ${ }^{133}$

Tenants in chief sometimes paid the scutage either to the sheriff, or to other of the royal officials at the exchequer, in the wardrobe, or "in camera."134 The sheriff did not make a general collection from rear-vassals, for he would not ordinarily collect anything from the tenants of those barons who had performed service and had received

129 Rot. Litt. Claus., I, 593b, 570b, 579a. For grants to tenants to have their scutage, see also above, p. 145, note 127 .

130 Pipe Roll, 8 Henry III, Wilts, m. 10; Rot. Litt. Claus., II, 92a. 131 Excerpta \& Rotulis Finium, ed. Roberts (Record Com.), I, 116. 132 Pipe Roll, 8 Henry III, War. and Leic., m. 8.

133 Pat. Rolls, I, 416; for Ralph de Trublevill (Rot. Litt. Claus., I, 579b); for Isabella de Dover (ibid., 583a).

134 "sciatis quod Willelmus Talebot pacavit in camera nostra $\mathbf{x x}$ sol. et ad scaccarium nostrum dimidiam marcam pro scutagio suo" (ibid., 574b); "computate Isabellæ de Bolebec ... xx marc. quas liberavit in garderoba nostra ... de scutagio" (ibid., 613b). 


\section{UNDER JOHN AND HENRY III}

writs of quittance and the right to collect it for their own use. Nor did he apparently enter at once the lands of those tenants who owed scutage in order to compel the sub-vassals to pay the money to the king. ${ }^{135}$ Evidence for this may be found in the orders issued to the sheriff, long after the scutage was put in charge, to allow a tenant to collect his scutage and respond for it $;^{136}$ and also in the fact that it was not necessary for tenants in chief to obtain writs of quittance immediately in order to avoid paying their scutage to the exchequer. ${ }^{137}$ The small proportion of the whole amount charged which had been paid by September, 1224, a year after the levy had been put in charge, points to the same conclusion. When the tenant collected scutage from his vassals, he often needed the king's aid, and the sheriff was ordered to assist with distraint. ${ }^{138}$

Returns for a tallage are given in twenty-four counties. This tallage had nothing to do with the campaign in Wales, for the writs to collect it were issued in February. It was assessed by the sheriff in conjunction with other

135 William Fitz Richard accounts for $16 \mathrm{~s} 8 \mathrm{~d}$ on one fee (Mortain); he pays $8 \mathrm{~s} 4 \mathrm{~d}$ and owes $8 \mathrm{~s} 4 \mathrm{~d}$ "sed non debet summoneri quia tenet illud dimidium feodum de episcopo Exon'" (Pipe Roll, 8 Henry III, Cornw., m. $15 \mathrm{~d}$ ); the bishopric, in hand, paid scutage this year, so that this means that the sub-tenant was to pay through the bishopric and not to the king direct. Several of the tenants who are granted half of their scutage are to collect it "per manum suam" (Scutage Rolls, no. 3, m. 3). 'Comitissa Oxon' habet literas de scutagio directas vicecomitibus Oxon', etc., et colliget scutagium suum per manum suam ad opus domini regis . . . et dominus rex habebit totum scutagium" (ibid., m. 2 d).

136 For Hugo de Balliol (Rot. Litt. Claus., II, 28, April, 1225); cf. the writ of December, 9 Henry III, for a similar order on behalf of Nigel de Mowbray (Madox, I, 679, n. $k$ ).

137 Rot. Litt. Claus., I, 606a, for a writ of June 23, 1224, to the sheriff not to distrain Hamo Peke; ibid., II, 22b.

138 For Hugo de Balliol (ibid., II, 28); for the bishop of Lincoln (ibid., I, 628b). 


\section{STUDIES IN TAXATION}

officials specially appointed for this work. ${ }^{139}$ The towns fined for it in lump sums and settled the incidence of it themselves; lump sums were also charged against manors, and some men dealt directly with the assessors. ${ }^{140}$ The amount charged was 4,680 marks. Part was paid by the towns directly to the exchequer and part to the sheriff. ${ }^{142}$

\section{The Scutage and the Carucage of Bedford, 1224}

This year occurred the rebellion of Falkes de Bréauté. The trouble between him and the government was brought to a head by the seizure of one of the king's justices by William de Bréauté and his imprisonment in Bedford castle by Falkes' orders. The news of this attack on a royal official was brought to a great-council which was holding at Northampton. By the advice of those present it was determined to attack the castle at once. ${ }^{142}$ Falkes

139 "Tallagium maneriorum et dominicorum regis in hoc comitatu (Stafford) assisum per Henricum de Alditheleg vicecomitem et Willelmum Rufum et Willelmum Pantolf" (Pipe Roll, 7 Henry III, m. 5 d). Rufus and Pantolf were justices (Pat. Rolls, I, 394; II, 218). "assignavimus ... Falkesium de Bréauté, Radulfum Hareng et Robertum de Salceto ad talliandum omnia dominica nostra de predictis comitatibus" (Pat. Rolls, I, 403) ; Falkes was the sheriff and the others were justices (ibid., 408; II, 84). Other appointments to levy the tallage are mentioned in Pat. Rolls, I, 403-404; the men associated with the sheriff are in most cases, probably in all, royal justices. The tallage given here all appears in the Pipe Rolls of 7 and 8 Henry III, except that of London, which is in the Pipe Roll, 10 Henry III, m. 13 d: "Cives London' $\mathbf{c}$ de $\mathbf{M}$ li. et $\mathbf{C}$ marc. de tallagio civitatis London' facto in anno vii regis coram ipso rege."

140 Pipe Roll, passim. For sums charged against manors, see Pipe Roll, 7 Henry III, Salop, m. $12 \mathrm{~d}$; for persons appearing in the roll (ibid., Northumb., York, m. 2, 11 d).

141 Thus in Northumberland, payments were made at the exchequer by the sheriff (ibid., m. 2); part of the tallage of the city of Lincoln was paid at the exchequer by the sheriff and part by the citizens (ibid., Linc., m. 8 d).

142 Wend., IV, 94-97; Dunst., p. 86. 


\section{UNDER JOHN AND HENRY III}

and his followers were excommunicated. The justiciar issued a general summons to the host, ${ }^{143}$ to which most of the earls and barons responded. ${ }^{144}$ On June 20 he laid siege to the castle which was defended by William. On August 15 it was taken and this marks the end of the campaign. ${ }^{145}$ It would not be necessary for the whole host to gather to subdue Falkes and probably tenants performed only part of their service. The tenants in chief of Devonshire who went to Bedford took only part of their quotas. ${ }^{146}$ The bishop of Exeter who aided the sheriff in his blockade of Plympton castle in that county sent only three knights and five sergeants ( $=$ two and a half knights), whereas he owed the service of $151 / 2$ knights. ${ }^{147}$ The besieging force was increased by two men from each hide on the demesnes of churchmen in the vicinity to work the machines. ${ }^{148}$ Towns were also summoned to send men to Bedford. Two are mentioned, Guildford in Surrey and Derby, and as these lie at a good distance from the castle, it is fair to conclude that the summons was not confined to towns in the vicinity of Bedford. ${ }^{140}$

143 "occasione generalis summonitionis factæ de summonendis omnibus qui de domino rege tenent in capite ad veniendum in exercitum Bedeford" " (Rot. Litt. Claus., I, 614b).

144 Cogg., p. 206. Only a fraction of the fees are charged with scutage; see the account below.

145 Other castles of Falkes' were attacked, e.g. Plympton in Devon (Shirley, I, 232); "rex autem interim de maneriis Falcasii et terris ubique per Angliam fecit fruges et armenta cum rebus aliis distrahi et infiscari" (Wend., IV, 97). Wendover says that the siege began June 16 and ended August 15 (see also Chron. Petroburgense, ed. Stapleton, Camden Soc., p. 8); Hubert signs at Bedford for the first time on June 21 (Rot. Litt. Claus., I, 605b).

146 The sheriff summoned the knights of Devonshire to blockade Plympton castle and they replied that they were not bound to do this as their lords were with the king at Bedford and it was to these that they owed service. Thus it is evident that all the rear-vassals had not gone to Bedford (Shirley, I, 232).

147 Ibid. The Scutage Roll gives evidence that lesser tenants still 


\section{STUDIES IN TAXATION}

The expenses of this campaign made extra taxation necessary. It consisted of a scutage at two marks per fee, a carucage, and fines paid by some of the towns.

The following is the account of the scutage:

Clerical tenants

$\begin{array}{lll}M & s & d\end{array}$

Nineteen lay tenants (each 5 or more fees) ${ }^{150} \quad 867 \quad 0 \quad 4$

Other lay tenants (each fewer than 5 fees,

Total etc. $)^{151}$

Paid, 1224 and 1225 .

Fees taxed, about, 680 .

continued to perform service in person or by furnishing men to the host and that in cases tenants furnished only part of their contingents:

\begin{tabular}{|c|c|c|c|}
\hline \multirow[b]{2}{*}{ Villiam de Fednes } & \multicolumn{2}{|c|}{$\begin{array}{l}\text { Knights } \\
\text { fur- } \\
\text { Fees nished }\end{array}$} & \multirow[b]{2}{*}{$\begin{array}{l}\text { Quit in Bucks and Bedf., Pipe } \\
\text { Roll, } 8 \text { Henry III. }\end{array}$} \\
\hline & 2 & 2 & \\
\hline tilbert de Laval & 2 & 1 & $\begin{array}{l}\text { Pardoned } 2 \mathrm{~m} \text {, owes } 2 \mathrm{~m} \text {, North- } \\
\text { umb., } 9 \text { Henry III. }\end{array}$ \\
\hline icot des Lasce & $21 / 2$ & 1 & Quit, Linc., 9 Henry III. \\
\hline eoffrey de Sau & I $21 / 2$ & 1 & $\begin{array}{l}2 \mathrm{~m} \text {, pays } 3 \mathrm{~m} \text {, Linc., } 9 \\
\text { III. }\end{array}$ \\
\hline lenr & 1 & 1 & 8 Henry III. \\
\hline Elias & $31 / 3$ & 1 & nt. and Hunt., 9 Henry \\
\hline Lug & $41 / 2$ & $2 s$ & Quit, Bucks, 8 \\
\hline rels & s $81 / 3$ & & Quit, Wilts, 8 Henry III. \\
\hline Ralph de Cameis & 1 & 2 serg. & $\begin{array}{l}1 / 2 \mathrm{~m} \text {, pays } 11 / 2 \mathrm{~m} \text {, Norf. } \\
\text { ff., } 9 \text { Henry III. }\end{array}$ \\
\hline Robert Lohol & 1 & 1 serg. & $\begin{array}{l}\text { Quit, Essex and Hert., } 9 \text { Henry } \\
\text { III. }\end{array}$ \\
\hline Abbc & & 1 & Quit, \\
\hline \multicolumn{4}{|c|}{$\begin{array}{l}\text { There are more cases in the Scutage Roll of lesser tenants who furnish } \\
\text { service. It will be observed from the list given, that if a tenant } \\
\text { provides part of his service, he may yet have to pay some scutage, } \\
\text { but in most of these cases, he pays nothing. The roll states in no } \\
\text { case how much service a great tenant provides. The above is from } \\
\text { Scutage Rolls, no. } 4, \mathrm{~m} .1,2 \text {. }\end{array}$} \\
\hline
\end{tabular}




\section{UNDER JOHN AND HENRY III}

The scutage was put in charge at the close of the siege $^{152}$ and was to be paid at the Michaelmas exchequer. ${ }^{153}$ As is seen from the account, this was not done. In November a new date for payment in January was set. ${ }^{154}$ By whose authority was it taken? On this point there is only the statement of Wendover that the lay and clerical magnates granted the king a carucage and he granted them their scutages. ${ }^{155}$ If the chronicler meant scutagium when he wrote carucagium, the passage might suggest that the king needed the consent of his barons to take the scutage. It is to be noted however that this was a scutage in the strict sense, that is, it was taken only from delinquents. It seems probable therefore that the authority to take it was based on the king's right to military service from his tenants. ${ }^{156}$

The scutage was all the composition which was demanded. No fines are recorded. ${ }^{157}$ As usual, the tenant who had performed his service received a writ of quittance

148 Pat. Rolls, I, 464-465; Dunst., above; Cogg., above.

149 Rot. Litt. Claus., I, 614b, 615a. Both of these towns fined to escape service.

150 Five of these tenants hold of the honor of Boulogne.

151 About $200 \mathrm{~m}$ are against tenants on honors in hand: Lancaster, Wallingford, Cornwall, Peverel, and Boulogne, leaving $220 \mathrm{~m}$ against tenants in chief.

152 Wend., IV, 99.

153 The accounts appear in the Pipe Roll of 1224.

154 Rot. Litt. Claus., II, 69b.

155 Wend., above.

156 "Nulla fit hic mentio de scutagio de Bedeford" quia omnes milites de comitatu fuerunt in servicio regis et habent generalem quietanciam per unum breve regis" (Pipe Roll, 8 Henry III, Kent, m. 9 d). "Quia Johannis Luvel fuit cum domino rege in exercitu Bedeford' ... mandatum est vicecomiti Norfolc' quod de scutagio quod ab eo exigit occasione prædicti exercitus de feodo 1 militis que de domino rege tenet in capite pacem ei habere faciat" (Rot. Litt. Claus., II, 10b; ibid., 14b, etc.).

157 It is not quite certain that no fines were levied, but it is likely that few were taken. Notice however the following entry from an 


\section{STUDIES IN TAXATION}

and was allowed to collect from his tenants. ${ }^{158}$ Nor was it necessary that a tenant perform all the service from his tenement in order to obtain all his scutage. Between 600 and 700 fees made a money contribution, leaving over 5,000 fees which received writs of quittance. The service from this number of fees is represented by the forces at Bedford and elsewhere; it is not probable that so large a number of knights would be assembled for this campaign. ${ }^{159}$ The sheriff accounted for part of the levy; he further aided tenants in chief by distraint to obtain the scutage from their vassals whether it was for their own use or for payment at the exchequer. ${ }^{180}$ It will be remembered that John often levied fines and scutages on the tenants of lands in hand heavier than they were accustomed to render to their lords. This policy was not followed in the early years of Henry III. In 1224, the fee of the earl of Devon was in hand. The tenants were ordered to pay for the scutage of Bedford what they used to pay their lord when he paid scutage to the king. ${ }^{161}$

account of 1224: $£ 99 \mathrm{Im}$ "de finibus plurimum qui finem fecerunt pro militibus et servientibus pro exercitu Bedeford' quorum nomina annotantur in rotulo que prædicti liberaverunt in garderoba" (Exch., L. T. R., Foreign Accounts, no. 1, m. 4).

158 Wend., above; service anywhere against Falkes was ground for exemption from scutage. The abbot of Tavistock was at the blockade of Plympton castle and received half his scutage; Ralph Marescallus was at Berchamstead and received all of his (Rot. Litt. Claus., II, 1a, 16a); Scutage Rolls, no. 4.

159 See above, p. 150, note 147 , as to partial service.

160 For Hugo de Balliol (Rot. Litt. Claus., II, 28a); 19a, 20b, 25a, 69b. Distraint for scutage was not merely threatened; it was carried out: 'Mandatum est vicecomiti Berk' quod demandam quam facit hominibus de Chaugrave per summonicionem scaccarii de scutagio exercitus Bedeford' ponat in respectum usque proximum compotum suum et averia eorum ea occasione capta deliberari faciet" (ibid., II, 34b).

161 "tale auxilium scutagii ... quale facere consueverunt... quando scutagium ab eis recepit pro exercitibus summonitis tam in Anglia quam Pictaria et alibi" (Pat. Rolls, I, 499). 


\section{UNDER JOHN AND HENRY III}

The government acted according to the law in the levy of the scutage.

It is a question of interest whether in the scutage and carucage we have two levies on the same men. Lay tenants in chief either performed service with the host or paid scutage. Some clerical tenants paid a carucage, performed service, or, in cases, were charged with scutage. Was the carucage therefore a general aid paid in addition to the scutage or in addition to the service performed by the tenants? ${ }^{\text {182 }}$ None of the sources state clearly that the carucage was paid by the lay barons. Four chronicles mention it, three of which speak of it in connection with the clergy only. The annals of Dunstable say that at the siege of Bedford the archbishop of Canterbury with his bishops and abbots came to the king's aid and in addition granted him a carucage, viz., half a mark on the caruce of their demesne lands, and two shillings on those of their tenants. ${ }^{163}$ There is no mention of the lay tenants in chief. The Coventry chronicle says that the aid was granted by archbishop Stephen and his suffragans who were at Bedford. ${ }^{184}$ Here, too, there is mention only of the prelates. Coggeshal refers apparently to the carucage, though not by name, when he speaks of the special assistance in men and money contributed by the prelates of Canterbury. ${ }^{165}$ Roger of Wendover states, however, that

162 "The grants made by the Canterbury clergy for the siege of Bedford were supplemented by a general carucage of two shillings on the hide, with a scutage of two marks on the knight's fee" (Ramsay, Dawn of the Constitution, p. 37); "the earls and barons, as well as prelates, of the whole province of Canterbury, joined to grant a carucage towards the expenses of the struggle"; "a scutage ... . of two marks . . . for the siege of Bedford" (Stubbs, Const. Hist. [4th ed.], II, 36, and note 3).

163 Dunst., p. 86.

104 Cov., II, 254.

185 "in hac autem die de obsidione specialiter claruit consilium et auxilium domini Cantuariensis et aliorum episcoporum et abbatum, 


\section{STUDIES IN TAXATION}

the laity and the prelates granted the king a carucage at two marks on the caruca and that he in turn granted the magnates their scutages at two marks on the fee. ${ }^{18 B}$ This statement is open to question. The rate of the carucage is wrong; Matthew Paris recognized the error and tried to correct it by changing the rate to two shillings, ${ }^{107}$ but even with this correction, the statement is incomplete. It seems probable that Wendover confused the two levies. From this evidence alone, we may doubt whether lay tenants paid the carucage. The Patent and Close Rolls are full of references to both the scutage and the carucage, but with a single exception all the notices of the latter tax relate to the carucage of the prelates. The roll does not state that this unique case of a carucage paid by lay tenants belongs to the carucage of Bedford, ${ }^{108}$ but the date of the entry falls during the siege of the castle and hence it may be connected with the levy of 1224. It belongs, however, I think, to the carucage of 1220. Though four years had passed since that tax had been put in charge, orders concerning it were still being issued. In May, 1223, the chancellor was ordered to allow the prior of Durham to collect his carucage by his own hand and respond for it at the exchequer. ${ }^{169}$ In June, 1223, the sheriffs of Kent and Yorkshire were allowed to

qui nimis fideliter regi cum toto conanime adhæserunt, qui pecuniis ac laboribus nihil hominibus suis in aliquo pepercerunt" (Cogg., p. 207).

160 "Regi vero, pro magnis laboribus suis et expensis, tam a prælatis quam a laicis concessum est per totam Angliam carucagium, de qualibet caruca duæ marcæ argenti; magnatibus item concessit rex scutagium, videlicet, de scuto quolibet duas marcas sterlingorum" (Wend., IV, 99).

167 Matthew Paris, III, 88.

168 This statement is not intended as evidence that the case does not belong to the carucage of 1224, but is introduced to bring out the point that the only reason for connecting the case with the carucage of Bedford is the date of entry in the roll.

169 Rot. Litt. Claus., I, 569b. 


\section{UNDER JOHN AND HENRY III}

postpone rendering their accounts of the carucage till September, 1223. ${ }^{170}$ On April 4, 1224, the sheriff of Northumberland was ordered to allow to Hugh de Balliol ten marks of the carucage demanded of him by the summons of the exchequer. ${ }^{171}$ On August 8, 1224, near the close of the siege, the king acknowledged the receipt of eight pounds from the prior of Ely de carucagio Comitum et Baronum, a payment that belongs to the levy of $1220 .{ }^{172}$ The possible exception referred to is an order to the sheriff of Northumberland on July 9, 1224, commanding him to pay to John Wascelin, constable of Bamborough, 50 marks "de denariis nostris quos recepisti de carucagio comitatus tui." ${ }^{\prime 173}$ It is not possible to fix certainly the date of the grant of the carucage of Bedford (see below), but the early date of this order, and the fact that the same sheriff had received orders not long before concerning the carucage of 1220 make it reasonable to assign this order to the earlier levy. ${ }^{174}$ Finally it should

170 Rot. Litt. Claus., I, 551b, 552a.

171 Ibid., 592a.

172 Ibid., 615b, 640a. This is the entry cited by Stubbs, Const. Hist., II (3rd ed.), 36, note 3, and by Ramsay, p. 37, as evidence that lay tenants paid the carucage. It is as follows: "Scias quod prior Elyensis reddidit nobis in garderoba nostra apud Bedeford" die Jovis proxima ante festum S. Laurentii anno etc. viii octo libras collectas per manus ballivorum suorum infra libertates suas in comitatu tuo de carucagio comitum et baronum." That this payment belongs not to the carucage of 1224, but to an earlier levy, probably to that of 1220 , is shown by an entry in the account rendered by Walter de Kirkeham and Walter de Brackele of their receipts from January 4 to October 28, 1224, one item of which is: "idem r c de ... viii libris de priore Elyensis de veteri carrucagio" (Exch., L. T. R., Foreign Accounts, no. 1, m. 4).

173 Rot. Litt. Claus., I, 610b.

${ }_{174} \mathrm{~A}$ case of February 1, 1225, refers to carucage on the land of lay tenants: "Idem etiam abbas (S. Edmundi) reddidit ... x libras et $\mathrm{v}$ solidos tamquam ballivus de carucagio militum et libere tenentium qui infra libertatem suam sunt et non tenent de eo" (Pat. Rolls, I, 505). It is likely however that this refers to the carucage of 1220 , for in that year the abbot was granted the privilege of collecting that 


\section{STUDIES IN TAXATION}

be observed that there are numerous references in the Patent and Close Rolls to the scutage of Bedford and over fifty references to the carucage of Bedford paid by the clergy. When such a wealth of writs exists concerning the taxation of the year, it is highly improbable that if there had been a general levy on the ploughlands of lay tenants, there should be so little evidence of it. It seems certain therefore that the carucage was paid only by the clergy.

This levy was an auxilium made by certain prelates, perhaps by all, though the evidence for this is not at hand, of the provinces of both Canterbury and York on all their tenants, without regard to whether they had their service in the army or not. ${ }^{175}$ As this was an aid, it could not be levied without the consent of the prelates. Some sort of agreement seems to have been arrived at among part at least of the clergy who were at the siege. ${ }^{278}$ This agreement was however a case of individual not of corporate consent; it bound no one but the grantor. Thus the king stated that the individual prelate granted him

carucage from all the tenants who held within his liberty whether they held of him or not, a permit which corresponds to this entry of 1225. The writ is on the Fine Roll: "Rex vicecomiti Suff" salutem. Scias quod concessimus abbati S. Edmundi quod colligat per manum suam caruagium ubique infra libertatem $S$. Edmundi tam de terra sua quam aliorum omnium quicumque ipsi fuerunt infra(?) eandem libertatem et nobis respondeat etc." (Fine Roll, 4 Henry III, part 1, m. 2).

175 That York as well as Canterbury paid it, see below, note 179 .

178 "ad castellum de Bedeford, tam clerus quam populus, pervenerunt" (Wend., IV, 95); "provisum fuit de quodam auxilio regi faciendo per dominum Stephanum Cantuariensem archiepiscopum ejusque suffraganeos et abbates ibi moram facientes; videlicet de singulis carucis etc." (Cov., II, 254); "in cujus auxilium venit Cantuariensis archiepiscopus, cum episcopis et abbatibus suffraganeis, et insuper concesserunt ei caruagium" (Dunst., p. 86); "ad quam obsidionem confestim advenit archiepiscopus Cantuariensis cum potenti virtute; renerunt et alii episcopi, abbates nigri, comites et barones fere totius Angliæ" (Cogg., p. 206). 


\section{UNDER JOHN AND HENRY III}

the carucage $\mathrm{e}^{177}$ and this statement was not a mere form. The archbishop of York and the bishop of Durham were not at first included, either because they were not present, or, if present, would not consent. ${ }^{178}$ Both these prelates later contributed. ${ }^{179}$ The early payments made by some prelates during the siege suggest that there was a series of individual grants at first. ${ }^{180}$ Later there was some concerted action which did not bind absentees. The grant was significant in another way. The king issued letters patent that it should not form a precedent for future levies. ${ }^{181}$ This was the first of a long series of such promises, indicating a growing sense of solidarity among the clergy and a feeling on their part that the government must be bound more strictly to prevent the extension of its claims in taxation.

There is no definite statement of the date of the grant. Most of the payments were made in October and November, 1224. ${ }^{182}$ Wendover says that the grant was made at the close of the siege. ${ }^{183}$ The king's writ to the clergy promising that the levy would not form a precedent for future taxation was issued on August $18^{184}$ and the general grant was probably made at the same time. There were cases however in which a carucage was paid by prelates during the siege. The king wrote, on July 18 or 19, to the bishop

177 "de carucagio episcopatus Hereford' quod idem episcopus nobis gratis concessit" (Rot. Litt. Claus., I, 613b); "de carucagio quod idem abbas (S. Edmundi) nobis gratis concessit ad auxilium nobis faciendum" (ibid., 616a); letters patent were issued to the bishop of Bath, acknowledging the receipt of the carucage, "de carucagio ipsius episcopi nobis concesso" (Pat. Rolls, II, 95).

178 "prælati provincie Cantuariensis" (ibid., I, 464).

179 Ibid., 494, 495, 505.

180 See below.

181 Pat. Rolls, I, 464; Rymer, I, 175.

182 Pat. Rolls, I, $473 \mathrm{ff}$.

183 Wend., IV, 99. The other chroniclers say that it was granted at the time of the siege.

184 Pat. Rolls, I, 464. 


\section{STUDIES IN TAXATION}

of Winchester concerning 125 marks of the carucage of the abbots and priors of his diocese. ${ }^{185}$ The bishop of Hereford paid $£ 20$ of carucage on July $25{ }^{188}$ The abbot of St. Edmunds paid 70 marks on August 13. ${ }^{187}$ These were probably individual grants before the clergy as a whole decided to make an aid.

The rate at which the carucage was levied on the clergy is given in detail in the king's letters patent. The demesne lands paid half a mark on the caruca; the knights, free tenants, and villeins, and those holding of the knights and free tenants, paid two shillings on the caruca. ${ }^{188}$ There is no case in which a prelate paid both scutage and carucage. ${ }^{189}$ Some service in the army was performed by clergy who paid the carucage. Those in the vicinity supplied men from their demesnes to work the machines. ${ }^{190}$ Probably they furnished their knights too. The abbot of St. Edmunds performed his service ${ }^{191}$ and paid carucage. ${ }^{102}$ So this levy was an aid and not a composition for military service. No statement is made concerning the method of assessment. No order was issued to a sheriff in connection with it. It was collected and paid at the exchequer by the officials of the clergy. ${ }^{103}$ It is not possible to say whether it was levied on the team

185 Rot. Litt. Claus., I, 612.

188 Ibid., 613b.

187 Ibid., 616a.

188 Pat. Rolls, I, 464.

189 The abbot of Tavistock was charged with scutage, half of which was remitted for service done in the host in Devon, but he may not have paid carucage (Rot. Litt. Claus., II, 16a). The abbot of Westminster paid carucage (Pat. Rolls, I, 494) and was charged with scutage (Pipe Roll, 18 Henry III, Wigorn., m. 10 d).

190 Pat. Rolls, I, 464.

191 Rot. Litt. Claus., I, 606b. Perhaps the service mentioned here refers to the grant of the carucage. The abbot was also pardoned half his scutage of Montgomery for this service at Bedford.

192 Pat. Rolls, I, 493.

193 Ibid., 473 ff. 
or on the land. The references all speak of the caruca, which may mean either. In Hertfordshire, two men were summoned "de singulis carrucis" to pull down the castle after its capture. ${ }^{194}$ It is interesting to compare the amount raised by the carucage with that realized from the scutage of Bedford. An incomplete account of the carucage gives $3,565 \mathrm{~m} 12 \mathrm{~s} 6 \mathrm{~d} .{ }^{195}$ The clergy therefore paid much more than they would have paid in scutage. ${ }^{196}$ As usual there are notices of borrowing money to carry on the campaign. ${ }^{197}$ An account of the siege gives the

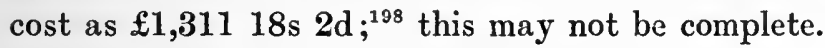

\section{The Taxation of 1225}

The truce between France and England ran out in 1224 and was not renewed. Louis VIII invaded Poitou and Gascony in the summer with success. Some reinforcements were sent from England. ${ }^{199}$ In June a great council was held at Northampton to consider the affairs of Gascony. The uprising of Falkes de Bréauté made it necessary to postpone the matter. ${ }^{200}$ Although the council believed that it would not be difficult to drive out the

194 Rot. Litt. Claus., I, 655a.

195 Exch., L. T. R., Foreign Accounts, no. 1, m. 4. This is the amount paid, not charged. Not all the religious clergy who contributed held by military tenure. Entries in the Patent Roll acknowledge the payment of $3,461 \mathrm{~m} 4 \mathrm{~s} 10 \mathrm{~d}$.

196 The clergy who held by military tenure and who paid carucage held 431 fees and paid $3,340 \mathrm{~m}$ of carucage. They would have paid $862 \mathrm{~m}$ of scutage.

187 Pat. Rolls, I, 453, 455, 456; Rot. Litt. Claus., II, 4 a.

198 "Et in neccessariis expensis et stipendiis militum, servientium, ingeniatorum et aliorum operariorum, petrariarum et mangellorum et aliorum neccessariorum in obsidione castri de Bedeford' $M$ et CCC et xi li. et xviii sol. et ii den. sicut continetur ibidem per partes" (Exch., L. T. R., Foreign Accounts, John and Henry III, no. 1, m. 4).

190 Matthew Paris, VI, 66-67; Cogg., p. 208; Dunst., p. 86.

200 Ibid.; Wend., IV, 94. 


\section{STUDIES IN TAXATION}

French they realized that men and money were necessary or the English possessions would be permanently lost. ${ }^{201}$ The question was again discussed by the magnates who came to Westminster to celebrate the Christmas festival. A great council of the tenants in chief was summoned to meet on February 2. Hubert de Burgh proposed either at Christmas, or in February, that an aid of a fifteenth of personal property should be given to carry on operations in southern France. After deliberation, the magnates agreed to the tax on condition that the charters were confirmed. ${ }^{202}$

There was no difference in principle between the council of Christmas and that of February. Both were composed of the tenants in chief, but that of February probably had a fuller attendance, to secure which the council was doubtless called at that time. Those present were the archbishops, bishops, abbots, priors, earls, and barons, and the term barones may include also the lesser tenants, the knights, who, theoretically, would have to give their consent to any aid. ${ }^{203}$

201 Shirley, I, 236.

202 Cf. Ramsay, Dawn of the Constitution, p. 39; Stubbs, Const. Hist., II (3rd ed), 38, says that the grant was made at the Christmas meeting; in the Select Charters, p. 353, he puts it at the February meeting. Wendover, IV, 99-100, says it was done at the Christmas meeting; Walter of Coventry, II, 256, gives the date as February 2, which seems to be correct, for the dates of the reissue of the charters (February 11) and of the writ of collection (February 15) point to the February meeting (Pat. Rolls, I, 560; Select Charters, p. 354). Dunstable mentions the grant, but does not give the date of the meeting.

203 The chroniclers do not mention the knights specifically as making the grant, but include them in describing those who pay the tax; "archiepiscopus et concio tota episcoporum, comitum, baronum, abbatum, priorum," were those present (Wend., IV, 100); "archiepiscopi, episcopi, comites, barones, et viri religiosi" (Dunst., p. 93); "convocantur ... proceres Angliæ ... concessa est domino regi a comitibus et baronibus et clero et populo ibidem præsentibus . . . de communi assensu"; notice who have to pay it; "episcopi, abbates, priores, 
There was a certain degree of corporate action by the members of the council in making this grant, as is evident from the circumstances. A bargain was made between the king on the one hand and the magnates on the other; the former promised to confirm the charter; the latter granted a fifteenth. The majority of all classes paid at this fixed rate, even of the clergy; and those of the latter who compounded in a lump sum seem to have done so by special favor, the government asserting that they were subject to the levy. Their fine was said to be a fine for the fifteenth. ${ }^{204}$ When some laymen refused to pay the tax, the government took action against them as though the tax were exigible from them according to the law, and distrained them to compel payment. ${ }^{205}$ All this looks like concerted action. ${ }^{208}$ It is probable that each magnate felt that he individually made the grant at this uniform rate and that the decision of the other magnates bound him to nothing. The letters patent to the bishop

comites, barones, et milites, universique alii et singuli etc." Here the knights appear, though no mention of them was made in the accounts of the council (Cov., II, 256, 257). The Waverley Annals state that the grant was made by the "archiepiscopi, episcopi, abbates, priores, comites, barones, milites et homines libere tenentes de regno," but this is evidently a description of the taxpayers (Wav., p. 300). The reissue of the charters has two descriptions. The king grants the liberties to the "archiepiscopis, episcopis, abbatibus, prioribus, comitibus, baronibus et omnibus de regno nostro"; in return, the fifteenth is granted by the "archiepiscopi, episcopi, abbates, priores, comites, barones, milites, libere tenentes et omnes de regno nostro" (Select Charters, pp. 353-354); the classes in the first description may be those present; the second description is a list of the taxpayers.

204 See below, p. 163.

205 See below, p. 166.

206 The mere fact that men paid at a uniform rate is no evidence of concerted action. There is no evidence that there was any corporate decision by the tenants in the case of the thirteenth in 1207; the king fixed the levy. But taken in connection with the discussion of this tax in 1225 and with the fact that there was a bargain, it shows united action. 


\section{STUDIES IN TAXATION}

of Durham express this feeling. The bishop had not been present at the council in February. ${ }^{207}$ The fifteenth was however paid in his diocese and the king referred to it as a grant made by the bishop's liberality. ${ }^{208}$ The same feeling is expressed in the instructions concerning payment by crusaders. The grant in the council had not altered their privilege to be exempt from contribution. But the king did not propose to allow them to escape. Some magnates had already agreed to pay, ${ }^{209}$ and those who refused were to be coerced by the threat that otherwise they would be denied the liberties granted by the king, ${ }^{210}$ an expression of the belief that the king granted certain liberties to all the men of his kingdom who paid him a certain sum in the form of a series of individual grants. When the chroniclers describe the tax as granted by every one in the kingdom as though each had been present at the council, they express the same belief. Even so, there can be hardly a doubt that there was united action by the great council.

The following classes paid the tax:

1. All men by whatever tenure they held on the fees of lay tenants in chief. ${ }^{211}$

2. The men on the royal demesne, the cities, and boroughs. ${ }^{212}$

3. The clerical tenants in chief (not including the - churches), though there were special arrangements concerning the assessment. They did not compound in lump sums, but the property of all their tenants, freemen, villeins, and men on their demesnes, as well as that of

$207 \mathrm{He}$ does not witness the reissue of the charter.

208 "ex mero liberalitatis vestræ dono" (Rot. Litt. Claus., II, 75b). 209 "magnatibus qui huic quintædecimæ dande se sponte submiserunt" (Pat. Rolls, I, 572).

210 Ibid.

211 Select Charters, p. 356 ; the writ mentions villeins.

212 Rot. Litt. Claus., II, 26a, 42b, 44b, 45b, 75b; Wend., IV, 138. 


\section{UNDER JOHN AND HENRY III}

those holding by military tenure, was assessed and taxed as prescribed by the great council. ${ }^{213}$

4. Religious houses which did not hold by military tenure. ${ }^{214}$

5. Merchants, especially mentioned for assessment. ${ }^{216}$ There were some, however, among whom were the Cistercians and Premonstratensians ${ }^{218}$ who did not pay on the assessed value of their property, but fined for it instead. This fine was called a fine for the fifteenth. The Cistercians compounded in some way, both for the revenues of their churches and for their lands. ${ }^{217}$ According to one writer, they paid a lump sum of 2,000 marks $;^{218}$ and we know that in June, 1226, they paid the king 1,000 marks. ${ }^{219}$ The Templars paid 500 marks. ${ }^{220}$ The Hospitallers were exempt, but later paid a sixteenth on their benefices. ${ }^{221}$

213 "de dominicis et villanis propriis et burgensibus ipsius episcopi (Norwicensis) et aliis liberis hominibus de feodo suo qui non tenent per servicium militare" (Pat. Rolls, I, 571); ibid., 572; Rot. Litt. Claus., II, 41a, 71a, 99a, 148b; Madox, II, 291, n. e; Select Charters, p. 357. This statement does not include certain religious orders, for which, see below.

214 "Mandatum est eisdem justiciariis quod dominus rex vult quod R. Sarresburiensis episcopus assideat et colligat quintamdecimam de ... mobilibus abbatum, priorum et aliorum virorum religiosorum et hominum suorum qui non tenent per servicium militare" (Pat. Rolls, I, 525, 566); Rot. Litt. Claus., II, 40b, 71a.

215 Select Charters, above; Cov., II, 257.

216 Cov., II, 257.

217 Rot. Litt. Claus., II, 177a.

218 Wav., p. 300.

219 Pat. Rolls, II, 40.

220 "pro quintadecima sua, quam nobis debuerunt pro se et hominibus suis cubantibus et levantibus in terris prædictorum magistri et fratrum, et pro omnibus rebus suis propriis et hominum suorum"; "de prædicta quintadecima per prædictum finem sint quieti" (ibid., II, 17).

221 Rot. Litt. Claus., II, 71b, 180a. No tax was to be levied on the property of those deceased before the day when the fifteenth was granted (ibid., 27a). In November, 1224, a tallage had been levied 


\section{STUDIES IN TAXATION}

The taxable goods were not described but a list of exempted property was made out with care. The intention was not to tax ornaments or property used for earning one's living. For churchmen and freemen who were not merchants, the following goods were exempt: books, church ornaments, war and draft horses, arms, jewels, vases, supplies of castles; for merchants, their arms, riding horses, household goods, and provisions for their own consumption; for villeins, their arms, tools, food, and farm products which were not for sale. ${ }^{22}$ The necessity for a careful statement of the taxable property was shown when disputes arose over the assessment of boats and their equipment, but in accordance with the principle that the tools of one's trade were not to be taxed, this property was exempted. ${ }^{223}$ The tax was to be paid half in June and half at Michaelmas, 1225. ${ }^{224}$ Part of it was still due in December, 1226. ${ }^{225}$

The machinery of the assessment and collection of this tax follows. ${ }^{26}$ The king appointed justices in each county; the number varied from three in some counties to nine in Norfolk and Suffolk. ${ }^{227}$ The sheriff summoned the county court to meet them on a certain day in March fixed in the writ. Knights were chosen on that day from each

on the Jews (Pat. Rolls, I, 496); Rot. Litt. Claus., II, 22a; it amounted, according to the Waverley Annals, to 5,000 marks (Wav., p. 300); in the Close Roll, there is a reference to a tallage on the Jews of 4,000 marks (Rot. Litt. Claus., II, 142a, October, 1226); in 1233, there is a reference to two old tallages on the Jews of 6,000 marks and 8,000 marks (Cal. Pat. Rolls, I, 13); also, in Shirley, I, 392, and Close Rolls, I, 580.

222 Select Charters, p. 355.

${ }^{223}$ Rot. Litt. Claus., II, 29b, 91 a.

224 Select Charters, p. 356; Wend., IV, 104. It was not all paid at this time. Orders were issued to render accounts in January and June, 1226 (Madox, II, 291, n. f; Rot. Litt. Claus., II, 152a).

225 Rot. Litt. Claus., II, 146a.

226 Select Charters, pp. 355-357.

227 Pat. Rolls, I, 511, 560-567 ; Rot. Litt. Claus., II, 146, 147. 


\section{UNDER JOHN AND HENRY III}

hundred, usually four in number, but there might be more or fewer, according to the size of the hundred. These elected knights did not serve in their own hundred. Both the justices and the knights swore in the presence of the county court to perform their duties faithfully. The assessment was then made. The justices sometimes personally assessed the tax in part of the county while the knights did the work in the rest. The justices were ordered to reserve some parts of the county to assess "in propriis personis" when there was need. Then in case of a dispute over the value sworn to by any taxpayer, the writ says, "milites ipsi . . . veritatem inquirant," as if the justices had not been present. Further, the justices in Surrey received a special order to perform the work in that county in person because it contained few hundreds. ${ }^{228}$ Whether any knights were elected there or not is uncertain. These entries show that the knights worked independently of the justices, whose business it was to have general supervision and to receive and guard the money when collected. Evidently the knights were divided into groups, else the regulation concerning a larger or smaller number according to the size of the hundred had no point to it. They then met the men of each vill, and at the meeting the bailiffs of earls and barons swore to the number, quantity, and value of their lord's moveables; and other men made the same oath as to their own goods and the goods of two of their neighbors. Disputes were settled by a jury. A roll of each vill was drawn up in duplicate, one copy being retained by the knights and the other delivered to the justices. The money was collected in each vill by the reeve and four men, who paid it to the knights and they in turn to the justices. It was deposited temporarily in a church, abbey, or priory, under the seal of both knights and justices. 228 Pat. Rolls, I, 511. 


\section{STUDIES IN TAXATION}

In this scheme, the subordinate position of the sheriff should be noted. He was to coopperate with the justices; he summoned the court to meet them; probably he summoned the men of the vill to meet the knights; he aided by distraint; he probably furnished transportation for the money collected; he distrained the justices to render their account, ${ }^{229}$ but the responsibility for the assessment and collection was taken entirely out of his hands. The assessment was searching, at least among the lower classes. Complaints arose among the poor, and the justices were finally ordered to spare them. ${ }^{230}$ The religious orders, as we have already seen, were opposed to the tax, and the government was willing to make special arrangements with them. Ordinary laymen met with no such consideration and were distrained if they refused to pay. ${ }^{231}$

We may notice some variations in the scheme of assessment. The clergy were in the beginning allowed to assess their demesnes by their own bailiffs. ${ }^{232}$ Later this privilege was extended to include all their freemen except those who held by military service. ${ }^{233}$ A churchman might be allowed to assess his knights also, one of the king's justices taking part in the work. ${ }^{234}$ According to the original plan, the bishop was to have charge of levying the tax on the property of religious bodies in his diocese. ${ }^{235}$ The king appointed a clerk to coöperate with the bishop's officials. ${ }^{236}$ But the abbots and priors often, perhaps

229 Ibid., I, 564-565; Rot. Litt. Claus., II, 73-75, 146, 152a.

230 Pat. Rolls, I, 572.

231 Rot. Litt. Claus., II, 26a, 40b, 66a; if a man had had property and had disposed of it before the fifteenth was granted, he might have to prove that fact in order to avoid being taxed or being fined (ibid., 62a).

232 Select Charters, above.

233 Pat. Rolls, I, 572.

234 Ibid., 571.

235 Ibid., 546; Rot. Litt. Claus., II, 71a, 99a.

236 Pat. Rolls, I, 571. 


\section{UNDER JOHN AND HENRY III}

generally, sought and obtained from the king permission to make the assessment by their own bailiffs with the help of an official of the bishop or a king's clerk. ${ }^{237}$ The particulars of the assessment on the lands of the clergy were entered on a roll. ${ }^{238}$

The great council provided that the money was to be kept in the castles of Devizes and Winchester in the care of the bishops of Bath and Salisbury. ${ }^{239}$ To these prelates the collectors rendered their accounts ${ }^{240}$ and through them the money was paid out. ${ }^{241}$ The provision concerning the care of the receipts suggests that there was an attempt by the barons to control the expenditure of the tax, and if so, then we have another evidence of the cor-

237 Ibid., I, 525, 570, 572; II, 18; Rot. Litt. Claus., II, 21b, 29b, 71a. 238 Rot. Litt. Claus., II, 148b; Pat. Rolls, II, 18.

239 "provisum est de consilio fidelium nostrorum nobis apud Lond" nuper assistencium quod medietas tocius quintedecime nostre tam clericorum quam laicorum reponatur salvo custodienda in castro nostro Wynton' in custodia venerabilis patris $R$. Sarr' episcopi et alia medietas in castro nostro Dyvis' in custodia vestra" (i.e. of J., bishop of Bath) (Rot. Litt. Claus., II, 73b) ; ibid., 64b, 74, 75, 76a, 81a. Pat. Rolls, II, 104.

240 Ibid.; also, 148b, 152a. Much of the money was paid at the New Temple at London (ibid., pp. 75, 76). In connection with this description of the arrangements for the care of the receipts from the fifteenth should be noticed the charge against Hubert de Burgh in 1239 and his reply. He was summoned to account for the fifteenth, "quæ per commune consilium totius regni custodiri et haberi debuit in deposito; et ita in deposito, quod nihil inde caperetur usque ad ætatem domini regis, nisi per visum sex episcoporum et sex comitum ad hoc specialiter attornatorum, et hoc non nisi ad defensionem regni"; "ad hoc (Hubert) respondit, quod domini Sarisberiensis et Bathoniensis episcopi illam pecuniam receperunt per commune consilium regni, et inde reddiderunt compotum suum, et inde quieti sunt per literas domini regis" (Matthew Paris, VI, 65-66). The justiciar's statement describes the way in which the money was actually handled. It is, however, possible that the council proposed to have a committee of six bishops and six barons supervise the expenditure of the money; perhaps they viewed the accounts of the two prelates. The account of the levy is not in the Pipe Roll.

241 Pat. Rolls, I, 524-545; II, 1-56. 


\section{STUDIES IN TAXATION}

porate action of the great council. The money was regarded as a special fund for the expenses of the war and the administration of Gascony. When the justiciar wished to use any of it for governmental purposes in England, he borrowed from the fund with the promise to repay. ${ }^{242}$ That there was difficulty in binding the king by such an arrangement is shown when the latter in acknowledging one of these loans said that if he did not repay the money, he would guarantee immunity to the bishops who were the guardians of the treasure. ${ }^{243}$

In March, 1225, Richard, the king's brother, was sent to Gascony as viceroy; he was accompanied by his uncle, the veteran earl of Salisbury, and a small force of knights. $^{244}$ Reinforcements were sent over in 1225 and 1226. ${ }^{245}$ No general summons to the host seems to have been issued, so that these forces were probably mercenaries. It is interesting to notice the amount of money expended in this expedition. From June 15, 1225, to August, 1226, nearly 54,000 marks were either sent to

242 The king borrows $£ 1,800$ which is repaid in October (Pat. Rolls, I, 547, 548; Rot. Litt. Claus., II, 64b); ibid., 66a; "de denariis quintedecime... centum libras de prestito" (Pat. Rolls, II, 42); also ibid., pp. 46, 48, 90; these may not have been all repaid. Part of the money was used for other purposes with no such reservation (ibid., pp. 26, 31,63, 88). That it was a special fund is suggested in the charge against Hubert de Burgh (see above, p. 167).

243 "et si non reddiderimus, volumus quod de tanta pecunia sint quieti et eos inde servabimus indempnes" (Pat. Rolls, I, 547). The promise seems to indicate that the bishops feared the magnates would call them to account for such a disposition of the money, but more probably it was merely a safeguard against a future account which they would have to render to the king; $c f$. Matthew Paris, VI, 65-66, where Hubert states that "inde (of the fifteenth) reddiderunt compotum suum, et inde quieti sunt per literas domini regis."

244 Serenty knights (Wint., p. 84); 40 knights (Wend., IV, 101); 77 men (Ramsay, Dawn of the Constitution, p. 4.0, from Pat. Rolls, I, 573-575).

245 Pat. Rolls, I, 539, 575, II, 15, 16, 21, 33, 35, 36, 53, 56; Rot. Litt. Claus., II, 49b, 58b, 59a, 110a, 113a, 117b, 118b, 122b, 127b. 


\section{UNDER JOHN AND HENRY III}

Richard or paid to soldiers on their way to Gascony or to merchants for loans made to Richard..$^{246}$ Thus a campaign in Gascony was a heavy expense and in this instance required the greater part of the fifteenth, the total amount of which was $£ 57,83813 \mathrm{~s} 6 \mathrm{~d} .{ }^{247}$ Two of the leaders of the expedition, the earl of Salisbury and Philip de Albiniaco, were allowed to levy an aid on all their tenants in October, 1225, to support themselves in the war. ${ }^{248}$ Their tenants had apparently to pay a double tax.

\section{The Sixteenth, 1226}

The government did not venture to collect the fifteenth from the beneficed clergy on the authority of a grant by the great council. One annalist says that the secular clergy would not pay this tax and so the king asked the pope for letters to the clergy, urging them to make a grant. ${ }^{249}$ However that may be, the pope wrote on February 3, 1225, asking that this be done ${ }^{250}$ and his letter may have been in answer to one of the king, written after Christmas, 1224, when, it may be, the clergy refused the grant. But no immediate use was made of the pope's letter as there is no record of an attempt to obtain a contribution from the secular clergy till May, 1226, when this letter with one from the king was sent out by archbishop Stephen, together with two letters of his own..$^{251}$

246 Pat. Rolls, I, 524-545; II, 1-56, passim.

247 Red Book, III, 1064; "summa fuit circiter quater viginti et novem milia marcarum" (Matthew Paris, VI, 66); one account, probably incomplete, is as follows: $£ 22,5896 \mathrm{~s} 7 \mathrm{~d}$ received by the bishop of Salisbury; $£ 15,34318 \mathrm{~s} 81 / 2 \mathrm{~d}$ by the bishop of Bath (Vincent, Lancashire Lay Subsidies, p. 16).

248 Pat. Rolls, I, 550, 554.

249 Dunst., p. 93.

250 Pat. Rolls, I, 585; Reg. S. Osm., II, 57; Wilkins, Concilia, I, 603; this letter is given in Coventry, II, 256, where the chronicler represents that it was used at the council which granted the fifteenth.

251 One draft of the king's letter is given in Rot. Litt. Claus., II, 


\section{STUDIES IN TAXATION}

The archbishop urged that a grant be made, suggesting a twelfth, or a fourteenth. The king promised that the tax should not form a precedent, and, as evidence of his good faith in the matter, declared that a tenth of the hay and of the product of the mills on his demesne should henceforth be given to the churches and that he would try to persuade the magnates to make a similar grant.

The records of Salisbury church show that there was much discussion over this request. All the canons were summoned and four main points were considered: whether they should make any grant; if so, how much; how to make it uniform; and how to prevent the establishment of a precedent. Furthermore, it was suggested that a council of all the churches be called. Evidently other churches had not made the grant as asked, for the archbishop summoned a council of deans, archdeacons, and regulars with representatives of absentees, to meet at London in October, 1226. Each church was to instruct its own delegates. ${ }^{252}$

After deliberation the council granted a uniform tax of a sixteenth of revenues according to the valuation of

152b; Wilkins, I, 603, 620; Register of S. Osmund, ed. Jones, Rolls Series, II, 55-56; a full account of this tax with all these letters is given in the Reg. S. Osm., II, 55-70; also in Wilkins, I, 603-605, which is taken from the register. On this tax, see Ernest Barker, The Dominican Order and Convocation, pp. 48-51.

252 The instructions given by the church of Salisbury show that the grant would be so hedged about by restrictions as to render the king entirely dependent on the will of the churches for any returns from the tax. The grant was to be made "de prebendis et redditibus et hoc secundum estimationem quæ facta fuit ad subventionem Terræ Sanctæ et nullo modo de mobilibus"; it was to be collected by the chapter, not by the bishop; no oath was to be taken; no sentence of excommunication issued; "prolixos terminos" for payment. One question to be asked at the council was what was to be done if some canons refused to do that to which the majority of the chapter agreed (Reg. S. Osm., above). 


\section{UNDER JOHN AND HENRY III}

the twentieth in $1216 .^{253}$ These values did not correspond to the true values, for they were usually made in round sums. ${ }^{254}$ The tax was collected in cathedral churches by the deans and the chapter, and in parochial churches by the archdeacon and other worthy men appointed by the bishop. It was to be paid, half in February, 1227, and half in the June following. Letters patent were issued declaring that the grant should not form a precedent. ${ }^{255}$ Part of the tax remained unpaid, for in 1229 the king wrote to several bishops complaining that considerable sums were still in arrears. The dean and chapter of Lincoln had paid nothing. ${ }^{256}$ Some churches raised the tax by taking an aid from their knights and free tenants. ${ }^{257}$ The Irish clergy were also asked to contribute, but were very unwilling to do so and may have escaped entirely. ${ }^{258}$ Thus at last, the government adopted the suggestion made long before that taxes be raised on personal property. So many men paid this time on the assessed or estimated value of their property that it was the exception to pay dona.

In 1226, Henry III was very desirous to lead in person an expedition to Gascony, but by counsel of the barons, he postponed the invasion. ${ }^{259}$ Though the pope too had

253 Ibid.; Theok., p. 69; Wig., p. 419; Annales Monasterii de Oseneia, ed. Luard, Rolls Series, p. 68; a fifteenth, Wend., IV, 139; Pat. Rolls, II, 64; Chronicon Thomo Wykes, ed. Luard, Rolls Series, p. 67 .

254 Reg. S. Osm., II, 70-75.

255 Rot. Litt. Claus., II, 211b; Pat. Rolls, II, 64. The clergy feared that the tax would lead to others, and the pope in his letter urging them to grant this tax had stated that it was not to be drawn into a precedent (Pat. Rolls, 1, 585).

256 Pat. Rolls, II, 249; Close Rolls, I, 380, 381.

257 Rot. Litt. Claus., II, 143a.

258 Pat. Rolls, II, 100, 101, 103, 104, 138; Close Rolls, I, 383.

250 Wend., IV, 126; Rot. Litt. Claus., II, 151a; Pat. Rolls, II, 44. 


\section{STUDIES IN TAXATION}

forbidden it, ${ }^{260}$ the king did not give up his plan. In June, 1227, he summoned the tenants in chief to meet on August 1 and ordered ships to gather at the same time for the invasion. ${ }^{261}$ The truce was however extended to 1228 and the summons was countermanded. ${ }^{262}$ For the expenses of the war in Gascony a tallage was levied in 1226 and $122 \%{ }^{263}$ The assessment was made in each county by the sheriff acting with commissioners who were appointed by the king. ${ }^{264}$ Many of the towns fined with the assessors for their tallage and assessed it themselves. ${ }^{265}$ A peculiar feature of the levy was the tallage of London which was assessed per capita. Though this was an ordinary way of levying a tallage, there was something unusual about it, for the king issued letters patent promising that as far as London was concerned it should

260 Shirley, I, 545-547.

201 Rot. Litt. Claus., II, 210b, 211a; to meet June 15 at Winchester (Reg. S. Osmundi, II, 55); some of the towns were to furnish ships in lieu of their tallage (Rot. Litt. Claus., II, 174b).

202 Ibid., II, 212a.

263 "de competenti auxilio nobis faciendo ad hereditatem nostram et jura nostra perquirenda in partibus transmarinis" (Pat. Rolls, II, 104); "auxilium ... ad opus ... R. comitis Pictaviæ" (Rot. Litt. Claus., II, 171a); the tallage was levied on London before December 22, 1226 (Pat. Rolls, above), but most of the orders for its collection were sent out in January and February, 1227 (Rot. Litt. Claus., II, 171a, 208b). It is mentioned in Theok., p. 69, Wend., IV, 138, and Wig., p. 419 ; Farrer, Lanc. Inquests, p. 135.

264 Rot. Litt. Claus., II, 171, 176a. These commissioners were royal justices; e.g. in Hereford, the tallage was assessed by $S$. de Segrave, William Fitz Warini, and Ralph Musard (Pipe Roll, 12 Henry III, m. 2 d), who were judges (Pat. Rolls, II, 107). Cf. the list of tallagers in Rot. Litt. Claus., II, 208, 209, with the itinerant justices (ibid., 151, 213).

265 Thus. towns responded for round sums; see also Rot. Litt. Claus., II, 208b. The bishop of Hereford had excommunicated forty citizens of Hereford because "in communi tallagio regis in civitate, homines suos (of the bishop) concires et inhabitantes civitatem et homines canonicorum talliaverant et namia pro tallagio ceperant" (Red Book, III, 1010); Madox, I, 707, n. $h, i$. 


\section{UNDER JOHN AND HENRY III}

not form a precedent. ${ }^{268}$ Wendover states that the king compelled the citizens to pay 5,000 marks, because they had paid that sum to Louis when he left England. ${ }^{267}$ Probably this sum was demanded and refused and the king then took a tallage per capita. The amount charged in twenty-nine counties in 1226 and 1227 was about 9,000 marks. Of this sum, $4,120 \mathrm{~m} 5 \mathrm{~s} 8 \mathrm{~d}$ were charged against London. In 1227, the government ordered all charters to be confirmed as the king was now declared to be of full age. Towns sometimes paid a lump sum for their tallage and for confirmation of their charters. The amounts do not appear exorbitant, ${ }^{268}$ and in many cases were afterward reduced. ${ }^{269}$

\section{The Scutage of Kerry, 1228}

In 1228, the Welsh attacked the castle of Montgomery, and to relieve it the host was summoned and Wales invaded. The campaign lasted about six weeks and was a failure. ${ }^{270}$ Most of the great tenants performed their

266 Pipe Roll, 12 Henry III, m. 6; Madox, I, 708, n. n; Pat. Rolls, II, 104, 132.

287 Wend., IV, 138; see above, p. 124, note 18. That this was not an isolated case of levy per capita is shown by the following: "Homines de Calne $\mathbf{r} \mathrm{c}$ de vi li. et xix sol. et ii den. de tallagio assiso super ipsos per capita" (Pipe Roll, 12 Henry III, Wilts, m. 2). 208 Salop 300m "pro taillagio suo assiso super eos per Henricum de Alditheleg et Johannem Bonet et pro habenda carta regis et confirmatione de libertatibus eis concessis per cartam regis $J$. et pro libertatibus per regem $H$. eis de novo concessis" (Pipe Roll, 11 Henry III, Salop, m. 2 d); Bedford $£ 100$ for tallage and confirmation (ibid., m. 2); Northampton $£ 200$ for the same (ibid., m. 10); Wendover (IV, 139) says that Northampton paid $£ 1,200$ "de auxilio"; Hereford, 120 marks (Pipe Roll, 12 Henry III, Heref., m. 2 d).

269 Newcastle from $£ 200$ to $£ 100$; Carlisle from $126 \mathrm{~m}$ to $60 \mathrm{~m}$; Norwich from $460 \mathrm{~m}$ to $200 \mathrm{ml}$ and then to $150 \mathrm{~m}$; Stafford from $100 \mathrm{~m}$ to $50 \mathrm{~m}$; Salop from $400 \mathrm{~m}$ to $300 \mathrm{~m}$; Winchester from $146 \mathrm{~m}$ 6s to $100 \mathrm{~m}$; Scarborough from $220 \mathrm{~m}$ to $150 \mathrm{~m}$, etc. (Rot. Orig., 11 Henry III, no. I, m. 5, 6) ; Rot. Litt. Claus., II, 180-186.

270 Wend., IV, 172-173; Dunst., p. 110; Brut y Tywysogion, ed. 


\section{STUDIES IN TAXATION}

service $;^{271}$ the army also contained lesser tenants and rear-vassals. ${ }^{272}$ Some tenants performed only part of their service. ${ }^{273}$ The fighting took place in the autumn and the exchequer had not sufficient money to defray expenses. ${ }^{274}$ Immediately after the king's return, writs were issued (October 24) directing a scutage at two marks on the fee to be paid on December 7 in most of the counties and in a few cases on January $20 .{ }^{275}$

Owen Jones, p. 317. Henry was at Montgomery from September 3 to some date between October 14 and 28 (Close Rolls, I, 78-129).

271 Most of them receive writs of quittance.

272 Scutage Rolls, no. 2, m. 4, 5; see also below.

273 Close Rolls, I, 118; Chron. Petrob., p. 10; Wykes, p. 70.

\section{Knights
Sur- \\ vice nished}

Walter de Ashley $10 \quad 1$

John de Villiers

John de Beauchamp

Henry Fitz Richard

Hugh Giffard

Michael de Colu

William de Ponte Arche 11

Roger Fitz Payn $15 \quad 1$

Robert de Amenevill 11

Henry de Oilli
$11 / 21$

72 serg.

21/2 1 serg.

Quit in Dors. and Somers., Pipe Roll, 13 Henry III.

Quit, Bucks and Bedf.

Quit, Bucks and Bedf.

Quit, Dors. and Som.

"debet" 5m, Heref.

Quit, Hants.

Quit, Hants.

Quit, Dors. and Som.

Quit, Glouc.

$321 / 36$ serg. Quit, Oxford

(Scutage Rolls, above.)

274 Sheriffs were to forward receipts directly to the army instead of to the exchequer (Close Rolls, I, 79-81).

275 Close Rolls, I, 118. This is the account:

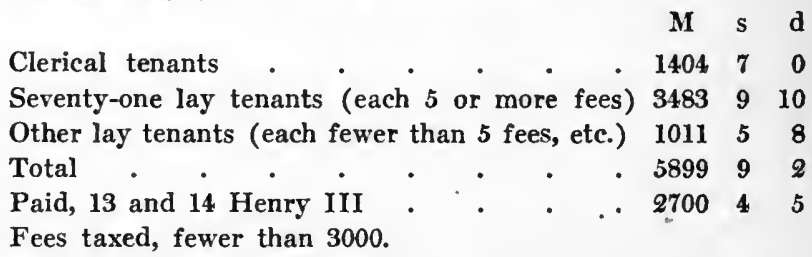

The 71 tenants include as one tenant each the honors of Eye, Chokes, and Richard de Reimes; also 12 tenants holding 5 or more fees each on great honors in hand such as Boulogne, Peverel, etc. In the sum charged against the lesser tenants (each fewer than 5 fees, etc.) 


\section{UNDER JOHN AND HENRY III}

This scutage was paid by tenants who had failed to answer the summons. A rear-vassal who was in the army received a writ of quittance and his lord was exempt that amount. ${ }^{276}$ In some cases the tenant in chief who had performed only part of his service paid no scutage at all. ${ }^{277}$ A tenant who did not pay might be disseized or distrained. ${ }^{278}$ Yet it was difficult to compel prompt payment. William de Ferrar held one fee of the bishop of Bath which William Marshal gave him with his wife in free marriage. The bishop tried to collect scutage from it, but the tenant refused to pay and was then distrained by the sheriff. He claimed that William Marshal ought to acquit him. The plea was not allowed because the sub-tenant ought to have proceeded against the donor and had not done so, though he had had sufficient time, over two years. So he was ordered to pay the scutage, and should he refuse the sheriff was to sell the goods which he was holding and pay the proceeds to the bishop. This case was not settled till $1231 .^{279}$ William de Vesey served in the army and was granted his scutage. The writ which the sheriff received stated that it was the scutage of Montgomery instead of Kerry. Consequently, the latter

are included $556 \mathrm{~m}$ charged against honors in hand, leaving about $450 \mathrm{~m}$ against tenants in chief, or 225 fees. Of the sum charged against the clergy and the lesser lay tenants, about two-thirds were paid in 1229 and 1230; of that charged against those laymen holding five or more fees, about one-third. Some of the great tenants who are charged and who pay are women: the countesses of Winchester, Oxford, and Salisbury. Some of the holdings in the list of five or more fees are probably in hand, but not all: Nigel de Mowbray and the earl of Warwick are both charged with scutage and both pay part of it.

276 Close Rolls, I, 83, 84, 85, 86, 121, 321.

277 See above, note 273.

278 "Preceptum est vicecomiti quod diss' heredes Mathei de Torington' et uxorem ejusdem M. pro scutagio de Kery" (Exch., K. R., Mem. Roll, no. 10, m. 4).

278 Close Rolls, I, 512. 
scutage was demanded of William. On his refusal to pay he was distrained and he then secured the correction of the writ. Yet the sheriff did not resort to these extreme measures till 1230, two years after the campaign. ${ }^{280}$ In 1239, two tenants were pardoned their scutages for this expedition. ${ }^{281}$ The scutage was ultimately paid by the rear-vassals. The king granted tenants the right to collect it from their men, the sheriff aiding with distraint, if necessary. ${ }^{282}$ The existence of such orders shows that the tenant in chief could not make such a collection without the king's consent. The same orders and the delays in payment show that the exchequer did not pass over the heads of the tenants in chief and levy the scutage on the sub-tenants. The scutage did not stop with the immediate vassal of the tenant in chief. ${ }^{283}$

\section{The Papal 'Tenth, 1229}

This year occurred another case of papal taxation to raise money to carry on war against the emperor, Frederick II. The demand was presented by the papal nuncio, Stephen, in a great council, composed of all the tenants in chief, the rectors of churches, and the

280 Close Rolls, I, 375.

281 Excerpta, I, 322.

282 Close Rolls, I, 118; for Matilda, wife of Richard de Redvers (Excerpta, I, 178); in the case of Oliver de Albiniaco, a rear-vassal, whose goods had been seized "et averia sua ea occasione capta sine dilatione deliberari faciat" (Close Rolls, III, 439); Scutage Rolls, no. 2. "Dominus rex concessit Willelmo Lungesp' quod per manum suam colligi faceret scutagium suum de feodis militum que de rege tenet in capite de hereditate uxoris, scilicet de scuto ii marc. pro exercitu de Kery ad respondendum inde per manum suam ad scaccarium ... et mandatum est vicecomiti Oxon' quod scutagium illud sic colligi permittat et sit in auxilium eidem W. ad distringendum milites et libere tenentes suos in ballira sua ad scutagium illud ei reddendum" (Fine Roll, 13 Henry III, m. 13); there are other cases on $\mathrm{m} .12,13$. 283 Distraint of the tenants of Geoffrey de Dunstanvill,' a rear- 


\section{UNDER JOHN AND HENRY III}

Templars and the Hospitallers. The laity refused to make the grant, but the clergy yielded. Wendover says that the king had promised the pope a tenth of the moveables of all in the realm in return for the cassation of the election of Walter de Eynesham as archbishop of Canterbury, and that for this reason he did not oppose the pope's demand. The earl of Chester refused to allow his clergy to be taxed and thus they escaped..$^{284}$

This tax should be noticed, not only as another case of the taxation of the clergy, but also as an attempt to base the tax on property. The pope sought to levy it on the actual value of the property and revenues. ${ }^{285}$ The papal nuncio had general charge of the assessment and collection and he appointed representatives for that purpose in the different dioceses. In each cathedral church and monastery, some of the canons or monks made the assessment under oath. ${ }^{286}$ As the assessment would take some time and there was need of the money at once, the clergy had to make immediate advances of money which

vassal (Close Rolls, I, 321); pardon of scutage to Philip de Albin' who held of Oliva who held of the honor of Brittany (ibid., I, 85).

284 Wend., IV, 184, 200-203; Dunst., pp. 114, 166; Osney, p. 70; Gerv. Cant., Continuation, II, 128; Theok., p. 73; Wykes, p. 70; Wig., pp. 421, 422; Burton, pp. 245, 364-365; Wint., p. 85; Wav., p. 305; Chron. Petrob., p. 10.

285 "decimam omnium bonorum" (Theok., p. 73); "decimam proventuum de omnibus terris, redditibus, decimis, oblationibus, non deductis expensis" (Dunst., p. 125); "non secundum taxationem factam in vicesima, ... . sed secundum quod melius possunt, . . . omnia bona et mobilia singulorum taxari; videlicet, de omnibus redditibus, proventibus, fructibus carrucarum, oblationibus, decimis, nutrimentis animalium et fructibus, et de omnibus obventionibus ecclesiarum vel aliarum possessionum, quocumque nomine censeantur, non aliquibus debitis rel expensis aliqua occasione deductis" (Wend., above); "A. D. 1229, decimata est universalis ecclesia Angliæ, et omnia mobilia et immobilia clericorum et religiosorum" (Burton, pp. 364365 , where also are given the details of the assessment).

286 "constitutis procuratoribus suis in singulis comitatibus regni" (Wend., IV, 202); "et taxationem rerum fecit fieri in ecclesiis 


\section{STUDIES IN TAXATION}

were later credited to them in the tenth. ${ }^{287}$ Prelates who refused to agree to the tenth, or to advance money, were threatened with excommunication. The attempt to base the tax on property, the use of sworn assessors, and the excommunication of those who opposed the levy caused great complaint. ${ }^{288}$

cathedralibus et monasteriis per canonicos et monachos eorum juramento astrictos" (Dunst., p. 114).

287 Wend., above; "unde pro festinato auxilio, domus de Dunstaple solvit viginti marcas"; the next year they paid 421/2 marks (Dunst., pp. 115, 125). After the assessment was made, the prior of Tewkesbury paid 109 marks, Norember 17, 1230 (Theok., p. 77). According to Wendover, some of the prelates were compelled to sell or pawn the gold and silver of the churches to raise the money. Matthew Paris adds that Stephen brought with him merchants who lent money to the clergy at ruinous rates (Matthew Paris, III, 188).

288 It may be questioned whether the assessment was as severe as the outcries of the chroniclers would indicate. The tax on one of the deaneries of the church of Salisbury in 1226 was 100s, which would give a value of revenue of $£ 80$ (the record gives $80 \mathrm{~m}$ but it is probably an error). A note gives another estimate of this property which seems to be that of 1229 , for it is that of the roll sent to Stephen, the pope's chaplain: (In rotulo misso Stephano capellano domini P. P. sic:") The estimate is $£ 100$. The valuation of this same deanery for the levy of the twentieth of 1216 was $133 \mathrm{~m} 10 \mathrm{~s}$ ("et sic fuit æstimatio decanatus et præbendæ decani cxx marc' et xiii marc' et x solidi") (Reg. S. Osm., II, 70, note 1). 


\section{CHAPTER VI}

\section{The Taxes in Detail from 1229 to 1242}

WITH 1229 Henry III began to direct his government. The period covered by this chapter is characterized by increase in taxation and by a corresponding increase of resistance on the part of the tenants in chief, though the opposition had not as yet reached the point where it placed an effective check on the growing power of the king. At the close of the period it was as yet uncertain whether or not the king would be successful in establishing the right to levy aids at will as long as he was careful to observe the form of assembling the great council and asking its consent. The advance in the demands of the king began on the occasion of the expedition to Gascony. Two scutages were taken, one of which was accompanied by fines. For the campaign against Richard Marshal in 1233, fines were also taken. Three aids were taken from 1232 to 1237 , that is, within six years, and two of these were on personal property. The king tried to have the aid of 1235 paid not merely on the usual number, but on all the knights' fees.

But while Henry III was thus establishing precedents which might lead to arbitrary taxation, there were not lacking indications of growing opposition among the barons. The bishops in 1229 held the king to what they evidently considered to be the law; they paid him an aid and not a scutage, thus asserting a claim that they did not owe service in France for their fees. In 1231, all the clergy paid an aid and not a scutage, and in so doing the 
religious houses seem to have asserted that the king had no right in law to a second scutage for the campaign in Gascony. No scutage was levied for the campaign against Richard Marshal and none for the expedition to Wales in 1241, and here no doubt we see the enforcement of the baronial will that scutage was not legally due in these cases. In 1235, it seems likely that the king did not succeed in his effort to have the aid paid on all fees instead of on the customary number, though of this we cannot be quite sure. ${ }^{1}$ There were numerous cases of debate and of postponement of the grant (1231, 1232, 1237). In 1237, proposals were made by the barons to control the royal expenditure and the king had to promise that he would not consider the thirtieth as a precedent for future demands.

Several dona were taken in connection with taxes on other parts of the community. The fact that the demesne paid a tallage instead of the thirtieth is interesting. Whatever the reason was, this substitution had the effect of denying that the grant by the great council bound the men on the royal demesne. The scutages of this period were all strict scutages. Tenants served in the host with only part of their quotas.

\section{The Taxation for the Campatgn of 1230}

Up to this time, in Henry III's reign, the scutage had been levied in connection with insular expeditions, had been put in charge at or near the close of the campaign, and had been regarded as the composition for service. For such campaigns, usually lasting not much longer than the feudal period of service and sometimes not as long and requiring a comparatively small number of knights,

1 The account of this levy is not in the Pipe Roll. The accounts entered in the Testa de Nevill do not permit one to say on how many fees the tax was paid. 


\section{UNDER JOHN AND HENRY III}

the government could afford to be lenient in the interpretation of the law of military service. The invasion of France was an affair requiring a much larger force than an expedition within England itself, and far more money. In 1226, about $£ 36,000$ of the fifteenth had been sent to Richard for his expenses in Gascony. Just before Henry III sailed in 1230, he acknowledged the receipt of 11,100 marks from the English treasury. ${ }^{2}$ While at Nantes, he borrowed 3,000 marks from Gascon merchants, ${ }^{3}$ and in July was writing to the exchequer for more money. ${ }^{4}$ Just before his return to England in September, he received 9,000 marks more, ${ }^{5}$ and at the same time bound himself to pay the count of Brittany 6,000 marks on his arrival home, and to send to the earl of Chester whom he left in charge in France 1,000 marks to carry on the war. ${ }^{8}$ The expectation of this heavy expense was probably Hubert de Burgh's reason for opposing the expedition.

In July, 1229, at a council of the lay tenants held at Northampton, it was resolved to invade France, and the great barons were then summoned to meet at Portsmouth on October 14. The general summons to the lesser tenants was issued in September. ${ }^{7}$ Partly on account of the season and partly on account of the insufficient number of ships, which the justiciar had succeeded in assembling, the expedition was postponed till the following Easter. ${ }^{8}$ On April 30, the host finally set sail, landed in Brittany

2 Pat. Rolls, II, 335, 337, 341.

3 Ibid., 378, 379.

4 Shirley, I, 382. In May, the king wrote to England for 6,000 marks of the tallage of the Jews and all the other money in the exchequer. Up to July 1 , he had received none of this (Close Rolls, . $1,411,417$ ).

5 Pat. Rolls, II, 397.

- Ibid., 400, 401.

7 Close Rolls, I, 248; Madox, I, 607, n. z.

8 Wend., IV, 204-205; Theok., p. 73; Close Rolls, I, 256, 380. 


\section{STUDIES IN TAXATION}

and marched south to Gascony. The campaign ended in September. ${ }^{9}$ The tenants were thus summoned twice. On both occasions, the army seems to have been large, though nothing definite can be said about it. ${ }^{10}$ At least 230 ships were employed for transportation. ${ }^{11}$ The Patent Roll gives the names of nearly 400 men who received letters of protection because they accompanied the king. ${ }^{12}$ The Scutage Roll of Poitou contains 161 names. ${ }^{13}$ The force would be larger than either of the last two numbers, for the great barons who received letters of protection or of scutage would be accompanied by knights. ${ }^{14}$ There were lesser tenants as well as greater in the host, ${ }^{15}$ and mercenaries were also employed..$^{16}$

It is quite certain that the barons did not answer the summons with their full contingents. In some cases the writ stated that the tenant was to come with only part of his men. The earl of Chester, at least 59 fees, was to come with 19 knights $;{ }^{17}$ Walter de Lacy, 511/4 fees, was

9 Rymer, I, 198; Pat. Rolls, II, 395.

10 Wav., p. 308; Wend., IV, 209.

11 Pat. Rolls, II, 370-374.

12 Ibid., $357 \mathrm{ff}$.

13 Genealogist, New Series (1884), I, 73-76, described as a Scutage Roll of the sixth year of Henry III; it should be the fourteenth year.

14 In many cases the Scutage Roll states "qui habuit milites suos."

15 See these cases: William de Siffrewast, 1 fee; Elias de Bolton, 1 fee of the honor of Boulogne; Eustace de Moreton, 3 fees of the honor of Peverel; Peter de Goldinton, 4 fees of the same honor. The Scutage Roll (see above) states that each of these men was with the host. The writs of quittance in the Pipe Roll include lesser tenants.

16 When the king came home, he left a force of 500 knights and 1,000 sergeants, "stipendiarios," to carry on the war; they had probably been employed before (Wend., IV, 217); in September, the king promised to maintain 400 knights and 100 mounted sergeants; of these, 100 knights were "de militibus nostris" and the rest "ad denarios nostros," (Rymer, I, 198); see also, Pat. Rolls, II, 399, 403, 405.

17 Close Rolls, I, 248. 


\section{UNDER JOHN AND HENRY III}

summoned with four knights; William de Worcester was to come with one knight, or alone, well prepared. ${ }^{18}$ The Scutage Roll of 1230 (Poitou) in a few cases gives the number of knights that the tenant had with him and from this it is seen that only a part of the service was performed. ${ }^{19}$

\begin{tabular}{|c|c|c|c|}
\hline & & $\begin{array}{l}\text { Knights } \\
\text { in array }\end{array}$ & Fees \\
\hline John de Heriz & $\cdot$ & . 1 & $4^{20}$ \\
\hline Hugo Painel & • & - $\mathbf{2}$ & $6^{21}$ \\
\hline Ralph de Sudley & • & . 1 & $\mathbf{8}^{22}$ \\
\hline Payn de Chaworth & ${ }^{\circ}$ & . 1 & $12^{1 / 2^{28}}$ \\
\hline Walter de Estlegh & $\bullet$ & . 1 & $10^{24}$ \\
\hline Ralph de Newland & • & . 1 & $2^{25}$ \\
\hline Baldwin de Redvers & $\bullet$ & . 1 & $5^{26}$ \\
\hline
\end{tabular}

These cases may fairly be regarded as typical.

It has been questioned whether one or two scutages were levied for this campaign. ${ }^{27}$ In the Pipe Roll of 1230 there appears a scutage of Brittany, or "de prima transfretatione"; in 1231, there is another scutage, whose account is rendered separately, called the scutage of

18 Close Rolls, 1, 256.

10 Genealogist, above.

20 Pipe Roll, 14. Henry III, Notts. and Derby.

21 Three fees in Linc. and three fees in York.

22 Pipe Roll, 15 Henry III, Glouc.

23 Ibid.

24 Ibid., 14 Henry III, Dors. and Somers.

25 Ibid., Essex and Herts, Honor of Boulogne.

26 "qui habet 1 militem pro se in servicio domini regis in partibus transmarinis," 14. June (Pat. Rolls, II, 380); he held 5 fees in the honor of Boulogne.

${ }^{27}$ Stubbs, Const. Hist., II (3rd ed.), 42, gives two scutages: Hall, Red Book, II, clxxxviii, gives only one scutage; Ramsay, Dawn of the Constitution, p. 57, note, gives the views of both; the last author cites a letter of the king from Shirley, I, 394, as evidence of one scutage only, but that letter refers to the second levy and does not exclude a previous scutage. 


\section{STUDIES IN TAXATION}

Poitou, "post primam transfretationem." Both were at the same rate, three marks per fee. The scutage of Brittany was accompanied by fines; that of Poitou was not. Unless there is evidence to the contrary, we may conclude from the separate entries that there were two levies. Further there were two grants of scutage; the first was fixed in a council at Northampton in July, 1229, and the second in September, 1230. ${ }^{28}$ The bishops did not pay scutage, but they made two separate grants of aid at three marks per fee. ${ }^{29}$ The accounts of individual tenants show that a second scutage was taken. Henry de Braybrook was charged with 60 marks fine and scutage on $13 \frac{1}{2}$ fees (scutage of Brittany), all of which was paid; he was also charged with $£ 27$ of the scutage of Poitou, ${ }^{30}$ nearly all of which was paid. Thomas Fitz William had a writ of quittance for the scutage of Brittany and was charged with $10 \mathrm{~m}$ for that of Poitou. ${ }^{31}$ Robert de Beauchamp paid $40 \mathrm{~m}$ of fine "ne transfretet" in lieu of the scutage of Brittany; he also paid the scutage of Poitou. ${ }^{32}$ The abbot of Peterborough paid $100 \mathrm{~m}$ "in auxilio" and $180 \mathrm{~m}$ scutage when the king crossed; when the latter returned, he demanded another scutage. ${ }^{33}$ Rear-vassals were sued at law by their lords for failure to pay two scutages at this time. ${ }^{34}$ There are two Scutage Rolls, one "pro exercitu nostro ad primam transfretationem" and another "pro exercitu nostro Pictaviæ post

28 See below, pp. 186, 191.

29 See below, pp. 189, 192.

30 Pipe Roll, 14, 15, and 16 Henry III, Northamp.

31 Ibid., 14 and 15 Henry III, York; half of the sum charged was paid in 1231 .

32 Ibid., 14, 15, and 16 Henry III, Dors. and Somers. This tenant held 17 fees of the honor of Mortain which paid at five-eighths the ordinary rate; consequently his scutage in each case would have been $317 / 8$ marks.

33 Chron. Petrob., p. 11.

3* Bracton, Note Book, cases 727, 789; cf. Excerpta, I, 210. 


\section{UNDER JOHN AND HENRY III}

primam transfretationem." ${ }^{35}$ It seems certain that two scutages were levied.

The account of the scutage of Brittany follows:

Scutage at $3 \mathrm{~m}$

$\begin{array}{lll}\mathrm{S} & \mathrm{d}\end{array}$

Bishops (auxilium at $3 \mathrm{~m}$ per fee) $\begin{array}{llll}36 & 1352 & 0 & 0\end{array}$

Twenty-one lay tenants (each 5 or

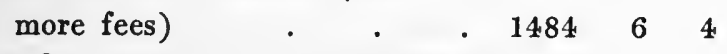

Other lay tenants (each fewer than 5

$\begin{array}{lllllll}\text { fees, etc. }^{37} & \cdot & \cdot & \cdot & 602 & 2 & 3\end{array}$

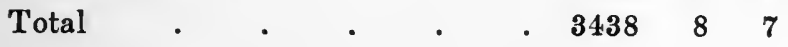

Fine Fees

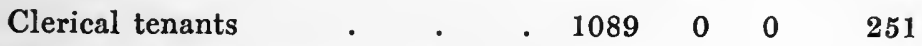

Twenty-six lay tenants (each 5 or

$\begin{array}{llllllll}\text { more fees }) \cdot & \text {. } & \text {. } & \text {. } & 1704 & 10 & 8 & 386\end{array}$

Other lay tenants (each fewer than 5

$\begin{array}{lllllllll}\text { (fees, etc. })^{38} & \cdot & . & & 1240 & 7 & 8 & 168\end{array}$

$\begin{array}{lllllllll}\text { Total } & . & . & . & & 4034 & 5 & 0 & 805\end{array}$

$\begin{array}{llllrrr}\text { Additional fine }^{38} & . & . & . & 340 & 0 & 0 \\ \text { Total tax . } & . & . & . & 7813 & 0 & 3 \\ \text { Paid, 1230, 1231 } & . & . & . & 5532 & 11 & 0\end{array}$

Fees taxed, about $2100 .^{40}$

35 The entries of the scutage of Brittany date from September 11, 1229; of Poitou, from September 17, 1230 (Scutage Rolls, no. 2, for Brittany ; no. 5, for Poitou).

30 The archbishop of Canterbury is charged with $200 \mathrm{~m}$, all of which was paid; the bishops of Winchester and Chichester were charged with $180 \mathrm{~m}$ and $12 \mathrm{~m}$ respectively, but the sums were later pardoned and have not been included here.

37 Of this sum, $244 \mathrm{~m}$ were on honors in hand.

$38438 \mathrm{~m}$ on 66 fees are on honors in hand, leaving about $800 \mathrm{~m}$ on 100 fees of tenants in chief.

39 Number of fees unknown.

40 The county of Cornwall no longer appears in the roll since it was given to Richard, the king's brother. 


\section{STUDIES IN TAXATION}

This was a scutage in the strict sense levied on the lay tenants, the abbots, and the priors who did not perform their service. ${ }^{41}$ A council of the earls and barons had been held at Northampton in July and there it was determined to invade France in October; at the same time it was agreed that a scutage at three marks per fee should be levied. ${ }^{42}$ As the king was able to force his tenants to accompany him on this expedition, as the scutage was taken from those who failed to answer the summons to the host, and as Henry III was able to exact from recalcitrants fines in addition to scutage, it seems certain that this scutage rested on the king's right to the military service of his tenants. The words of the bishops point to the same conclusion. Their statement that they would make an aid, but not because they were summoned to cross with the king, implies that the payments of other tenants were made because of this summons. ${ }^{43}$

Although it had been determined in July, 1229, to take a scutage, the collection did not begin at once, for the

41 In each county, there are writs of quittance in the Pipe Roll.

12 One account of this council suggests that it was summoned to grant the scutage: "cum scutagium esset assisum, scilicet, de feodo militis $3 \mathrm{~m}$ de consilio comitum et baronum ... ad hoc vocatorum" (Madox, I, 607, n. $z$ ). But it seems probable that the main business was to get the barons to agree to invade France. The king had been anxious to do this for the past three years, but had been unable to bring it about. In 1226 and 1227, he had proposed it (see above, p. 171). At Christmas, 1228, he was with difficulty persuaded to defer the matter (Wend., IV, 179); in February, 1229, he wrote to the magnates concerning an expedition which was soon to be undertaken (Close Rolls, I, 232), so that the July meeting was probably called for this purpose. Further, the writs of summons to the host say "de consilio comitum et baronum nostrorum Angliæ, firmiter proposuimus ... transfretare." They were sent out July 27 , five days after the council (Close Rolls, I, 248).

43 "concesserunt tantum dare in auxilium ... non propter summonicionem eis factam ad habendum totum servicium suum quod domini regi debent apud Potesmue ad transfretandum cum eo" (Madox, above). 


\section{UNDER JOHN AND HENRY III}

account does not appear in the Michaelmas roll of this year. ${ }^{4}$ In September, notices of fines for exemption from service and for having scutage are found, so that orders for the collection of the tax were probably issued soon after September 10, the date of the general summons to the host. ${ }^{45}$ This scutage was paid by those who failed to answer the summons of October. ${ }^{48}$

The tenant who failed to serve did not always escape with a payment of scutage. Fines were levied. They usually included the scutage, but not always. Robert de Beauchamp paid $40 \mathrm{~m}$ ne transfretet and to have quittance of the scutage of 17 fees. Robert de Novo Burgo accounted for $20 \mathrm{~m}$ fine for his passage, saving to the king the scutage from 15 fees. ${ }^{47}$ The average rate per fee on the holdings of the lesser tenants was nearly eight marks, while on the religious houses and the greater lay tenants it was less than five marks per fee. Thus the

${ }^{4} \mathrm{Cf}$. above, the scutage of Bedford, not put in charge till August, yet it appears in the roll of the same year.

45 Excerpta, I, 188; Close Rolls, I, 214, 215, 220. As the scutage was not an aid, the orders for the collection could hardly be issued till the summons to the host went out. Writs de habendo scutagio were issued September 11 (Scutage Rolls, no. 2) and this is probably the date when orders to collect the scutage were issued.

48 Thus those who had agreed to come were allowed to have their scutage. In some cases, it is stated that the tenant had his scutage because he appeared at Portsmouth in October, 1229: "Quia Galfridus de Nevill' fuit apud Portesm' a die S. Michaelis etc. ... promptus et paratus transfretare cum rege, concessit ei rex scutagium suum" (Close Rolls, I, 314); also for Henry de Tebbetot (ibid., $335)$; for other notices of the levy of this scutage in connection with the summons of October, 1229, ibid., 266, 281, 285, 293, 298, 300, 321, 342, 346. The same tenants do not pay both the scutages of Brittany and Poitou, a fact which suggests that they were levied in connection with different summons.

47 Pipe Roll, 14 Henry III, Dors. and Somers.; Madox, I, 661, n. i. Robert de Beauchamp held of the honor of Mortain which paid at five-eighths the ordinary rate, so that his scutage would have been $317 \% 8$ marks. 


\section{STUDIES IN TAXATION}

larger proportion of the fines fell on the lesser tenants. ${ }^{48}$ Some of the heaviest fines on important vassals were (fine including scutage) : the abbot of Ramsey, $50 \mathrm{~m}$ on 4 fees $; ;^{40}$ the abbot of Abingdon, $120 \mathrm{~m}$ on 30 fees $;{ }^{50}$ the abbess of St. Edwards, $40 \mathrm{~m}$ on 7 fees $;^{51}$ the abbot of Westminster, $100 \mathrm{~m}$ on 15 fees $;^{52}$ Margaret de Redvers, $200 \mathrm{~m}$ on about 53 fees $;^{53}$ the countess of Oxford, $180 \mathrm{~m}$ on $301 / 8$ fees $;^{54}$ John de Stutevill, $75 \mathrm{~m}$ on 15 fees. $^{55}$ In some of these cases the fine was so heavy that the tenant might well have preferred to perform his service, if the choice were given him, especially since only service in part was required. The tenant in chief who had satisfied the king for his service received permission to collect scutage from his vassals and was aided in this by the sheriff. ${ }^{58}$ The

48 See above, p. 185.

49 Pipe Roll, 14 Henry III, Cant. and Hunt.

50 Ibid., Berks.

51 Ibid., Dors. and Somers.

52 Ibid., Wigorn.

53 Ibid., Oxf.

34 Ibid., Essex and Herts.

55 Ibid., Notts. and Derby.

${ }^{56}$ For Ralph de Freskenvill' (Close Rolls, I, 222); see also, pp. 214, 215, 220 for cases. "Nicholaus de Guronde ... distringendus est in Kancia" (Madox, I, 647, n. $z$ ). "Rex vicecomiti. Precipimus tibi quod sis in auxilium Hugoni le Poer ad distringendum Jacobum de Soleriis et Thomam de Bakervill' ad faciendum eidem Hugoni servicium quod facere debent et solent... ne per defectum tui remaneat quo minus idem Hugo nobis possit sufficienter respondere de scutagiis nostris que nobis debet de eisdem tenementis" (Exch., L. T. R. Mem. Roll, m. 5, 14 Henry III); Jordan de Arch' of the honor of Wallingford was granted delay in paying his fine "et averia sua ... capta ei deliberes" (ibid., m. 4). The tenant who fined was allowed to collect scutage and no more, from his tenants: "Henricus de Braybroc finem fecit cum domino rege per lx marc. pro passagio suo et pro habendo scutagio suo de feodis militum que de rege tenet in capite, scilicet, de scuto iii marc. pro exercitu regis ad primam transfretationem suam etc." (Fine Roll, 14 Henry III, part $1, \mathrm{~m} .7$ ); the amount which is pardoned a rear-vassal by the king is scutage when the lord fines and scutage only is what is deducted from the lord's fine: thus the abbot of Abingdon fined in 


\section{UNDER JOHN AND HENRY III}

incidence did not stop with the immediate vassal of the tenant in chief; men further down the feudal ladder had to pay scutage. ${ }^{57}$

A remarkable feature of this levy was the action of the bishops. They had not been present at the meeting at Northampton in July and were called together at London in October. They opposed the levy of the scutage and instead were allowed to grant the king an aid on all their fees at three marks per fee, a grant that had nothing to do with the summons to the host. They also received letters patent promising that the grant should not constitute a precedent. By their action the bishops seem to claim that they did not owe service in France. Henry III did not meet the issue squarely; his letters patent stated that the aid of the bishops should not form a precedent but that his rights were neither increased nor decreased. ${ }^{58}$

$£ 80$ for his 30 fees; he paid $£ 78$ "et in perdonis Petro filio Herberti (his vassal) iii marc. de $\mathrm{i}$ feodo per breve regis et (abbas) quietus est" (Pipe Roll, 14 Henry III, Berks, m. 9). The king might help the tenant in chief pay the fine by granting him "literae deprecatoriae" asking his men to help their lord pay his fine by making him an aid (Pat. Rolls, II, 268, 273). The tenant who paid only scutage received a writ allowing him to collect scutage from his vassals; Robert Fitz Walter paid scutage only (Pipe Roll, 14 Henry III, Essex and Herts.); he was allowed to collect scutage from his tenants to respond at the exchequer (Fine Roll, 13 Henry III, m. 2). The tenant who performed service was allowed the writ de scutagio habendo.

57 The sheriff was to distrain the tenants of Geoffrey de Dunstanvill, a rear-vassal (Close Rolls, I, 321).

58 Madox, I, 607, n. $z$. In the Pipe Roll, the payments of the bishops are usually entered separately, as "de auxilio ad primam transfretationem." The bishop of Ely however paid 120m "de fine pro scutagio 40 militum quos recognoscit" and accounted for $£ 241 \mathrm{~m}$ on 121/3 fees "quos non recognoscit" (Pipe Roll, 14 Henry III, Cant. and Hunt.). This claim of the bishops may be a recurrence of the claims set forth in 1198. That Henry III allowed it would not prove that he had no legal right to the service. It was characteristic 


\section{STUDIES IN TAXATION}

Religious houses which did not hold land by knights' service were also compelled to contribute. ${ }^{58}$ A tallage was levied, accounts of which appear in thirty counties in 1230 and $1231 .^{60}$ The towns fined in lump sums and thus had charge of the assessment and collection. In each county the levy was in charge of a committee consisting of the sheriff and some other royal officials, usually judges, specially delegated for this work. In some cases, these were itinerant justices. ${ }^{61}$ The money was generally

of him that as long as he got the money, he would not quibble about the form.

59 Wend., IV, 209 ; the abbot of Fiscamp paid $200 \mathrm{~m}$ "de dono in auxilium ad primam transfretationem regis" (Pipe Roll, 14 Henry III, Sussex); the prior of Worcester 24 marks "in subsidium guerræ suæ" (Wig., p. 422); Theok., p. 77.

60 It was put in charge in 1229 (Close Rolls, I, 276; Dunst., p. 120), and is referred to under 1230 by Wendover (IV, 209). The accounts appear for the most part in the Pipe Roll of 1230. Hereford, Sussex, Surrey, Westmoreland, Rutland, and Cornwall are omitted.

61 London is included, paying $1,000 \mathrm{~m}$ "de auxilio promisso regi ad primam transfretacionem suam" (Pipe Roll, 15 and 16 Henry III, Lond. and Midd.). In Salop and Stafford, the tallage was levied by Henry de Alditheleg, the sheriff, and William Basset; in Wilts, by Henry de Scaccario and Walter de Rumeseye, justices; in Gloucester, by William de Putot, sheriff, and William Rufus, justice; in Hants, by Henry de Bada, under-sheriff, John de Gatesden, and William de Insula, itinerant justice (Bracton, Note Book, I, pp. 140, 141); in Northampton, by Stephen de Segrave, sheriff and also itinerant justice (Bracton, above) and "socios suos"; in Norfolk and Suffolk, by Godfrey de Craucumb and William de Haverhull, justices. The persons by whom the tallage is levied are given in the Pipe Roll; the fact that these men are justices is given in the Patent Rolls. The sheriff is not always mentioned as one of those who levy the tallage so that perhaps he did not always act, but the method employed in Lincolnshire is probably typical: the tallage was laid by the sheriff, Walter de Erermuth', and Walter de Brackel', a clerk of the wardrobe. Twelve men from each part of the demesne were summoned to meet this committee of three and they in coöperation with the three assessors fixed the tallage of their part of the demesne: "de singulis dominicis ejusdem comitatus duodecim... homines ad tallagium illud assidendum, tam super dominica predicta quam in civitate predicta" (Close Rolls, I, 280). 


\section{UNDER JOHN AND HENRY III}

paid to the sheriff and he accounted for it at the exchequer. The receipts amounted to about 5,400 marks, not an exorbitant sum. The Jews were also taxed, apparently in a sum of 8,000 marks. ${ }^{62}$

The returns of the scutage of Poitou follow. They are given in the Pipe Roll of 1231 ; the only prelate charged was the abbot of Ramsey.

Scutage at $3 \mathrm{~m}$

$£ \quad s \quad d$

$\begin{array}{lllllllllll}\text { Abbot of Ramsey } & . & \text {. } & \text {. } & \text {. } & & 8 & 0 & 0\end{array}$

$\begin{array}{lllll}\text { Sixty lay tenants (each } 5 \text { or more fees) }{ }^{63} & .2772 & 12 & 8\end{array}$

Other lay tenants (each fewer than 5 fees,

Total etc. $)^{64}$

. 699310

Paid, 15 and 16 Henry III . . . $1593 \quad 14$

Fees taxed, about, 1750.

The scutage of Poitou was put in charge in September, 1230 , by the advice of the magnates who were with the host $^{65}$ and was to be paid at the exchequer on December $1 .^{68}$ It was not an aid, but a scutage in the strict sense. ${ }^{67}$

62 A third of their goods (Wend., IV, 209); a tallage of 8,000 marks is mentioned in the Pipe Roll, 14 Henry III, Hereford; Cal. Pat. Rolls, I, 12-13; Shirley, I, 392.

${ }^{63}$ Nearly all are tenants in chief.

64 About $£ 250$ are charged against honors in hand: Boulogne, Camiel, Peverel, and Lancaster. Beginning with this tax, the honor of Wallingford never pays to the king; it is in the hand of Earl Richard of Cornwall.

65 Wend., IV, 218, 219; Genealogist, New Series, I, 73, contains 161 writs de habendo scutagio issued at this time.

68 "Mandatum est vicecomiti Cumbr' quod de omnibus feodis militum que de rege tenentur in capite ... habeat scutagium ad scaccarium regis in crastino $S$. Andree anno etc. $\mathrm{xv}$ scilicet de scuto iii marc. pro exercitu regis Pictaviæ post primam transfretationem suam" (Fine Roll, 15 Henry III, part 1, m. 9); see also the writ for Walter Clifford concerning this date (ibid., m. 8).

${ }^{8} \mathrm{~T}$ See the writs of quittance in the Pipe Roll of 1231 and Genealogist, above, for writs of scutage. 


\section{STUDIES IN TAXATION}

The clergy objected to the levy and on December 15, 1230, orders were issued not to distrain them till January 27 , $^{68}$ when a meeting of the great council was held and the scutage was discussed ${ }^{68}$ The archbishop of Canterbury and some of the bishops opposed paying it on the ground that it had been granted by the lay tenants abroad and that the clergy were not bound by the decisions of the laity. ${ }^{70}$ As a result of the discussion, the sheriffs were ordered not to collect the tax from any of the clergy. ${ }^{71}$ The latter met after Easter and granted an aid at three marks per fee; the king issued letters patent promising that the grant should not constitute a precedent for future levies but adding that by it his own rights were neither increased nor decreased. ${ }^{72}$

Among the lay tenants, the tax was paid only by those who had failed to perform their service. The right to take it therefore rested on the king's right to military service. This seems to be implied in the speech of the

68 The clergy paid none of the scutage and their opposition was at once heeded. On December 2 , distraint of the bishop of Rochester was forbidden till January 6 (Fine Roll, above, m. 8); on December 15, distraint was suspended till January 27 throughout almost all the province of Canterbury (ibid.); for York and Durham on January $\mathcal{2}$ (ibid., m. 7 ).

69 The council met on January 26 (Wend, above).

70 "quod non tenentur viri ecclesiastici judicio subjici laicorum, cum absque illis concessum fuisset scutagium in finibus transmarinis" (Wend., above).

71 Roger of Wendorer says that part of the clergy agreed to the king's demand. This may be true, but no clerical tenant, except the abbot of Ramsey, is charged with scutage in the Pipe Roll and the orders to the sheriffs state that none of the clergy is to pay it (Close Rolls, I, 474, 475).

72 Shirley, I, 394; Pat. Rolls, II, 429; Close Rolls, I, 554, 593. The prelates were to meet on April 6 (Wend., IV, 219); the letters patent were issued on April 14, so that the grant was made between these dates. The aid was to be paid half on June 24 and half on August 15. A separate account was kept of it (Fine Roll, 15 Henry III, part 1, m. 5). It does not appear in the Pipe Roll. 
earl of Chester in opposing the aid of the fortieth in 1232, when he declared that inasmuch as the lay tenants had served personally with the king in France, they legally owed him no aid..$^{73}$ The action of the clergy (bishops in 1229 and all clerical tenants in 1230) in refusing to pay a scutage and paying instead an aid thus seems to be an encroachment on the king's rights to military service. On both occasions, Henry III promised that the grant should not form a precedent. Each time however he inserted a statement safeguarding his own rights, and this may relate to his right to military service. ${ }^{34}$ The letters patent which he issued in return for aids to which he had no right, except through the grant by the tenants, contained no such reservation in his own favor. ${ }^{75}$

The number of lay tenants who held ten or more fees and paid scutage was larger than usual. Of these thirteen held more than twenty fees each. ${ }^{76}$ Thus some of the greater barons were liable for the tax. No fines were levied, so that the scutage was the composition for service. It has been said that the barons served with only part of their contingents, though each received all his scutage. ${ }^{37}$ The method of collection shows no change. Some

73 "comites, barones ac milites, qui de eo (rege) tenebant in capite, cum ipso erant ibi corporaliter præsentes, ... unde regi de jure auxilium non debebant" (Wend., IV, 233).

74 In 1229: "ita quod per hanc concessionem suam domino regi vel heredibus suis, seu episcopis vel successoribus suis, nichil juris accrescat vel decrescat" (Madox, I, n. $z$ ); in 1231: "nolumus etiam quod propter hanc concessionem nostram quam fecimus, aliquid nobis vel hæredibus nostris accrescat vel decrescat" (Pat. Rolls, II, 429).

75 See the taxes of 1224, 1235, 1237, pp. 157, 209, 214.

70 William Fitz Warren, 30 fees (fee of John de Wahull), Henry de Oilli; $321 / 3$ fees, the countess of Oxford, $301 / 8$ fees, Walter de Lacy, 511/4 fees, Ralph de Sumery, 50 fees, earl Warenne, 60 fees, were among them.

77 Those men cited above, p. 183, as having performed only part of their service received all their scutage (Genealogist, above). 


\section{STUDIES IN TAXATION}

tenants collected the scutage themselves and responded either to the exchequer or to the sheriff, who delivered it at the exchequer. ${ }^{78}$ The sheriff distrained tenants to pay their scutage to the $\mathrm{king}^{79}$ and rear-vassals to pay it to their lords. ${ }^{80}$ Sometimes he may have collected it from rear-vassals for the exchequer, ${ }^{81}$ but he did not collect it from all rear-vassals. ${ }^{82}$ The scutage ultimately fell on the

78 In the Pipe Roll, some tenants are represented as responding at the exchequer while the sheriff responds for others. In the Close Roll, there are references to the fact that tenants collect their scutage from their vassals: "filius et heres Henrici de la Pomeraye, qui est in custodia Radulfi de Trublevill'... per manum suam colligat scutagium" (Close Rolls, I, 466); "per manum suam colligat scutagium" (ibid., p. 467); "nisi idem Rogerus scutagium illud receperit a predictis militibus (his tenants)" (ibid., 491); "Mandatum est vicecomiti Linc' quod non distringat Hugonem de Nevill' pro scutagio exercitus Pictavie ... de quo colligendo non habuit breve regis nec illud colligit, ut dicit" (ibid., II, 201); see cases of tenants who had writs to collect their scutage and respond at the exchequer, earl Warenne, Robert Fitz Walter, etc. (Fine Roll, 15 Henry III, part 1 , m. $6,7,8)$.

79 Roger de Sumery (Close Rolls, I, 491); forbidding distraint (ibid., 495; II, 201).

80 Thus the writ by which the tenant was allowed to have his scutage was addressed to the sheriff ordering him to cause the tenant to have his scutage (ibid., I, 484); order to distrain the countess of Oxford, as a sub-tenant (ibid., 313); see above, note 78 .

81 William de Hastings accounted for $£ 10$ in Gloucester, of which $£ 3$ were paid by the sheriff of Oxford; Ralph Musard accounted for $£ 30$ in Notts. and Derby; part of this was paid at the exchequer by the sheriff of War., and Leic. Thomas de Birkin accounted for $£ 24$ in Notts. and Derby, of which $40 \mathrm{~s}$ was paid by the sheriff of Leic. (Pipe Roll, 15 Henry III). Ralph de Sumery owed $£ 102$ of scutage; he paid $£ 10$ in Staffordshire, $£ 13$ by the sheriff of Bucks, $£ 5$ by the sheriff of War. and Leic., $£ 76$ s by the sheriff of Wigorn., $£ 2$ by the sheriff of Oxford, and $£ 16$ ss by H. de Scaccario (ibid., 15 and 16 Henry III, Staff.). It was thought that the scutage of Hugh de Nevill was collected from his vassals by the sheriff (Close Rolls, II, 201); the sheriff of Devon collected part of the scutage of the fee of Henry de la Pomeraye (ibid., I, 551).

$82 \mathrm{He}$ collected nothing as a rule from the tenants who served or who had writs to collect their own scutage. A further indication that the sheriff deals with the tenant in chief rather than with the 


\section{UNDER JOHN AND HENRY III}

sub-tenant. If however the latter had performed service, he was exempted by the king. ${ }^{83}$ The aid of the clergy was collected by them from their tenants. The sheriff assisted the prelates with distraint. Any sum pardoned to a rear-vassal by the king was deducted from the aid due from his lord. The prelate who could not distrain his tenants to pay was no longer held accountable for that amount. $^{84}$

Thus it is seen that the ordinary revenue was insufficient to defray the expenses of a foreign war and that the money for this purpose was raised by laying different classes under contribution in a manner similar to that employed by Henry II. ${ }^{85}$

\section{The Scutage of Elveyn, 1232}

Hardly had the question of the payment of the aid of the clergy been decided, when a new occasion for taxation

rear-vassal is that a tenant responds in one county for scutage which he owes in another. Peter Fitz Herbert was charged with $£ 29$ 8d scutage in Hereford "sed respondit inde in Glovernia in rotulo sequenti" (Pipe Roll, 15 Henry III, Heref.). Godfrey de Alno owes 40 s on 1 fee in Wilts "sed non debet summoneri in hoc comitatu quia non tenet nisi unicum feodum et de illo respondit in Sumersat" " (ibid., 16 Henry III, Wilts, m. 17 d).

83 Thus Anketill Malore, Robert Aguillum, and Godfrey de Craucumb were pardoned their scutage on fees held of tenants in chief (Pipe Roll, 15 Henry III, York, Bucks and Bedf.; Close Rolls, I, 461); this was probably on account of service, for they had writs of protection to go with the king on the expedition of 1230 (Pat. Rolls, II, 359, 360).

84 Pat. Rolls, II, 429; "si nos aliquid perdonaverimus tenentibus de predictis prelatis vel si ipsi aliquos tenentes de se distringere non possint id eis allocabitur.... Mittimus etiam vobis literas nostras directas vicecomiti nostro Surreiæ per quas ei damus in mandatis quod vobis et aliis prelatis ... de singulis feodis ... xl sol. habere faciat ad predictum auxilium nobis faciendum" (Fine Roll, 15 Henry III, part 1, m. 5).

85 An unusual contribution was that from the king of Scotland who gave $2,000 \mathrm{~m}$. It was not to be drawn into a precedent (Pat. Rolls, II, 332, 348, 414). 


\section{STUDIES IN TAXATION}

arose. The renewed activity of the Welsh made an expedition against them necessary. ${ }^{80}$ The campaign lasted from the end of July till the end of September, about two months. ${ }^{87}$ Besides the knights, part of the "jurati ad arma" and men of the towns were ordered to perform service in the army for forty days. ${ }^{88}$

86 Dunst., p. 127; Wend., IV, 220-223; Wig., p. 422; Osney, p. 72; Wykes, p. 72; Brut, p. 319.

87 The host assembled in July (Close Rolls, I, 592, 594, 595); the king was at Hereford on July 27, at Elveyn on July 30 and remained in Wales till September 22, was again at Hereford on September 25, where he remained till October 1, when he started for London (ibid., 536-561).

88 Ibid., 592, 595, 597; Rymer, I, 200. Lesser tenants either served or furnished their service; some tenants performed only part of their service as will be seen from the following table:

\begin{tabular}{|c|c|c|c|}
\hline & $\begin{array}{l}\text { Ser- } \\
\text { vice } \\
\text { owed }\end{array}$ & $\begin{array}{l}\text { Knights } \\
\text { fur- } \\
\text { nished }\end{array}$ & \\
\hline Jordan de Saukevill & 1 & 1 & Quit, Oxford. \\
\hline Henry Fitz Richard & 7 & 2 serg. & Quit, Dors. and Somers. \\
\hline Walter de Pavilly & 1 & 1 & Quit, Wilts. \\
\hline Matthew Wake & 1 & 2 serg. & Quit, Wilts. \\
\hline Robert de Saliceto & 1 & 2 serg. & owes $20 \mathrm{~s}, 1$ fee, Notts. and Derby. \\
\hline Roger de Sumery & 50 & 3 & Quit, Staff. \\
\hline Hugh le Poer & $21 / 2$ & 1 serg. & Quit, Heref. \\
\hline Thomas de Canvill & 3 & 1 & Quit, Essex and Hert. \\
\hline Ralph Pirot & 4 & $\begin{array}{l}1 \text { kn'ht } \\
2 \text { serg. }\end{array}$ & $\begin{array}{l}\text { Quit, Essex and Hert., Cant. and } \\
\text { Hunt. }\end{array}$ \\
\hline William de Nevill & $81 / 3$ & 1 & Quit, Wilts. \\
\hline Joslan de Nevill & 1 & $\mathbf{1}$ & Quit, Kent. \\
\hline Richard Luvel & 18 & 1 & Quit, Dors. and Som. \\
\hline Norman de Arescy & 20 & 1 & Quit, Linc. \\
\hline Robert de Pinkney & 17 & $\begin{array}{l}1 \text { kn'ht } \\
2 \text { serg. }\end{array}$ & $\begin{array}{l}\text { Quit, Essex and Hert., Bucks and } \\
\text { Bedf. }\end{array}$ \\
\hline Michael de Columbar & $r^{\prime} 1$ & 1 & Quit, Hants. \\
\hline John de Heriz & 4 & 1 & Quit, Notts. and Derby. \\
\hline Nigel de Amundevill & $31 / 3$ & 1 & Quit, Cant. and Hunt. \\
\hline Baldwin de Rivera & 5 & 1 & Quit, Essex and Hert. \\
\hline Henry de Oilli & $321 / 3$ & 7 serg. & Quit, Oxford. \\
\hline Albreda des Boterels & $81 / 3$ & 1 & Quit, Wilts. \\
\hline Robert de Pavilly & 4 & 2 serg. & Quit, Notts. and Derby. \\
\hline
\end{tabular}

The number of knights furnished is given in Scutage Rolls, no. 2. The number of knights owed and the fact that each tenant is quit 
The lack of money in the treasury is shown by the means employed to raise the sums necessary for such a campaign as this. In August the justiciar of Ireland was to forward at once all the money possible. ${ }^{89}$ The farms of towns on the Welsh frontier which were not due till September were ordered on August 1 to be paid immediately. ${ }^{90}$ The aid granted by the prelates in April had not been entirely paid, but all that had been received was sent to the king $;^{91}$ in August Henry III wrote to each of the prelates, asking that the part in arrears be paid without delay and complaining bitterly that this was the third time he had been obliged to write about it. ${ }^{92}$

The rate of scutage was reduced to twenty shillings though the campaign had lasted two months. This reduction was probably due to the high rates of the preceding years, and is an indication that the tenants exercised a certain control over the scutage. The levy was put in charge on September 6, before the close of the campaign..$^{93}$ It amounted to $£ 1,54714 \mathrm{~s} 11 \mathrm{~d}$, of which 1828 2s $7 \mathrm{~d}$ were paid in 1232 and $1233 .{ }^{94}$ It was

of scutage are taken from the Pipe Roll, 16 Henry III. I am not certain that in each case $I$ have the total number of fees held by each tenant, but each held at least as many as given here.

89 Close Rolls, I, 599.

90 Ibid., 538.

91 Ibid., 544.

92 Ibid., 598. In July, the king was trying to borrow 1,200 marks (Pat. Rolls, II, 440).

93 On September 6, writs de scutagio habendo were issued to tenants (Scutage Rolls, no. 2) and this is probably the date when the scutage was ordered.

94 The account appears in the Pipe Roll of 16 Henry III, as follows :

Scutage at $20 \mathrm{~s}$

Clerical tenants . . . . . . 641060

Thirty-two lay tenants (each 5 or more fees) $604 \quad 17 \quad-4$

Other lay tenants (each fewer than 5 fees, etc.) $301 \quad 11 \quad 7$

Total . . . . . . . . $1547 \quad 14 \quad 11$

Paid, 16 and 17 Henry III . . . . $828 \quad 27$ 


\section{STUDIES IN TAXATION}

the composition for service; no fines are recorded. Those who served did not pay scutage. They received writs de scutagio habendo ${ }^{95}$ and if necessary, the sheriff assisted the tenant in chief with distraint. ${ }^{98}$ The tenant in chief who compounded was also allowed to collect scutage from his tenants in order to respond at the exchequer. ${ }^{97}$ Thus the tax fell back on the rear-vassal. An interesting feature of this levy is that in several counties those jurati ad arma who held of the king and did not take part in the campaign were fined, the assessment being made by the sheriff and another official appointed by the king. ${ }^{93}$ Some of the towns which were summoned to send men to the army fined to escape service, but the amounts paid were merely nominal. ${ }^{99}$

The tenant was still liable to be distrained for his scutage by the sheriff. The amount for which he was responsible was determined by the number of fees for which he customarily paid. Additional fees created by him were not bound to contribute to the royal exchequer. Further, if the sheriff distrained for payment, he distrained the goods of the tenant in chief, not those of the rear-vassal. Thus the sheriffs were ordered to distrain for the scutage of Elveyn, but only for as many fees as

Of the sum charged against lay tenants, each fewer than 5 fees, etc, $£ 120$ were against tenants on the honors of Boulogne, Peverel, Lancaster, and Brittany. This leares about $£ 180$ against the lesser tenants in chief, or 180 fees. Of the total amount recorded as paid, $£ 52719 \mathrm{~s} 4 \mathrm{~d}$ were paid by the clergy.

95 Scutage Rolls, No. 2.

96 Thomas, earl of Warwick, for the army of Elveyn, "in quo habuit milites suos per preceptum regis" (Close Rolls, I, 570).

97 "R. Sarresbiriensis episcopus habet literas regis quod per manum suam colligat scutagium regi debitum etc. pro exercitu de Elvein ad respondendum regi in octav' S. Andree anno etc. xvi" (Fine Roll, 16 Henry III, m. 7); other similar entries on this roll.

98 Close Rolls, I, 561, 597.

99 Derby, £4; Merleberg, 5m; Nottingham, 10m (ibid., I, 542, 545,548 ). 


\section{UNDER JOHN AND HENRY III}

a tenant "is held to respond at the exchequer" and to distrain only those tenants who held of the king in chief. ${ }^{100}$ Two men were charged with scutage in Wittshire, but it appeared that they held of Robert de Mandevill, not of the king, and the roll states that Robert ought to acquit them. ${ }^{101}$

\section{The Fortieth, 1232}

In 1232, the king asked for an aid to pay his debts occasioned by the campaign in Gascony. ${ }^{102} \mathrm{He}$ was really short of money. At the beginning of the year, Peter, count of Brittany, had arrived in England and asked for aid. On March 10, Henry agreed to pay him 3,000 marks and as security deposited his plate and jewels with the Templars. ${ }^{103} \mathrm{He}$ also borrowed of Florentine and Sienese money lenders, 2,420 marks, promising to repay the loan at Michaelmas; failing to keep his word, he was to pay interest at ten per cent. per month. ${ }^{104}$ The debt to Count Peter was paid in the summer, but in September, the king agreed to pay him 6,000 marks more at Michael-

100 "Mandatum est vicecomiti Cornubiæ quod, occasione præcepti regis, quod ei fecit de districcione facienda pro scutagio exercitus de Elvein, nullum distringat nisi pro tot feodis quot regi tenetur respondere ad scaccarium, et pro eodem scutagio non distringat, nisi tantum eos qui de rege tenent in capite." The same order was issued to other sheriffs (Close Rolls, II, 10).

101 "Anno regis Henrici, filii regis Johannis, in residuo de Wiltesira, post Devonesiram, Robertus Maudut, dimidiam marcam de tertia parte 1 feodi de scutagio de Elevein. Willelmus Comin, dimidiam marcam de tertia parte 1 feodi de eodem scutagio. Sed Robertus de Mandeville debet eos acquietare, quia Robertus Maudut debet tenere feodum illud de eodem Roberto de Mandeville.... et Willelmus Comin debet tenere feodum illud de eodem Roberto de Mandeville" (Red Book, II, 770; Pipe Roll, 16 Henry III, m. 6 d). 102 Wend., IV, 233-234; "pro debitis, quibus comiti Britanniæ tenebatur astrictus" (ibid., 249); see above, p. 181.

103 Pat. Rolls, II, 465, 490.

104 Ibid., 514, 515. 


\section{STUDIES IN TAXATION}

mas. ${ }^{105}$ About this time the Jews paid a tallage of 10,000 marks. ${ }^{106}$

There were two or three meetings of the council to consider this aid. On March \%, the magnates assembled in response to a general summons, but for some reason many ecclesiastics were absent. The king asked for the aid and the earl of Chester replied for the lay tenants that they had personally served with the king in France and hence did not legally owe him any aid. With the king's permission, the laity then withdrew. The clergy who were present asked for a delay because many were absent. So the council was prorogued till after Easter. ${ }^{107}$ A second meeting of the earls and barons was held at London after that festival, but it is not known what was done. ${ }^{108}$ In September, a council composed of the prelates, the earls, and the barons granted an aid of a fortieth of personal property. If the lesser tenants in chief were present at any of these councils, they were included in the term barones, for they were not separately mentioned as forming part of the council. ${ }^{109}$

105 Pat. Rolls, II, 490, 501.

106 Cal. Pat. Rolls, I, 12-13, March, 1233.

107 Wend., above.

108 "Comites et barones qui de mandato regis convenerunt apud London a die Paschæ in tres septimanas" (Pat. Rolls, II, 473).

109 "de communi consilio et unanimi assensu omnium magnatum de regno nostro, tam episcoporum, quam comitum, baronum, abbatum et priorum, concessum fuit" (Close Rolls, II, 311); Shirley, I, 415; "episcopi et alii ecclesiarum prælati cum proceribus regni" (Wend., IV, 249); Theok., p. 87; Dunst., p. 131; Gerv. Cant., II, 129; Osney, pp. 73-74; Wykes, pp. 72, 74. Notices which include more classes than those given here are merely descriptions of the taxpayers, that is, of an ideal council, not of the actual members of the council; thus the writ of collection says that the tax was granted by the "archiepiscopi, episcopi, abbates, priores, et clerici terras habentes qui ad ecclesias suas non pertinent, comites, barones, milites, liberi homines et villani de regno nostro" (Select Charters, p. 360; Wend., IV, 254). The description given in Waverley, p. 310 , is probably taken from the writ. Stubbs (Select Charters, p. 360) says that if the words 


\section{UNDER JOHN AND HENRY III}

The levy was paid by the following men:

1. All laymen holding of lay tenants or of the king down to and including villeins. The royal demesne was included, though there was no special reference to it in the writ. As the fortieth was assessed on the men of Pevensey, Hastings, and Rye, it is evident that no exemption was intended for the king's lands. ${ }^{110} \mathrm{~A}$ reference to some boroughs might perhaps be taken to mean that they were excepted. The assessors were ordered not to demand the fortieth from the burgesses of Grimsby in Lincolnshire, and Scarborough in Yorkshire, except on those chattels which they held outside their boroughs. ${ }^{111}$ But this meant probably that the assessment would be made in the borough by special officials, or that the borough might fine in a lump sum for its tax. In 1225 there were somewhat similar cases. London merchants having goods in other counties were allowed to pay the fifteenth on those goods when the fifteenth of London was collected. ${ }^{112}$

\section{All churchmen except the beneficed clergy who}

of the writ "are to be understood literally, the freeholders and villeins must have been consulted in the shire moots, or else the lords must have been supposed to represent their own villein-tenants in the 'Commune Consilium.'" Aside from this expression in the writ, there is nothing to suggest that the first alternative is true. An expression in the king's letter to the abbot of Coggeshal describing the grant of the fortieth suggests that it was understood that the lords represented their tenants. The king states "concessum fuit nobis ab ipsis (the magnates) auxilium, scilicet, quadragesima pars omnium mobilium suorum et aliorum de regno nostro" (Close Rolls, II, 311). The expression "suorum et aliorum" means the goods of the tenants in chief and those of their men; $c f$. for a similar use of these pronouns, and in this sense exactly, the writ to tenants to assist in ploughing the king's demesne: "faciatis auxilium de carucis vestris et aliis, ad terras nostras . . excolendas" (Pat. Rolls, I, 323).

110 Close Rolls, II, 297.

111 Ibid., 307, 311.

112 Rot. Litt. Claus., II, 26a. 


\section{STUDIES IN TAXATION}

were specially exempted in the writ. ${ }^{113}$ With this exception, the tax was demanded not merely of the churchmen who were military tenants, but also of all sorts of religious houses and orders. Those who wished to escape assessment of their property had to get a writ to that effect from the king. The order of Sempringham obtained such a writ $;^{114}$ as also the brothers of St. Lazarus for their own property, though the goods of their men were assessed. ${ }^{115}$ The opposition of the Hospitallers, Templars, and Cistercians resulted in a delay in assessment. ${ }^{116}$ Most of these orders probably paid a lump sum as a fine for their fortieth, with the possible exception of the Cistercians who may have paid nothing in the end. While the tax was being collected, the king wrote to the Cistercian abbot of Coggeshal saying he had never heard that the Cistercians should be exempt from this sort of a general subsidy and begging him to make an aid as others were doing, even if it were not a fortieth. ${ }^{117}$

There was an effort in the writ to make a clearer statement of the goods to be assessed. Instead of enumerating those excepted, the writ named the kinds of property to be taxed, grain, plows, oxen, sheep, hogs, and work horses. ${ }^{118}$ Nevertheless there were complaints that the

113 Select Charters, p. 360; Close Rolls, II, 155.

114 Close Rolls, II, 292.

115 Ibid., pp. 290, 291, 295, 303; III, 114. Similar cases are giren in these references.

116 Ibid., II, 284, 285, 292, 293, 294, 300. The Hospitallers paid 300m: "prior Hospital' S. Johannis Jerosolim' in Anglia r c de CCC marc. pro quadragesima mobilium suorum et hominum suorum; in thesauro liberavit et quietus est" (Pipe Roll, 18 Henry III, Lond. and Midd., m. 7) ; the Templars paid $300 \mathrm{~m}$ and the order of Sempringham $£ 100$ (Fine Roll, 17 Henry III, m. 6, 9).

117 "Rogamus attentius quatinus, etsi non nomine quadragesimæ subsidium consimile aliis de regno nostro nobis duxeritis impendendum, ad tale et tam efficax auxilium nobis faciendum de bonis vestris manum nobis porrigere velitis" (Close Rolls, II, 311).

118 Select Charters, above; Osney, p. 73; for a part of a roll of 


\section{UNDER JOHN AND HENRY III}

justices assessed goods not liable and orders were issued to them to note carefully the taxable property described. ${ }^{119}$ The method of assessment differed somewhat from that employed in 1225. To each county was sent by the king a certain number of men called assessors and collectors. Sometimes they went through the county in pairs. The number varied: in most of the counties there were four; in several there were two; in Lincolnshire and Norfolk, there were six; in Yorkshire, eleven; in Suffolk, eight. ${ }^{120}$ Before these collectors the sheriff summoned the men of the vill at certain places on certain dates. Four of the vill were chosen, who with the reeve in the presence of the royal commissioners swore to the value of each man's chattels in the vill, except their own, which were appraised in the same way by two other men of the vill. ${ }^{121} \mathrm{~A}$ roll of the vill was drawn up, in which was stated the barony or liberty to which each man belonged. As soon as the assessment was completed, a copy of the roll was sent to the exchequer. The manner of collection differed also. Those men having part of their baronies or a liberty in the vill were allowed to collect the fortieth, but they paid the money to the royal commissioners, not to the exchequer. ${ }^{122}$ If they did not collect it, the sheriff was to dis-

assessment, see Niemeyer, "An Assessment for the Fortieth of 1232," in $E . H . R .$, XXIV, 733-735.

119 Close Rolls, II, 288, 290, 291. To the assessors in Suffolk, "diligentius inspicientes verba brevis eis directi de prædicta quadragesima assidenda et colligenda."

120 Ibid., 156-160.

121 That the men of the township and not merely the four chosen men came before the commissioners is shown by two facts: the order states "mandavimus vicecomiti ... quod singulas villatas comitatus sui certis diebus et locis . . . ad mandatum nostrum coram vobis venire faciat" (Select Charters, above); the manner of assessment of the goods of the four chosen men indicates the presence of the other men of the vill.

122 This was the provision made in the writ of collection; $c f$. the order to these men in Yorkshire (Close Rolls, II, 299). 
train those who were assessed to pay it to the collectors. The money was deposited in a safe place, such as a castle, sealed with the seals of the sheriff and the collectors, till it was later forwarded to London. ${ }^{123}$ The sheriff cared for the transportation. ${ }^{124}$ The roll of receipts was forwarded as soon as the money was collected. ${ }^{125}$ No one was to be assessed unless he had at least forty pence worth of property. The writs of collection were sent out September 28 and the assessment began in October. ${ }^{128}$

Some men were not compelled to submit to assessment and collection by royal officials. Several churchmen obtained writs of exemption. The Hospitallers assessed their property by their own men and a number of bishops and heads of religious houses did likewise-the bishops of Ely, Hereford, Durham, Worcester, the abbots of Reading, Ramsey, and St. Mary's of York, and the prior of Wenlac. ${ }^{127}$ A lay tenant also might obtain this privilege. ${ }^{128}$ A powerful baron seems to have been able to prevent the assessors from taxing his men. In March, 1235, the assessors in Yorkshire were ordered to assess and collect the fortieth on the lands of W., earl of Albemarle, John, earl of Lincoln, and Richard de Percy, and the king requested these tenants to allow this to be done. ${ }^{129}$ This order was issued over two years after the tax had been granted. Richard refused and the tax was not assessed on his men till September, 1236, when he per-

123 Close Rolls, II, 255, 300; Cal. Pat. Rolls, I, 33, 42, 45.

124 Cal. Pat. Rolls, I, 33, 37, 42, 45, 60.

125 Close Rolls, II, 295.

126 Ibid., 156.

127 Ibid., II, 160, 283, 285, 287, 288, 290, 294, 301. Such tenants might be allowed also to pay the tax to the king direct, not to the county assessors; the bishop of Ely was permitted to do this (Close Rolls, II, 301, 302). Thus the royal officials would be kept entirely off their lands.

128 Ibid., 295, Richard Marshal.

129 Cal. Pat. Rolls, I, 124. 


\section{UNDER JOHN AND HENRY III}

mitted it to be done. ${ }^{130}$ Distraint was however employed to compel payment. ${ }^{131}$ The greater part of the tax was turned in during 1233 and $1234 .^{132}$ But some accounts were unpaid for a long time. ${ }^{133}$ The total amount received was $£ 16,475$ os $9 \mathrm{~d},{ }^{134}$ a much less proportionate yield than was received from the fifteenth. There is no record that the money was placed in the care of special officials or held as a special fund, as was the case with the previous tax on moveables.

Certain points of difference between the fifteenth and the fortieth may be noticed. Some of the changes in the assessment of the latter were evidently the result of the experience gained in 1225. The change in the description of the goods to be taxed is a case in point, as it was an attempt to word the writ more clearly. The goods taxed were in both cases the same. The provision in 1232 that no one was to be taxed who had not at least forty pence worth of property was introduced undoubtedly because of complaints of the poor in 1225, when the king issued a special order not to $\operatorname{tax}$ them. ${ }^{135}$ The machinery of assessment was simplified: the elected knights of the county were dropped and for the individual oaths of the men of the vill was substituted the assessment by the reeve and four men. The interests of the tenants in chief were protected in a different way: in 1225, though the tax was collected by the reeve and four men, the bailiffs swore to the value of their lords' chattels; in 1232, the men of the vill assessed all the goods, but the

130 Cal. Pat. Rolls, I, 159; a similar case of failure to collect on account of the opposition of the tenant (Close Rolls, III, 184).

131 Madox, II, 193, n. $z$; Close Rolls, III, 404.

132 Most of the notices of payment are in those years (Cal. Pat. Rolls, I).

133 Madox, abore, from 27 Henry III.

134 Red Book, III, 1064.

135 Pat. Rolls, I, 572. 


\section{STUDIES IN TAXATION}

bailiffs were allowed to collect the tax on their lords' lands. The sheriff remained subordinate to the collectors.

The campaign against Richard Marshal in 1233 was waged partly with the aid of tenants in chief and partly by mercenaries. ${ }^{136}$ No scutage was levied. Fines were however assessed on tenants for failure to perform service and for having their scutage. Some of these fines were paid, but many stand in the roll either unpaid or pardoned. Important tenants paid fines, ${ }^{137}$ but probably these payments were made early in the campaign and when it was known that no scutage would be taken, they were stopped. ${ }^{138}$ That in the end a scutage was not levied indicates that the king recognized the necessity of consulting the tenants in chief before declaring a scutage which he was unable to levy at will. He took measures to protect against loss a tenant who fined and who might not be able to recoup himself by taking a scutage from his men. The bishop of Lincoln made a fine of $£ 110$. If the scutage did not run, the king promised him letters to his men to make him a reasonable aid to pay his fine. This also shows that the scutage fell

136 The tenants were summoned to meet in August and again on November 2 (Wend., IV, 271, 277; Cal. Pat. Rolls, I, 22, 24); on mercenaries (Wend., IV, 269, 272, 279, 280; Dunst., p. 136).

137 Madox, I, 617, n. e; 661, n. $l$; Excerpta, I, 251; Close Rolls, III, 116, 117, 129; Pipe Roll, 18 Henry III, passim, under the title "Nova Oblata." The bishop of London fined in $60 \mathrm{~m} ; 40 \mathrm{~m}$ were pardoned and he paid $20 \mathrm{~m}$. The abbot of Abingdon fined in $100 \mathrm{~m}$, of which he paid $50 \mathrm{~m}$; the bishop of Bath fined in $£ 90$, of which he paid $£ 45$ and was pardoned $£ 45$; the abbot of Ramsey fined in $20 \mathrm{~m}$ and paid it; the abbot of Tavistock, in $25 \mathrm{~m}$ and paid it (Pipe Roll, 18 Henry III, m. 7,9 d, 13 d, 14, 15 d).

138 The occasional introduction of the clause, if scutage run, shows that the king began to collect the fines before the close of the campaign. By the fine the tenant escaped service and had his scutage from his tenants, although the latter provision is not always introduced. 
back on the rear-vassal, a fact which is further illustrated by the pardons for scutage which it was expected might be issued to sub-tenants. If the rear-vassal was pardoned his scutage, the amount due from him was deducted from his lord's fine. ${ }^{139}$ The pardoning and non-collection of fines when scutage did not run indicate that the fine and scutage were identical in character, the commutation of service.

From 1232 to 1235 no general aid was granted to the king. In 1234, he levied a tallage. ${ }^{140}$ It was taken in the customary way. Towns and boroughs compounded for it. The assessment was made in each county by a committee of royal officials; one of these was sometimes the sheriff; royal judges also were used in this work. ${ }^{141}$ Sometimes the fine which a town offered for its tallage

139 Madox, I, 617, n. e; "W. Wigorn' episcopus r c de C li. de fine pro eodem, ita quod in fine allocabuntur ei feoda illa que de eo tenentur et sunt in manu regis et similiter feoda illorum qui de illo tenent et quorum scutagia rex eis perdonabit vel pro habendo auxilio illorum feodorum si scutagium non assideatur. In thesauro nichil et in perdonis ipsi episcopo $\mathrm{C}$ li. per breve regis et quietus est" (Pipe Roll, above, m. 10 d); “J. Bathon' episcopus $\mathrm{r} c$ de quater $x \mathbf{x}$ et $x$ libris ut sit quietus de militibus mittendis ad exercitum regis contra $R$. marescallum et pro habendo scutagio suo ejusdem exercitus de feodis militum que de rege tenet in capite ita quod si rex aliquid de scutagio illo perdonaverit alicui allocabitur ei in fine predicto sicut continetur in originali" (ibid., m. $13 \mathrm{~d}$ ).

140 Wykes, p. 77; Osney, p. 77; Cal. Pat. Rolls, I, 36; Pipe Roll, 18 Henry III; Madox, I, 707, n. $k$; 743, n. $p, q$.

141 Thus the sheriff is mentioned as one of the tallagers in York, Notts. and Derby, Hants, Northamp., Linc., Oxford, Bucks and Bedf. (Pipe Roll, 18 Henry III) (in some of these cases it is the undersheriff who is mentioned). In Northampton, the tallage was laid by the sheriff, John de Ulecot and Robert de Salceto. John acted as a judge in 1235 (Cal. Pat. Rolls, I, 127); Robert was a justice in eyre in 1234 (ibid., 77). In Notts. and Derby one of the tallagers was William Basset; one of the justices in eyre in those counties in 1232 was a William Basset (Close Rolls, II, 136). 


\section{STUDIES IN TAXATION}

was raised by the king ${ }^{142}$ in several cases the tallage laid by the justices was reduced. ${ }^{1+3}$

\section{The Aid of 1235}

In the spring of 1235, when Isabella, John's second daughter, was married to Frederick II, Henry III promised her a dowry of 30,000 marks. As she was not the king's eldest daughter, the feudal aid was not legally due. ${ }^{144}$ To help raise this sum, the great council was summoned and it granted an aid in the form of a scutage at two marks per fee. ${ }^{145}$ This council was composed of the lay and clerical tenants in chief. ${ }^{148}$ Though the eccle-

142 The burgesses of Oxford offered $100 \mathrm{~m}$, but the king refused to accept less than $£ 100$ (Madox, I, 743, n. $p$ ). The burgesses paid $100 \mathrm{~m}$ and the king gave them the other $50 \mathrm{~m}$ "ad villam suam claudendam" (Pipe Roll, 18 Henry III, Oxf., m. 3).

${ }_{143}$ Close Rolls, II, 389, 391, 393, 396, 401, 407. Some towns responded for their tallage to the sheriff; others responded directly to the exchequer, e.g. Southampton (ibid., 459). The amount of the tallage charged in 21 counties in the Pipe Rolls of 18 and 19 Henry III is about 2,200 marks. London does not appear in the rolls of these years as tallaged.

144 "casus in quibus licet dominis auxilia . . . exigere ab hominibus suis, . . si primogenitam filiam suam maritaverit" (Glanvill, lib. ix, cap. 8, in Select Charters, p. 163); Magna Carta, cap. 12. Cf. however the testament of Elzear, seigneur of Uzès, of 1254: remission of all "tallias ... preterquam in iv casibus, scilicet . . vel maritare filiam vel sororem suam" (Hist. Languedoc, VIII, No. 400, col. 1330, in $\mathrm{H}$. See, Classes rurales, p. 485 , note); here it is not restricted to the eldest daughter. (For this reference, I am indebted to Professor Adams.) No aid had been levied when Joanna, John's eldest daughter, had been married to the king of Scotland in 1219; a tallage had been levied on the Jews (Receipt Roll, Auditor's, no. 1, 5 Henry III).

145 It is called "auxilium" and "scutagium" in the writs (Select Charters, p. 364; Close Rolls, III, 186, 189); also, "generale scutagium" (Dunst., p. 142) ; "tallagium" (Theok., p. 97) ; "carucagium" (Matthew Paris, III, 327); "scutagium retus et novum" (Burton, p. 364).

146 "archiepiscopi, episcopi, abbates, priores, comites, barones, et omnes alii de regno nostro Angliæ qui de nobis tenent in capite spontanea voluntate sua et sine consuetudine concesserunt"; "comites, 


\section{UNDER JOHN AND HENRY III}

siastics met probably at the same time as the lay barons, ${ }^{147}$ they seem to have dealt separately with the king. They had a different method of collection and they received letters patent promising that their grant should not form a precedent for future levies. ${ }^{148}$ This then was a general tax on knights' fees and was taken by the authority of the great council. Theoretically, however, each tenant made the grant for his own fees. ${ }^{149}$

The levy was as follows:

1. A scutage at two marks on all fees of laymen, half to be paid at Michaelmas, 1235, and the other half at the following Easter. The writs for collection were issued July 1\%. ${ }^{150}$ Special machinery was employed. Two knights were chosen in each county to receive the tax which was collected by the bailiffs of the tenants in chief. $^{151}$ If the barons were unwilling or unable to force

barones et omnes alii de toto regno nostro" (Close Rolls, III, 186, 189); "per commune consilium regni concessæ" (Madox, I, 593, n. $d$ ). It cannot be concluded from this that all the tenants in chief, particularly the lesser tenants, were present. This is a list of the men who in theory compose the great council.

147 The writs of collection for both classes were sent out at about the same time; for the clergy, July 10; for the laity, July 17 (Close Rolls, above).

148 Ibid.; Madox, I, 607, n. b; Cal. Pat. Rolls, I, 145.

149 Thus the council is composed of all the tenants in chief. Cf. the writ to the barons of the exchequer concerning the aid due from the fee of a tenant: "pro auxilio quod idem Nicholaus regi concessit ad Isabellam sororem regis . . maritandam" (Excerpta, I, 438).

150 Select Charters, above; Close Rolls, III, $189 \mathrm{ff}$. The first half was not all paid at Michaelmas and orders were issued to the collectors to pay it in some counties on the morrow of Martinmas (November 12) and in others on the morrow of St. Andrew (December 1) (Fine Roll, 19 Henry III, part 1, m. 1). This was not carried out and the half was ordered paid on February 12, 1236 (ibid., 20 Henry III, m. 14). Some still remained due (ibid., m. 13).

151 Select Charters, above; Close Rolls, above. In Yorkshire and Lincolnshire, there were six each. A roll of the receipts was drawn up by the collectors and sent to the exchequer. It contained the names of the tenants, the amounts paid by each, and the names of 


\section{STUDIES IN TAXATION}

their tenants to pay the aid, the sheriff distrained the latter to pay it to the collectors. ${ }^{152} \mathrm{~A}$ point of some importance, showing that the sheriff did not customarily collect from the rear-vassal, is that tenants often paid the whole sum due from them to the sheriff of the county where lay the bulk of their fees. They were evidently following the usual practice. ${ }^{153}$

2. A scutage at the same rate on the clerical tenants in chief. Each prelate collected and paid it at the exchequer. The sheriff aided with distraint, if necessary. ${ }^{154}$ Some of the clerical tenants made a fine for their aid which was larger than the aid itself would have been. ${ }^{155}$ The fine was doubtless for the lands which they did not hold by military tenure and was taken because

the persons who gave the money to the collectors: "Rotulus collectorum auxilii in comitatu Wiltes'; de Ela comitissa Sar' xlii li. iiii den. per manum Petri de Salceto, etc." (Subsidies, Bundle 196, no. 2). In this roll of Wilts, there are 32 names. The persons who give the money to the collectors (per manum, etc.) are different for each tenant; they are probably the bailiffs as the writs of collection provided. Twice they are described: "De Johanne de Balun xiii sol. iiii den. per Willelmum prepositum; de Reginaldo de Moun xiii sol. iiii den. per Johannem hominem suum." Twice the tenant is said to give the money himself to the collectors. Thus the sheriff did not collect the aid.

152 Close Rolls, III, 329-330; "et si predicti senescalli non possint illos distringere qui auxilium illud deberent dominis suis ipse (the sheriff) eos sine dilatione distringat ad predictum auxilium predictis militibus solvendum ad opus regis" (Fine Roll, 20 Henry III, m. 14); Madox, II, 192, n. $w$; 193, n. $z$.

153 Thus men holding in Gloucestershire paid in other counties where they had more fees (Bristol and Gloucester Archoological Society Transactions, XIII, 309).

154 Rotulorum Originalium in Curia Scaccarii Abbreviatio, Record Com., p. 1, for the bishop of Winchester.

155 "E. archiepiscopus Cantuar' r c de CCC marcis de auxilio concesso ad maritagium imperatori sororis regis, viz., de $\mathrm{C}$ marcis ultra omnia feoda sua que non debet sicut continetur in rotulo" (Testa, p. 218b); the abbot of St. Albans fined in 50 marks and had his scutage (Fine Roll, 20 Henry III, m. I1). 


\section{UNDER JOHN AND HENRY III}

the king levied a donum upon those religious houses which did not hold by knights' service. All tenants, clerical and lay, were to pay on both the old and new enfeoffment. ${ }^{156}$

The amount realized from the new basis of assessment did not meet the expectations of the exchequer. It was believed that many fees were escaping taxation. ${ }^{157}$ Measures were taken to prevent this loss to the treasury. In May, 1236, the sheriffs were ordered to report to the exchequer the number of fees held in each vill by the lesser tenants; the prelates and the greater lay tenants were to make similar reports by vills of all their fees and those who held them. All land held by military service was to be included. ${ }^{158}$ An inquest may have been held by the sheriff to enable him to make out his report, but no orders to this effect exist. The sheriff of Lancashire reported the number of fees of the honor without holding an inquest, and, in order to be sure that no mistake had

156 Madox, I, 607, n. b; Cal. Pat. Rolls, I, 145; Close Rolls, III, 186, 189; "generale scutagium ... non solum de feodis habitis in capite de rege, sed etiam de aliis cultis" (Dunst., p. 142); "scutagium vetus et novum" (Burton, p. 364). Round, Commune of London, p. 275, suggests that the aid of 1235 may have been assessed on the returns of the inquests of 1212: "in the case of Middlesex, the returns of 1212 were made the basis for collecting the aid for the marriage of the king's sister, in 1235, the same personal names appearing in both lists." It should be observed not only that the same personal names appear in both lists, but that they appear in the same order. This is quite unusual and suggests that the inquest belongs to 1235, rather than to 1212 .

157 That the exchequer expected a large increase in the tax is indicated, apart from the fact of the inquests, by the statement, purporting to come from Stephen de Segrave "qui tunc temporis fuit exulatus, in abbatia de Leycestria latitans et moram faciens, asserebat et affirmabat, vetus scutagium ad xxxii milia scuta assummabatur et irrotulabatur; et ad tantumdem plene et plane potuit novum scutagium de novis terris assummari et inrotulari" (Burton, p. 364).

158 Farrer, Lanc. Inquests, pp. 143-144; Testa, p. 44. The terms, "old enfeoffment" and "new enfeoffment" are probably not used in the technical sense employed under Henry II. By them is meant all land held by military tenure. 


\section{STUDIES IN TAXATION}

been made, he sent a transcript of the royal writ to the keeper of the honor that the latter might report from his records. ${ }^{159}$ This effort to obtain detailed information was not successful. Some tenants apparently did not try to supply it. Arnold de Bosco held seven fees and a half of the earl of Leicester; it was not known in what vills. ${ }^{160}$ The abbot of St. Edmunds reported the number of his fees and the counties in which they lay, but "in what vills they lie and how much in each place, God knows."181 In 1248, the jury was employed to find out these facts in connection with this aid in the county of Hereford. ${ }^{162}$ The method of this inquest was like that of 1166 . Its aim was purely financial: to furnish the government with an exact account of the amount of land held by military tenure in order that the payment of the aid might be enforced.

3. A donum or auxilium of the clergy who did not hold by military service. ${ }^{163}$ This was not levied by the authority of the great council. In July, August, and September, the heads of these religious houses were summoned to meet the king or special officials at convenient places to discuss this aid. ${ }^{164} \mathrm{~A}$ roll of the contributors was drawn up and in this roll the clergy who held by

159 Farrer, p. 144.

160 Bristol and Gloucester Arch. Soc., XIII, 326.

161 Testa, p. 415.

162 Madox, I, 593, n. $d$.

163 Testa, pp. 23b, 38b, 73b; Madox, I, 593, n. e; Dunst., p. 142; Theok., p. 97; "de auxilio quod viri religiosi nobis per regnum nostrum concesserunt" (Close Rolls, III, 223, 211, 212, 221, 228).

164 Close Rolls, III, 187-188. All the houses did not comply with the summons and were later called together to meet officials of the king and make a contribution (Fine Roll, 19 Henry III, part 1, m. 1). The officials who sought the aid from them were the tallagers. The consent of the religious houses was individual and not corporate. The orders of Cistercians, Premonstratensians, and of Sempringham were exempt. 


\section{UNDER JOHN AND HENRY III}

military service often appear. ${ }^{165}$ The amounts raised by the donum were considerable. In Gloucestershire, it yielded $£ 1892 \mathrm{~s} 3 \mathrm{~d}$, almost as much as the scutage brought in (£210 \%s 5d). ${ }^{166}$ Property was not assessed; each house paid a lump sum. ${ }^{167}$

4. The sheriff was to report also the names of those tenants who held of the king by sergeanty and socage and in what vills their holdings lay and what service they rendered. Perhaps such tenants were expected to contribute also. ${ }^{168}$

5. A tallage was levied. ${ }^{169}$

165 Testa, above; "in rotulo de auxilio prelatorum" (Madox, I, 593, n. e).

166 Bristol, etc., XIII, 354, 355.

${ }_{167}$ Sir Henry Barkly thinks that this donum was very strictly exacted, for he says that the branches of five foreign houses contributed for the first time.

168 Farrer, p. 143; Bristol, etc., XIII, 355.

169 Theok., p. 97; "talliari fecimus dominica nostra per Angliam" (Close Rolls, III, 206); ibid., 206-316, passim; Madox, I, 735, notes; Pipe Roll, 19 Henry III. The tallage was assessed by committees of royal officials. The sheriff is mentioned as one of these committees in Hereford, Gloucester, Cumberland, Salop, Stafford, Norfolk and Suffolk (Pipe Roll, 19 Henry III). Royal judges also served: Thomas de Muleton was a tallager in Northumberland; he was an itinerant justice in 1235 (Bracton, Note Book, p. 141); Eudo de Beauchamp was one of the tallagers in Worcester and was a judge of assize in 1235 (Cal. Pat. Rolls, I, 108); R. de Lexinton was a justice in eyre in Somerset in November, 1235, and he ("et socios suos") was tallaging the demesne in Gloucester that year (Close Rolls, III, 209, 212). In Yorkshire and Lincolnshire, the tallagers were William Bretun and Roger de Essex (Fine Roll, 19 Henry III, part 1, m. 1); Roger de Essex was a king's escheator and a forest justice in 1236 (Close Rolls, III, 269, 344); William de Eboraco "et socii sui" tallaged Hants and Surrey (Fine Roll, above, m. 1); William was an itinerant justice in 1235 (Close Rolls, III, 111). The towns compounded in lump sums for their tallages. The amount charged in 30 counties was 3,400 marks. London paid 1,000 marks (Pipe Roll, 21 Henry III, m. 7). 


\section{STUDIES IN TAXATION}

The amount of the dowry was raised in some way. The last payment of 10,000 marks was made in June, 1237. ${ }^{170}$

\section{The Thirteth, 1237}

On January 13, 1237, the great council met at London $^{171}$ in response to a special summons. There was a large attendance; those present were the prelates, the earls, and the barons. If the lesser tenants in chief attended, they did not receive special mention as a separate class. ${ }^{172}$ The distinction made in the writ of collection between knights and barons may imply that the latter term when used alone included only the greater lay tenants. ${ }^{173}$

170 Cal. Pat. Rolls, I, 188; Rymer, I, 232.

171 Matthew Paris says that the council met January 13 (III, 380); the Close Roll gives January 20, octave of St. Hilary's day (III, 543). The council lasted several days (Matthew Paris says four) and the decision to make the grant may have been taken on the octave.

172 'Those summoned were: "archiepiscopis, episcopis, abbatibus, et prioribus installatis, comitibus, et baronibus" (Matthew Paris, III, $380)$; these met: "infinita nobilium multitudo, scilicet, regni totalis universitas" (ibid.); "convocato magno colloquio archiepiscoporum, episcoporum, abbatum et priorum, comitum et baronum, civium et burgensium et aliorum multorum" (Theok., p. 102); "tam a clero quam a populo" (Wykes, p. 83) ; Osney, p. 84.

173 Three descriptions of the tenants are given: the king states that those who assembled were: "archiepiscopi, episcopi, abbates, priores, comites et barones totius regni nostri et tractatum haberent nobiscum"; and then that "iidem archiepiscopi, episcopi, abbates, priores et clerici terras habentes que ad ecclesias suas non pertinent, comites, barones, milites et liberi homines pro se et suis villanis nobis concesserunt in auxilium tricesimam partem etc."'; and finally he confirms the charters to "archiepiscopis, episcopis, abbatibus, prioribus, comitibus, baronibus et vobis omnibus aliis de regno nostro" (Close Rolls, III, 543-545; Select Charters, pp. 366-368). The last phrase is also given, "et aliis magnatibus regni nostri" (Close Rolls, III, 546). The second description is that of the taxpayers; the other of the members of the council. The concluding phrases "vobis omnibus aliis de regno nostro," etc., do not seem to refer to a definite class at the council, but seem to be used vaguely to include all to whom 
The king asked for an aid of a thirtieth of moveables. His reasons for the request were that his officials had been dishonest in the management of his income and that the heavy expenses of his own marriage and that of his sister had depleted the treasury. ${ }^{174}$ All this was probably true. The dower of the empress was still in arrears.

The demand met with opposition at once. Considerable discussion ensued, but finally it was agreed to make the grant. The king was to admit three barons to his council and reconfirm the charters; a new sentence of excommunication was proclaimed against violators. No one was to pay unless he had more than forty pence worth of goods. That property was to be taxed which would be held on September 14, 1237, when the assessment was to begin. The dates of payment were half on December 1, 1237, and half on May 31, 1238. ${ }^{175}$ The clerical tenants in chief made a separate arrangement with the king, though they paid the same tax. The words of Matthew Paris in describing the grant suggest this, when he says that the archbishop of Canterbury with his bishops and clergy first agreed to a thirtieth. ${ }^{176}$ The clergy furthermore assessed and collected the tax on their own lands. ${ }^{177}$

the grant of the charters might apply. The reference to citizens and burgesses in the Tewkesbury chronicle probably refers merely to the presence of some Londoners. At any rate, it was of no importance as a precedent.

17 . Matthew Paris, III, 380-383.

175 Select Charters, above; Close Rolls, above. The original dates of a payment were not always enforced (Close Rolls, IV, 116, 117, 119, 130, 263). Sometimes a taxpayer obtained a postponement of the date of payment (ibid., pp. 115, 130). Besides the chroniclers cited above, the tax is noted by Dunst., p. 147; Wav., p. 317; Wint., p. 87; "vicesima," Wig., p. 428; Gerv. Cant., II, 130; Ann. Camb., p. 82.

176 "consientibus igitur primum archiepiscopo Cantuariensi cum suis episcopis et clero" (Matthew Paris, above).

177 See below, p. 217. 


\section{STUDIES IN TAXATION}

The persons who paid the thirtieth seem to have been the same as in the previous cases of taxes on personal property. ${ }^{178}$ The beneficed clergy were again exempt. ${ }^{178}$ Great foreign orders did not pay the tax as granted by the council. The abbot of Cluny made a separate grant of a thirtieth and received letters patent stating that it was a free gift and not owed and that it was not to form a precedent. ${ }^{180}$ The Cistercians, the Premonstratensians, the Templars, and the Hospitallers did not pay the thirtieth and may have paid nothing at all. ${ }^{181}$ Some religious houses had their property assessed, but were finally exempted. ${ }^{182}$ The royal demesne probably did not pay the thirtieth. ${ }^{183}$

The method of assessment did not vary materially from that employed in 1232. The king sent commissioners, four knights and a clerk, called assessors and collectors, to each county. ${ }^{18 *}$ The sheriff summoned the men of the vills to meet them and four men were chosen from each

178 See note 175 . The writ enumerates the same persons as in 1232. The wording is exactly the same except for the last phrase: in 1232, "liberi homines et villani"; in 1237, "liberi homines, pro se et suis villanis." The change is due to the desire to make a more careful statement. The same desire is shown by the fact that for the first time both the taxable and the exempt property is enumerated. The list of taxable goods is practically the same as in 1232 except that more discretion is given the assessors by the addition of the phrase, "et aliis pecoribus et bonis."

179 Select Charters, above.

180 Cal. Pat. Rolls, I, 205; Close Rolls, IV, 9.

181 Close Rolls, III, 567, 569; IV, 45, 67, 114, 119.

182 Ibid., III, 569, 570, 575; IV, 2, 8, 20, 29.

183 The reference to citizens and burgesses in the great council suggests that the demesne paid the thirtieth (Theok., p. 102), but in 18 counties, the assessors were directed not to assess the tax on the royal demesne (Close Rolls, III, 575 ; IV, 37, 115); in the following year the king levied a tallage, which he would hardly have done had the demesne just paid the thirtieth.

18* Except in Yorkshire and Lincolnshire. In the East and North Ridings of Yorkshire there were two knights and a clerk; in the 
vill to assess the tax. There does not seem to be any difference between this method of choosing the local assessors and that of $1232 .{ }^{185}$ These four men, in the presence of the county commissioners and of the bailiffs of the lords of the vill, if they wished to be present, were to swear to the number and value of the chattels of each man in the vill, except their own, which were to be assessed by four other men chosen in the same way. The valuation was to be reasonable. A roll of the vill was to be drawn up and after it had been approved by the commissioners, the four men of the vill were to collect the tax and pay it to the commissioners for deposit in a safe place (a castle, an abbey) till it was brought to London. ${ }^{186}$ The method of collection therefore differed from that of 1232 . The barons were not to collect. Their interests were safeguarded in another way, viz., by the presence of their bailiffs when the assessment was made. ${ }^{187}$ The county officials did not assess the property of the clergy. The same method was employed, but each prelate had charge of the assessment and made use of his own knights or freemen, who however needed a royal writ to undertake this work. ${ }^{188}$ After the money had been collected, it was delivered to the royal commissioners. Efforts were made to escape assessment. Tenants concealed their goods.

West Riding, four knights and a clerk. In each of the three parts of Lincolnshire, Lindes', Ketsteven, and Holland, there were four knights and a clerk (ibid., III, 546-554).

185 See above, p. 203.

${ }_{186}$ Close Rolls, III, 546-554; IV, 12, 111, 116, 118, 119, 388, 389; Cal. Pat. Rolls, I, 225. The sheriff was to provide transportation for the money. He was to distrain men to pay the tax to the county assessors: "et si indigeant auxilio tuo circa districtionem faciendam in collectione dicte pecunie, tu eis auxilium parabis" (Close Rolls, III, 545; IV, 116; Cal. Pat. Rolls, I, 231).

${ }^{187} \mathrm{~A}$ lay baron however might be allowed to collect from his men; e.g. Gilbert de Umfravill (Close Rolls, IV, 45).

188 Select Charters, p. 367; Close Rolls, III, 555, 557, 559; IV, 4, $15,18$. 


\section{STUDIES IN TAXATION}

Some juries of the vills were corrupted, assessing property at less than its real value. Whenever this fraud was discovered, the property was re-assessed by a new jury and the former jurors were punished for perjury. ${ }^{189}$

The amount received was $33,811 \mathrm{~m} 2 \mathrm{~s} 1 \mathrm{~d}^{190}$ The greater part of the tax was probably paid in 1238; most of the notices of payment are of that year, ${ }^{191}$ though there are references to payment years afterward. ${ }^{192}$ As in 1225 , the receipts were regarded as a special fund for use on extraordinary occasions. The king borrowed from this fund and promised to repay the loan from the ordinary income of the exchequer. ${ }^{193}$ Mention has been made of the three magnates who were to have been added to the king's council. According to Matthew Paris, the magnates in 1242 claimed that the king had promised to store the money in castles under the care of four magnates and to spend it only by the advice of the latter, but that none had been thus spent so far as they had heard. ${ }^{194}$ This was not the regulation which the same chronicler describes in 123\%. Yet Henry III had taken some measures to restrict his expenditure. On November $28,123 \%$, he declared that he would store the thirtieth in some safe place and spend none of it except by the advice of the legate, Otho. ${ }^{195}$ A part of the tax of Lincolnshire was left in 1242 and was still in the custody

189 Close Rolls, III, 569. An interesting entry is one concerning a man whose grain was destroyed after the assessment was made and his thirtieth was pardoned (ibid., IV, 15).

190 Red Book, III, 1064.

191 Cal. Pat. Rolls, I, passim.

192 Excerpta, I, 449, anno 1246; II, 279, anno 1258. Both of these cases refer to collectors who apparently had levied the tax but had not closed their accounts with the exchequer.

193 Cal. Pat. Rolls, I, 212.

194 Matthew Paris, IV, 186.

195 Cal. Pat. Rolls, I, 205. 


\section{UNDER JOHN AND HENRY III}

of the collectors, ${ }^{196}$ and a part was still at the Temple. ${ }^{197}$ Yet early in 1238, the king had succeeded in getting rid of 12,480 marks of this tax. A thousand pounds were lent to the prior of the Hospitallers to spend in the Holy Land. Five hundred pounds were sent as a gift to the Greek emperor. Six thousand marks were paid to Richard, earl of Cornwall, to advance his interests at Paris. ${ }^{198}$ Three thousand marks which Henry III promised to repay went to pay knights in Gascony. ${ }^{198}$ The rest went in gifts, loans, and expenses. An interesting feature of this levy is the king's promise that the aid should not form a precedent for future taxation. He had made such promises before, but only to the clergy; now the promise was made to the laity as well.

Another tax of 1237 was a tallage of 6,000 marks levied on the Jews; half was to be paid to the earl of Cornwall to supply him with money for a pilgrimage and half to the king. ${ }^{200}$ The magnates in Ireland had been asked in 1235 to grant an aid to the king similar to that paid in England that year. Up to the close of 1237, they had not complied with the request. They were now asked to make a further grant of a thirtieth, and some contributed. ${ }^{201}$

As has been said, the royal demesne does not seem to have paid the thirtieth, ${ }^{202}$ but in 1238 it paid the king a

198 The collectors of the thirtieth in that county were to deliver $\$ 453$ 10s of the thirtieth in their custody to the sheriff to bring to London (Cal. Pat. Rolls, I, 275, 277).

$1871,247 \mathrm{~m}$ 2s 101/2d (ibid., 281).

198 Ibid., 209, 217, 222.

199 Ibid., 212.

200 Ibid., 173, 178.

201 Ibid., 215; Close Rolls, III, 571-575.

202 There are orders not to assess or collect without the special order of the king the thirtieth on the demesne in eighteen counties (Close Rolls, III, 575; IV, 115); “Quia rex wult quod manerium de Bruges Walteri tallientur inter dominica regis, cum rex fecerit ea talliari, mandatum est assessoribus et collectoribus tricesime in 


\section{STUDIES IN TAXATION}

tallage, a levy which apparently took the place of the aid of the previous year. ${ }^{203}$ The demesne thus paid a tax to which the king was entitled by customary law, not one which he levied by virtue of a grant by the great council. Three years later, in 1241, another tallage was levied on the demesne. In twenty counties, the sum charged amounted to 4,240 marks. ${ }^{204}$ As usual towns fined for the levy. Sometimes the tax was assessed by the sheriff alone; sometimes special officials assessed it either alone or in conjunction with the sheriff. These officials were usually, perhaps always, royal judges. ${ }^{205}$ In the same year, a tallage of 20,000 marks was levied on the Jews. ${ }^{208}$ There was also an expedition against the Welsh, who how-

comitatu Sumers' quod nullam tricesimam in eodem manerio assideri vel colligi faciant" (ibid., IV, 16).

203 On October 18, 1238, the king granted the earl of Cornwall the right to tallage his demesnes "quia rex talliari facit civitates, burgos et alia dominica sua" (ibid., IV, 109). In 1236 and 1237, the bishoprics of Durham and of Norwich were void and were tallaged (Cal. Pat. Rolls, I, 158, 169, 173, 185, 190), but this was done before the thirtieth was collected and had nothing to do with the tallage on the demesne.

204 The accounts appear in the Pipe Rolls of 1241, 1242, and 1243. London is included; it fined in $£ 1,000$. For other references to this tallage, see Cal. Pat. Rolls, I, 275; Vincent, p. 61; Madox, I, 723, n. $c$; Liber Mem. de Bernewelle, p. 78; Matthew Paris, IV, 95; Close Rolls, IV, 281-339.

205 In Salop and Stafford, John Lestrange, the sheriff, was appointed to assess it (Cal. Pat. Rolls, I, 273; Pipe Roll, 26 Henry III, Salop). Henry de Bathonia and William de S. Edmundo were appointed to assess it in four counties (Cal. Pat. Rolls, I, 293); the first was a justice in eyre in Hants in January, 1241; the second was a justice in eyre in 1238 and was acting as a judge in December, 1240 (Close Rolls, IV, 58, 345; Cal. Pat. Rolls, I, 262). John Gumbaud and Richard Duket, justices in eyre in January, 1241, assessed the tallage in seven bailiwicks, probably always in conjunction with the sheriff (Cal. Pat. Rolls, I, 263; Pipe Roll, 26 Henry III, Cant. and Hunt., Bucks and Bedf., Norf. and Suff., York, Cumb., Northamp., and Northumb.).

206 Close Rolls, IV, 281, 312; Cal. Pat. Rolls, I, 247, 249; Madox, I, 224, notes. 


\section{UNDER JOHN AND HENRY III}

ever submitted without any fighting. ${ }^{207}$ Accordingly a scutage was not levied. We have already noted that many tenants no longer served with their full contingents and that the reduced service was considered to be the total service owed by the holding. An entry on the Close Roll of 1241 suggests that the practice had become so common that a roll had been drawn up stating the amount of the new servitium debitum, as it may properly be called. On July 25, Henry III wrote from Gloucester to his treasurer ordering him to examine the exchequer rolls and report to the king the amount of service owed by the tenants in chief as contained in a certain roll of that service. ${ }^{208}$

207 Matthew Paris, IV, 149-151; Theok., p. 120; Wint., p. 89; Wav., p. 328; Ann. Camb., p. 83; Brut., p. 329; Cal. Pat. Rolls, I, 254, 256, 257, 264; Close Rolls, IV, 326.

208 'Mandatum est W. de Haverhull', thesaurario regis, quod diligenter scrutatis rotulis de scaccario, significet regi quod et quantum servicium regi debetur ab archiepiscopis, episcopis, abbatibus, prioribus, comitibus, baronibus, militibus et servientibus, in quodam rotulo servicium illud continente. Hoc cum summa festinatione faciat et regi transmittat" (Close Rolls, IV, 360). 'The probability that the text gives the correct interpretation of this extract from the Close Roll is strengthened by the fact that we have such a roll of the new servitium debitum from the expedition to Wales of 1245 (see below, pp. 246, 247). 


\section{CHAPTER VII}

\section{The Taxes in Detail From 1242 to 1253}

$\mathrm{U}^{\mathrm{P}}$ to this time, there had been evident a disposition on the part of the barons to criticise the financial demands of the government and to make some efforts to unite in opposition to the king. These efforts had culminated in 1237 in the suggestion that there should be some baronial supervision of royal expenditure and in the king's promise that the thirtieth of that year should not form a precedent for future demands. But the opposition of the tenants in chief never reached the point where the king failed to have the tax granted.

Beginning in 1242, a further step was taken by the barons. They refused to grant aids to the king. The reasons which Henry III gave at that time and afterward to explain why taxes were necessary were the same that he had given before. In 1242, he wanted to raise money for the expedition to Gascony ; later, he needed it to pay his debts. But to these demands the barons turned a deaf ear. The cause for their refusal was twofold. They did not deny that the king was. in want of money, but they felt that this want was due to his own mismanagement of his income and that therefore such frequent taxes were unnecessary. At the same time, they feared that the king was establishing a right of arbitrary taxation, and on this account they demanded that the king allow them to supervise his expenditure and thus enable them to decide when taxes were necessary. The claim that Henry III should live of his own probably states in exaggerated form the belief of the barons that extraordinary 


\section{UNDER JOHN AND HENRY III}

levies should be demanded less frequently. The king's refusal to admit any control of his expenses was met by the barons' refusal to grant aids. That this refusal was effective is shown by the king's fruitless appeals to individuals, which now appear for the first time, and by his frequent summoning of the great council to persuade its members to make him a grant. Baronial control is illustrated in 1245 when the tenants refused to grant any aid other than the one which the feudal law gave the king, the aid to marry his daughter, and in the low rate which was fixed, twenty shillings per fee.

The taxes of the period therefore comprise only those levies to which Henry III was entitled by feudal law, with one possible exception, the donum from religious houses in 1248. There were two scutages, an aid to marry the king's daughter, three tallages, and three dona from religious bodies. Both the scutages were legal (in 1242 for Gascony and in 1246 for Wales). They were both accompanied by fines, but were not aids, that is, they were paid only by the tenants who had failed to perform their service. In the case of the levy of 1242, it will be noticed that the king tried to enlarge the number of fees which paid scutage. As far as the scutage of Gascony was concerned, the effort was in part at least unsuccessful and it certainly did not result in a permanent increase in the number of fees from which the king could collect scutage. ${ }^{1}$ The bishops in 1242 again renewed the claim successfully that they did not owe scutage for a campaign in Gascony; they made instead an aid at the same rate as the scutage. This seems to be a denial of military service overseas. There was an expedition to Scotland in 1244, but no scutage was taken, clearly because there was no fighting. Thus scutage could not

1 There is no change in the number of fces for which individual tenants account at the exchequer after 1242. 


\section{STUDIES IN TAXATION}

be levied at the will of the king. For the first time, the rate of scutage for a campaign in Wales was three marks, an increase which shows the king's lack of money. In this campaign, too, we see that the incomplete quotas with which tenants had long been serving were coming to be regarded as the servitium debitum of their holdings. It will be noticed that in 1245 the barons put a check on the efforts which the king had been making to increase the number of fees which should pay scutage. The writs of collection state that the aid was to be paid on the number of fees which paid customarily. With 1246, there began a barren period for the exchequer. The only levies till 1253 were two tallages on the demesne and one donum on religious bodies. It is noteworthy that the latter were now taxed for the first time when no aid or scutage was levied on other classes of the community.

\section{The Taxation of 1242}

On December 14, 1241, Henry III issued writs summoning the tenants in chief to meet at London on the January 27 following. ${ }^{2}$ January 8, 1242, he ordered the sheriffs of the maritime counties to provide ships at Portsmouth before April 13, ready to cross the seas with him. ${ }^{3}$ January 28, the great council met and was asked to grant the king an aid for the campaign in France, a demand which, in accordance with a previous agreement among themselves, the magnates refused. After some attempts, partly successful, to persuade the tenants singly

2 Close Rolls, IV, 428. The writ given is addressed to the archbishop of York; "eodem modo scribitur omnibus episcopis, abbatibus, comitibus et baronibus." The business is described as follows: "ad tractandum nobiscum una cum ceteris magnatibus nostris quos similiter fecimus convocari de arduis negociis nostris statum nostrum et tocius regni nostri specialiter tangentibus." See also Matthew Paris, IV, 180.

3 Close Rolls, IV, 429. 
to grant him money, the king dissolved the council. ${ }^{4} \mathrm{He}$ did not however give up his proposed expedition. Orders were immediately issued to collect money from religious bodies, ${ }^{5}$ and on February 8, the military tenants were summoned to meet at Winchester on April 27. ${ }^{\circ}$ They were reluctant to serve, but some met and on May 9, the king sailed for France with eight earls and 300 knights. ${ }^{7}$ He had no intention of carrying on the campaign with this force alone. Those tenants who had failed to answer the summons were distrained to appear at London on July 15 and cross to Gascony. ${ }^{8}$ As soon as the king arrived in France, he wrote urgently for 200 knights, 100 sergeants, 500 good Welshmen, and money. Fines were to be remitted and money paid to knights if they would come to his aid. ${ }^{9}$ On the same date, he wrote to fifty tenants,

4 Matthew Paris, IV, 181-188. Those summoned were "archiepiscopis, episcopis, abbatibus, prioribus, comitibus, et baronibus"; those present were "totius Angliæ nobilitas, tam prælatorum quam comitum et baronum"; "dominus Eboracensis archiepiscopus et omnes episcopi Angliæ, abbates et priores, per se, vel per procuratores suos, necnon et omnes comites et fere omnes barones Angliæ ad mandatum domini regis convenissent."

5 Close Rolls, IV, 430, 431. This probably began during the council: "protendens rotulum, in quo scriptum monstravit, quid ille vel ille abbas vel prior tantum vel tantum promisit se daturum" (Matthew Paris, IV, 182, 189).

B Close Rolls, IV, 431. Another summons was issued to this effect to all sheriffs on March 24 (ibid., p. 435; Vincent, p. 64).

7 Rymer, I, 246; Matthew Paris, IV, 192; Theok., p. 122. May 5, Dunst., p. 158; May 9, Wav., p. 329, and Wint., p. 89.

8 "et quia plures... non venerunt ad transfretandum nobiscum sicut summoniti fuerunt, tibi (vicecomiti) præcipimus quod omnes tales distringas per terras et catalla quod sint apud Lond' . . parati ad transfretandum post corpus nostrum" (Close Rolls, IV, 486). This order was enrolled May 19. The order to distrain was not a mere threat, but was carried out; see the cases of Isabella de Mortimer, William de Ros, and Robert de Hayford (ibid., pp. 427, 453, $465,472)$.

9 Rymer, I, 246; Close Rolls, IV, 496-499. William de Cantilupe, who was a leader of the reinforcements which later crossed, received a loan of $100 \mathrm{~m}$ that was afterward pardoned (Pipe Roll, $26 \mathrm{Henry}$ 


\section{STUDIES IN TAXATION}

summoning them to come at once. ${ }^{10}$ Nor was this order disregarded. Tenants were going over to Gascony throughout the summer. ${ }^{11}$ Some tenants who served this year came with only part of their contingents. ${ }^{12}$ Mer-

III, Dors. and Somers.). Matthew Paris says that the count of la Marche had advised the king to bring money, not men, as he would provide a sufficient military force (IV, 189); the king therefore may have been unusually lenient in allowing men to fine for their service.

10 Rymer, above; Close Rolls, IV, 498, 527.

11 August 28, men were being sent over (Rymer, I, 248); see also Cal. Pat. Rolls, I, 302; Close Rolls, IV, 460; Matthew Paris, IV, 198. William de Albiniaco, Andrew Lutrel, and Thomas Gresley fined (Rymer, I, 246; Pipe Roll, 26 Henry III, Linc., War. and Leic.), but later crossed to the king (letters of protection for them, Cal. Pat. Rolls, I, 291-297). Vital Engayne fined in $40 \mathrm{~m}$ and later sent his son and part of his fine was pardoned (Close Rolls, IV, 473); William de Siff rewast (ibid., no. 58, m. 15). Thomas de Berkeley fined in $60 \mathrm{~m}$, then sent his son with two knights and his fine was pardoned (ibid., m. 14); Robert de Hayford was to be distrained to cross on October 6 "cum aliis militibus qui ad mandatum nostrum tunc ad regem similiter transfretabunt" (ibid., IV, 465). For the persistent opposition of the barons to this expedition, in spite of which they were still obliged to serve, see Dunst., pp. 158-159: "rex ... a magnatibus suis Angliæ fere omnibus ibi (at Bordeaux, after the campaign) dimittitur, sine quorum consilio ab Anglia fuerat profectus." Matthew Paris rather exaggerates this feeling when he says that the king had to persuade rather than to command the magnates to accompany him, "datis muneribus preciosis" (Matthew Paris, IV, 189). By these gifts are meant probably loans (see above, note 9); they were not uncommon under John (see above, pp. 37, 97, 111).

12 Richard de Munfichet, $471 / 4$ fees, had two knights with the king and received all his scutage (Michel, Rôles gascons, no. 145; Close Rolls, IV, 493); the earl of Arundel, 841/2 fees, had five knights in the host and was granted all his scutage (Michel, no. 138; Close Rolls, above); Thomas de Berkeley, five fees, first fined in $60 \mathrm{~m}$, then sent his son "se tertio" and his fine was pardoned (Rymer, I, 246; Close Rolls, no. 58, m. 14); "Rex dedit respectum Johanni de Stutevill' de servicio trium militum quod regi debet donec rex venerit in Wasconiam" (Close Rolls, IV, 413); he held fifteen fees. Notice however that Andreas Peverel and Richard de Harecurt each sent one knight to Gascony (ibid., 493); they held respectively one fee, and a third of a fee (Pipe Roll, 29 Henry III, Sussex, Oxon., m. 9, 7 d); in War. and Leic. a Richard Fitz William de Harecurt held 
cenaries were employed. ${ }^{13}$ Thus the king was able but with difficulty to compel tenants to perform their service.

In connection with this expedition, there were levied a scutage at three marks on the fees of religious houses and of lay tenants together with fines, an aid at the same rate on the bishops, and dona (contributions in lump sums) on religious houses. ${ }^{14}$

The scutage on religious houses and the laity was put in charge before the king's departure. On May 19, a writ was issued to the sheriff of Yorkshire ordering him to collect scutage at three marks from all fees in hand and from rear-vassals of all tenants who had no writs of scutage, and to have the money at the exchequer on October 13. ${ }^{15}$ Before the date of sailing, grants were made to tenants in chief of the scutage of their vassals. On May 1, the sheriffs in whose bailiwicks Richard, earl of Cornwall, had fees were to cause him to have his scutage at three marks per fee at the coming October 13, 1242,

two fees (ibid., m. 10) and he may be the Richard de Harecurt mentioned above; in any case, the entries illustrate the fact that a small tenant might furnish all or nearly all his service.

13 Rymer, I, 247, 249; Cal. Pat. Rolls, I, 308, 316; Michel, no. 248; Close Rolls, IV, 406; in August, efforts were being made to provide 500 Welshmen, probably the force concerning which the king had written in June (ibid., 458); in September, 100 knights, 100 sergeants, and 4,000 Welsh (ibid., 514).

14 No tallage was levied throughout England for the expedition. The entries concerning tallage which appear in the Pipe Roll of 1242 belong to the levy of 1241. Matthew Paris says that in 1243 the citizens of London were compelled to pay a tallage under the following form: "Venerunt exactores et regales æditui ad illum vel illum civem, dicentes; 'Tantam et tantam oportet te pecuniam domino regi, in longinquis partibus pro commoditate regni militanti et nimis indigenti, donec in regno suo restauretur, commodare.' Et secundum voluntatem et æstimationem extortorum pecuniam civium mutilarunt" (Matthew Paris, IV, 242). Probably this was done, for in the Pipe Roll of 1242 two Londoners pay each $£ 40$ "de auxilio" (Pipe Roll, 26 Henry III, Lond. and Midd.).

15 Close Rolls, IV, 486. 


\section{STUDIES IN TAXATION}

because he accompanied the king. ${ }^{16}$ The date, October 13, is that on which the scutage was to be paid at the exchequer by the sheriff according to the writ of May 19; the order suggests therefore that the scutage had already been put in charge on May 1. On this same date, May 1, the king acknowledged the receipt of fifty marks on April 30 from the abbot of Hyde in aid of his crossing and released him of the scutage due on five of the twenty fees which the abbot held. ${ }^{17}$ Men fined before the king started with the proviso "saving to the king his scutage." It seems clear therefore that the levy was fixed before the king crossed.

The account of the tax in the Pipe Roll is incomplete. The title is "Fines militum ne transfretent cum rege in Wasconiam præter scutagia sua quæ regi sponte concesserunt ad istam transfretationem." The returns of the scutage (at three marks) are not given $;^{19}$ no lists of men granted writs of quittance appear; only fines for default

16 Vincent, p. 116. Other cases are cited here.

17 Cal. Pat. Rolls, I, 284; Madox, I, 609, n. d. The writ in Madox was issued 27 Henry III. On May 4, 1242, the sheriffs were ordered to allow the abbot of Hyde to have his scutage "ad respondendum inde regi scaccarium" (Fine Roll, no. 38, part 1, m. 3).

18 Vincent, p. 117. The introduction of this saving clause shows that the scutage had been declared. Had the levy not been fixed already, the clause introduced would have indicated that fact. $C f$. the fines in connection with the campaign against Richard Marshal in 1233, which were made when no scutage had been put in charge; they say "si scutagium currat" (see above, p. 206).

19 The scutage does not appear in the later Pipe Rolls. The account was made in a separate roll, which is mentioned in the Pipe Roll: "sicut continetur in rotulo compoti hujus scutagii" (Pipe Roll, 27 Henry III, passim, from Hall, Red Book, II, p. clxxxix, note 5). Mr. Hall speaks as though only the scutages which were unpaid at Michaelmas, 1242, were entered in this roll, but all the scutage which came in was entered in it: "Hec summa vera est et soluta unde vicecomes protulit talliam coram baronibus a die S. Michaelis in $\mathrm{xv}$ dies anno xxvito" (Testa, p. 14b). This seems to refer to the compotus which the sheriff presented at the exchequer on October 13, 1242, the date when the first rendering of the scutage was due. 


\section{UNDER JOHN AND HENRY III}

of service are entered and the list of these is not complete. The title implies that all these fines were paid in addition to the scutage. This is not always the case; sometimes the fine included the scutage. ${ }^{20}$ The scutage was not an aid in the technical sense, but was the composition for service. ${ }^{21}$ Those tenants who were in the host did not pay it, but were granted permission to collect it for their own use from their vassals. There is a roll containing the names of seventy-seven tenants who accompanied the king and for this reason received writs de habendo scutagio. ${ }^{22}$ The order instructing the sheriff to collect scutages exempted those who had such writs. ${ }^{23}$ Mention should be made in this connection of the king's letter of June 8, directing fines to be remitted and even money paid in addition to those tenants who would join him in France. ${ }^{24}$ This seems evidence enough to show that the tenant in chief was exempt from all taxation on his tenement, if he served. Nor was it necessary for a vassal to provide his full contingent in order to be exempt from all money payment. ${ }^{25}$

Some tenants who failed to perform their service did not escape with scutage only. Fines were also levied, often very heavy. A few cases may be given: William de Percy, $100 \mathrm{~m}$ on 15 fees $;^{26}$ Gilbert de Umfravill, $100 \mathrm{~m} ;{ }^{27}$ John de Bayeux, $100 \mathrm{~m} ;{ }^{28}$ Henry de Pinkney,

20 See below, note 35 .

21 Not the full composition in all cases, perhaps not in most, but not a general aid on knights' fees.

22 Scutage Rolls, No. 6; Bristol and Glouc., etc., XIV, 22, note. For such writs, see Close Rolls, IV, 489-493.

23 Madox, I, 682, n. s; see above, p. 227, note 15.

24 See above p. 225, note 9.

25 See above, p. 226, note 12.

26 Pipe Roll, 26 Henry III, York.

27 Ibid., Northumb. He held $21 / 2$ fees.

28 Ibid., Linc. The servitium of this fee was 20 knights (Round, Feudal England, p. 253); the old enfeoffment was $151 / 2$ fees and the 


\section{STUDIES IN TAXATION}

30m $;^{29}$ Elias Giffard, 35m, 9 fees $;^{30}$ Robert de Everingham, $50 \mathrm{~m}$ not to cross and to have his scutage $;^{81}$ Thomas Gresley, $100 \mathrm{~m}$ not to cross and to have his scutage $;^{32}$ Roger de Merlai, 50m on 4 fees. $^{83}$ The amount of fines charged in the Pipe Roll in twenty-nine counties was 3,146 marks of which 1,555 marks were entered as paid. There seems to have been a tendency to separate the fine from the scutage. The title of the levy in the Pipe Roll speaks of "fines ... præter scutagia" and there was a separate account of the scutage. Some of the fines were evidently payments in addition to the scutage $;^{84}$ other fines however included the scutage. ${ }^{35}$ There was nothing new in the separation of the two payments and we can hardly say whether or not the practice was more common

new, 41/5 fees (Red Book, I, 387); in 1230 and 1246 it accounted for 161/21\% fees (Pipe Roll, 14 and 30 Henry III, Linc.).

29 Ibid., Bucks and Bedf.; 15 fees; probably a fine in addition to scutage.

30 Ibid., Glouc.

31 Vincent, p. 117, quoting Fine Roll, 26 Henry III.

32 Vincent, p. 118, quoting Fine Roll, 26 Henry III; 12 fees.

33 Pipe Roll, 26 Henry III, Northumb.

${ }^{34} E . g$. the countess of Warwick, 100s (ibid., Oxon.); William Fitz Hamon, 10m (ibid., Bucks and Bedf.); Robert de Novo Burgo, $20 \mathrm{~m}$; Walter de Estleg, 10 fees, 10m (ibid., Dors. and Somers.).

35 Robert de Everingham paid $50 \mathrm{~m}$ not to cross and to have his scutage (Vincent, p. 117); similarly, Thomas Gresley, $100 \mathrm{~m}$ (ibid., p. 118); Gilbert Gaunt "finem fecit cum rege pro eodem (scutagio suo et pro relaxacione passagii sui) per CC marc." (ibid.). He held $681 \frac{1}{3}$ fees so that he really paid only scutage. John de Bayeux, $100 \mathrm{~m}$ "de eisdem finibus" (Pipe Roll, 26 Henry III, Linc.); this fine includes his scutage, for "finem fecit pro habendo scutagiis suis per $\mathrm{C}$ marcas" (Testa, p. 306b). The earl of Warwick, 180 marks "pro omnibus feodis suis et pro habendo scutagio suo" (Pipe Roll, abore, War. and Leic.); in the Fine Roll he is charged with the same amount "pro scutagio suo et pro relaxacione passagii sui" (Vincent, above). He held $1021 / 3$ fees. Dugdale, I, 72b, quotes the rolls of 25 and 26 Henry III to show that the earl paid two fines of $£ 120$ each, one to be absent from attendance on the king in Gascony and the other to levy scutage on his tenants. It is unlikely that there were two distinct fines. 
this year than in previous years. Some, perhaps all, of the fines were levied at the beginning of the campaign. ${ }^{36}$

The method of collection of the levy varied. If a tenant in chief received a writ for having his scutage, he collected from his tenants and accounted either to the sheriff or to the exchequer. Such a writ was granted both to tenants who fined and to those who paid scutage. If the tenant did not secure the writ the great council had provided that the sheriff should collect from his rear-vassals. ${ }^{37}$

36 Vincent, above; $c f$. Rymer, I, 246; the king writes from France, June 8: "Fines rero quos a quibusdam militibus recepimus"; see above, p. 228.

3i The writ of collection of May 19 orders the sheriff "quod de omnibus feodis militum que tenentur de tenentibus de nobis in capite in balliva tua et que ipsi de nobis tenent in capite que quidem brevia nostra tibi non tulerint de habendo scutagio suo etc. . . . scutagium nostrum colligi facias" (Close Rolls, IV, 486). This means that the sheriff will collect from the rear-vassals unless the tenant in chief has a writ which empowers him to collect. The expression "brevia nostra ... de habendo scutagio suo" refers not only to the men who have performed their service and hence have their scutage for their own use, but also to those who have fined and those who pay scutage only and who are allowed to collect from their vassals. For cases of the latter, see note 35; also the case of Earl Ferrers (Testa, p. 15a) from whose tenants the sheriff collects nothing, but who will respond himself. The abbot of Peterborough, 60 fees, paid $£ 120$ (his scutage only) at the exchequer "licet non colligerit illud scutagium, ut dicit, nec milites sui qui de illo tenent scutagia sua solverunt et ideo tibi (vicecomiti) præcipimus que sis in auxilio ipsi abbati ubi non sufficiat in balliva tua ad distringendum dictos milites suos ad reddendum ei scutagia sua de quibus illos acquietavit ad scaccarium (Exch. L. T. R. Mem. Roll, 27 Henry III, m. 3). The abbot of Westminster was allowed to collect his scutage from his tenants (ibid.); also Robert de Stafford (ibid., 28 Henry III, m. 2). See also the cases of Ada, wife of John, son of Robert (Close Rolls, IV, 452); the abbot of Hyde (see above, p. 228); William Marshal (Excerpta, I, 390). But if the tenant did not secure such a writ, the sheriff collected from the rear-vassals. If such a tenant tried to collect, the rear-vassal could appeal to the king who would interfere to prevent it. Thus Payn de Clermund was summoned before the exchequer to explain why he had distrained his tenant William Hayrun "contra provisionem prædictam," viz., "quod scutagia nobis concessa ad transfretationem nostram in Wasconiam colligerentur 


\section{STUDIES IN TAXATION}

This was the method employed in the aid of 1217; doubtless the same method was often followed in the collection of a scutage.

per vicecomites nostros" (Madox, I, 682, n. $r$ ). The case of Alexander Swereford: 'Questus est nobis ... Alexandr' thesaurarius S. Pauli London' que cum per commune consilium regni nostri sit provisum quod scutagia nobis concessa ... colligantur per manus vicecomitum in singulis comitatibus exceptis feodis illorum quibus scutagia sua concessimus, $H$. comes Kanciæ distringit eum pro scutagio unius militis in warda sua in Middleton' licet non concesserimus eidem scutagia sua et que tu (the sheriff) potius deberes levare quam ipse," and so the goods of Alexander are to be released and he is to be distrained by no one but the sheriff (Exch. L. T. R. Mem. Roll, 27 Henry III, m. 4). These writs might seem to mean that the sheriff collected from all the rear-vassals, but the cases cited above show that he took it only from the sub-tenants of those barons who had not writs for collecting their own scutage. Whether the sub-tenant always held his lord to the strict letter of the provision concerning the method of collection, we cannot say. The reason for the protest in the two cases cited above was not merely that the tenant in chief collected without the king's authority. Payn de Clermund had distrained his tenant for scutage "et etiam plus quam idem Willelmus recognoscit se debere"; concerning the fee of Alexander Swereford, "pendet adhuc placitum in curia nostra coram justic' nostris inter dictum comitem (who had distrained it) et Willelmum de Bellocampo ad quem illorum pertinebit dicta warda." In another case in which the tenant in chief had collected from the rear-vassal "contra provisionem nostram desicut vicecomes noster per præceptum nostrum prædictum scutagium nostrum debuit colligisse," the sheriff was merely ordered to release the distraint which he had made against the rear-rassal and distrain the tenant in chief to pay at the exchequer (Exch. L. T. R. Mem. Roll, 27 Henry III, m. 2, the case of Robert le Buteiler and David de Garpunvill', his lord). But a writ on the Close Roll possibly refers to the collection of scutage from rear-vassals by tenants in chief who had not receired the king's permission to do this; if so, it indicates that the king intended to prevent such collection: the regents were to inquire "qui magnates de Anglia, sive episcopi, sive alii, tallagium vel scutagium in auctoritate sua propria super liberos homines suos assiderunt et ab eisdem ea ceperunt contra consuetudinem Anglie ... ita quod rex ... in adventu suo in Angliam possit testificari" (Michel, no. 1633). The collector of the scutage might be an official other than the sheriff; in Gloucestershire, it was the abbot of Chichester (Bristol, etc., XIV, 19-37). 
This scutage was to be paid by all knights' fees on the holdings of lay tenants and religious houses. ${ }^{38}$ It was believed that many of these fees were escaping taxation and a determined effort was made to ascertain the total amount of land held by military service in England. ${ }^{39}$ In the writ of collection of May 19 the sheriff had been ordered to find out and report on October 13 the number of fees held in his bailiwick both of the old and the new enfeoffment. ${ }^{40}$ The returns made were evidently unsatisfactory. This was due partly at least to the opposition of the tenants. On October 29, another order was issued in sharper language. The sheriffs had been negligent; if they did not wish their own lands and chattels to be seized by the government, they were to present at the exchequer on December 7 all the arrears of scutage and a complete report of all fees. Any tenant who opposed the collection or the inquest was to be summoned before the exchequer barons. ${ }^{41}$ But the report rendered in consequence of this order was unsatisfactory. Many men had claimed that they did not hold by military service of any one and hence owed no scutage. Accordingly, on December 9, new writs were issued containing detailed

38 The writs cited below say that the scutage was to be paid both on the new and the old enfeoffment; these terms are not used in the technical sense employed in the reign of Henry II and his sons. They mean all the land held by military service whenever enfeoffed (see the form of the inquest, Madox, I, 681, n. $q$ ).

39 Although the bishops did not pay on all their fees, they were to certify to the king the number of fees held of them (see the report of the bishop of Worcester, Testa, p. 44b).

${ }_{40}$ Close Rolls, IV, 486. This report was to cover all fees whether or not the tenant in chief owed scutage. See below, p. 234, note 43, where the sheriff later tried to hold inquests on the lands of tenants who had writs of quittance, but as they were unwilling, he was unable to do so.

41 Madox, I, 682, n. $s$; "et si quos inveneris tibi resistentes quo minus colligere prædicta scutagia et inquisitionem prædictam facere possis, summone eos . . . quod tunc sint coram baronibus responsuri." 


\section{STUDIES IN TAXATION}

instructions for an inquest of knights' fees all over England. This was not to be done as in $\mathbf{1 2 3 5}$ by the tenants in chief. The sheriff was to conduct it by the aid of twelve legal men, knights or others, who were under oath. They were to inquire the location of all fees, the number each man held and of whom he held them. ${ }^{42}$ All this information together with the arrears of scutage was to be delivered at the exchequer on January $27,1243 .^{43}$ The opposition of the tenants to the inquests was so strong that on January 30, a writ was issued to the sheriffs directing them not to hold the inquests on the lands of those tenants who had writs for having their scutage. ${ }^{44}$ The king's effort to get a complete report of the land held by military service therefore failed. These inquests are of interest because they were made for purposes of taxation; they are another example of the use of the jury in that connection. All this, the collection from rearvassals by the sheriff or some special collector, the inquests, the separation of the fine from the scutage, indi-

42 In addition, a roll was to be drawn up of the other lands of the county made out by hundreds, containing the names of the vills and their holders, of whom and by what service they held them (Madox, I, 681, n. $q$ ).

43 Madox, I, 681, n. p, q; Farrer, Lanc. Inquests, p. 145. The writs both of October and December show that tenants paid the scutage unwillingly and opposed the inquest. If the tenant was unwilling, the sheriff was unable to hold the inquest: "Comes de Ferrar fecit de securitate satisfac' de scutagio. Et ballivi sui non permittunt quod vicecomes intret infra libertatem suam ad inquirendum quot feoda militum teneantur de ipso"; "isti vero qui habent breve de habendo scutagio non permittunt quod inquisitio fiat de feodis militum que teneantur de ipsis"; the names of seventeen tenants follow (Testa, p. 15a).

44 "Mandatum est vicecomiti (Oxon') quod nullam faceret inquisitionem in comitatu suo de feodis prælatorum, baronum, vel militum qui tulerunt sibi brevia regis de scutagiis suis habendis; quia rex non vult quod inquisiciones fiant de feodis illorum de quibus non recepit scutagia sua" (Exch. L. T. R. Mem. Roll, 27 Henry III, m. $6 \mathrm{~d})$. This order was given to the sheriffs of nineteen other counties. 


\section{UNDER JOHN AND HENRY III}

cates a tendency to make the scutage a general tax payable at the exchequer. The fine represented the service of the tenant in chief for his holding; the scutage levied on the holdings of the rear-vassals was their fine for service. As most of the rear-vassals did not go on the campaign, the scutage would become in effect a general tax on knights' fees. At the same time, the king retained his right to demand service or a fine from his barons. But it must be remembered that those tenants who served obtained the scutage on all their fees, that there were tenants who paid scutage only, that both these and those who fined might collect from their vassals, and that the inquests were incomplete. Thus as far as the exchequer was concerned, this levy differed in no respect from previous levies of scutage; part of the fees paid to the king and part did not.

Distraint was used to force tenants to pay the scutage. ${ }^{45}$ If the sub-tenant continued to be unwilling, it seems to have been difficult to compel him to pay. In 124\%, Henry de Tracy had not collected all the scutage due him from his vassals and the sheriff was ordered to come to his assistance. ${ }^{46}$ What authority had the king for making this levy? A writ issued in 1242 states that the scutage was granted "per commune consilium regni." The Pipe Roll says that the scutages were willingly

45 Madox, I, 672, n. $i$; "mandatum est vicecomiti Kanciæ quod averia militum qui tenent de $\mathbf{R}$. comite Pictaviæ et Cornubiæ in balliva sua de dote comitisse Isabelle quondam uxoris suæ et que averia cepit pro scutagio deliberari faciat" (Close Rolls, IV, 477); for the earl of Oxford, Johanna Briwere and Hugh de Verly (ibid., $466,471,478)$. Distraint was made both on the demesne of the tenant in chief and on his vassals; each of the latter was to pay only so much as pertained to his fees (case of Henry de Merck, ibid., 469).

46 Madox, I, 677, n. e; in 1254 all of the scutage of 1242 had not been paid, e.g. fee of William de Kaines (Exch. K. R., 38 Henry III, Mem. Roll, m. 27 d).

47 Madox, I, 681, n. $p$. 


\section{STUDIES IN TAXATION}

granted by the knights. ${ }^{48}$ As the king demanded and obtained military service from his tenants, as he took scutage from those only who failed to serve, and as he was able to levy fines as well as scutage on recalcitrants, it is likely that he took the scutage because of his right to military service. Probably the king consulted with the tenants concerning the levy and they agreed that the rate should be three marks per fee and that the collection should be made at the opening of the campaign. To this extent, it may be said that they granted the scutage.

The bishops made a separate arrangement as they had done in 1229. Instead of paying a scutage, they granted an aid at three marks per fee and on their servitium debitum only. They received letters patent stating that the grant should not form a precedent. They were allowed to collect the aid from their tenants. ${ }^{49}$ It is difficult to see why the bishops should pay an aid instead of a scutage, as it was a denial of the king's right to military service in France. The last sentence of the letters patent

48 "Fines militum ... præter scutagia sua que regi sponte concesserunt ad istam transfretationem."

49 Madox, I, 609, n. $c$; Close Rolls, IV, 487; if a rear-vassal was exempt, so was his lord (ibid., 507, fees held of the bishop of Norwich). It is not stated when the bishops made this grant, but it is likely that it was done early in May. The orders to the sheriffs to aid the bishops to collect the aid from their tenants were issued on May 21. The Tewkesbury chronicler speaks of a meeting of the bishops at London about May 6 and this was probably the assembly which agreed to the aid. The chronicler states that the king crossed to Gascony on May 6 and that the abbot paid him $20 \mathrm{~m}$ at Portsmouth; he continues: "audito ibidem de morte Nicholai personæ de Merlawe, dominus abbas adivit episcopum Lincolniæ apud Londoniam, ubi tunc multi fuerunt episcopi in unum congregati" (Theok., p. 122). It was not granted before May 2 , for on that date the king issued at Marwell the following writ: "Rex concessit Roberto le Noreis senescallo N. Dunholm' episcopi quod per scutagium suum regi dandum quietus sit de transfret' in Pictaviam; et mandatum est vicecomiti Cantebr' quod per predictum scutagium ei pacem de transfretacione predicta habere permittat" (Fine Roll, 26 Henry III, part 1, m. 3). 


\section{UNDER JOHN AND HENRY III}

may have been added by the king to prevent, if possible, such an interpretation. He declares that this concession which he has made shall neither increase nor decrease his own rights nor those of his heirs. ${ }^{50}$ Although the aid was to be paid only on the servitium debitum, the inquest into the military service in England extended to the fees of the $\operatorname{clergy} .^{51}$

A donum also was asked from religious houses, both from those which held by military tenure and those which did not. In the case of the former, it did not take the place of the scutage. The abbot of Hyde gave $50 \mathrm{~m}$. He was pardoned the scutage of five of his twenty fees. ${ }^{52}$ Requests were already made from the prelates in the council of January, 1242. ${ }^{53}$ The work was continued by special collectors and the sheriffs throughout the kingdom. ${ }^{54}$ Many of these amounts were paid before the king set out. ${ }^{55}$ There was no assessment of property; each house paid a lump sum. An aid was also asked from the

50 "Nolumus etiam quod per hanc concessionem nostram quam fecimus, nobis et heredibus nostris accrescat vel decrescat" (Madox, above). It may relate to the king's concession to the bishops to collect the aid from their tenants.

51 The clergy reported the number of their fees and an inquest was not held on their lands by the sheriff and the twelve legal men; e.g. the bishop of Worcester made a report of his fees to the king (Testa, p. 44b).

52 Cal. Pat. Rolls, I, 284.

53 "Petensque ab eis auxilium pecuniare, (rex) ait; Ecce, quid concessit ille abbas mihi in subsidium; ecce, quid alius; et protendens rotulum, in quo scriptum monstravit, quid ille vel ille abbas vel prior tantum vel tantum promisit se daturum" (Matthew Paris, IV, 182).

54 The king sent a clerk to coöperate with the sheriff in the dioceses of Lincoln and Ely (Cal. Pat. Rolls, I, 272, 282, 287); Matthew Paris, IV, 189 ; Theok., p. 122.

55 Bristol, etc., XIV, 20-21; in the Testa are given lists of contributors, many of them small; the total amount given there is 1,6851/2 marks (Testa, pp. 22a, 37b, 44a, etc.). Some cases follow: abbot of St. Mary's of York, $100 \mathrm{~m}$; prior of Kenilworth, $30 \mathrm{~m}$; prior of St. Swithin, $200 \mathrm{~m}$; prior of Worcester, $30 \mathrm{~m}$; abbot of St. Edmunds, 


\section{STUDIES IN TAXATION}

Cistercians and Premonstratensians before the king crossed, but the request was refused..$^{58}$ In October, the former were again asked to contribute and again refused; then the king asked for their wool for a year. This they refused on the ground that such a contribution needed the consent of the order. ${ }^{57}$ The clergy in Ireland were asked to contribute with the promise that the grant should not form a precedent. What answer was given is not known. ${ }^{58}$

The several devices employed to raise money increased the revenue of the year. The Pells Issue Rolls for 1242 record $£ 38,60610$ s $13 / 4$ d, to which, according to Ramsay, should be added the average amount received directly at

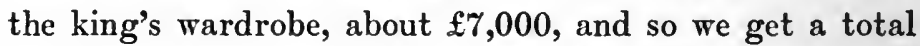
income for the year of about $£ 45,000\left(67,500\right.$ marks). ${ }^{59}$ From March, 1242, till September, 1243, the king gave orders covering over $£ 36,000$ from England, all of which was spent either in Gascony or in preparation for the expedition. $^{60}$ While abroad, he borrowed about $\$ 10,000{ }^{61}$

$100 \mathrm{~m}$; abbot of Abingdon, $100 \mathrm{~m}$; bishop of St. Davids, $40 \mathrm{~m}$; prior of Lewes, $50 \mathrm{~m}$ (Cal. Pat. Rolls, I, 278-298); these sums were all received between March 28 and May 20, 1242. See also, Close Rolls, IV, 417-421, 430, 431; Vincent, p. 60; Theok., p. 122; Wig., p. 433.

56 Cal. Pat. Rolls, I, 279, 280; Close Rolls, IV, 430.

57 Cal. Pat. Rolls, I, 330, 336; Matthew Paris, IV, 234-235.

58 Cal. Pat. Rolls, I, 378; Close Rolls, IV, 407.

59 R. J. Whitwell in E. H. R., XVIII, 710; Ramsay, Dawn of the Const., pp. 294-295.

00 Orders were issued to pay the following sums: $3,000 \mathrm{~m}$ on March 7; 3,005m 9s 61/2 d, April 19; 10,000m out of the exchequer of the Jews on the same date; $291 \mathrm{~m}$, April 25. The following sums were acknowledged as received in Gascony from England: $2,500 \mathrm{~m}$, July $27 ; 5,345 \mathrm{~m} 7 \mathrm{~s} 9 \mathrm{~d}$, October $17 ; 10,000 \mathrm{~m}$, January 8,$1243 ; 12,000 \mathrm{~m}$, April 16;2,000m, July $8 ; 6,000 \mathrm{~m}$, August 30 . This gives a total of $54,142 \mathrm{~m} 3 s$ 11d or over $£ 36,000$ (Cal. Pat. Rolls, I, 274, 281, 282, 313, $332,355,372,384,394)$. We cannot be certain that the sums ordered out of the exchequer were actually paid, but they do not appear excessive unless one takes exception to the 10,000 marks of the Jews. As to that, it must be remembered that a tallage of 20,000 marks had been levied on them in 1241 and that this sum must have come in part into the exchequer. 


\section{UNDER JOHN AND HENRY III}

Some of the loans were repaid out of moneys received in Gascony from the English treasury, but some were to be paid at the exchequer in England. The cost of the expedition therefore will probably approach $£ 40,000$ $(60,000$ marks $){ }^{62}$

\section{The Scottish Campaign, 1244}

On May 13, the host was summoned to meet on August 1 at Newcastle-on-Tyne for a campaign against Scot-

61 Ibid., 315-406. Part of this money is given in pounds and shillings of Bordeaux which $I$ have reduced to English money at the rate of $3 \mathrm{li}$. $(=60 \mathrm{~s})$ to $\mathrm{lm}$ sterling, but the ratio fluctuated (ibid., 368, 389).

${ }^{62}$ With this account of the scutage, compare Stubbs, Const. Hist. II (3rd ed.), 61: "Henry wished to raise as his father had done, a scutage by way of fine from the barons who had left him alone in Gascony, besides that which he received, twenty shillings on the fee, from those who had stayed at home." Stubbs bases this on Matthew Paris, IV, 227, 233. But the chronicler does not refer to the levy of a scutage of twenty shillings as a fine on those who had left the king in Gascony. He says that Henry III wished to confiscate the lands of those who had left him as if they were traitors, but that the archbishop of York did not do so (IV, 230-231). The reference on p. 227 speaks of a scutage of 20 s which "per totam Angliam" the king "fecit extorqueri"; that on p. 233 is as follows: "Præter scutagium quod extorserat rex Angliæ, omnia jam consumpserat inutiliter quæ in bonis habuit et eguit. [This is the title of the chapter.] Ipso quoque tempore, rex a Pictavensibus et Wasconensibus undique delusus, immo potius defraudatus, in tantam paupertatem et ignominiam delapsus est, quod scutagio extorto et omnibus thesauris et donativis ei collatis inutiliter consumptis, nccnon extorsionibus, tallagiis, et aliis collectis excogitatis, post amissionem terrarum suarum et honorum in Pictavia, jam in Wasconia aere alieno graviter est obligatus, licet in dicto scutagio, non sine multo gravamine Anglorum, pro scuto viginti solidos extorserit." It is clear that we have here not a reference to another scutage, but a commentary on the royal exactions of the year. Such a statement is natural as this chapter comes at the end of the history of 1242. All the other references speak of only one scutage of $40 \mathrm{~s}$ (e.g. Dunst., p. 160; Cont. Flor. Wig., II, 178; Wykes, p. 91; Pipe Roll, 26 Henry III). 


\section{STUDIES IN TAXATION}

land. ${ }^{63}$ The army assembled, but there was no fighting. A treaty was made; Henry's daughter, Margaret, was betrothed to Alexander's son. No scutage was taken, but some tenants fined for their service before the host gathered. ${ }^{64}$ These fines were fixed by an agreement between the king and the tenant in chief, and the rearvassal was not responsible for their payment. Legally the latter could not be forced to help his lord discharge this debt if he were unwilling. But there was a method by which the sub-tenant could probably be compelled to help pay the fine, or, if he were very stubborn, to render more than an equivalent. He could be legally distrained by the sheriff to perform his military service for his lord, and in this way, the king could practically enforce the payment of the fine by the sub-tenant. ${ }^{65}$ The situation here involved indicates the unwillingness with which rearvassals performed their service. ${ }^{66}$

63 Vincent, Lanc. Lay Subsidies, p. 77, quoting the Close Roll, 28 Henry III; Paris, IV, 379-380, 385; Lanercost, p. 51 ; Dunst., p. 164; Wint., p. 90; Wav., p. 333; Lords' Report on the Dignity of a Peer, vol. III, App. I, p. 9.

64 Two laymen each paid a fine of $1 \mathrm{~m}$ to be exempt from service "salvo regi scutagio si scutagium debeat dari"; the abbots of Winchcomb and Holme fined in $10 \mathrm{~m}$ and $20 \mathrm{~m}$ respectively besides scutage if it were given; the abbot of Abingdon fined in $£ 40$ "ita quod si scutagium assessum fuerit pro exercitu illo idem abbas habebit scutagium suum et accrescet finis suus usque ad lx libras" (Fine Roll, no. 41, part 1, m. 4). The archbishop of Canterbury made an aid (Cal. Pat. Rolls, I, 433).

65 The bishop of Lincoln fined in $60 \mathrm{~m}$ in addition to his scutage, if scutage should be levied, and the sheriff of Northamptonshire was ordered "quod milites ipsius episcopi qui prefato fine assentire vel portionem ipsos de prefato fine contingentem solvere noluerint distringat ad veniendum in predictum exercitum, allocato predicto episcopo in prefato fine servitio predictorum militum qui in predictum exercitum venerint" (Fine Roll, above).

66 Cf. the case of the knights of the abbot of St. Albans in this campaign (Matthew Paris, VI, 437, 439). 


\section{The AID of $1245^{67}$}

Early in May, 1244, a meeting of the great council (prelates, earls, and barons) ${ }^{68}$ was held at Westminster. 'The king asked for an aid to pay debts incurred in Gascony. The magnates withdrew to deliberate; a committee of twelve representatives (four each from the bishops, the earls, and the barons) was appointed to draw up a common reply. They asked for the appointment of a justiciar and a chancellor. As the king declined to agree to this the council was prorogued till February 23, 1245. If by that time Henry III had reformed his government, the magnates declared that they would consider making an aid, but that it must be spent by the advice of the committee of twelve. ${ }^{69}$ On September 9, another council of the prelates and barons was held at Windsor. The lay magnates refused to do anything before February. The prelates were presented with a papal letter which urged them to grant the king an aid. After a discussion lasting seven days, they too declined to accede to the king's request. $^{70}$ On February 23, 1245, the great council met ${ }^{71}$

67 In this account of the councils of 1244 and 1245 , the statement given by Plehn, Der Politische Charakter von Matheus Parisiensis (pp. 124-126) has been followed.

68 "convenerant regia submonitione convocati Londoniis magnates totius regni, archiepiscopi, episcopi, abbates, priores, comites et barones" (Matthew Paris, IV, 362). Matthew Paris does not date this council. It met before the summons to the Scottish campaign was issued (May 13). That summons was sent out "de communi consilio regni nostri"; probably the decision to attack the Scots was taken in the same council in which the aid was asked for. The statement of Matthew Paris that the king asked for an aid to pay his debts incurred in Gascony, "sub silentio præteriens propositum suum de rege Scotiæ potenter expugnando," does not contradict this conclusion. That description applies to the king's speech at the opening of the council.

69 Matthew Paris, IV, 362-363.

70 Dunst., p. 164; Wav., p. 332; Matthew Paris, IV, 363-366; the king was at Windsor at this time (Cal. Pat. Rolls, I, 435). Matthew Paris speaks of a meeting of the magnates on November 3 in which 


\section{STUDIES IN TAXATION}

and after long discussion agreed to grant an aid of twenty shillings on the fee to marry the king's eldest daughter, half to be paid at Easter and half at Michaelmas. ${ }^{72}$ The king promised to observe the charters. He was reminded of the numerous taxes which he had received, and a scheme for the reform of the government was presented to him which however was not put in force. ${ }^{73}$

In form this grant of twenty shillings was one of the feudal aids. It was not the kind of a grant which the king desired, but the council would agree to nothing else, ${ }^{74}$ and their determination in this particular is a further illustration of the united attitude of the tenants in chief. The barons could not refuse the aid, but they apparently could limit the rate to twenty shillings. They also had another grievance to remedy, the number of fees on which the aid should be paid. In 1235 and 1242, the king tried to have all land held by military service contribute, an effort which had been strongly opposed by the tenants in the latter year. ${ }^{75}$ Probably to prevent a recurrence of such attempts the barons in 1245 provided that they

they refused the king an aid (IV, 395). Plehn rejects this and thinks that it has been confused with the meeting of September 9. His argument does not seem conclusive.

71 "magnatibus cum prælatis."

72 Matthew Paris, IV, 372-373; Dunst., p. 167, giving only the fact of the grant. "Provisum est per commune consilium magnatum Angliæ" (Madox, I, 593, n. f); Red Book, III, 1064.

73 Matthew Paris, IV, 366-368, 373.

74 "cum nullo modo ad aliam formam possent flecti." As the princess was yet a child, the aid would not ordinarily be taken at this time. Its payment was a sort of compromise. The magnates paid an aid, but only one to which the king had a legal right. For the law as enforced at this time did not insist that the aid to marry the lord's daughter should be taken at the time of the marriage. In 1251, the earl of Gloucester collected an aid to marry his daughter although she was not yet betrothed: "Ricardus de Clare comes Gloucestriæ exegit a suis auxilium ad filiam suam maritandam, quam necdum scivit cui"' (Theok., p. 146).

75 See above, pp. 211, 233. 


\section{UNDER JOHN AND HENRY III}

should pay the aid on the number of fees for which they customarily responded, ${ }^{78}$ not on the total number of fees on their lands. ${ }^{77}$ No special officials were appointed to collect the tax. The levy fell ultimately on the rearvassals. $^{78}$ Distraint was employed to enforce payment. ${ }^{79}$ The greater part of the aid was entered in the Pipe Roll of 1245. The total amount charged was $£ 6,00115 \mathrm{~s} 0 \mathrm{~d}$, of which sum $£ 2,4809 \mathrm{~s} 4 \mathrm{~d}$ were paid in $1245-124 \% .^{80}$ An

78 That is, on the servitium debitum or the old enfeoffment, as the case might be.

77 The fact that the barons stipulated that the king should not try to collect the aid on all land held by military service is suggested by a writ on the Memoranda Roll which states that the magnates provided that the aid was to be paid on all the fees which they held of the king in chief and from which they owed military service: "Quia provisum est per commune consilium magnatum Angliæ, quod ipsi reddant regi de singulis feodis militum quæ de rege tenent in capite et de quibus debent servicium militare, $\mathrm{xx}$ sol. ad primogenitam filiam regis maritandam" (Madox, I, 593, n. $f$ ). That this description was restrictive as stated above is shown by the fact that in the account of the aid in the Pipe Roll, tenants paid on the number of fees for which they had long been accustomed to account. The new enfeoffment was not paid for unless the servitium debitum exceeded the total enfeoffment or unless the honor was in hand, e.g. the bishopric of Chichester (Pipe Roll, 29 Henry III, Sussex). However the extra enfeoffments might be entered in the roll. If one examines the writs of collection of 1235 and 1242 (Close Rolls, III, 186,189 ; IV, 486), it will be found that the clause restricting payment to those fees from which the barons owe military service is not introduced in those years.

78 Orders to the custodians of the bishopric of Chester and of William de Percy and the earl of Devon to collect the aid from the rear-vassals; pardon of the aid to one of the tenants of the earl of Oxford (Rot. Orig., I, 8b, 9a; Madox, I, 593, n. $f$ ).

79 Madox, I, 672, n. $k$.

80 The account is as follows:

Clerical tenants. $\begin{array}{lll}\boldsymbol{f} & \mathrm{s} & \mathrm{d}\end{array}$

One hundred and seventy-one lay tenants (each 5 or more fees)

Other lay tenants (each fewer than 5 fees, etc.)

Total

Paid, 1245, 1246

$\begin{array}{lll}4763 & 8 & 9\end{array}$

$\begin{array}{lll}530 & 4 & 3\end{array}$

$600115 \quad 0$

$2480 \quad 9 \quad 4$ 


\section{STUDIES IN TAXATION}

aid was also taken from the abbots and priors who did not hold by military service, and was collected in each county by the sheriff and a clerk of the king. ${ }^{81}$ It amounted in twenty-three counties to $£ 58013 \mathrm{~s} 4 \mathrm{~d}^{82}$

\section{The Scutage of Gannoc, 1246}

In the fall and winter of 1244-1245, the Welsh invaded English territory. A force of mercenaries was sent against them without success. ${ }^{83}$ The king celebrated the feast of Pentecost (June 4, 1245) at Westminster with the magnates and it was then determined to summon the host for an invasion of Wales. The campaign was carried on under the personal direction of Henry III from August 29 till October 28, about two months. ${ }^{84}$ The army was composed of tenants, both great and small, either performing their service, or providing their due contingents of knights. A tenant however did not have to furnish

The number of great lay tenants, 171, includes 7 tenants on the honor of Boulogne, 4 on Lancaster, and 1 on Peverel. Of the sum charged against the lesser lay tenants, $£ 157$ were charged against tenants on the honors of Boulogne, Lancaster, and Peverel. This roll therefore gives a total of about 6,000 fees in the kingdom. Mr. Round has made the total number of clerical fees in England 784; if we add 76 fees of the clergy which have been omitted this year, and 220 fees of the county of Cornwall, about 100 fees of the honor of Wallingford, and 127 fees of the honor of Brittany, we get over 6,500 fees. If we make some deduction for scattered fees of great baronies which have been entered twice, we still get a total of probably 6,500 fees.

81 Cal. Pat. Rolls, I, 463; Dunst., p. 167; Wig., p. 436; Madox, I, 595 , n. $q$; 596, n. $r$, $s$; Pipe Roll, 29 Henry III, passim.

82 Pipe Roll, 29 Henry III.

83 Matthew Paris, IV, 385, 386 ("trecentis commilitonibus stipendiariis"), 407, 409.

84 Ibid., p. 423; a sort of preparatory summons was sent out on June 7 , to be followed by a later one fixing the date for the host to assemble (Close Rolls, No. 58, m. 8 d). The king was at Chester August 17, in Wales, August 29, where he remained till October 29 (Cal. Pat. Rolls, I, 459-465; Matthew Paris, IV, 481, 486, 487); Ann. Cambr., p. 85; Brut., p. 331 ; Dunst., p. 168. 


\section{UNDER JOHN AND HENRY III}

his full quota of men. ${ }^{85}$ This had been a customary practice for a long time. But already a further step was being taken; this incomplete service was now coming to be regarded as all that could legally be demanded from the holding. There is a roll of the service which tenants had performed in Wales in 1245. It states the number of knights or sergeants furnished by each tenant and in addition the number which he recognized that he owed.

85 The Scutage Roll sometimes states how many knights or sergeants were provided by the tenant. From the examples given below it will be seen that lesser tenants were compelled to give service and that for the greater tenants probably only service in part was the rule. The number of fees assigned to each tenant is taken from the Pipe Rolls of 1245 and 1246.

\begin{tabular}{|c|c|c|c|c|}
\hline & & & $\begin{array}{c}\text { Knights } \\
\text { fur- } \\
\text { nished }\end{array}$ & $\begin{array}{l}\text { Fees } \\
\text { held }\end{array}$ \\
\hline Hugo Fitz Ralph & • & . & . 1 & 3 \\
\hline Ralph de Gaugy & • & • & & 3 \\
\hline Roger Bertram & • & $\bullet$ & . 1 & 5 \\
\hline Nicholas de Bassingt & burn & - & - 1 serg. & 1 \\
\hline Ralph de Cameys & . & $\bullet$ & . 1 & $11 / 2$ \\
\hline Ralph de Haya & . & • & . 1 serg. & 1 \\
\hline Henry de Merk & . & - & . 2 serg. & 3 \\
\hline Roger de Albemarle & & • & . 1 serg. & 1 \\
\hline Roger Fitz Ralph & . & $\bullet$ & & 1 \\
\hline William de Hastings & & $\bullet$ & . 1 & $11 / 2$ \\
\hline Roger de Muschamp & & • & - 2 & 4 \\
\hline Joanna de Neville & . & • & . 1 & $81 / 3$ \\
\hline Ralph Ridel & - & & . 1 serg. & $1 / 2$ \\
\hline John de Pabeham & - & & . 1 serg. & $1 / 4$ \\
\hline Richard Luvel & $\bullet^{\circ}$ & $\bullet$ & . 1 & 18 \\
\hline (Saher) de Wahull & . & • & & 30 \\
\hline
\end{tabular}

(Scutage Rolls, no. 7). The entry in each case is "qui habuit $\mathbf{x}$ milites" etc. I am not certain that I have the whole number of fees held by each man, but each held at least as many as are given above. Mercenaries were also employed; 3,000 footmen came from Ireland who received 2 d a day ( $\mathrm{Cal}$. Pat. Rolls, I, 458, 461). Service in the army was not limited to 40 days: 'Quia Stephanus Lungesp' est in expedicione exercitus Walliæ et quamdiu ibidem erit ignoratur" etc. (Close Rolls, no. 58, m. 4 d). If the rear-vassal refused to obey the summons of his lord, the sheriff distrained him; the vassals of the abbot of Abingdon were thus distrained (ibid., m. 3, 5). 


\section{STUDIES IN TAXATION}

In the case of the greater tenants, both the service done and the service recognized were sometimes smaller than the old servitium debitum. Sometimes the old service was recognized, though it was not performed. Sometimes a tenant performed de gratia more than he recognized. ${ }^{86}$

Immediately after the resolution to make war had been taken, the king set about providing the money. During the month of June, the Italian merchants in England were summoned to appear at Westminster at the end of the month to grant either an aid or a loan of 6,000 marks or less. Failing a satisfactory reply, they were to be expelled the kingdom. ${ }^{87}$ The Jews owed the treasury 4,000 marks, due on September 29. After the campaign began, the king ordered that if they failed to pay, some of the wealthiest should be seized and sent to him in Wales, whence he would send them to Ireland to be kept in prison. ${ }^{88}$ Money was borrowed from the earl of Cornwall. ${ }^{89}$ All this shows the poverty of the exchequer.

For this campaign, a scutage at three marks per fee was taken, levied while the host was in Wales. ${ }^{90}$ It appears in the Pipe Roll of 1246. This was not an aid, but was paid by those who had not performed their service. Some tenants seem to have fined in addition to paying scutage. ${ }^{91}$ Tenants who served were allowed to collect scutage from their men, even when service in part only was performed. ${ }^{92}$ Distraint was used to compel rearvassals to pay scutage to their lords and to enforce the payment of the tax at the exchequer. The collection might be long delayed. ${ }^{93}$ The total amount charged was $£ 3,903 \mathrm{5s} 8 \mathrm{~d}$, of which $£ 756 \mathrm{16s}$ 11d was paid in 1246 and $1247 . .^{94}$

86 "Servicium factum domino $H$. regi Angliæ in Wallia anno regni sui vicesimo nono." The entries which contain notices of the service which the tenants recognized run as follows: "Johannes de Curteney se tercio-non plus recognovit"; "Robertus de S. Johanne se quinto 


\section{UNDER JOHN AND HENRY III}

militum-recognovit servicium trium militum et residuum facit de gratia." The following are some cases:

\begin{tabular}{|c|c|c|c|c|}
\hline & & $\begin{array}{l}\text { Old } \\
\text { servi- } \\
\text { cium }\end{array}$ & $\begin{array}{l}\text { Knights } \\
\text { fur- } \\
\text { nished }\end{array}$ & $\begin{array}{l}\text { Service } \\
\text { recog- } \\
\text { nized }\end{array}$ \\
\hline Bishop of Bath . & - & 20 & 2 & 2 \\
\hline Philip de Columbiers & - & 10 & \multicolumn{2}{|c|}{$\begin{array}{l}1 \text { knight } \\
2 \text { serg. }\end{array}$} \\
\hline Abbess of St. Edwards & - & 7 & \multicolumn{2}{|c|}{$\begin{array}{l}3 \text { knights } \\
8 \text { serg. }\end{array}$} \\
\hline Robert de Novo Burgo & - & 15 & 2 & 12 \\
\hline Albreda des Boterels & - & 8 & 2 serg. & 1 \\
\hline Bishop of Salisbury & • & 32 & ( 2 knights & 5 \\
\hline Abbot of Abingdon & - & 30 & 4 & 30 \\
\hline Saher de Wahull . & - & 30 & 2 & 2 \\
\hline Abbot of Peterborough & - & 60 & \multicolumn{2}{|l|}{1 knight } \\
\hline Ralph Basset & - & 15 & 2 & 15 \\
\hline William Fitz Hamon & . & 15 & 2 & 15 \\
\hline Earl of Winchester & - & 60 & 10 & $\begin{array}{l}\text { 31/2 "et residuum } \\
\text { de gratia." }\end{array}$ \\
\hline \multicolumn{2}{|c|}{ John de Curteney (Okehampton) } & 92 & 3 & 3 \\
\hline Robert de St. John & . & 55 & 5 & $\begin{array}{l}\text { "et residuum } \\
\text { facit de gratia." }\end{array}$ \\
\hline Hugh Fitz Ralph . & . & 3 & 1 & 3 \\
\hline Joanna de Nevill . & . & 8 & 2 serg. & 1 \\
\hline Godfrey de Alno. & . & 1 & 2 serg. & 1 \\
\hline Robert Belet & - & 1 & 2 serg. & 1 \\
\hline Walter de Pavilly . & . & 1 & 2 serg. & 1 \\
\hline Henry Hose . & . & 2 & 1 & 1 \\
\hline William Maudut . & . & 1 & 2 & 1 \\
\hline Roger de St. John & . & 1 & 1 & 1 \\
\hline William de Hampton & . & 1 & 1 serg. & $1 / 2$ \\
\hline Nicholas de Bassingbur & $n$ & 1 & 1 serg. & 1 \\
\hline Gilbert de Bolebec & - & 1 & 1 & 1 \\
\hline Peter de Sabaudia ( $\mathbf{H}$ & aor Rich- & & & \\
\hline mond) & . & 140 & 13 & $\begin{array}{l}5 \text { "et residuum } \\
\text { facit de gratia." }\end{array}$ \\
\hline
\end{tabular}

(Chancery, Miscellanea, bundle 5, no. 1.)

The old service in the case of most of the greater tenants has been taken from the reign of Henry II, but in the case of the smaller tenants, I have given the number of fees for which they account in the Pipe Roll of the scutage of Gannoc, 1246.

The legal reduction of the old service at this time is also illustrated by the grant of the honor of Richmond. That honor con- 


\section{STUDIES IN TAXATION}

tained 140 fees. In 1241, it was granted to Peter de Sabaudia (Cal. Pat. Rolls, I, 251); the service which he was to perform for it was that of only five knights: "ex concessione vestra (i.e. regis) hactenus tenui honorem Richemundiæ a robis pro servitio quinque militum" (Shirley, II, 210). See also above, p. 221, note 208.

87 Close Rolls, no. 58, m. 7, 8.

88 Ibid., m. 2.

$892,000 \mathrm{~m}$ (ibid., m. 2) ; of this sum, $1,750 \mathrm{~m}$ were a loan and $250 \mathrm{~m}$ were the earl's fee (Cal. Pat. Rolls, I, 456, 459); 3,000m "sub pignore jocalium regis" (Matthew Paris, IV, 487); probably this is the same loan as that mentioned in the Patent Roll, as both are secured in the same way. See Cal. Pat. Rolls, I, 458, for another loan; $£ 39710$ s 6 d of the treasure of Ireland were paid at Gannoc (ibid., 361); September 14, the king asked the officials of the exchequer to forward him $3,000 \mathrm{~m}$ at once, or at least $2,000 \mathrm{~m}$ (Close Rolls, no. 58, m. 2).

90 "Scutagium exercitus domini regis de Gannok concessum apud Gannok" (Scutage Rolls, no. 7, m. 1).

91 The bishop of Winchester was charged with scutage and also with a fine of $100 \mathrm{~m}$ (Pipe Roll, 30 Henry III, Hants, m. 12 d).

92 Scutage Rolls, no. 7 . The men who furnished only part of their nominal service were granted all their scutage in the Scutage Roll.

93 Madox, I, 678, n. $g$, 40 Henry III; n. $f$, 38 Henry III; distraint of the tenants of Nigel de Amundevill' (Exch. K. R. Mem. Roll, 38 Henry III, m. 11); distraint on the lands of Ralph Musard to pay scutage to the exchequer (ibid., m. $25 \mathrm{~d}$ ); distraint of tenants of Roger de Luretot to pay him his scutage (Exch. L. T. R. Mem. Roll, 39 Henry III, m. 10) which he owed at the exchequer (Pipe Roll, 32 Henry III, Cant. and Hunt.). When the orders to collect the scutage were originally issued, the sheriff was to take nothing from the lands of those who had writs of scutage: "Quia alias mandatum est vicecomiti quod de singulis feodis militum que de rege tenentur in capite in comitatu suo levaret xl sol. de scutagio de Gannok præterquam de feodis illorum qui ei detulerunt brevia regis de scutagio suo habendo" (Exch. K. R. Mem. Roll, 36 Henry III, m. 17 d). Thus there was not a general collection from the rearvassals.

94 The account follows:

Clerical tenants . . . . . . . 380

Fifty-nine lay tenants (each 5 or more fees) . $\quad \begin{array}{rr}2909 & 3 \\ 10\end{array}$

Other lay tenants (each fewer than 5 fees, etc.) $\quad \begin{array}{rrr}614 & 1 & 10\end{array}$

Total

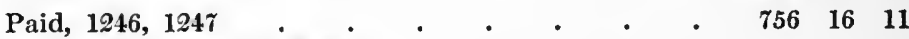

Fees taxed, less than 2,000 .

Of the sum charged against lay tenants, each fewer than 5 fees, etc., 


\section{UNDER JOHN AND HENRY III}

In 1245, a tallage was assessed on the royal demesne. Towns and cities fined for it. The levy was made by the sheriffs and other royal officials, assigned to this work..$^{95}$ An incomplete account (twenty-three counties) gives 6,646 marks charged.$^{96}$ In 1247 , the king received a loan of 10,000 marks from the earl of Cornwall. ${ }^{97}$ In July, 1248, after the great council had refused him an aid, Henry III sold his plate and jewels to the Londoners to raise money. ${ }^{98}$ At the close of this year and in 1249 , as he was still unable to get a grant from the council, he asked contributions from individual barons and clergy, claiming that he owed 30,000 marks. ${ }^{99}$ He obtained some from religious houses. St. Albans paid sixty marks and promised sixty marks more in 1250; Dunstable paid ten marks; the priory of Worcester, fifteen marks. ${ }^{100}$ Simon Passelew was sent into Essex and Hertfordshire with orders to coöperate with the sheriff to collect an aid from religious houses. ${ }^{101}$ A tallage was levied, amounting in

$£ 205$ were charged on tenants on the honors of Boulogne, Lancaster, and Peverel, leaving about $£ 400$ on tenants in chief, or 200 fees.

95 In Northumberland, it was assessed by the sheriffs of Northumberland and Cumberland (Cal. Pat. Rolls, I, 502); in Chester, by the justice of Chester and Henry de Wengham, a royal justice (ibid., 467); in Yorkshire, by Richard de Tatesden and John Gumbaud, a royal justice (Pipe Roll, 30 Henry III, York; Close Rolls, IV, 345). 96 This includes London, $2,000 \mathrm{~m}$. These entries are from the Pipe Rolls of 1245, 1246, 1247. There are references to this tallage in Madox, I, 707, 709, 710, 711, 735, 743, 755; II, 116, n. $x$; Maitland, Manorial Courts, pp. 10-14. The reference in Madox, I, 739, n. $c$, to a tallage on London per capita and by wards, taken from the roll of 31 Henry III, refers to the tallage of 1226 .

${ }_{97} \mathrm{Cal}$. Pat. Rolls, I, 505. He also borrowed $£ 350$ from Florentine merchants (ibid., II, 1); in January, 1246, he was loaned $1,000 \mathrm{~m}$ by Siennese merchants and $500 \mathrm{~m}$ by the Hospitallers (Pells Receipt Rolls, No. 124).

98 Natthew Paris, V, 20-22.

99 Ibid., pp. 50-53.

100 Ibid., p. 52; Dunst., p. 176; Wig., p. 439. Some houses refused. 101 Matthew Paris, V, 53; Cal. Pat. Rolls, II, 34. In the Pipe 


\section{STUDIES IN TAXATION}

thirty counties to about 6,000 marks. ${ }^{102}$ In this year also, Henry III borrowed from Italian merchants to pay the pope's tribute. ${ }^{103}$ In 1250 , the pope is said to have granted the king a twenty-third of the goods of all the clergy, but little was realized from this because some of the bishops opposed it. ${ }^{104}$ This year, the king is said to have reduced the expenses of his court and at Christmas to have made none of the customary presents to his familiars. ${ }^{105}$ On December 26, 1251, the marriage was celebrated between Margaret, Henry III's daughter, and the king of Scotland; the English king promised to pay 5,000 marks as a dowry within the next four years. ${ }^{108}$ To raise this sum, a tallage was levied. Towns fined for

Roll of 1249, there are given in 11 counties, 78 houses which contributed 370 marks; "et de $\mathrm{C}$ et xlvi li. xiiis iiiid de abbate de Cogeshal' et aliis diversis abbatibus de ordine Cyscestrens' . . . et de MCC lxiii $m$ et dim. de privatis donis quorundam abbatum et priorum ... et de $M$ d c lxxvi li. xvs iiid de donis diversorum" (from a Wardrobe Account, 29-36 Henry III, Pipe Roll, 35 Henry III, m. 7).

102 Devon, Lincoln, Essex and Hertford, and Sussex are the missing counties. London paid $£ 1,000$. In the counties of Notts. and Derby, Cumberland, York, Lancaster, Northumberland, and Worcester, the assessment was made by the sheriff and Thomas de Stanford and William de Axemuth. In May, 1248, Thomas was the king's escheator in all these counties except Worcestershire (Cal. Pat. Rolls, II, 16); William is spoken of as a king's clerk in 1248 and as a judge in 1249 (ibid., pp. 24, 34, 51, 53). In Stafford, Dorset and Somerset, Salop and Gloucester the assessment was made by the sheriff and Henry de Wengham, later, chancellor, an escheator (ibid., II, 11, 72); in Northampton, by William de Axemuth, Fulk de Orreby, escheator of Chester (ibid., 40, 41), and J. de Grey, justice of Chester (ibid., 45); in Surrey by the sheriff and Simon Passelew, a king's clerk. The tallage is mentioned in Madox, II, 215, n. $y$; Lanc. Record. Soc., XLVIII, 176. The Jews were tallaged this year in $500 \mathrm{~m}$ of silver and $20 \mathrm{~m}$ of gold (Cal. Pat. Rolls, II, 46; Matthew Paris, V, 114, 136).

${ }_{103}$ Cal. Pat. Rolls, II, 41, 42.

104 Theok., p. 139.

105 Matthew Paris, V, 114, 199.

108 Cal. Pat. Rolls, II, 121. 


\section{UNDER JOHN AND HENRY III}

it as usual. The total amount recorded as levied is $7,100 \mathrm{~m} 10 \mathrm{~s} 5 \mathrm{~d}$ of silver and $20 \mathrm{~m}$ of gold. ${ }^{107}$ It was assessed by the sheriff and other royal officials. ${ }^{108}$

107 The account is taken from the Pipe Rolls of 1252, 1253 and 1254. Only Devon, Sussex, and Cornwall are omitted, so that we have practically a complete account as far as the Pipe Rolls record it. London paid $1,000 \mathrm{~m}$ of silver and $20 \mathrm{~m}$ of gold (Close Rolls, 39 Henry III, m. 20 d); Matthew Paris, V, 333, mentions only the $20 \mathrm{~m}$ gold.

108 In London, it was assessed by John Mansell, "chancellor of London, ... . the king's secretary" (Cal. Pat. Rolls, II, 230), William de Haverhull, the treasurer, and Edward de Westmonasterio, a clerk of the exchequer (ibid., II, 142); in Dorset and Somerset, by the sheriff and William de Axemuth, a justice (Pipe Roll, 37 Henry III, Dors. and Somers.); in Cant. and Hunt., by Richard de Sireburne and Richard Rus, clerks of the exchequer (Cal. Pat. Rolls, II, 218, 277). Other notices of this tallage: Theok., p. 145; Cal. Pat. Rolls, II, 139; Excerpta, II, 126, 145; Madox, I, 752, n. $g$. 


\section{CHAPTER VIII}

\section{The Taxes in Detall from 1253 to 1258}

THE taxes in this period consisted of an aid to knight 1 the king's son, a scutage, the tenths on the clergy, a tallage and an aid on the towns, and a donum from religious houses. The tenants in chief continued to refuse to grant a gracious aid on their military fees, and the king did not try to collect it without their consent. It is likely that the aid to knight the king's son was taken after the failure to obtain a gracious aid from the great council for the expenses of the campaign in Gascony. The two expeditions of the period (one to Gascony in 1253 and one to Wales in 1257) were both properly occasions for scutage. None was taken in 1253, doubtless on account of the aid of that year. Both expeditions were accompanied by fines; in both, tenants served with only part of their contingents. Though the barons thus had to perform service overseas, they were disposed to set limits to it. They objected to fighting against the king of Castile, and Henry III promised that such service should not be considered a precedent.

The refusal of gracious aids on military fees was one important feature of this period; the taxation of the clergy was the other. That Henry III should succeed in taxing a class which apparently had successfully resisted John is sufficiently striking, the more so that he did it at a time when the opposition to his extraordinary levies had so greatly increased. The reasons for the king's success lie in the support which he received from 


\section{UNDER JOHN AND HENRY III}

the pope and in the attitude of neutrality adopted by the lay tenants in chief. The historical preparation for this taxation is to be found not in the sixteenth of 1226 or in the dona which Henry III levied on religious bodies, but in the repeated taxes on church property which the pope had levied. The levy of the tenths caused great opposition. The king was unable to collect them till the clergy had given their consent. The method of assessment was by a jury which was composed of the clergy. The whole work of assessment was in the hands of the clergy, not of lay officials. Even the disbursement seems to have been controlled by the papal nominee, Rostand. The sums received were spent not in England, but in furthering the war in Sicily. The opposition of the clergy was so strong that the tenth for the last two years was compounded for in a lump sum. Finally, it will be observed that the tenths were much heavier than the papal taxes which had immediately preceded them, and this increase was no doubt one of the causes of complaint.

\section{The Taxation of 1253}

On October 13, 1252, the prelates and lay tenants in chief met by special summons at Westminster. The king proposed to lead an expedition at this time to Gascony, but it was postponed on account of the opposition of the magnates. ${ }^{1}$ Henry III asked the clergy for the tenth of ecclesiastical revenues which the pope had granted him, but they refused. His request to the laity to grant him an aid for the crusade met with the response that they

1 Matthew Paris, V, 324, 334-337; Burton, p. 305; Bémont, Simon de Montfort, p. 278, citing a writ from the Close Roll of August 6, 1252, summoning tenants to Westminster on October 13, ready to cross with him; men of the coast towns were to have ships at Portsmouth on October 6 ad transfretandum nobiscum in Vasconiam, Close Rolls, No. 65, m. 7 d; Lords' Report on the Dignity of a Peer, III, App. I, p. 11. 


\section{STUDIES IN TAXATION}

would do nothing without the clergy. The whole matter was finally postponed to a meeting of the great council which was to be held in the spring of $1253 .{ }^{2}$ On April 27, 1253, the council met; the prelates granted the tenth and all the tenants in chief agreed to pay an aid of three marks on the fee for the knighting of Edward, half to be paid at Michaelmas, 1253, and half at Easter, 1254. In return the great charter was confirmed. ${ }^{3}$ The prince was knighted in 1254, but the aid on military tenants, though nominally levied for this purpose, seems really to have been taken to defray the expenses of the campaign in Gascony. ${ }^{4}$ The king was unable however to obtain the kind of grant that he wished and had to resort to one of the regular aids.

After the meeting, the host was summoned to meet at Portsmouth at the end of June. ${ }^{5}$ The departure of the fleet was delayed till August 6, on account of adverse winds, according to Matthew Paris, but there seems to have been some opposition to the expedition among the barons. ${ }^{8} \quad$ Thus the king expected his tenants in chief to

2 Matthew Paris, above; Burton, above.

3 A special summons to the council was issued: "tota edicto regio convocata Angliæ nobilitas" (Matthew Paris, V, 373). Those present were "cum comitibus et baronibus quamplurimis archiepiscopus Cantuariensis B., episcopi Angliæ fere omnes" (ibid.); "episcopis, comitibus, baronibus, militibus, abbatibus, prioribus" (Dunst., p. 186); Matthew Paris, VI, 250; Close Rolls, no. 66, m. 11.

4 "convocavit rex magnates suos pro succursu habendo ad terram Wasconiæ recuperandum. ....Et tunc petiit auxilium" (Dunst., above).

5 The barons of the Cinque Ports were ordered to have their ships at Portsmouth on June 22 to transport the host (Close Rolls, no. 66, m. 12 d); Cal. Pat. Rolls, II, 230; Matthew Paris, V, 381.

6 Matthew Paris, V, 383; Dunst., above; Theok., p. 153; Cal. Pat. Rolls, II, 236; "quia plures tenentes de nobis in capite . . . sepius a nobis requisiti ut nobiscum transfretarent in Vasconiam ... mandata nostra contempnentes nobis super hoc respondere ... tibi districte precipimus ... quod ipsos contemptores distringas ad veniendum ... coram consilio nostro" (Close Rolls, no. 66, m. 4 d). 
perform service in Gascony and was able to compel them to serve. ${ }^{7}$ Some were distrained; some fined to be allowed to remain at home; some were excused because they were on the Welsh frontier and were to assist in keeping order there. ${ }^{8}$ It was not necessary for the tenant to furnish his whole quota of knights. Service in part was considered to be the equivalent of full service. ${ }^{9}$ In addition to the fines from military tenants, the king, as usual, collected contributions from religious houses, some of which did not hold by military service. The prior of Tewkesbury paid 20 marks; the prior of Dunstable, $£ 10$; the prior of Worcester, 40 marks ; the abbot of St. Albans, 70 marks ;

7 Over 300 writs of protection were issued to men accompanying the king (Cal. Pat. Rolls, II, 231, 235).

8 William de Beauchamp, $45+$ fees, fined in $£ 100$ for his passage (Close Rolls, No. 66, m. 9) ; Roger de Huntingfield fined in 60 marks, but afterward sent one knight instead (Madox, I, 669, n. z); Philip de Colombiers (10 fees) fined in 30 marks (Excerpta, II, 186); Henry de Tracy (56 fees) "C marcas de auxilio contra transfretacionem regis in Vasconiam"; Ralph de Valtort $£ 10$; Matthew de Luvein (10 fees) 20 marks; Richard de Munfichet (47+fees) 100 marks; Earl Ferrers (681/2 fees) 200 marks (Pipe Roll, 38 Henry III, Devon, Essex and Hertford, Notts. and Derby); "quia Willelmus Maudut transfretaturus est cum rege in Vasconiam mandatum est vicecomiti Wiltes' quod districcionem quam ei facit pro dicta transfretatione penitus relaxet" (Close Rolls, no. 66, m. 5); "quia Hugo de Bolebec finem fecit cum rege pro transfretatione sua cum rege in Vasconiam mandatum est vicecomiti Norhumbr' quod districcionem quam facit super eum occasione prædictæ relaxet" (July 16, ibid., m. $8 \mathrm{~d}$ ); also the cases of William de Ros, Reginald de Mohun, Gilbert de Gaunt (ibid., m. 6, m. 6 d, m. 8 d); Walter de Clifford and John de Monmouth were excused on account of service in the march of Wales (ibid., m. 6 d).

๑ The summons issued August 6, 1252, called for partial service. Warner de Munchanesy was to come se quinto; Hugo de Vivoniis, se altero (Bémont, op. cit., p. 278). They held respectively $141 / 2$ fees and $11+$ fees (half of the fee of William Malet) (Pipe Roll, 38 Henry III, Kent, Dors. and Somers.). Philip de Colombiers served se quarto (Excerpta, II, 186); he held 10 fees. William de Say was summoned se tercio; he held 42 fees. The writ of summons rarely states with how many knights the tenant is to come. 


\section{STUDIES IN TAXATION}

the prior of Wotton, 10 marks; the abbot of Tavistock, £10. Some of these sums were paid before the king set out. $^{10}$ This was not a part of the tenth; it was a donum for the king's crossing. ${ }^{11}$ A tallage had recently been levied for the marriage of the king's daughter and Henry III apparently did not venture to collect another in 1253 . Instead, he sent out officials to ask the tenants on his demesne to contribute an aid to his crossing and to pay it before June 22. ${ }^{12}$ In these ways, money was gathered in addition to the aid granted by the great council. No scutage was taken for the expedition, though the possibility of such a levy was considered. ${ }^{13}$

10 Theok., p. 152; Dunst., p. 186; Wig., p. 442; Matthew Paris, VI, 251 ; Madox, I, 268, n. s; Cal. Pat. Rolls, II, 236; Pipe Roll, 38 Henry III, Deron; Wav., p. 345. The prior of Tewkesbury paid about February 2; the abbot of St. Albans on June 19.

${ }^{11}$ E.g. "de promisso ad ultimam transfretationem regis" (Madox, above); "to receive from the said abbots ... a competent aid" (Cal. Pat. Rolls, above); several contributions appear in the Pipe Roll from religious bodies "de auxilio ad transfretationem regis in Wasconiam"; as not all the payments were made at the exchequer, this list is probably not exhaustive.

12 "To all the tenants of the king's manors in the counties of ... As the king cannot enter upon the business, ... without the aid of them and other his tenants, he is sending them his clerk ... to explain ... a and to require of them a competent aid against his said crossing" (Cal. Pat. Rolls, II, 229); "competens auxilium de gratia" (Close Rolls, no. 66, m. $11 \mathrm{~d}$ ); Cambridge, $£ 20$ "in auxilium transfretationis" (Madox, I, 609, n. g); London, 500 marks "quas regi promiserunt in subsidium eundi in Vasconiam et pro quibusdam libertatibus" (ibid., n. $h$ ); "de auxilio ad passagium" (Madox, II, 240, n. $k$ ); the Liber de Antiquis Legibus (p. 19) mentions this payment by London, but says it was for certain liberties, pro illa carta habenda; Madox, I, 718, n. o; 747, n. $m$; Rot. Orig., I, 12b; in the Pipe Roll, there are some cases, e.g. "totum hundredum de Middelton' r c de $\mathrm{C}$ marcis de auxilio ad transfretationem regis in Vasconiam" (Pipe Roll, 38 Henry III, Kent, m. 12 d). The accounts of the tallage in the Pipe Roll of 1253 belong to the tallage of 1251.

13 William de Beauchamp fined in $\mathfrak{f 1 0 0}$ for his crossing "et rex concessit ei quod si ratione transfretacionis illius scutagium currat quod idem Willelmus habeat scutagium suum sicut etiam ceteri magnates qui cum eo transfretant" (Close Rolls, no. 66, m. 9). 


\section{UNDER JOHN AND HENRY III}

The aid to knight the king's son was an aid in the technical sense. ${ }^{14}$ Though taken at the time of the expedition to Gascony, it was not paid in lieu of military service. The earl of Warwick took part in the campaign, yet he was liable for the aid on all his lands. ${ }^{15}$ The earl Warenne paid the aid and accompanied the king. ${ }^{18}$ Both clerical and lay tenants shifted the tax to their vassals. ${ }^{17}$

14 This the account:

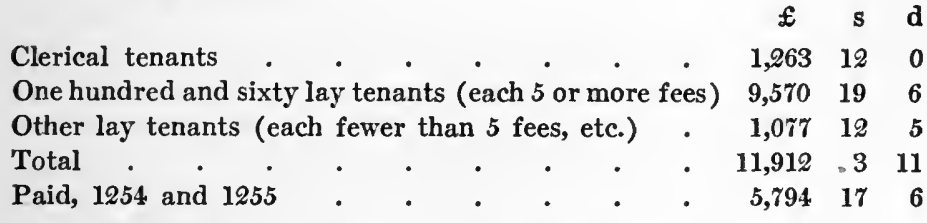

Ten of the 160 greater lay tenants are on honors in hand. Of the sum charged against tenants holding fewer than five fees each, etc., $£ 317$ were against fees on honors in hand, leaving not over $£ 760$ on tenants in chief. The total number of fees charged with the aid in the roll is 5,956. The following number of fees was omitted: clerical fees, about 150; the county of Cornwall, 220 fees; the honor of Wallingford, 100 fees; and 113 fees of the honor of Brittany (that honor had 140 fees). This gives a total number of fees which accounted at the exchequer of 6,537 .

$15 \mathrm{He}$ had a writ of protection for accompanying the king (Cal. Pat. Rolls, II, 232); "as he ought shortly to pay for all his fees the aid due for making the king's first-born son a knight" (ibid., II, 393); Madox, 1,617 , n. $f ; 683$, n. $w$.

18 Dugdale, The Baronage of England, I, 77b; Philip de Arcy accompanied the king (Cal. Pat. Rolls, II, 231), probably in place of his father Norman who had been given into his care (ibid., II, 264), yet the fee of his father paid the aid (Pipe Roll, 38 Henry III, Linc.); cf. Roger de Sumery (Cal. Pat. Rolls, II, 233 and Excerpta, II, 187); William Bardolf (Dugdale, I, 681); Philip Marmiun (Cal. Pat. Rolls, II, 232; Madox, I, 597, n. y, and Michel, Rôles gascons, I, 307, no. 2361). Those men who fined to escape service paid both the fine and the aid: William de Beauchamp fined in $£ 100$ and paid his aid (Close Rolls, no. 66, m. 9; Pipe Roll, 38 Henry III, m. 4 d); Henry de Tracy fined in 100 marks and paid the aid (Pipe Roll, 38 Henry III, m. 5 d).

17 For the prelates (Matthew Paris, VI, 250; Madox, I, 598, n. $d$; Red Book, III, 842). No general order to this effect has been found for lay tenants, but the following cases show that such was probably 


\section{STUDIES IN TAXATION}

The arrangements for the collection of the aid are worth notice. As this was an aid to knight the king's son, the tenants in chief could not legally refuse either to grant or to pay it. But if they had to pay the tax, they proposed that the king should collect it strictly according to the law. The sheriff could distrain for payment, but his distraint was to be done legally. ${ }^{18}$ He was not to enter a holding and distrain the rear-vassals without the consent of the tenant in chief. Thus clerical tenants had arranged with the king to take the aid from their vassals who were to be distrained by the sheriff to pay it, not to the exchequer, but to the prelates who would respond. ${ }^{19}$ In accordance with the provisions of the royal writ, the sheriff was further to distrain only the immediate tenant of the prelate. ${ }^{20}$ When he distrained the lay barons to pay the aid, he was to distrain the demesne, not the knights enfeoffed on their lands. ${ }^{21}$ All these regulations

issued: order to the sheriff of Devon not to distrain the demesne of the countess of Devon for the aid "et distringat omnes tenentes per servicium militare tam de eadem comitissa quam eodem B. (de Insula, part of whose lands she held at farm) ad reddendum regi prædictum auxilium" (Exch., K. R. Mem. Roll, 38 Henry III, m. $12 \mathrm{~d})$; to the sheriff of Salop "quod distringat tam tenentes de feodo Roberti de Stafford' quam ipsum R. per dominicum suum ad reddendum regi auxilium, etc." (ibid., m. 23 d); "Quia Johannes de Pleissis comes War' non potest habere auxilium ad primogenitum etc. de tenementis suis de prædicto comitatu eo quod illum comitatum non tenet hereditarie, mandatum est vicecomiti quod de demanda quam facit prædicto comiti de prædicto auxilio pro prædictis tenementis pacem etc. et distringat prædictos tenentes ad reddendum regi prædictum auxilium" (Madox, I, 683, n. $w$ ).

18 "Willelmus de Michedeure, vicecomes Surr' et Sussex', venit coram baronibus et recognoscit quod ceperat averia plurimum magnatum in comitatibus suis pro auxilio ad primogenitum etc. et ea tenuerat per tres septimanas et amplius et quia hoc est contra assisam regni consideratum est quod prædictus vicecomes est in misericordia" (Mem. Roll, above, m. $17 \mathrm{~d}$ ).

19 See above, note 17.

20 Madox, I, 597, n. $z$; 598, n. $c, d$.

21 'Monstravit regi Radulfus Dayrel' quod cum ipse nichil teneat 


\section{UNDER JOHN AND HENRY III}

do not mean that the different grades of rear-vassals escaped paying the aid; they were designed to prevent the entrance of the sheriff on the tenants' lands without their knowledge or consent, and were a protest against the increasing activity of the royal administration. The

de rege in capite in comitatu Buk' vicecomes injuste distringit ipsum ad reddendum regi xl sol. de auxilio ad primogenitum filium etc. de feodo unius militis ... de $\mathrm{H}$. de Ver comite Oxoniæ ut dicit et ideo mandatum est vicecomiti quod si ita est tunc de demanda quam facit ei de prædicto auxilio pacem etc. et distringat prædictum comitem ad reddendum regi prædictum auxilium" (Exch., K. R. Mem. Roll, 38 Henry III, m. 13); see also the cases of the earl of Gloucester and David de Flutewik (ibid., m. 15, 15 d) ; Madox, I, 597, n. $a, b$.

The following entry is difficult to explain satisfactorily: "Monstravit regi Galfridus le Chamberleing' quod cum magnates Angliæ concesserint regi auxilium ad primogenitum etc. de dominicis feodis suis et non de feodis que de eis tenentur, vicecomes injuste distringit ipsum ad reddendum regi prædictum auxilium desicut ipse nichil tenet de rege in capite set de Avic' de Ferlinton' ut dicit, et ideo mandatum est vicecomiti quod si ita est tunc de demanda quam facit prædicto Galfrido pacem etc. et distringat prædictam Aviciam etc." (Mem. Roll, above, m. $17 \mathrm{~d}$ ). This statement that the magnates granted the aid on their demesne fees and not on the fees held of them cannot mean that the tenant in chief paid the aid on the fees which he held in dominico only, for in the Pipe Roll each tenant accounts for the usual number of fees. It cannot mean that the baron paid the aid due on all the fees of his barony out of his demesne alone, while his vassals escaped. It is difficult to see why the barons should make such a grant; the permits to the clergy to collect from their tenants and the cases of lay tenants cited in note $\mathbf{1 7}$ show that the rear-vassals paid the aid. What this statement must refer to is the way in which distraint is to be applied to enforce the payment of the aid. 'In collecting the aid, the king is not to pass over the heads of the barons and deal directly with the rear-vassals. For the complaint in all the cases given in this note is not merely that the sheriff has distrained the rear-vassal, but that he has distrained him to pay the aid to the exchequer. It is true that in cases the sheriff does this and no complaint seems to be raised (note 17), but in each of these cases either some agreement has been made between the king and the tenant in chief, or there is some reason why the tenant cannot collect from his vassals. Exidently this has not been done here and hence the sheriff has done wrong to distrain the sub-tenant. It is possible that when the magnates granted the aid, they stipulated that Henry III was not to deal with the sub-tenant without further warrant. At 


\section{STUDIES IN TAXATION}

king's letter to the barons of the exchequer states that fees both of the new and the old enfeoffment were to be taxed. $^{22}$ This means that each tenant paid on the number of fees for which he ordinarily responded at the exchequer. ${ }^{23}$ Tenants by military service in Ireland were also asked to make an aid or-serve and the clergy and the towns were to contribute money. ${ }^{24}$

Matthew Paris says that the expenses of the campaign were $£ 2,700,000$ and that when the king returned, he owed 300,000 marks. ${ }^{25}$ These figures are too high. The expedition, however, made a heavy extra demand on the exchequer which it was impossible to satisfy without loans. $^{28}$ The expenses of the king in Gascony amounted to at least 45,000 marks. ${ }^{27}$

At the end of December, 1253, letters were received by the regents from Henry III which stated that he was

any rate, the king is held to this regulation. Another example of the way in which the government is held to the letter of the law is that the sheriff is permitted to distrain only the immediate tenants of the clergy to pay them the aid (Matthew Paris, VI, 250 and above, note 20 ).

22 Vincent, p. 87 ; Close Rolls, no. 66, m. 11.

23 The expression is no longer anything but a form.

24 Cal. Pat. Rolls, II, 229, 316; Close Rolls, no. 66, m. 12 d.

25 Matthew Paris, V, 450, 484, 488.

26 See the king's letter of August 31, 1254, requesting a loan from his brother, "as the king is so much in debt that he cannot leave Gascony before" October 13 (Cal. Pat. Rolls, II, 326).

27 The following sums were received from the treasury:

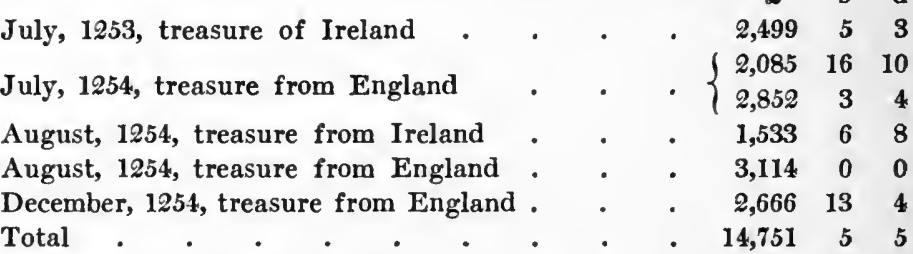

These sums are taken from the Cal. Pat. Rolls, II, 216, 314, 317, $320,386$.

The following sums were borrowed and were to be repaid in Eng- 
threatened by an attack from the king of Castile. Aid was asked from England. The great council was summoned and met on January 27 at Westminster. ${ }^{28}$ After considering the king's situation, the great barons and some of the prelates promised to go in person to the king's aid after Easter, if there was really danger from the Spanish king. The rest of the prelates agreed to contribute money at that time. The lesser lay tenants were not present and the great lay lords declined to make an answer for them. The regents therefore summoned two representatives from each county to meet at Westminster after Easter and report what contribution the lesser tenants of each county would make to the king. The

land, after the king's return. Of this money part, at least, was for use in Gascony.

July, 1253, from the earl of Cornwall . . . $\quad 4,000 \quad 0 \quad 0$

February, 1254, from the same . . . . . $\quad \begin{array}{rrr}2,666 & 13 & 4\end{array}$

September, 1254, from citizens of Agen . . $\begin{array}{rrrr}1,440 & 8 & 4\end{array}$

March, 1255, bond to Luccan merchants . . $\quad \begin{array}{llll}1,497 & 18 & 7\end{array}$

March, 1255, bond to Luccan merchants . . . $\quad 1,411 \quad 4 \quad 0$

March, 1255, payment of loan by merchants of Toulouse $\begin{array}{rrrr}760 & 0 & 0\end{array}$

December, 1254, residue of debt of king to the arch-

$\begin{array}{lllllllll} & \text { bishop of Bordeaux } & \text {. } & \text {. } & \text {. } & \text {. } & 733 & 6 & 8\end{array}$

September, 1254, bond to merchants of Bordeaux . $\begin{array}{rrrr}3,333 & 6 & 8\end{array}$

Total . . . . . . . . . $15,84217 \quad 7$

These sums are taken from the Cal. Pat. Rolls, II, 236, 300, 315, $328,335,340,341,353,359,364,386,404,405,528,555$.

The total received from the exchequer and borrowed is $£ 30,594,3 \mathrm{~s}$ $(45,891 \mathrm{~m} 3 \mathrm{~s})$. This is an incomplete account. No money is reported as received from the English treasury till July, 1254. The loans recorded in the Patent Roll amount to much more than the sum given above, but part of them were paid by money receired from home and by other loans, how much it is impossible to say; those given here were not paid till Henry III returned to England. Cf. Ramsay, Dawn of the Constitution, p. 148, note 4, for money received from England; also p. 294; R. J. Whitwell, E. H. R., XVIII, 710, for the income of the year 1253-1254.

28 It was composed of "archiepiscopos, episcopos, abbates, priores, comites et barones regni Angliæ" (Matthew Paris, VI, 282). 


\section{STUDIES IN TAXATION}

regents also asked for an aid from the lower clergy which the prelates would not grant at this time. In return for the promises of aid, the king confirmed the charters in the counties and promised that the assistance given him at this time should not be considered as a precedent. ${ }^{29}$ There was some opposition to the aid among the barons, for it was thought that there was no danger of an attack from Spain. ${ }^{30}$ In addition to the help promised by the council, the regents ordered the sheriffs to hire as many knights and sergeants as possible to cross with the barons in the spring. ${ }^{31}$ The magnates met at London on April 26, as had been agreed at the January meeting. An order from the king was produced asking for money to help him against the king of Castile. The magnates doubted whether the king was really in danger; if he was, they offered to go to his assistance, but they do not seem to have granted him any money. ${ }^{32}$ When the queen sailed

${ }^{29}$ Shirley (II, 101) and Matthew Paris (VI, 282) give letters of the regents to Henry III describing the action taken at the January council; Theok., p. 154; Dunst., p. 189; Matthew Paris, V, 423-425; in the Cal. Pat. Rolls, II, 279, 281, are given the letters patent that the assistance shall not be a precedent and there is mention there of the order to the sheriffs to proclaim the charter in the counties; Lords' Report on the Dignity of a Peer, III, App. I, pp. 12-13.

30 Natthew Paris, V, 424.

31 Order to the sheriff of Wiltshire (Close Rolls, no. 67, m. 12 d); the same order was given all the sheriffs (Matthew Paris, VI, 287). 32 Matthew Paris says that Henry III was merely talking of the king of Castile to help persuade the magnates to grant him money, that the earl of Leicester was present and told them the true situation, and that they returned home without doing anything $(V, 440)$. Negotiations between Henry III and Alfonso had been in progress for some time and this was probably the cause of the magnates' suspicions. The treaty was made on April 1 (Rymer, I, 297-298) and news could have reached England while the barons were meeting. The Annals of Tewkesbury say that the council met first at Portsmouth, then moved to London, and then to Winchester, and that the earl of Gloucester, all the magnates assenting, refused to go to Gascony unless the lands of which he had been deprived were returned to him (Theok., p. 155). 
for France in May, she was accompanied by some knights and the archbishop of Canterbury ${ }^{33}$ The representatives of the counties also met, but it is not known what action they took. ${ }^{34}$ At the same meeting of the magnates, the arrangements for the immediate collection of the tenth were made. ${ }^{35}$ Part of the clergy had promised in January to bring an aid for the king at Easter time, and one case is given where this was done. The abbot of St. Albans gave to the queen $£ 50$ when she crossed and to earl Richard an equal sum. ${ }^{36}$ Probably others did the same.

The account of this expedition shows that the king was still able to enforce military service in France from his tenants and that they disliked it. The speech of the earl of Gloucester, as reported by Matthew Paris, shows that they wished to hold Henry III within the limits of the feudal contract. ${ }^{37}$

\section{The Tenth of $1254^{38}$}

Before discussing this tax, it will be necessary to notice the taxes on the clergy which were levied by the pope for

33 Matthew Paris, V, 447; a list of letters of protection, issued on May 3 to persons going with the queen, is given in Cal. Pat. Rolls, II, 374; not all of these were tenants in chief and not all of these went, e.g. the earl of Gloucester who received a letter did not cross till September (Theok., p. 154).

${ }^{34}$ The writ of summons is in the Close Rolls, no. $67, \mathrm{~m} .13 \mathrm{~d}$; Select Charters, p. 376; Matthew Paris, VI, 286. The orders were carried out and choice made, for one of those elected in Essex could not serve and on April 2, the sheriff was ordered to have another chosen in his stead (Close Rolls, no. 67, m. 9).

35 See below, p. 271.

36 Matthew Paris, VI, 293. This was not a delayed payment of the aid for the king's crossing in 1253; see above, p. 256, note 10.

37 "Comes insuper Gloverniæ auxilium secundum posse suum spopondit; addens quod nullo modo ipsum regem juvaret ad adquirendum terram, sed ad corpus suum, si ipsum rex Castellæ hostiliter impeteret, liberandum" (Matthew Paris, V, 424).

38 On the taxation of the clergy from 1254 on, see the article by Miss Rose Graham, on "The Taxation of Pope Nicholas IV," in 


\section{STUDIES IN TAXATION}

the benefit of the Roman curia after 1229, for such cases serve as an introduction to the royal taxation of the clergy.

In 1238, the pope was in want of money to carry on the war against the emperor and he wrote to the legate, Otho, suggesting that the English clergy give a thirtieth of their revenues for three years. ${ }^{39}$ In 1240 , the legate asked for a fifth of the revenues of foreigners beneficed in England and also for a contribution from the native clergy. ${ }^{40}$ There was much opposition to this demand. Otho held a meeting of the bishops and abbots in the early part of the year to obtain their consent to the levy, but they asked that the matter be postponed..$^{41}$ Later he met the bishops and they declined to agree to the tax without the consent of the archdeacons. Accordingly another meeting was held in July when the legate received nothing more than reasons for not making a grant.. ${ }^{42}$ Then he called together the rectors of Berkshire, who also refused to assent to the tax. ${ }^{43}$ He was more successful when he approached the prelates individually. Many yielded, in

E. $H . R$., XXIII, 434, which has been freely drawn upon here. On the tenth of 1254, see the raluable essay by W. H. Hudson on "The Norwich Taxation of 1254," in Norfolk and Norwich Archoological Society Publications, XVII (1910), 43-157, of which I regret that I have not been able to make extended use. See also Barker, pp. 55-59.

39 Bliss, Calendar of Papal Registers, I, 177; "de . . tricesima" (Matthew Paris, VI, 91).

40 Matthew Paris, IV, 9; a fifth from foreign clerks and lump sums from the prelates (Dunst., p. 154); a fifth from foreign clerks and "xii omnium bonorum beneficiatorum Angliæ" (Theok., pp. 115, 116); a fifteenth (Wint., p. 88); Burton, p. 257; Hist. et Cart. S. Petri Glouc., I, 28; Barker, p. 54.

41 Matthew Paris, IV, 10.

42 Ibid., IV, 37; Theok., p. 115.

43 Matthew Paris gives objections as coming from the rectors of Berkshire when the demand for the tax was made from them "et quosdam alios" (IV, 38-43). The Burton annalist gives practically the same document, omitting the last four arguments against the 


\section{UNDER JOHN AND HENRY III}

each case paying a lump sum. The archbishop of Canterbury paid 800 marks; the church of Lincoln, $£ 100$; the prior of Dunstable, 20 marks; the bishop of Lincoln, 600 marks for his secular clergy; the prior of Tewkesbury, 50 marks; the abbot of Burton, 30 marks; the prior of Worcester, 140 marks. $^{44}$ Another papal delegate, Peter Rosso, had arrived in England to collect money. He obtained considerable sums from religious bodies, dealing with each separately. Each house paid a lump sum and its revenues were not assessed. ${ }^{45}$ At a final meeting of the clergy on November 1, the legate obtained the tax from all who up to that time had resisted..$^{46}$

In 1244, Martin, a papal clerk, was sent to England by Innocent IV, with powers of suspension and interdict, to collect arrears of papal taxes and to exact money in procurations, provisions, etc., from the English clergy. ${ }^{47}$ In addition he demanded the immediate payment of a lump

tax, but he states that it came from the rectores ecclesiarum Anglice and related to the levy of 1244 demanded by Innocent IV (Burton, pp. 265-267). There is nothing contradictory in the statements of the two chroniclers as to the source of the document; as to the date, one item in the list of objections shows that Matthew Paris is correct: "item, quod nuper alias præstiterunt contributionem in casu consimili, et promissum esset prebentibus, auctoritate istius ejusdem Papæ, quod de cætero non fieret hujusmodi exactio, etc." (Burton, p. 266; Matthew Paris, IV, 41). This seems to mean that the contribution now demanded was to be made to that pope who had formerly promised that another exaction of this kind should not be made. This would refer to Gregory IX, who died in 1241, and not to Innocent IV, for the contribution which he demanded in 1244 was his first.

44 Matthew Paris, IV, 15, 32; Dunst., pp. 154, 155; Theok., p. 116; Burton, p. 366 ; Wig., p. 432.

45 Matthew Paris, IV, 35-37. Peter and a companion went to Scotland where they obtained $£ 3,000$ (ibid., 55, 160).

46 Ibid., IV, 60; Theok., p. 116. The collection of this levy for the pope continued through 1240 and 1241 (Matthew Paris, IV, 137); Close Rolls, IV, 361. Matthew Paris says that a twentieth was collected in Ireland (ibid., p. 160).

47 Matthew Paris, IV, 284, 379, 391; Dunst., p. 166. 


\section{STUDIES IN TAXATION}

sum of 10,000 marks from the clergy as a whole, a demand that was strongly opposed by the king as well as by the clergy and lay magnates. The papal emissary was finally obliged to leave the country in 1245 and the question of the subsidy was postponed till the council of Lyons met. ${ }^{48}$ Then the pope asked for a twentieth of the revenues of the clergy for three years. ${ }^{49}$ A great council was held at London on March 18, 1246, and the grievances of the English against the Roman curia were discussed. Letters were written to the pope, one by the bishops, one by the abbots and priors, one by the laity, and one by the king who also wrote to the cardinals. Pending the pope's reply, the twentieth was not to be levied. ${ }^{50}$ The council of London had hardly dissolved when the bishop of Norwich issued orders for the collection of a subsidy of 6,000 marks for the pope. It appeared from the papal letter which the collector enclosed that the bishops who were at Lyons had agreed that the English church should pay this amount. ${ }^{51}$ Henry III at first forbade this to be paid,

48 Matthew Paris, IV, 311-316, 368-370, 374-376, 379, 416, 419-422; Dunst., p. 167; Roberti Grosseteste Epistolæ, pp. 276-277; Cal. Pat. Rolls, I, 463. The annals of Burton give a reply of the clergy, for which, see above, note 43 .

49 Matthew Paris, IV, 458; Burton, p. 269.

50 Matthew Paris, IV, 526-536; Burton, pp. 278-280, 283-285. The whole extract from Burton is the same as part of the extract from Matthew Paris. The latter states that this action was taken before the decision was made to pay 6,000 marks, the twentieth; the former connects all the protests with the second payment of 11,000 marks.

51 Matthew Paris, IV, 555-557. This order was issued on March 24. Delegates had been sent by the king and magnates to protest at the council of Lyons against the papal exactions. These had refused to agree to any payment by the English church (Matthew Paris, IV, 419-420; Dunst., p. 167). The bishops however had consented; notice also "de importabili contributione prætacta, ad quam episcopi in generali concilio clerum infeliciter obligarunt" (Matthew Paris, IV, $590)$. 


\section{UNDER JOHN AND HENRY III}

but was finally forced to yield. ${ }^{52}$ The tax was not based on an assessed value of clerical revenues; the bishops had agreed to pay a lump sum of 6,000 marks and this was apportioned among the dioceses. ${ }^{53}$

In the same year, the pope made another demand for money, from certain clergy half of their revenues, from others a third, and from others a twentieth, all for three years. ${ }^{54}$ Clergy, laity, and king all strongly opposed this contribution. The pope had appointed the bishop of London to carry out his mandate. On December 1, 1246, the latter held a meeting of some of the bishops in London and they, fortified by the king's command, refused to consent to this tax. ${ }^{55}$ On February 2, 1247, there was another council of the lay magnates and the archdeacons, who had been specially summoned; the bishops however absented themselves. Letters protesting against the tax were drawn up and sent to the pope and cardinals. ${ }^{56}$ On April $\mathbf{7}$, however, the prelates gave way. A lump sum of 11,000 marks was granted, which was paid to the bishops of Norwich and Winchester, the collectors of the previous subsidy. ${ }^{57}$ The pope sent out friars to collect sums from individual churchmen. ${ }^{58}$

52 Matthew Paris, IV, 554, 557-558, 560-561, 577.

53 Ibid., IV, 555-557; "cum nuper nomine vicesimæ sex milia marcarum domino papæ sint soluta" (ibid., p. 584); Burton, p. 282; Wykes, p. 94; Rob. Grosseteste Epist., pp. 340-341.

54 An interesting feature of this demand is that certain ecclesiastics were to pay a twentieth on incomes of $100 \mathrm{~m}$ and less; when the income exceeded $100 \mathrm{~m}$, a third of the excess was to be paid.

55 Matthew Paris, IV, 580-585; Burton, pp. 277-278, 280-282.

58 Matthew Paris, IV, 590, 594-597.

57 Ibid., IV, 622-623; in 1246, Dunstable paid $6 \mathrm{~m} 5 \mathrm{~s}$ and in 1247, $24 \mathrm{~m}$ (Dunst., pp. 171, 175); the priory of Worcester paid in both years (Wig., p. 438). The pope's demand is also given in Wykes, p. 94. Perhaps the bishops at the council of Lyons had also agreed to this levy, for Matthew Paris says "de importabili contributione prætacta, ad quam episcopi in generali concilio clerum infeliciter obligarunt" (IV, 590). He may however be confusing this with the twentieth. It is apparent from the protests that the sum of 11,000 


\section{STUDIES IN TAXATION}

In 1250, the clergy despatched representatives to Rome to work against the right of visitation of the archbishop of Canterbury. An aid of an eightieth of revenues was taken to provide the delegates with funds. ${ }^{59}$ In 1252 , they were successful in obtaining a limitation of the archbishop's right of visitation, for which they paid the pope 6,000 marks, apportioned among the bishoprics. No assessment of property seems to have been made. ${ }^{60}$

Henry III's promise to assume the cross led to the systematic taxation of the clergy for the king's benefit. He first obtained from the pope a grant of the sums collected in England for the crusade. ${ }^{61}$ In 1250 , the pope

marks was fixed as a composition for the tax by the clergy in England, not by the pope and bishops at Lyons.

58 The bishop of Lincoln was asked for 6,000 marks, which he refused (ibid., 600). The abbey of St. Albans was asked for $400 \mathrm{~m}$; it appealed to the pope and the amount was reduced to $200 \mathrm{~m}$. More trouble arose when it was asked to contribute to the donation of 11,000 marks (ibid., pp. 600, 617-622).

59 "Acceperunt igitur a beneficiatis de qualibet marca duos denarios" (Matthew Paris, V, 186); "pro qualibet marca duos denarios exigendo" (Dunst., p. 181).

60 Matthew Paris, V, 346, VI, 232; $£ 6,000$ (Theok., p. 150); 4,000 marks, Burton, p. 300; Osney, p. 104; Wykes, p. 104; Wig., p. 441. The chronicle of Dunstable, p. 186, says that a twentieth was paid; probably this was because the sum, 6,000 marks, was what the clergy had paid for the twentieth of 1246 and the assessment of that year may have been followed.

There is another case of assessment of ecclesiastical goods in 1252. The bishop of Rochester took a fifth for five years: "a beneficiatis in suo episcopatu quintam partem reddituum suorum usque in quinquennium, ... non secundum æstimationem bonorum ecclesiasticorum a subjectis, sed quocunque modo ex bonis ecclesiasticis emergentium" (Matthew Paris, V, 273). In 1256, there is another case. The dean and canons of St. Martin's, London, gave "with no one contradicting" "the yearly value of their prebends, calculated according to the ancient taxation, in aid of their church, so that in the first year, one quarter, in the second year, the second quarter, ... shall be given, etc.," that is a fourth for four years. The money was to be collected by one of the canons (Cal. Pat. Rolls, II, 588).

61 Gasquet, Henry III and the Church, p. 276. 


\section{UNDER JOHN AND HENRY III}

gave the king a tenth of all the revenues of the clergy for three years, to be collected by the prelates after the king should swear to go on the crusade and had fixed a date for his departure. The yield of the first two years was to be collected and delivered to the king when he was ready to set out. ${ }^{62}$ After Easter, 1252, Henry III swore to leave on June 24, $1256 .^{63}$ He then asked the archbishop of Canterbury to issue orders for the collection to be begun on September 29..$^{64}$ Similar orders were sent to the archbishop of York. The clergy of the latter province refused to allow the grant without the assent of the whole church of England. ${ }^{65}$ Accordingly the prelates were summoned to meet at Westminster on October 13, 1252, and the question of the tenth was discussed. The king asked that the money of at least two and a half years be paid him at once. The prelates proposed conditions which the king refused, and they then declined to make the grant. Henry III tried to break up the opposition by approaching each singly, but the attempt failed. Another council was appointed to meet after Easter, $1253 .^{68}$

Despite this refusal, the king sought to begin the collection before the council met again. In November, 1252, he appointed as collector the bishop of Chichester ${ }^{67}$ In January, 1253, the bishops of the province of Canterbury

62 Rymer, I, 272, 274; in 1252 (Theok., p. 150). February 16, 1251, the pope asked the bishops and archbishops to allow the first two years of the tenth to be collected for the king before he set out (Bliss, I, 267).

63 Rymer, I, 282.

64 Vincent, p. 85, citing Rot. Litt. Claus., 36 Henry III, m. 18 d. 65 Shirley, II, 95.

.66 Matthew Paris, V, 324-333; Burton, p. 305. According to Matthew Paris, the king produced an order from the pope, directing the tenth of the first two years to be collected for the king before he started. Probably this was the papal letter of September 1, cited by Bliss, I, 279 .

67 Rymer, I, 288; Cal. Pat. Rolls, II, 164. 


\section{STUDIES IN TAXATION}

met at London and the tenth was again discussed. They finally agreed that if the king would promise to redress certain grievances of the church, they would make him a liberal grant of aid, though they did not as yet agree to the tenth. The king was willing to promise. Articles containing the grievances were to be drawn up. ${ }^{68}$

On April 27, a great parliament met at London. After a session lasting over two weeks, the king obtained the grant of a tenth for three years and in return swore to observe the charters. ${ }^{69}$ The collection however did not begin till after Easter, 1254. The pope had instructed the clergy that the money of the first two years should be collected and delivered to the king when he started, and this was apparently interpreted to mean that the collection should not begin till two years before the sworn date of his departure. ${ }^{70}$ On September 12, 1253, the pope wrote, appointing new collectors and directing them to begin the work at once, but his orders were not carried

68 The proceedings described here are giren in Matthew Paris, V, 359-360; a meeting of the bishops is mentioned in Cal. Pat. Rolls, II, 171.

69 "concessa est igitur decima pars proventuum ab ecclesia recipienda cum iter Jerosolimitanum (arriperet) . . . per triennium"; at this meeting the aid to knight the king's son was also granted: "et a militibus, scutagium illo anno" (Matthew Paris, V, 373-377). Excommunication of violators of the charters is given in Burton, but there is no mention of the grant of the tenth at this time (Burton, p. 305); Rymer, I, 289; Bliss, I, 306.

70 "fraternitate vestra ... mandamus quatinus postquam statutum fuerit ejus passagium et juratum, per biennium ante idem passagium decimam . . . colligentes etc." (pope's letter to the prelates, 1250, Rymer, I, 274); Bliss, I, 279; in May, 1253, the king declared to the crusaders coming from Ireland that he had sworn to leare on the crusade at midsummer, 1256 (Cal. Pat. Rolls, II, 191). So the regents writing to Henry III in February, 1254, say "decima clericorum robis concessa de crucesignatione de primero anno quæ in præsentia debet incipere" (Shirley, II, 101); the same to the same, "propter decimam colligendam ... in proximum" (Matthew Paris, VI, 283). 


\section{UNDER JOHN AND HENRY III}

out. $^{71}$ At a meeting of the magnates at Westminster on January 27, 1254, the king through the regents asked that the tenth of the first year should be given him to use in Gascony. The prelates refused to agree to this, ${ }^{72}$ nor do they seem to have granted the request at the Easter meeting. ${ }^{73}$ Finally in May, 1254, the arrangements were made for the immediate levy of the tenth. The bishops of Chichester and Norwich and the abbot of Westminster were in charge of the work. ${ }^{74}$ Each prelate

71 Matthew Paris, VI, 296; Bliss, I, 290; Cal. Pat. Rolls, II, 164. These collectors were the same as those who took charge in 1254, viz., the bishops of Chichester and Norwich and the abbot of Westminster.

72 Matthew Paris, VI, 283; Shirley, II, 101; Dunst., p. 189.

73 This is not quite certain. According to the letter of the regents, the prelates doubted whether the lower clergy would agree to the use of the first year's tenth in Gascony unless the king issued letters patent declaring that this took the place of the first year's tenth for the crusade, and unless the king postponed the collection of the last two years till just before he started ("collecta ejusdem decimæ de duobus annis sequentibus... ponatur in respectum usque ad terminum duorum annorum ante passagium vestrum," Shirley, II, 101). The Dunstable annals say that the clergy demanded papal letters to the effect that this took the place of the tenth of the first year for the crusade (Dunst., p. 189). No such letters patent have been found, but arrangements to collect the tenth were made after Easter, 1254, and most of the chroniclers say that it was granted at that time (see below). Furthermore the whole yield of the first year was to be paid on September 29, if possible (Close Rolls, no. 67, m. 8 d). The date of payment suggests that the tenth was to be used by the king in 1254. The clergy therefore may have agreed to the king's request. But it is to be observed that when the collectors in July, 1254, ordered the tenth to be paid, they enclosed a papal letter written September 12, 1253, which, they declared, was "non cancellatum, non abolitum, non in aliqua sui parte vitiatum." This papal order stated "volumus autem quod in tutis locis dicta pecunia fideliter deponatur, assignanda eidem regi pro præfatæ Terræ (Sanctæ) subventione, cum iter arripuerit transmarinum, ita quod nihil interim sumatur vel extrahatur exinde absque mandato sedis Apostolicæ speciali" (Matthew Paris, VI, 296). The Burton annalist says, after describing the assessment on his priory, "facta est autem solutio istius pecuniæ primo anno nunciis ejusdem episcopi ... et in depositum missa" (Burton, p. 327).

74 Cal. Pat. Rolls, II, 370, 377; Matthew Paris, VI, 297. The fact 


\section{STUDIES IN TAXATION}

had a different district to supervise, but the levy is generally known as the Norwich taxation. The tax fell on spiritualities (tithes, offerings) and temporalities (rents, income from lands). ${ }^{75}$ The abbot of St. Albans paid the tenth of all the revenues of his churches, "præter baroniam." The prior of Worcester paid $£ 7$ s $1 \frac{1}{2} \mathrm{~d}$ on spiritualities and $£ 1910 \frac{1}{2} \mathrm{~d}$ on temporalities. ${ }^{77}$ Land held by military service was however exempt. ${ }^{78}$

A new assessment was made. In each deanery, the dean and three important rectors or vicars made oath to fix a just valuation of all the incomes of the churches and

that the assessment was not made till 1254 leads all the chroniclers to put the date of the grant in 1254: Dunst., p. 190; Wykes, p. 107; Osney, p. 107; Wint., p. 95; Theok., p. 156; Wig., p. 443; Wav., p. 348; Cont. Flor. Wig., II, 184; Burton, p. 325, who speaks of the bishop of Norwich only as the assessor. Both Burton and Matthew Paris say that the bishop of Norwich acted unwillingly. It is to be noticed however that the bishop had been one of the assessors of the papal subsidy of 1247 and had apparently done his work so well that the pope now appointed him to do similar work. Further, according to a writ on the Close Roll, he, as one of the assessors, was responsible for a measure designed to make the clergy pay on the full value of their property, viz., that if they thought that any one had made too low an estimate, the truth should be ascertained by their oath and that of their neighbors: "cum nuper consilio nostro ... per litteras vestras significareritis quod in imponenda decima... formam subscriptam provideritis . . . videlicet per sententiam excommunicationis promulgandæ in omnes personas ecclesiasticas qui justam proventuum suorum estimationem ... ocultabunt et si aliquos merito suspectos habueritis quod sua beneficia minus plene estimaverint per sacramentum ipsorum vel vicinorum suorum rei veritatem plenius eruendo, robis significandum duximus quod ex quo vobis videtur quod forma illa est ydonea eam approbamus" (Close Rolls, no. $67, \mathrm{~m} .8 \mathrm{~d}$ ).

75 The prelates had not wished to include income from their lands, but the pope refused to admit this: "faciatis . . . de maneriis eisdem decimam ... exhiberi" (Rymer, I, 280, anno 1252); Bliss, I, 284.

76 Matthew Paris, V, 451.

77 Wig., p. 443; "tam de laico feudo quam de ecclesiis" (Dunst., p. 196); for the prior of Malton, see Graham, in Royal Hist. Soc. Trans., New Series, XVIII, 148; Theok., p. 156; Burton, pp. 325-327.

78 See below. 


\section{UNDER JOHN AND HENRY III}

of the clergy. If necessary, they could compel anyone to swear to the value of any goods. They were also to assess property which lay in the deanery but belonged to religious houses outside. The rest of the property of religious houses, except parish churches and goods in the king's hand, was to be assessed by the head and some other members of the house. Those who opposed the tax or swore falsely were liable to excommunication. A roll of the assessment was to be drawn up and returned to the chief collector, to whom the tax was later to be paid. ${ }^{79}$ The detailed account of the goods and revenues, the use of the jury, the oath, and the penalty of excommunication were all designed to get at the real value of clerical property. No such searching inquiry had been made since 1229 and the severity of the measures caused complaint. The whole yield of the first year was to be paid on September 29, if possible; if not, part then and part later. ${ }^{80}$ The money was stored in churches and monas-

79 Burton, pp. 325-327; Matthew Paris, V, 451; Close Rolls, No. 67, m. 8 d. For returns made, Burton, pp. 327, 366; Registrum Malmesburiense (Rolls Series), I, 268-271; Liber Mem. Ecclesie de Bernewelle, pp. 190-199. The last is apparently the valuation made in 1254, but the tax levied was a twentieth, not a tenth, perhaps the levy of 1268. See also Graham, E.H.R., XXIII, 436, "The Taxation of Pope Nicholas IV," for references to other returns. See also Royal Hist. Soc. Trans., in note 77.

80 "primum terminum ad pecuniam solvendam circa festum $\mathrm{S}$. Michaelis proximo futurum præfigatis et si ad unum terminum haberi non poterit præfigatis alios terminos solutionis ejusdem pecuniæ prout vobis magis videritis expedire" (letter of the regents to the collectors, May 28, 1254, Close Rolls, no. 67, m. 8 d). Thus it was hardly expected that the assessment would be completed as early as this. On October 9, Henry III wrote to the official of the archbishop of Canterbury, asking him to ascertain carefully the value of the tenth, although he said it might seem difficult or even impossible to do so (quod cautiori modo et certiori quo poterit, diligenter scrutari et inquiri faciat estimacionem et valenciam decime) (Michel, Rôles gascons, no. 3727). Miss Graham, E. H. R., XXIII, 467, thinks that this request was an order for a new, independent inquiry into the value of church property and connects it with the writ for 


\section{STUDIES IN TAXATION}

teries and remained in charge of the collectors; it was not turned over to the exchequer. ${ }^{81}$

Henry III was not satisfied with the grant which had been made. He desired to extend the tenth to the baronies of the clergy. This was opposed and on February 5, 1255 , orders were issued to suspend such demands till the meeting of the great council after the following Easter. ${ }^{82}$ At that time the king asked for a tenth from the baronies of both laity and clergy. After deliberation the council asked for the confirmation of the charters and for the appointment of a justiciar, a chancellor, and a treasurer who should not be removed without the consent of the magnates. The king declined to agree to this request and the meeting was finally prorogued till October. ${ }^{83}$ The entrance of Henry III into the Sicilian affair gave the pope a more direct interest in the product of the tenth. The king had promised to pay a lump sum of 135,541 marks together with interest for the expenses already incurred by the papacy in Sicily. ${ }^{84}$ In May, 1254, the pope extended the period of the tenth from three to five years and ordered the collectors to store the receipts in safe places, where they were to be kept, not, as

an inquest into the manors of religious houses issued October 13 from the chancery, given in Matthew Paris, V, 464 (see also, Hall, Studies in English Official Historical Documents, p. 299, note 9). But it seems better to connect it with the writ cited from the Close Rolls and to regard it merely as an order to find out the amount of the tenth.

81 "the money for the Holy Land deposited in divers churches and monasteries" (Cal. Pat. Rolls, II, 429, 500); the collectors were in charge of the tenth when Rostand arrived, paid some of it to merchants by his orders, and turned the rest over to him (ibid., pp. 462, 508); "solutio istius pecuniæ ... in depositum missa" (Burton, p. 327).

82 Cal. Pat. Rolls, II, 396.

83 Burton, p. 336; Matthew Paris, V, 493-495; Dunst., p. 195; Wint., p. 95.

8ะ Rymer, I, 318; 135,501 marks (Shirley, II, 115). 
before, till the king set out on the crusade, but until the pope should decide how it should be spent for the crusade. $^{85}$ The statement suggests that it was planned to spend some of the tenth in Sicily. Finally in May, 1255, Alexander IV commuted the king's vow to go to the Holy Land into a vow to invade Sicily. Rostand, a papal subdeacon, was sent to England to take charge, in company with the archbishop of Canterbury, of the collection of all moneys for the crusade, including the tenth. ${ }^{86}$ On October 13, 1255, he summoned the clergy to Westminster and demanded that they should honor bills drawn on them in favor of Italian merchants, that the payment of the tenth of the second year should be hastened, and that the lay fees of the clergy should pay the tenth; at the same time, the king asked for an aid from his lay tenants. The prelates demurred and finally their answer was postponed till January, on account of the absence of some important bishops. Protests were sent to the pope. From the laity the king obtained nothing. ${ }^{87}$

Rostand however proceeded to issue orders for a new assessment which should include the baronies of the clergy. ${ }^{88}$ New deputies, some of whom were foreigners, but all clergymen, were appointed. ${ }^{89}$ The method of assessment was the same as in the preceding year, ${ }^{90}$ but the assessment was much stricter and was to be done

85 Rymer, I, 303. The grant of the tenth for five years was confirmed by Alexander $\mathrm{V}$ in the spring of 1255 (Bliss, $\mathrm{I}, 314$ ). Matthew Paris, V, 452.

86 Rymer, I, 319, 322; Matthew Paris, V, 519-520; Burton, pp. 350352; Dunst., p. 196.

87 Matthew Paris, V, 520-521, 524-526, 530-532; Burton, p. 360.

88 Burton, p. 354.

89 Ibid., p. 353; Cal. Pat. Rolls, II, 485, 505, 514, 515, 519.

90 In each deanery, the dean and four jurors under oath made the assessment of all the goods and revenues of the churches; each abbot and prior with some members of his house assessed their own property by inquest (Burton, pp. 350-360). 


\section{STUDIES IN TAXATION}

more rapidly. The only deduction allowed in the valuation was for the necessary expenses of gathering crops. All manors and baronies were to be included. No religious house of any sort was to be exempt. No item of property or income was to be omitted. Prices had risen and valuations were to be increased accordingly. No attention was to be paid to previous assessments. ${ }^{91}$ The roll was to be forwarded to the chief collector early in January at the latest; all the arrears of the first year and the whole product of the second year were to be paid in January and February, 1256. ${ }^{92}$ To allay discontent, the collectors stated that the tenth was to be paid for three years only, ${ }^{93}$ despite the fact that the pope had already granted it for two years more. This new assessment

91 "decimam de vestris maneriis ac etiam baroniis quam pro anno præterito non solvistis"; "justas æstimationes omnium ecclesiarum et capellarum exemptarum et non exemptarum, et omnium proventuum ecclesiasticorum, quocumque nomine censeantur, secundum quod ad firmam poni solebant vel poni possint communibus annis, nullo deducto præter expensas necessarias circa fructus colligendos factas, ... præsentetis"; "fideli, legitima, et justa æstimatione facta omnium possessionum suarum temporalium et spiritualium"; "æstimationes omnium non fictas sed veras"; "non timeant taxatores præteriti anni quod reprehendentur de perjurio, si modo plus solito taxaverint, quia tunc multa deducta fuerunt quæ modo non deducuntur, et blada carius venduntur"; "nulla sit portio adeo modica, in quibuscumque consistat in pondere, numero, et mensura, terris, pratis, pascuis, pannagiis, auro, argento, grano, liquore, operibus, servitiis liberis vel rusticis consuetudinibus, in panibus deferendis ad Natale Domini, gallinis, ovis, et quibuscumque aliis ad ecclesias vel ecclesiasticas personas spectantibus, quin taxetur et æstimetur"; "religiosorum nullum excipimus, nisi privilegium istius exemptionis ... contra Mamfredum . . . ostendat, vel per literas magistri Rostandi immunis sit" (Burton, pp. 350-360).

92 Burton, pp. 354, 355; Matthew Paris, VI, 312, 313. Rostand was successful in making the clergy pay more promptly; Dunstable did not pay the first year's tenth till November 11, 1255, eighteen months after the tax was put in charge and after Rostand began his work; the second year's tenth was paid on time, about February 2, 1256 (Dunst., p. 196).

93 Burton, p. 357. 


\section{UNDER JOHN AND HENRY III}

aroused much complaint. On January 13, 1256, Rostand met an assembly of the clergy at London, composed of the prelates and representatives of the lower clergy. So strong was the opposition to the new valuation that Rostand abandoned it and ordered the tenth of the second year to be collected on the basis of the assessment of $1254 .{ }^{94}$ It is not stated whether any of the clergy paid the tenth on their land held by military service. The bishops however did not do so; after Easter, 1256, they again refused to assent to it. The pope continued to order it to be paid. ${ }^{95}$

In 1257, the period of the three years of the tenth which the clergy had granted ended. The pope had already extended the period from three to five years. The king was unable to collect it on this authority alone. After the middle of March, 1257, a great council composed of the barons, the prelates, and representatives of the lower clergy met at Westminster and remained in session till the early part of April. ${ }^{96}$ The king asked for an aid from both the clergy and the laity for the Sicilian affair, but they refused to grant it. ${ }^{97}$ On April 2, Rostand

94 Matthew Paris, V, 539, VI, 314; Burton, p. 363. Rostand's order to go back to the Norwich assessment was issued January 29, 1256, after this meeting, apparently as a result of the opposition there. One of the complaints of the lower clergy was that the tax had been levied on them without their consent: "Procuratores clericorum beneficiatorum archidiaconatus Lincolniæ pro tota communitate proponunt, quod gravati sunt, eo quod decima beneficiorum suorum domino regi fuit concessa, ipsis non vocatis; maxime, cum agitur de aliquo obligando, necessarius est ejus expressus consensus"; "Proponunt procuratores subditorum ecclesiarum Covintrensis et Lichfeldensis dioecesis; ... item, gravantur in eo, quod decima bonorum suorum ecclesiasticorum concessa fuit domino regi in subsidium executionis voti sui in Terram Sanctam, ipsis penitus irrequisitis" (Burton, pp. 360, 362).

95 Matthew Paris, V, 553; Rymer, I, 342, 345, 346.

96 Burton, pp. 384, 388; Matthew Paris, V, 621.

97 Burton, p. 386; Matthew Paris, V, 623; Dunst., pp. 199-200. 


\section{STUDIES IN TAXATION}

asked the clergy to continue the tax on clerical property for two years more and gave papal authority-for this demand. At first he met with no success. Finally, he produced a papal letter addressed to himself and to the bishops of Norwich and Salisbury, directing them to compound for this tenth in a lump sum. It was agreed that the meeting should be prorogued till May 8 and that in the meantime the prelates should consult the clergy at home and learn their will. ${ }^{98}$ When they met again,

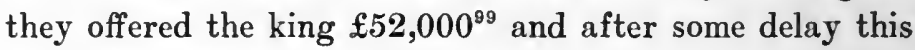
may have been accepted. ${ }^{100}$

At the close of this year, the pope sent Herlot, another nuncio, to England with Rostand to get money. In a great council, held on March 31, 1258, the king asked for an aid. This was refused repeatedly by the magnates, although Henry prolonged the council till May 5 in the hope of breaking down their opposition. ${ }^{101} \mathrm{He}$ also applied to religious houses to go surety for him for considerable sums and was partly successful. ${ }^{102}$ The revolution of 1258 finally put an end to the taxation for the war in Sicily. ${ }^{103}$

Burton and Dunstable give this under the year 1256, which is a mistake (Ramsay, Dawn of the Constitution, p. 163, note).

88 Burton, pp. 388-389.

99 Burton, p. 402; 52,000 marks, Matthew Paris, V, 623-624, 637. Ramsay, p. 163, thinks that it was never paid.

100 Matthew Paris, V, 637; "per totam Angliam exactum fuerat soccagium" (Theok., p. 159). Matthew Paris says that the king promised to redress grievances of the church. The articles containing them are given in VI, 353. Mention of the grievances which were to be discussed at a convocation on August 22 is made in Burton, pp. 401-408; Wint., p. 96.

101 April 2, Matthew Paris, V, 673, 676, 680, 682, 688; "quinzaine of Easter," that is, March 31 (Cal. Pat. Rolls, II, 626); Dunst., p. 208; Bliss, I, 354; Rymer, I, 370.

102 Matthew Paris, V, 682-687; Cal. Pat. Rolls, II, 631, 634; Gesta Abbatum, I, 373-379.

103 The king ceased to ask for a subsidy, but the pope continued to send men to collect all arrears of tenths, twentieths, remission of 


\section{UNDER JOHN AND HENRY III}

The receipts of the tenth could not come in fast enough to satisfy the papal demands. It was necessary to borrow money. By 1256, merchants of Siena had advanced 41,000 marks which were to be repaid out of the tenth. ${ }^{104}$ In June, 1256, the king gave power to borrow 10,000 marks to envoys who were going to Rome. ${ }^{105}$ In June, 125\%, the queen and prince Edward went security for a loan of 10,000 marks which was to be made by Italian merchants, ${ }^{100}$ while at the same time orders were being issued to forward 20,000 marks of the tenth to Rome. ${ }^{107}$ One of the devices employed for raising money quickly was that begun by Innocent IV and with which the bishop of Hereford was later so closely identified. Sums were borrowed and religious houses were pledged to repay them. ${ }^{108}$ The clergy resisted this vigorously. In October, 1255, and January, 1256, the king was unable to get them to accept these bills drawn on them without their knowledge and consent. They appealed to the pope, who ordered them to pay, but agreed that the money should be counted as part of their tenth. Houses which resisted were excommunicated and put under an interdict and the clergy were finally obliged to yield..$^{100}$ The amount which was borrowed and secured in this way was estimated by

crusaders' vows, etc. After a time the government seems to have opposed this (Cal. Pat. Rolls, III, 8, 9; Bliss, I, 383, 385).

104 Shirley, II, 115; Cal. Pat. Rolls, II, 519.

$105 \mathrm{Cal}$. Pat. Rolls, II, 481; a notice of a loan of 2,000 marks actually made on this authority (ibid., II, 520).

106 Ibid., p. 562.

107 Ibid., p. 563.

108 Rymer, I, 301 ; Bliss, I, 316; Matthew Paris, V, 510-513.

109 Matthew Paris, V, 522, 523, 525-527. 532, 533, 539-540, 552, 558, 581-584; VI, 305, 307, 315; Gerv. Cant., II, 205; Osney, pp. 107-112 ; Dunst., p. 199; Cont. Flor. Wig., II, 185; Gesta Abbatum, I, 379-384; Shirley, II, 115; Cal. Pat. Rolls, II, 515, 557, 558, 651; Memorials of S. Edmunds Abbey, III, 29-30. No house was to pay more than its tenth for five years would amount to (Matthew Paris, VI, 315-317, $323,350,382$ ). 
the king in 1256 to amount to 30,000 marks besides 5,000 marks "damna et expensas." 110 In the Patent Roll there are fifty-eight houses which went security for about 20,000 marks. ${ }^{111}$

One cause of the opposition to the tenth was the belief that the king was not sincere in his promise to lead a crusade but intended to spend the proceeds of the tax in other ways. ${ }^{12}$ The pope however had no intention of allowing it to be spent for any other purpose than the crusade. ${ }^{113}$ With the entrance of the king into the Sicilian affair, the papal attitude changed somewhat. The tenth was conceded for two years more, probably in the expectation that the extra sum would be used in Sicily, ${ }^{114}$ but the king was not yet released from the crusade to Palestine. ${ }^{115}$ In the autumn of 1254, Henry III was already promising to pay debts incurred at Rome out of the proceeds of the tenth. ${ }^{118}$ It must have become evident to the pope that the king could not fulfill his contract for the Sicilian crown and carry on the crusade at the same time. At any rate, in May, 1255, Alexander IV commuted the king's vow as a crusader into a vow to invade Sicily and sent Rostand to England to take charge of the collection of the tenth. ${ }^{117}$ As far as the evidence of the Patent Rolls goes to show, all the receipts from the tax were sent to

110 Shirley, II, 115.

111 Cal. Pat. Rolls, above.

112 Matthew Paris, V, 282, 327; in 1252, the clergy stated that if they granted the tenth "utiliter distribuenda ... prout fidelibus suis cautius solito videbitur expedire" (ibid., p. 328). When the tax was granted, the chronicler states that it was "per visum magnatum in viaticum distribuenda" (ibid., p. 375).

113 See above, p. 271 , note 73.

114 See above, p. 274.

115 Rymer, I, 304, 308, 316.

116 Cal. Pat. Rolls, II, 344, 358.

117 See above, p. 275. Probably the change in the king's vow was made at this time because it was when the final arrangements for the bestowal of Sicily on Edmund were made. 


\section{UNDER JOHN AND HENRY III}

Italy or paid to merchants for loans made to the pope. ${ }^{118}$ In April, 1257, the king forbade Rostand to make any payments to any one in connection with the realm of Sicily, ${ }^{119}$ probably to induce the pope to modify the conditions of the Sicilian grant. ${ }^{120}$ To this policy, Henry III did not adhere, for in June he was trying to borrow money to use at Rome, and Rostand, who was leaving England, appointed a clerk to receive in his absence the tenth and all other money of the cross. ${ }^{121}$ Thus while the receipts from the tax must have been large, the king was able to use very little of it for his government in England except in the shape of loans which he had to repay. In 1256, 2,000 marks of the tenth were paid him and he promised

118 "mandamus quatenus vos vel alter vestrum omnem pecuniam ... ex quacumque causa Terræ Sanctæ deputatam . . . integre recipere, ac eidem regi pro executione negotii regni Ciciliæ assignare curetis" (letter of the pope to the archbishop of Canterbury and Rostand, 1255, Burton, p. 351); "pecuniam Terræ Sanctæ . . nulli alii quam nobis assignetis, nisi etiam de speciali mandato magistri Rostandi" (letter of the collector, William de Ros, to certain archdeacons) (ibid., p. 356); the abbot of Westminster paid $£ 1,75517 \mathrm{~s} 8 \mathrm{~d}$ and other sums to merchants of Siena by order of Rostand and was to turn over to him the rest of the tenth which he had if any were left (Cal. Pat. Rolls, II, 462); the bishop of Norwich paid 5,500 marks of the tenth to merchants of Siena by Rostand's orders (ibid., II, 508); similar payments (ibid., p. 514); in October, 1256, the pope granted the king a delay for fulfilling the conditions of the Sicilian affair till June 1, 1257, "provided that the tithe of church revenue as granted to the king be paid over to merchants for paying the debts of the Roman church" (Bliss, I, 338); in June, 1257, 20,000 marks were to be delivered to Florentine merchants to be carried to Rome; this was done by the advice of the king's council, one of whom was Rostand (Cal. Pat. Rolls, II, 563); "it has been provided by the council that the money of the cross and of the tenth ... shall be deposited with certain merchants" (ibid., p. 605; see also pp. 566,587 ); in 1258 , the king is said to have sent the pope 5,000 marks (Matthew Paris, V, 666).

119 Cal. Pat. Rolls, II, 566.

120 Ibid., 567.

121 Ibid., 562, 566. The king also sent money after this (see above, note 118). 


\section{STUDIES IN TAXATION}

to repay the money out of the income of church lands in hand. ${ }^{122}$ For another loan of 1,300 marks, he pledged the gold in his treasury. ${ }^{123}$ He was throughout this period short of money. In 1255 he borrowed 1,000 marks from the bishop of Durham, and to repay it assigned to the bishop the issues of the archbishopric of York and of Yorkshire. $^{124}$ In February, 1256, a loan of 800 or 1,000 marks was to be raised on the security of certain church lands which were in hand. ${ }^{125}$ William de Valence lent the king 1,100 marks in November, 1257. ${ }^{128}$ Merchants of Siena lent $£ 550$ in May, 1258, on security of the royal jewels. ${ }^{127}$ The same year, 2,250 marks were lent by Italians, secured by the abbot of Westminster, who was in turn secured by the pledge of the king's jewels. ${ }^{128}$ In November, 1256, the king delivered to his brother, the earl of Cornwall, 1,207 marks of gold, pledged to the latter for a loan of 10,000 marks of silver made to the king during the last campaign in Gascony. This transaction shows the poverty of the exchequer. ${ }^{129}$ The same year, Henry III declared that he had no ready money to buy goods at the Boston fair, except the fines and amercements in the eyres of the northern counties, though all that he wanted was 700 marks. ${ }^{130}$ In 1257 , the treasurer was ordered to sell wood to raise three or four thousand marks. ${ }^{181}$

Templars, Hospitallers, and Cistercians were exempt

122 Cal. Pat. Rolls, II, 480.

123 Ibid., 498, 500.

124 Ibid., 423, 448.

125 Ibid., 461.

126 Ibid., 603.

127 Ibid., 629.

128 This was to pay the pope's tribute for two years, 2,000 marks, with 250 marks profit for the merchants (ibid., 631, 634).

129 Ibid., 528.

130 Ibid., 483.

131 Ibid., 544, 550. 


\section{UNDER JOHN AND HENRY III}

from the tenth unless they held churches as private persons. ${ }^{132}$ Efforts were made to extend the levy to all the property of the Cistercians, but the latter were finally excused by the pope. ${ }^{133}$

After Henry III's return from Gascony in 1255, a tallage was levied. ${ }^{134}$ Most of the towns compounded. The assessment was made usually, perhaps always, by royal judges, sometimes aided by the sheriff. ${ }^{135} \mathrm{~A}$ controversy arose between the king and the citizens of London concerning the character of the contribution which the city should pay; the dispute illustrates the fact that tallage was still levied per capita. The exchequer demanded 3,000 marks as a tallage from London. The Londoners refused to pay this amount, offering instead 2,000 marks as an aid and declaring that they were not liable for tallage. The king then ordered that the city should be tallaged per capita, but the justices could not carry out these orders. In February, 1256, the citizens appeared before the king to settle the matter. An examination of the records showed that the Londoners had been paying tallages, not aids, and the citizens then admitted that they could be tallaged and were charged with 3,000 marks. ${ }^{138}$ The amount of the tallage in twentyeight counties was about 8,500 marks. ${ }^{137}$

132 Cal. Pat. Rolls, II, 524; Matthew Paris, V, 553, 555, 610, 637; Wav., p. 348.

133 Rymer, I, 323.

134 Madox, I, 712, n. $a$.

135 In Norfolk, the tallage was assessed by William Brito, a justice in eyre in 1255, and by the sheriff (Cal. Pat. Rolls, II, 436; Pipe Roll, 39 Henry III, Norf. and Suff.); in Notts. and Derby, by William Trussel and Roger de Whytcestre, who were justices in eyre in 1255 (Cal. Pat. Rolls, II, 436; Pipe Roll, above, Notts. and Derby).

136 Madox, I, 712, n. a; Exch. K. R. Mem. Roll, 39 Henry III, m. 9 d; Close Rolls, No. 69, m. 20 d. For a discussion of this tallage on London, see Adams, E. H. R., XXIV, 490, who shows that the point at issue between the king and the citizens was whether they owed aid or tallage and that the latter had to admit that they owed tallage. In 


\section{STUDIES IN TAXATION}

Throughout 1256 and 1257, there had been fighting on the Welsh frontier. In $125 \%$, the host was summoned to meet on August 1 at Chester and a brief campaign in Wales followed. ${ }^{138}$ Tenants were summoned to come with part only of their quotas. ${ }^{139}$ An excuse (e.g. sickness, old age) was still necessary to exempt from personal service any tenant, great or small. ${ }^{140}$ There is some evidence that it was still difficult to exact service from rear-vassals. ${ }^{141}$ Toward the close of the campaign, it was determined to levy a scutage at three marks per fee. ${ }^{142}$ From some tenants, both clerical and lay, the king

the citation from the Memoranda Roll as given by Madox, four cases were found when they searched the rolls, in which the citizens had been tallaged, viz., in 1214, 1223, 1242, and 1253. Both the Memoranda Roll itself and the Close Roll give two more cases: "et anno ejusdem xxix talliati fuerunt ad duo millia marcarum, et anno ejusdem xxxiii ad mille libras" (above). Three cases at least do not appear in the record of this dispute as having been cited: the tallage on London of 1226 , which was levied per capita, the tallage in 1230 of $1,000 \mathrm{~m}$ "de auxilio promisso regi ad primam transfretationem," and the tallage of 1235 (see above, pp. 172, 190, 213). That the method of levying tallage was still either "per capita," or "in communi" is also shown by the following: "ad assidendum tallagium nostrum in civitatibus, etc., separatim per capita vel in communi" (Close Rolls, 39 Henry III, m. 19 d).

137 Pipe Roll, 39, 40, 41 Henry III. For other references to this tallage, see Madox, I, 356, n. $z ; 726, \mathrm{n} . l$; another case of tallage per capita, 740, n. $d$; II, 232, n. i; Excerpta, II, 211 ; Rot. Orig., I, 15; Cal. Pat. Rolls, II, 404. Matthew Paris, V, 568, says that the Londoners were tallaged in $500 \mathrm{~m}$ in 1256 "et ut color causæ variatus est, nunc ad opus regis, nunc ad opus reginæ, expectantes ad opus Edwardi, quasi servi ultimæ conditionis, etc." The Jews were bound to pay the earl of Cornwall 8,000 marks (Cal. Pat. Rolls, II, 400); Rymer, I, 315.

138 Close Rolls, 41 Henry III, m. 6 d; Rymer, I, 361; Matthew Paris, V, 639, 645-647, 649; Theok., p. 158; Dunst., p. 203. The king was at Chester till August 17, when he went into Wales, and was again at Chester on September 12 (Cal. Pat. Rolls, II, 573-577). Men were on the king's service in Wales at different times all summer (ibid., pp. 586, 595-598).

139 The following cases show that only part of the tenant's service was summoned. The amount of service owed is taken from the Pipe 


\section{UNDER JOHN AND HENRY III}

Roll of 42 Henry III, in the account of the scutage. Fractions are omitted. The service summoned is given in the Close Rolls, 41 Henry III, m. 6 d; Rymer, I, 361; Lords' Report on the Dignity of a Peer, III, App., I, p. 14.

\begin{tabular}{|c|c|c|c|c|}
\hline & & Service & $\begin{array}{c}\text { Knights } \\
\text { summoned }\end{array}$ & County \\
\hline Roger de Mohun & • & 41 & 4 & Dors. and Somers. \\
\hline Philip de Columbariis & . & 10 & 2 & Dors. and Somers. \\
\hline Hugh de Nevill & . & 20 & 2 & Dors. and Somers. \\
\hline Henry de Noro Burgo & . & 15 & 1 & Dors. and Somers. \\
\hline William de Kaynes & . & 3 & 2 & Dors. and Somers. \\
\hline Aluredus de Lincoln & . & 24 & 2 & Dors. and Somers. \\
\hline Hugh de Vivoniis & • & 11 & 2 & Dors. and Somers. \\
\hline John de Curtenay. & . & 92 & 3 & Devon. \\
\hline Henry de Percy & . & 30 & 4 & York. \\
\hline Roger de Sumery . & . & 50 & 5 & Staff. \\
\hline Robert de Brus & . & 10 & 4 & Essex and Hert. \\
\hline Jordan de Saukvill & 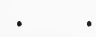 & 1 & 1 & Oxford. \\
\hline Peter Achard & . & 1 & 1 & Berks. \\
\hline Reginald (Roger) de & Pavilly & 1 & 1 & Wilts. \\
\hline Almaricus de S. Aman & & $11 / 2$ & 2 & Oxford \\
\hline Ralph Musard & 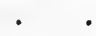 & 15 & 2 & Notts. and Derby. \\
\hline
\end{tabular}

From this list we see that some tenants were expected to perform full service. The abbot of St. Albans, 6 fees, sent two knights and eight sergeants (= four knights) (Matthew Paris, VI, 373-374).

140 "W. de Fortibus comes Albemarl' qui propter infirmitatem suam illi exercitui interesse non potuit et habuit milites etc. et habet scutagium" (Scutage Rolls, no. 8); other cases are given in this roll.

141 The abbot of St. Albans summoned his knights to serve. On this barony, it was the custom for the tenants by military service to assemble and choose six representatives, the others contributing to their support in the army. But the abbot was unable to force his tenants to serve and had himself to provide the service of his fee (Matthew Paris, VI, 374-376). The abbess of Wilton was unable to distrain her knights to serve, "quod milites vestros ad sua servicia facienda distringere non valetis" (Close Rolls, 41 Henry III, m. 4 d).

142 On September 14, the king granted Philip Basset his scutage "quia per commune consilium comitum, baronum, et aliorum magnatum nobiscum in Wallia nuper existentium provisum est quod habeant scutagium suum"; in a similar writ dated September 25 , the last expression runs: "provisum est quod nos et ipsi qui servicium nobis fecerunt in Wallia habeamus scutagium nostrum" (Scutage Rolls, no. 8, m. 1); Dunst., p. 207; Theok., p. 158; Madox, II, 70, n. g. That the levy was not put in charge before the campaign is shown by two entries: one showing that on July 18, the king remitted to his 


\section{STUDIES IN TAXATION}

took a fine or aid which was greater than their scutage. ${ }^{148}$ Rear-vassals were asked to grant their lords an aid to help pay the fine. ${ }^{144}$ A tenant who performed his service, even when he furnished only part of the quota due from him, was allowed to collect scutage from his vassals with the king's permission. ${ }^{145}$ The incidence of the levy did not stop with the immediate vassal of the tenant in chief. ${ }^{148}$

brother, Richard, all his service for this army, "and if a scutage be levied for the said army, the king grants, etc." (Cal. Pat. Rolls, II, 571); the other that of the bishop of Bath (ibid., p. 564).

143 "De hiis qui fecerunt finem pro servicio suo et pro scutagio habendo"; "Abbas de Abbindon' similiter finem fecit cum rege pro servicio suo quod regi debet et pro scutagio suo habendo" (Scutage Rolls, no. 8); sometimes a tenant paid part fine and performed part of his service: Ralph Basset "tam per finem quam per servicium suum satisfecit regi pro scutagio suo habendo" (ibid.). These fines do not ordinarily appear in the Pipe Roll, but there are some entries: "Abbas de Burgo debet $\mathrm{c}$ et $\mathrm{xx}$ li. de $\mathrm{lx}$ feodis sed non debet inde summoneri per finem cc marcarum inde factam sicut continetur in rotulo principali"; William de Dyva $20 \mathrm{~m}$ fine "pro exercitu Walliæ sicut continetur in rotulo de eisdem finibus" (Pipe Roll, 42 Henry III, Northamp., Oxf., m. 9 d, 18 d). In the Patent Roll, the payment over and above the scutage is called an aid: "the king . . . is requiring from their lord a competent aid beyond the service due from him" (Cal. Pat. Rolls, II, 599, 600).

${ }_{144}$ Cal. Pat. Rolls, above.

145 Scutage Rolls, no. 8; the tenants, cited in note 139, who were summoned with part of their service received writs of quittance. Some of them fined instead of serving, e.g. Peter Achard and Ralph Musard (ibid.).

148 Thomas de Whereweton, a rear-vassal, paid scutage to his lords and was allowed to collect it from his tenants (Cal. Pat. Rolls, II, 666).

This is the account of the scutage:

Scutage at £2.

Clerical tenants . . . . . . $\quad .451 \quad 134$

Forty-six lay tenants (each 5 or more fees) . $2004 \quad 17 \quad 6$

Other lay tenants (each fewer than 5 fees, etc.) $670 \quad 10 \quad 2$

Four clerical tenants who fined . . . $\quad 280 \quad 0 \quad 0$ (89 fees)

Sergeants . . . . . . . . 13180

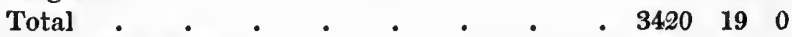

Paid, 1258, 1259 . $\quad . \quad . \quad$. $\quad . \quad$. 27246

Fees taxed, about, 1600. 


\section{UNDER JOHN AND HENRY III}

Among the 46 greater lay tenants the following are reckoned as one tenant each: the honors of Henry de Essex ( $£ 113$ 4s), Hagenet ( $£ 100)$ and an entry of $£ 63$ for the honor of Peverel in Essex and Hertford. Five more of these tenants hold of the honor of Boulogne. Of the sum charged against the lesser tenants, $£ 211$ are on the honors of Boulogne and Peverel, leaving about $£ 460$ charged against tenants in chief. A charge of $£ 1318 \mathrm{~s}$ against sergeants should also be noticed. The account that $I$ have of the scutage of this year is incomplete, for I failed to copy from the Pipe Roll the scutage in the following counties: Salop, Stafford, Gloucester, Lancashire, and London and Middlesex. 


\section{CHAPTER IX}

\section{The End of the Reign}

A FTER 1258, there was a lull in the struggle over ment was reflected in the cessation of demands for aid from them. None was asked for till 1269, when a twentieth was granted for the crusade. Thus the king succeeded in obtaining at that time what he had failed to get in 1253 from the tenants in chief. It is likely that his success was due to the belief that he really did intend to use the money for the crusade. The clergy however demanded that the twentieth should be held in deposit till Henry III or his son departed. Without doubt, the barons were influenced to grant the twentieth by the fact that Henry III had levied no tax on property since 1237, and thus had convinced them that there was no danger of his establishing the right to tax them at will. The method of assessment and collection resembles that employed in the early part of the reign. To say that the council granted the twentieth does not accurately describe the issue of this tax. The military tenants agreed to it; then the bishops conceded it on their demesnes; later the beneficed clergy consented to it; the towns paid a tallage. This division of the levy suggests that each part of the community granted its own tax and that the council of military tenants in chief represented only those who held by knights' service.

The chief feature of this period was the taxation of the clergy. Following the precedent established before the revolution of 1258 , they were taxed four-tenths and 
a twentieth. In each case, the pope or his legate assented to or requested it, but the consent of the English clergy was also requisite. Generally the levy was made on the basis of the assessment of 1254, though not always. The assessment and collection were usually in the hands of the clergy. Composition was often allowed. Thus the clergy granted the tax, and in the main assessed and collected it, and in a measure tried to supervise the expenditure. Two tallages were taken and a donum on religious bodies, and there was also papal taxation of the clergy.

In 1260, a tallage was levied. The kingdom was divided into districts, each embracing several counties. Two commissioners were sent to each district to assess the tallage, except in London and Middlesex, where the assessment was made by the justiciar, Hugh Bigod. The assessors delivered a copy of their roll to the sheriff who collected the money. They could at their discretion allow a city to compound in a lump sum, or they could assess it per capita, and they were to see that the rich did not shift the burden of the tax onto the poor. The writs of assessment were sent out in June and the tallage was to be paid at the exchequer, half on November 1 and half at the Easter following. ${ }^{1}$ A contribution was also asked from the moneyers, who protested that they were not accustomed to pay a tallage. They finally agreed to

1 Rot. Orig., I, 16b; Vincent, p. 110; Cal. Pat. Rolls, III, 75-76. Royal officials were appointed as assessors. Geoffrey de Leuknor was in 1262 appointed justice in eyre (ibid., p. 200); William de Hecham and William de Engleby were in 1260 appointed to view the sale of wines in certain counties (ibid., pp. 66,67), and in the same year the former was to hold an inquest into the seizure of a ship (ibid., p. 103); Robert de Crepping was in 1259 appointed keeper of the lands of William de Valence (ibid., pp. 15, 22, 35); Hugh Bigod was justiciar. The sheriff of one of the counties in the district might be a tallager, 6.g. Hamo Hauteyn, sheriff of Lincoln, and Robert de Meisy, sheriff of Hereford, helped to tallage their counties. 


\section{S'TUDIES IN TAXATION}

pay 200 marks on condition that their liberties were confirmed. ${ }^{2}$

In 1262, the pope asked the prelates individually to make him an aid for the business of Sicily, and he followed it up the next year with an order to the clergy to pay a hundredth of church revenues for five years for the Holy Land. ${ }^{3}$

In the summer of 1264, after the battle of Lewes, there was danger of an invasion by the king's continental friends. ${ }^{4}$ Great preparations for resistance were made. The sea was guarded and all the ports except Dover closed. The tenants by military service were summoned to arms in August. In addition, each vill, city, and borough was to furnish a quota of armed men. ${ }^{5}$ By decision of the bishops, religious orders and the beneficed clergy were either to pay a subsidy or to furnish armed men. ${ }^{6}$ At some time before September 4, the prelates granted a tenth for one year of ecclesiastical goods. Each bishop collected it in his diocese; it was to be levied

2 Cal. Pat. Rolls, III, 89.

3 Bliss, I, 379, 382, 383, 394. One chronicler states that in 1259 a thirtieth of all ecclesiastical revenues was to be collected and paid to the bishops of Bath, Ely, and Rochester, together with arrears of tenths and other past contributions, to make up the sum of 5,500 marks. To this amount these bishops had gone security to the pope for the king to enable him to avoid excommunication and an interdict (Flores Historiarum, ed. Luard, Rolls Series, II, 433; III, 349-354). In December, 1257, the pope suspended these penalties for a time (Bliss, I, 354); Matthew Paris says, V, 666, that the pope threatened an interdict and excommunication, which the king avoided by sending him 5,000 marks; the pope in a letter of December, 1257, speaks of 5,500 marks to be paid to these three bishops (Rymer, I, 368).

4 Cal. Pat. Rolls, III, 338; Shirley, II, 257-273.

5 Cal. Pat. Rolls, III, 340, 341, 349, 351, 352, 354-368; Shirley, II, 259, 269, 271 ; Cont. Flor. Wig., II, 192; Lib. de Ant. Leg., pp. $67-69$.

6 Cal. Pat. Rolls, III, 365. This payment was probably the tenth spoken of below, although Dunstable sent four horsemen and six footmen and also paid the tenth (Dunst., p. 233); Shirley, II, 273; Chronicon Willelmi de Rishanger (Camden Society), p. 35. 


\section{UNDER JOHN AND HENRY III}

secundum communem astimationem of the revenues. ${ }^{7}$ As an instance of the despotic power of Simon may be cited the order which he issued in September to the bishops to pay the tax at once, or the sheriffs would collect it. ${ }^{8}$ As soon as the pope heard of the levy, he commanded the bishops to turn the receipts over to his legate, Ottobon. ${ }^{9}$ The death and overthrow of Simon did not cause the cessation of the tax. It was still collected and the pope ordered it to be delivered to the king. ${ }^{10}$

The restoration of Henry III to power in 1265 was attended by fines on those who had been partisans of the earl of Leicester, especially the towns. London paid 20,000 marks, Oxford 500 marks, Hereford 600 marks, and Lincoln 1,000 marks. ${ }^{11}$ Some prelates paid fines. ${ }^{12}$

\section{The Tenth, $1266^{13}$}

The expenses of the war and the disorder of the kingdom made new taxation necessary. The pope's tribute had not been paid in five years. ${ }^{14}$ Clement IV was asked to aid the king from the revenues of the English church

7 Cal. Pat. Rolls, III, 345, 346, 568; Dunst., p. 233; Lib. de Ant. Leg., p. 69; Wykes, p. 155; Flores Hist., II, 499; Rymer, I, 445; Bliss, I, 432; Chron. Will. de Rishanger, p. 36; Lords' Report on the Dignity of a Peer, Vol. III, App. I, p. 32.

8 Rymer, I, 445.

9 Ibid., I, 459 ; Bliss, I, 432.

10 Rymer, I, 462.

11 Lib. de Ant. Leg., p. 80; Cal. Pat. Rolls, III, 530, 548, 554, 567, 576; ibid. (Record Com.), p. 40b; Annales Londonienses (ed. Stubbs), p. 70 .

12 Cont. Flor. Wig., II, 194; the bishop of Lincoln, 500 marks "whereby he made a fine with the king for not having done his service that time"; he paid $£ 100$ and the rest of the fine was pardoned (Cal. Pat. Rolls, III, 333); the bishop of Winchester, 600 marks (ibid., 342).

13 The volume of Calendar of the Patent Rolls, 1266-1272, came to hand too late to be used in the following taxes.

14 Ottobon was to collect the $5,000 \mathrm{~m}$ due out of the tenth (Bliss, I, 423, 424). This was not done: "de solvendo Clementi Papæ $7,000 \mathrm{~m}$ 


\section{STUDIES IN TAXATION}

and in 1266 he granted a tenth of the spiritualities and temporalities of the clergy for three years, except those of certain orders. The grant was confirmed by the English prelates before it was collected. ${ }^{15}$ At the meeting where this was done, the king tried to get the clergy to consent to pay a larger sum, but the request was refused..$^{10}$ The collection was in charge of the papal legate, Ottobon; under him each bishop collected it in his diocese. ${ }^{17}$ The tenth was to be assessed "according to the true, and not according to the old valuation."18 But the valuation according to which the tax of the first year was levied seems to have been that of 1254 , the Norwich assessment. ${ }^{19}$ The king was not satisfied with this, but as long as the legate remained in England, no change was made. Ottobon departed, however, in 1268, leaving strict orders that the tenth was not to be assessed or collected by the laity and that lay force should not be employed to compel payment. ${ }^{20}$ Immediately, royal officers were sent out to make a new assessment by means of juries of the locality. ${ }^{21}$

de areragiis annui census, 1,000m per annum" July, 1267 (Cal. Pat. Rolls, Record Com., p. 40a; Rymer, I, 473).

15 Gasquet, Henry III and the Church, p. 412; Wig., p. 457; Cotton, p. 141; Wykes, p. 212; Osney, p. 198; Cont. Flor. Wig., II, 198; Wint., p. 104; Wav., p. 371; Gerv. Cant., II, 242; Rymer, I, 473; Bliss, I, 432; Annales Lond., p. 80; Chron. Will. de Rishanger, pp. 61,64 .

16 Dunst., p. 244.

17 Gasquet, p. 413; see letters of Ottobon concerning the tenth (Raine, Letters from Northern Registers, pp. 7, 13) ; Bliss, I, 432.

18 Bliss, I, 432.

19 Graham, E. H. R., XXIII, 438. The case of the abbot of St. Edmunds given below suggests, though it does not state, that the assessment which was used at first was that of the bishop of Norwich.

20 Wilkins, Concilia, II, 21. Lay force should not compel payment unless ecclesiastical penalties failed, and the initiative in its employment should not come from the king, but from the clergy.

21 "secundum verum valorem ... per æestimationem plebeiorum ad hoc vocatorum" (Cont. Flor. Wig., II, 202). It is clear that this was done after Ottobon's departure. In July, 1268, just before he left, 


\section{UNDER JOHN AND HENRY III}

The new assessment was much more stringent than the old, so much so that the bishops preferred to compound for their tenth. The abbot of St. Edmunds had paid his tenth of the first year, but to avoid the new assessment, he paid the bishop a tenth for three more years, calculated on the Norwich assessment, on the property which had been included in that valuation. That assessment had however omitted certain property of the abbot on which he now had to pay the tenth for the two remaining years according to the new valuation made by the royal assessors. ${ }^{22}$ In 1269, the clergy stated that in some cases the new assessment had raised the valuation of their property from ten marks in 1254 to twenty-six marks in the new tenth and so on in proportion. ${ }^{23}$

the legate wrote to the archbishop of York that the tenth was not to be assessed or collected by the laity (Wilkins, II, 21). The Continuator of the Flowers of Worcester states that the tenth of the first year had already been paid when the new valuation was made; he refers to the assessors as "exactores ... regales" and contrasts them with the "episcopales exactores" and gives the date of the assessment as 1268, the year of Ottobon's departure (Cont. Flor. Wig., II, 202); in 1269, the clergy complained that the tenth was collected by the laity (Wilkins, II, 19). See also Cal. Pat. Rolls, IV, 247, 311, 313, 332, 352, 379, 380, 404.

22 Cont. Flor. Wig., II, 202; the bishop of Winchester paid $£ 3,000$ for the tenth of his diocese for three years (Vincent, p. 94, citing Patent Rolls, 54 Henry III, m. 11). Probably other prelates in addition to the abbot of St. Edmunds paid the tenth for four years according to the old valuation in order to escape the new assessment: "rex . . . tandem extorsit, ut pro recompensatione veri valoris non percepti per triennium decimam quarti anni singuli reddere cogerentur"; "per quadriennalem decimarum extorsionem" (Wykes, pp. 225, 227); in 1269, the king, according to one authority, tried to collect the tenth for a fourth year, but the clergy protested (Cont. Flor. Wig., II, 203); the chronicler may however refer to the payments described in this note. The total amount of composition was about 40,000 marks in the following dioceses: Worcester, Bath, Salisbury, Winchester, Norwich, London, Ely, Lichfield, Lincoln (Cal. Pat. Rolls, IV, 247, 267, 269, 352, 354, 356, 359, 373, 417).

23 Wilkins, II, 19. This tenth was extended to Ireland (Rymer, I, $485)$. 


\section{STUDIES IN TAXATION}

In 1268, a tallage was levied ${ }^{24}$ assessed by royal officials who were delegated for this work probably by the exchequer. $^{25}$ As usual, towns and vills either compounded or paid a per capita charge. Even in the former case, the royal officials exercised some supervision over the assessment, for they were instructed to prevent unfair taxation of the poor. The collection was made by the sheriff. ${ }^{28}$

Peace between the king and the last of the rebellious barons was finally made in 1268 . The latter were allowed to redeem their lands, but they claimed that they were too poor to do this. Influenced by Ottobon, the bishops agreed to the levy of a twentieth on the spiritualities and temporalities of the clergy to be paid to the king on behalf of the disinherited barons. ${ }^{27}$ The tax was levied according to the assessment of $1254^{28}$ and was collected by the bishops and archdeacons. ${ }^{29}$

24 Madox, I, 727, n. $m$; 748, n. $n$; 749, n. $x ; 756$, n. $s ;$ Vincent, pp. 109, 111 ; Cal. Pat. Rolls (Record Com.), pp. 41b, 42b.

25 In Cambridgeshire, the king's escheator made the assessment (Liber Mem. de Bernewelle, p. 80).

26 The tallage was to be levied "separatim per capita, rel in communi, prout magis viderit expedire"; if a fine were made in grosso, the tallager was to remain till the tallage was assessed "ita quod divitibus non parcatur, nec pauperes indebite graventur. Et extractas tocius tallagii predicti liberetis vicecomitibus nostris citra Trentam, ad illud tallagium levandum" (Rymer, I, 478).

27 Raine, pp. 17, 18; Wykes, pp. 219-220; a fortieth, Osney, p. 218. 28 "secundum taxationem domini Walteri de Suthfeud, quondam episcopi Norwycensis" (Bartholomew Cotton, Historia Anglicana, ed. Luard, Rolls Series, p. 141); "taxacio facta per bone memorie dominum Walterum episcopum Norwycensem" (Liber Mem. de Bernewelle, p. 191); there is no date given for this last valuation; the amount paid was a twentieth and the valuation refers either to the levy of 1268 or to the twentieth for the crusade of 1270 .

29 Thus the archbishop of York ordered the archdeacon of Richmond to make a payment of fifty marks out of the twentieth which the latter had collected (Raine, p. 19). 


\section{The Twentietir, 1269-1270}

The purpose of the twentieth was to supply money for the crusade made by Edward in 1270. As this was not one of the regular feudal aids in England, the king could not levy it at will, nor did he obtain from any single body of men the authority to collect it from all the property in the realm. At some time before August $7,1269,{ }^{30}$ the

30 The date of the grant can not be exactly fixed. Thomas Wykes says that Henry III summoned the prelates, lay magnates, and important men of the towns to London to celebrate the translation of the remains of St. Edward on October 13, 1269 (convocatis universis Angliæ prælatis et magnatibus, necnon cunctarum regni sui civitatum pariter et burgorum potentioribus) (Wykes, p. 226) ; afterward, a council was held and the king asked for a grant for the crusade. The question was discussed and a twentieth of the goods of the laity and of the lay fees of the clergy was granted (coeperunt nobiles, ut assolent, parliamentationis genere de regis et regni negotiis pertractare . . concessum est quod de universis laicorum mobilibus per regnum Angliæ sibi vicesima solveretur) (ibid., p. 227). According to this source, the grant was made about the middle of October. Furthermore, we know that there was discussion of the twentieth at this time, for on October 14, the clergy refused to agree to it on the property of the churches and of religious houses which did not hold by military service (Wilkins, II, 19-20). But a letter from Henry III to the bishop of Worcester shows that the tax had already been granted when the October council met. This letter speaks of the tax as "vicesimam . . nobis a magnatibus et aliis regni nostri fidelibus in subsidium terræ sanctæ concessum"; the date of the document is given at its close: "Teste me ipso apud Cicestr' vii die Augusti, a. r. n. liii," or August 7, 1269 (Wilkins, II, 20; Vincent, p. 93). Henry III was at Chichester on August 7 and 8 only, during the fifty-third year of his reign (Vincent, above). The instructions to the bishop show that the date of this letter is correct. He is ordered to have the knights, already chosen as assessors and collectors of the tax, take the oath which has been provided so that on the morrow of Michaelmas (1269) they could at once proceed to carry out the orders concerning the twentieth which were sent with the letter (vobis mandamus rogantes quod a . . Willielmo de Salsomarisco, etc. electis ad vicesimam hujusmodi colligendam, recipiatis sacramentum ... ita quod in crastino $\mathrm{S}$. Michaelis proxime futuro sine ulteriore dilatione procedere possint, ad faciendum in hac parte quod eis de prædicta vicesima secundum dictam formam injunxeritis) (Wilkins, 


\section{STUDIES IN TAXATION}

lay and clerical tenants in chief granted a twentieth of the personal property on all lands of lay tenants in chief and on the lands which the clergy held by knights' service. ${ }^{31}$ Toward the end of April, 1270, the bishops and

II, 20). Now the work for which preparation was to be made during August and September and which was to begin on September 30 was the assessment of the twentieth. The testimony of Wykes bears directly on this point; the goods which were assessed, he says, were those which were held on September 29, 1269 (regia cupiditas ... compulit ut secundum fere verum valorem, prout in festo $\mathbf{S}$. Michaelis proximo præcedente, quæcumque bonorum genera habebant, mobilia pariter et immobilia, taxarentur) (Wykes, p. 228). The twentieth on lay fees was granted, therefore, and the method and time of assessment provided in some council which met before August 7 , 1269. What then was the action of the council described by Wykes? The chronicler can not be referring to the refusal of the clergy of October 14, for he states specifically that it was the laity who were taxed: "concessum est quod de universis laicorum mobilibus per regnum Angliæ sibi vicesima solveretur ut non solum ut prædiximus clericorum marsupia per quadriennalem decimarum extorsionem vacua redderentur sed et regis insatiata cupido laicorum medullas profundissime scrutaretur" (ibid., p. 227). The grant of October must have been a confirmation of the previous decision to pay the twentieth, an action which was necessitated by the opposition to the tax (see below). Such a confirmation would have especial force because there was a very large attendance at the October session, due to the unusual character of the religious ceremonies in connection with the feast of St. Edward in 1269; no doubt many more were present than at the previous meeting.

31 Vincent, pp. 92-96; Gerv. Cant., II, 250; Cont. Chron. Will. de Novo Burgo, II, 556, 557; Lib. de Ant. Leg., p. 122; Ann. Cestrienses, p. 100; Cotton, pp. 143, 144. That the grant made at this time extended to the lay fees of the prelates is not certain. Thomas Wykes says that the tax was granted on the property of the laity, "de universis laicorum mobilibus." $\mathrm{He}$ is however contrasting this levy with the clerical tenths which had not been paid by property on land held by military tenure. The chronicler's phrase therefore may mean the moveables on land held by lay tenure. There is also a writ on the Close Roll which, as paraphrased by Vincent (pp. 93-94), speaks of the "twentieth ... granted ... by the magnates and knights and other laymen; commanding those assigned for levying the tax not to intermeddle at present with the goods of ecclesiastical persons," but the meaning of the document is not clear. In the council of April 20, 1270, the bishops and heads of religious houses granted the 
heads of religious houses agreed that the twentieth should be paid on their demesne lands. This grant by the prelates was not to form a precedent; the receipts were to be devoted only to the crusade and were to be held in deposit till the king or his son departed. ${ }^{32}$ In October, 1269, the beneficed clergy and the abbots and priors of the province of Canterbury refused to concede the twentieth. $^{33}$ At some time in 12\%0, however, the bishops agreed that the property of the churches should pay the levy ${ }^{34}$ and to this the beneficed clergy later assented..$^{35}$ The twentieth was also collected on the royal demesne, apparently by virtue of the grant made by the tenants in chief. The towns often compounded for it, so that in effect they paid a tallage, a customary due. ${ }^{36}$ Thus in spite of opposition, ${ }^{37}$ the king finally obtained the tax from all classes in the kingdom.

The government intended to make a new valuation of all property which was held on September 29, 1269. The assessment was often delayed till the goods were sold or consumed and the choice of that date aroused complaint. ${ }^{.8}$

twentieth on their demesnes. This means, not that their fees were to escape, but that arrangements had already been made to tax them. We can say certainly that the prelates agreed to the tax on their fees at some time before April 20, 1270, and that probably the decision was made when the laity agreed to the twentieth.

32 Shirley, II, 336; Vincent, p. 94; Raine, pp. 23, 24; Wilkins, II, 21, 22; meeting of the council mentioned and the twentieth (Wint., p. 108).

33 Wilkins, II, 19-20.

34 Raine, p. 25.

35 Raine, p. 38.

36 Vincent, pp. 97, 104.

37 See above, note 33; Wykes, p. 228. The statement of Cotton that the twentieth was asked for in 1269 but not granted till 1270, shows the opposition to the tax (Cotton, pp. 143, 144).

38 "vicesimam veræ æstimationis" (Raine, p. 38); "secundum fere verum valorem, prout in festo $S$. Michaelis proximo præcedente" (Wykes, p. 228); Vincent, p. 93. 


\section{STUDIES IN TAXATION}

The method of assessment was about the same as in 1237, but there was a new device for choosing the jurors of the vill. The king sent assessors and collectors, usually four in number, into each county. ${ }^{39}$ These royal officials chose twelve men in each hundred; the latter then chose six men from each vill who swore to the value of the personal property of every man in the vill. The property of the jurors was assessed by six other men of the vill. All the officials were under oath. The goods assessed as well as those exempt were enumerated in the writ; they comprised the same kinds of property as before. ${ }^{40}$ The royal commissioners received the money and delivered it to a body of three men who stored it in the New Temple at London. ${ }^{41}$ There were some exceptions to this scheme of assessment. The clergy were allowed to assess and collect the tax on their demesnes and on the property of the churches. ${ }^{42}$ There is no evidence to show whether they made a new assessment or levied the tax on the basis of the valuation of $1254 . .^{43}$ Some churchmen fined for the twentieth. ${ }^{44}$

The complete account of the tax was not rendered till

39 In Bucks, there were two assessors; in Yorkshire, six.

40 Vincent, pp. 92, 93, 94; Wilkins, II, 20.

41 Vincent, pp. 98, 100-105. The three men who received the money were a Templar, a Hospitaller, and a clerk of the wardrobe; the whole of the twentieth was paid to them, both that coming from the regular county assessors and that from the clergy and the towns.

42 Shirley, II, 336; Vincent, p. 94; Raine, pp. 23, 24, 25; Wilkins, II, 22. The king at first thought of compelling the clergy to pay to his own assessors: "si necesse fuerit, ipsam vicesimam levari faciant in manu forti" (Raine, p. 25), but thought better of it (Wilkins, II, 22). He tried the plan in the archbishopric of York, but the archbishop intervened successfully to prevent its execution (Raine, p. 38).

43 Probably the assessment used was that of 1254. The churchmen had preferred that in 1266 and 1268 (see above, pp. 292, 294); the tenths of 1273 were based on that valuation: "secundum taxationem Northwicensem" (Dunst., p. 256); see above, p. 293, note 22.

44 Raine, p. 38; Dunst., pp. 254, 257. 


\section{UNDER JOHN AND HENRY III}

1273, but much of the money had been paid before Edward set out in $12700^{45}$ The account of the twentieth follows : $:^{46}$

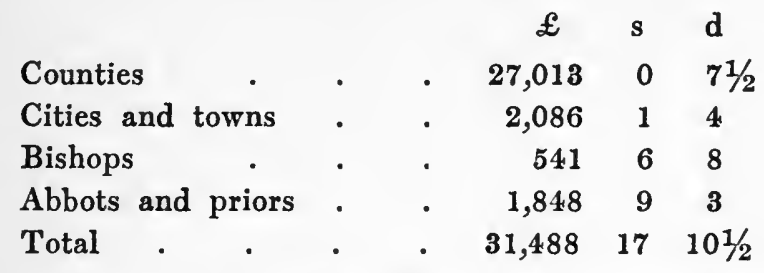

Nearly the whole of this sum was spent on the crusade.

$45 \mathrm{He}$ sailed August 20 (Ramsay, p. 272).

46 Vincent, pp. 100-105; Madox, I, 610, n. $i$. 


\section{CHAPTER $\mathrm{X}$}

\section{SumMary}

I $\mathrm{N}$ our study of the material thus far presented, certain 1 tentative conclusions have already been advanced. In this chapter, however, we shall endeavor to draw those conclusions together in a final statement which will deal in turn with the military service under John and Henry III, the scutage and the fine, the tallage, the donum, the carucage, and the tax on personal property, and, because of its marked development in the thirteenth century, with the great council and its relation to taxation.

As the scutage grew directly out of knights' service, any study of it in the thirteenth century involves an examination of the amount of military service rendered to the king by his vassals. Round has estimated the servitium debitum under Henry II at about 5,000 knights, a number which does not seem too large. For calculations dealing with the service due from England as a whole, it is however more convenient to take the number of fees on which scutage was paid to the king rather than the servitium debitum. In a great many cases, we cannot do otherwise, for the amount of the latter is known in only about two-thirds of the lay holdings of five or more fees each, ${ }^{1}$ and furthermore, in making our calculation on this basis no great error will be introduced. If we say that one-fourth of the fees of England compounded in any given year while three-fourths were exempt on account of service, and if we base each amount on the number of fees which accounted at the exchequer, we shall reach a proportion that would not be essentially different from that obtained by using the servitium debitum. The

1 Round, Feudal England, p. 292. 
number of fees which accounted at the exchequer probably became fixed at some time before the close of the twelfth century, and certainly did not change materially after 1211.2 The number was somewhat greater than the servitium debitum. If the old enfeoffment exceeded the servitium debitum on any holding, then the old enfeoffment was taxed; contrariwise, if the servitium debitum exceeded the old enfeoffment, the servitium debitum was taxed. The new enfeoffment was never taxed except when the honor was in hand, though there were many cases when it was entered in the roll. ${ }^{3}$ Ordinarily the old enfeoffment

2 The number of fees is regularly stated in the roll beginning with 1211.

$\mathbf{3}$

Hugh de Dover, Kent . . . . . 121/2 $21 / 2 \quad 14$

William de Abrincis, Kent . . . $211 / 2 \quad 21 / 2 \quad 211 / 2$

Walkelin de Mamignot, Kent . $\quad . \quad \begin{array}{llll} & 27 & 1 & 27\end{array}$

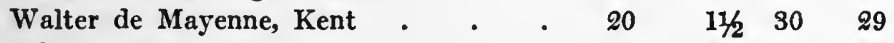

John de Port, Hants . $\quad \begin{array}{lllll} & \text {. } & 55 & 2 & 55\end{array}$

Aluredus de Lincoln, Dors. and Somers. $\quad 25 \quad 4 \quad 24$

Gerbert de Percy, Dors. and Somers. . $30 \quad 1 \quad 30$

$\begin{array}{lllll}\text { William de Curcy, Dors. and Somers. } & \cdot & 251 / 4 & 4 & 24\end{array}$

$\begin{array}{llll}\text { William de Mohun, Dors. and Somers. . } & 391 / 2 & 4 & 41\end{array}$

$\begin{array}{llll}\text { Robert de Beauchamp, Dors. and Somers. } & 15 & 17 & 17\end{array}$

$\begin{array}{llllll}\text { Walter Waleram, Wilts . } & \cdot & \cdot & 12 & 25 & 25\end{array}$

Humphrey de Boun, Wilts . . . . $\quad 301 / 2$ 91/2 $\quad 301 / 2$

Earl of Essex, Essex and Herts . . $\quad 971 / 3$ 15 $60 \quad 981 / 3$

Walter Fitz Robert, Essex and Herts . $\quad 631 / 2$ 3 $350 \quad 631 / 2$

William de Munfichet, Essex and Herts . $\quad 471 / 2 \quad 1 / 2 \quad 40 \quad 471 / 4$

Earl of Arundel, Sussex · . $\quad \begin{array}{ccc}8412 & 26 & 841 / 2\end{array}$

Gervase Painel, Staff. . . . . . . $\begin{array}{cccc}50 & 52 / 3 & 50,51\end{array}$

$\begin{array}{lllll}\text { Baderun de Munemue, Hereford . } & 10 & 15 & 15\end{array}$

Walter de Wahull, Bucks and Bedf. • $271 / 41 / 3$ 11/2 $30 \quad 30$

$\begin{array}{lllll}\text { Robert de Albeny, Bucks and Bedf. - } & 13 & 25 & 25\end{array}$

$\begin{array}{llllll}\text { Richard de Haia, Lincoln . . . } & 11 & 4 & 20 & 16\end{array}$

Roger de Mowbray, York · • • $\quad 881 / 2 \quad 11 \% 360 \quad 881 / 4$

The clergy regularly paid on the fees quos recognoscit only. 


\section{STUDIES IN TAXATION}

exceeded the servitium debitum. The total number of fees which were liable for scutage in the thirteenth century was somewhat over $6,500 .^{4}$

When we examine the scutage accounts of the first half of the thirteenth century, we see that the king in summoning the host did not actually secure all this service in the field. The number of fees which purchased exemption by scutage or fine varied from 800 in 1221 to 4,000 in $1205 .^{5}$ If we consider the holders rather than the fees, we get the same result. Taking 150 as a fair number of lay tenants holding five or more fees each in the kingdom, we see that although a majority of them usually continued to perform their service, yet many compounded for it. Not only did part of the tenants fail to serve, but those who answered the summons to the host brought with them only part of their nominal contingents. We cannot say when this practice of serving with only fractional quotas became widespread, but probably it was customary from the beginning of John's reign. ${ }^{6}$ The king sometimes summoned only a fraction of the knights: Henry II, in 1157, called out a third $;^{7}$ Richard in 1194, a third, and in 1198 a tenth $;^{8}$ and John in 1205 a tenth. ${ }^{\circ}$ These summons have been treated as though they were merely examples of an occasional practice, ${ }^{10}$ but taken in conjunction with the other evidence of reduced service, they seem to be the substi-

4 See above, pp. 127, note 33 ; 243, note 80 ; 257 , note 14 .

Morris, The Welsh Wars of Edward $I$, p. 36, gives about the same figures: "towards 7,000." He bases his conclusions on the Pipe Rolls of 7 and 8 Edward I. Morris, however, is wrong in thinking that his conclusion differs from that of Round. They are calculating different things. Round is estimating the servitium debitum and Morris is taking the number of fees that pay scutage, a number which in the thirteenth century is larger than the servitium debitum.

5 See above, pp. 71, 139.

6 See above, pp. 48, note $166 ; 64$, note $257 ; 97,110,111,150,174$, 183, 196, 226, 245, 255, 285. 


\section{UNDER JOHN AND HENRY III}

The composition of an army of 1218 shows partial service: "Exercitus summonitus apud Stamford'... anno regni domini Henricis regis secundo" (Scutage Rolls, no. 2). The following are some examples:

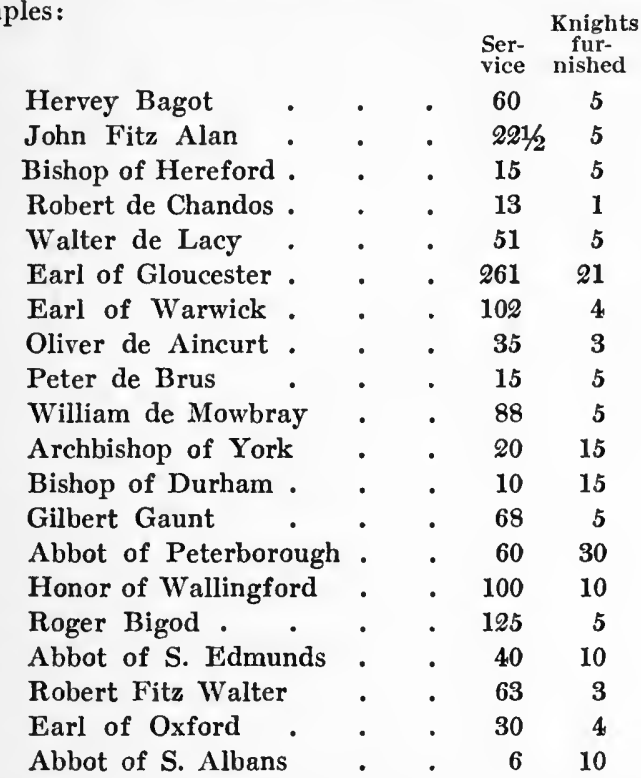

From an account of another army (during the minority, for Falkes de Bréauté served), the following cases are taken (Scutage Rolls, no. 3):

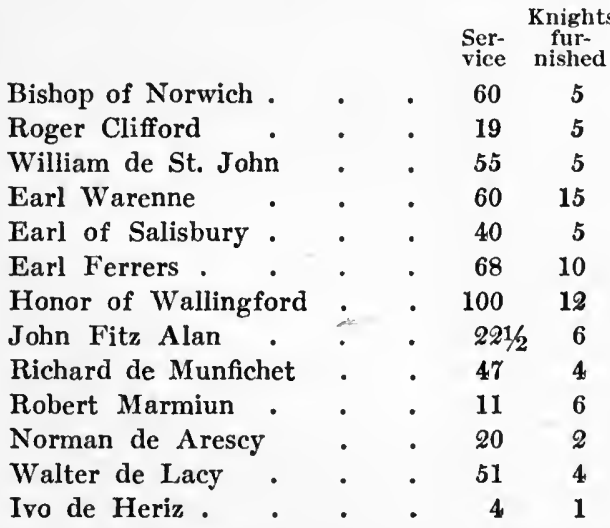

7 Chronica Roberti de Torigneio, ed. Richard Howlett, Chronicles of the Reigns of Stephen, Henry II and Richard I, IV, 193. 


\section{STUDIES IN TAXATION}

tution of a uniform fractional part of the service for the irregular fractional contingents which the tenants ordinarily brought to the host. By the middle of Henry III's reign, the partial service from the greater fees was coming to be recognized in law as the total service which the king could exact from the holding. ${ }^{11}$ That is, a new servitium debitum had been created. By Edward I's day, the king had abandoned in many cases any claim which in theory he might still have maintained to more than a small fraction of the old servitium debitum. ${ }^{12}$ If the greater tenants (each five or more fees) had their service thus reduced, it might be expected that the lesser tenants (each fewer than five fees) would have their service entirely commuted into money. This was true of the majority, though some lesser vassals continued to serve with the host in person or by deputy. ${ }^{13}$

The reduced amount of service was insufficient for the king's needs, at least for campaigns abroad. Both John and Henry III continually employed mercenaries as well as tenants in their armies. ${ }^{14}$ Special inducements were made to tenants to serve overseas for a long period. In 1204, Henry de Scalariis crossed to Normandy with two knights and in return his father was acquitted of his scutage and pardoned a forest fine of sixty marks. ${ }^{15}$ William de Mara owed the Jews £25 10s which was par-

8 Hov., III, 242; Chron. Joc. de Brak., p. 63. See also Powicke, The Loss of Normandy, ch. VIII, and especially p. 315 , in regard to a summons of 1196. Professor Powicke's book contains much material on the financial and military aspects of John's reign, but it came to hand too late to be of service here.

8 Rot. Litt. Pat., p. 55a.

10 Pollock and Maitland, History of English Lav (2d ed.), I, 255.

11 See above, pp. $221,245 \mathrm{ff}$.

12 Parliamentary Writs, I, 197; Morris, p. 43 ff.

13 See index: lesser tenants.

14 See index: mercenaries.

15 Rot. Lib., p. 89. 


\section{UNDER JOHN AND HENRY III}

doned by the king in June, provided he served with three knights and five sergeants till the following Easter. ${ }^{16}$ A debt of 250 marks owed by Geoffrey de Say to the Jews was pardoned under similar conditions. ${ }^{17}$ In 1213, men promised to serve the king usually for a year, and in return debts to the exchequer were cancelled. ${ }^{18}$ Did the king want more or fewer English tenants with him? For the Welsh wars, a large force of knights was not necessary, as the most valuable army was a combination of knights and footmen, a condition due to the mountainous character of the country, ${ }^{19}$ and it is likely that the king obtained knights enough from his tenants. ${ }^{20}$ But in France conditions were different. The king's dependence there was mainly on knights, and he does not seem to have succeeded in obtaining a sufficient number from his English tenants. The loss of Normandy was due in part to the withdrawal of the English vassals. In 1205 and in 1213 , campaigning on a large scale was abandoned because the English tenants refused to take part. ${ }^{21}$ In 1214, after considerable success, John asked that more tenants come to his aid. ${ }^{22}$ Henry III undertook to invade France in 1229 only after consultation with the barons; he also

16 Rot. Lib., p. 42.

17 Ibid., p. 48. In 1204 a certain de Nevill fined in $60 \mathrm{~m}$ and one palfrey to marry the widow of Jordan de Anevill and have her land "et serviet regi solus miles cum equis et armis per annum unum ad custum suum" (Pipe Roll, 6 John, m. 3 d).

18 Rot. Obl., pp. 465-476.

19 Morris, pp. 16, 18.

20 Mercenaries however were used against the Welsh; tenants were disseized for failure to serve. In 1211 an insufficient number answered the first summons (see above, pp. 101, 145, 206, 244, 245). In 1245, the host which accompanied the king's person was sufficient: "Quia rex credit sufficientem gentem se habere ad inimicos regis gravandos" (Close Rolls, no. 58, m. 3 d); additional knights were to go to other parts of Wales.

21 See above, p. 69, and below, p. 310.

22 See above, p. 112. 


\section{STUDIES IN TAXATION}

granted them their scutages before the host assembled, evidently that they might be able to come as well equipped as possible. ${ }^{23}$ On two other occasions he showed his reliance on the English tenants. ${ }^{24}$ The same desire of the king is shown when we look at the tenants who appeared in the host. The greater tenants for the most part continued to serve, although a fine or a scutage would often have been less burdensome. It is also noteworthy that lesser tenants, even men holding one or two fees, continued to serve in person or by deputy. ${ }^{25}$

Furthermore, a tenant who failed to answer the summons to the host might still fear the loss of his lands. The abbot Samson hastened to satisfy Richard for his knights lest he should lose his barony as others had done before him. ${ }^{26}$ There are several cases of disseizin under John, though none of a great baron. ${ }^{27}$ Under Henry III there are frequent references either to disseizin or to dis-

23 See above, pp. 171, 181, 186, note 42; 187.

24 In 1242 and 1253 (see above, pp. $224 f f ., 254,261$ ff.).

25 If we take 150 as the number of tenants who held five or more fees each, we see that usually only a minority paid scutage or fine, except in 1205, when only a picked body of knights was sent. See above for the number of greater tenants who compounded, pp. 22, $23,36,47,48,55$, and see index: tenants. In 1242, eight earls went with Henry III (Matthew Paris, IV, 192). The king's letter of that year in which he asked knights to come to his aid and promised them remission of fines and also wages, if they demanded them, does not show that the king was unable to enforce service in Gascony (Rymer, I, 246). The tenants had already agreed to fine and Henry III was unable to set this bargain aside at will. He had therefore to ask them for service as a favor. Notice the entry in the Dunstable annals, above, p. 226, note 11 . Some cases of tenants holding fewer than five fees who served have been given above in the references on p. 302, note 6 ; see p. 304 , note 13.

26 "timens ne amitteret saisinam baronie sue pro defectu servicii regis, sicut contigerat episcopo Lundoniensi et multis baronibus" (Chron. Joc. de Brak., p. 63).

27 Henry de Criketot in 1205 (Rot. Obl., p. 301); Malgerus le Vavasur in 1210 (Madox, I, 663, n. y); William de Kav' in 1207 (Rot. Litt. Claus., I, 85a); Hugh de Gornaco, Fulk Fitz Warin, and 


\section{UNDER JOHN AND HENRY III}

traint to compel tenants to serve. ${ }^{28}$ Some of the orders thus referred to may have been merely formal, yet the practice of disseizin or distraint, as a means of compelling obedience to the summons, must have been in force, else it is difficult to see how the king could have got so much service out of his tenants, particularly for campaigns in France. ${ }^{29}$

One cause of the decrease in the amount of service rendered by the greater tenants was their inability to exact knights' service from their vassals. The latter were reluctant to serve. In 1198 the tenants of the abbot of St. Edmunds claimed that they were bound to pay scutage, but not to serve outside England. ${ }^{30}$ The tenants of the abbey of Evesham were unwilling to serve. ${ }^{31}$ In 1258, the tenants of the abbot of Ramsey refused to serve and the abbot had to hire knights and sergeants. ${ }^{32}$ In 1257 the abbot of St. Albans with difficulty got his knights to acknowledge that they owed service. ${ }^{33}$ The success of

Badwinus de Hodenet for withdrawing from the king's service in 1203 (Rot. Lib., pp. 73, 74) ; Philip de Aire for failure to answer the summons (ibid., p. 69); Matthew de Clivedon, Elias Ginant, and Robert of London in 1210 (Madox, I, 491, n. $b, d, e$ ); Duncan de Lasceles for the Scottish expedition (ibid., p. 663, n. $w$ ); Albreda de Lincoln in 1210 (Pipe Roll, 12 John, Dors. and Somers., Nova Oblata).

28 In 1221 the sheriff was forbidden to trouble those tenants who did not answer the summons to the army of Biham (Rot. Litt. Claus., I, 475a); in 1223, tenants who had failed to serve in the army of Wales were disseized (ibid., 572b); the case of Robert de Amauri (ibid., 617a) ; see also above, pp. 225, 226, 245, 254, 255.

28 This conclusion seems to be warranted also by the fact that when the tenant was excused from the host by the king, a writ was issued to the sheriff not to distrain him for his service: Henry de Waltham in 1229, the Templars in 1231; Thomas Mauduit was in the host and was not to be distrained for his service (Close Rolls, I, 216, 540, 593).

30 Chron. Joc. de Brak., p. 63.

31 William Salt Arch. Soc. Coll., V, part I, p. 2.

82 Maitland, Manorial Courts, pp. 60-62.

83 Matthew Paris, VI, 375-376. See above, pp. 240, 245, 285. 


\section{STUDIES IN TAXATION}

the rear-vassals has been attributed to the lack of power of the baronial courts. The lords were unable to compel their knights to perform their service without the aid of the king's court, which gave them little assistance. ${ }^{34}$ Although there is evidence that royal aid was necessary during John's reign, ${ }^{35}$ this explanation of the decline of service is on the whole unsatisfactory because it implies that the king was indifferent to the number of knights which he obtained from his vassals, whereas the contrary seems to have been true. It has also been suggested that sub-infeudation was so great that there were few actual knights left who were holding land, ${ }^{36}$ and undoubtedly this was an important factor. ${ }^{37}$ But of greater importance were the character of the campaigns and the increased value of a knight's service. Tenants were expected to serve both in England and in France. At home, cam-

34 Pollock and Maitland, I, 272.

35 For the earl of Chester (Rot. Litt. Pat., p. 88b, 1209). In 1203, Thomas de Arcy was to be helped in making his tenants serve: "Rex etc. G. filio Petri etc. . . . et milites ipsius Thomæ distringatis que ei servitia sua faciant que facere debent" (Rot. Lib., p. 44).

36 Pollock and Maitland, I, 272-274.

37 Most of this sub-infeudation in the higher ranks of rear-vassals must have taken place before the thirteenth century. The practice of dividing fees into fractional parts should not be exaggerated, though many examples can be cited of tenants who held tenth, twentieth, fortieth, and sixtieth parts of fees. Some of these were new creations. It is likely that the size of holdings among rearvassals remained fixed in the thirteenth century just as they did among the tenants in chief, and that there were therefore many rearvassals who held more than one fee. If one compares the account of the escheated honor of Peverel in 1211 with the account in 1246 (Pipe Roll, 13 John, m. 2 d; 30 Henry III, m. 6 d), it will be seen that there has been very little change. Only a few of the tenants hold less than one fee each. Certainly at the opening of John's reign, sub-infeudation had not been carried to such an extreme that it would be impossible to get military service (see the account of the honor of Gloucester, part of the bishopric of Lincoln, and the honor of Wallingford; Rot. Canc., $3 \mathrm{~J} \mathrm{ohn,} \mathrm{pp.} \mathrm{55-56,} \mathrm{278-279,} \mathrm{266-268;}$ also the account of the honor of Boulogne, Pipe Roll, 17 John, m. 1). 


\section{UNDER JOHN AND HENRY III}

paigns were like raids; it was not necessary to assemble the whole host, a fact which would tend to reduce the number of knights which each tenant furnished. In France, campaigns required more men, but the long period of service which was often demanded ${ }^{38}$ helped equally to reduce the quotas which the king took from his vassals. The increase in the value of a knight's service as shown by the increase in his wage also served to keep down the quotas. The ordinary pay under Henry II was eight pence a day. ${ }^{39}$ In the thirteenth century it had risen to two shillings, ${ }^{40}$ and in some cases it might be more. The knights whom the abbot Samson hired in 1198 were to receive three shillings a day. ${ }^{41}$ The abbot of St. Albans hired two knights and eight sergeants in 1257 and paid nearly 100 marks. ${ }^{42}$ In 1258, the knights of the abbot of Ramsey received four shillings a day for their expenses. ${ }^{43}$ This increase in the wages of the knight was in part due to the general rise in prices which took place in the thirteenth century, but it was in great measure due to the more elaborate equipment required. ${ }^{44}$

At the average rate of two shillings a day, the wages for forty days would be six marks ( $£ 4$ ), a much higher amount than any scutage and higher than the average rate of the fine. ${ }^{45}$ Yet it may be questioned whether the feudal term of service should be thus limited. ${ }^{46}$ Almost

38 The campaign in France might last eight months, as in 1214.

39 Round, Feudal England, pp. 271-273.

40 The pay of the knights furnished in 1205 was two shillings. Tenants had knights in the expedition of 1214 at this rate (Rot. Litt. Claus., II, 87a); in 1230, the king was to support knights in France at two shillings (Pat. Rolls, II, 403).

41 Chron. Joc. de Brak., p. 63.

42 Matthew Paris, VI, 374, 438.

43 Maitland, Manorial Courts, pp. 60-62.

44 Morris, p. 49.

45 E.g. above, pp. 23, 36, 48, 65, 71, 185.

46 "Even the limit of forty days seems to have existed rather in 


\section{STUDIES IN TAXATION}

all of the campaigns of John and Henry III lasted more than forty days and some, particularly those in France, much longer. Thus in practice, the knights must have served more than forty days. In $\mathbf{1 1 9 8}$ the abbot Samson provided his knights with the expenses for this period, but he was advised to fine with the king, else he would have to pay the wages of the knights throughout the war, which, it was said, might last a year. ${ }^{47}$ That there was no set term of service is further shown by two cases. In 1212 the four knights of the abbey of Ramsey were to be supported by their fellow tenants as long as they were in the king's service. ${ }^{48}$ In 1213, the host had been summoned in April to resist an expected invasion by Philip, whose fleet was destroyed in May. In August, John proposed to the knights to invade Poitou, but they complained that their means had already been exhausted and refused to go unless their expenses were paid. John was enraged at this demand and refused it. ${ }^{49}$ This is the time when some barons claimed that they did not owe service in France. ${ }^{50}$ Neither demand seems to represent the general practice. After the middle of the century, there are cases which speak of forty days as the period of service. $^{51}$ Despite this fact, it seems probable that John and Henry III did not as a rule regard that period as

theory than in practice and its theoretic existence can hardly be prored for England out of any authoritative document" (Pollock and Maitland, I, 254).

47 Chron. Joc. de Brak., p. 63. He did so for $£ 100$.

48 Rot. Litt. Claus., I, 123a.

49 Wend., III, 261.

50 Cogg., p. 167.

31 In 1258, the knights of the abbey of Ramsey were to serve forty days and to receive four shillings a day (Maitland, Manorial Courts, pp. 60-62); in 1267, they served for the same period (Vincent, p. 116, quoting Patent Roll, 52 Henry III); in 1277, the knights of St. Albans served for eight weeks, for forty days at their own expense and for the rest of the time in the pay of the king (Gesta Abbatum, I, 435). Other cases are given in Morris, pp. 69, 70, 75, 132, 137. 


\section{UNDER JOHN AND HENRY III}

the limit of service, ${ }^{52}$ though they had no right to demand unlimited service from their vassals. That John made special arrangements with tenants whereby they were to serve for long periods would prove this to be the case. ${ }^{53}$ The service should be reasonable.

52 Their campaigns were not limited to forty days. See also, above, pp. 21, 77, 96, 101, 109, 137, 143, 149, 173, 181, 196, 244, 284. Notice also the case of the abbot of St. Albans in the war against the barons after the battle of Evesham. Henry III summoned the host to meet at the feast of St. Lucy the Virgin (December 13); the abbot sent his knights with twenty horses and they remained with the army (though apparently without fighting) from December 13 till the feast of St. Vincent (January 22), or just forty days. The service however was not concluded. The king demanded sixty marks per knight from those who wished to retire: "Cumque ibidem a festo S. Luciæ usque ad festum S. Vicentii proximum sequens cum $\mathbf{x x}$ equis dies (sic) continuassent, in multis expensis et angustiis, dominus rex pro quolibet milite lx marcas exegit a viris religionis servitium militare debentibus, et pro militibus finem facere volentibus" (Chron. Will. de Rishanger, p. 50 ).

53 The following case is cited in Pollock and Maitland, I, 255, as possible evidence that the king had the right to demand longer service than forty days, if he paid wages for it: "Rex B. de Podio, majori Engolism' et G. de Nevill' camerario, R. de Faya, E. de Chawurt', Petro de Faya, salutem. Mandamus vobis quod cum terminum militum nostrorum qui nobiscum sunt transfretaturi venerint de tempore quo nobis ad custum suum servire debent juxta scriptum quod inde habetis eos de denariis nostris quos ad hoc recepistis pacari faciatis tamquam si essent in Pictavia" (Rot. Litt. Claus., I, 117b). There is no mention specifically of the forty days, but the statement, "the time during which they ought to serve us at their own cost," may refer to that period. The men to whom the writ was addressed were leaders of an expedition going to Poitou (ibid., p. 117a), and the knights whom they were to pay were the men with them, not knights with the king. If these knights were tenants performing their service and if the period refers to the forty days, then payment for service beyond the forty days was a regular custom. For so common is it that the leaders carry a scriptum, a list of the knights with the wages (see ibid., pp. 185a, $188 \mathrm{~b}, 192 \mathrm{~b}$, for three examples of a scriptum in this sense). Why then should the king refuse to pay the expenses of the knights in 1213 and be enraged at the demand? In the expedition to Ireland in 1210, the king made many payments to knights with him, but 


\section{STUDIES IN TAXATION}

The king therefore continued to insist on the performance of service by his military tenants, great and small. In doing so, he was only partly successful. The greater tenants served but with reduced contingents. Some tenants did not serve at all, but compounded each time, though not necessarily for scutage only. It is clear that the tenant had acquired no right to compound at will. Further, since the king did not allow the development of this right and his armies of tenants were often not large enough for his needs, it is evident that he preferred the service to the money. Hence it follows that the commutation of service into money was not a custom favored by the king in the first half of the thirteenth century, but was forced on him by conditions over which he had no control. ${ }^{54}$

they were loans, not wages, and were made at irregular intervals, before and after the forty days had expired (Rot. Lib., p. $172 \mathrm{ff}$.). It seems possible that those knights mentioned in the writ above from the Close Roll were mercenaries who had agreed to serve for a certain period at their own cost. John led no general expedition to Gascony in 1212, though he seems to have been thinking of one toward the end of June (Rot. Litt. Claus., I, 130b); the writ discussed above was issued May 23. John had different kinds of arrangements with hired knights. English tenants were granted favors (usually pardon of a debt) in return for which they were to serve the king for a long period, at their own cost, and this without regard to the service owed for their fees (see note 18). In 1213, Hugh de Fornes of Flanders was to furnish five knights; they were to be sent to England ad custum suum, they were to serve John for 120 days and then were to be sent back to Flanders ad custum nostrum (i.e. at John's cost). Hugh was also, if necessary, to furnish 500 or 1,000 sergeants "et a die quo ultimo a portu recesserint transfretantes in Angliam erunt ad liberaciones nostras dum fuerint in servicio nostro" (Rot. Litt. Pat., p. 98b). There is mention of Flemish knights who held feoda of John (i.e. money fees) in return for which they did him a certain amount of service: "nobis faciunt servicium quod nobis facere debent"; "veniatis ad faciendum nobis servicium que nobis debetis" (ibid., pp. 11b, 12a, 26b; Rot. Litt. Claus., I, 183a).

54 This would not be true of those campaigns in which the king summoned knights simply as an excuse to raise money. 


\section{UNDER JOHN AND HENRY III}

Before discussing the scutages of John and Henry III, something should be said about the account of the scutage as rendered in the Pipe Roll. That account falls into two parts: first, the portion containing the names of the men who were charged with scutage or fine; secondly, that containing the names of the men who received writs of quittance with the title "Isti habent brevia de quietantia." The latter were the tenants who had performed their service and hence were excused from any money payment. $^{55}$ The men whose names appear in the roll were always the tenants in chief, never the rear-vassals, except in cases when the honor was in hand. ${ }^{56}$ Consequently when a tenant was entered as acquitted, his land paid nothing, as far as we can judge from the evidence of the Pipe Roll. ${ }^{57}$ Similarly, the fine or scutage charged against the tenant is all that appears against any of his lands. ${ }^{58}$ Taking the men who were quit and the men who were charged with

55 A comparison of the Scutage Roll with the names of those in the Pipe Roll who are entered as having writs of quittance shows that this is true in the main. Occasionally a tenant who fined is entered as quit "per finem," but usually those who fine are entered in the part of the roll above the list of writs of quittance.

$58 E . g$., in 1201 , the tenants of the honor of Gloucester appear in the roll (Rot. Canc., p. 55). After Isabella had been re-endowed and married to the earl of Essex, only the tenant in chief appears (Pipe Roll, 16 John, Glouc., m. 5 d). The custodian might account for an honor as if he were tenant in chief, and in that case his name only appears; e.g. Guido de Chancels accounts for the scutage of Wales of the honor of Gloucester as if he were the tenant in chief (Pipe Roll, 13 John, m. 17 d).

57 Thus a tenant is entered as quit in the different counties where he holds fees; see above, pp. 28, 50, 58, 73.

58 That is, the tenant in chief and his vassals will not be charged with scutage or fine. It is true that the tenant in chief may be charged in more than one county. Sometimes, the amount charged in any given county will be paid elsewhere; sometimes it will be entered as paid in that same county, but in any case, the tenant will not pay for the same fees twice over (see above, pp. 29, 51, 59, 74). 


\section{STUDIES IN TAXATION}

fine or scutage, the roll gives a fairly complete account of the fees in the kingdom. ${ }^{59}$ A comparison of the scutage accounts given in the Pipe Rolls of Henry II, Richard, John, and Henry III shows that the entries become fuller, more exact, and more detailed as time goes on till near the end of John's reign (1211), when the account appears in a form which remains practically the same throughout the reign of his son. ${ }^{80}$ It might be suggested that in the matter of the fines, the Pipe Roll would be defective and that it would contain only the scutages, while the fines would appear mainly in the Fine Roll. This is not so. Practically all the fines in the Fine Roll are found entered in the Pipe Roll also. ${ }^{61}$

A distinction should be noted in the financial levies of the time, which is often ignored, viz., between aids and scutages. The aid could not be levied by the king without the consent of the vassal; it was not obligatory on the latter to pay it if the king asked for it. If he did pay it, he made in theory a free grant to the king as lord. It might take the form of a tax on the ploughland, as in

59 This is true for all of John's scutages except that of 1204 and the scutage of Ireland which are incomplete.

60 Under Henry II, the men who are taxed, not those who receive writs of quittance, are the ones entered in the roll. In 6 Richard, the latter begin to be entered. The number of fees which each man holds is not given. Such an entry would not be necessary when scutage only was paid. Under Richard, the reports of sheriffs concerning fees in their counties which hold of baronies whose heads lie in other counties are entered in the roll. Under John the account is thus rendered in two parts: first the tenants who are charged with fines or scutage and second those who are quit; sometimes the number of fees is given but there is no regularity about it. Beginning with the roll of $13 \mathrm{John}$, the practice is set up of entering the number of fees after the name of each tenant whether he is charged with scutage or is quit. This remains the custom throughout the reign of Henry III.

61 Two of the years in which there are a large number of fines entered in the Fine Roll are 1201 and 1230. Nearly all are also found in the Pipe Roll. 


\section{UNDER JOHN AND HENRY III}

the carucage; of a tax on personal property; of a tax on the knight's fee, as in the aid of 1217; or of a lump sum, not based on property. On the other hand, scutage in the strict sense of the word was a composition for military service and as such was owed. If the king waged a campaign, he was entitled by law to a scutage at least from such tenants as had failed to come to the host. The custom of taking scutage was well established before the close of the twelfth century; it was levied in connection with military expeditions, and was usually taken at the close of the campaign. It was in general the full commutation for service, and the customary rate was $£ 1$ ( $1 \frac{1 / 2}{2}$ marks) or less per fee.

The occasion for the scutage remained the same. John usually observed the form though not the spirit. In 1199, a truce was concluded as soon as the king landed in June and fighting did not begin till September. ${ }^{62}$ In 1201, there was no fighting at all. ${ }^{63}$ In 1204 and 1205 , the host was summoned, but was not despatched; in the latter year, a picked body of knights was sent. ${ }^{64}$ On all these occasions scutage was taken. In 1209 , the host was summoned and the king led it against the Scots. The difficulty was settled without fighting, but a scutage was taken. ${ }^{65}$ On other occasions, the scutage was levied for campaigns which were actually waged by the king at the head of the host. ${ }^{68}$ Henry III only once took a scutage to which he was not fully entitled by feudal law. ${ }^{67}$

62 See above, p. 21.

03 Hov., IV, 161, 164; Norgate, John Lackland, p. 81.

64 See above, pp. 64, 69. Some tenants seem also to have gone in 1204.

65 See above, p. 94.

60 In 1202, 1203, 1206, 1210, 1211, 1214 (see above, pp. 46, 53, 77, 96, 101, 109).

67 In 1231, after the campaign in Poitou, for which he had taken a scutage once (see above, p. 191). 


\section{STUDIES IN TAXATION}

Several of John's scutages were put in charge probably when the host was summoned, or soon after, and not at the close of the campaign; but this was not an invariable rule. $^{68}$ Henry III, however, put the scutage in charge at or near the close of the campaign, except in 1229 and 1242, on the occasion of the expeditions to France. ${ }^{.9}$ At other times he levied fines for exemption from service during the campaign. ${ }^{70}$ In many cases, therefore, the baron knew what the rate of scutage would be. In others, if he did not perform his service, he would naturally expect to pay scutage at least, though this was not certain, for the rule was not invariable that a scutage should be taken for each campaign. ${ }^{71}$ The account was entered in the Pipe Roll of the financial year when the scutage was put in charge. ${ }^{22}$ The advantage to the king of levying scutage and fines at the opening of the campaign is obvious. Not only would he be able to use part of the money in carrying on the war, but he would have more complete control of the right to fix the rate and determine the circumstances under which scutage was due.

The rate too was raised by John. His first scutage was placed at two marks per fee, "a change which caused

68 In 1209 the scutage seems to have been levied after the host had met that of the king of Scots and a treaty had been made; in 1211, the scutage of Wales was taken at the close of the campaign (see above, pp. 94, 101).

69 See above, pp. 184, 227.

70 See above, pp. 206, 240, 255, 286.

71 It was always taken under John. Under Henry III, none was taken for the campaign against Richard Marshal in 1233; none for the march against Wales in 1241, Scotland in 1244, or Gascony, 1253 (see above, pp. 206, 220, 240, 256).

72 The scutage of Scotland was spread over the three years, 12091211. The siege of Bedford ended in the middle of August, 1224, yet the scutage was entered in the roll of that year. If a campaign did not end till the close of September, the account was not entered till the following year (see abore, pp. 94, 15I, 196, 197). 


\section{UNDER JOHN AND HENRY III}

unfavorable comment," marks. ${ }^{74}$ During the minority of Henry III, the rate fell, ${ }^{75}$ but rose again to three marks in 1229 , a figure which became common. Though the change was thus considerable, it is clear that the king was not unrestricted in determining the rate.

The most important question in connection with the scutage is its character, for with it the king began to take fines, "pro passagio," "ne transfretent," which usually included the scutage, but were often distinct from it, that is, were in addition to it. ${ }^{76}$ We should remember that the king was also trying to get as much service as possible out of his English tenants. Was the scutage, therefore, especially in John's reign, transformed to any extent into a general tax on the rear-vassals while at the same time the king was getting the service of the fee from the tenant in chief, either in knights, or by a fine? ${ }^{77}$ It is hard to believe that even John, strong though he was, could carry through such a financial and military revolution as is implied by this query. Though examples of a double contribution will be pointed out, it seems unquestionable that they were exceptions, and that in general scutage did not become a general tax, but retained its original character as the composition for service, though often not the only composition. To put it another way, the tenants who performed their service, or paid a fine,

73 "gravis exactio scutagii"; "nunquam amplius quam viginti solidi ad scutum exigerentur" (Cogg., pp. 101, 102).

74 Ireland and Poitou (see above, pp. 98, 112).

75 Biham 10s; Wales, Bedford, and Kerry, two marks.

76 The fincs begin to appear under Richard (Red Book, I, 99, 102, 115; Madox, I, 676, n. $t$ ). They perhaps go back to Henry II.

77 " $A$ nd so in the thirteenth century the king, while he is exacting military service or fines from his tenants in chief, will also collect scutage from their military tenants. Theoretically he is not entitled to be paid for the same thing twice over" (Pollock and Maitland, I, 270). 


\section{STUDIES IN TAXATION}

made no additional payment for their fees to the king. Unless the Pipe Rolls are far more defective than they seem to be, they offer good evidence that scutage did not become a general tax. The total number of fees on which scutage might be paid was about 6,500 . If scutage were a general tax, the number of fees taxed should remain approximately the same and should approach 6,500. But this is not the case. The number never rose above 4,000 and varied from one levy to another, apparently according to the amount of service which the tenants performed. Furthermore, the tenants who are not charged with scutage or fine in the roll are not left unaccounted for. They also appear in the roll as receiving writs of quittance. ${ }^{78}$ It might be suggested that the king took a fine or service from the tenant in chief and in addition collected scutage from the rear-vassals, but the accounts of scutage in the Pipe Roll support no such theory. ${ }^{79}$

When we turn to individual cases we get the same result. Tenants who performed their service were acquitted of part or all their scutage and received writs de scutagio habendo. Such a writ exempted the whole holding of the tenant from paying scutage to the exchequer. ${ }^{80}$ If a

78 It should be observed that in the account of most scutages a fairly complete statement of the fees of the kingdom is rendered, either charged with scutage or fine or receiving writs of quittance; and that the writ of quittance means that the tenant in chief had performed his service and was allowed to have his scutage for his own use (see above, pp. 18, 313, 314).

79 If we add together the sums charged against tenants in chief who hold five or more fees and to this sum add the scutage charged against fees on honors in hand which can be identified, and then subtract this total from the total amount of the scutage proper which appears in the roll, the remainder will be far too small to represent anything like a general payment by rear-vassals. Even this remainder could not all be charged against rear-vassals, for from it would have to be deducted scutage charged against tenants in chief holding fewer than five fees each (e.g. above, pp. 22, 23, the account of the first scutage of John).

80 See above, pp. $24,36,40,48,50,55,58$, and index: service. 


\section{UNDER JOHN AND HENRY III}

tenant did not obtain a writ at first, he might be charged with scutage; later, when he secured the writ, his account would be written off. ${ }^{81}$ Sometimes part of the scutage was collected; if so, it was either returned to the tenant or credited to some account of his other than scutage. ${ }^{82}$ Tenants who fined or who paid only scutage were allowed to collect scutage from their vassals and nothing but that fine or scutage was paid from all their holding to the exchequer. ${ }^{83}$ A tenant might hold fees in other counties than where the head of his barony lay. If the sheriff of the county in which these detached fees lay collected the scutage from them, either from the rear-vassals or from the tenant's steward, the amount collected was credited to the tenant in chief in the main account of his honor. This shows that a double payment was not made by the tenants and his vassals. ${ }^{84}$ Then there are several cases of men who are charged with scutage in the roll. Apparently they protested, for an inquest was held to determine whose tenants they were. It was found that they were rear-vassals and accordingly they were excused from paying to the exchequer. ${ }^{85}$ Thus the king's courts protected the sub-tenant from such an extension of the royal authority. Again, when the tenant in chief opposed the payment of scutage, the sheriff did not collect it, but distrained him to compel payment. ${ }^{86}$ The tenant might be disseized if he refused to pay, as in the case of the archbishop of York. ${ }^{87}$ Occasionally the tenant fined in an

81 See above, pp. 25,37 , note $99 ; 51,73$, note 313.

82 See above, pp. 50, 51, note $181 ; 56,58,67$.

88 See above, pp. 27, 28, 42, 60, 68, 75, 76, 80.

84 See above, pp. 28, 40, 41, 51, 59, 74, 80, 103.

85 See above, pp. 52, 59, 67, 74, 81, 100, 116.

86 'Henricus (de Pinkeni) promisit coram justic' quod acquietabit averia sua que capta sunt pro scutagio; recognovit enim quod idem debet" (Rot. Curia Regis, II, 43, anno 1 John).

87 Rot. Litt. Claus., I, 11b. Cecilia de Crevequor was disseized "eo quod proinde finem (pro passagio) ... non fecerat" and it was 


\section{STUDIES IN TAXATION}

unusual way. He himself paid no scutage, but allowed the king to collect it from all his military tenants. Here the collection by the king from the rear-vassal seems unusual. ${ }^{88}$ Stewards of tenants in chief continually appeared before the exchequer to answer for the scutage of their lords ${ }^{89}$ and secured the king's aid to distrain the

ordered "quod (vicecomes) faciat ei habere scutagium suum de feodis militum que de domino rege tenet in capite in balliva sua." She had fined in 40 marks as a result of the disseizin (Rot. Obl., p. 302). Notice that the king had not collected from the rear-vassals.

88 "Fulco Painel dat domino regi scutagia septime militum et aliorum militum si plures de domino rege teneat in capite pro passagio suo et passagio prædictorum militum. Et mandatum est vicecomitibus . . . quod colligant scutagia de feodis omnium militum suorum quos de domino rege tenet in capite" (Rot. Obl., p. 131). "A Willelmo comite de Vernun (earl of Devon) nullum scutagium requirendum est in aliqua summa quia finivit cum rege pro licentia remanendi ut rex capiat de omnibus militibus suis scutagium suum quos tenet de rege in capite" (Rot. Canc., p. 263). That these cases mean that the king takes from all the knights whom the tenant in chief had enfeoffed and not merely from the servitium debitum is shown by the case of the earl of Deron who this year in another part of the roll paid on fifteen knights "quos recognoscit" and fortyfive knights "quos non recognoscit (Rot. Canc., p. 26). If the collection from the rear-vassals by the king comes in, it is under John. What the abbot Samson feared in 1198, if he failed to satisfy the king was that he would be disseized, not that the king would collect scutage from his men (Chron. Joc. de Brak., p. 63).

89 "Simon de Charterai senescallus Willelmi de Brause affidavit facere pacem de xxviii li. de secundo scutagio (of Richard) sicut vicecomes dicit et non venit; habeat judicium senescalli"; "Ricardus del Estre debet xvi sol et viii den. de primo scutagio regis Ricardi ... senescallus ejus affidavit facere pacem et non venit"; Hugo de Morba senescallus Henrici de Trasci affidavit facere pacem de L marc. et dim. de scutagio suo sicut vicecomes dicit et non renit" (Exch. L. T. R., bundle I, no. 3, Mem. Roll, 1 John m. 19, 17, 19 d). "Eustachius filius Willelmi senescallus Eustachii de Vesci affidavit h' de ... xx li. de sexto scutagio (of John)"; "Eadmundus clericus senescalli Roberti filii Walteri affidavit facere pacem ... de xx marcis de fine et de quater $\mathrm{xx}$ et iii li. et $\mathrm{i}$ marc. de scutagio sexto"; "Rogerus de Lilleston' senescallus comitis Alberici affdavit facere pacem de ... lx marc. at $x l$ den. de iiii scutagio ... et de $x x x$ marc. de scutagio vi"; "Willelmus de Rollest' senescallus Jollani de 


\section{UNDER JOHN AND HENRY III}

rear-vassals to pay to their lords the scutage which was owed to the king. ${ }^{90}$

That the king tried to get scutage, fine, or service out of every fee in England held of him is certain. In so doing, he systematized the collection of the money and at times overstepped his rights. Putting the scutage in charge early in the campaign made it possible for him to demand and in some cases to collect from rear-vassals before it was known whether or not the tenant in chief owed scutage. $^{91}$ The fact that rear-vassals had to protest against payment shows the activity of the exchequer. Sheriffs were ordered to report the number of fees held in their counties by tenants in chief, ${ }^{92}$ and the latter were no longer charged with their whole scutage in one county only, but were entered either charged or acquitted, in each county in which they held fees. Sometimes the whole amount due was charged in more than one place; some-

Nevill' affidavit de ii marc. de vi scutagio et de $\mathrm{xx}$ sol. de vii scutagio; non venit; judicium"; "Comes de Ferar' debet xxxii marc. de vi scutagio; Willelmus de Radewar' senescallus affidavit et non venit" (ibid., bundle 1, no. 4, Mem. Roll, 10 John, m. 4a d; m. 8a; m. 11a or m. 10). Below, p. 336.

90 In 1220, Melicent de Stafford agreed with the king that he should collect the arrears of scutages due on the fee of Hervey Bagot (her deceased husband) since the early part of John's reign. The king evidently had not collected from the rear-vassals (Madox, I, 680, n. $m$ ). "Episcopus Linc' debet scutagia vii militum de militibus quos non potest distringere de baillia de $\mathbf{N}$. ut baillivus suus dixit" (Exch. L. T. R. Mem. Roll, 2 Henry III, m. 6 d); "Rex vicecomiti. Precipimus tibi quod sis in auxilium Willelmo de Mowbray ad distringendum milites suos quos tenet de nobis in capite in balliva tua ad reddendum ei scutagium Pictaviæ de feodis que ipsi tenent de eo, scilicet, iii marc. de scuto quia idem Willelmus inde debet respondere" (ibid., 7 Henry III, m. 13); similarly for the abbot of Holme (ibid., m. 6 d); for the abbot of Peterborough (ibid., 6 Henry III, m. 2 d); for Margaret de Cressy (ibid., 8 Henry III, m. 4); for the abbot of Westminster for the scutages of Biham and Bedford (ibid., 9 Henry III, m. 2).

91 See above, p. 319 , notes $81,82$.

${ }_{92}$ See above, pp. 29, 30, 44, 51, 60. 


\section{STUDIES IN TAXATION}

times the amount due from the fees held by each tenant in each county was charged. ${ }^{93}$ This work of locating the fees was only partly carried out by John. At the close of his reign, in 1212, there was the great inquest of service to find out the location of the fees of the tenants in chief as well as the total service of the kingdom. This inquest did not result in any increase in the number of fees for which each tenant accounted at the exchequer. ${ }^{94}$

An indication that the king got both scutage and service from his direct tenants is to be found in the fact that some tenants in chief performed their service and were charged with scutage. ${ }^{95}$ In some of these cases part of the scutage may have been legally due because the tenant had performed only part of his service. Yet there were unquestionably times when the king exacted not only all the scutage but some service also. ${ }^{96}$ Moreover, men with small holdings appear and disappear in the roll. Such tenants might be taken to be rear-vassals accounting for scutage directly to the exchequer while their lords had either served or compounded elsewhere. Wherever they can be traced, some of these men are found to be sergeants while others are indeed rear-vassals, but on honors in hand. In any case, the number of fees which they held was too small to represent a general tax on knights' fees. ${ }^{97}$ All this shows that John was collecting his scutages with great care and that the exchequer was locating fees owing scutage rather than making a general collection of the tax from rear-vassals, in addition to scutage, fine, or service from the tenant in chief.

The scutage at a fixed rate per fee would not always

93 See above, pp. 28, 41, 51, 59, 74 .

94 See above, p. 301.

95 See above, pp. 23, 24, 38, 56.

96 Ibid.

97 See above, p. 40, note 126. 


\section{UNDER JOHN AND HENRY III}

exempt a tenant from taking part in a campaign. From many tenants John took a larger amount than the scutage, called a fine. All classes, great vassals and lesser vassals, lay tenants and clerical tenants, paid fines. ${ }^{98}$ Each year some tenants paid scutage and others fines; the same tenant paid fine one year and scutage another. ${ }^{99}$ The fine was usually a lump sum paid by the tenant in chief in return for which he was exempted from service and was given the right to collect scutage from his tenants. ${ }^{100}$ Sometimes, however, the vassal paid in addition to his scutage a fine, ${ }^{101}$ and occasionally the fine was levied at a fixed rate per fee. ${ }^{102}$ Legally the king had warrant for this extra demand. He was entitled to full military service from his tenants. If they did not wish to serve, they would have to pay whatever sum he might fix or lose their lands. The sums which he took in fines were usually smaller than the cost to the tenant of answering the summons to the host with his full contingent. Yet as partial service in the field seems to have been the equivalent of the old servitium debitum, the scutage was probably regarded as a fair amount of composition, especially as it had been the full composition before. There can be no doubt that the extra amount of composition was regarded as excessive. At the close of his reign when discontent was growing, John stopped taking fines. ${ }^{103}$ When the barons were in control of the government, during

98 With few exceptions, bishops never paid fines.

99 E.g. Henry de Oilli paid scutage in 1199 and 1203 and a fine of 97 marks in 1201; William Painel paid scutage in 1199 and 1202 on 15 fees and in 1201 a fine of 40 marks.

100 The fine is paid "ne transfretet et pro habendo scutagio suo," "pro passagio et ad habendum scutagium suum."

101 See above, pp. $27,40,49,58,66,73,79$.

102 "Henricus de Oilli $r$ c de 97 marcis de fine que fecit scilicet pro quolibet milite que tenet de rege $3 \mathrm{~m}$ " (Rot. Canc., p. 279).

103 No fines were taken for the last two scutages, Wales and Poitou, and few for the Scottish scutage. 


\section{STUDIES IN TAXATION}

the minority of Henry III, scutage was all that was demanded.

The fine was not an amercement in any sense different from the scutage, not the punishment on the tenant who had failed to answer the summons to the host and had stayed at home. It was not the substitute for disseizin or distraint as a means of eompelling the vassal to serve. ${ }^{104}$ Later the two levies may have been distinet in character, ${ }^{105}$ but in the first half of the thirteenth century, the fine was a composition for service which differed from the scutage in form only. The fines were levied at the beginning of the campaign when the king was gathering the host, not at the end when he might be determining the punishment to be inflicted on defaulters. ${ }^{108}$ Some of the fines were hardly larger than the scutage would have

104 The purpose of the scutage and the fine was not to punish the tenant so that he would not repeat the offence, but to charge an amount commensurate with the amount of service which the king had lost. It is true that a high rate of composition contains an element of amercement, for such a rate will retard a tendency to commute service into money. If that element was present in the fine, it was also present in the scutage, particularly among the greater tenants. If Ralph de Sumery who holds 50 fees pays 100 marks scutage and thus buys the exemption from service of 50 knights, then his scutage is a mere nominal composition; if he pays 120 marks fine instead of scutage (see below, note 107), his fine is also only nominal. In either case, the tenant would gain by compounding. The point has already been made that military service in the thirteenth century had become reduced. If Ralph would have served with only 10 knights instead of with 50 , then his fine of 120 marks doubtless has an element of amercement, but so has the scutage of 100 marks.

105 "In Edward I's day, the fine for default is an utterly different thing from the scutage" (Pollock and Maitland, I, 268).

106 See above, pp. 35, 70, 187, 206, 228, 240, 255 .

The abbot of St. Edmunds went to the king at the opening of the war and fined for his service (Chron. Joc. de Brak., p. 63); the abbot of St. Albans in 1265 sent his knights to the meeting of the host under two of his officials to see whether the king would use them on the campaign or to fine (Chron. Will. de Rishanger, p. 50). 


\section{UNDER JOHN AND HENRY III}

been, ${ }^{107}$ and occasionally the scutage was called a fine. ${ }^{108}$ The fact should be recalled that ordinarily most of the great barons paid neither scutage nor fine ${ }^{109}$ for the reason that the king refused to allow them to compound, preferring the service to the money. For a tenant to pay scutage or fine, the king's permission was necessary. ${ }^{110}$ That the fine and scutage had different names does not mean that there was anything different in principle between them. Composition in a lump sum was at the time new; it was assessed and in part collected by special officials. Naturally it was given a different name. ${ }^{111}$ The separation of the fine from the scutage suggests that the

107 It is possible to cite fines that were enormous in comparison with the full service of the tenant, but with these will be found others which are small. Notice such fines as the following: Hervey Bagot, $20 \mathrm{~m}$ fine and $120 \mathrm{~m}$ scutage on 60 fees (Pipe Roll, 4 John, Staff.); Doun Bardolf, 60 marks fine on 25 fees (includes scutage at $2 \mathrm{~m}$ per fee) (ibid., 5 John, Notts. and Derby); Geoffrey Fitz Hugh de Scalariis, $50 \mathrm{~m}$ fine on 15 fees (includes scutage at $3 \mathrm{~m}$ per fee) (ibid., 14 Henry III, Cant. and Hunt.); Simon de Beauchamp, 100m on about 45 fees (Rot. Canc., p. 354); the earl of Warwick, $20 \mathrm{~m}$ and his scutage on 1021/21/3 fees (Pipe Roll, 4 John, War. and Leic.); Ralph de Sumery, $20 \mathrm{~m}$ fine and his scutage on 50 fees (ibid., 7 John, Staff.).

108 "Hubertus filius Radulfi $\mathrm{r}$ c de 30 marcis de fine suo" (Pipe Roll, 7 John, Notts. and Derby, sixth scutage); as he held 15 fees, this was really a scutage. "Willelmus comes Waren' 120 marc. de fine pro passagio (et) scutagio, qui finis intravit per breve regis" (ibid., 7 John, Norf. and Suff.); the service of the earl was 60 fees and as scutage was at the rate of $2 \mathrm{~m}$, this was scutage. "Baldwinus Waac $r$ de 20 marcis de eodem (fine et scutagio) qui finis intravit per os justiciar" (ibid., 5 John, Linc.). He held 101/8 fees and the rate of scutage was $2 \mathrm{~m}$, so that this was a scutage.

109 See above, p. 302.

110 The evidence of this has already been mentioned. It is shown by the use of distraint and disseizin to enforce service, by the fact that a tenant might have to pay a fine instead of a scutage, and by the fact that tenants sought exemption by fines at the opening of the campaign; see also above, pp. 305-307, 312.

$111 \mathrm{C} f$. the farm of the county, the increment, and the proficuum. The farms of some of the counties were increased by a sum called 
two differed in character. The difference however was merely one of form and depended on the bargain which the tenant had made with the king. Sometimes the tenant preferred to pay a lump sum in addition to the scutage; sometimes to pay a sum which should include the scutage. Both arrangements continued side by side throughout the reigns of John and his son. ${ }^{112}$ Nor does the separation mean that the tenant in chief paid the fine personally while the king took a scutage from the rear-vassals, unless there was a special agreement, as in the case of the earl of Devon in $1201 . .^{118}$

The question may be raised whether the heaviest fines were paid by the greater or by the lesser lay tenants. ${ }^{114}$ Taking the total amount of the fines in any given year, it will be found that the rate was without exception higher on the lesser than on the greater tenants. ${ }^{115}$ That is, considering the fine as a tax on the land and measuring the ability of the tenants to pay by the number of fees

increment under Henry II; in 1205, some farms were increased by another sum called the proficuum. Instead of calling the whole sum the farm, each amount was kept separate with its own name.

112 Thus in 1242, both kinds of fines were made (see above, p. 230); in the scutage of 1257 , the last of Henry III's reign, several tenants fined as follows: "Abbas de Abbindon' similiter finem fecit cum rege pro servicio suo quod regi debet et pro scutagio suo habendo; habet scutagium suum in comitatibus etc." The title of the section containing these names is "De hiis qui fecerunt finem pro servicio suo et pro scutagio habendo" (Scutage Rolls, no. 8).

113 See above, p. 39 . Robert Fitz Walter in 1205 fined in 20 marks and all his scutage which was collected by himself (Rot. Litt. Claus., I, 43b).

114 The term fine is used here to mean the total amount of composition charged against those tenants who fined, not the amount over and above their scutage. The statements which follow in the text relate only to lay tenants.

315 See above, pp. $23,36,48,55,65,71,78,98,185$. It is however posisible to cite examples of fines on great tenants which are as high in rate as the arerage rate of fines on the lesser tenants (see above, pp. 66, 99, 188, 229). 


\section{UNDER JOHN AND HENRY III}

which they held, it will be found that the burden of the fines always fell on the lesser tenants. But there is another phase of the question to be considered. The fine was the composition for service and the quotas which the tenants led to the host had become reduced. Now if we divide the amount of money paid by a great tenant in either scutage or fine by the number of knights which he would have supplied had he served, we find that the rate of composition per knight furnished was very high in the scutage as well as in the fine. ${ }^{116}$ From this point of view, the fine may have been heavier on the greater than on the lesser tenant. All the fines seem to have become heavier in John's reign as time went on, till we reach the Irish scutage when the great barons paid very heavy fines and the lesser tenants averaged ten marks per fee. ${ }^{11 \tau}$ Yet this policy did not continue; after 1210, John levied no more fines on the tenants as a whole. Why some men paid fines and others scutage is not clear. Perhaps those men who were charged with scutage performed part of their service in addition, ${ }^{118}$ or paid a fine which is nowhere entered. Yet it might be expected that John would not be able, indeed probably would not try, to substitute at one stroke the new way of composition for the old. Sometimes the fine was little greater than the scutage, an indication that there was a gradation in composition beginning with the scutage and rising through fines of varying amounts. ${ }^{119}$

In the first four levies of Henry III's reign, the scutage was the entire composition for service, ${ }^{120}$ but in 1229, the

116 See below, p. 363.

117 See above, p. 99.

118 There are some cases in which this seems to be true (see above, pp. 24, 38, 99, 286).

110 See above, p. 324.

120 Scutages of Biham, Wales, Bedford, and Kerry (see above, pp. 139, 144, 151, 175). Perhaps there were some fines in the 


\section{STUDIES IN TAXATION}

king began to levy fines as well as scutages, though not as an invariable rule, for no fines were levied in $1231 .^{121}$ Fines were taken for campaigns in which scutage did not run, though some of these were afterwards pardoned..$^{122}$ The levy of 1253 was an aid to knight the king's son, and not a strict scutage, so that it had no connection with the campaign in Gascony of that year. Fines were however taken from tenants who did not perform their service. ${ }^{123}$ Only in 1229 and 1242 was the number of fines considerable that was entered in the roll. As under John, the scutage was sometimes the full commutation for service, though at times a fine was paid in addition and in other cases the scutage was replaced by a fine. In general, tenants who had performed partial service made no payment at all. ${ }^{124}$ It is possible to quote examples of very heavy fines, but as a rule, the amount paid over and above the scutage was not as heavy as in some of John's levies. ${ }^{125}$ As before, the burden of the fines fell on the lesser tenants. ${ }^{126}$ The fine was collected at the beginning of the campaign, thus showing that it was not an amercement on the tenant who had failed to serve, but was a commutation for the service, like the scutage. ${ }^{127}$ Thus the scutage did not become a general tax on knights' fees, payable to the king, but retained its original character as the commutation for service, though the fine often replaced it. There was however a tendency to make the

campaign of Bedford, but they were not generally taken. The levy of 1217 is not here included, for it was an aid, not a scutage in the strict sense.

121 See above, p. 191.

122 See above, pp. 206, 240.

123 See above, p. 255. No scutage was taken for that campaign.

124 See above, pp. 150, 174, 193, 196, 226, 246.

$125 \mathrm{Cf}$. the rate of the fines in 1229 with that of 1210 (see above, pp. 98, 185).

126 See above, p. 185.

127 See above, pp. 187, 206, 228, 255. 


\section{UNDER JOHN AND HENRY III}

scutage and the fine different in character, the former to be a tax on the rear-vassals, the latter the composition of the tenant in chief for his service. This tendency is shown by the levy of fines for campaigns when no scutage was taken and by the separation of the fine from the scutage to such an extent that in 1242 a roll was drawn up containing scutage only. ${ }^{128}$

The tenant in chief therefore discharged his obligation of military service in one of three ways : he performed the service, he paid a scutage, or he paid a fine. ${ }^{129}$ To fulfil his duty to the king, he relied on his tenants, for they formed part at least of the men whom he led to the host. ${ }^{130}$ If he performed all his service, he made no payment to the exchequer. If he furnished what the king considered a reasonable fraction of his nominal service, no money would be demanded of him. But the matter did not stop with a settlement of this obligation. The king granted the tenant in chief a writ de scutagio habendo, giving him the power to collect the scutage from his vassals and instructed the sheriff to assist him with distraint in obtaining it. Tenants in chief who fined and those who paid scutage only received the same writ. Thus the scutage fell back on the rear-vassal. The nature of the obligation of these men must be carefully stated. If the rear-vassal had performed his service, he owed no scutage, whatever bargain had been made between the king and his lord. Sometimes a writ of scutage especially exempted

128 See above, p. 228.

129 The tenant might fulfil his obligation partly in one way and partly in another; he might pay part of his scutage and perform part of his service (see above, note 118).

130 Disseizin of a rear-vassal by his lord, Geoffrey Fitz Peter, for failure to serve (Rot. Litt. Claus., I, 148a); see above, pp. 307, 308, note 35. Rear-vassals are acquitted of paying scutage to their lords evidently because they have performed their service (see above, pp. 140, 175, 195). 


\section{STUDIES IN TAXATION}

him. ${ }^{131}$ He owed scutage not to the king, but to his lord. ${ }^{132}$ Now, though the scutage was owed to the lord, the latter could not collect it without a royal writ. ${ }^{133}$ In this way the king had a check on the tenants in chief. But the writ was important in another way, for the tenant sometimes could not force his vassals to pay without the king's aid. ${ }^{134}$ The necessity for this assistance is shown by the fact that when there was a dispute over the scutage between the tenant in chief and his vassal, the case had to be brought before the king's court. The baronial courts were not sufficiently powerful. Thus when the abbot Samson and his tenants quarreled over their liability for scutage, the case was tried in the royal court. ${ }^{135}$ It follows that the king would not collect from his tenants unless they had collected from their vassals. ${ }^{136}$ The

131 See above, p. 140.

132 Because he owed service to the lord. If he paid scutage to the king, the presumption was that the fee was held of the king. See the case in 1208 in which a tenant paid scutage to the king, but made homage to another. He was summoned to court to show by what warrant he made homage to another when he made the service of the fee to the king: "Ricardus filius Guarneri affidavit facere pacem de 20 solidis de quinto scutagio. Idem $R$. tenet feodum de Seirico de (Lacy?) unde reddet scutagium ad scaccarium et inde fecit homagium suum prædicto Seirico de Lacy. Et ideo datus est ei dies ad clausum Paschæ, ut ostendat quo waranto fecerit homagium suum Seirico de feodo unde facit servicium domino regi" (Exch. I. T. R., bundle 1, no. 4, m. 8 a or 7).

133 This seems to be shown by the fact that the king continually issued such writs. In 1305, the king was petitioned to grant the barons these writs for wars in which they (the barons) had performed their service (Memoranda de Parlamento, p. 122).

134 See above, pp. 31 , note $58 ; 76,140,147,152,188,194,198,231$, 235, 248, 321.

135 The abbot of Abingdon sued Peter Fitz Herbert for scutage (Close Rolls, II, 154); the bishop of Bath sued William de Ferrar who refused payment (ibid., I, 512); cf. Bracton, Note Book, cases $190,202,664,1049,1674,1687$.

136 See the case in 1233 in which the tenant declares that he had not collected his scutage and the sheriff is ordered not to distrain 


\section{UNDER JOHN AND HENRY III}

tenant in chief collected scutage from all the knights whom he had enfeoffed, but he paid the exchequer only on a customary number, usually only the servitium debitum or the old enfeoffment. Sometimes therefore he made a profit on the scutage. ${ }^{137} \mathrm{By}$ the inquests of 1166, the king had tried to get the benefit of the extra enfeoffments. As a rule he was not successful in obtaining scutage from the new enfeoffment, when it exceeded the servitium debitum. ${ }^{138}$ If however the barony was in hand, the king collected from all the knights enfeoffed. ${ }^{139}$

Thus the rear-vassal was responsible for the scutage, but he was not liable for the part of the fine which was over and above the scutage. Ordinarily that came out of the coffers of the tenant in chief. What the writ de scutagio habendo stated was that the lord was to have scutage. ${ }^{140}$ Sometimes the rate was mentioned, which was the same as the rate of scutage of the year. ${ }^{141}$ When the fine and the scutage were separated, the latter only was to be collected from the rear-vassal. ${ }^{142}$ When a rearvassal was exempted by the king from paying while his lord was charged with a fine, the sub-tenant was pardoned scutage only and that was the amount deducted from his

him: "Mandatum est vicecomiti Lincoln' quod non distringat Hugonem de Nevill' pro scutagio exercitus Pictaviæ post etc. reddendo de feodis militum que de rege tenet in capite in balliva sua de quo colligendo non habuit breve regis, nec illud collegit, ut dicit" (Close Rolls, II, 201); see above, pp. 104, 195, 321, note 90.

137 Thus in 1198, the abbot Samson owed the service of 40 knights to the king and tried to collect scutage on 50 knights whom he had enfeoffed. The knights claimed that they owed scutage on 40 fees only. The abbot won his case in the king's court (Chron. Joc. de Brak., p. 63); that the tenant collected on all the knights enfeoffed is implied in note 139 .

138 See above, p. 301.

139 See above, pp. 43, 52, 104.

140 See above, p. 75.

141 See above, pp. 43, 188, note 56 .

142 See above, p. 75 , note 319 . 


\section{STUDIES IN TAXATION}

lord's fine. ${ }^{143}$ A method remained however by which the lord could shift the fine to his tenant: by a royal writ granting him permission to collect an aid from his men. ${ }^{\mathbf{1 4}}$ The aid would in theory not be obligatory on the subtenant. How generally such permission was granted by the king, it is impossible to say; only a few cases have come down to us. The fine therefore bore with especial force on the tenants in chief and probably for this reason they were opposed to it. John was not content with collecting scutage from all the knights enfeoffed; when an honor fell into his hand. In addition he collected heavy fines as though the sub-tenants were tenants in chief. ${ }^{145}$ This was a cause for complaint. ${ }^{146}$ Henry III abandoned his father's policy, except in the case of honors which had been long in hand. ${ }^{147}$

From the point of view of the exchequer, the scutage did not become a general tax in the reign of John or his son. It remained the composition for service. But from the point of view of tenants, both tenants in chief and rear-vassals, it did not fall much short, if at all, of being a tax on all the fees held by military service in the realm. Scutage was of course paid by all men holding by military service on the lands of those tenants in chief who paid fine or scutage to the exchequer. The rest of the tenants in chief performed service and so made no payment to the king. Those of their vassals however who had not performed their service in the host had to pay

143 See above, pp. 60 , note 236 ; 80 , note 352 ; 188 , note 56 ; 207.

144 See above, pp. 66, 206, 240, 286.

145 See above, pp. 36, 48, 55, 65, 71, 78, 95.

146 Is this not legislated against in Magna Carta, cap. 16? "Nullus distringatur ad faciendum majus servitium de feudo militis, nec de alio libero tenemento, quam inde debetur."

${ }_{147} \mathrm{Cf}$. the king's letter concerning the scutage of the tenants of the earl of Devon in 1224 (see above, p. 152). Fines were paid by tenants on such honors as Mortain (Pipe Roll, 14 Henry III, Dors. and Somers.). 


\section{UNDER JOHN AND HENRY III}

scutage to their lords. But the reduction in the amount of service which each tenant in chief furnished the king means that a large part of the rear-vassals paid scutage instead of serving, though the payment was made to their lords, not to the king. ${ }^{148}$ The service did not stop with the immediate vassal of the tenant in chief. ${ }^{149}$ The subtenants of lower rank would be still more likely to pay scutage than to serve, for their holdings would be smaller. The tendency may be illustrated by the fact that tenants in letting land arranged for the incidence of scutage which was called the service of the fee. ${ }^{150}$ The tenures of these

148 See above, p. 302.

149 Tenants on honors in hand collected scutage from their vassals; e. g., above, p. 66, note 268. Here is an example of a long chain of tenants: "Hæc est inquisicio facta de scutagio in comitatu Wigorn' per sacramentum Simon' de Frankeleg et (11 others). In Holreton' dimid' feod' quod Ricardus de Karsy tenet de Willelmo de Wasseburn, Willelmus de Rogero de Clifford, Rogerum de Waltero Clifford, Walterum de Willelmo de Stutevill, ipse de domino rege" (Testa, p. 39a). Bracton, Note Book, cases 657, 660, 1211. Geoffrey de Mandevill paid scutage on one fee which he held of Robert de St. John, who held it of the abbot of Hyde who held it of the king (Exch. L. T. R. Mem. Roll, 27 Henry III, m. 7); Michael Belet paid scutage on three fees which he held of William de Say and he of the earl Warenne and he of the king (ibid., m. $\boldsymbol{\gamma} \mathrm{d}$ ).

150 Stephen de Croherst holds land of Roland de Acsted for 4 shillings per annum and 2 shillings "ad scutagium quando scutagium eveniret, scilicet 2 solidos ad 2 marcas et ad plus plus et ad minus minus" (Bracton, $N . B$., case 4.77 ); one Gilbert gave to Simon land for the yearly service of one pair of gilt spurs or $6 \mathrm{~d}$ at Easter and performing at a scutage of 20 shillings, when any should happen, 1d, and so proportionately more or less (Record Society of Lancashire and Cheshire, xxxix, 92, 30 Henry III). Adam granted to Robert land for the forinsec service belonging to one carucate, whereof $91 / 2$ carucates make one fee, at a scutage only, for all service (ibid., p. 104); Richard le Boteler gave to Walthere de Waleton 2 bovates of land by knight service where 10 carucates of land make the fee of one knight (ibid., xlviii, 10). "tenuit idem Walterus de Gretona terram illam per servicium militare ... reddendo inde per annum xii d et faciendo servicium forinsecum, scilicet ad scutagium viginti solidorum iii den. et ad plus plus et ad minus minus" (Bracton, $N$. B., case 33; also cases $288,361,477,795)$. 


\section{STUDIES IN TAXATION}

men were called military, though they did not have to perform military service. All this suggests that at some point in the feudal ladder, every fee in the kingdom was held by a man whose tenure was military, yet who did not and was not expected to perform military service, except by paying scutage. From the standpoint of these men of different grades, the king's summons to the host was merely the occasion for the levy of a tax. The existence of the scutage as a general tax on the rear-vassals helps to explain the feeling in the thirteenth century that the increase in the rate and the greater frequency of the levy was a burden under John. Such a feeling would not be confined to rear-vassals, but would animate tenants in chief as well, though the majority of the latter usually performed their service in the field, for they would find it increasingly difficult to collect from their men. ${ }^{151}$ Moreover, if discontent were aroused, it would all be directed against the king, for he was the cause of the levy. ${ }^{152}$

151 This feeling of the rear-vassals and its influence is a matter of conjecture. There are cases when rear-vassals resist the collection of scutage, but one cannot safely generalize from them (see above, p. 321). The cases cited ahove in which men were enfeoffed for a payment of scutage will illustrate the feeling of the sub-tenant. They usually were to pay scutage as often as it should run, and not at a fixed rate, but at so much and ad plus plus et ad minus minus. When the scutage was only an occasional levy as under Henry II and was never taken at more than 20 s, as was the case for years, the amount of such an additional rent would be clearly understood; when however these men who had enfeoffed for such amounts found that sometimes they had to pay every year and at a much higher rate, it is likely that they would be discontented.

152 The king decided on the war and summoned the host. He levied the scutage, he gave tenants permits to collect scutage from their vassals, and his officer distrained those of the latter who were unwilling or were slow to pay; sometimes the king collected it directly 'from the sub-tenant for the exchequer. It was to the king that the rear-vassal could appeal if his lord tried to collect scutage from him unjustly. Thus the whole levy centered in the king. 
Part of the scutage and fine was paid at the exchequer, and part of it was paid either to the king himself, "in camera," into the wardrobe, or to the sheriff. ${ }^{153}$ How was the money collected? When the scutage was put in charge, did the sheriff immediately begin to collect it from the rear-vassals, or did he deal with the tenant in chief? Two varieties of cases arose: that of the tenant in chief who performed his service and that of the tenant who paid a fine or scutage. Sometimes the sheriff collected scutage from the rear-vassals of the tenant who had served, but in general such a tenant received a writ from the king (de scutagio habendo) allowing him his scutage in whole or in part. Such a writ covered all his fees. ${ }^{154}$ The sheriff had his work to do here. He aided the tenant with distraint, if necessary; he reported the number of his fees at the exchequer and he certified to the exchequer barons that the tenant had received a writ of quittance. ${ }^{155}$ When the tenant in chief owed fine or scutage, there are cases in which the sheriff seems to have collected from the rear-vassals. ${ }^{156}$ But the normal method is probably given in the instructions for the levy of the aid of 1217 . Those tenants who desired it obtained a royal writ to collect from their vassals. If they failed to do this, the sheriff entered their lands and collected the aid from the rear-vassals. ${ }^{157}$ It is not possible to prove that the tenant in chief would ordinarily prefer to secure such a writ, but probably that was the case, for such a writ would keep the king's official off his land. Tenants were continually receiving these writs. ${ }^{158}$ Throughout the period,

${ }^{153}$ E. g., see above, pp. 28, 29, 44, 146.

154 See above, p. 318.

155 See above, pp. 29, 30, 152, $318 f f$.

156 See above, p. 321.

157 See above, p. 128.

158 See above, pp. 140, 147, 152, 230, 319. See also such writs

for the scutage of Kerry in Fine Roll, 13 Henry III, m. 12, 13; 


\section{STUDIES IN TAXATION}

stewards of tenants in chief were summoned to appear at the exchequer to account for the scutage of their lords. ${ }^{159}$ The charge in the Pipe Roll was always against the tenant in chief, never against the rear-vassal, except sometimes when the barony was in hand. ${ }^{160}$ Rear-vassals of whom scutage was demanded by the sheriff for the exchequer protested that they were not tenants in chief and the demand was remitted. ${ }^{181}$ When a tenant in chief refused to fine, he was disseized, or distrained, and for the time nothing was collected from his land. ${ }^{162}$ When a scutage was paid to the overlord, the presumption was that the fee was held directly of him. ${ }^{183}$ Tenants in chief

for the scutage of Poitou of 1231 in Fine Roll, 15 Henry III, part I, m. 6, 7, 8; for the scutage of Elveyn, ibid., 16 Henry III, m. 7 .

159 "Ricardus del Estre debet xvi sol. et viii den. de primo scutagio Regis Ricardi... senescallus ejus affidavit facere pacem et non venit; in termino pasch" " (Exch. L. T. R. bundle 1, no. 3, Mem. Roll, $1 \mathrm{John}, \mathrm{m} .17$ ). See also Simon de Charterai, steward of William de Braose (ibid., m. 19, m. 19 d). "Hugo de Morba senescallus Henrici de Trasci aff' facere pacem de $\mathbf{L}$ marc. et dim. de scutagio suo sicut vicecomes dicit et non venit" (ibid., m. 19 d). See also the cases of summons of stewards of Eustace de Vescy, Robert Fitz Walter, Aubrey de Ver, Joslan de Nevill, Earl Ferrers (Exch. L. T. R., bundle 1, no. 4, Mem. Roll, $10 \mathrm{John}, \mathrm{m}$. 4a dorso, 8a, 11a). "Hamo Pech' debet xiiii li. viii sol. $x$ den. de scutagio Regis $H$. tercii, de scutagio Walliæ xx marc.; senescallus ejus R. de Craweden' aff. que fac' pacem de prædicto debito" (Proceedings of His Majesty's Commissioners on the Public Records, 1832-1833, ed. C. P. Cooper, Record Com., p. 455; Mem. Roll, K. R., 3 Henry III); other references to the stewards on pp. 385, 392, 459. "Humfr' de Bohun debet xxii li. et 1 marc. de scutagio pictavix; Robertus de Suham senescallus aff". Fiant brevia et colligatur illud scutagium" (Exch. L. T. R., Mem. Roll, 9 Henry III, m. 9 d). See references to stewards of Hugh de Nevill, William Fitz Hamon, Robert Fitz Walter, the heir of Robert de Ver, the earl of Chester (ibid., 27 Henry III, m. $13 \mathrm{~d}, 14,15,15 \mathrm{~d}$, 16); see also William Marshal (ibid., 28 Henry III, m. 16); Cristiana Ledet (ibid., 40 Henry III, m. 21).

160 See above, p. 42.

161 See above, p. 319.

162 See above, pp. 31, 67, 74, 99.

163 See above, p. 330. It was to the interest of the mesne lord to defend those tenants who owed no scutage against the distraint 
were charged with scutage in more than one county, yet the amount due in one county might be paid in another. ${ }^{164}$ It is likely therefore that in ordinary cases, when the payment of scutage was not too long delayed, the sheriff dealt with the tenant in chief rather than with the rear-vassal. Besides the sums which were paid to the sheriff and for which he accounted to the exchequer, some payments were made by tenants in chief directly to the exchequer. ${ }^{165}$ Possibly some of the fines were paid to special justices who had levied them. ${ }^{108}$ The question may be raised whether the king when he came to distrain for his scutage paid any attention to the arrangements by which tenants in chief and sub-tenants had distributed the incidence of scutage and service. According to the law, every part of the tenement was responsible to the king for the whole of the service due from the tenement. ${ }^{167}$ Consequently the king in order to get his scutage could enter any holding which owed military service and distrain any property which he found there. ${ }^{168}$ Yet some attention was paid to arrangements of the sub-tenants. If the rear-vassal had paid his lord the scutage, he would not be distrained. ${ }^{169}$

of the overlord; otherwise, he might lose those lands which would then hold directly of the former overlord (Bracton, Note Book, cases $563,674,1622$ ).

164 See above, pp. $29,41,51,59,75,81$.

165 See above, p. 320.

166 See above, pp. 44, 53, 61.

107 Pollock and Maitland, I, 261.

168 Bracton, Note Book, cases 202, 657, 660, 674, 1146, 1211.

160 'Milites tenentes de honore de Stafford' venerunt ad scaccarium ... Omnes dicunt quod soluerunt scutagia regis domine Milisente . . Mandatum est vicecomiti quod non distringat eos" (Exch., L. T. R., Mem. Roll, 5 Henry III, m. 1 d). "Mandatum est vicecomiti quod distringat milites tenentes de abbatia Sancti Augustini Cantuar' in bailiva sua ad reddendum eidem abbati scutagium de Biham nisi habeant quietanciam per breve regis vel nisi fuerint in exercitu" (ibid., 6 Henry III, m. 2 d). "Mandatum est vicecomiti quod pacem habere permittat Willelmo de Gernun de demanda scutagii de terris que tenet de Ernulfo de Maundevill' quas idem Ernulfus tenet de 


\section{STUDIES IN TAXATION}

If he had neither paid nor performed his service, then both he and his lord might be distrained, though the rearvassal was only responsible for the amount due from his holding. ${ }^{170}$

About three-fourths of the fine and scutage entered under John is recorded as paid in the first two years after the levy. ${ }^{171}$ In Henry III's reign, the proportion is still less. ${ }^{172}$ After the first two years, little scutage is recorded as paid. The debts ran on for years. ${ }^{173}$ Payments were made and the scutage pardoned long after the levy was put in charge. This means that the machinery for compelling payment was inefficient, a condition true with reference to other debts owed to the crown.

What authority had the king for the levy of a scutage? The question that arises is whether the king took it by virtue of a right which he possessed as feudal lord, or whether, as in the case of the aids, he could levy it only by the consent of his tenants. It seems unquestionable that the king took the scutage as his due. In the first place, by the terms of the feudal contract, the tenant in

domino rege in capite quia idem Ernulfus debet inde respondere" (ibid., 7 Henry III, m. 12). See the case of Robert le Buteiler (ibid., 27 Henry III, m. 2); of Geoffrey de Mandevill' (ibid., m. 7); of Michael Belet (ibid., m. 7 d); of the abbot of Beaulieu (ibid., m. $8 \mathrm{~d}$ ); of the tenants of the bishop of Durham (ibid., 39 Henry III, m. 13). This was the custom under Henry II (Dialogus do Scaccario, ed. Hughes, Crump and Johnson, p. 148).

170 That both might be distrained, see the Dialogus, above, note 169 ; that the rear-vassal only for the amount due from his holding, Bracton, Note Book, cases 624, 657, 1146.

171 See above, pp. 23, 36, 48, 55, 65, 71, 78, 98, 102.

172 See above, pp. 139, 144, 150, 174, 185, 191, 197, 248.

173 The abbot of Ramsey paid the first scutage of John in 1205; the abbot of Westminster in 1207; Eustace de Balliol paid on the same scutage $£ 15$ in 1208 and $£ 1018$ s $8 \mathrm{~d}$ in 1209 ; in 1227, the bishop of Salisbury was pardoned sums due for the first six scutages of John because of services performed for Henry III (Rot. Litt. Claus., II, 195a); in 1251, scutage of Elveyn (123I) was pardoned a tenant (Excerpta, II, 102, 157). 


\section{UNDER JOHN AND HENRY III}

chief was bound to serve the king in war. If he failed to perform this service, he failed to keep his contract and his fee was technically forfeit. The king would have an undoubted right to a money composition. There was therefore in the scutage no question of the consent of the tenant. In the second place, to say that the tenants granted the scutage is to say that scutage was an aid. Such a statement involves a difficulty at once. Many scutages were declared at the close of a campaign in the presence of the host. Those present would not as a rule pay, for they had performed their service. The scutage thus would be granted by the men who did not pay it at all, or in other words, the barons throughout Henry III's reign acknowledged the validity of the principle that the consent to a tax of those present bound those who were not present. When however we examine the history of the aids, we find that even at the close of Henry III's reign, the tenants in chief doubted their right to levy aids on the property of absentees. ${ }^{174}$ Hence we may question whether consent was involved in taking scutage. Furthermore, for thirty years after 1237, the barons refused to grant the king aids. ${ }^{175}$ Yet during this time, three scutages were levied. ${ }^{176}$ In view of the attitude of the barons toward extraordinary taxation at this time, and considering the fact that these scutages were the composition for scrvice, it seems clear that the power to take them rested in the king's right to military service rather than in a grant by his tenants. Although this is true, there yet remain other questions which need answering, particularly in the case of a king like John who insisted on his rights to the utmost. The king had the

174 See below, p. 388.

175 Two aids were levied in this period, that of 1245 to marry the king's daughter, and that of 1253, to knight his eldest son; they were obligatory.

$1761242,1246,1257$. 


\section{STUDIES IN TAXATION}

right to levy the scutage, but could he arbitrarily determine the rate? Could he levy it on some men while others were not asked for either service or scutage? Could he levy fines as well? Was he the only one to decide when scutage was legally due? The expansion of the king's power along these lines led to the provisions introduced into Magna Carta. ${ }^{177}$

The tallage was levied on the royal demesne, including all demesne cities and boroughs. It was owed to the king, though he was not unrestricted in taking it. On an average he levied a tallage only once in three years. ${ }^{178}$ Tallage was not always the correlative of the scutage, to the extent that when the scutage was taken from the military tenants, a tallage was levied on the demesne. This was done in many cases, but in many other instances, tallage was levied when no scutage was taken and scutage when there was no tallage, so that it is fair to say that the two levies were independent of each other. John levied both scutage and tallage in six or perhaps eight cases $;^{178}$ he levied no tallage when he took scutage in at least three cases. ${ }^{180}$ Henry III levied both scutage (or an aid on knights' fees) and tallage four times. ${ }^{181}$ He levied scutage and no tallege nine times, ${ }^{182}$ and tallage, but no scutage, eleven times. ${ }^{183}$ When the king took an aid from the tenants by military service, he took a tallage from the demesne. This was the case in $121 \%, 1235$, and $1245 .{ }^{184}$ In 1253, no tallage was levied, although there was an aid

177 See below, p. 361.

$178 \mathrm{~J}$ ohn took a tallage six or eight times in 17 years; Henry III 15 times in 56 years.

179 In 1199, 1202, 1204, 1206, 1210, 1214, and perhaps in 1203 and 1205: See index: tallages, list of.

$1801201,1209,1211$.

181 1217, 1229, 1235, 1245.

$1821221,1223,1224,1228,1231,1232,1242,1246,1257$.

183 1223, 1227, 1234, 1238, 1241, 1249, 1252, 1255, 1260, 1268, 1269.

184 See above, pp. 128, 213, 249. 


\section{UNDER JOHN AND HENRY III}

to knight the king's son. The omission was doubtless due to the fact that a tallage which had not yet been fully collected was levied in 1252. The king however asked the towns to make him a gracious aid for the expedition to Gascony. ${ }^{185}$ The demesne paid the new taxes on property. ${ }^{188}$ In 1237 and 1270, however, the towns paid a tallage instead of the thirtieth and twentieth. ${ }^{187}$

The scutage never became fixed at a certain rate, yet its variations were within limits. As the tallage was always levied in a lump sum, its variations could not have the regular character of the scutage. Yet with the exception of the tallages of 1210 , there is a sort of limit beyond which the king did not go in the amount which he took from the towns. ${ }^{188}$ Just as the rate of scutage 185 See above, p. 256.

186 In 1207, 1225, and 1232; probably part of the demesne paid them in 1237 and 1270 , that is, the part outside the towns.

187 See above, pp. 219, 297.



$1179 \mathrm{~m} \mathrm{12s} 8 \mathrm{~d}$ in Pipe Roll of $5 \mathrm{John}$.

$2383 \mathrm{~m} 8 \mathrm{~s} 8 \mathrm{~d}$ in Pipe Roll of 4 John.

3 In Pipe Roll of $6 \mathrm{John}$; in $5 \mathrm{John}$ there is a tallage of 500 marks on York.

4 In Pipe Roll of 6 John. 


\section{STUDIES IN TAXATION}

increased toward the close of Henry III's reign, so the tallages seem to have become heavier.

In Henry II's reign, the tallage was levied by the itinerant justices. ${ }^{189}$ The same method continued in the thirteenth century. The itinerant justices, justices of assize, or some other royal official specially assigned to this work, made the levy, often, perhaps always, aided by the sheriff. ${ }^{190}$ The method of assessment which is

188 (Continued)

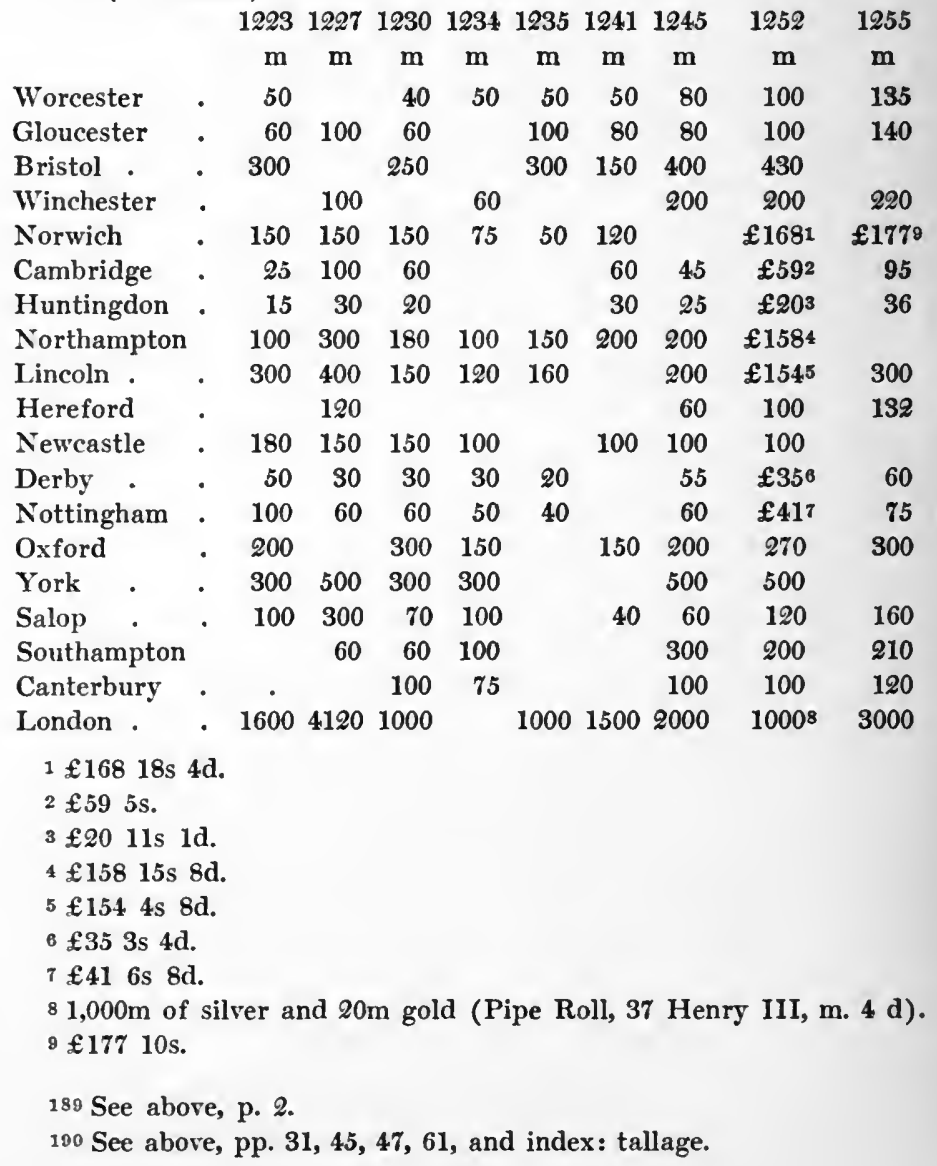




\section{UNDER JOHN AND HENRY III}

described in the Dialogus was followed. A town either paid a lump sum or was tallaged by the justices per capita. If the sum offered by the town was not sufficient, the citizens had to increase it till the royal officers were satisfied, or be tallaged per capita. ${ }^{191}$ Men outside the towns might pay per capita $;^{192}$ a vill or hundred might fine in a lump sum. ${ }^{193}$ Property however was not to be assessed. ${ }^{194}$

Religious houses which held land by military tenure paid fine or scutage. Sometimes the fine was called a donum. ${ }^{195}$ When a scutage was taken, or an aid on knights' fees, the king might ask religious houses which did not hold by knights' service to grant him an auxilium or a donum. John did this four times in connection with scutages. ${ }^{196}$ Henry III took a donum from religious houses in connection with the aids of 1235 and $1245,{ }^{197}$ and when he went to Gascony. ${ }^{198}$ He took one donum from them when no scutage or aid was levied. ${ }^{199}$ The amounts raised in this way were often considerable. ${ }^{200}$

The scutages, fines, and tallages were sometimes sufficient to defray the cost of a campaign. In 1210, these levies yielded not far from 25,000 marks, ${ }^{201}$ a sum which would probably pay the expenses of the expedition to Ireland. Usually however they fell short of supplying the necessary money. As the king did not always levy

191 See above, pp. 32, 68, 76, 82, 148, 172, 207.

192 See above, pp. 45, 61, 82, 100, 128, 148.

193 See above, pp. 32, 61, 76, 82, 128.

195 This is indicated by the lump sums which individuals and towns paid.

195 See above, pp. 32, 61.

196 See above, pp. 32, 61, 68, 70, 77.

197 See abore, pp. 212, 244.

198 See abore, pp. 190, 237, 255.

129 See above, p. 249.

200 See above, notes 196-199.

201 See above, p. $98 f f$. 


\section{STUDIES IN TAXATION}

a tallage, he often had only the scutage to increase his income. In 1214, John took with him at least 40,000 marks, not counting money which he sent to Flanders; the scutage and tallage (amount charged not paid) amounted to about 18,000 marks. ${ }^{202}$ The campaign of Bedford cost about 2,000 marks, while the scutage on laymen amounted to about 1,350 marks, of which 300 marks were paid in 1224 and $1225 .^{.03}$ The expedition of 1225 cost at least $£ 36,000$; that of 1242 , about 60,000 marks; that of 1253 , at least 45,000 marks. ${ }^{204}$

It is not possible to state exactly the total income of either John or his son, but it is quite evident that the former was well supplied with money during the greater part of his reign. In 1200 , he was able to pay 20,000 marks to Philip. ${ }^{205}$ In 1204, he is said to have sent much money to Poitou. ${ }^{208}$ In 1206, he had a large sum on hand in the autumn at the close of his long campaign in France. ${ }^{207}$ The thirteenth of 1207 brought in at least

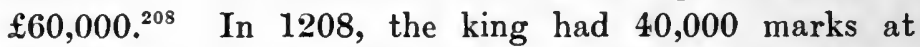
Winchester. ${ }^{209}$ In 1212, he was keeping at the single castle of Nottingham over 50,000 marks. ${ }^{210}$ In the last half of the year 1213 and the early part of 1214, there are notices, which do not seem to be duplicates, of over

202 See above, pp. 110-118.

203 See above, pp. 150, 159.

204 See above, pp. 168, 238, 260.

205 See above, pp. 32, 34. For 1203, see Powicke, p. 348.

208 28,000 marks (Cogg., p. 147); Davis, Normans and Angevins, Oman Series, p. 345 , says, "This is preposterous."

207 See above, p. 82.

208 See above, p. 91.

209 "et in liberationibus thesaurarii et camerariorum qui moram fecerunt apud Winton' ad numerandum xl millia marcarum ibidem" (Pipe Roll, 10 John, Hants, m. 6 d).

210 Thus on July 26 he sent there from Bristol over 48,000 marks and he acknowledged the receipt at Nottingham of $3,900 \mathrm{~m}$ from London on August 19 (Rot. Litt. Claus., I, 122a, 123b); there is a sum of $18,000 \mathrm{~m}$ received at Merleberg (ibid., 116b). 


\section{UNDER JOHN AND HENRY III}

80,000 marks of money on hand. ${ }^{211}$ Unlike his father, Henry III was always short of money when he had no grant from the great council. ${ }^{212}$ This lack was due in part to his extravagance and bad management ${ }^{213}$ and in part to the expense of certain outside interests: Gascony, Sicily, and his sister's marriage. But these explanations are not sufficient; his predecessors also had a share in foreign affairs, yet they levied few aids. Two other causes helped to bring about the financial troubles of Henry III : a rise in prices ${ }^{214}$ and the reduction by Magna Carta of the ordinary income of the king. ${ }^{215}$

The origin of modern taxation is not to be found in the development of scutage from its original character as a

211 In July, 10,000m and in August $2,000 \mathrm{~m}$ were to be sent from the Templars in London to Flanders (Rot. Litt. Claus., I, 145b; Rot. Litt. Pat., p. 103b); the king had left $20,000 \mathrm{~m}$ at the Temple to be drawn on for this purpose (Rot. Litt. Claus., I, 136b; Rot. Litt. Pat., p. $100 \mathrm{~b}$ ); in August, $5,410 \mathrm{~m}$ were sent to Poitou (Rot. Litt. Pat., p. 102b); in December, 1213, and January, 1214, 27,000m were paid to the clergy (see above, p. 109); and the king took $40,000 \mathrm{~m}$ with him to France in February, 1214 (see above, p. 110); this gives a total of over 84,000 marks. There is an entry in the Close Roll which mentions three items footing up to 120,000 marks, but the sums may not be mutually exclusive: "et pro cariagio quinquaginta millia marcarum a Bristoll' usque Divis' per Thomam de Saunford' C sol. ... et Hugoni de Nevill' $x \nabla$ li. ad liberaciones faciendas quinquaginta et duarum quadrigarum qui portaverunt $\mathbf{x x}$ millia marcarum ... a Bristoll' usque Cant' . . . Item pro cariagio xv carectarum qui portaverunt thesaurum nostrum scilicet $\mathbf{L}$ milia marcarum a Bristoll' usque Corf'" (Rot. Litt. Claus., I, 152b).

212 See index: Henry III.

213 The most striking case of his lack of foresight is in the Sicilian affair. He had for several years been short of money although at the time he had had no great extraordinary expense; he had just concluded an expensive campaign in Gascony partly on borrowed money. Yet he agreed to pay the pope 135,000 marks for expenses which the papacy had already incurred in Sicily with no certainty that he would be able to use any of the tenth of 1254 to pay this debt (see above, p. 274).

214 Ramsay, Dawn of the Constitution, p. 301.

215 See above, p. 119. 


\section{STUDIES IN TAXATION}

commutation of military service into a general tax on all fees levied by the exchequer whenever the king waged war. The scutage retained its original character throughout Henry III's reign and continued to be levied without difficulty while the king and his barons were struggling over the question of taxation. ${ }^{218}$ The source of modern taxation was the feudal aid, the voluntary contribution which the vassal made to relieve the wants of his lord. There were certain aids which were not voluntary, but which were fixed by the feudal law. In France, there were the three regular aids, to which was added later the aid for the crusade. ${ }^{217}$ In Normandy, the vassal owed aids for the lord's relief, the marriage of his daughter, and the knighting of his eldest son. ${ }^{218}$ In the Latin kingdom of Jerusalem, the king could levy an aid to provide for his ransom and to pay a debt incurred for the general welfare. ${ }^{219}$ The aids in England were fixed by Magna Carta at three, ${ }^{220}$ but the previous practice recognized an aid to pay relief. ${ }^{21}$ It is however not with the aids which had become fixed that we are chiefly concerned, but with those which still remained voluntary, the gracious aids. Examples of these aids appear under Henry II, granted by the tenants to their lords for expenses on trips abroad on the king's service, for war, to pay the lord's debts, and simply as auxilium, made gratis, bona voluntate. ${ }^{22}$

216 In 1242, 1246, and 1258.

217 Esmein, Cours élémentaire du droit français, ed. 1901, p. 190.

218 Très ancien coutumier, cap. 47, 48; also, to ransom the lord, Ancien coutumier, cap. 33.

219 Dodu, Institutions monarchiques dans le royaume latin de Jérusalem, p. 249.

220 Cap. 12.

221 Glanvill, cap. 4, 8; Stubbs, Select Charters, p. 163.

222 Red Book, II, cclxvii-lxxx, Appendix A. The date of the returns is 1170 (Round, Commune of London, p. 125). "Quando comes perexit ad servandas les Marches de Wales pluribus vicibus, scilicet, homines de domenio suo dederunt 100 solidos; et Ricardus filius Atrac et sui pares de uno socagio dederunt 3 marcas gratis.... Sed postea 


\section{UNDER JOHN AND HENRY III}

They continued in John's reign. Isabella de Bolebec paid 300 marks and three palfreys for certain privileges and to have a reasonable aid from her tenants to pay this fine. ${ }^{23}$ Warren Fitz Gerold had a reasonable aid to pay his debts. ${ }^{224}$ The abbot of Westminster had a reasonable aid from his free tenants secundum quantitatem tenementorum suorum to pay the aid promised by him to the king $;^{225}$ likewise the prior of Acra. ${ }^{226}$ Such permits except in the three regular cases were forbidden by Magna Carta of 1215 (cap. 15), but the article was dropped in reissues of the charter. Henry III issued numerous writs requesting the tenants of his vassals to make their lords an aid. Though in theory these aids were of grace, the frequency with which the king made such requests for the benefit of his vassals suggests that his request had the force of a command. The causes assigned were to pay the lord's debts to the king and others, to sustain a tenant in the king's service, to discharge reliefs, to take up knighthood, to marry the lord's eldest daughter, to go on a crusade, etc. ${ }^{227}$ The general levies made by John and Henry III were the application of this custom to

homines de domenio comitis dederunt 11 marcas ad quietanda debita comitis; et Ricardus filius Atraci et sui pares dederunt 4 marcas et hoc bona voluntate (no. 1). Homines inde (de Dentuna) dicunt quod post transitum domini regis in Normanniam, dederunt eidem Roberto filio Hugonis domino suo 10 solidos ad exercitum domini regis Walliæ; et dederunt illi in auxilio, ad quietanda debita adversus Judæos, 16 sol. et 8 den., gratis (no. 45)."

223 Madox, I, 616, n. $b$.

224 Rot. Litt. Pat., p. 85a.

225 Rot. Litt. Claus., I, 59b.

226 Ibid., p. 32b. For similar aids, see Madox, I, 411, n. $t$; for the earl of Salisbury, for the earl of Winchester, for the earl of Surrey to sustain himself in the king's service, for earl Ferrers (Rot. Litt. Claus., I, 127a, 144a, b, 211a); for the constable of Chester, for the prior of S. Swithin (Rot. Litt. Pat., pp. 41b, 52a).

227 For the bishop of Worcester "pro expensis quas fecit in servicio domini J. regis"; to the knights and free tenants of the abbot of St. Edmunds, to make him a reasonable aid "pro amore et petitione 


\section{STUDIES IN TAXATION}

the kingdom as a whole with the king as chief lord..$^{228}$ Such levies had the same name and the reasons assigned for them were similar. ${ }^{229}$ A somewhat similar development was attempted by the French kings about a century later. Philip IV tried to establish a uniform tax by exacting the feudal aid in more than the four regular cases. He was only partly successful in doing so; the aids needed the consent of the taxpayers and varied in amount from one district to another. ${ }^{230}$ Thus the starting point of the change in both countries was the same, viz., the feudal aid.

The aid was levied in three forms: a general aid on knights' fees, called also scutage; a carucage; and taxation of a certain percentage of personal property, the tax on moveables.

None of the scutages levied by John were aids; all were compositions for service. Under Henry III four aids on all knights' fees were taken ${ }^{231}$ two aids were taken on the fees of bishops (in 1229 and 1242) and one aid on the fees of all the clergy (1231). The first aid was

nostra" to pay his debts to the king, "tantumque inde pro nostra petitione faciatis quod preces nostras sibi sentiat fructuosas et nos robis inde ad grates teneamur"; for the new abbot of Fiscamp, a reasonable aid "ita quod dominus rex eos inde commendare debeat"; for the constable of Chester "pro expensis suis factis in servicio crucis"; for the prior of Stokes, to pay his debts to the king; for the bishop of London, to pay his debts; John Marescallus has litteras deprecatorias to pay his debts (Pat. Rolls, I, 143, 223, 270, 284, 329, 363, 372). There are many examples of these in the Patent Rolls of Henry III.

228 They were not of course compulsory.

229 Thus the carucage of 1200 , the thirteenth of 1207 , the fifteenth of 1225, etc., were called auxilia. The cause assigned was to pay the king's debts, to carry on war, etc.

230 Vuitry, Régime financier de la France, II, 144, 169-170. Vuitry classes under the aids the "retribution également proportionnelle aux fortunes et liberrant du service de l'armée." This was in England the fine and scutage, which had an independent development.

$2311217,1235,1245,1253$. 


\section{UNDER JOHN AND HENRY III}

levied by reason of the grant of the great council. ${ }^{232}$ The king had no legal right to it without this grant. The second general aid (1235) was also made by grant of the great council, though perhaps it was thought that the king was legally entitled to it. ${ }^{233}$ To the third and fourth aids $(1245,1253)$ the king was entitled by law without the consent of his vassals for they were of the three regular aids which every lord could levy. ${ }^{234}$ Both were indeed levied at a meeting of the great council. Consent to the aid was however not involved. In both cases, the king tried to get a gracious aid from the tenants, was unsuccessful, and then turned to the feudal aid which had to be paid. ${ }^{235}$ It is probable that he could not fix the rate: in 1245 , the fact that only twenty shillings per fee were taken was doubtless due to the unwillingness of the barons to pay more. The other three cases of aids are interesting because they look like a denial of the king's right to service in France from the fees of bishops. ${ }^{236}$ They are perhaps to be connected with the claim set up in 1198. Bishops however had furnished knights to serve in France in John's reign. ${ }^{237}$ A statement in Henry III's letters patent which were issued to the clergy in connection with these aids was perhaps intended to guard against the establishment of a precedent that the clergy did not owe service in France. ${ }^{238}$

Like the scutage, the aids fell back on the rear-vassals.

232 See above, p. 125.

233 See above, p. 208.

234 To marry the king's daughter and to knight his eldest son.

235 See above, pp. 241, 254.

236 See above, pp. 189, 193, 236.

237 They receive writs of quittance in John's reign. "Milites archiepiscopi Cantuar' qui fuerunt in servicio regis ultra mare" (Rot. Canc., p. 220); Powicke, pp. 239, note 4, 319.

238 See above, note 236 . The scutage of 1242 on all tenants in chief except the bishops was not an aid, but a scutage in the strict sense, viz., the commutation for service (see above, p. 229). 


\section{STUDIES IN TAXATION}

As to the collection, ordinarily the tenant in chief received a letter from the king, which authorized him to collect an aid from his tenants and respond at the exchequer. If he did not receive such a letter, the sheriff collected the aid from the rear-vassals. ${ }^{239}$ In 1235, a new method, copied probably from the taxes on moveables, was employed. Two knights were appointed in each county to receive the aid from the tenants in chief in that county, but the innovation was not permanent. ${ }^{240}$ The sheriff aided the tenants with distraint. Each tenant in chief responded for the same number of fees as in the scutage proper. The king attempted to increase the number ${ }^{241}$ but his efforts were not successful. ${ }^{2+2}$ As with the scutage, there were many delays in payment. The aid on military tenants was usually supplemented by a tallage on the demesne and by dona from religious houses. ${ }^{243}$

The aid on knights' fees, the tallage, and the dona covered after a fashion most of the property in the king-

239 See abore, p. 128.

240 It was not done in the cases of the later aids.

241 The aid of 1235 is not given in the Pipe Roll and we cannot say on how many fees it was paid in general. Inquests were made in 1235 and 1242.

242 The number of fees is not increased in the case of tenants holding five or more fees each in the accounts of the aids of 1245 and 1253. Mr. Inman has compared the tenants holding ten or more fees in the roll of 1253 with the holdings of 1166 and says that new enfeoffments have been entirely omitted (Feudal Statistics, p. 51). In the roll of 1253 there are some sergeants holding by small fractional parts of fees who are charged with aid; these may be the results of the inquests (Pipe Roll, 38 Henry III, passim).

243 No dona from religious houses were taken in 1217 in connection with the aid, probably because the clergy had just made a contribution to the king (see above, p. 123). Dona were taken in 1229, 1235, 1242, and 1245. Those taken in 1253 are said to have been taken for the expedition to Gascony, not for the knighting of the king's son. No tallage was taken in 1253, probably because one had been levied in 1252 which had not yet been entirely paid. The king however asked the towns for an aid for the campaign in Gascony (see above, pp. 341, 343). 


\section{UNDER JOHN AND HENRY III}

dom. The scutage was levied at a uniform rate. It also fell back on men who were not the king's vassals and hence owed him nothing. These levies helped to form the idea of a general tax, taken for the needs of the government and paid by all who were in its care. Yet directly out of these taxes was to grow no system of national taxation, or perhaps it would be better to say that no further development was to be made along this line. This was the old method of raising extraordinary revenues. It was inelastic. At a time when the expenses of the government were increasing, it could not respond. The rate of scutage had become fixed at not more than three marks per fee; the number of fees which should pay had also become fixed. The contributions of the towns might be somewhat enlarged, though custom restrained too great an increase. The dona from religious houses could not be too large. The levies were not based on property so that there would be no increase in the amount of the tax corresponding to a rise in the value of the property. The method of collection was old and evidently ineffective, so that in the scutage at least the government could hardly realize more than half of the nominal tax charged. ${ }^{244}$

The other forms which the aid assumed, the carucage and the tax on moveables, brought about a revolution in taxation. With them modern taxes began. In the first place, the basis of these levies was property not tenure; men paid directly to the king, no matter of whom they held or by what tenure. ${ }^{245}$ In the second place, though the members of the council which granted these aids may have thought that each acted for himself, individually, yet the result of the deliberations was to create a uniform

244 See above, p. 338.

245 There were many exceptions to this, but it was the normal method; in the case of the aids on knights' fees, the rear-vassals normally paid to their lords. 
tax, proportional to the amount of property. ${ }^{246}$ Finally, the machinery of assessment and collection was new (in taxation) and was national, not feudal. This machinery was in general in two parts: commissioners to each county representing the king, whose main duty was to supervise the assessment and receive the money; a committee from the locality, on whom fell the burden of assessment and collection. ${ }^{247}$ The sheriff coöperated as a subordinate. He summoned the men of the locality to appear before the justices for the assessment; he distrained men to pay the tax; he furnished the transportation for the money; he distrained the collectors to pay the money at the exchequer. ${ }^{248}$ The use of local bodies in taxation is regarded as one of the roots of the representative system. ${ }^{249}$ This does not mean that under John and Henry III, they acted as a check on the king's power, protecting the taxpayer from unjust assessment. It is likely that the employment of the jury was a royal device in taxation as well as in other cases in which it was introduced. ${ }^{250}$ The rights of the barons were protected in other ways. ${ }^{251}$ There is evidence that both the clergy and

246 That is, uniform within the class on which it was levied, not necessarily throughout all England: e.g. the carucage of 1224 on the clergy only; the sixteenth of 1226 only on the beneficed clergy; the tenths of 1253 and after, on the clergy only.

247 In 1207, each man made oath personally before the king's commissioners. In the other cases where we have a complete description of the machinery, the locality is represented.

248 See above, pp. 90, 122, 135, 166, 204, 216.

249 Adams, Political History of England, 1066-1216, p. 386 ; Stubbs, Const. Hist., I (4th ed.), 652.

250 It seems to have been the natural way to get at the value of property. Notice that in the levy of the fifteenth on merchants and the aid on the Channel Islands, the jury was used (see above, pp. $45,69)$.

251 In 1225, the bailiffs of the earls and barons made oath to the value of their lords' property; in 1232, the collection was in the hands of the barons; in 1237, the bailiffs of the barons were to be present when the assessment was made. 


\section{UNDER JOHN AND HENRY III}

the laity disliked the inquests into their property and did not therefore regard the jury as a means of protecting their rights. ${ }^{252}$

Most of the property in the kingdom paid the new taxes according to an assessment made as just described, but there were many exceptional cases. One can hardly say that there was a gradual change from payment of aid in lump sums to payment on an assessed valuation of property. It would be better to say that in the presence of so great a change the king was unable to enforce the new method against everyone. Thus in 1198, we know that most of the counties fined for their carucage; perhaps all did. ${ }^{253}$ In 1207 , most of the clergy seem to have fined or paid dona for their thirteenth. ${ }^{254}$ In the aids of Henry III, there are many special provisions made for the assessment and collection on the lands of the clergy. ${ }^{255}$ Religious orders often were allowed to fine and so their property was not assessed..$^{256}$

The carucage was taken from more men on the holding of any tenant in chief than was the scutage, for it was paid by men who did not hold by military tenure. One cannot say whether more men were liable for it on the royal demesne than for the tallage. The tax on moveables fell on more men than the scutage on land held by military tenure and probably on more than did the carucage. ${ }^{257}$ Doubtless, it was paid by more men on the

252 In 1198, the inquests ordered were not taken in the majority of cases (see above, p. 8); in 1207, the clergy often paid lump sums for their thirteenth (see above, p. 88); in 1225, the clergy were to assess their demesnes themselves; in 1237, all their property; in 1242, the inquests were opposed; in 1253, there was opposition to the method of levying the tenth (see above, pp. 166, 217, 234, 273).

253 See above, p. 8.

254 See above, p. 88.

255 See above, pp. 136, 166, 204, 210, 215.

256 See above, pp. 135, 163, 202, 216.

257 The main difference between the carucage and the tax on moveables was not in the amount of property which was assessed; 


\section{STUDIES IN TAXATION}

demesne than was the tallage. ${ }^{258}$ In some cases, the carucage yielded more than the scutage though this may not have been true in every county. ${ }^{259}$ The tax on moveables however yielded unquestionably far more than any scutage or carucage which was taken at the customary rate. ${ }^{260}$

A characteristic of the new levies was that a new assessment was made each time the tax was taken. ${ }^{261} \mathrm{~A}$ roll of the property was drawn up and sent to the exchequer which thus had a fairly complete "extent" of the whole kingdom along certain lines. This was probably done at the king's wish, not at that of the barons, for the possession of such an extent was wholly to the king's advantage. The new assessment would prevent the growth of immunities and keep the tax increasing with the increasing wealth of the community. Whether the tax did so increase under Henry III is doubtful. The thirteenth of 1207 yielded about $\$ 60,000$, showing an assessed value of property of $£ 780,000 .{ }^{262}$ The fifteenth yielded about $£ 57,000$, an assessed value of $£ 850,000$; the fortieth yielded $£ 16,000$, an assessment of $£ 640,000$; the

for in that respect there would not be much, if any, difference. It lay in the rate of assessment; the rate of two or three shillings per carucate would not yield as much as a fifteenth, etc.

258 On the demesne, there would be men in the towns who would not pay the carucage, but who would pay the tax on moveables. Some men would not pay the tallage because they had a charter of exemption from tallage; they would not be exempt from the tax on moveables.

259 See above, p. 136 and Baldwin, p. 38.

260 Thus the thirteenth in 1207 yielded $£ 60,000$, more than any scutage or carucage yielded.

261 Notice, too, that the thirtieth of 1237 and the twentieth of 1269 were taken in September, when the largest quantity of farm products would be on hand; the carucage of 1220 was to be levied in June, when the amount of land to be put under cultivation would be the greatest.

262 See above, p. 91. 


\section{UNDER JOHN AND HENRY III}

thirtieth, $£ 22,000$, an assessed value of $£ 660,000$; the twentieth of $1270, £ 32,000$, an assessed value of $£ 640,000 .^{263}$ These figures may be incomplete, for the fifteenth of 1275 yielded $£ 80,000$, an assessed value of $£ 1,200,000 .^{204}$ The increase may be due to more careful assessment, for John and Henry III did not always insist that the property be assessed, accepting lump sums instead.

As the taxes on property were new, old immunities from taxation were disregarded. Thus Richard taxed the churches and the Cistercians. ${ }^{25}$ John tried to tax the beneficed clergy, but does not seem to have been successful up to the time of the interdict. ${ }^{268}$ Under Henry III, the clergy became regular contributors to the king for property which in part at least had never been taxed before. ${ }^{267}$ Beginning with 1253, they paid taxes to the king in eleven different years either on the assessed value of their property or in lump sums calculated on the basis of such an assessment. ${ }^{288}$ These levies were bitterly resisted for two reasons: the clergy objected in the first place to paying any levy at all and in the second to the method of levy. In the first case they failed. It is clear that they preferred to grant a lump sum like a donum and to divide it up themselves among the different ecclesiastical divisions, thus avoiding the assessment of

263 See above, pp. 169, 205, 218, 299.

204 Ramsay, Dawn of the Constitution, p. 536.

265 Baldwin, p. 70 ; see above, p. 7.

268 See above, p. 86 . During the interdict, all the clergy including all kinds of religious orders were taxed (see above, p. 106).

267 They had paid on their land held by military tenure; religious houses had paid dona. The beneficed clergy had never been taxed by the king before 1226 and for the dona on religious bodies was substituted a tax on the assessed value of their property.

268 For five years beginning in 1253, then in 1264, 1266, 1268, 1269 (see above, pp. 263, $290 f f$. ). 


\section{STUDIES IN TAXATION}

their property. In this they were partly successful. ${ }^{209}$ The alliance between the pope and the king was the immediate cause of the heavy taxation of the clergy which began in 1253. But the levy of a tax on the assessed value of the property of the clergy (other than their land held by military tenure) was no new thing. At least three different valuations had been made before. ${ }^{270}$ In three or four other cases, a lump sum had been levied on the whole church, had been divided up among the different bishoprics, and had been called a certain fractional part of the church revenues. ${ }^{271}$ The difference between the preceding assessments and that of 1253 lies in the severity of the latter, ${ }^{272}$ which however did not give the full value of the revenues. ${ }^{273}$ Thus the clergy finally became subject to royal taxation.

The assessment of the new taxes was mainly in the king's hands. ${ }^{274}$ The disbursement of the money was wholly in his power. Some attempts had been made to restrain him in this, but they had been unsuccessful. ${ }^{275}$

269 The last two years of the tenth of 1253 was compounded for in a lump sum of $£ 52,000$. There was composition by individuals in 1266 (see above, pp. 278, 293) and a kind of composition was made generally for the tenth of 1266 when the clergy agreed to pay a tenth for three years on the assessment of 1254 rather than pay a tenth for the last two years of the levy on a new assessment (ibid., p. 293); there was composition by the clergy in 1269 (ibid., p. 298). 270 In 1216, 1226, 1229 (see above, pp. 121, 170, 177, 178).

271 Perhaps in 1240; certainly in 1245, 1246, 1252 (see above, p. $264 f f$.).

272 See above, pp. 273, 275, 276.

273 Graham, in E. H. R., XXIII, 434; Hudson, "The Norwich Taxation of 1254," in Norf. and Norw. Arch. Soc. Publ., XVII (1910), 43-157.

274 Except in the taxes on the clergy.

275 For the fifteenth of 1225, see above, p. 167. The thirtieth was to be spent by the advice of some of the magnates who were added to the council; it was also to be stored in some safe place "ut si forte velit rex a proposito . . . resilire, reddatur unicuique quod suum est, fideliter distributum" (Matthew Paris, III, 383, 410; IV, 


\section{UNDER JOHN AND HENRY III}

The main significance of the changes thus far discussed lies in the growth of the king's power. The new taxes gave him an increased revenue over which he had complete control; they provided him with a definite basis for future levies and with the machinery for their assessment and collection; they brought under contribution classes which formerly paid nothing or an amount greatly beneath their capabilities; and they swept away the checks on his taxing power which lay in the feudal system. It becomes necessary therefore to examine the way in which the king's power was checked and controlled.

The origin of that control is to be found in the feudal principle that for the levy of any extraordinary contribution by the lord on his vassal, the consent of the latter was necessary. Such contribution was a gracious aid. It is unquestionable that this principle was well understood and in full force, and was not the shadow of a theory. ${ }^{278}$ Otherwise it is difficult to see why John, strong as he was, never ventured to levy a tax on property in defence of which he could not allege some law, though he well knew how great an addition to his income it would make to do so. ${ }^{277}$ The case of the thirteenth of 1207 does not form an exception to this statement, for that tax

186). In 1244, the magnates asked for the appointment of twelve councillors satisfactory to them by whom any aid which might be granted should be expended (ibid., IV, 363); another account makes the number of councillors four, but this was probably another proposal (ibid., p. 367; Plehn, Der Politische Charakter von Matheus Parisiensis, p. 125). In 1248 and later, the magnates demanded the appointment of a chancellor, a justiciar, and a treasurer with their approval (Matthew Paris, V, 5, 20).

270 "For the shadow of the feudal fiction, that the taxpayer made a voluntary offering to relieve the wants of his ruler, seems to have subsisted throughout the period" (Stubbs, Const. Hist., I, 4th ed., $619)$.

277 Thus the thirteenth yielded nearly $£ 60,000$. For the carucage of 1200 , the excuse was that it was a relief for his lands in France; the seventh was a fine for desertion (see above, pp. 32, 62). The 


\section{STUDIES IN TAXATION}

was taken with the consent of a great council of tenants in chief. ${ }^{278}$ Historically the control of the king in taxation was brought about by the growth of a feeling of corporate unity among the members of the great council. There is not much trace of this in questions of taxation except among the clergy before the reign of Henry III. ${ }^{\mathbf{2 7 9}}$ But the feeling of unity in general began to grow during John's reign. ${ }^{280}$ In 1201 occurred the meeting at Leicester in which the earls agreed not to follow the king to France unless he gave them back their rights. ${ }^{281}$ It is not known whether their demands were granted, but in some way their opposition was overcome, for they accompanied the king to France. ${ }^{282}$ In 1203, there was a plot of some of the barons to withdraw from the king's service, which was related to the king and which he frustrated in part. ${ }^{283}$ In 1205, John was forced at a meeting of the magnates to swear to preserve the rights of England. ${ }^{28 *}$ Some kind of united action is indicated this same year when John gave up his invasion of France at the wish of the barons. ${ }^{285}$ In 1207 , the bishops and abbots refused to allow a con-

scutages of John were owed to the king, for they were taken in place of military service, consequently consent was not inrolved.

278 See above, p. 8\%. The consent was individual and not corporate; the action of one tenant had no binding force on another.

279 The cases of 1163 and 1197 have been shown by Round not to involve the constitutional discussion of taxation (Feudal England, pp. 497, 528).

280 For a discussion of this, see Plehn, pp. 9-14.

281 Hov., IV, 161.

282 Adams, Political History of England, 1066-1216, p. 398; William of Albini who was one of the leaders is found with the king in this expedition for he has a writ of quittance for scutage in 1201 (Rot. Canc., pp. 89, 193, 305, 355).

283 Rot. Litt. Pat., p. 29a.

284 "ipse quoque rex, convocatis magnatibus Angliæ ad Oxonefordiam, jurare compulsus est, quod jura regni Angliæ de eorum consilio pro posse suo conserverat illæsa" (Gerv. Cant., Gesta Regum, II, 97). 285 "prohibente sibi Cantuariensi archiepiscopo et aliis multis" (Wend., III, 132) ; Cogg., p. 152; Hist. G. le Mar., 1. 13103 ff. 
tribution from the beneficed clergy. ${ }^{288}$ In 1212, the king received warning of a combination of the barons against him, a warning moreover which he heeded. ${ }^{287}$ These cases show not merely discontent with John, but efforts at united action. This union came quickly at the close of the struggle with the pope; in 1215, a strong coalition of the barons obtained Magna Carta from the king. The corporate unity of the barons which was so important a factor under Henry III thus began to appear under John. The question of taxation appears at the close of his reign as one of the causes which drew a section of the magnates together. ${ }^{288}$

It is necessary therefore to ask what was the bearing on taxation of the provisions in Magna Carta. The articles cover all the levies which the king might take from his military tenants. Only two terms are mentioned, the auxilium and the scutagium. The auxilium used loosely may mean any kind of a contribution, a donum, a thirteenth, a carucage, or a scutage in the strict sense. ${ }^{289}$ The scutagium in the same way may mean an aid to marry the king's daughter (1168); to ransom the king (1194); a gracious aid (1217); to knight the king's son (1253); and the composition for military service. It is likely that in articles 12 and 14, both terms were used in the strict technical sense, the scutage as the composition for service

286 "consilio inito, omnes tam Cantuarienses quam Eboracenses metropolitani unanimiter responderunt, Anglicanam ecclesiam nullo modo sustinere posse. . . . Rex ergo saniori usus consilio, exactionem illam penitus relaxavit" (Wav., p. 258).

287 Wav., p. 268; Cov., II, 207; Wend., III, 239.

288 Cov., II, 217-218.

${ }^{289}$ See above, pp. 32, 61, 87. The money paid by the tenant in Normandy was called auxilium exercitus. The tallage on the towns for the Irish expedition was called auxilium villarum (Pipe Roll, 12 John, passim). The fine which the abbot of Malmesbury paid for his knights was called auxilium (Rot. Obl., pp. 13, 32). The scutage of 1204 was called auxilium by Wendover, auxilia militaria (Wend., III, 175). 


\section{STUDIES IN TAXATION}

and the aid as the gracious aid which from time to time the vassal might make to relieve the wants of his lord. ${ }^{290}$

The articles provide that for the levy of a scutage or of a gracious aid, the great council shall be summoned. An interval of at least forty days shall elapse between the date of the summons and the time of meeting. Those who answer the summons shall have the power to grant or to refuse either a scutage or an aid and their decision shall be binding on those who failed to come. The regulation was a great change in several ways. It made it obligatory always to summon the great council for aids and scutages. It changed an occasional practice into a rule. The aid of 1207 had been taken in such a council. Whether the carucages of Richard and John had been granted in a great council, we do not know. The scutage of 1204 had been taken in such an assembly, but this was not John's ordinary procedure. Another change was that the articles substituted corporate for individual consent. Finally, scutage was transformed from the composition for military service into an aid which the king could only levy with the consent of his tenants.

But the articles were not satisfactory. In 1217, the barons said that they contained grave and doubtful matters, which seems to mean that the barons had not said in 1215 exactly what they wished to say. One of these doubtful matters was the question of corporate consent in connection with aids. It was a principle not fully accepted at the close of the reign of Henry III. A case involving it arose with the aid of $121 \%$, levied while these articles were being recast. The bishop of Winchester claimed that he had never agreed to this aid, and accord-

290 That they are used in this strict technical sense is suggested by the fact that another sort of aid is carefully distinguished from these two levies, viz., the aid in the three regular cases, to knight the king's son, etc. 


\section{UNDER JOHN AND HENRY III}

ingly the government exempted him from paying it. ${ }^{291}$ But the great difficulty lay with the regulation of the scutage, and it was scutage that the barons had chiefly in mind. There can hardly be a doubt of the truth of this last statement, for the final version of the charter mentions scutage only. Hence in order to understand the regulation in the charter of 1215 , we must consider the character of John's scutages in order to ascertain the grievance which the barons sought to remedy. At the outset it must be remembered that all of John's scutages were scutages in the strict sense, the composition for service; they were not aids. The right to take them therefore rested on the king's right to military service from his tenants, not on their consent. Now the barons had no wish to change the feudal law by which they held their fees. It follows that the introduction of consent to scutage in the charter of 1215 was not due to a wish to change the fundamental principle upon which the levy was based, but rather to correct abuses and to fix the limits within which it could be legally taken. The abuses had arisen in connection with the rate of scutage, the fines, and the occasions on which scutage had been demanded.

For forty years before the accession of John, the rate of scutage had not exceeded $£ 1$ (one and one-half marks) per fee. John had immediately raised the rate to two marks and finally to three marks per fee. In addition, he had collected fines which still further increased the amount of composition, taking them from both greater and lesser tenants. The fines seem to have become heavier as the reign went on. Levied at no customary rate, usually in a lump sum, the fine threatened to become a heavy burden. To say however that the rate of scutage was increased from one and one-half to three marks per

291 See above, p. 127. 


\section{STUDIES IN TAXATION}

fee and that the average rate of the fine (including scutage) was four or five marks per fee still leaves the grievance almost inexplicable, for the price of a knight's service far exceeded any rate of scutage, or the average rate of the fine. The difficulty lies in the fact that the amount of composition has been compared with the conventional number of fees on which a tenant paid scutage or fine at the exchequer, in the belief that such a number equalled the quota of knights which the tenant would otherwise have furnished. The solution will be found if we remember that military service had become reduced and that the tenant's contingent therefore was smaller than the number of fees on which his scutage was computed. Thus if a tenant held fifty fces, he might answer the summons to the host with ten knights, and in doing so he would be considered to have performed his full service. If the rate of scutage were two marks, his scutage would have been one hundred marks; that sum of money however would have bought the exemption from service, not of fifty, but of ten knights. The rate of composition therefore would really have bcen, not two marks, but ten marks per knight actually furnished, an amount which would in some cases have been the full commutation for service. Now the king was increasing the rate of scutage and he was levying fines as well; that is, he had broken away from the customary rate of composition. There was only one logical limit to his exactions, a rate which should be the equivalent of full service from each tenant in chief, or something like ten marks per fee. There were cases in which he had actually demanded this amount, ${ }^{292}$ but in the state of military service at that time, a rate of ten marks per fee meant in cases a composition of twenty or thirty or more marks per knight actually furnished. Thus the increase in the rate of scutage and the fines 292 See above, p. 98 and below, note 294 . 
was not a theoretical but a real grievance. ${ }^{293}$ Again, when a scutage was not taken throughout the kingdom and when the host was not summoned, John would demand service from a section of the tenants and collect fines from such as did not wish to go. In 1211, no general expedition was sent to France, yet the king summoned the knights of Robert Fitz Walter and Eustace de Vescy, both honors being in hand, and the tenants on the fees of bishops in exile, sent 100 knights to France, and compelled the rest to fine at ten marks per fee. ${ }^{294}$ Moreover,

293 That tenants served with only part of their nominal contingents from the beginning of the thirteenth century, see above, p. 302. The difference between the rate of scutage and the composition per knight furnished can be well illustrated from the scutage of Ireland, taken at three marks per fee (see above, p. 97). The following table gives the number of fees held by each tenant, the scutage which he would have paid, the number of knights furnished in the campaign, and the rate of commutation per knight furnished.

\begin{tabular}{|c|c|c|c|c|}
\hline & $\begin{array}{l}\text { Number } \\
\text { of } \\
\text { fees }\end{array}$ & $\begin{array}{l}\text { Scutage } \\
\text { at } 3 \mathrm{~m} \\
\mathrm{~m}\end{array}$ & $\begin{array}{c}\text { Number } \\
\text { of } \\
\text { knights } \\
\text { furnished }\end{array}$ & $\begin{array}{c}\text { Rate of } \\
\text { commutation } \\
\text { per knight } \\
\text { furnished } \\
\text { m }\end{array}$ \\
\hline Earl Warenne & 60 & 180 & 8 & $221 / 2$ \\
\hline Robert de Tateshal & 25 & 75 & 3 & 25 \\
\hline William Malet & 21 & 63 & 5 & 12 \\
\hline Earl Aubrey de Ver & $301 / 8$ & $903 / 8$ & 6 & 15 \\
\hline Bishop of Salisbury & 32 & 96 & 9 & 10 \\
\hline Ralph Sudley & 3 & 9 & 2 & $41 / 2$ \\
\hline Robert de Turnham & 31 & 93 & 3 & 31 \\
\hline Henry de Oilli & 32 & 96 & 2 & 48 \\
\hline Geoff rey Fitz Peter & $981 / 3$ & 295 & 10 & $291 / 2$ \\
\hline Earl of Hereford & $301 / 2$ & $911 / 2$ & 10 & 9 \\
\hline Countess of Clare . & 9 & 27 & 2 & $131 / 2$ \\
\hline Nigel de Luvetot. & 15 & 45 & 2 & $221 / 2$ \\
\hline Robert Marmiun . & 25 & 75 & 3 & 25 \\
\hline Gilbert Gaunt & $681 / 3$ & 205 & 6 & 34 \\
\hline Gilbert Peke & 19 & 57 & 2 & 28 \\
\hline
\end{tabular}

This explanation makes intelligible the minimum rate of scutage at one mark given in the "Unknown Charter of Liberties." If tenants served with their full contingents, such a rate would be absurd.

294 Dunst., p. 35. 


\section{STUDIES IN TAXATION}

John had collected scutage when the feudal law would hardly justify him in so doing. That he was able to do this was partly due to the fact that he put the scutage in charge at the opening of the campaign. Then whatever happened afterward, he continued to collect the levy. In 1199 and in 1201 there was little or no fighting after the king crossed to France, yet a scutage was taken. ${ }^{295}$ In 1204, some knights were sent and a scutage was paid, but the king neither went nor led the host to France. ${ }^{298}$ In 1205 only a picked body of knights was sent; still the king collected scutage. ${ }^{297}$ In 1209, the host was summoned and the king led it against the king of Scots. When the two hosts met, there was no fighting; a treaty was made. Those tenants who had not been present in the host paid a scutage. ${ }^{298}$ In 1214, the question that arose over the scutage was not whether it had been granted by the tenants, but whether the king was legally entitled to it. The barons claimed that they did not owe service across the seas and that consequently scutage was not due. ${ }^{299}$

Indications of discontent with the fines and scutages are not wanting during the reign. In 1199, one chronicler calls the scutage of that year a gravis exactio and says that never before had more than twenty shillings been paid. $^{300}$ In 1206, though the campaign was to be fought in France, the rate was reduced to twenty shillings. ${ }^{301}$ In 1209 and in 1211, John took hardly any fines. In 1214, no fines were levied, but the rate was raised to three

295 See above, pp. 21, 315.

290 See above, p. 64.

287 See above, p. 69.

298 See above, p. 94.

299 See above, p. 112.

300 Cogg., p. 101.

301 The concession, if it was a concession, was more apparent than real. Nearly the whole lery consisted of fines (see abore, p. $77 f$.). 
marks per fee. Now here is a great grievance, felt by the barons since the beginning of John's reign and based on a legal right of the king, the law of military service. The tenant was bound to serve the king in war; if he wished to be exempt, he must pay any sum that the king demanded, or forfeit his lands. Thus the king had the right to much more than he took in fines and scutages. If he retained this right in entirety, he had a tremendous weapon of financial extortion. The reform therefore which the barons desired was that the commutation of military service should be uniform, reasonable, and taken only when the king had a legal right to it. The question at issue was accordingly not whether they should have the right to grant or to refuse a scutage. The tenants would come very near to this, especially in determining whether or not a scutage was legally due, yet the real point to be decided would not be consent. When the king had waged a proper campaign at the head of the host, there would be no question of his right to take a scutage. This can be well illustrated from the reign of Henry III. Beginning with 1242, the barons refused again and again to grant the king an aid except those to which he was entitled by the feudal law. Yet during this time, three scutages were taken, that of Gascony of 1242, that of Gannoc of 1246, and that of Wales of 1258, all based evidently on the king's right to military service.

This interpretation of articles 12 and 14 shows why the articles were dropped by the barons. As to the aids, the reason was because corporate consent was substituted for individual consent. As to scutage, it was because this levy had been changed from the composition of military service into an aid. Moreover, it was a cumbrous procedure to summon the great council to discuss a scutage which could be conveniently declared at the close of the 


\section{STUDIES IN TAXATION}

campaign. As many of the tenants in chief would be present, they could watch over their rights as effectually as in a specially summoned council. The charter of $\mathbf{1 2 1 7}$ answers to the desires of the barons. It limited the regulation to the scutage, a word which might be interpreted to mean either the composition for military service or one kind of an aid. ${ }^{302}$ The abuses of scutage from which they had suffered under Richard and John were to be abandoned, though no method by which this reform was to be enforced was prescribed. In all probability, the omission was due to the difficulty of framing such an article. Furthermore, John was dead and his successor was a boy who was controlled by the barons. Under these conditions, the king would hardly violate the law which, though well understood, was hard to put into words. ${ }^{303}$

The expectation of the barons was in great measure realized. The reign of Henry III shows that the king was restricted in determining the time and the circumstances under which a scutage would be due. A campaign against a rebel might sometimes be considered a sufficient cause for a levy but not always. ${ }^{304}$ Once the host was

302 "Scutagium capiatur de cetero sicut capi consuevit tempore Henrici regis avi nostri."

303 Professor Adams, whose interpretation of the articles I have followed, says: "There is certainly some ground for thinking that the barons may have been conscious that in their statement about scutage in clause 12 they had gone farther than they were justified in going and that, therefore, as scutage was the main reason for the clause the whole subject was omitted in 1216, with a general reference to dubitabilia, because no satisfactory substitute could be thought of in the hurried conditions of the moment, and later, still troubled by the difficulty of accurate statement, they contented themselves with the historical reference to the time of Henry II, which did really state vaguely but accurately what they wanted" (Origin of the English Constitution, p. 223).

304 It was so considered in 1221 and 1224, the campaigns of Biham and Bedford; no scutage was however levied in 1233 for the campaign against Richard Marshal. 


\section{UNDER JOHN AND HENRY III}

summoned and marched to Wales and once it was led against the Scots, but there was no fighting in either case and no scutage was taken. ${ }^{305}$ Throughout the reign, the scutage was regularly levied at or near the close of a campaign. When in 1229 and 1242, the king wished to take it at the outset, he did so with the consent of the barons. ${ }^{306}$ The rate gradually rose again to three marks per fee, yet it seems in general to have been fixed by consultation with the barons. ${ }^{307}$ As to the fines, few if any were taken while the barons were in control of the government. Beginning with 1229, after Henry III took charge, fines reappeared. The barons were therefore unsuccessful in making scutage the sole composition for service. But the importance of the fines diminished after 1230 because the struggle then was no longer over the scutage, but over the taxes on personal property.

As to the aids, although the machinery for summoning the council was dropped from the charter, the king conformed to the regulation laid down in 1215. He never took an aid except by the consent of the great council. It is likely that this was due to the growth of corporate feeling among the magnates, rather than to a desire to conform to article 14. However that may be, the method followed was the same as that provided in the dropped articles. There need therefore be no surprise that the articles were never reinstated, though there was much discussion of taxation under Henry III. The policy which they embodied was practically carried out. The barons in the course of the reign faced a new problem, to devise a method to prevent the king from levying aids at will when he summoned the great council. The charter of 1215 would not help them in this.

305 The expedition against Wales in 1241; against the Scots in 1244 . 306 See above, pp. 186, 227, 236.

307 See above, note 306, and pp. 139, 151, 197, 246, 284. 
At the opening of Henry III's reign, the king had no unrestricted right to tax. It was still necessary for him to get the consent of his vassals if he wished a contribution over and above those given him by the feudal law, but it was individual consent, not corporate, and except in the case of an aid on knights' fees, the right was not protected by the charter. ${ }^{308}$

The men who obtained the charter were the tenants in chief described in clause 14. It was thus a bargain, a

308 Cf. Stubbs, Const. Hist., II (3rd ed), 21: "The constitutional clauses, those touching taxation and the national council, were omitted. . . . The reasons for this course are obvious. The baronage was for the moment in the place of the king; to limit the taxing powers of the crown would be to tie their own hands"; and again, p. 27, on the charter of 1217: "the 44th (clause) which provides that scutages shall be taken as in King Henry's time, may show that in some points, the current of recent history had been retrogressive"; and in note 2, p. 27: "the exact force of the clause (44) is however uncertain: if as may be thought, it was to restrict the amount of scutage, it was a concession on the part of the crown; if it means that scutages should be taken without asking the commune concilium, it was a retrograde act. The scutage taken nearly at this time was assessed by the commune concilium." Stubbs believed that John's scutages were general taxes, levied by the sole authority of the king and that in theory they needed the consent of the barons; hence these statements. Scutage however under John was not a general tax, but was the commutation for knight service, and as such did not in law need the consent of the tenants. The scutage of 1217 should not be classed with John's scutages, for it was an aid and therefore was taken and had to be taken with the consent of the barons. Clause 44 of the charter of 1217 had the same aim as clauses 12 and 14 of the charter of 1215 ; it undoubtedly restricted the amount of composition which the king could demand, as Stubbs says, though it did not provide any method by which that was to be accomplished. But the reason for dropping the constitutional clauses was not to untie the hands of the barons in the matter of taxation (see above, p. 365). Cf. Petit-Dutaillis, Studies Supplementary to Stubbs' Constitutional History, pp. 141-142: "This wording (of the charter of 1217) clearly proves that the barons ... only wished to be secured, in some way or other, against the too frequent return and the raising of the rate of scutage." $C f$. McKechnie, Magna Carta, pp. 282-284. 
treaty between the king and his vassals. There existed among the latter a certain feeling of unity which had been called into existence by the tyranny of John, but was not yet permanent. Nor did the barons represent the nation; ${ }^{309}$ they were not the regnum. The phrase "per commune consilium regni," on which some emphasis has been laid, ${ }^{310}$ as representing a new conception of their assembly by the barons, was merely a form, a variant of the familiar "per consilium baronum nostrorum" etc. ${ }^{311}$ The settlement of the question of taxation was yet in the future. It was the work of Henry III's reign to establish certain precedents concerning the levy of taxes, to make this corporate feeling permanent, and to change individual into corporate consent. It is the purpose of this section to outline the steps by which this was accomplished.

The cause of the conflict between the king and his barons which resulted in the control of taxation by parlia-

309 Adams, Pol. Hist. of England, 1066-1216, p. 437 ; Petit-Dutaillis, Studies, p. 129; Norgate, John Lackland, p. 234.

310 "Der dem Parlament mit den deutschen Landständen gemeinsame Anspruch, die Vertretung des ganzen Landes zu sein, tritt bereits in der Magna Charta hervor. Hier findet sich zum ersten Male die später regelmässig gebrauchte Formel: nach dem gemeinsamen Rate des Landes (per commune consilium regni), wodurch die Zustimmung des Parlaments zu Gesetzen und Verordnungen ausgedrückt wird" (Plehn, p. 14).

$311 \mathrm{John}$ issued orders per consilium baronum, etc. The assize of the fifteenth on merchants, 1204, per consilium fidelium nostrorum (Rot. Litt. Pat., p. 42); a safe conduct, juxta consilium vestrum et aliorum fidelium nostrorum (ibid., p. 48b); liberation of ships, communi consilio baronum nostrorum (ibid., p. 52b); for nine knights to equip a tenth, cum assensu archiepiscoporum, episcoporum, comitum, baronum et omnium fidelium nostrorum Angliæ (ibid., p. 55a); for the levy of the thirteenth, per commune consilium et assensum concilii nostri (ibid., p. 72b); assize concerning clippers and counterfeiters of money, per commune consilium regni nostri (ibid., p. 54b); in 1194, John was disseized per commune consilium regni (Hov., III, 236). 


\section{STUDIES IN TAXATION}

ment was the king's lack of money. ${ }^{312}$ Henry III tried to increase his insufficient income by taxes granted by the great council, and the frequency and severity of his demands led to the development of corporate unity among the barons and to a measure of corporate consent. According to Magna Carta, the great council was composed of the tenants in chief, viz., the clerical tenants, the greater barons, and the lesser barons or knights. The clergy and the greater barons were summoned by individual writs; the knights by a general writ transmitted to them by the sheriff. This body, known as the great council, varied greatly in its composition and in the conditions under which it met. It was usually specially summoned, ${ }^{313}$ but the tenants in chief in the host with whom the king would consult in levying a scutage after a campaign would be equally regarded as the great council. When the body was specially called together, the writs of summons stated the time and place of the meeting. The business to be transacted was described in general terms, e.g. "tractaturi de magnis et arduis negotiis nostris."314 Magna Carta stated that forty days

312 See above, p. 345. A great difficulty seems to have been that Henry was not a good financier.

313 E.g. in 1225 when the fifteenth was granted; "convocantur ... proceres Angliæ" (Cov., II, 256); "convenerunt ... ad vocationem regis magnates Angliæ tam laici quam prælati" (Wend., IV, 233); "misit... scripta regalia, præcipiens omnibus ... videlicet archiepiscopis, etc., ut omnes ... Londoniis convenirent" (Matthew Paris, III, 380, 1237); also, ibid., IV, 180, 1242; "regia submonitione convocati" (ibid., 362, 1244) ; "rex, missis literis suis, . . . convocavit" (ibid., 511, 1246); "per scripta sua regia... convocari" (ibid., 590, 1247); "edicto regio convocata" (ibid., V, 5, 1248); "vocavit dominus rex per literas suas" (ibid., 47-48, 1249); "ex edicto regio convocati" (ibid., 324, 1252); in 1253, 1254, 1255 (ibid., V, 373, 493; VI, 282).

314 Select Charters, p. 282, summons to the bishop of Salisbury in 1205. In 1237, the council met "credentes se vel imperialia vel alia ardua negotia provisuros" (Matthew Paris, III, 380); in 1242, a writ summoned the members of the great council to London to deliberate on difficult affairs of the kingdom which admitted no delay; 


\section{UNDER JOHN AND HENRY III}

must elapse between the time when the summons was sent out and the meeting of the council. The regulation was not always observed, but about a month was regarded as the necessary interval. ${ }^{315}$ As to those who attended such a council, no hard and fast rule can be laid down. The membership varied from one time to another. Only those came who were summoned, and attendance was obligatory. But a summons was not regarded as a privilege, for in 1258 an arrangement was made by which the presence of all would not be necessary. ${ }^{316}$ If a tenant failed to come, an excuse was given or a substitute sent. ${ }^{317}$ Not all were always summoned. In 1220 , the carucage was granted, according to the king's writ, by all the magnates and faithful of the realm. Yet the tenants of Yorkshire were neither present nor summoned. ${ }^{318}$ In 1229, the earls and barons were summoned to meet at Northampton and the bishops met later at London. ${ }^{319}$ Sometimes the tenan's were unwilling to take any action because of the absence

this was to get an aid for the invasion of Gascony (ibid., IV, 180); in 1248 "edicto regio convocata totius regni Angliæ nobilitas convenit Londoniis"; that the writ did not state that an aid was to be asked is indicated by Matthew Paris: "et cum proposuisset dominus rex (non enim propositum suum latuit universitatem) pecuniare auxilium postulare etc." (ibid., V, 5, 6).

315 In 1253, the regents received the king's letters at Christmas to summon the council on January 13 to get an aid for him. The interval was too short, so it was summoned for January 27 (ibid., $\mathrm{V}, 423$, giving the date of the meeting; ibid., VI, 282, for the statement of the regents).

316 There were three parliaments to meet whether summoned or not and composed of twelve men chosen by the commonalty (Select Charters, p. 396 ).

317 Thus in the April parliament of 1253, "archiepiscopus vero Eboracensis ... excusavit se, asserens se esse remotum et senem"; "pro Cestrensi autem absente valitudo manifeste allegavit" (Matthew Paris, V, 373). The cases of substitutes relate to the clergy (ibid., IV, 185, 372; Wilkins, II, 20.)

318 Select Charters, p. 352; Shirley, I, 151.

319 Madox, I, 607, n. $z$. 


\section{STUDIES IN TAXATION}

of some members. In 1232, in response to the king's demand for an aid, the clergy asked for a postponement of the matter because many bishops and abbots were absent. ${ }^{320}$ In 1249, the absence of Richard of Cornwall prevented the barons from taking action on the demands which they had previously made of the king. ${ }^{321}$ In 1252, the clergy refused to act on account of the absence of the archbishops of Canterbury and York. ${ }^{322}$ In 1254, at the Easter meeting of the magnates in London, a demand for money was presented from the king who was in Gascony. The barons replied that they had now been waiting for three weeks for earl Richard and some other magnates who delayed in coming. No further action was taken, except to repeat that they would come personally to the king's aid as they had promised in a previous meeting. ${ }^{323}$ In 1255 , the clergy refused a demand for money on account of the absence of the archbishop of Canterbury and of some bishops. ${ }^{324}$ In this same year, the barons refused to take any action on a request for money, because their peers had not been summoned to the council. ${ }^{325}$

There were no fixed dates on which the council met, but favorite times were early in February, after Easter and after Michaelmas. Nor were the meetings always held at the same place, though toward the end of the reign, London and Westminster were often selected. ${ }^{326}$

When the council met, the initiative was taken by the king. The aid was asked for either by the king in person

320 See above, p. 200.

321 Matthew Paris, V, 73.

322 Ibid., 328.

323 Ibid., 424, 440.

324 Matthew Paris, V, 532.

325 "Et responsum fuit quod omnes tunc temporis non fuerunt juxta tenorem magnæ cartæ suæ rocati, et ideo sine paribus suis tunc absentibus nullum voluerunt tunc responsum dare, vel auxilium concedere vel præstare" (ibid., 520).

326 Other places were Winchester, Oxford, and Northampton. 


\section{UNDER JOHN AND HENRY III}

or by deputy. The tax was not merely demanded; reasons for its necessity were always given to persuade the barons to make the grant. Sometimes the demand was for a special kind of tax. In 1225, Hubert de Burgh asked for a fifteenth; in 1237, a thirtieth was requested; in 1257, a tenth from the clergy for two years. ${ }^{327}$ The council might substitute a different kind of an aid for the one which the king wanted. ${ }^{328}$ Discussion always followed, which was usually secret. ${ }^{329}$ It ended in all cases in a definite reply which a committee might announce to the king. In case the response of the magnates was unsatisfactory, the king communicated further with the mem-

327 In 1225, Hubert de Burgh explained why an aid should be made (Wend., IV, 99); in 1237, William de Ralegh spoke "quasi mediator inter regem et regni magnates"; the king was however present and later spoke to the magnates, "quod cum rex audisset (complaints of the magnates) ... pollicebatur" (Matthew Paris, III, 380-382); in 1242, the king seems to have addressed the barons, for they "contradixerunt igitur regi in faciem" (ibid., IV, 182); in 1244, the king asked "ore proprio"; in 1245, "in propria persona"; in 1246, "ore proprio" (ibid., 362, 373, 526); in 1248, the king was present and probably made the demand: "cum proposuisset dominus rex. ... Hæc (the complaints) cum audisset dominus rex, confusus in semetipso erubuit" (ibid., $\mathrm{V}, 6,7$ ); in 1255 , "prius rex alloquebatur fratrem suum" (ibid., 520); in 1257, "rex ... in audientia totius populi .... ait" (ibid., 623).

328 "cum nullo modo ad aliam formam (auxilii) possent flecti (magnates) (ibid., IV, 373); in 1257, the clergy granted an aid of $£ 52,000$ which was not what the king wanted.

329 The cases in which the king was present seem to have been exceptional. In 1225, the discussion concerning the fifteenth seems to have taken place in the presence of the justiciar who represented the king (Wend., IV, 100); this would hardly be a fair example of the usual practice, for the king was young and his representative, Hubert de Burgh, was one of the tenants in chief. There are cases later in which the magnates sometimes did not hesitate to express openly their opinions concerning the king's demand, e.g. in 1237; perhaps in 1248; in 1255, the earl of Cornwall was first asked to contribute and refused; the other barons then refused to give a decision on account of the absence of their peers (Matthew Paris, III, 381; V, 6, 21, 520). 


\section{STUDIES IN TAXATION}

bers of the council in person or by representatives, at times approaching them singly in the hope of breaking down their opposition. ${ }^{330}$ There is a suggestion that the barons conferred together after the demand for a fortieth in 1232, because the earl of Chester is made to reply "for the magnates." to discuss the aid while the king waited in the hall to hear their decision. ${ }^{332}$ In 1244, after hearing the royal demand, the barons made no answer except that they would deliberate. The clergy and the laity met separately and finally appointed committees to draw up a common reply. In one of the parliaments of that year, the king sent representatives to plead with the clergy. Suddenly he himself appeared before them and begged for the aid, but withdrew when met with the reply that they would consult upon it. The answer was postponed to a later meeting, ${ }^{833}$ which was held the next year when the king renewed his petition for aid, summoning the magnates day after day and making many promises, in person or by deputy. ${ }^{334}$ In 1252, the king was clearly absent from the discussion; his representatives labored with the bishops who declined to accede to his demand for aid and announced their refusal to him by a committee. The king then sent word changing his demand to a request, but the decision of the prelates remained unaltered. ${ }^{335}$ In April, 1255, the barons decided to make certain demands on the king and to postpone further action till September to see if he would perform what they had asked. This decision was prob-

330 For cases of asking the magnates singly for an aid, see above, pp. 224, 249.

331 "pro magnatibus loquens" (Wend., IV, 233).

332 Matthew Paris, III, 380-383.

з3з Ibid., IV, 362-366.

334 "circa quod de die in diem convenit eos dominus rex, tum in propria persona, tum per internuntios sollempnes, per quos promisit etc." (Matthew Paris, IV, 372-373).

335 Ibid., V, 324-328, 334, 336. 


\section{UNDER JOHN AND HENRY III}

ably made at a meeting from which the king was absent, for it was announced to him ex parte universitatis. ${ }^{336}$

The reason for secret deliberation was probably the unwillingness of the magnates to oppose the king singly to his face. Not everyone would dare risk the royal displeasure even by a smaller display of independence than was made by the earl marshal when he called the king a liar, unless he knew that the magnates as a whole would support him. Thus in 1226, when the pope's nuncio, Otho, demanded aid for the pope, the clergy retired and decided on a common reply which was delivered by one of their number. ${ }^{37}$ No individual prelate wished to draw on himself the papal hostility. In 1242, the barons could contradict the king to his face without first going into special session because they had sworn beforehand not to grant an aid. ${ }^{338}$ The fear of the king is plainly shown in the statement of Matthew Paris that the prelates did not wish to respond with an out and out refusal. ${ }^{339}$ In 1256, when the prelates were about to make a common reply by one of their members, Rostand stopped the speaker, demanding that each one reply for himself so that the king and the pope might know the opinion of each. This was what the prelates wished to avoid. ${ }^{340}$ The difference in attitude of the barons when they faced the king and when they faced another of whom they were not afraid is seen in the council of 1229 when the papal nuncio demanded tenths for the pope. The king in the council kept silent, as he had been persuaded

330 Matthew Paris, V, 493-494.

337 "cum super rebus propositis diutius deliberassent, responsum suum in ore magistri Johannis . . communiter posuerunt" (Wend., IV, 115).

338 Matthew Paris, IV, 181.

339 "sed ne frontose viderentur cum præcisa negatione respondisse domino suo regi" (ibid., V, 328).

340 Ibid., 539-540. 


\section{STUDIES IN TAXATION}

by Gregory IX not to oppose the demand. The clergy deliberated and finally yielded, fearing excommunication or interdict. But the laity spoke out boldly at once and refused the grant. ${ }^{341}$

The meetings of the council were not long. The chroniclers usually measure them by days. ${ }^{342}$ They became longer in the latter part of Henry III's reign, not because more business was transacted, but because of the king's attempts to overcome the opposition of the magnates to granting aid. In 1229, the council which considered the tenth lasted four days $;^{343}$ in $123 \%$, four days $;^{844}$ in 1244 , Matthew Paris says that the king kept the magnates at the council many days as if wishing to weary them out, but this long council lasted only seven days. ${ }^{345}$ In 1253, the deliberations lasted fifteen days and more $;^{346}$ in 1254, at least three weeks $;^{347}$ in 1255 , a month $;^{348}$ and in 1258 , the first parliament was held from April 2 to May $5 .^{349}$

Just as the tenants who were summoned were obliged to attend, so they were not allowed to leave without the king's permission. Thus the latter was able to prolong the period of the council much beyond the desires of the magnates in the hope of breaking down their resistance to his demands for aid. ${ }^{350}$

341 "comites rero et barones ac laici omnes plane decimas se daturos contradixerunt" (Wend., IV, 201).

342 "per plures dies protraheret eos dominus rex, volens eos quasi tædio affectos flectere ad consensum" (Matthew Paris, IV, 363); "circa quod de die in diem convenit eos" (ibid., 372); "per plures . . . dies" (ibid., 594). The council which granted the thirteenth to John in 1207 lasted a week (see above, p. 87).

343 Wend., IV, 201.

344 Matthew Paris, III, 382; perhaps a week (see above, p. 214).

345 Ibid., IV, 365.

346 Ibid., V, 374.

347 Ibid., 440.

348 Ibid., 521.

349 Ibid., 676, 688.

350 In 1226, after the pope's demand had been refused by the king, 


\section{UNDER JOHN AND HENRY III}

It is a matter of great interest to know whether the knights, the lesser tenants, continued to attend the great council. In the meetings which were specially summoned, the notices given in the writs and chronicles afford no evidence to show that they were in attendance during the reign of Henry III up to 1248. Two terms used in describing the members of the council may relate to the knights: barones and milites. The term barones might mean any tenant in chief, as barones majores et minores; but it might also mean the great lay tenants only. ${ }^{351}$ In some of the descriptions, it seems to be used in the restricted sense. The term milites in the writs really tells nothing as to the composition of the council. When the king is said to grant liberties to classes among whom the knights are mentioned, it does not mean that they were present. Since the liberties applied to several classes,

the prelates and the lay magnates, "concessa est omnibus licentia recedendi" (Wend., IV, 124); in 1232, "et sic, petita licentia, laici omnes recesserunt" (ibid., 233) ; in 1252, the elect of Winchester came to the king, "ut vale dicto licentiatus repatriaret ... Cui (regi) ait electus: Domine, mihi videtur solvitur concilium; patefactum est vobis, prout mihi videtur, prælatorum incommutabile propositum. In procinctu sum, ut de vestra licentia redeam præmaturus" (Matthew Paris, V, 332); in 1270, the prior of Worcester had returned home without the king's permission and Henry III wrote to him, "de tractatu nobiscum habendo supersedimus ad præsens propter quod vos a curia nostra sine colloquio nobiscum habito recessistis" (Raine, p. 24). Cf. the case of 1244; the lay magnates had gone home, but the king kept the clergy and tried to break down their opposition to a grant. Finally he asked them to come one day more; they were unwilling and "sumo mane recedentes, retia, quibus aliquando involvebantur, prudenter evaserunt. Et murmurante et rege, solutum est concilium" (Matthew Paris, IV, 366). This was however unusual.

351 In Magna Carta, clause 2, is the statement concerning the relief of an earl, a baron, and a knight; in clause 21, is the provision that earls and barons shall only be amerced by their peers. In 1222, an aid was levied for the relief of the Holy Land, as follows: on each earl, 3 marks; each baron, 1 mark; each knight, 1 shilling (Rot. Litt. Claus., I, 516b). 


\section{STUDIES IN TAXATION}

these classes were all mentioned. ${ }^{352}$ When the knights among others are said to grant a tax to the king, we seem to be getting a list of the taxpayers, men who, according to the feudal theory, would have to give their consent to the tax, not an enumeration of the men who actually had a part in the deliberations of the council. ${ }^{353}$ This does not mean that the knights did not attend, only that these notices do not prove their presence. On the other hand, the fact that representatives were introduced at the close of the reign is not necessarily evidence that the knights had ceased to attend. All through the reign the exchequer believed that much land held by military service was not paying scutage, that its holders were not taking up knighthood, and that tenants were fining to escape becoming knights. Inquests were held to get hold of men who should hold by knights' service, but without success. $^{354}$ The use of representatives was probably another way of bringing these men under contribution.

There are however references to the knights in the great council. Article 14 of the charter of 1215 mentions them. In this connection, it should be recalled that although this article was later dropped, the policy

352 See above, pp. 161, 162, 214.

353 See abore, pp. 160, 200, 214.

354 See above, pp. 211, 233, in 1235 and 1242. The barons put a stop to these inquests in 1245 (see above, pp. 242, 243). Inasmuch as the king held one great council for the whole kingdom, it would probably be a burden for the knights to attend and we might expect therefore that the king would exempt them from being present. There is a case which has some similarity to this; in 1235, heads of small religious houses were summoned to meet the king to confer about an aid, not in one place, but in different places, conrenient to them, throughout the kingdom (see above, p. 212). Yet on the other hand, the king summoned all the sergeants to meet him at Westminster on a certain day (Close Rolls, no. 59, m. $24 \mathrm{~d}$ ). It would be as burdensome for them to attend as for the knights, yet the king summoned the sergeants to meet at one place. 


\section{UNDER JOHN AND HENRY III}

embodied in it seems to have been carried out. ${ }^{355}$ In 1248, Matthew Paris says that knights were present at a meeting of the great council. ${ }^{356}$ In 1254, the knights were absent, but the great barons in response to the king's demand for an aid refused to answer for them. ${ }^{357}$ In 1255, the barons declined to take any action on a tax on account of the absence of their peers, a term which may refer to the knights. ${ }^{358}$ At the parliament of Oxford in 1258, the knights were present. ${ }^{359}$ All the cases mentioned are of councils specially summoned for purposes of deliberation. But the tenants in chief met and deliberated at other times, though they were not primarily summoned for that purpose, viz., when the host was called together. On such occasions there is no doubt that the lesser tenants met all through Henry III's reign. ${ }^{360}$ These would be considered meetings of the great council and at them the tenants present discussed taxation. ${ }^{361}$ It seems fair to conclude therefore that the lesser tenants continue to attend the great council.

The council did not act as a unit in taxation. The division into groups which is seen in Edward I's reign, when barons, clergy, knights, and towns each made a separate grant, begins to be seen early in the thirteenth

355 See above, p. 366 .

356 "edicto rcgio convocata totius regni Angliæ nobilitas convenit Londoniis. . . Advenerunt igitur illuc, excepta baronum et militum, nobilium, necnon ct abbatum, priorum, et clericorum multitndine copiosa, norem episcopi cum totidem comitibus" (Matthew Paris, $\mathrm{V}, 5$ ).

357 See above, p. 261.

358 Matthew Paris, V, 520-521.

359 "totius regni magnatibus cum equis et armis majoribus et minoribus" (Burton, p. 438).

360 Because they continued to serve in the host (see above, p. 304).

361 Thus scutage was determined at the close of campaigns: 1223, 1224, 1228, 1231, 1245, 1257 (see above, pp. 144, 151, 174, 191, 197, 246, 284). The host was summoned to meet in October, 1252, and when it met the question of an aid was discussed (ibid., p. 253). 


\section{STUDIES IN TAXATION}

century; the two classes which appeared were the clergy and the barons. Thus the feeling of corporate unity, when it developed, was strongest among members of a certain class, rather than among the members of the council as a whole. This is most clearly seen in the case of the clergy. The prelates were tenants in chief, but they were also officials of the church and it was the latter bond which was chiefly strengthened. ${ }^{362}$ In John's reign, a certain distinction had already been made. Fines for exemption from military service were paid by all tenants, but not generally by the bishops. Instead of paying the thirteenth on the assessed value of their property, the clergy seem to have fined for it. ${ }^{333}$ In 1224, the clergy made an independent grant of a carucage to the king while the lay tenants paid scutage. ${ }^{364}$ In 1225 , the prelates paid the fifteenth, but were allowed to assess and collect it on their demesne lands. ${ }^{365}$ In 1229, the bishops did not pay a scutage, but made a grant of an auxilium and were given letters patent affirming that this grant should not prejudice them in the future. ${ }^{388}$ In 1231, all the clergy owing military service made a grant of this kind and received similar letters. ${ }^{367}$ In 1232 , the clergy and laity deliberated separately on the aid; the laity refused a grant and were allowed to withdraw, while the clergy obtained a delay because many of their number were absent. ${ }^{368}$ In 1235, the clergy obtained writs declaring that the grant of aid should not constitute a precedent

362 See Stubbs, Const. Hist., II (3rd ed), 175, on the development of the system of estates.

363 The account of the thirteenth is given: the common thirteenth, the fines of abbots, and the dona of bishops (see above, p. 89).

364 See above, p. $148 f f$.

365 See above, p. 166.

366 See above, p. 189.

367 See above, p. 192.

368 See above, p. 200. 
for future demands by the king. ${ }^{389}$ In 1237 , the thirtieth was granted first by the archbishop of Canterbury and his prelates, and all the clergy were allowed to assess and collect it on their lands. ${ }^{370}$ In 1242, the bishops and in 1269 all the clergy received writs that the aid should not prejudice their rights. ${ }^{371}$ In 1244, clergy and laity deliberated separately and each body agreed to do nothing without the other. ${ }^{372}$ In 1252, the barons stated that their reply to the king's demand for an aid depended on the reply of the prelates. ${ }^{373}$ In 1254, the clergy and the barons made separate replies to the king's request for aid in Gascony. ${ }^{374}$ In 1256, bishops refused a separate grant to the king from their baronies. ${ }^{375}$ The growth of unity among the clergy was furthered by the special taxes which they paid, first, to the pope and later to the king, levied partly on property which laymen did not have (spiritualities); the barons moreover did not aid them to prevent this taxation. ${ }^{376}$ Thus several grants of money were made by the clergy while the lay tenants were untaxed. $^{377}$ By the close of Henry III's reign, the clergy

369 See above, p. 209.

370 See above, p. 215 .

371 See above, pp. 236, 296, 297.

372 See abore, p. 374.

373 "eorum (i.e. baronum) responsio a prælatorum responsione dependebat, nec voluerunt ab eorum assertione discrepantes sequestrari" (Matthew Paris, V, 335).

374 See above, p. 261.

375 Matthew Paris, V, 553.

370 "magnates matri suæ ecclesiæ non compatiebantur" (ibid., V, 526). This was in 1255 when Rostand was demanding aid for the king by papal authority. See above, p. $263 \mathrm{ff}$., for the taxes which the clergy had to pay to the pope. When it was a question of taxing the baronies of the clergy, the lay barons came to their aid and encouraged the prelates to refuse.

377 The tenths for five years for the Sicilian affair, a tenth in 1264, a tenth for three years in 1266, a twentieth in 1268. All military tenants paid aids in 1245 and 1253, but these were owed and so are not exceptions to the statement in the text. 


\section{STUDIES IN TAXATION}

formed a definite part of the great council and responded separately for their taxes.

Of a division between the greater and lesser lay tenants, there is evidence in the different form of summons in Magna Carta. The refusal of the great men to reply for the lesser tenants in $\mathbf{1 2 5 4 ^ { 3 7 8 }}$ indicates the same. Other than these cases, there is little proof of such a division under Henry III. ${ }^{\text {s79 }}$

In what sense is it true that the great council of tenants in chief represented those who were neither present nor summoned? To what extent did it act as a unit? Was the council regarded as the universitas Anglix, the regnum, in taxation? In the earliest taxes, the tenant represented all the men on his land and granted the king a tax on them. ${ }^{380}$ This view of the matter apparently came from the feudal system, for the French kings levied taxes in the same way. ${ }^{381}$ In theory, such a procedure was impossible; the tenant in chief had no right to take such a tax from his men without their consent. How then could he grant the king the right to tax them? The solution is not to be found by stating that the tenant put the king in his place and allowed him to ask the subtenants for an aid. There is no evidence that the king

378 See abore, p. 261.

379 If one thinks that the introduction of representatives was due to the fact that the lesser tenants had ceased to attend the great council, then that fact should be mentioned. To the writer, the introduction of representatives has no direct bearing on the normal attendance of the lesser tenants who had formerly been accustomed to attend, but is to be connected with the tenants who ought to have held by military service, and who never had attended the great council (see above, p. 378).

380 In 1207, the consent of the tenants was individual; thus each must have made the grant to the king for his own men and hence each represented his men. Cf. the grant of the carucage in 1224 (see above, p. 156); see also the letter of the king to the abbot of Coggeshal, above, p. 201, note 109.

381 Vuitry, II, $144 f f$. 


\section{UNDER JOHN AND HENRY III}

took any consent but that of the barons; when this had been obtained, the writs of assessment were issued..$^{382}$ The explanation seems to be that the barons did not conform strictly to the law, but followed one of their common practices in a modified form. With the king's permission, when in financial need, they constantly applied to their vassals for auxilia. ${ }^{3 s}$ Legally the vassals could not be forced to pay such aids; they were aids of grace. At the same time, as feudal tenants, they were under obligation to come to their lord's assistance when necessary, and partly for this reason, no doubt, the requests of the tenants in chief for aid were commonly granted. Such an occasion for seeking an aid from their men arose when the barons granted an auxilium to their lord, the king. Instead however of raising the money by asking their vassals for a gracious aid ${ }^{384}$ with the help of royal literae deprecatoriae, the tenants in chief modified the procedure by allowing the government to collect the aid directly from the sub-tenants. ${ }^{885}$ In so doing, they changed the character of the levy. From being a voluntary grant by the barons' men to their lords, it became a compulsory payment, enforced by all the power of the king. Yet as the aid, in any case, would fall back in part on the sub-

382 Plehn, p. 16.

383 See above, pp. 346, 347.

384 In 1207, however, many of the prelates paid lump sums for their aid to the king; to pay the money they asked their tenants for an aid (see above, pp. 88, 89, notes 8, 21, for the abbot of Abingdon and the bishop of Durham); for two cases in other years when the tenant promised the king an aid and to pay it asked his vassals for an aid, see above, p. 347, notes $225,226$.

385 Many times when property was assessed, the work of assessment and collection was in the hands of the tenants; nearly all the cases in which this was done relate to the clergy. Aids on the property of laymen were regularly assessed by the royal officials; the rights of the tcnants in chief were protected in different ways (see above, pp. 205, 217). 


\section{STUDIES IN TAXATION}

tenant, the change may well have seemed mainly one of form.

After 1215, the view that each baron represented all his men began to be supplemented by a feeling that the council of lay and clerical tenants in chief represented property holders who were not in attendance. This development was due to the increased frequency of taxes, to the fact that they were granted in one great council, and that they were paid, not only by all the men on the lands of tenants in chief present, but also by laymen, who were not rear-vassals; some of these laymen had been summoned, but were not present, and others had not been summoned. ${ }^{386}$ If such men were represented at all, they were represented by the council as a whole. ${ }^{387}$ It is not probable that the powers of the council were clearly defined in the minds of either the king or the magnates. Yet the language of the writs of assessment shows that this question was considered. There was a steady advance in the belief that the council as a body represented men who did not attend it and in the effort to express the limits of this representation completely and precisely. In 1207 , the writ states merely that the aid was provided and granted by the common advice and assent of the council. $^{388}$ In 1220, all the magnates and faithful of the realm granted the carucage. ${ }^{389}$ In 1225 , the fifteenth was granted by the archbishops, bishops, abbots, priors, earls, barons, knights, free tenants, and all in the kingdom. ${ }^{\mathbf{3 9 0}}$

386 These laymen who had not been summoned would be men on the royal demesne and probably some minor tenants in chief.

387 Cf. Plehn, p. 16.

388 "per commune consilium et assensum concilii nostri . . p provisum est . . . (et) concessum est" (Rot. Litt. Pat., p. 72b).

389 "concesserunt nobis sui gratia communiter omnes magnates et fideles tocius regni nostri" (Rot. Litt. Claus., I, 437a).

390 "archiepiscopi, episcopi, abbates, priores, comites, barones, milites, libere tenentes et omnes de regno nostro" (Select Charters, p. 354). 


\section{UNDER JOHN AND HENRY III}

The fortieth was granted by the archbishops, bishops, abbots, priors, and clergy having lands which did not belong to their churches, earls, barons, knights, freemen, and villeins of the kingdom. ${ }^{391}$ The aid on knights' fees of 1235 was granted by the archbishops, bishops, abbots, priors, earls, barons, and all others of the realm of England who held of the king in chief. ${ }^{392}$ The thirtieth in 1237 was granted by the archbishops, bishops, abbots, priors, and clergy having lands which did not belong to their churches, earls, barons, knights, and freemen for themselves and their villeins. ${ }^{393}$ In theory, then, every taxpayer was represented in the council or was present.

In practice, also, there was much corporate activity by the council. The meetings in which taxes were considered were characterized frequently by animated discussion, especially in the latter part of the period. ${ }^{394}$ This was a sign of corporate feeling and a cause of its growth. Taxes were granted as a result of a bargain between the king and the magnates. ${ }^{395}$ Taxes were at first postponed and finally refused altogether. ${ }^{396}$ The council was described in terms which imply a unified body, as barna-

391 Select Charters, p. 360; "archiepiscopi, episcopi, abbates, priores, et clerici terras habentes quæ ad ecclesias suas non pertinent, comites, barones, milites, liberi homines et villani de regno nostro" (Close Rolls, II, 155).

392 "archiepiscopi, episcopi, abbates, priores, comites, barones et omnes alii de regno nostro Anglie qui de nobis tenent in capite" (Close Rolls, III, 186).

393 The same classes as in note 391 , except at the end "et liberi homines pro se et suis villanis" (Close Rolls, III, 544).

394 See above, pp. 160, 177, 200, 215, 224, 241, 249, $253 \mathrm{fj}$.

395 In 1225, the king confirmed the charter and was in return granted the fifteenth; also in 1237 (see above, pp. 160, 215).

398 In 1231, the aid of the clergy was made after it had been first denied; in 1232, there was a postponed meeting to grant the aid; in 1242 and in 1245, the king was unable to get the kind of an aid which he had wanted; in 1252 , the grant of the aid was postponed. There were numerous refusals of aid after 1245 . 


\section{STUDIES IN TAXATION}

gium, universitas, communitas, regnum. The king's efforts, which were often unsuccessful, to get a contribution by appealing to tenants individually imply unity of action by the tenants. ${ }^{397}$ In general it was the growth of this corporate feeling which made it possible to resist successfully the king's demands for taxes.

At the same time certain qualifications must be introduced to show that the corporate activity of the great council and the representative character of the great council were imperfect. The previous practice had been to make aids by bargain between the king and the vassal. That this theory of individual consent should die out at once is hardly possible. The fact that the taxes were uniform in rate in great part gives them the appearance of being the result of corporate action, more than was perhaps actually the case. ${ }^{398}$ The great barons would attend the council and there give their consent. Naturally therefore they would be the ones who could make most effective opposition. A small tenant who opposed, and there were such, could easily be distrained by the royal officials, fortified by the support of the magnates. ${ }^{399}$ The persistence of the practice of individual consent is shown by cases scattered through the reign. In 1217, the bishop of Winchester protested that he had never consented to the aid of that year and he was excused payment by the king's council. ${ }^{400}$ In 1220, the tenants of Yorkshire refused to pay the carucage, because they had not been summoned to the council which granted it. ${ }^{401}$

397 See above, pp. 224, 249, 263, 269, 373, note 329 .

398 The thirteenth of 1207 and the aid of 1222 were at a uniform rate, yet there seems to have been no corporate action; if there was corporate action in the grant of the carucages of 1220 and 1224 , it did not bind absentees (see above, pp. 87, 131, 141, 157).

399 See above, pp. 166, 205, 217, note 186 .

400 See above, p. 127.

401 Shirley, I, 151. 


\section{UNDER JOHN AND HENRY III}

Some great men in other counties refused to allow distraint to be made on their lands for that carucage, and the royal officials seem to have been powerless. ${ }^{402}$ The poll tax of 1222 was by individual consent. ${ }^{403}$ The special carucage of the clergy in 1224 bound only those prelates who agreed to it. ${ }^{404}$ In 1225, the bishop of Durham received the king's writ stating that the fifteenth had been granted "ex mero liberalitatis vestræ dono." connection with the discussion over the sixteenth of 1226; the church of Salisbury asked the question what was to be done if some canons refused to grant the sum to which the majority of the chapter agreed. ${ }^{408}$ In 1232, the clergy, on the ground that many were absent, asked for and were granted a delay in order to consider the king's request for an aid. ${ }^{407}$ The earl of Albemarle, the earl of Lincoln, and Richard de Percy refused to allow the fortieth to be collected on their property up to March 12, 1235, and not till 1236 was it collected from Richard "who then prevented it, but now has granted that it shall be collected." "408 A notice concerning the aid of 1235 due from the fee of a certain tenant takes the form of individual consent. ${ }^{409}$ In 1237, the words of Matthew Paris in describing the conditions under which the grant was made imply individual consent. ${ }^{40}$ In 1257, the grant of $£ 52,000$ was made by a council in which absentees were represented on condition that the absent prelates should

402 See above, p. 132.

403 See above, p. 141.

404 See above, p. 156.

405 Rot. Litt. Claus., II, 75.

406 See above, p. 170.

407 Wend., IV, 233.

408 Cal. Pat. Rolls, I, 124, 159.

409 See above, p. 209, note 149.

410 "Consentientibus igitur primum archiepiscopo Cantuariensi cum suis episcopis et clero"; "sæpe tamen annexum fuit in conditione" (Matthew Paris, III, 383). 


\section{STUDIES IN TAXATION}

give their consent to it. ${ }^{411}$ In $12 \% 0$, the bishops granted a twentieth on their demesnes, but bound only those prelates who were present. ${ }^{412}$ It is evident that the definite establishment of the principle, that the consent of those present to a tax binds the absentees, does not take place in Henry III's reign, and that the members of the great council consciously recognize this fact.

If there is thus doubt about the corporate activity of the great council, we cannot state definitely that the council as a whole represented the kingdom. There were some classes over whom its authority did not extend. One of these classes was the beneficed clergy. In 1207, the grant of the thirteenth did not extend to them. ${ }^{413}$ In 1225, the churches made a separate grant, and in 1232 and 1237 no grant at all. ${ }^{414}$ In 1240, the papal legate dealt with the rectors of Berkshire concerning taxation for the pope. ${ }^{415}$ In 1247, the council held to consider another papal aid contained the archdeacons. ${ }^{418}$ In 1253, the tenth seems to have been granted by the prelates without consulting the lower clergy, who however later complained of it. ${ }^{117}$ Perhaps as a result of this feeling, the prelates in 1254 refused to answer for the lower clergy concerning an aid. ${ }^{418}$ In 1256 and 125\%, the tenths were discussed by the lower as well as the higher clergy. ${ }^{410}$ In the grants of aid in 1264, 1266, and 1268 only the

411 "ac prælati absentes oblationem prædictam duxerint acceptandam" (Burton, p. 402).

412 "Nos episcopi, qui præsentes sumus, quantum in nobis est, parati sumus gratanter subvenire de vicesima terrarum nostrarum et tenementorum feudalium, quæ tenemus in dominico" (Wilkins, II, 21). 413 See above, p. 88.

414 See above, pp. 169, 201, 216.

415 See above, p. 264.

416 See abore, p. 267.

417 See above, p. 277.

418 See above, p. 262.

419 See above, pp. 277, 278. 


\section{UNDER JOHN AND HENRY III}

higher clergy seem to have been consulted ; ${ }^{420}$ the twentieth of 1270 was discussed by the lower clergy. ${ }^{421}$

Another class regarding whom the same question may be raised was the religious orders which did not hold by military tenure. When the king received a grant of a tax on personal property from the great council, he demanded it from all sorts of religious houses. In order to escape paying any tax at all, to avoid the assessment of their property, or to be allowed to fine, these houses had to get a special writ from the king. When they fined, their fine was called a fine for the fifteenth. ${ }^{422}$ Thus the presumption was that they owed the tax. This looks very much as though the king felt that the grant in the great council empowered him to collect from them although they were not members of the council. If however we remember that it was customary to collect dona from religious houses when scutage was levied, or even when no scutage was taken (1248), it will seem probable that the king was following this custom in connection with the aids on personal property, rather than levying a tax by the authority of the great council. Nevertheless, a change had been brought about in the relation of these religious bodies toward taxation which was due to the fact that taxes were levied on property. In the case of the ordinary dona, no house would be liable unless it were approached by officials specially appointed to ask for a contribution; in the case of the dona taken in connection with the aids on moveables, the mere fact that a house possessed property rendered it liable to assessment by the ordinary assessors of the county.

The other class which was not represented in the great council was the tenants on the royal demesne. They paid

420 See above, pp. 290, 292, 294.

421 See above, p. 297.

422 See above, p. 163. 


\section{STUDIES IN TAXATION}

the taxes on personal property in 1225 and 1232 . In 1237, part, perhaps all, of the demesne paid a tallage. ${ }^{23}$ In 1270, the towns on the demesne again paid a tallage instead of the twentieth on the assessed value of their property. ${ }^{42+}$ Henry III levied tallages during his entire reign, independently of any grant by the great council, but a tallage was not based on property. He never levied a tax on the property of the demesne except when he had received a grant from the great council. This suggests that the council represented the demesne. But when the towns paid a tallage instead of a twentieth or a thirtieth, they paid the old customary levy which they owed to the king and over which the council had no control. Such a payment had the effect of denying the authority of the council to tax them. Therefore at the close of Henry's reign, the council cannot be regarded as the representative of the towns.

Certain other influences operated to prevent the formation of the great council into a unified body which represented the whole kingdom. The great growth of corporate feeling was after 1237. As this feeling grew, there was a tendency for the council to split into groups, each of which should have charge of its own taxes. ${ }^{425}$ The result

423 See abore, pp. 162, 201, 216.

424 See above, p. 297.

425 In 1229, the bishops paid an aid while the lay tenants and the religious houses which held by military tenure paid fines and scutages; in 1231, the laity paid scutage while all the clergy paid an aid. In 1237, the clergy were allowed to assess and collect the thirtieth themselves. In 1242, the laity and the religious houses paid fines and scutages and the bishops paid aid. In 1244, groups appear in the council (see above, p. 381). In 1252, the laity stated that their reply to the king for an aid depended on the reply of the clergy (see above, ibid.). In 1253, the clergy granted a tenth on their property other than their baronies. In 1254, the great barons refused to reply for the other laity. In 1255, the clergy refused the grant of the tenth on their baronics. There are taxes on the clergy only in 1264, 1266, and 1268. In 1269, the tenants in chief granted the 


\section{UNDER JOHN AND HENRY III}

would be to restrict rather than to broaden the representative character of the assembly. By whom would the unrepresented elements be taxed? That was a matter which could be settled only by precedent. But the action of the council after 1237 as to taxes on laymen was negative. The tenants refused to grant aids. General taxes on laymen, except those legally due, ceased for over a generation (from 1237 till 1269). ${ }^{426}$ The principle was thus established that the king could not tax without the consent of the tenants in chief. But the precedents by which that principle was fixed by no means established the principle that the tenants in chief were competent to grant taxes on property other than their own. That was left for another generation to work out.

Another question arises: When the great council, or a group in it, refused a tax, was the king able to exact the tax from another group or from individual members? Up to 1242 , there is no evidence that an effort was made to obtain money from individuals when the group had refused it. In 1231, though scutage was being collected from lay tenants, nothing was demanded from clerical tenants till the grant of aid was made by them. ${ }^{427}$ After 1242, demands were made on individuals for aid. But the frequent refusals and the recourse of the king to money lenders show how insufficient were the sums which could be raised if there was not a grant by the council. ${ }^{428}$ The magnates were continually summoned and asked for aid. The lay tenants were especially successful in escaping

twentieth on their baronies, then the bishops on their demesnes, then the religious houses, probably on property other than lands held by military tenure; the towns also paid a tallage (see above, p. $296 \mathrm{f}$.). 426 The only taxes levied were the scutages and the aids of 1245 and 1253, to marry the king's daughter and to knight the king's eldest son.

427 See above, p. 192.

428 See above, p. 241 ff. 


\section{STUDIES IN TAXATION}

taxation. In 1258 they did not complain of excessive taxes; it was the clergy and the towns that had suffered..$^{429}$

\section{Conclusion}

As between the king and the tenants in chief, the scutage therefore never became a general tax; it remained the composition for military service. It was however often accompanied or replaced by a fine. Military service was essentially changed. The old servitium debitum disappeared, and a new servitium debitum took its place. In the case of the greater tenants, the new service was usually only a fraction of the old service; in the case of the lesser tenants, it was often, probably generally, commuted into money. The scutage or fine was the composition for this reduced service; the scutage was computed at a customary rate and the fine was taken at a lump sum which was restricted in amount by custom. The number of fees for which a tenant was held to respond at the exchequer had also become fixed at a number representing either the old servitium debitum or the old enfeoffment of the time of Henry II. Attempts to increase the rate and the number of fees failed. The scutage however did not stop with the tenant in chief; it was shifted from one grade to another of holders of land. The decline in the amount of military service which tenants in chief furnished the king means that the great majority of rear-vassals ceased to serve in the field, but performed their service by paying scutage. Each military expedition for which scutage was levied became therefore the occasion for a tax on all land held by military service. Thus the scope of the scutage as a tax is far wider than is represented by what the king received or what the Pipe Rolls record. As between the king and his vassals, the 428 Select Charters, pp. 394, 395. 


\section{UNDER JOHN AND HENRY III}

scutage continued to be the composition for service, levied only on part of the fees; as between tenants of different grades, it was a tax on all the fees. The opposition of tenants in chief to John's scutages was probably in part the result of the opposition of the sub-tenants to the greater frequency of the levy and the increase in the rate.

The same method of collection persisted throughout the period. The sheriff usually supervised the collection, though twice special officers were appointed. Tenants who served retained the scutage from their lands for their own use. Other tenants were allowed to collect from their vassals and to respond either to the sheriff or directly to the exchequer. The sheriff was constantly brought into direct relations with the sub-tenants. He distrained them to pay scutage to their lords; if the latter refused to pay, he distrained both lord and vassal. If the lord had no writ to collect his scutage, the royal officer collected it from the rear-vassals. But in general, the scutage was not paid by the rear-vassals to the sheriff for the exchequer.

The abuses of scutage under John were twofold: the increase in the amount of composition and its levy on improper occasions. These abuses brought about an attempt to regulate them in Magna Carta of 1215. The provision there made covered all kinds of extraordinary levies on tenants in chief, aids as well as scutages. It was dropped chiefly because it changed scutage into an aid, but the abuses remained reformed under Henry III.

The tallage retained its original character. It was levied from time to time independently of other levies. Towns, vills, and individuals paid lump sums assessed by royal officers, usually judges, who were generally assisted in this work by the sheriff. It was paid either to these assessors, or to the sheriff, or directly to the exchequer. 


\section{STUDIES IN TAXATION}

The amounts charged varied within limits. There was no assessment of property.

The dona from religious houses remained the same, lump sums, not based on property, assessed and collected in about the same way as the tallage. They were always taken, up to 1248 , in connection with a levy on tenants in chief, but in that year one was taken although the military tenants paid nothing. The king therefore was establishing the right to take this voluntary levy independently of other taxes.

These three levies, the scutage, the tallage, and the donum, therefore became stereotyped. It was clearly understood when and how they were to be taken. The amount which could be demanded, even in the case of the fines, was practically fixed. Henceforth it would tend to diminish rather than increase. The development of a system of taxes along this line had stopped. The further growth of taxation was connected with these levies only in an indirect way, viz., through the king's power to obtain service in money by means of them.

The necessity of the government for a larger income led to modern taxation. Its origin was the voluntary feudal aid, a levy never taken by the king on a grand scale before Richard I, but constantly taken by the barons. Thus an occasion for repeated levies was found in the financial necessities of the feudal lord, in this case the king. But of greater importance was the form which the aid assumed in the carucage and the tax on moveables. They were based on property. New machinery of assessment and collection was devised, representing both the central government and the locality. Ultimately all classes in the community were brought under contribution on the assessed value of their property. Along with this went a change in the feeling toward these extraordinary levies. By the end of Henry III's reign, it was admitted 


\section{UNDER JOHN AND HENRY III}

that the king could not live of his own, but that from time to time he needed an aid to supplement the ordinary income of the state. All this meant an immense increase of the royal power.

At the same time, an effective check on the king's taxing power was developed through the growth of a feeling of unity among the tenants in chief. This check first appeared under John, partly caused by his levy of scutage. At the close of his reign the barons succeeded through combination in placing limits to the king's rights over scutage. The great development of corporate feeling however was under Henry III. The strength of the combination of the barons made the king observe in the main the regulation laid down for scutage. It was not hard for the tenants to combine to this end, for they understood clearly what they desired. If the king had waged a proper campaign, he should have scutage from those who had failed to serve; he might also have a fine on occasion. If there had been no proper campaign, then no scutage was due. Rate of scutage and fines should be reasonable.

It was less easy for the barons to arrive at a satisfactory arrangement of the aid. They would hardly deny the truth of the proposition that, if a lord were in financial straits, his vassals ought to come to his assistance. Such a situation however should occur infrequently and it was hard to know what to do with a king like Henry III who was always short of money. Furthermore, the aids which the king finally came to ask had dangerous forms. All property was to be assessed by juries under the supervision of royal officers, and a certain proportion of the value was to be paid. This payment looks very much like rent (consuetudo). If the requests of the king were always granted, he would develop a customary right to aids corresponding to his right to tallage. Never- 


\section{STUDIES IN TAXATION}

theless, resistance was difficult. The royal demand was based on feudal custom practised by the barons themselves and the king was very strong. Hence arose the combination of the barons to resist the royal power and refuse to grant aids. To the custom that the lord could ask aids of his vassals when he was in great need, the tenants opposed the principle that consent to the aid was necessary. The consent was however in origin individual, but by the union of the barons a measure of corporate consent was developed.

The composition of the great council was ill-defined under Henry III. In theory that body was composed of all tenants in chief by military service; in practice there was much variation. Probably many of the lesser tenants ceased to attend just as they had ceased to go to war with the host, but neither in fact nor in theory was the council composed only of the greater tenants in chief.

The authority of the council was equally ill-defined. In the early part of the reign it granted several taxes. These were levied on men who were not represented in it. Then ensued a period of thirty-two years (1237-1269) in which the council refused to grant aids, and the refusal was effective as far as the property on land held by military service was concerned. The principle was thus established that the king could not tax his military tenants without the consent of the great council. During this period, no aids were levied on the demesne. It may be that the refusal of the tenants in chief was partly responsible for this, but it must be remembered that the aid of 1237 was not levied on all the royal demesne. Instead the king took a tallage. It is likely therefore that the refusal of the great council was not the reason why the king did not levy aid on his demesne and that refusal did not operate to prevent the king from taxing 


\section{UNDER JOHN AND HENRY III}

the property of the clergy which was not held by military service. The corporate activity of the tenants in chief therefore seems to have applied only to their own property. Nor was that activity complete, for the idea of individual consent persisted throughout Henry III's reign. The council tended to split into groups. Thus though the king could not tax his military tenants without their consent when they were gathered in an assembly, the principle was not yet established that the council could tax any property other than that of its members. The questions of the final composition of the council and the definition of its authority were left for a later age. 



\section{INDEX}

Aid: distinct from scutage, pp. 13, 314, 315;

gracious, pp. 346-349;

kinds of, fixed by feudal law, p. 346;

levies included under, pp. 13, 314, 315, 348, 359;

points discussed under each, pp. 13, 14;

reasons for asking, pp. 346-348; see each aid.

refusal of; by the clergy to the king, 1207, p. 87; in 1217, p. 123;

by lay tenants in $1220, \mathrm{pp} .130-132$; by lay tenants to the pope, 1229, p. 177; to the king, 1232, p. 200 ; in 1242, p. 224; in 1244, p. 241 ; in 1248,1249, p. 249 ; in 1252, pp. 253,269 ; in 1254, pp. 262,271 ; in 1255-1258, pp. 274-278; in 1266, p. 292 ; in general, pp. $385,386,387$.

regulated in Magna Carta, pp. $359 \mathrm{ff}$.

requests for, from individuals; by the pope, 1240 , p. 264 ; $1245-$ 1247 , p. 267 ; 1252 , p. 269 ; 1262 , p. 290 ; by the king: 1242 , pp. 224,225 ; 1248, p. $249 ; 1252$, p. 269 ; 1254, p. 263 ; p. 373 note 329 ; in general, p. 374 .

Aids, list of: see aids on knights' fees; carucages; personal property, taxes on; dona.

on knights' fees: list of : pp. 348-350; in 1217, p. 125; 1229, on bishops, p. 189; 1231, on clergy, p. 192; 1235, p. 208; 1242, on bishops, p. $236 ; 1245$, p. 241 ; 1253, p. 253.

amount yielded, p. 354;

assessment and collection, in general, p. 350; see also each aid. authority for the levy of: in 1217 , p. 125; 1229, p. 189; 1231, p. 192 ; 1235 , p. 209 ; 1242, p. 236 ; 1245, p. 242; 1253, pp. 253, 254.

exemption from, in 1217, pp. 127, 128.

Army, composition of, pp. 304-306, and see each scutage.

Assessment and collection of taxes: aids on knights' fees, p. 350; carucage and taxes on personal property, pp. 352-353; scutage, pp. 335-337; tallage, pp. 342-343; and see each tax.

Auxilium; see aid.

Bedford, scutage of, p. 148; carucage of, p. 148.

Beneficed clergy: not represented by the great council, p. 388; taxation of, by the king, pp. 14, 355-356, and see list of taxes on personal property; taxation of, by the pope, p. 356 . exempt from aids on personal property granted by the great council, p. 388. 


\section{INDEX}

Biham, scutage of, p. 136.

Bishops: paid aid in 1229 , p. 189 ; in 1242, p. 236 ; seldom paid fines

for knights' service: in 1201, p. 40; in 1203, p. 57; in 1204, p. $66 ; 1206$, p. 79 .

Burgh, Hubert de, marches into Wales, 1223, p. 143; asks for a fifteenth, 1225, p. 160; his account of the fifteenth, p. 167 note; opposes the expedition of 1230, p. 181.

Campaigns, cost of, pp. 159, 343-344;

length of: in 1199 , p. $21 ; 1201$, pp. 34,$35 ; 1206$, p. $77 ; 1210$, p.

96 ; 1211 , p. 101 ; 1214 , p. 109 ; 1221, p. 137 ; 1223, pp. 143-

144 ; 1224 , p. 149 ; 1228, p. 173 ; 1230 , p. 181 ; 1231, p. 196;

1245 , p. 244 ; 1257 , p. 284 note; in general, pp. 310-311.

Carucage: amount yielded, p. 354; assessment and collection, p. 352 ;

change in the character of taxation in the, p. 351 ; compo-

sition for, p. 353 ; incidence of, pp. 351, 353; inquests into

the, in 1198, p. 8; number of men paying the, p. 353;

opposition to the, in 1198 , p. 7 ; in 1200 , p. 34 ; in 1217 , p. 123 ;

in 1220 , p. 130.

Carucages, list of : in 1194, p. 7 ; 1198, p. 7 ; 1200, p. 32; 1217, p. 121; 1220 , p. 129 ; 1224, on clergy, p. 148.

Channel Isles, aid on the, in 1201, p. 45 ; fifth on the, 1203, p. 63.

Chester, earl of, opposes the tenth of 1229, p. 177; opposes the fortieth, 1232, p. 193.

Commune consilium regni, meaning of, p. 369 .

Composition for taxes: see carucages; personal property, taxes on.

Confirmation of charters, 1227, p. 173.

Consent to taxation: see individual consent; great council, corporate action of.

County farm, amount of, p. 15.

Demesne, royal: not represented by the great council, p. 389 ; pays the thirteenth, 1207 , p. 89 ; pays the carucage, 1220 , p. 134; the fifteenth, 1225, p. 162; the fortieth, 1232, p. 201; partly exempt from the thirtieth, 1237, pp. 216, 219; and from the twentieth, 1269, p. 297.

Disinherited, twentieth paid by the clergy for the, 1268, p. 294.

Disseizin: for fine: in 1205 , p. $74 ; 1210$, pp. 99-100; in general, p. 336.

for knights' service: in 1203, p. 62 ; 1209, p. 96; 1210, p. 99; 1223 , p. 145; in general, pp. 306-307.

for scutage: 1204 , p. 67 ; 1210 , p. $99 ; 1228$, p. 175 ; in general, p. 319.

for tax on personal property: in 1207, p. 90.

Distraint: for fines for military service: in 1199, p. 31; in general, p. 336.

for aids: in 1217, p. 128; 1225, p. 166; of clergy, 1231, p. 195; 


\section{INDEX}

1232 , p. 205 ; 1235 , p. 210 ; 1237, p. 217 note; 1245 , p. 243 ;

1253, pp. 258-259; in general, p. 386.

for knights' service: 1210, p. 99 ; 1242, pp. 225, 226; 1244, p. 240;

1245 , p. 245 note; 1253, pp. 254, 255 ; in general, p. 307.

for scutage: in 1199, p. 31 ; 1205, p. 76 ; 1221, p. $140 ; 1223$, p.

147 ; 1224, p. 152 ; 1228, pp. 175,176 ; 1229, p. 188 note; 1230 ,

pp. 194, 195; 1231, p. 198; 1242, p. 235; 1245, pp. 246-248;

in general, pp. 319-320, 330, 335-338.

Dona from religious houses: in general, pp. 9, 343, 350.

assessment and collection, see references in the list below.

list of: in 1199, p. $32 ; 1203$, p. $61 ; 1204$, p. 68; 1205, p. $70 ; 1206$,

p. 77 note; 1210 , p. 105 ; 1217 , p. $121 ; 1220$, p. $135 ; 1230$, p.

190 ; 1235, p. 212 ; 1242 , pp. 225, 237-238; 1245, p. 244; 1249-

1250 , pp. $249-250$; 1253, p. $255-256$; 1254, p. 263 ; 1255, p.

275 ; 1264, p. 290.

Eightieth of 1250 , p. 268.

Elveyn, scutage of, p. 195.

Falkes de Bréauté, rebellion of, p. 148.

Fifteenth: of merchants, 1204, p. 69; of personal property, 1225, p. 159.

Fifth: of Channel Isles, 1203, p. 63; on the clergy for the pope, 1240 , p. 264.

Fine for knights' service: meaning of, pp. 26, 324, 325; general statement concerning, pp. 322-323.

assessed by special justices: in 1201, p. $44 ; 1202$, p. 53 ; 1203 , p. 61.

date of levy of, pp. 316, 324, 328.

opposition to, pp. 323, 324;

paid by bishops; see bishops.

rate of the: in 1201, p. $39 ; 1202$, pp. 48,$49 ; 1203$, pp. 55,57 ;

1204 , pp. 65,66 ; 1205, pp. 71, 73; 1206, p. 78; 1210, p. 99;

1229, pp. 185, 187; in general, pp. $326,327,328$.

two forms of: in 1199 , p. $27 ; 1201$, p. $39 ; 1202$, p. $49 ; 1203$, p.

57; 1204, p. 66 ; 1205, p. 73; 1206, p. 79; 1229, p. 187; 1242,

pp. 228-230; in general, pp. 323, 326, 328.

incidence of: in 1201, p. $43 ; 1203$, p. $60 ; 1204$, p. 66 note; 1205,

p. $76 ; 1210$, p. $100 ; 1233$, pp. 206,$207 ; 1244$, p. $240 ; 1257$,

p. 286; in general, pp. 331-332.

Fines, list of: under Henry II and Richard I, pp. 5, 26;

in 1199 , p. 22 ; 1201 , p. $35 ; 1202$, p. $48 ; 1203$, p. $54 ; 1204$, p. 65 ;

1205 , p. 70; 1206, p. 77; 1209, p. 95; 1210, p. 98; 1211, p. 363;

$1215-1217$, p. 121 ; 1224, p. 151 note; 1229 , p. 187 ; 1233, p. 206 ; 1242 , p. 224 ; 1244 , p. $240 ; 1245$, p. 246 ; 1253, p. 255 ; 1257, p. 286. 


\section{INDEX}

Fines for the aid of 1235 , p. 210 ; paid by the partisans of Simon de Montfort, 1265, p. 291.

Fortieth, the, 1201, p. 45; of 1232, p. 199.

Forty days, the, pp. 245 note, 309-311.

Gannoc, scutage of, p. 244.

Gascony, expeditions to; see Henry III.

Great council: representative character of the, pp. 369, 382-385, 388 ff.;

composition of the, pp. 370-372, 377-379; and see list of meetings; corporate action of, pp. 358, 360, 369, 382, 391; and see list of meetings; dates of meeting, p. 372 ; discussion in the, pp. $372-375$, 385; length of sessions of the, p. 376; writ of summons to, p. 370 ;

list of meetings mentioned: 1204, p. 63 ; 1207, p. $86 ; 1217$, pp. 122,125 ; 1220, p. 130; 1221, pp. 137, 139; 1222, p. 141; 1224, p. $148 ; 1225$, pp. $159-161$; 1229, pp. 176, 181, 189; 1230, p. 191 ; 1231 , p. 192 ; 1232 , p. 200 ; 1235 , p. 208 ; 1237, p. 214 ; 1242, pp. 224, 236; 1244-1245, pp. 241, 242; 1246-1249, pp. 249, $250,266,267 ; 1252$, pp. 253, 269; 1253, pp. 254, 270; 1254, pp. 261-263; 1255, pp. 274, 275; 1256-1258, pp. 277, 278; 1264 , p. $290 ; 1266$, p. 292 ; 1269 , p. 295.

Half of revenues of clergy demanded by the pope, 1246, p. 267.

Henry III: insufficient income and loans: in 1217, pp. 121, 124; 1220 , pp. 129 , 130 ; 1221 , p. 138 ; 1224, p. 159 ; 1231, p. 197 ; 1232 , p. 199 ; 1235 , p. 208 ; 1237 , p. 215 ; 1242 , p. 238 ; $1244-$ 1245, pp. 241, 246; 1247-1250, pp. 249-250; 1253-1258, pp. 260, 279, 281, 282.

and Gascony: sends money to, in 1226-1227, p. 168; desires to lead expedition to, pp. 171, 172; leads expedition to, in 1230, p. 181 ; in 1242 , p. 224 ; in 1253, p. 253; expenses in, in 1230 , p. 181 ; in 1242 , p. 238 ; in 1253 , p. 260 ;

and Sicilian crown, pp. $274 \mathrm{ff}$;

assumes the cross, p. 268 ;

causes of his poverty, p. 345 ; of his conflict with the barons, pp. 119, 345, 370;

measures to restrict his expenditure, in 1237, p. 218;

promises that aid shall not form a precedent; see precedent.

Herlot, papal delegate to England, 1257, p. 278.

Hidage; see carucage.

Honors in hand, scutage and fine on; in 1201, pp. 39, 43; 1202, p. 52; 1203 , pp. 57,60 ; 1206, p. 79 ; 1211, p. 104; 1224, p. 152 ; in general, pp. 331-332.

Hundredth, on the clergy for the pope, 1263, p. 290.

Increment of county farm, amount of, p. 15. 


\section{INDEX}

Indemnity of 1217, pp. 124, 125.

Individual consent to taxation: in 1217, p. 127; in 1220, pp. 131, 132; in 1222, p. 141 ; in 1224, p. 156 ; in 1225, pp. 161,162 ; in 1226 , p. 170 ; in 1235 , p. 209 ; in general, pp. 379 ff., 386-388.

Inquests: of 1166 , p. 3 ; 1198, p. 8 ; 1212, p. 322; 1235, pp. 211-212; 1242, pp. 233-234, 237, 353.

Interdict, tallage for the, 1214, p. 117; income from church lands during the, pp. 106-108.

Ireland, expedition to, 1210, p. 96; taxation of, 1217, p. 129; in 1220 , p. 135; clergy, 1226, p. 171; in 1235-1237, p. 219; from clergy, 1242, p. 238; in 1253, p. 260; twentieth for the pope, 1241, p. 265 note; tenth, 1266, p. 293.

Jews, tallages of: in 1210, p. 105; 1220, p. 208 note; 1224, p. 163 note; 1230 , p. $191 ; 1233$, p. $200 ; 1237$, p. $219 ; 1241$, p. 220 ; 1249, p. 250 note; 1256, p. 284 note.

John: treaty with Philip Augustus, 1200, p. 32; money in hand in 1206, p. 82; income from church lands during the interdict, pp. 106-108; funds in 1214, p. 110 note; royal income under, pp. 15, 16, 344.

Jury, a royal device in taxation, p. 352 .

Knights; see lesser tenants.

Knights' service: fines of towns for: in 1224, p. 149; 1231, p. 198; 1264, p. 290;

performed by rear-vassals: in 1221 , p. 140 ; 1228 , p. 175 ; 12291230 , p. 195 ; in general, p. 329 ;

reduction of: in 1202 , p. 48 note; 1204, p. 64 note; 1210 , p. 97; 1211, p. $101 ; 1213$, pp. 109-110; 1214, p. 111; 1221, p. 138; 1223, p. 146; 1224, pp. 149-152; 1228, p. 174; 1229-1230, pp. $182-183,193$; 1231, p. 196 ; 1241, p. 221 ; 1242, p. 226 ; 1245, pp. $245-248$; 1253 , p. 255 ; 1257 , pp. $284-285$; in general, pp. 11, 302-304, 362-363; causes of reduction, pp. 307-309; unwillingness to perform, in 1213-1214, p. 113; 1242, p. 225; 1244 , p. 240 ; 1253, pp. 253-254; 1254, pp. 261-263; 1257, p. 284 ; in general, pp. 307-308.

Lambeth, treaty of, 1217, p. 124.

Lesser tenants: in the great council: in 1225, p. $160 ; 1232$, p. 200 ; 1235, p. 208 note; 1237, p. 214; 1254, p. 261 ; in general, pp. $377 \mathrm{ff}$.

rate of fines on: p. 328, and see references in list of fines.

service of, in the host: p. 306, and see references to host in list of scutages.

London, tallage on, per capita, 1226, p. 172; dispute over the tallage of, 1255 , p. 283.

Louis of France, in England, pp. 121-125. 


\section{INDEX}

Magna Carta: provisions concerning taxation, pp. $359 \mathrm{ff}$; these provisions obeyed under Henry III, pp. 366-367;

grievances concerning scutage in, pp. 10-12, $361 \mathrm{ff}$;

reduction of royal income resulting from, p. 119.

Martin, papal delegate to England to collect money, 1244, pp. 265266.

Mercenaries, use of: in 1199 , p. $21 ; 1201$, p. $35 ; 1202$, p. $46 ; 1203$, p. 53 ; 1204, p. 64 ; 1210, p. 96 ; 1214, p. 111 ; 1221, p. 138; 1225 , p. 168 ; 1230 , p. 182 ; 1233, p. 206 ; 1242, pp. 225, 227; 1245 , pp. 244, 245; 1254, p. 262; in general, pp. 304-305; 311 note 53.

Modern taxation, origin of, p. 346.

Moneyers, tallage of, p. 289.

Montgomery, scutage of, 1223, p. 143.

New enfeoffment, p. 3.

Norwich, bishop of: collector of papal subsidies, 1246-1247, pp. 266,267 ; collector of the tenth, 1254, p. 271.

Norwich taxation, pp. 272, 292, 294, 298 note.

Old enfeoffment, p. 3.

Otho, papal legate, levies taxes on the clergy, 1238-1241, pp. 264-265.

Ottobon, papal legate, pp. $291 \mathrm{ff}$.

Personal property, taxes on: assessment and collection, pp. 352-356; change in the character of taxation in the, p. 351; composition for the, pp. 353, 355; incidence of, pp. 351-353, 355356 ; number of men paying the, p. 353; occasion for, pp. 347-348; receipts from, pp. 354-356; rights of barons protected in the, pp. 205, 217, 352; and see each tax.

Personal property, taxes on, list of: 1166, p. 6 ; tenth, for the crusade, 1188 , p. 6; fourth, for Richard's ransom, 1194, p. 6; levied during the reigns of John and Henry III: fortieth, for the crusade, 1201, p. 45; aid on the Channel Islands, 1201, p. 45; fifth on the Channel Islands, 1203, p. 63 ; seventh, fine for desertion, 1203 , p. 62 ; thirteenth, 1207 , p. 84; twentieth, on the clergy, 1216, p. 121; fifteenth, 1225, p. 159; sixteenth on the clergy, 1226, p. 169; tenth on the clergy, 1229, papal, p. 176; fortieth, 1232, p. 199; thirtieth, 1237, p. 214; thirtieth, papal, on the clergy, 1238, p. 264; fifth, papal, on the clergy, 1240, p. 264; twentieth, papal, on the clergy, 1246, p. 265; papal levies of 1247, on the clergy, p. 267; twenty-third, 1250, p. 250; eightieth, on the clergy, 1250, p. 268; twentieth, on the clergy, 1252, p. 268; tenth, for five years, 1253, on the clergy, pp. 254, 263; hundredth, papal, on the clergy, 1263, p. 290; tenth, on the clergy, 1264, p. 290; tenth, for three years, 1266, on the 


\section{INDEX}

clergy, p. 291; twentieth, on the clergy, for the Disinherited, 1268, p. 294; twentieth, for the crusade, 1269, p. 295.

Poll tax of 1222, p. 141.

Precedent, letters patent that taxes shall not form a: in 1224, to clergy, p. 157; in 1227, to the beneficed clergy, p. 171; in 1229 , to the bishops, p. $189 ; 1231$, to clergy, p. $192 ; 1235$, to clergy, p. 209 ; 1237 , to all tenants, p. $219 ; 1242$, to bishops, p. 236; tax on the clergy of 1269 , not to be a, pp. 296, 297.

Proficuum, amount of, p. 15.

Quota, service by; see knights' service, reduction.

Revenue, king's: classification of, p. 1; ordinary revenue insufficient, p. 2; amount of ordinary revenue under John, p. 16; total revenue in 1242, pp. $238-239$; in $1253, \mathrm{pp} .260,261$; in general, under John and Henry III, pp. 344, 345.

Richard I, taxation for the ransom of, p. 6 .

Richard, earl of Cornwall: in Gascony, 1226, p. 168; receives money from Henry III, p. 219; loans to Henry III, pp. 246, 249, 282; accompanies Henry III to Gascony, 1242, p. 227; absent from the great council, p. 372.

Richard Marshal, fines for campaign against, 1233, p. 206.

Rosso, Peter, papal delegate to England, p. 265.

Rostand, sent to England to assess the tenth, pp. $275 \mathrm{ff}$.

Round: estimate of the servitium debitum, pp. 4, 300 .

Saladin tithe; see tenth of 1188 .

Scotland, scutage of, 1209-1211, p. 94.

Scutage: abuses of, under John, pp. 361-366; amount of, paid, p. 338; assessment and collection, pp. 335-338, and see each scutage; authority for the levy of: in 1204, p. 64 ; in 1221 , p. 139 ; 1224, p. $151 ; 1229$, p. $186 ; 1230$, p. 191 ; 1231, p. $197 ; 1233$, p. 206 ;

1242, pp. 235-236; in general, pp. 338-340.

character of, pp. 10-13, 317-321, 332-334.

date of levy of, p. 316 ; see each scutage.

delays in paying, p. 338;

description of account of, in the Pipe Roll, pp. 17-18, 313-314; more complete form of account of, in 1211, p. 104.

incidence of, pp. 329, 330, and see each scutage.

incomplete accounts of, in 1204, p. 314 note; 1210 , p. 98 ; 1242, p. 228;

in Magna Carta, p. 359;

levies included under, p. 359;

number of fees paying, in the thirteenth century; in 1217, p. 127 ; 1245 , p. 243 ; 1253 , p. 257 ; also, pp. 4, 300-302, 331.

number of greater tenants paying, or fine, pp. 302, 306, and see each scutage; 


\section{INDEX}

paid and service rendered: in 1199 , pp. 23, 24; 1201, p. 38; 1203 , p. 56 ; 1214, p. 115; in general, p. 322 ;

opposition to: 1214, pp. 112-114; 1229, of bishops, p. 189; 1230, of clergy, p. 192; in general, pp. 333-334, $361 \mathrm{ff}$. pardoned in part: in 1201, p. 38 ; 1223, pp. 145, 146; points discussed in connection with each, p. 10.

rate of: under Henry II, p. 4; in 1210, p. 98; in general, pp. 316-317;

the entire composition for service, pp. 17, 317-322, 328, and see each scutage;

under Henry III, pp. 366-367; and fine under Henry III, pp. 327-329.

Scutages, list of, levied by John: 1199, p. 22; 1201, p. 34; 1202, p. 46; 1203 , p. 53 ; 1204 , p. 63 ; 1205 , p. 69 ; 1206 , p. 77 ; 1209 , Scotland, p. 94; 1210, Ireland, p. 96; 1211, Wales, p. 101; 1214, Poitou, p. 109;

levied by Henry III: 1221, Biham, p. 136; 1223, Montgomery, p. 143; 1224, Bedford, p. 148; 1228, Kerry, p. 173; 1230, Brittany, p. 180; 1231, Poitou, p. 191; 1232, Elveyn, p. 195; 1242, Gascony, p. 224; 1246, Gannoc, p. 244; 1258, Wales, p. 284.

Scutagio habendo, the writ de, examples of, pp. 140, 147, 152, 230, $318,335$.

Service exempted from scutage and fine, pp. 317, 318, 328, 329, and see each scutage; not commuted at the will of the tenant, p. 312.

Servitium debitum, amount of, pp. 3, 4, 300.

Seventh, 1203, pp. 54, 62.

Sheriff, duties of, in connection with scutage, pp. 335-338; tallage, p. 342 ; taxes on personal property and carucages, p. 352; and see each tax.

Sicilian crown, taxation for the, pp. $274 \mathrm{ff}$.

Sixteenth on the beneficed clergy, 1226, pp. $169 \mathrm{ff}$.

Sub-infeudation, extent of, p. 308 .

Tallage: assessment and collection, pp. 342-343, and see each tallage; character of, p. 10; frequency of, p. 340; levied in connection with aids, p. 340; relation of, to scutage, p. 340 ; restrained in amount, pp. 341-342;

Tallages, list of, under John and Henry III: 1199, p. 31; 1201, p. 45; 1202 , p. 47 ; 1203 , pp. 54,$61 ; 1204$, p. 68 ; 1205 , p. $76 ; 1206$, p. $82 ; 1210$, p. 100 ; 1214, p. 116 ; 1217, p. 128 ; 1223, p. 147; 1226 , p. $172 ; 1230$, p. 190 ; 1234 , p. 207 ; 1235 , p. 213 ; 1238, p. $219 ; 1241$, p. $220 ; 1242$, p. 227 note; 1245 , p. $249 ; 1249$, p. $250 ; 1251$, p. $250 ; 1253$, aid on the towns, p. $256 ; 1255$, p. 283 ; 1260 , p. $289 ; 1268$, p. 294 ; 1269 , p. 297. 


\section{INDEX}

Tenants, division into greater and lesser, p. 382; continue to serve with the host, pp. 305-306; number of greater tenants who compound for knights' service, pp. 302, 306, and see each scutage.

Tenth of personal property, of 1188, p. 6;1229, p. $176 ; 1253$, pp. 254, 263 ; 1264, p. 290 ; 1266, p. 291.

Third of personal property, from the clergy by the pope, 1247, p. 267. Thirteenth of personal property, 1207, p. 84 .

Thirtieth, 1237, p. 214; for the pope, 1238, p. 264.

Twentieth of personal property, 1216, p. 121; 1246, p. 265; 1247, p. 267 ; 1252 , p. 268 ; 1268 , p. 294 ; 1269 , p. 295.

Twenty-third, 1250, p. 250.

Wages of knights, pp. 5, 309.

Wales, scutage of, 1211, p. 101; 1258, p. 284.

Welsh, expedition against the, 1241, p. 220. 



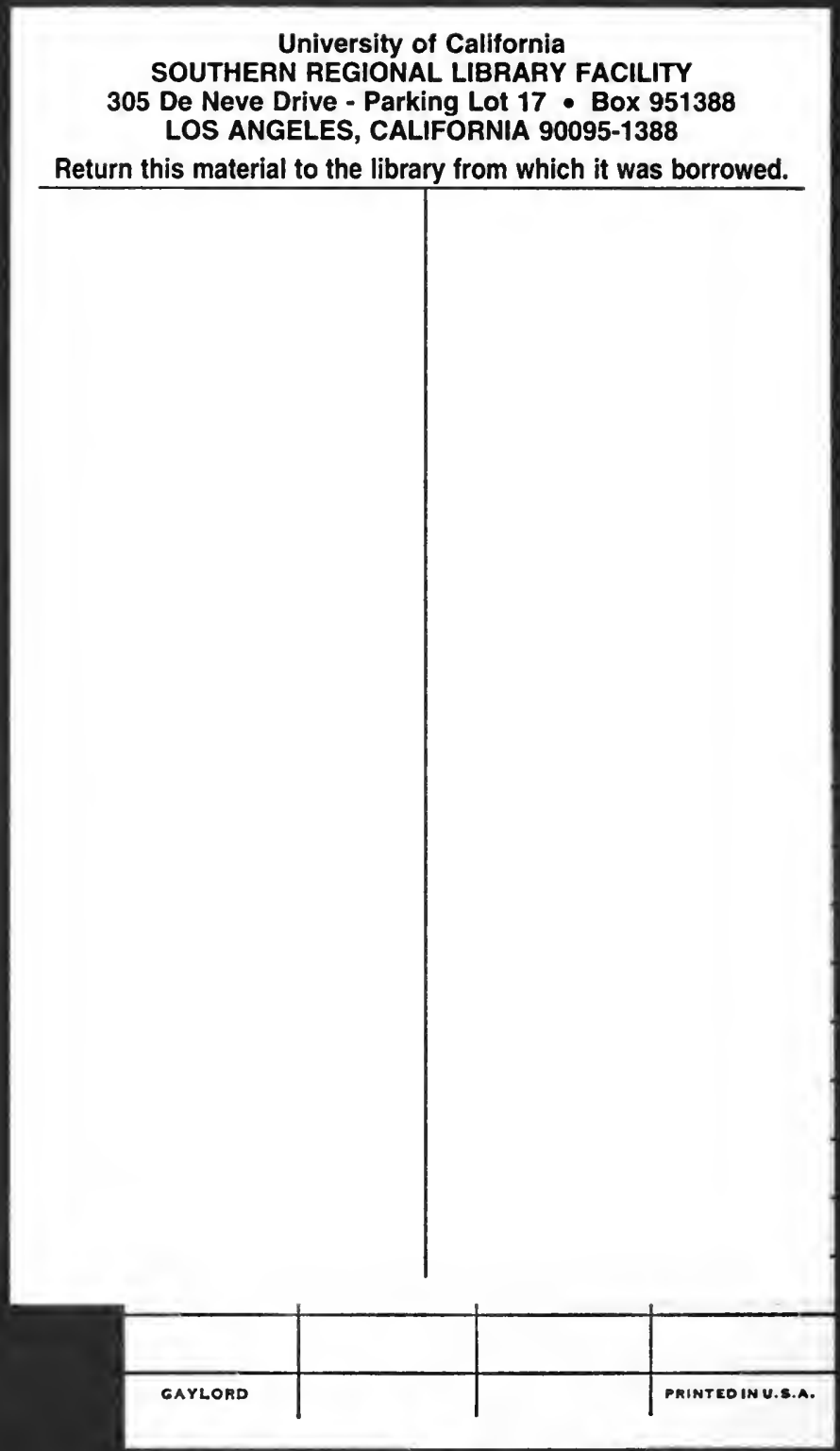




\section{A 000628257 (I)}


